\title{
Regionalizar para governar (1973-1985): Território, geopolítica e neoliberalismo no Chile autoritário
}

Rodolfo Iván Quiroz Rojas

Orientadora: Profa. Dra. Mónica Arroyo 


\section{Regionalizar para governar (1973-1985): Território, geopolítica e neoliberalismo no Chile autoritário}

Rodolfo Iván Quiroz Rojas

Tese de Doutorado apresentada ao Programa de Pós-Graduação em Geografia Humana do Departamento de Geografia da Faculdade de Filosofia, Letras e Ciências Humanas, da Universidade de São Paulo, como parte dos requisitos para obtenção do título de Doutor em Geografia.

Orientador: Profa. Dra. Mónica Arroyo

Versão Corrigida

São Paulo - SP

Outubro 2021 
Autorizo a reprodução e divulgação total ou parcial deste trabalho, por qualquer meio convencional ou eletrônico, para fins de estudo e pesquisa, desde que citada a fonte.

Catalogação na Publicação

Serviço de Biblioteca e Documentação

Faculdade de Filosofia, Letras e Ciências Humanas da Universidade de São Paulo

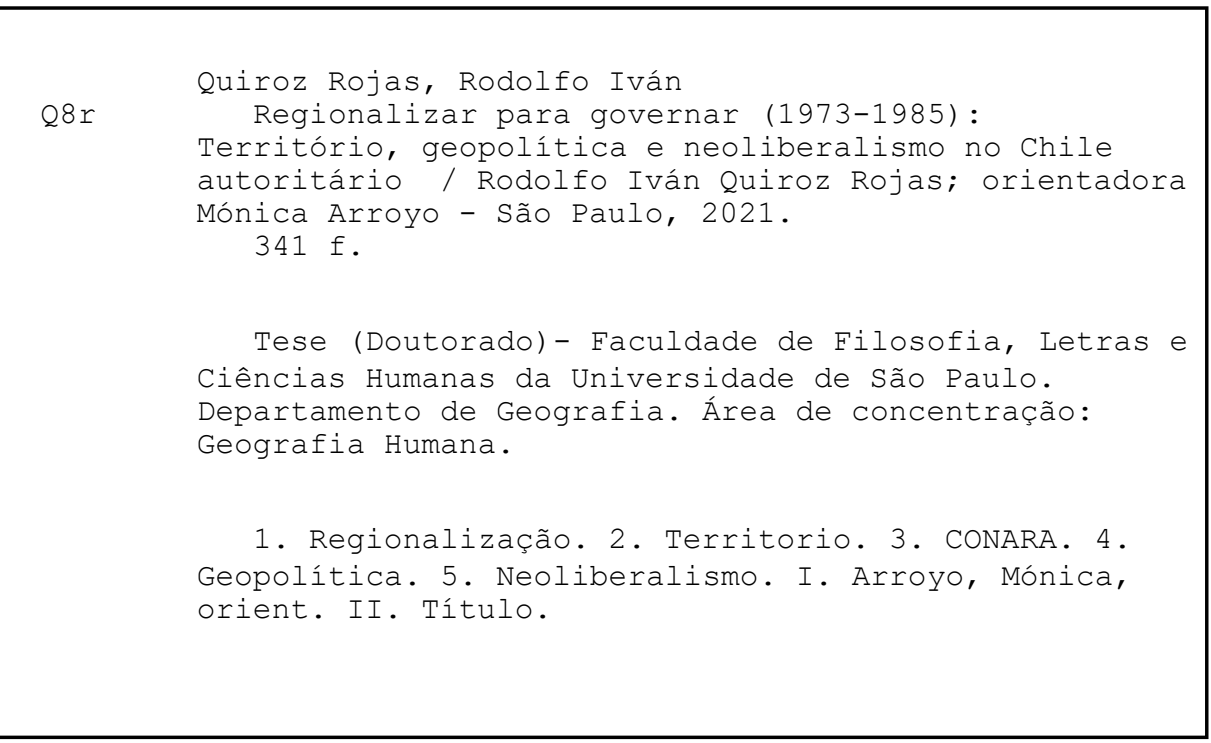




\section{ENTREGA DO EXEMPLAR CORRIGIDO DA DISSERTAÇÃO/TESE}

\section{Termo de Ciência e Concordância do (a) orientador (a)}

\section{Nome do (a) aluno (a): _Rodolfo Iván Quiroz Rojas}

Data da defesa: 23/08/2021

Nome do Prof. (a) orientador (a): Mónica Arroyo

Nos termos da legislação vigente, declaro ESTAR CIENTE do conteúdo deste EXEMPLAR CORRIGIDO elaborado em atenção às sugestões dos membros da comissão Julgadora na sessão de defesa do trabalho, manifestando-me plenamente favorável ao seu encaminhamento e publicação no Portal Digital de Teses da USP.

São Paulo, 14/10/2021

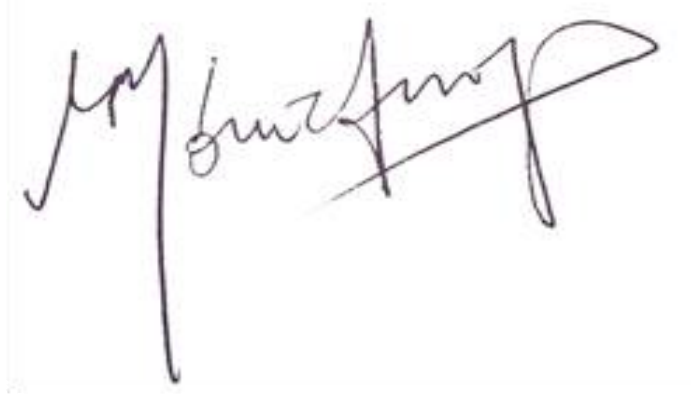

Prof. Mónica Arroyo - Orientadora 


\section{LISTA DE SIGLAS}

ANEPE - Academia Nacional de Estudios Políticos y Estratégicos

ARNAD - Archivo Nacional de la Administración

BCN - Biblioteca del Congreso Nacional de Chile

BID - Banco Interamericano de Desarrollo

BIP - Banco Integrado de Proyectos

CAS -Comités de Asistencia Social

CCHC - Cámara Chilena de la Construcción

CEPAL - Comisión Económica para América Latina y el Caribe

CENABAST - Central Nacional de Abastecimiento

CLAD- Centro Latinoamericano de Administración para el Desarrollo.

CNI - Central Nacional de Inteligencia

CIAPEP- Curso Interamericano en Preparación y Evaluación de Proyectos de Inversión

COAJ - Comité Asesor de la Junta de Gobierno

CONARA - Comisión Nacional de la Reforma Administrativa

CORFO - Corporación de Fomento y la Producción

CODECO - Consejo de Desarrollo Comunal

COREDE - Consejo Regional de Desarrollo

CORMU- Corporación de Mejoramiento Urbano

CUT - Central Unitaria de Trabajadores

DC - Democracia Cristiana

DIGEDER - Dirección General de Deportes y Recreación

DINA - Dirección de Inteligencia Nacional

DIPRES - Dirección de Presupuestos

DINACOS - División Nacional de Comunicación Social

DPDU - Dirección de Planificación del Desarrollo Urbano

FF.AA. - Fuerzas Armadas.

FACH- Fuerza Área de Chile

FJUN - Frente Juvenil de Unidad Nacional

FNDR - Fondo Nacional de Desarrollo Regional

FPMR - Frente Patriótico Manuel Rodríguez

FCM - Fondo Común Municipal

FONASA - Fondo Nacional de Salud 
IGM - Instituto Geográfico Militar

ILPES - Instituto Latinoamericano de Planificación Económica y Social

INE - Instituto Nacional de Estadísticas

ISP- Instituto de Salud Pública

JAP - Juntas de Abastecimiento y Control de Precios

MIR - Movimiento de Izquierda Revolucionaria

MINVU- Ministerio de Vivienda y Urbanismo

MAPU - Movimiento de Acción Popular Unitario

ODEPLAN - Oficina de Planificación Nacional

ORPLAN - Oficinas Regionales de Planificación

PCCH - Partido Comunista de Chile

PEM - Programa de Empleo Mínimo

POJH - Programa de Ocupación para Jefes de Hogar

PDC - Plan de Desarrollo Comunal

PRC - Plano Regulador Comunal

PNUD- Programa de Naciones Unidas para el Desarrollo

PN - Partido Nacional

PR - Partido Radical

PS - Partido Socialista

PUC- Pontificia Universidad Católica de Chile

$\mathrm{RN}$ - Renovación Nacional

RM- Región Metropolitana

SIGORE - Sistema de Gobierno e Administración Regional

SNJ- Secretaría Nacional de la Juventud

SNSS - Sistema Nacional de Servicios de Salud

SERPLAC - Secretarías Regionales de Planificación y Coordinación

SEREMIS - Secretarías Regionales Ministeriales

SECPLAC - Secretarías Comunales de Planificación

SERVIU - Servicio Regional de Vivienda y Urbanismo

SNI - Sistema Nacional de Inversiones

SUBDERE - Subsecretaria de Desarrollo Regional

UP - Unidad Popular

UDEC- Universidad de Concepción

UDI - Unión Demócrata Independiente 


\section{Regionalizar para governar (1973-1985): \\ Território, geopolítica e neoliberalismo no Chile autoritário}

Resumo: A reforma político-administrativa promovida pelo regime autoritário chileno foi estrategicamente funcional para a instalação do neoliberalismo. Utilizando uma revisão dos documentos oficiais, artigos de imprensa e entrevistas com acadêmicos e funcionários públicos da época, são analisadas as estruturas técnico-políticas da divisão políticoadministrativa realizada no Chile entre 1974 e 1985. No trabalho se descreve com ênfase como a definição de fronteiras internas também ativou dispositivos governamentais que condicionaram a deliberação popular e a acomodação do neoliberalismo em termos de projeção burocrática territorial. Analisa-se, então, o uso político do território durante o Chile autoritário, aproximando-se de suas lógicas internas, redes políticas e agências burocráticas do Processo de Regionalização e o Sistema de Governo e Administração Regional (SIGORE). Neste sentido, explica as trajetórias combinadas da Comissão Nacional de Reforma Administrativa (CONARA) e do Escritório Nacional de Planejamento (ODEPLAN) e, sobre elas, o papel (geo)político transcendental de Pinochet durante todo o processo territorial. Se trata de entender uma estrutura territorial com níveis mais elevados de integração no funcionamento de seus governos internos, embora sempre mais guardada e vigiada pela lógica neoliberal e geopolítica de subordinação ao poder central. Essa combinação entre autoritarismo e descentralização foi fundamental para a instalação de um novo tipo de gestão territorial, caraterizada pela tendente privatização dos antigos serviços públicos e a naturalização de práticas locais autoritárias, dependentes dos órgãos centrais, embora com uma maior focalização baseada no padrão econômico dominante.

Palavras-chave: regionalização, território, CONARA, geopolítica, neoliberalismo. 


\title{
Regionalizing in order to govern (1973-1985): \\ Territory, geopolitics and neoliberalism in authoritarian Chile
}

\begin{abstract}
The reform to the political and administrative jurisdictions that was carried out by the authoritarian regime in Chile was functional to the implementation of neoliberalism. Through a review of official documents and press articles, and interviews with academics and officials in charge at that time, this research analyses the technical and political structures of the political and administrative division that was carried out in Chile between 1974 and 1985. It describes how the definition of internal borders activated government mechanisms that structurally lacked popular deliberation and gave social and bureaucratic shape to neoliberalism. Therefore, it analyzes the political use of territories during the authoritarian regime, studying its internal logics, political networks and bureaucratic agencies. Specifically, the research documents the combined trajectories of two organizations: the Comision Nacional de Reforma Administrativa (CONARA) and the Oficina de Planificación Nacional (ODEPLAN), as well as the transcendental (geo)political role of Pinochet during the reform. The new political and administrative jurisdictions were part of a territorial structure that had higher levels of integration than in the previous governments, but that was more shielded and surveilled by the geopolitical logic of subordination to the central government. This combination of authoritarianism and decentralisation was fundamental for the installation of a new type of territorial management, characterised by a tendency to privatise former public services and the naturalisation of authoritarian local practices, dependent on central bodies, although with a greater focus based on the dominant economic pattern.
\end{abstract}

Keywords: regionalization, territory, CONARA, geopolitics, neoliberalism. 
AGRADECIMENTOS .............................................................. 8

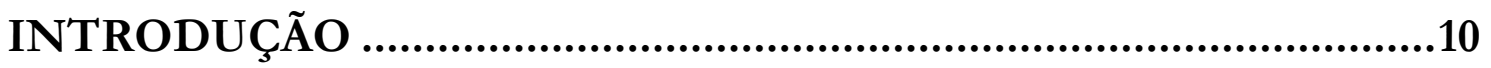

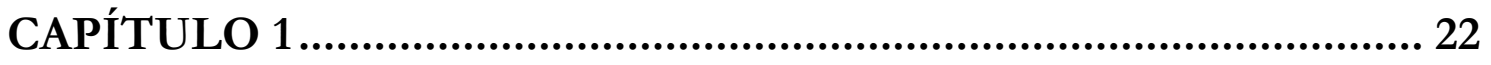

A Regionalização no Chile autoritário ............................................ 22

1.1 Os desafios e particularidades da pesquisa ........................................................................22

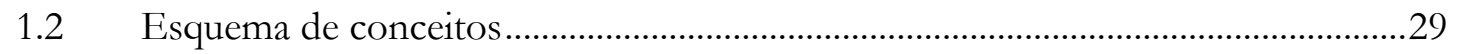

1.3 Território, hegemonia, interesses de classe e gestão do território ....................................37

1.4 Dispositivos, recortes, arranjos e escalonamentos ...............................................................4

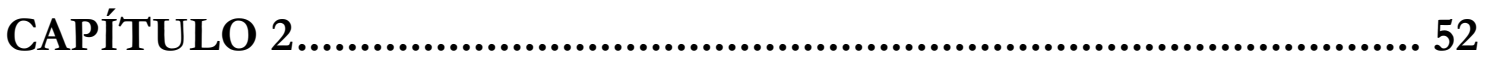

Regionalizar para Governar................................................... 52

2.1 A regionalização antes do Golpe de Estado ........................................................................52

2.2 Geografia dos Estados Maiores, crise social e representação nacional..........................64

2.3 A construção de uma imagem: a naturalização das regiões .............................................. 82

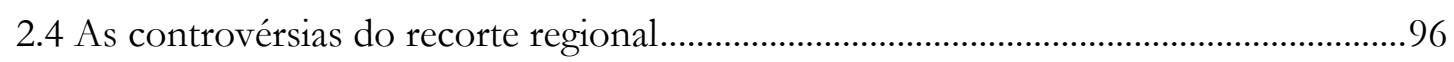

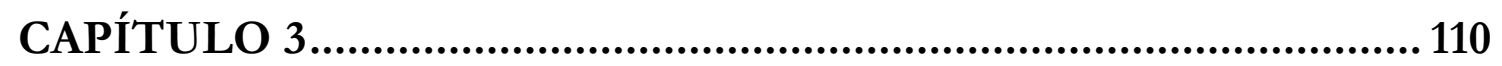

Regiões: um imperativo estratégico do poder nacional........................ 110

$3.1 \mathrm{O}$ arranjo regional estrutural: centralização, poder regional e politização ...................110

3.2 Intendentes militares e estrutura regional: o sistema territorial de Pinochet ...............127

3.3 Da coesão territorial integrada as tensões na estrutura regional...................................149

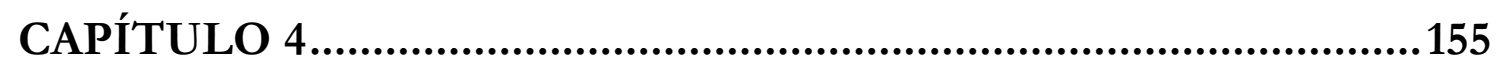

Regiões, burocracia e neoliberalismo ................................................155

4.1 De burocracias regionais a informações estratégicas.....................................................155

4.2. Secretários Regionais de Planejamento e Coordenação: o poder burocrático do

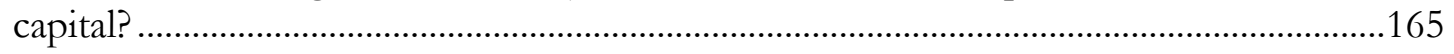

4.3 O Artifício da Região Metropolitana de Santiago .............................................................188

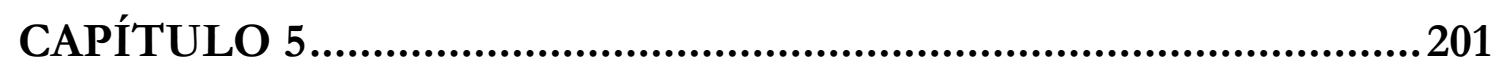

Províncias, geopolítica e vigilância ..................................................201

5.1 Províncias: novas ou velhas fronteiras internas? ...........................................................201

5.2 A dimensão geopolítica das províncias limítrofes .......................................................211 


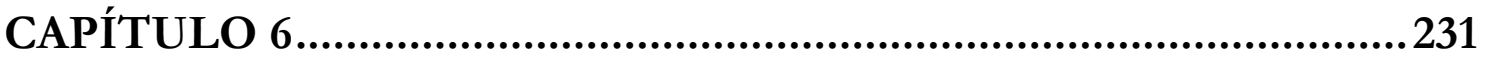

Municipalizar para neoliberalizar..................................................2231

6. 1 A batalha pelas fronteiras comunais: o poder da base? ................................................231

6.2 Espírito de corpo, profissionalização e neoliberalismo: o modelo municipal do

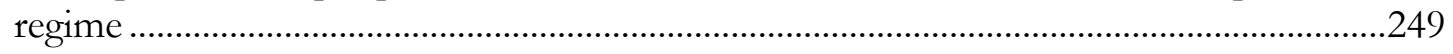

6.3 A disputa pelos pobres na neoliberalização municipal..................................................278

6.4 O recorte das comunas da Região Metropolitana de Santiago ........................................296

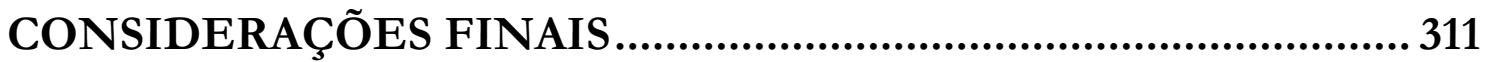

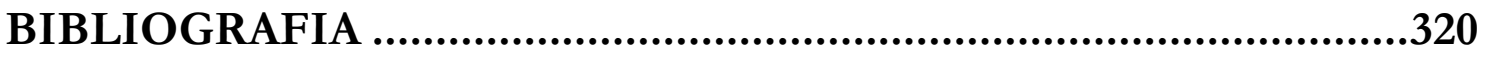

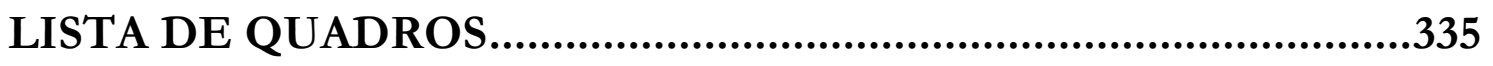

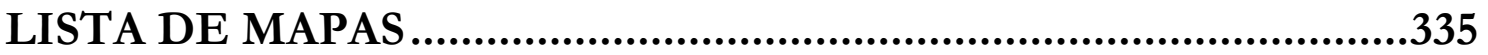

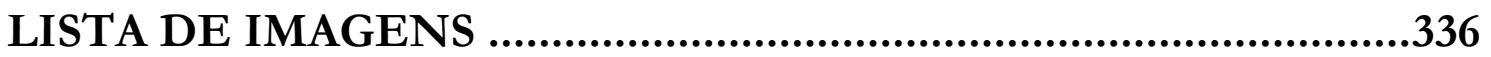

LISTA DE FIGURAS ......................................................................336

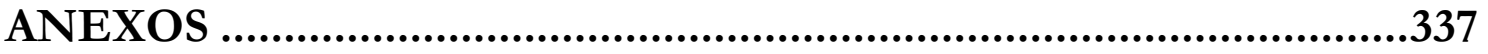




\section{AGRADECIMENTOS}

Antes de mais nada, agradeço a minha mãe, María Isabel Rojas, por seu amor infinito e seu desejo de fazer da vida cotidiana um lugar alegre, compartilhado e de letras. Para minha irmã Loreto, por corrigir cada uma de minhas inconsistências e por ser uma lutadora por amor. Agradeço a meu pai por seu carinho e a admiração pelo Valparaíso. Ao meu sobrinho Santiago, por suas rebeldes geografias adolescentes e sua amizade. Sem seu apoio incondicional, nada haveria concluído nem começado. Agradeço também o apoio fundamental da Agência Nacional de Pesquisa e Desenvolvimento do Chile (ANID) que me permitiu estudar na Universidade de São Paulo (USP) por quase quatro anos, graças ao programa Becas Chile. Sou também grato ao Programa de Pós-Graduação em Geografia Humana (PPGH) da Faculdade de Filosofia, Letras e Ciências Humanas (FFLCH) por ter me acolhido durante estes últimos anos que me permitiram pesquisar e mergulhar nos caminhos da surpreendente geografia brasileira. Também devo muito aos meus colegas do Laboratório de Geografia Política e Planejamento Territorial e Ambiental (LABOPLAN), a Igor Venceslau, Melissa Steda, Aline Oliveira, Bruno Santos, André Pasti, Antonio Gomes, Carolina Israel, Ruth Alexandre, por compartilhar cada um dos nossos seminários e trabalhos e, acima de tudo, por me atualizarem sobre as tão flutuantes e fundamentais geografias do meio técnico-científico-informacional do Brasil e de nossa América Latina. Aos professores André Roberto Martin e Márcio Cataia por seus comentários aguçados e por estimular o desenvolvimento deste trabalho durante o início e tratamento da banca. Um agradecimento especial a Manoel Fernández pela amizade e o apoio logístico de meus últimos meses por São Paulo.

Este trabalho não teria consistência sem o testemunho de todas as entrevistas realizadas, sem dúvida foram fundamentais e por isso, meus sinceros agradecimentos a todos e todas. Ofereço especial agradecimento aos funcionários da Comissão Nacional de Reforma Administrativa (CONARA) e a Secretaria Regional de Planejamento e Coordenação (SERPLAC) de BíoBío da época investigada. Em particular, agradeço a Benjamin Valle, Mario Rocha, Dionisio Vio, Hernán Muñoz, Luis Alfonso Rivas, Pedro Ramírez, Diego Benavente e Alejandro Fernández. Graças aos seus relatos pude perceber de forma direta as geografias mais específicas do processo de regionalização original. Também sou grato à cordial colaboração de Luis Lira e José Abalos que me guiaram com suas excelentes indicações. 
Também agradeço a todos meus colegas do Departamento de Geografia da Universidade Alberto Hurtado. Por terem apoiado tanto a minha partida como meu retorno ao país natal. Nesse sentido, um agradecimento especial a Manuel Fuenzalida por sua disposição na projeção de minha geografia na UAH e também a Loreto Rojas, por ter me estimulado decididamente em minha volta ao país. Um agradecimento fraternal ao meu colega Paulo Contreras, quem construiu e acompanhou cartograficamente cada um dos recortes territoriais, sempre com um sorriso e uma paciência inquebrantável frente às minhas constantes dúvidas logísticas e existenciais. Agradeço a Andrés Estefane e Felipe Irrarázaval por suas palavras de alento e estímulo ao meu trabalho, embora muitas vezes fosse um barco em meio a uma tormenta e sem timão. Sou muito grato pelo apoio fraternal de Alexis Cortes no antes, durante e também após minha travessia pela USP. Igualmente agradeço as indicações de Cristóbal Abarca, quem desde sua chegada a São Paulo alegrou minhas percepções da cultura paulista, com inteligência de saúde coletiva. Minha gratidão também a Emilio Urzúa e Valentina Guillén por incluir-me em seus projetos imaginários. A minhas maestras de São Paulo, Vivi, Mariana e Anabel, por suas companhias e sábias dicas paulistas. A meu colega Vitor Ramirez pela cumplicidade cinéfila e vocação coletiva. Sou muito grato de Larissa Santos, sempre profunda e sensível à minhas perguntas, pela leitura e comentários sobre o capítulo dos SERPLAC. Nesta última etapa de trabalho também me sinto muito grato pelo apoio de Javiera Araya e Andrea Roca, maestras dos estudos e a cotidianidade profunda. Agradeço também a Roberto Celedón por me guiar através da difícil geopolítica da masculinidade e o retorno ao Chile. Um agradecimento muito afetuoso a Sabrina Aquino, pela extraordinária revisão linguística e por seu apoio mineiro-porteño para terminar a edição de cada um destes capítulos. Sem ela, dificilmente teria conseguido a expressão das ideias e contextos narrativos deste trabalho.

Foram quase quatro anos de caminhadas e belos encontros entre a FFLCH e a Praça Elis Regina. Nunca me senti tão em casa como quando morei no Butantã. E nada disso teria sido possível sem o apoio da professora Mónica Arroyo, a verdadeira arquiteta deste caminho pela USP. Para mim é extremamente difícil transmitir em palavras a gratidão que sinto em relação a ela, por algo que vai muito além das convenções acadêmicas. São muitas paisagens de compromisso, paixão por ensinar e sentir o território latino-americano. Sua orientação para este trabalho e sua generosidade comigo não têm limites, nem palavras de equivalências. Minha admiração é eterna, querida Professora. 


\section{INTRODUÇÃO}

Apenas três meses após do Golpe de Estado de 11 de setembro de 1973, o regime autoritário criou a Comisión Nacional de Reforma Administrativa (CONARA), máxima agência de governo encarregada de impulsar uma reforma integral do Estado em termos de estrutura e funcionamento público. Se nomeou como processo de regionalização o conjunto de leis e reformas institucionais que mudariam progressivamente a relação dos poderes territoriais no marco da ação da CONARA. Tratou-se, pois, de uma série de recortes territoriais e mudanças na estrutura administrativa do país que se prolongariam por mais de uma década (1973-1985), sendo entendidas como uma modernização do aparelho administrativo e fortalecimento do governo nacional. Tudo isso ancorado em um projeto de corte fundacional sem prazos nem restrições, como bem definia a Declaração de Princípios publicada em Março de 1974: "Las Fuerzas Armadas y de Orden no fijan plazo a su gestión de Gobierno, porque la tarea de reconstruir moral, institucional y materialmente el país, requiere de una acción profunda y prolongada. En definitiva, resulta imperioso cambiar la mentalidad de los chilenos" (GOBIERNO DE CHILE, 1974a, s./r.).

Dessa maneira, a regionalização acompanhou as principais estruturas políticas, econômicas e culturais que iriam a marcar os inicios institucionais do regime (VALDIVIA et. al. 2012). Nesse sentido, é interessante apontar que o processo de regionalização se adscreve em um particular cenário de transformação do Estado chileno onde a representação emerge como contrapartida da violenta queda do governo da Unidade Popular (UP) e uma sistemática e seletiva repressão das forças políticas da esquerda chilena (HUNEEUS, 2016). Com efeito, segundo a Comisión Nacional sobre Prisión Politica y Tortura ${ }^{1}$ (2005), entre 11 de setembro de 1973 e 10 de março de 1990 (o período da ditadura civil-militar chilena), foram vítimas de prisão política 4.899 mulheres e 33.355 homens, onde mais de três mil pessoas perderam a vida, além das mais de 10 mil vítimas de torturas e outros mil desaparecidos (HUNEEUS, 2016). Precisamente, foi nesse complexo e dramático quadro de mudanças históricas que a regionalização foi desenvolvendo-se de maneira criativa, sistemática e permanente, sob um estrito consenso técnico-político liderado pela CONARA e a Oficina de Planificación Nacional (ODEPLAN).

\footnotetext{
${ }^{1}$ A Comisión Nacional sobre Prisión Politica y Tortura foi uma política de reparação do Estado chileno que buscou determinar o universo de pessoas que sofreram privação de liberdade e torturas por razões políticas entre setembro de 1973 e março de 1990. Se constitui em 2003 sob o governo de Ricardo Lagos, e seu informe foi publicado em 2005, sendo conhecido como Informe Valech, pela importante direção e liderança na comissão do sacerdote católico Sergio Valech.
} 
O comandante em chefe do Exército e presidente da Junta de Governo que tomou posse do Golpe de Estado em 11 de setembro de 1973, general Augusto Pinochet Ugarte, rapidamente conformou o Comité Asesor de la Junta de Gobierno (COAJ) - assessoramento composto pelos oficiais das três Forças Armadas (FF.AA.), constituídos pelo Exército, Marinha e Força Aérea, em conjunto com a Polícia Nacional Uniformizada, Carabineros de Chile. A partir do COAJ, dirigido pelo então coronel do Exército, Julio Canessa Robert, emergiu a CONARA: "No llegué a CONARA, yo la creé. Fue bija legitima del Comité Asesor de la Junta de Gobierno" (ARANCIBIA, BALART, 2006, p. 201), diria Canessa em seu livro de entrevista, máxima chefia militar do processo de regionalização e da CONARA até 1980. Com essa dupla estrutura militar e administrativa do poder central, a CONARA liderou e impulsionou uma complexa redefinição das fronteiras internas, convertendo o exercício da administração pública territorial do país em um importante fator de inventiva política sem precedentes.

$\mathrm{Na}$ prática, entre 1974 e 1981, a divisão político administrativa do país mudou completamente, embora algumas das antigas estruturas estatais tenham conseguido se manter através de diferentes dispositivos e mecanismos burocráticos que foram espalhados nacionalmente. Cada nível geográfico da administração pública do país foi configurado em unidades territoriais que a partir de então passam a articular uma reconfiguração alternativa do sistema nacional de governo. A nível subnacional, por exemplo, as 25 províncias existentes se rearticularam em 13 novas regiões em julho de 1974. A nível intermediário, desaparecem os 95 antigos departamentos que agrupavam as prefeituras para formar 51 novas províncias entre 1975 e 1981, o dobro do período anterior. A nível mais local e próximo à comunidade, as 302 subdelegações existentes em 1974, passam oficialmente a ser 335 prefeituras entre 1979 e 1981. O que estava em jogo nesses recortes? Uma racionalidade do Estado? Uma fração do poder autoritário? Uma garantia de agencias estatais com interesses econômicos particulares?

De maneira geral as pesquisas específicas sobre a regionalização do período autoritário apresentam enfoques descritivos gerais, sem instituir um contexto histórico específico das principais etapas e tramas políticas pelas quais foi desenhada e impulsionada. Se trata de artigos e ensaios destinados a descrever os elementos jurídicos e administrativos fundamentais da reforma, centrando um olhar sobre o que fora feito, mas sem contemplar a dimensão política e econômica circundante ao processo de definição das fronteiras internas. 
Carece-se, assim, de uma leitura interpretativa histórica-geográfica que assegure uma compreensão dos fundamentos e das práticas políticas envolvidas na regionalização, tomando seguimento de seus processos econômicos gerais e, sobretudo, das trajetórias políticas particulares pelos quais se reestruturou a malha territorial do país.

Prevalecem enfoques predominantemente descritivos e atemporais que, se bem, por um lado apresentam abundantes fontes estatísticas, econômicas e jurídicas da regionalização (APEY, 1983; CUMPLIDO, 1983; JORDÁN, VILLARROEL, 1990; SZARY, 1997; CEA, 1994, 1997), mas, por outro, não identificam as diversas crises sociais e contradições econômicas do período, especialmente no interior dos grupos do regime e suas tendências políticas. Assim, se perde de vista o conjunto de desdobramentos na cadeia de comando territorial e a particularidade das representações e blocos de poder internos do período. Portanto, a maior parte das pesquisas destacam assuntos fundamentalmente institucionais que, além de reproduzir ou explicar os argumentos oficiais da divisão das fronteiras internas, omitem e desconhecem os efeitos e cálculos políticos que incidiam nas estruturas burocráticas internas e equipes encarregadas de recortar ou nomear o território oficial. Dessa forma, a visão em retrospectiva da regionalização do período se volta a uma narrativa funcional dos entes administrativos abstratos, sem aprofundar nas diferentes tensões, disputas ou contradições, próprias de qualquer transformação estatal significativa.

Por sua vez, uma parte importante dos estudos sobre regionalização foi escrita e divulgada pelos militares e funcionários civis do regime - intelectuais que participaram da mesma tarefa de legitimar o processo regional - no mesmo período em que a regionalização fora impulsionada (CONARA, 1976, 1979, 1982; GONZALEZ SAMOHOD, 1976, 1978; SUAREZ, 1975, 1976; CASTRO, 1976; BARRIENTOS, 2016; VIO, 1981; CANESSA, 1982; AYLWIN, 1985; VON CHRISMAR, 1986; GARCÍA, 1989; EUGENIN, 1990). Se trata de estudos e informes divulgados pelos organismos oficiais do governo (ODEPLAN ou CONARA) e revistas de circulação afim ao regime, e de tal maneira, carecem de um mínimo afastamento do objeto da análise.

Não obstante, entre 1973-1990, também se produziram estudos mais críticos da regionalização (CHATEAU, 1978; BORJA, VALDES, POZO, MORALES, 1986; BALBONTIN, 1984; LIRA, RIVEROS, 1985; GARCÍA, 1985; ABALOS, LIRA, 1986; RACZYNSKI, 1986; MORALES, POZO, ROJAS, 1988; POZO, 1988) divulgados pelos 
centros de estudos independentes ${ }^{2}$. Com exceção do trabalho Geopolitica y regionalización. Algunas relaciones do Jorge Chateau (1978) e o ensaio Significado político-ideológico de la regionalización y municipalización en el actual régimen de Ignacio Balbontin (1984), a temática transversal da maioria desses trabalhos se concentra em assuntos urbanos e municipais que parcialmente apontam ou permeiam na regionalização material como escala geográfica central de inovação territorial. Isto significa que são trabalhos e referências que, de maneira geral, analisam os efeitos de outras reformas que dialogam com a regionalização, entretanto, sem maior desenvolvimento específico e análise profunda do conjunto de desdobramentos associados aos novos tipos de hierarquização e distribuição de aparatos burocráticos.

Por outra parte, quando os trabalhos se destinam a problematizar a regionalização e a escala geográfica regional como forma específica, trata-se de artigos, ensaios ou informes de pouca extensão que atendem fundamentalmente assuntos particulares da reforma, tais como as dinâmicas de crescimento econômico, formas dos governos locais, tipos de fundamentos regionais ou orçamentos regionais. Porém, essas contribuições não aprofundam no conjunto de mecanismos internos entrelaçados que organizam e dão funcionamento orgânico às políticas públicas durante o ciclo completo do regime autoritário. O trabalho de Chateau (1978), por exemplo, é uma análise incisiva da dimensão geopolítica da regionalização em seus primeiros anos. Entretanto, ao ser desenvolvido apenas nos primeiros anos do regime e no fundamento das regiões, desatende praticamente uma década de reforma e seus consecutivos recortes escalares interiores - comunas e provinciais - (1976-1981), assim como também não considera seus desdobramentos capilares internos na relação agência regional e programas de governo local.

Dessa maneira, se constituiu uma visão parcial do processo de regionalização que desconhece seus diferentes agentes e interesses antagônicos. A partir de 1990 até nosso tempo, as tendências anteriormente descritas são quase em totalidade similares, marcando apenas uma diferença: praticamente desaparecem os trabalhos de funcionários militares e civis do regime, e, por consequência, se acrescentam os enfoques propriamente acadêmicos (BOISIER, 2000, 2010, 2011; ARENAS, 2009; VALENZUELA, 2015). É representativa a carência de estudos destinados a problematizar os conteúdos geográficos e históricos específicos do processo regional envolvidos durante o período autoritário. Além disso, é

\footnotetext{
${ }^{2}$ Destacam-se nessa linha as contribuições da Facultad Latinoamericana de Ciencias Sociales (FLACSO), Corporación Sur (SUR), Instituto Latinoamericano de Planificación Económica y Social (ILPES), Centro de Estudios del Desarrollo (CED), Corporación de Estudios para Latinoamérica (CIEPLAN), entre outros.
} 
particularmente curioso que na maioria das contribuições escritas no período democrático 1990 em diante -, os pesquisadores projetam ampliar e aprofundar seus conteúdos sem necessariamente estabelecer um balanço crítico com o passado. Sergio Boisier, por exemplo, máxima referência dos estudos, destaca que a regionalização do período militar foi uma criação sistêmica e profunda, um campo de desafios e mudanças básicas que, inclusive, reforça a democracia:

La acción del Gobierno Militar en este campo de las políticas públicas fue profunda, sistémicamente pensada, parcialmente ejecutada y entregó a los gobiernos que lo han sucedido una responsabilidad y unos desafíos no sólo importantes en la permanente modernización de Chile, sino que sumamente atrayentes en la tarea de construir un futuro en el que se entienda que la "variedad territorial" en estilos de vida, enmarcados en la "unidad nacional" de una sociedad más equitativa, es la mejor expresión concreta de una democracia propia del siglo XXI (BOISIER, 2000, p. 14).

A dificuldade da avaliação de Boisier é que a regionalização do período autoritário se simplifica a uma esfera administrativa do arranjo territorial sem contradições. Novamente, se valorizam uma série de dispositivos técnicos da regionalização sem considerar seus usos políticos e econômicos entrelaçados e como foram calculados e projetados. Seguindo o roteiro de Boisier, assim, as pesquisas, em geral, vão direta e isoladamente à análise dos dispositivos institucionais e seus efeitos mais aparentes. Dessa maneira, não excursionam nas particulares trajetórias de como foram inseridos os recortes territoriais, omitindo suas diferentes estruturas logísticas ou práticas burocráticas inseridas na gestão territorial do período. Paradoxalmente, se "des-regionaliza" a regionalização do período enquanto poder concreto de práticas políticas estatais, criando uma perda analítica da materialidade históricogeográfica da reconfiguração territorial do regime.

Não se trata de que todos os trabalhos entre 1990 até hoje omitiram os conteúdos contraproducentes da reforma ou tentaram conscientemente legitimar parcial ou totalmente o processo da regionalização. Entretanto, salvo contadas contribuições (CHATEAU, 1978; BALBOLTIN, 1984; DIAZ, 1989; LIRA, 2004, VALDIVIA, 2012; 2015; SANTANA, 2013; ESTEFANE, 2017; LEYTON, 2015, 2020), a maioria dos estudos da regionalização do período impõem um particular enfoque analítico do passado, no qual a dimensão políticaterritorial da regionalização é por pouco anulada ou bem, passa a ser subentendida desde outras preocupações empíricas e temáticas. Se reproduz assim a advertência que Beatrice Giblin apontava para o contexto francês da década de 1980: “os geógrafos especializaram-se na análise regional, mas frequentemente omitem a política como um dos fatores da dinâmica 
das regiões" (COSTA, 2013, p. 321). Em 2007, por exemplo, um informe acadêmico que tinha por objetivo analisar a divisão político administrativa do país, em relação a regionalização do período, destacava que:

Si bien estos conceptos fueron planteados en 1974 en un contexto político y social muy distinto al actual, se rescata de ellos y es atingente también al año 2007, el intento de contar con una administración más flexible, dado que bajo esta premisa se alcanzaría la integración y el desarrollo del país, por ello se postula que para lograr las metas del desarrollo económico y social, se requiere una mejor utilización del territorio y de sus recursos. Esto implicaba la necesidad de establecer una jerarquización de las unidades territoriales; pensamos que dicha estructura regional permite responder a las necesidades de administración del territorio actualmente y que esta no debería ser modificada, dado que para hacer más eficiente la administración de los espacios regionales es más efectivo avanzar en materias de desconcentración y especialmente, de descentralización territorial (entendiéndose entonces este concepto sólo como una disminución del centralismo y no como creación de instancias autónomas), y no necesariamente en la creación de nuevas unidades político - administrativas (SUBSECRETARIA DE DESARROLLO REGIONAL, 2007, p. 24)

É importante assinalar que do conteúdo total do relatório, quase 180 folhas, a referência analítica ao período autoritário é mínima, destacando-se apenas os principais discursos e fontes oficiais, sem contrastar com as práticas, estatísticas e processos históricos reais. $\mathrm{O}$ efeito analítico concreto desse exercício é que se projeta uma atualização por inércia dos supostos princípios da eficiência, flexibilização e hierarquização da regionalização do período militar. Mas novamente, sem questionar e analisar minimamente o que significou geográfica e historicamente a eficiência, a flexibilização e a hierarquização enquanto práticas concretas da regionalização, entendidas em seu particular contexto de múltiplas transformações. Nessa mesma lógica, o Presidente da Câmara de Deputados José Antonio Viera-Gallo, em 1999, desatacava que a regionalização desenhada pelos militares havia adquirido legitimidade política na democracia, pois, as prefeituras haviam sido democratizadas em 1993 pelos governos da Concertación ${ }^{3}$ (VIERA-GALLO, 1999).

No entanto, a estrutura regional e municipal feita pelo regime continuava intacta, assim como seus principais artefatos burocráticos espalhados pelo conjunto espacial do país. Com efeito, as prefeituras constituídas no período democrático tinham uma estrutura orçamentaria definida no período anterior que, embora limitava sua ação como órgão descentralizado ou plenamente democratizado, se aceitavam política e legitimamente como estruturas administrativas naturais. Entre 1990 e 2000, assim, se naturalizaram uma série de

\footnotetext{
${ }^{3}$ Coalizão de partidos políticos de centro-esquerda que governou em Chile apos do processo autoritário (1990).
} 
práticas, arranjos e mudanças da estrutura territorial do Estado chileno herdado, sem nenhum tipo de questionamento. Um balanço crítico da regionalização do período autoritário, então, é um ajuste de contas com a própria geografia chilena e as políticas regionais oficiais que, em geral, desativam ou silenciam as contradições do processo político de definição de fronteiras internas. Nossa pesquisa procurou fundamentalmente criar uma interrogação ao tipo de consenso territorial definido pelo regime autoritário e das pesquisas tradicionais. Nesse sentido, se trata de uma tentativa de ensaio histórico geográfico para responder à necessidade de aprofundar maiores ideias do sistema territorial herdado do regime e pensar como as atuais dinâmicas políticas, ou o próprio debate regional contemporâneo, ainda enxerga as marcas do passado autoritário. Como destacava em 1997, em plena democracia, o ainda comandante do Exército, general Pinochet:

De las obras que se realizaron en el gobierno militar, en el ámbito de las modernizaciones, la reforma administrativa y la regionalización - proceso que aún continúa su evolución y perfeccionamiento - son, junto con la Carretera Austral, las que mayores elogios y, por cierto, consensos han suscitado. Ambas, por su envergadura y proyección, aún contienen retos orientados a consolidarlas (PINOCHET, 1997, p. 93)

A pergunta de fundo é: como se possibilitou a ideia de consolidar a regionalização na democracia, ao ponto de que já não fosse necessário observá-la a partir de suas origens? Desde meus primeiros anos de estudante de geografia no porto de Valparaíso, na década de 2000, percebi os ambíguos e omissos assuntos envolvidos na regionalização do período autoritário. Embora se reconhecesse que a regionalização era um momento significativo das estruturas regionais, paralelamente não existiam interligações nem relações com as fortes transformações econômicas e processos políticos traçados. A divisão político administrativa do país mais importante do século XX se apresentava totalmente indiferente à dramática violação dos direitos humanos e o processo de neoliberalização fundacional.

Uma década depois, meus questionamentos só fizeram aumentar. Agora, já não apenas pelo acesso a outras fontes teóricas e críticas, mas também, pelos iminentes problemas regionais e locais que, de tempos em tempos, explodem em multitudinárias mobilizações, embora acabem reduzidas pelos aparelhos administrativos de Santiago. Parte importante dessas leituras críticas se relacionam com o descobrimento dos trabalhos dos historiadores Andrés Estefane (2017), Verónica Valdivia (2012, 2015), Cesar Leyton (2015, 2020), Rolando Alvarez (2012) e das colocações de geógrafos e outros cientistas sociais como Isabel Jara (2011), Luis Lira (2004), que, ao meu ver, implicitamente, projetariam outras significações geográficas e políticas sobre o processo de regionalização e da consolidação do 
neoliberalismo nas relações territoriais do Estado. Linhas e enfoques de trabalho que, se bem ajudam a ampliar os significados da reforma, ainda são pouco exploradas nas raízes políticas do processo de regionalização.

Fazer um estudo crítico da regionalização impulsionada no período autoritário, assim, permitiu problematizar os fundamentos da divisão política administrativa do Estado como o uso político do território (SANTOS, 2000). Nosso objetivo de pesquisa foi compreender os fundamentos e as práticas políticas em que se vincula a regionalização do período autoritário, em especial atenção, os agenciamentos de seus principais agentes responsáveis: a CONARA e a ODEPLAN. Quais elementos estavam em jogo ao momento de regionalizar o território no contexto particular do regime? O que implica a divisão política e administrativa no funcionamento interno do Estado e suas hierarquias? Que tipo de função estabeleceu a regionalização dentro do regime autoritário chileno como projeto político? Quais foram os principais desdobramentos econômicos do processo de definição de fronteiras internas em regiões, províncias e comunas?

Para desenvolver tais questões, organizamos três estratégias de pesquisa, executadas de forma simultânea e em permanente diálogo com o esquema conceitual traçado: a) consulta e análise de fontes documentais e jornalísticas, b) realização de entrevistas a autoridades da época e acadêmicos especialistas, c) revisão sistemática de bibliografia especializada e construção de cartografia. Em primeiro lugar, se elaborou um trabalho de arquivo para conhecer as principais agências e representações da regionalização da época. Assim, se realizou um trabalho de campo na Sessão de Processamento de Imprensa dependente do Departamento de Produção de Recursos de Informação da Biblioteca do Congresso Nacional (localizado no centro de Santiago), que permitiu o aceso mais de 400 tipos de notícias específicas da regionalização entre 1973 e 1979, correspondentes a jornais de circulação nacional, as quais foram consultadas, selecionadas e sistematizadas, permitindo organizar um arquivo de imagens e dados que foram consultados e contrastados com outros catálogos e fontes de informação. Do total desse registo, finalmente se selecionaram e sistematizaram 59 recortes de imprensa como material de análise para a tese (anexo $n^{\circ} 1$ ). Dessa maneira, se conseguiu reconhecer tramas do contexto histórico dos agentes da regionalização, que aliás, faz parte de um significativo arquivo de imagens associadas ao processo de implementação da reforma regional. 
Em segundo lugar, se realizaram entrevistas semiestruturadas dirigidas especificamente a autoridades da época e acadêmicos especialistas na matéria. No transcurso da investigação se desenvolveram 40 entrevistas (anexo $n^{\circ} 2$ ), as quais não só permitiram aprofundar assuntos inéditos do processo específico dos debates e procedimentos próprios na hora dos recortes territoriais, mas também abrir novos focos de pesquisa. Aliás, muitos desses entrevistados permitiram o aceso a novas fontes documentais e diálogos que implicaram um reconhecimento mais aprofundado das linhas técnicas da gestão territorial regional e as limitações que se apresentaram no processo a partir das agências oficiais inseridas. Com base na análise desse trabalho de entrevistas e contraste com as outras fontes monumentais, se conseguiu estabelecer descrições mais pormenorizadas dos recortes territoriais e das trajetórias políticas envolvidas, distinguindo contradições e controvérsias tanto no interior da estrutura de governo, assim como também nos desdobramentos do processo territorial descrito. Dessa maneira, as entrevistas foram uma das principais chaves de nossa interpretação do processo de regionalização.

Por último, se desenvolveu um trabalho cartográfico apoiado no seguimento da temporalidade dos recortes territoriais de regiões, províncias e comunas. Esse processamento cartográfico foi elaborado mediante a recopilação e consulta dos decretos leis inseridos no processo (quadro $n^{\circ}$ 2) e a informação entregue pelo Instituto Nacional de Estatísticas (INE) do Chile. Desses cruzamentos de informação se conseguiu desenvolver uma cartografia evolutiva dos recortes territoriais, o que nos permitiu reconhecer áreas específicas e combinadas de cada recorte territorial (região, províncias e comunas), assim como também problematizar as lógicas e fundamentos dos arranjos e recortes territoriais oficiais.

Assim sendo, a tese se articulou em seis capítulos de desenvolvimento, mais as considerações finais. No capítulo I, A Regionalização no Chile Autoritário, se identificaram as principais decisões e focos da nossa interpretação, fundamentando a necessidade de estabelecer um enfoque geográfico relacional e coexistente dos processos materiais da regionalização. Nesse capítulo também se estabelecem os principais assuntos teóricos e conceptuais a tratar: território, hegemonia, territorialidade, gestão do território, dispositivos, recortes, arranjos e escalonamentos.

No capítulo II, Regionalizar para Governar, se analisaram os antecedentes históricos do processo regional antes do Golpe de Estado e a respetiva transformação do Estado em 
termos das novas estruturas burocráticas e territoriais. A partir do contexto de violência política, também se explicam os fundamentos da regionalização oficial e, especialmente, como ditos ideários foram articulados em uma lógica de Geografia dos Estados Maiores destinada, principalmente, ao controle da crise social e a representação de um projeto nacional em construção. Se bem se discute a construção discursiva da regionalização e suas principais dissidências e debates - como por exemplo a discussão da Região de Valdivia -, se explica o sentido logístico da reforma regional enquanto estrutura de governo e funcionamento dos órgãos territoriais, sendo uma questão política do regime e o processo de transformação do Estado neoliberal.

Por sua parte no capítulo III, Regiões: um imperativo estratégico do poder nacional, se explicou a mudança do arranjo regional de 1974, concentrando a análises na relação dos Intendentes regionais e a centralidade do general Pinochet no funcionamento da regionalização. Por sua vez, se analisou a lógica militar do comando territorial do país, particularmente a política interna da seleção e rotações dos Intendentes, assim como também se constatou a coesão territorial integrada das novas burocracias regionais, embora a presença de certas tensões e contradições na estrutura regional.

No capítulo IV, Regiões, burocracia e neoliberalismo, se destacou o papel estratégico das Secretarias Regionais de Planejamento e Coordenação (SERPLAC), sendo as principais burocracias encarregadas de materializar o processo de regionalização. $\mathrm{Na}$ configuração operativa das SERPLAC se articulariam às principais interligações orçamentais das diferentes autoridades territoriais, criando um dispositivo de poder altamente funcional ao poder político e suas transformações econômicas. Se analisou o perfil político e técnico dos Secretários Regionais de Planejamento e Coordenação, as bases institucionais que iriam modelando uma gestão territorial ancorado nos princípios do neoliberalismo. Por último, se avalia a definição técnica e política do arranjo metropolitano de Santiago e suas principais contradições enquanto mecanismo compensador de desequilíbrios territoriais.

No capítulo V, Provincias, geopolitica e vigilância, se analisou o fundamento e o recorte das províncias entre 1975 e 1981 como uma forma de acrescentar o poder regional da estrutura hierárquica do sistema de governo interior. Se aprofundou também na lógica geopolítica do arranjo provincial, especialmente no recorte de províncias de 1979 e seus desdobramentos militares em algumas fronteiras externas ligadas a conflitos limítrofes com 
Perú e a Argentina. Dessa forma, se discutiu o papel do Governador Provincial enquanto sua dupla estrutura militar e política no sistema de governo interior, sua função de vigiar e manter o controle das prefeituras e a ordem pública, além da segurança nos territórios internos, sempre ligado ao poder regional ou eventualmente às orientações do poder executivo central.

No capítulo VI, Municipalizar para neoliberalizar, se analisaram as trajetórias dos recortes territoriais comunais e as caraterísticas políticas das prefeituras enquanto intermediação com a comunidade local ou base de apoio do regime. Se questionaram os fundamentos burocráticos oficiais das comunas a partir das lógicas políticas e técnicas do arranjo comunal do regime. Em vista disso, se descreveu como foram se incorporando maiores faculdades e orçamentos nas prefeituras, gerando diversas contradições, como por exemplo, a administração dos serviços primários de saúde e a educação que antigamente não dependiam de suas responsabilidades. A partir da lógica de subsídios e focalização da pobreza também se explica o funcionamento orçamental das prefeituras e a seleção dos prefeitos. Por sua vez, se distingue um funcionamento territorialmente mais orgânico nas prefeituras em regiões que na capital do país, onde se combinam diferentes processos geopolíticos e econômicos que conjugam um arranjo comunal como dispositivo de disciplinamento funcional às dinâmicas urbanas.

Com esses capítulos, se distingue o carácter estrutural do processo de regionalização como projeção do governo autoritário e o funcionamento interno das burocracias territoriais como características de um modelo de neoliberalização. Verifica-se ainda a importância da regionalização no terreno político e econômico do país. Nossa hipótese de trabalho propõe, então, que, mais que uma reforma administrativa ou econômica, a regionalização foi uma empresa de caráter técnico-política com a finalidade de governar. Nesse sentido, a regionalização não só buscou construir hegemonicamente uma hierarquia político-territorial do Estado, mas também, e principalmente, teve como propósito buscar uma maior legitimação via controle político do território, ocupando a rede pública estatal com quadros políticos, técnicos-chaves e afins ao novo modelo econômico que, ao longo do processo, organizaram e redefiniram um ordenamento territorial diferente ao ciclo anterior. Uma formação socio-espacial que por um lado, ditavam uma ordem territorial funcional para a manutenção do Estado autoritário, naturalizando a forma de governo e, por outro, definiam uma projeção neoliberal dos diferentes níveis orçamentais que permitiram ampliar o 
processo de privatização da administração pública e as agências privadas territoriais. Em consideração a esses assuntos, pretendemos ampliar os significados da regionalização, demostrando que sua condição de mecanismo de poder se traduz em um conjunto de práticas estatais implicitamente ligadas ao processo de politização que se vivia com a Unidade Popular: uma regionalização da luta de classes, um produto de interesses antagônicos postos em valor a partir de um novo comando de relações territoriais. 


\section{CAPÍTULO 1}

\section{A Regionalização no Chile autoritário}

\subsection{Os desafios e particularidades da pesquisa}

A diferencia dos estudos tradicionais do processo de regionalização com foco nos efeitos econômicos ou nas relações jurídicas enquanto reforma administrativa do Estado, nossa pesquisa se centra nos desdobramentos e relações de poder dos agentes que impulsaram o processo da regionalização e procura compreender os interesses em jogo do peculiar entramado burocrático que foi inserido nos recortes territoriais. O que significa a regionalização para o movimento político-militar que encabeçou o Golpe de Estado? Essa busca epistemológica se traduz metodologicamente em analisar cada um dos recortes territoriais (regiões, províncias e comunas), reconhecer as agências institucionais e interesses particulares do regime, além de aprofundar nos suportes e cálculos do novo funcionamento burocrático operativo do Estado territorial. Como se recorta o território do regime e sob quê instituições e interesses vai se organizando a malha territorial do país?

Como havíamos apontado anteriormente, o primeiro recorte do território do período foi aplicado em julho de 1974, através de dois decretos leis nomeados, respectivamente: Estatuto del Gobierno y Administración Interiores del Estado (decreto-lei no 573) e Regionalización del País (decreto-lei $n^{\circ}$ 575). Esses decretos-leis marcaram uma nova divisão política administrativa do país com treze regiões que, aliás, foram impulsionadas junto com uma hierarquização das autoridades e funções territoriais em um novo sistema de governo. Com efeito, a regionalização estruturalmente recriava quatro níveis de escala geográficas e hierarquias de autoridades que interagiam umas com outras: a nível nacional com o Presidente da República de Chile; a nível regional com Intendentes Regionais; a nível provincial com Governadores Provinciais, a nível comunal com Prefeitos Comunais. Espacialmente, assim, a regionalização significava que o país era dividido em três escalas geográficas interiores: regiões, províncias e comunas. No entanto, cada uma dessas escalas tinham uma absoluta dependência e interligação direta com a estrutura nacional hierárquica representada no Ministério do Interior e, em última instância, pelo próprio Pinochet. Os desafios da nossa pesquisa foi então reconhecer as interligações internas de cada uns desses recortes e distinguir quais eram seus principais mecanismos de reprodução e organização burocrática interdependente, ou suas agências e capacidades operativas enquanto rede oficial do governo nacional. 
Nessa primeira fase de recortes territoriais, duas caraterísticas se sobressaem: a celeridade do programa da regionalização e a participação direta do próprio general Pinochet com outras altas patentes militares, mostrando um particular interesse e proximidade com a equipe responsável do processo: a CONARA. Para esses efeitos, a CONARA foi criada em 21 de dezembro de 1973 através do decreto-lei no 212. De imediato, essa comissão se instalou no Ministério do Interior, onde executou tarefas legislativas e de assessoria para a Junta de Governo, tal como formar parte de uma primeira linha do Exército que operava como órgão assessor pessoal do próprio general Pinochet, o Comité Asesor de la Junta de Gobierno (COAJ). O COAJ reunia os melhores oficiais do Exército e outras Forças Armadas para projetar e defender os interesses corporativos na Junta de Governo e deliberar estratégias sob qualquer assunto que envolvia a participação dos membros da Junta, sobretudo, o Exército (HUNEEUS, 2016). É desse órgão assessor de absoluta confiança que, em novembro de 1973, Pinochet buscou encomendar o trabalho da regionalização, nomeando, por esse momento, o coronel maior Julio Canessa Robert, quem desde o início foi o chefe do COAJ e o presidente da CONARA, máxima autoridade de governo na regionalização. A CONARA, entre outras tarefas, deveria fundamentalmente:

a) Estudiar y proponer las modalidades necesarias a la legislación y reglamentación administrativa; b) Estudiar y proponer modificaciones estructurales generales de la Administración del Estado o modificaciones orgánicas de determinados Ministerios, Servicios Públicos centralizados o descentralizados o de las Municipalidades, pudiendo señalar las pautas técnicas a las cuales deberá ceñirse la estructura interna de cada una de aquellas instituciones; d) Velar por el cumplimiento de las instrucciones y pautas técnicas que se impartan en ejercicio de sus facultades; f) Planificar, coordinar e impulsar la aplicación de programas específicos de acción y difundir su contenido incentivando a los encargados de su ejecución inmediata; g) Controlar el avance de la puesta en práctica de estos programas; h) Recomendar oportuna y fundadamente a la Junta de Gobierno las decisiones que deben tomarse a este nivel para el éxito de los programas de reforma administrativa que se pongan en marcha; j) Estudiar y proponer medidas tendientes a hacer efectiva una adecuada regionalización administrativa del país (GOBIERNO DE CHILE, 1973b, s./r.).

Com amplos poderes políticos e legislativos, e com comunicação direta com o Presidente e a Junta de Governo, a CONARA manteve uma estrita estrutura militarizada em sua direção durante todo o período de sua existência (1973-1981). Se bem na CONARA também houve membros das outras FF.AA. e profissionais civis, como arquitetos, advogados, geógrafos, economistas, a estrutura de comando foi de controle absoluto do Exército. Em virtude disso, as três principais hierarquias internas da CONARA, Presidente, Vice-presidente e Secretário Executivo, invariavelmente, foram todos cargos exercidos por pessoal da primeira hierarquia 
do Exército e proximidade do general Pinochet. A CONARA foi dessa forma a responsável de levar a reforma administrativa integral do Estado, criando vastas equipes multidisciplinares e estudos que não apenas reformaram as funções e estruturas do Estado, como também configurariam os limites e capilaridades de cada um dos recortes territoriais e as funções burocráticas administrativas. Um particular interesse de nossa pesquisa, então, foi distinguir o funcionamento interno da CONARA e reconhecer suas lógicas técnicas e políticas como Estado Maior do general Pinochet e a divisão política territorial do país, embora tenha emergido aparentemente como apenas um órgão técnico executor dos recortes territoriais da regionalização e administração pública da Junta de Governo.

É importante destacar que, se bem o processo de regionalização da CONARA incorporou outras instituições - como o Instituto Geográfico Militar (IGM), a Comissão Constitucional $^{4}$, o Conselho de Estado, as prefeituras, o Colégio de Arquitetos, entre outras -, sem dúvida, a agência co-produtora do processo de regionalização foi a Oficina de Planificación Nacional (ODEPLAN). Portanto, a CONARA e a ODEPLAN, cumpriram funções de assessoria direta ao Presidente da República (Pinochet), sendo as principais instituições responsáveis do conjunto amplo e diverso de leis e decretos que finalmente serão impulsionados no processo de regionalização. Durante o regime autoritário foram desenvolvidos mais de vinte decretos-leis destinados a aprofundar e estabilizar o processo de regionalização e sua reforma administrativa no territorial (quadro $\mathrm{n}^{\circ} 1$ ). Todos eles foram analisados e revisados pela CONARA e a assessoria da ODEPLAN, demostrando ser as principais agências estratégicas do regime. Dessa forma, nossa pesquisa analisou as relações de colaboração e interdependência entre ambas instituições e os dispositivos burocráticos que permitiram suas interligações.

Quadro $\mathrm{n}^{\circ}$ 1. Decretos leis associados ao processo de regionalização

\begin{tabular}{|c|c|c|}
\hline $\begin{array}{c}\mathbf{N}^{\mathbf{0}} \\
\text { decreto } \\
\text { lei }\end{array}$ & Nome & Data \\
\hline 212 & Crea Comisión Nacional de la Reforma Administrativa & $17 / 12 / 1973$ \\
\hline 573 & Estatuto del Gobierno y Administración interiores del Estado & $08 / 07 / 1974$ \\
& Asigna denominación a XI Región & $28 / 10 / 1974$ \\
\hline 712 & Aprueba presupuesto de la nación para el año 1975 & $04 / 12 / 1974$ \\
\hline 785 & \multicolumn{2}{|c}{} \\
\hline
\end{tabular}

\footnotetext{
${ }^{4}$ Órgão técnico-político composto com juristas afins ao regime, que a partir de Outubro-Novembro de 1973 começaram a discutir o projeto constitucional do país. Este trabalho terminará na nova Constituição em 1980.
} 


\begin{tabular}{|c|c|c|}
\hline 69 & $\begin{array}{c}\text { Programas correspondientes a las } \\
\text { Secretarías Regionales de Planificación y Coordinación }\end{array}$ & $17 / 01 / 1975$ \\
\hline 937 & $\begin{array}{l}\text { Crea plantas y establece normas para las secretarias } \\
\text { Regionales de Planificación y coordinación }\end{array}$ & $26 / 03 / 1975$ \\
\hline 746 & $\begin{array}{l}\text { Aprueba reglamento orgánico de las Secretarias } \\
\text { Regionales de Planificación y Coordinación }\end{array}$ & $22 / 07 / 1975$ \\
\hline 1230 & $\begin{array}{c}\text { Denomina "Magallanes y Antártica Chilena" y "Región } \\
\text { Metropolitana" }\end{array}$ & $27 / 10 / 1975$ \\
\hline 870 & $\begin{array}{l}\text { Crea cargos de Secretarios Regionales Ministeriales del } \\
\text { Ministerio de Obras Públicas, suprime cargos que señala y } \\
\text { Radica funciones y atribuciones que indica }\end{array}$ & $27 / 10 / 1975$ \\
\hline 1289 & Ley orgánica de las municipalidades & 14/01/1976 \\
\hline 1367 & $\begin{array}{c}\text { Establece normas para el manejo del Fondo Nacional de Desarrollo } \\
\text { Regional }\end{array}$ & $11 / 03 / 1976$ \\
\hline 397 & $\begin{array}{l}\text { Reglamento Organico de las Secretarias Ministeriales } \\
\text { de Vivienda y Urbanismo }\end{array}$ & $08 / 02 / 1977$ \\
\hline 2093 & $\begin{array}{c}\text { Modifica la naturaleza jurídica de la } \\
\text { Comisión Nacional de } \\
\text { Reforma Administrativa y fija planta de su personal }\end{array}$ & $04 / 01 / 1978$ \\
\hline 2339 & $\begin{array}{l}\text { Otorga denominación a la Región Metropolitana y a } \\
\text { Las regiones del país, en la forma que indica }\end{array}$ & $02 / 10 / 1978$ \\
\hline 420 & Modifica plan intercomunal de Santiago y su ordenanza & $20 / 11 / 1979$ \\
\hline 3063 & Ley de rentas municipales & $29 / 12 / 1979$ \\
\hline 3260 & $\begin{array}{c}\text { Establece Régimen de Gobierno y Administración de la Región } \\
\text { Metropolitana de Santiago. }\end{array}$ & $01 / 04 / 1980$ \\
\hline 3642 & $\begin{array}{l}\text { Modifica decreto ley } 3.260 \text { que establece régimen de Gobierno y } \\
\text { administración de la región metropolitana de Santiago }\end{array}$ & $07 / 03 / 1981$ \\
\hline 83 & $\begin{array}{c}\text { Actualiza y fija texto definitivo del Reglamento } \\
\text { Especial de viviendas económicas a que se refiere el } \\
\text { Artículo } 1^{\circ} \text { del d.f.l. } \mathrm{n}^{\circ} \text { 2, de } 1959\end{array}$ & 08/09/1982 \\
\hline 18.359 & $\begin{array}{c}\text { Crea el cargo de Subsecretario de Desarrollo Regional y } \\
\text { administrativo en el Ministerio del Interior }\end{array}$ & $17 / 11 / 1984$ \\
\hline 168 & $\begin{array}{l}\text { Fija texto actualizado del reglamento especial de viviendas } \\
\text { Económicas a que se refiere el artículo } 1^{\circ} \text { del d.f.l. }{ }^{\circ} \\
2 \text {, de } 1959\end{array}$ & $29 / 11 / 1984$ \\
\hline $1-18.359$ & $\begin{array}{c}\text { Traspasa y asigna funciones a la Subsecretaria de desarrollo } \\
\text { Regional y administrativo }\end{array}$ & $14 / 11 / 1985$ \\
\hline
\end{tabular}

Fonte: elaboração própria.

Para compreender a profundidade do trabalho da CONARA é preciso distinguir, em primeiro lugar, que o processo de regionalização do regime autoritário nasceu dentro de um clima de radicalidade das mudanças que ultrapassou a mencionada perseguição política das esquerdas. Em definitiva, se trata de compreender como o bloco civil-militar que impulsionou o Golpe de Estado rapidamente entendeu o imperativo de mudar as bases estatais e redes políticas das esquerdas, aplicando uma série de diretrizes conservadorastotalitárias que só podiam ser impulsionadas no contexto de um Estado fortemente 
militarizado e hierarquizado. O desafio da pesquisa foi compreender essas lógicas totalitárias na própria ideia de regionalização e seus diferentes mecanismos burocráticos, principalmente, na configuração dos atributos das autoridades oficiais e a legitimação da administração pública posta em movimento. Como diz a Declaração de Princípios, importante documento oficial do regime, publicado em março de 1974:

La consolidación e institucionalización de un auténtico poder social como el descrito ha de considerarse como el medio más eficaz para constituir en Chile una sociedad tecnificada, en que la palabra de los que saben prevalezca por sobre las consignas, y de una sociedad de verdadera participación, en que la voz del pueblo organizado emerja sin desfiguraciones partidistas y sin mezquindades que la empobrezcan. Nuestra democracia será entonces orgánica, social y de participación (GOBIERNO DE CHILE, 1974a, s./r.).

Essas paráfrases são fundamentais porque implicitamente serão o fundamento discursivo e material dos arranjos e recortes territoriais, sobretudo, na conjugação de um particular tipo de autoridade territorial que será recriada sistematicamente ao longo do processo de regionalização. Dessa forma, se constata que parte desse entramado institucional emergiu a partir da hipervalorização do direito de propriedade privada como uma forma essencial do Estado que, aliás, segundo os golpistas, estava ao máximo nível de hierarquia estatal junto com a segurança nacional e o princípio de subsidiariedade (GOBIERNO DE CHILE, 1974a). Esse último, o princípio de subsidiariedade, significaria a expressão de um Estado mínimo no social, mas fortemente privatizador do público, que tinha responsabilidades somente naquelas funções que os grupos sociais ou particulares privados não estavam em condições de cumprir (Defesa, Polícia, Relações Exteriores) ou assumir, como no caso da extrema pobreza. Assim sendo, a regionalização deveria criar uma institucionalização que defendesse a iniciativa privada, mas, sobretudo, restituísse o caráter "apolítico" da Administração Pública (GOBIERNO DE CHILE, 1974a).

A diferença de outras experiências autoritárias na América Latina, Pinochet concentrou a máxima autoridade ao longo do período (1973-1990). Imediatamente após o Golpe foi eleito presidente da Junta de Governo, o órgão executivo do regime composto pelos três comandantes-chefes das FF.AA. e o diretor geral dos Carabineros de Chile; e posteriormente, em dezembro de 1974, Pinochet foi nomeado Presidente da República e Chefe de Estado da Nação, além de ter permanecido como Comandante-Chefe do Exército (situação que só vai ser modificada com a volta das eleições democráticas em 1995). Ao longo do regime, assim, Pinochet administrou um forte controle do poder político que também significou uma destacada presença de militares em altas hierarquias da administração do Estado, além de 
uma supremacia do Exército sobre as outras FF.AA., tendo como consequência um aparelho estatal que acrescentou e amplificou sua autoridade (HUNEEUS, 2016). Nesses termos de poder político, a implementação dos novos órgãos políticos territoriais do Estado significou também uma sofisticada redefinição das fronteiras internas e expressão geopolítica desses poderes político-militares.

A regionalização montou uma nova rede político-administrativa dentro da velha maquinaria pública que, aliás, não só devia ampliar e fortalecer o poder burocrático do Estado nas novas unidades territoriais oficiais - regionais, provinciais e comunas -, mas também, e principalmente, precisava ampliar e recriar a representação dos cidadãos, segundo as novas pautas do regime. Na estrutura territorial do país - região, província, comuna -, cada nível contava com autoridades definidas que, ao mesmo tempo, mantinham uma assessoria técnica em apoio à gestão territorial, com atribuições e funções específicas, mais um mecanismo de participação que devia expressar as novas forças vivas da sociedade chilena. Nossa pesquisa fez um seguimento específico aos diferentes recortes territoriais (quadro $n^{\circ} 2$ ) e o tipo de agencias e interesses que se conjugavam entre suas ligações estruturais de governo - regiões, províncias e comunas - e a nova arquitetura financeira do sistema regional integrado.

\section{Quadro n $^{\circ}$ 2. Recortes territoriais (1974-1981)}

\begin{tabular}{|c|c|c|c|c|}
\hline Ano/data & Decreto & Regiões & Províncias & Comunas \\
\hline $10 / 07 / 1974$ & 575 & 13 & & \\
\hline $27 / 10 / 1975$ & 1230 & & 16 & \\
\hline $31 / 12 / 1975$ & 1317 & & 24 & \\
\hline $20 / 09 / 1979$ & 2867 & & 5 & \\
\hline $26 / 10 / 1979$ & 2868 & & & 283 \\
\hline $01 / 04 / 1980$ & 3260 & & & 34 \\
\hline $19 / 11 / 1980$ & 1204 & & & 54 \\
\hline $10 / 12 / 1980$ & 1325 & & & 31 \\
\hline $07 / 03 / 1981$ & 3642 & & & 51 \\
\hline $17 / 03 / 1981$ & $1-3260$ & & 13 & 535 \\
\hline
\end{tabular}

Fonte: elaboração própria sobre a base dos decretos-leis.

Todos esses recortes territoriais foram postos em diálogo com as redes políticas no período autoritário. Paralelamente, é importante destacar que durante o período, Pinochet constituiu uma base de apoio dividida em quatro setores estratégicos, além de uma primeira 
linha do Exército e as outras Forças Armadas (FF.AA.) (HUNEEUS, 2016) ${ }^{5}$, onde destacariam dos setores. Por um lado, com o grupo de apoio constituído pelos economistas neoliberais que deram consistência teórica e prática ao conjunto das políticas econômicas e sociais regionais, os famosos Chicago boys, o grupo de economistas chilenos de pós-graduação da Escola de Economia de Chicago, os quais reivindicavam o "pensamento econômico neoclássico caracterizado por ser profundamente conservador e ortodoxo" (RIFFO, 2005, p. 152). Por outro, com o grupo denominado gremialismo, setor original da direita conservadora que nasceu dentro do movimento estudantil da Universidade Católica de Chile sob a liderança do intelectual Jaime Guzmán e que ocupou uma importantíssima participação em altas funções públicas (MUÑOZ, 2016). O interessante do processo de regionalização foi a capacidade de integrar esses diversos grupos em um sistema territorial voltado ao consenso neoliberal, criando uma nova elite política e econômica de perfil autoritária, em que a figura do Pinochet teria o símbolo da integração do poder do Estado regional e a neoliberalização do sistema público. Nossa pesquisa, assim, tentou analisar as redes e interligações de dois grupos na construção do Estado territorial.

Por sua vez, vale ressaltar que o regime autoritário expulsou do mapa político a todas as representações de esquerda com o argumento da despolitização, quando simultaneamente se encaixavam e colocavam em valor outras representações políticas, neste caso, militares e grupos de direita, que foram adquirindo repertórios e orçamentos da burocracia chilena para impulsionar seus próprios projetos e modelos de sociedade. Como foi dito por uma alta patente militar do período, para a manutenção da paz social e a segurança nacional se "requiere de una Administración del Estado racionalizada, moderna y funcional, depurada de todo influjo políticopartidista, y en la cual el espíritu de servicio público y la eficiencia sean sus rasgos distintivos" (LABBÉ, 1984, p. 6). Nossa pesquisa, assim, tentou entender o significado dessa depuração em termos de gestão do território, e essencialmente, analisar como o regime provocou limpar, purificar, em busca de restituir a política de supostos conteúdos saudáveis, fora da contaminação ideológica da UP. Esse sentido político higienista e depurativo dos aparelhos públicos também se conectava diretamente com o sentido de segurança nacional que deveria projetar

\footnotetext{
${ }^{5}$ Seguindo o trabalho de Huneeus, os grupos de apoio seriam 1) economistas neoliberais; 2) seguidores do ex Presidente Alessandri; 3) militantes do Partido Nacional; 4) gremialistas. O grupo foi denominado "alessandristas" eram pessoas do mundo da direita e próximas ao antigo presidente Jorge Alessandri (19581964), caracterizadas por suas críticas dos partidos e do parlamento, que entregaram uma certa legitimidade histórica ao projeto autoritário. O grupo do Partido Nacional (PN), tradicional setor de direita que paulatinamente foi retomando posições, ocupando, com Sergio Onofre Jarpa, o Ministério do Interior em 1983 (HUNEEUS, 2016).
} 
a regionalização: extirpar pela raiz o inimigo interno, ou seja, depurar o Estado territorial do marxismo e as organizações de esquerda, ou visualizar as consequências das próprias palavras do Ministro do Interior, o general Cesar Raúl Benavides, em 1975: "La regionalización será una palanca de apoyo más para nuestro histórico despegue iniciado el 11 de septiembre de 1973" (LA TERCERA DE LA HORA, Santiago, 12 julho 1975). A conformação de cada capítulo de nossa pesquisa tentou argumentar precisamente como essas mudanças territoriais configuram um particular cenário político e econômico favorável a quem fizeram o Golpe de Estado.

\subsection{Esquema de conceitos}

A pretensão de conceitualizar o ato de regionalizar, ou a regionalização, tem sido um dos debates mais polêmicos e revisitados no desenvolvimento do pensamento geográfico ocidental. As razões desses debates se originam fundamentalmente na abrangência dos termos teóricos-metodológicos ou numa multiplicidade polissêmica de relações sócio espaciais (internas-externas) e de escala geográfica, nos quais foram inseridas distintas regiões naturais, culturais, econômicas, políticas, ambientais, burocráticas, etc. As construções regionais oficiais, no entanto, por um lado, deveriam legitimar as fronteiras e os limites operativos dos Estados-nacionais (CASTRO, 2010; RIBEIRO, 2004). Mas também explicar a complexa mudança das condições técnicas, científicas, econômicas e políticas que modificaram radicalmente as pautas do ordenamento dos fluxos, agentes e ações do padrão de acumulação mundial, principalmente depois da Segunda Guerra Mundial (SANTOS, 2017). Além das diferentes confusões e polêmicas e seus desdobramentos particulares, ao longo de século XX poderíamos sintetizar que a regionalização basicamente foi inserida como: 1) um objeto próprio da modernização liberal do Estado com a geografia como principal disciplina científica articuladora; 2) um ato técnico-político ancorado em agentes estatais que produziam unidades territoriais de diferente complexidade e escala; 3) uma pulsão epistemológica entre dois extremos contraditórios e irresolutos enquanto categoria da prática ou categoria da análise (HAESBAERT, 2010).

$\mathrm{Na}$ América Latina, as pioneiras regionalizações datam a partir da década de 1940 e foram influenciadas pela geografia francesa e as lógicas institucionais ligadas ao Tennesseee Valley 
Authority (1933) ${ }^{6}$. Até os anos sessenta, por regra geral, as regiões deveriam se diferenciar de outras, procurando "sua personalidade, sua singularidade, aquela combinação de fenômenos naturais e humanos que não se repetiria" (LOBATO CORREA, 1987, p. 29). No entanto, a partir das primeiras experiências e segundo as complexidades geográficas dos próprios países e o nível de desenvolvimento de suas políticas de planejamento regional, as regionalizações iriam variando enquanto forma espacial. Prontamente, as regionalizações foram assumindo perspetivas mais quantitativas e articulando-se em dois grandes enfoques: regiões simples ou regiões complexas. Se nas regiões simples se agrupam em fatores a partir de apenas um âmbito (solo, renda, etc.), nas regiões complexas se introduzem múltiplas variáveis, que geralmente se percebia “através de uma técnica estatística mais sofisticada, a análise fatorial” (LOBATO CORREA, 1987, p. 34). Essas regionalizações complexas, por sua vez, podiam ser funcionais ou homogêneas. A região homogênea se definia por unidades de áreas agregadas onde não existia uma movimentação no tempo e espaço, por exemplo, área de produção agropecuária, área de níveis de renda de uma população ou área de tipologia de climas em regiões naturais, etc. Contrariamente, a região funcional se definia pelo movimento das pessoas, mercadorias, informações, decisões ou ideias da distribuição territorial física. Se definiam assim "regiões de tráfego rodoviário, fluxos telefônicos ou matérias-primas industriais, migrações diárias para o trabalho, influência comercial das cidades etc." (LOBATO CORREA, 1987, p. 35).

A partir da influência do enfoque quantitativo e sobretudo pela presença de ferramentas estatísticas, entre as décadas de 1960 e 1970 se origina, talvez, o período de maior movimentação de regionalizações em América Latina: Brasil, 1969; Chile; 1968-1974; Panamá, 1963; México, 1960-1970; Uruguai, 1976; Perú, 1969; El Salvador, 1964; Venezuela, 1969. Paralelamente, começa a se movimentar a escala geográfica de intervenção regional: se as pioneiras experiências regionais do continente tinham uma composição de escala intrarregional ancorada em estruturas e nós geográficos naturais, significativos por sua função econômico-social (por exemplos o Vale de Tecalpatec, o Vale de São Francisco e o Vale do Cauca), depois de 1960 se privilegiam experiências de polarização, sendo a escala geográfica regional a principal ferramenta de intervenção pública em um plano nacional, mas ancorada fundamentalmente ao desenvolvimento de uma estratégia urbano-regional.

\footnotetext{
${ }^{6}$ Segundo o trabalho de Riffo (2014), podemos distinguir as experiências pioneiras de Corporação Santa Perú (1943), Comissão de Tecalpatec em México (1947), Comissão do Vale de São Francisco no Brasil (1948), Corporação do Vale do Cauca em Colômbia (1954).
} 
A partir da década de 1960, os países da região começam os primeiros processos oficiais de adaptação nacional-territorial ou regionalizações, desta vez, guiados pela criação de organismos técnicos na escala nacional com o objetivo geral de equilibrar o desenvolvimento econômico-regional do país, tentando eliminar o crescimento díspar de suas regiões e o centralismo da capital nacional enquanto exagerada concentração produtiva em determinadas áreas geográficas ${ }^{7}$ (RIFFO, 2014; INSTITUTO PANAMERICANO DE GEOGRAFÍA E HISTORIA, 1968; STOHR, 1968; BOISIER, 2011). A posteriori, na década de 1970, se aprofunda o processo e o desenvolvimento regional ganha maior legitimidade, o que se traduz em políticas públicas em vários países da região. Um papel importante nesse processo teve o Instituto Latino-americano da Planificação Econômica e Social (ILPES), dependente da CEPAL localizada em Santiago (Chile) e, em especial, seu curso internacional de Planejamento Regional do Desenvolvimento, que reuniu e disseminou um importante grupo de intelectuais e planejadores de desenvolvimento regional entre as mais diversas nacionalidades da América e do mundo. Segundo Riffo (2014), no curso do ILPES coexistiam cinco pilares teóricos: 1) o enfoque centro-periferia da CEPAL; 2) a teoria dos pólos de crescimento (PERROUX, 1963); 3) a teoria de causação circular acumulativa (MYRDAl, 1959); 4) O desenvolvimento desequilibrado (HIRSCHMANN, 1964); 5) a teoria da base de exportação (NORTH, 1955).

Apesar das diversas críticas e diferenças internas entre as teorias do desenvolvimento regional, o interessante a destacar é que todas elas remarcavam que era o mercado a principal fonte dos desequilíbrios regionais e, portanto, era o Estado o principal agente de intervir ativamente. Todos esses consensos do desenvolvimento regional, no entanto, serão paulatinamente transformados/desmontados na próxima década, produto das diversas crises políticas e econômicas da região, em especial, a imposição de regimes autoritários e uma mudança estrutural do sistema capitalista globalizado (mais à frente, voltaremos a este debate para entender o caso do Chile autoritário).

Ao mesmo tempo, é interessante lembrar que, já nos inícios da década dos setenta na América Latina, existia uma reflexão crítica sobre os limites do desenvolvimento regional (RIFFO, 2014; SANTOS, 2003). O próprio ILPES desenvolve uma crítica sobre o papel da

\footnotetext{
${ }^{7}$ Além das diferenças internas por países, pelo geral, as regiões se estruturam em princípios comuns: 1) Integração geográfica, econômica e cultural; 2) Equilíbrio demográfico e os recursos; 3) Flexibilidade regional para a melhor administração setorial; 4) Unidade técnica nos projetos; 5) Administração do desenvolvimento; 6) Inter-regionalidade; 7) Polos e centros focais (RIFFO, 2014).
} 
industrialização enquanto geradora de desequilíbrios: migração campo-cidade, marginalidade e desigualdade regional (BELDRACK, 1974). Por sua vez, se destaca que no desenvolvimento regional impulsionado não existe uma transformação econômica social estrutural mas, pelo contrário, se prolonga um colonialismo interno. Convém observar que o colonialismo se entende como uma continuidade histórica no uso dos territórios latinoamericanos em um duplo processo de exploração econômica e racial (RIFFO, 2014). O espaço nacional invariavelmente responde a relações de dominação-dependência, onde o centro captura parte substancial dos recursos - acumulação circular - aumentando sua capacidade de dominação (DE MATTOS, 1972, 2015).

A principal corrente da época, a teoria dos pólos de desenvolvimento, foi fortemente impugnada por essas colocações. Se questionou a efetividade real das políticas de pólos, reconhecendo a existência de um conjunto de "filtrações" para o exterior das regiões que impedem a valorização dos pólos, tais como a importação do insumo desde outras regiões, a saída de excedentes, a imigração de mão de obra, etc. (RIFFO, 2014; BELDRACK, 1974). Em um polêmico artigo, em 1974, José Luis Corraggio demostrará que a teoria dos pólos de crescimento e sua implementação em países subdesenvolvidos tem um efeito negativo, fortalecendo os processos de dominação neocolonial (CORAGGIO, 1981). Segundo Riffo (2014), já na década de 1980 existem duas correntes no interior do ILPES que divergem em seus postulados: por um lado, os contestatários céticos representados na figura de Carlos de Mattos, David Dunhan e José Luis Coraggio e, por outro, os regionalistas participativos representados no trabalho de Sergio Boiser e Walter Stöhr (RIFFO, 2014).

Pois bem, teoricamente, é interessante distinguir o trânsito da região na esfera pública, ou seja, compreender a passagem de uma lógica eminentemente estatal de planejamento com importante ajustes e adaptações territoriais, a uma perspetiva analítica sem maiores impactos na realidade social que define ou orienta eventualmente as políticas públicas. É a regionalização uma fonte válida de políticas estruturais ou diagnósticos da realidade? Seria a regionalização apenas uma construção estritamente intelectual ou o inverso? A regionalização é uma condição imanente das políticas, resultado de sua materialidade concreta dos entrelaces sociais-culturais-físicos que articulam histórica e diferencialmente o espaço geográfico? 
Ana Clara Torres Ribeiro assinalou que, na intensa movimentação dos agentes e ações no território, sempre dependentes de um período histórico, existe um constante elo e interligação entre a condição de fato e ferramenta no interior da regionalização. Mas se por um lado o fato mobiliza e articula interpretações que inserem aspetos e condições "historicamente construídas da reprodução social” (RIBEIRO, 2004, p. 4), por outro, a sua dimensão ferramenta se articula a partir da "ação hegemônica" enquanto particularidades e relações de poder no espaço. Dessa forma, a compreensão da regionalização não poderia prescindir da estrutura do fato, mas tampouco da sua ferramenta, pois ambas "produzem e expressam a questão regional e, portanto, a região como espaço herdado e como dinâmica política plena” (RIBEIRO, 2004, p. 4). Dado o exposto, a região implicaria compreender uma “expressão espacial dos interesses e das práticas de distintos agentes e, também, da influência exercida por diferentes esferas da vida coletiva" (RIBEIRO, 2004, p. 8) na qual, ao menos, se pressupõem duas naturezas de ações: 1) "o poder de criar e estabelecer formas espaciais"; 2) "o poder de institucionalizar (e garantir permanência a) estas formas" (idem, p. 8).

Rogério Haesbaert, por sua vez, destaca que qualquer tipo de regionalização implica necessariamente recortar, classificar e nomear o espaço, portanto, é sempre uma forma de domínio sobre a sociedade que involucra técnicas de controle do espaço. Por consequência, "a regionalização deve estar sempre articulada em análise centrada na ação dos sujeitos que produzem o espaço e na interação que eles estabelecem" (HAESBAERT, 2010: p. 24). Em sua proposta conceitual, a região artefato, Haesbaert propõe estabelecer uma regionalização analítica-relacional enquanto a constante e movediça compreensão do componente dado, artifício e ferramenta política:

A região vista como artefato é concebida no sentido de romper com a dualidade que muitos advogam entre posturas mais estritamente realistas e idealistas, "construto" ao mesmo tempo de natureza ideal-simbólica (seja no sentido de uma construção teórica, enquanto representação do espaço, seja de uma construção indenitária a partir do espaço vivido) e material-funcional (nas práticas econômico-políticas com que os grupos ou classes sociais constroem seu espaço de forma desigual/diferenciada). "Artefato" com (com hífem) também permite indicar que o regional é abordado ao mesmo tempo como criação, auto fazer-se ("arte") e como construção já produzida e articulada ("fato") (HAESBAERT, 2010, p. 109$110)$.

A região artefato implicaria, então, em uma combinação entre o fato e o artifício da regionalização levada pelos grupos e classes sociais, ao tempo que paralelamente significaria compreender seu desdobramento enquanto ferramenta política. Nessa linha, o enfoque de 
Haesbaert propõe três grandes desdobramentos analíticos, onde a regionalização seria internalizada como: 1) produto-produtora de diferenças (discretas e continuas segundo a natureza); 2) produto-produtora da globalização e fragmentação; 3) esfera de sujeitos e suas relações de poder (HAESBAERT, 2010). Portanto, essa categorização diferenciada de níveis analíticos regionais é estimulante porque abrange diferentes escalas geográficas que interatuam e atualizam as contradições e resistências do sistema no espaço, ao passo que torna possível imaginar outras regionalizações a partir de problemáticas ambientais, econômicas, culturais e políticas em curso.

Considerando as precauções dos autores e em vista do tipo de reforma políticoeconômica do caso do Chile, a regionalização será entendida em um constante questionamento entre o fato e o artifício, que irá transitando entre seus fundamentos e suas práticas ligadas sempre a um particular regime político que, com o passar do tempo, criaria suas próprias movimentações econômicas. Evidentemente, isso não significa levar à frente cada uma das considerações dos autores destacados mais acima. Mas sim, compartilhar certas precauções gerais, como são: 1) a necessidade de analisar a agência dos sujeitos que produzem a regionalização e sua interação interna; 2) a performativa interligação entre sua condição de fato e ferramenta mediante um conjunto de mecanismos e relações sociais que disputam a intervenção estatal e a representação social; 3) compreender a particular esfera de sujeitos e relações de poder que emanam da regionalização posta em jogo.

Enquanto a ordem dos conteúdos envoltos na problemática particular de nossa pesquisa, propomos que a regionalização no projeto político da ditadura chilena se estruturou sobre a base de duas forças estruturantes: o neoliberalismo e o autoritarismo. Nesse sentido, entendemos o autoritarismo como um regime político que estabelece uma particular pauta de mediação entre a sociedade civil e o Estado que se carateriza por uma lógica excludente na toma de decisões (GARRETÓN, 2015, p. 166). Algumas caraterísticas essenciais dos regimes autoritários latino-americanos, segundo Garretón, foram: 1) emergem em países com certo nível de desenvolvimento, sucedendo a um período de ampla e intensa mobilização popular; 2) no bloque que assume a direção do Estado, as Forças Armadas passam a ter uma função fundamental (impõem uma institucionalidade hierarquizada); 3) na esfera de governo se expressam através de interesses de classes dominantes que exercem "sobre el aparato estatal a través de equipos tecnocráticos" (GARRETÓN, 2015, p. 168); 4) na lógica projetiva do governo-Estado criam projetos de reestruturação da sociedade em termos de 
novos mecanismos e patrões de acumulação, distribuição e reordenamento político, ao qual, se carateriza pela imposição de uma pauta autoritária e excludente, ou seja, "exige el uso de la fuerza represiva, de manera de eliminar, desarticular o controlar las organizaciones populares de clase y políticas, así como las demás organizaciones políticas sobrevivientes del período anterior" (Idem, p. 168). A crise política, segundo Garretón, articulou a lógica fundacional dos regimes autoritários na região. Isso implica que, o autoritarismo teria sido essencialmente um sistema político de reação ou contenção que busca "poner orden, desmovilizar, "normalizar", "apaciguar"” as relações conflitivas e lutas de classes (GARRETÓN, 2015, p. 171) através da presença de outro ator dotado de legitimidade (FF.AA.), tendendo a romper parcial ou totalmente com o regime político anterior.

Por outra parte, entendemos o neoliberalismo como a progressiva e diferenciada aniquilação do Estado de bem-estar (ou "criação destrutiva") caraterizada pela desregulação dos mercados e a penetração do lucro em uma ampla esfera de relações sociais que operam fundamentalmente como uma "negación de los derechos generales de los trabajadores y de los movimientos populares" (AGASSINO, 2006, p. 3). Sendo uma estratégia particular da acumulação a nível global, o neoliberalismo se caracterizou pelo forte apoio a uma classe empresarial que a seu inverso, "debilitava profundamente o poder social dos trabalhadores, conformando-se assim uma nova "matriz de poder social" (RIFFO, 2005, p. 151). Essa desigual matriz social produz um cenário político-institucional altamente funcional ao fluxo de capitais e à privatização do sistema público, rompendo "com os esquemas clássicos centro e periferia, e tende a gerar configurações espaciais fortemente fragmentadas” (RIFFO, 2005, p. 147) que, interna e progressivamente, anulam ou atrofiam o poder cidadão (SANTOS, 1993). Ao mesmo tempo em que omite sua participação estatal na área produtiva, o neoliberalismo exige que "a noção de direitos políticos e de direitos individuais teve que ser desrespeitada, se não frequentemente pisoteada e anulada [...] O modelo político e o modelo cívico foram instrumentais ao modelo econômico" (SANTOS, 1993, p. 3). Dito ordenamento político-econômico do neoliberalismo expressou a nível global o redesenho do papel do Estado na estruturação produtiva da sociedade, criando uma diferente mediação das áreas da vida e dos mecanismos burocráticos, e desta vez, definidos rigorosamente pelos princípios do mercado. Para o caso chileno, o neoliberalismo significou uma radical mudança da estrutura produtiva, dos direitos sociais e suas principais tradições políticas e culturais, além de uma complexa transformação institucional que alterou a noção do público e do privado. O rápido consenso autoritário dos princípios neoliberais no seio do direcionamento 
político-econômico do regime se deu fundamentalmente ao controle de altas chefias ministeriais dominadas pelos economistas da escola de Chicago (HUNEEUS, 2016; GARATE, 2012). Foi esse pequeno grupo de economistas jovens, os Chicago Boys, quem praticamente definiram quase a totalidade das políticas econômicas desenvolvidas pelo regime $^{8}$ (GARATE, 2012) ${ }^{9}$. Dada a profundidade, permanência e institucionalização dessas políticas ultraliberais no sistema chileno a partir de sua Constituição aprovada em 1980, o historiador Manuel Garate destaca o caráter revolucionário do sistema capitalista impulsionado pelo regime autoritário chileno e aprofundado posteriormente baixo governos democráticos (1990-2003). Em palavras de Boccardo (2019):

lo que ocurrió efectivamente fue una brutal mercantilización en que todo vínculo humano quedaba subsumido en el capital. No sucedió únicamente con educación, salud o pensiones, sino con los cuidados, los afectos, el cuerpo y las experiencias. La fábrica y la oficina automatizadas comenzaron a depender menos del trabajo especializado y a demandar trabajadores cuya socialización es su principal herramienta. La flexibilidad del trabajo hace de la incertidumbre el elemento distintivo de la vida y torna cada espacio en potencial lugar de trabajo (p. 1)

Então, o particular processo de regionalização do regime se dá na forma combinatória de duas forças estruturantes, o neoliberalismo e o autoritarismo, que criaram e manifestaramse em uma complexa teia de relações territoriais, um conjunto de redes, recursos e capacidades no interior do Estado. Sugerimos, assim, três tipos específicos de desdobramentos analíticos ancorados nas particularidades e efeitos da regionalização do período autoritário chileno: 1) formas de poder nas autoridades políticas e funções territoriais; 2) mudança das formas e lógicas da circulação de informação política na teia de relações territoriais do Estado (país-região/região-comuna/região-província); 3) escalamentos do poder nos quais vincula-se internamente às mudanças na configuração organizacional e espacial do Estado propiciada pela condução de uma particular gestão do território projetada nos termos do projeto neoliberal-autoritário chileno. Em definitiva, tratase de entender a tecnologia espacial do poder do Estado (BECKER, 2012) dirigido pelo regime autoritário chileno no processo de regionalização compreendido entre 1973 e 1990.

\footnotetext{
${ }^{8}$ Praticamente desde o momento mesmo do Golpe de Estado, 11 de setembro de 1973, os Chicago boys entram em ação no terreno de governo. Em um primeiro momento, sua participação está ligada ao círculo da Marinha, localizando-se estrategicamente na ODEPLAN. Posteriormente sua influência vai ir expandindo-se ao Ministério de Fazenda e diversos serviços públicos.

${ }^{9}$ Segundo o trabalho de Garate: "La fase de implantación ideológica del modelo neoliberal, iniciada en 1975, fue denominada como el Plan de Recuperación Económica, aunque la mayor parte de la literatura sobre el tema se refiere a esta etapa como el plan o tratamiento de shock" (GARATE, 2012, p. 197).
} 


\subsection{Território, hegemonia, interesses de classe e gestão do território}

A continuação tentaremos explicar o roteiro dos principais conceitos e categorias envolvidas, procurando visualizar aquilo que está em jogo no processo de regionalização: território, hegemonia, interesses de classe, gestão do território. Mais ao final do apartado, também tentaremos explicar as categorias ligadas aos mecanismos do Estado que permitiram executar a regionalização enquanto objeto técnico-político e distinguir um certo tipo de ordem espacial-político: dispositivos, recortes, arranjos, escalonamentos. Antes disso, é importante destacar os conceitos referidos aos regimes territoriais. Essa discussão implica o reconhecimento dos limites e funções enquanto organização espacial do Estado e, portanto, a diferenciação dos regimes territoriais enquanto forma do Estado e distribuição de poder estatal: Estados unitários ou Estados federais (BARRIOS-SUVELZA, 2017; CASTRO, 2013; RODRIGUEZ, DUCCI, 2006).

Teoricamente, a literatura do campo sustenta que existem quatro níveis de distribuição do poder sub-nacional: devolução, descentralização, desconcentração e delegação (RODRIGUEZ, DUCCI, 2006; BOISIER, 2011). A diferença da regionalização que buscaria levar um desenvolvimento nacional-regional em territórios diferenciados, pelo geral, a descentralização se refere a "mallas territoriales relativamente rígidas que soportan asignaciones competenciales" (BARRIOS-SUVELZA, 2017, p. 57). Essa forma descentralizada do Estado, permitiu usar a região na execução de tarefas públicas em uma escala intermediária do nacional e o local, mas sempre ancorada em funções de competências específicas e formais que respeitavam os limites territoriais fixos (BARRIOS-SUVELZA, 2017, p. 57). Dentro dos tipos de Estado (unitários e federais), os regimes territoriais transitam geralmente a partir da descentralização até a delegação do campo administrativo do Estado. Se bem os autores discordam em seus limites e funções (CASTRO, 2013; BARRIOS-SUVELZA, 2017; VALENZUELA, 2015), pelo geral, se entende que uma descentralização estatal implica a transferência de poder horizontal de uma instituição do Estado central à outra organização territorial do país, "sin que exista dependencia jerárquica entre ellas" (RODRIGUEZ, DUCCI, 2006, p. 572). Por outro lado, a desconcentração, em câmbio, se define como uma transferência vertical de competências e recursos do governo central dirigida à organismos de hierarquia inferior, os quais executam as políticas que continuam sendo prerrogativa do governo central (RODRIGUEZ, DUCCI, 2006). 
Segundo Barrios-Suvelza (2017), desconcentrar implica possivelmente na presença administrativa dos ministérios setoriais no território, sob a base de uma figura de autoridade de coordenação, porém, as cadeias verticais hierarquizadas ficam essencialmente inteiras ( $p$. 57). Por último, a delegação implicaria em uma agência de ação sub-nacional com possibilidades de impulsionar políticas públicas sem necessariamente mediar um controle hierarquizado, podendo ser inclusive ligada à instituições privadas (BARRIOS-SUVELZA, 2017). No caso da regionalização autoritária do Chile, como veremos mais na frente, os autores coincidem que se tratou fundamentalmente de um modelo de desconcentração e delegação, mas sempre dependentes da estrutura nacional (RODRIGUEZ, DUCCI, 2006; ARENAS, 2006; VALENZUELA, 2015; BOISIER, 2011).

Funcional ao processo de regionalização, o conceito território tem sido um objeto apreciável de fontes e controvérsias. No entanto, do ponto de vista analítico, é mais ou menos um consenso dizer que o território é sempre resultado de relações desiguais, históricas e assimétricas entre atores e forças políticas nas quais se envolve uma ação/posição do Estado que, com o transcurso do tempo, vão instituindo um domínio político e econômico de um espaço formal e simbolicamente definido, embora contraditoriamente conjugado (GONCALVES, HAESBAERT, 2006). Segundo o geografo inglês Stuart Elden, o território sempre deve ser pensando por meio de uma estratégia genealógica e construtiva, desenvolvida historicamente nas técnicas de medição da terra e do controle do terreno (ELDEN, 2016). Daí que conceitualizar sobre o território nunca implica "definir território de uma vez por todas, mas sim indicar o que está em jogo na forma como foram interpretados em diferentes contextos históricos e geográficos” (ELDEN, 2016, p. 54). Sendo uma questão histórica, o território sempre é produzido, mutável e fluido, carregando as contradições da sociedade e seus movimentos que devem ser estudados genealogicamente (ELDEN, 2016). Do ponto de vista político, por sua vez, o território deve ser entendido de uma maneira ampla, pois abarca os campos econômicos, estratégicos, jurídicos e técnicos; mas, por fim, é sua especificidade histórica e geográfica conceitual a qual define o território político específico (ELDEN, 2016). 
Figura $\mathrm{n}^{\circ}$ 1. Esquema Conceitual

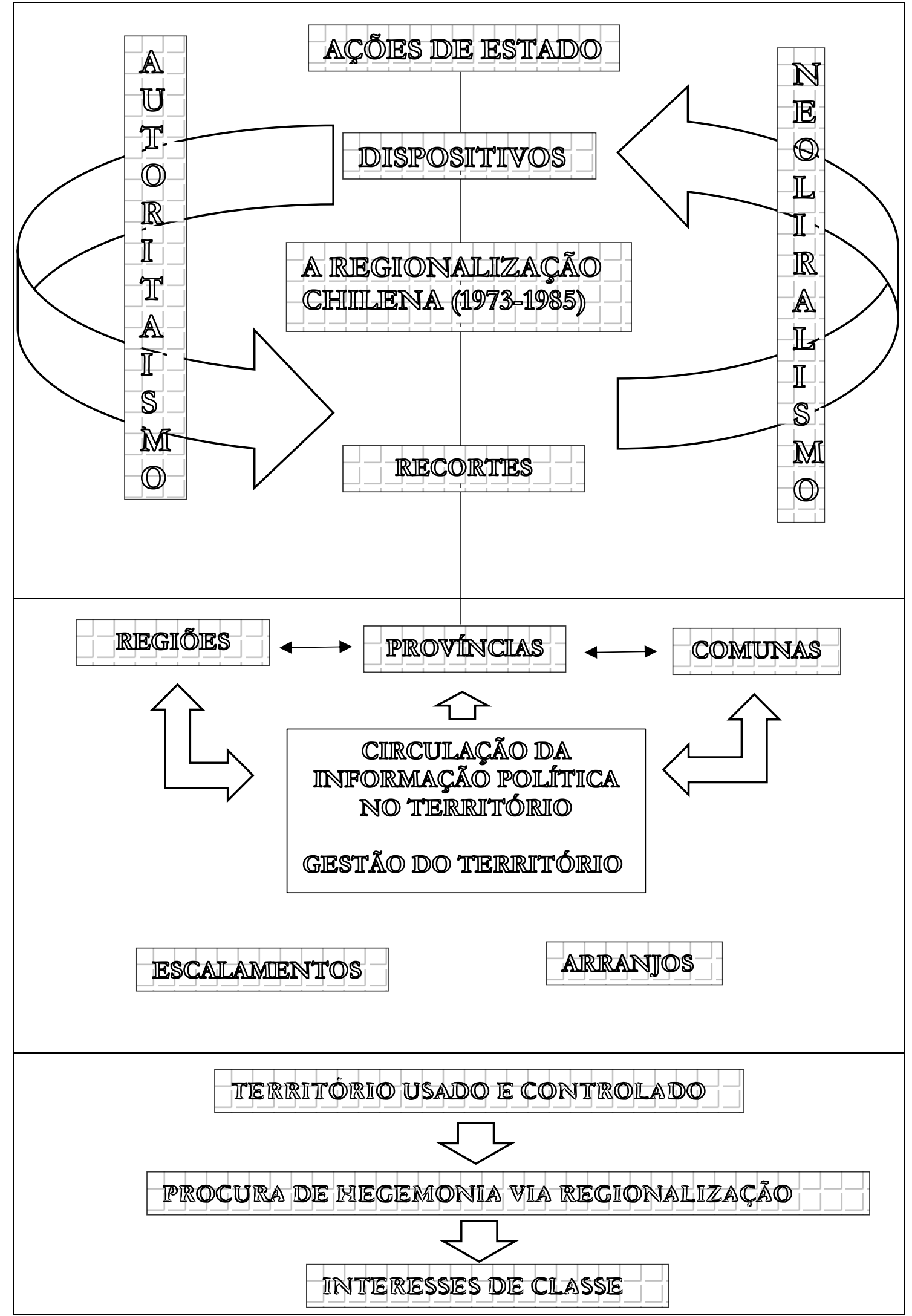

Fonte: Elaboração própria. 
Todos esses elementos anteriores indicam que o território pode ser entendido como uma tecnologia política em constante movimento que implica toda uma série de técnicas de prática estatal (segurança, gestão, administração, etc.) (ELDEN, 2016). Trata-se de um selecionado corpus de técnicas de controle espacial desenvolvidas pelo Estado, capazes de implementar o controle das fronteiras externas e internas através do uso de um específico conhecimento e do poder de representação do espaço, sendo a cartografia oficial a mais relevante. Lembremos que as técnicas de mapeamento e estatísticas foram fundamentais para o processo de consolidação do Estado territorial, sendo os Estados os principais promotores e difusores dos avanços da cartografia e da estatística, alicerçando diferentes relações espaciais até que estruturaram a base do aparelho político do Estado: sua soberania exata. Em outras palavras: foi o uso de técnicas de representação e medição do espaço, fórmulas estatísticas e de controle da ocupação espacial e a população, as que permitiram consolidar um território fixo, nacional, com categorias e formas jurídicas capazes de estabelecer uma “dominação política sobre o espaço"10 (ELDEN, 2016, p. 52).

Berta Becker afirma que não é possível compreender o território sem o Estado e destaca que é possível distinguir espacialmente o Estado em dois sentidos. Por um lado, o "Estado como relação social" que produz um território nacional que vai transformando e engendrando relações sociais que contraditoriamente irá estabilizando sua própria ordem, espaço regulador e ordenador: "organização da hegemonia ou do poder, no sentido gramsciano de Estado lato sensu, e não do aparelho de Estado apenas” (BECKER, 2012, p. 123). Por outro, se trata de entender o poder estatal como tecnologia espacial no sentido de inter-relacionar a racionalidade-social posta no jogo do território:

conjunto de ligações, conexões, comunicações, redes e circuitos [...] São os recursos, as técnicas e a capacidade conceitual que permitem ao Estado tratar o espaço em grande escala [...] Ele tende a controlar os fluxos e estoques econômicos e produz uma malha de duplo controle, técnico e político, que impõe uma ordem espacial vinculada a uma prática e a uma concepção de espaço global, racional, logística, de interesses gerais, estratégicos, representadas pela tecnoestrutura estatal, contraditória à prática e concepção de espaço local de interesses privados e objetivos particulares dos agentes da produção do espaço. Cria, assim, um espaço

\footnotetext{
${ }^{10}$ É justamente nesse percurso de relações sociais e políticas que emerge, segundo Elden, o talento de Foucault para captar a mudança epistemológica do território, uma mudança que vai da categoria de povo à de população e, por consequência, do problema da terra e do terreno ao assunto do território: "As estratégias aplicadas ao território - em termos de seu mapeamento, ordenamento, medição e demarcação, e a forma como é normalizado, pela permissão de circular e sua regulamentação interna - são objeto de cálculo. Território é mais do que meramente terra, e vai além de terreno, sendo interpretado como um conceito emergente de "espaço" como categoria política: é propriedade, distribuído, mapeado, calculado, delimitado e controlado" (ELDEN, 2016, p. 52).
} 
global/fragmentado, global porque homogeneizado facilitando a interagilidade dos lugares e dos momentos; fragmentado porque apropriado em parcelas (BECKER, 2012, p. 123)

A importância desse processo de dominação política no poder estatal e sua tecnologia espacial radica em que a gestão territorial do Estado está sempre ancorada a uma certa arena de subjetividade dos governos que implica uma correlação das forças sociais em permanente movimento, contradição e busca de hegemonia (MORAES, 2005), vale dizer, a procura ou intento de transformação ou manutenção, segundo um determinado direcionamento ao conjunto da sociedade (GARRETÓN, 2015a). Originalmente o conceito de hegemonia se entronca às reflexões dos Cadernos do Cárcere (1929-1935) do intelectual italiano António Gramsci e sua particular contribuição crítica do poder burocrático no capitalismo ou, como destaca Hobsbawm, sua capacidade analítica para entender a dimensão política do capitalismo a partir do programa marxista (HOBSBAWM, 2011). O propósito central de toda hegemonia é legitimar "um determinado proyecto de orden social, facilitando la labor del gobierno mediante la producción de consenso y reduciendo por tanto la necesidad de coerción y uso de la fuerza" (SEVILLA, 2014, p. 55). Dessa maneira, qualquer poder hegemônico é fruto da combinatória de uma relação coercitiva e de consenso, que um determinado grupo dirigente exerce sobre a sociedade, pois controla o Estado e os principais aparelhos culturais desse consenso (SEVILLA, 2014). O Estado, portanto, representa tanto a sociedade política como a sociedade civil (MOREIRA, 2011), adquirindo uma função complexa que, entre outras coisas, busca evitar os conflitos por meio da regulação contenciosa (COSTA, 2013). Em outras palavras, a hegemonia permite que o poder do governo seja exercido além do monopólio da violência, pois envolve um convencimento moral e coletivo que organiza e permite coesão na sociedade (MORAES, 2005). Para Gramsci, acima de tudo, o Estado capitalista tem três funções básicas: garantir a unidade nacional, conceber a integração territorial e defender os princípios da propriedade privada (COSTA, 2013). Para consolidar uma hegemonia, segundo Gramsci, se articula um bloco histórico que agrupa as forças sociais numa plataforma comum: um projeto (MOREIRA, 2011). O bloco histórico se compõe de uma classe dominante mais geral, que agrupa os interesses econômicos, mas também, internamente, se compõe de uma classe dirigente que lidera o campo da política e uma fração reinante que habita no aparelho do Estado (MORAES, 2005). O tipo de relações e dinâmicas em jogo no bloco histórico é altamente diversificado e ligado às múltiplas formas e alianças políticas. Mas, a disputa central da hegemonia se configura no movimento da sociedade civil, na dinâmica das relações sociais e na constituição de sujeito político que exerce o poder hegemônico. 
Em termos geográficos e territoriais, a hegemonia se revela no problema regional e emerge dentro de uma estratégia política (MARTIN, 1993), pois é "no jogo de hegemonias, definido a partir de bases geográficas e históricas "regionais" específicas, que se desenha o quadro regional" (HAESBAERT, 2010, p. 55). Dessa maneira, a hegemonia sempre está atravessada tanto por uma dimensão simbólica (discurso), quanto por uma dimensão material (prática), sendo produzida na totalidade contraditória da realidade histórico-geográfica. No âmbito territorial, Gramsci distinguiu que a hegemonia expressava um conjunto de interesses regionais, que ligados a outros em disputa, refletem as vantagens primordiais do processo político numa base material concreta da existência:

La dimensión material se refiere al sentido en el que la hegemonía de un conjunto de intereses regionales sobre otro tenderá a reflejar las ventajas en términos de recursos, redes y capacidades organizacionales, mientras que el elemento discursivo señala la necesidad de que el grupo dominante desarrolle una narrativa convincente y coherente de la región, que fomente un apoyo ideológico más extenso (CUMBERS, MACKINNON E MCMASTER, 2013, p. 421)

Segundo esses autores, para compreender as relações de poder na chave hegemônica, o foco da análise deve estar orientado nos grupos e instituições que são capazes de defender e cumprir seus interesses particulares ao mesmo tempo em que ampliam a sua legitimidade (CUMBERS, MACKINNON, MCMASTER, 2013, p. 411): “(...) el poder no es simplemente una posesión de ciertas instituciones políticas y económicas, sino que está presente en un rango de relaciones y de actividades sociales rutinarias” (CUMBERS, MACKINNON, MCMASTER, 2013, p. 411). Para uma perspetiva específica das dinâmicas do poder, é sempre útil localizar o desenvolvimento das regiões num contexto maior dos processos políticos, econômicos e sociais mais amplos. Isso implica distinguir um conjunto de conceitos intermediários que permitam interligar as condições concretas com mecanismos mais abstratos (CUMBERS, MACKINNON, MCMASTER, 2013, p. 419).

Em termos metodológicos-analíticos, os autores também propõem duas linhas de trabalho. Por um lado, aprofundar a relação entre os interesses regionais e as instituições do Estado, procurando conhecer como esses interesses podem chegar a ser institucionalizados e reproduzidos no Estado (afetando outros interesses) e, por outro, analisar as estratégias e as práticas que as instituições particulares e os grupos de elite levam no imaginário de uma maior comunidade (às vezes com a construção de um interesse regional), olhando também as respostas que engendram (CUMBERS, MACKINNON, MCMASTER, 2013, p. 422). 
Erik Swyngedouw, nesse mesmo sentido, destaca a importância hegemônica da mediação das escalas geográficas nas estruturas de poder, tanto na mediação como na cooperação, ou na inversão entre os empoderamentos versus as possíveis perdas de poder. Segundo ele, a hegemonia pode ser definida como:

la capacidad de un grupo dominante (o una alianza de fracciones de clase) que impone una serie de prácticas sociales en una escala espacial particular que son para su ventaja, o de manera más general, la hegemonía es la capacidad de un modelo de relaciones sociales para imponerlas como el modelo deseado ante el resto de la sociedad, y aun en aquellas sociedades que todavía no están bajo su dominio (SWYNGEDOUW, 2013, p. 511)

Portanto, essa dimensão hegemônica implica reconhecer a prevalência de interesses de classe inseridos na condução política do regime e suas práticas no interior do processo de regionalização. Segundo Pérez, baseado em Thompsom, a consciência de classe se define como "aquéllas características de la subjetividad de las personas que son el resultado del proceso a través del cual ellas, en tanto miembros de una clase social, construyen su identidad de clase y toman conciencia de sus intereses de clases" (PEREZ, 2014, p. 133). Por outro lado, a identidade de classe é o reconhecimento interno das pessoas de serem membros de uma classe "a partir de la identificación de una situación de clase común" (PEREZ, 2014, p. 133), onde os interesses constatam os objetivos dos membros de uma classe em relação aos regimes de exploração e "las consecuencias sociales que ellas generan" (PEREZ, 2014, p. 134). Tanto identidade como interesses de classe são também o resultado de uma criação coletiva que se articula em um particular processo histórico que, porém, sempre está estruturalmente desenhada pelas relações de produção e exploração: o suporte estrutural das classes (PEREZ, 2014, p.134). A formação de classes sociais se situa, por consequência, a partir da formação de atores coletivos organizados em torno a posições objetivas da estrutura de exploração econômica que define uma interdependência antagônica de interesses materiais (WHRITH, 1995). A consequência dessa definição de consciência e identidade de classe é que, mais que centrar analiticamente numa classe determinada (a classe operária por exemplo), o fundamental é compreender a dinâmica de poder inter-classes, pois, aí radica a capacidade de observar as pautas de variabilidade social historicamente produzidas (PEREZ, 2014, p. 135). A perspetiva analítica de classes sociais, então, não apenas trata da dinâmica de influência de uma classe sobre o regime político, mas também da forma em que essa ação, esses interesses, geram mudanças e comportamentos nas outras classes sociais. No caso chileno Pérez destaca:

El ejemplo más palpable de estas pautas desiguales de formación de clases es, tal vez, el caso de Chile. Ahí, la profundidad de la transformación neoliberal, así como el grado extremo de la represión dictatorial, determinó la aparición de una clase capitalista extremadamente fuerte, 
con altos grados de cohesión interna y altamente clara en sus intereses, mientras que al mismo tiempo destruyó tanto a las organizaciones tradicionales de clase trabajadora como sus vínculos con partidos y organizaciones de izquierda (PEREZ, 2014, p. 135).

A importância da perspetiva de classe na tecnologia espacial do Estado se funda na projeção estratégica que cria o Estado territorial do regime ou na manifestação de grupos de interesses antagônicos que criam uma determinada prática do poder como uso do território (SANTOS \& BECKER, 2002). A vantagem da categoria território usado, destaca Milton, é que permite compreender o movimento hegemônico sobre a relação territorial e seus desdobramentos sociais, políticos e econômicos. Revela, assim, a estrutura global da sociedade e, de outro lado, a própria complexidade do seu uso: "Para os atores hegemônicos o território usado é um recurso, garantia da realização de seus interesses particulares" (SANTOS, 2000, p. 13). Na construção do território é preciso criar aparelhos de dominação que permitam assegurar a execução da política oficial. Neste sentido, Becker sugere compreender dois níveis conceituais em relação ao poder espacial no Estado: a territorialidade e a gestão do território. A primeira se define como a dimensão prática espacial do Estado que implica, entre outras coisas, limites custodiados sobre um determinado espaço, usos vividos pelos atores, tentativas de afetar, influenciar e controlar ações em determinadas áreas geográficas, manifestações de poder atravessadas em todas as escalas da vida e cruzada por bases culturais e reapropriações no espaço, de distintos ciclos históricos (BECKER, 2012). A segunda via, a gestão do território, essencialmente, deve ser entendida como uma função estratégica do Estado que implica, por um lado, uma racionalidade científica que imprime "coerências as múltiplas decisões e ações para atingir uma finalidade" (BECKER, 2012, p. 128) e, por outro, produz saberes de administração governamental - tipo empresas privadas -, onde o conhecimento científico se instrumentaliza pelo direcionamento político do Estado "que tende a se identificar com a logística, no sentido da poderosa preparação de meios e da velocidade de sua atuação, referente esta não só à rapidez como à projeção para o futuro” (BECKER, 2012, p. 128).

A importância da gestão do território se conjuga no exercício do poder político do governo no território e na busca de sua territorialidade como fonte de legitimidade. Com efeito, política e historicamente, destacam-se três formas elementais do exercício do poder estatal moderno enquanto ferramenta de punição e regras. Primeiro, o poder despótico ao qual se articula a partir da coerção, o medo e a violência física, exercida como ameaça a um outro, ou a destruição. Em segundo lugar se apresenta o poder como autoridade, exercido pelo reconhecimento e a aceitação geral das pessoas, o qual funda e justifica a fonte de sua 
legitimidade. Segundo Weber, o princípio de autoridade funciona a partir da capacidade de exercer o mandato mediante leis, tradições ou por carisma pessoal de determinados governantes. Por último, emerge o poder político do Estado propriamente moderno, quem combina tanto o monopólio da violência como o princípio da autoridade, sendo a sínteses e a aceitação de ambas (CASTRO, 2013). Segundo o trabalho de Osório (2015), a ideia gramsciana do "consentimento ativo dos governados" se funda precisamente no processo de identificação do povo com o Estado e se resolveu na exigência da "mobilização da antiga noção de nação como elemento de mediação entre um ou outro. Estado-nação é o Estado que faz do nascimento (o nativo) o fundamento de sua própria soberania" (OSORIO, 2015, p. 246). Se o poder político do Estado é o instrumento geral de regulação e controle coercitivo de uma classe dominante, o governo do território pode ser entendido como um "ensamble de instituciones diseñado para lidiar con los problemas de la vida consociacional de una manera ordenada" (BOOKCHIN, 2019, p. 27) e funcional ao poder hegemônico.

\subsection{Dispositivos, recortes, arranjos e escalonamentos}

A partir do problema da hegemonia e os interesses de classe, a regionalização também pode ser entendida como produto e produtora de diferentes dispositivos ancorados ao autoritarismo e o neoliberalismo. Giorgio Agambem definiu que um dispositivo é "un conjunto de prácticas y mecanismos (invariablemente, discursivos y no discursivos, jurídicos, técnicos y militares) que tienen por objetivo enfrentar una urgencia para obtener un efecto más o menos inmediato" (AGAMBEM, 2011, p. 254). Nesse sentido, a multiplicidade e simultaneidade de ações que engendram os dispositivos (capturar, orientar, determinar, intersetar, modelar, controlar, etc.) no interior das condutas, das opiniões e dos discursos, implicam necessariamente uma construção teórica como mecanismo do poder. De fato, "todo dispositivo implica un proceso de subjetivación sin el cual no podría funcionar como dispositivo de gobierno" (AGAMBEM, 2011, p. 261). Trata-se de uma subjetivação desenvolvida numa série de práticas e discursos, de saberes e exercícios que, no processo, criam corpos que aceitam as normas, mas também são livres. Por isso, em primeiro lugar, um dispositivo é “una máquina que produce subjetivaciones y, por ello, también es una máquina de gobierno" (AGAMBEM, 2011, p. 261). Os dispositivos nunca são totalmente inertes, autônomos, racionais. Pelo contrário, eles transmitem um nível de agência que, eventualmente, pode conseguir alterar o estado atual das coisas. Assim, mais que representar ideias ou imaginar condutas sociais, os dispositivos estão envolvidos diretamente na existência social na medida em que projetam realidades (URETA, 2017). Segundo Ureta, existem três características essenciais dos dispositivos, inclusive os mais simples. Primeiro, 
são entidades difusas, compostas por diversos formatos, elementos e materiais que se espalham amplamente em diferentes tempos e lugares: geralmente adquirem a forma de um coletivo formado por várias entidades (URETA, 2017). Em segundo lugar, os dispositivos nunca são "criados" ou "construídos" de uma maneira definida, para posteriormente serem aplicados. Pelo contrário, eles são essencialmente performativos, ou seja, estão permanentemente sendo atualizados, de forma a alterar o desenho anterior. Em síntese, um dispositivo não é apenas uma projeção ou "protótipo" de conduta social, mas também é a expressão de práticas sociais concretas (URETA, 2017). Em outras palavras, os dispositivos são tanto espaços sociais desenhados como também experiências, e devem ser olhados como "formas de poderpolítico, estableciendo jerarquías y diferencias, exclusiones e integraciones" entre os grupos que interagem com eles (URETA, 2017, p. 29).

Michel Foucault destaca que mais que definir o poder, o significativo é explicar seu conteúdo, que, pode deduzir-se como um "conjunto de mecanismos y procedimientos cuyos papel o función y tema, aun cuando no lo logren, consisten precisamente en asegurar el poder" (FOUCAULT, 2006, p. 16). O poder, então, está sempre inserido em múltiplas relações sociais e depende da natureza particular de negociação ou encontro dos agentes, podendo mudar seu caráter relativo e relacional ou sua positividade e negatividade (ALVES, 2013). Na análise de Foucault o conceito de território se situa na "arte de governar" e a emergência "dos grandes estados territoriais" que reforçam a "territorialidade feudal” (MORAES, 1988, p. 134). Isto demanda a movimentação de um determinado saber estratégico - estatista, economia política, cartografia, etc. - que implica "estabelecer uma rede de relações entre a população e o território", pois, essas seriam bases do fundamento da soberania (MORAES, 1988, p. 134). Dai o destaque sobre as histórias ou genealogias da governabilidade que abordem as mudanças das “instituições, procedimentos, cálculos, e táticas de exercer o poder" enquanto território (MORAES, 1988, p. 134). A importância de problematizar os dispositivos no campo político se conecta com a capacidade de compreender as relações de poder e as estratégias da posse no e do território que, sempre é "tanto um meio como uma condição de possibilidade de algumas destas estratégias" (CASTRO, 2013, p. 95). Mais internamente, significa também compreender o debate sobre a consolidação do Estado territorial moderno e sua máquina administrativa: "uma rede conectiva, única e unitária, que modelou a estrutura organizativa formal da vida associada, transformando-se em autêntico aparelho de gestão do poder sobre a sociedade e sobre o território" (CASTRO, 2013, p. 126). 
Cabe aprofundar que, do conjunto operativo dessa poderosa rede e dispositivos, os Estados-nacionais implementaram seus principais processos políticos e financeiros, consolidando a continuidade de suas fronteiras internas e a gestão de conflitos políticosociais que, paulatinamente, e não sem violência, permitiram a aceitação geral do exercício monopólio de seu poder (CASTRO, 2013). Para o desenvolvimento desse processo de consolidação os Estados-nacionais tiveram que definir suas fronteiras internas, é dizer, impulsionar diferentes tipos de regionalizações ou recortes. Como assinala Cataia, "As fronteiras são uma necessidade política da organização dos territórios. Usar o território para vencer constrangimentos exigiu e exige uma organização política do território que tomou forma jurídica na figura do Estado-Nação" (CATAIA, 2001, p. 26). Segundo Bourdieu, as regionalizações, entre outras funções, se fundamentam para naturalizar relações e processos que, sobre outra perspetiva, ocultam interesses e diferenças (BOURDIEU, 1989; RIBEIRO, 2004). Já seja por critérios técnicos ou identitárias, as regiões respondem, por um lado, "representações mentais, quer dizer, de atos de percepção e de apreciação, de conhecimento e de reconhecimento em que os agentes investem os seus interesses e os seus pressupostos" (BOURDIEU, 1989, p. 112). Mas, por outro, projetam "representações objetais, em coisas (emblemas, bandeiras, insígnias, etc.) ou em atos, estratégias interessadas de manipulação simbólica que tem em vista determinar a representação mental que os outros podem ter destas propriedades e dos seus portadores" (BOURDIEU, 1989, p. 112). Dessa maneira, as regiões não podem ser ignoradas da realidade social, pois operam na prática "como sinais, emblemas ou estigmas, logo que são percebidas e apreciadas [...] propriedades (objetivamente) simbólicas, mesmos as mais negativas, podem ser utilizadas estrategicamente em função dos interesses materiais e também simbólicos do seu portador” (BOURDIEU, 1989, p. 112).

Qualquer tipo de regionalização, portanto, implica em uma naturalização através de mecanismos de oficialização ou atos de Estado que imprimem um poder simbólico (BOURDIEU, 2014). Ditos mecanismos e atos de Estado legitimam a criação de novas fronteiras internas. Mas em contrapartida, estruturam sua função específica e simbólica como autoridade reconhecida, capaz de impor o controle ao conjunto dos outros agentes, sendo reconhecido por todos, onde são expostas publicamente as práticas e representações como limites espaciais previamente calculadas enquanto di-visão oficial (BOURDIEU, 1989). O traçamento das fronteiras internas e externas, por consequência, precisa da mais alta 
autoridade na hierarquia do Estado, enquanto reconhecimento do espaço social. Como destaca Lobato Correa enquanto a validez ou aplicação da regionalização:

A sua ratificação ou retificação se dá a cada momento, conforme os interesses e os conflitos dominantes de cada época. São eles que, por outro lado, levam as unidades territoriais de ação e controle, a serem organizadas de modos diferentes: de um lado, a partir de um governo de nível hierárquico inferior ao do núcleo de dominação; de outro, de um mais ou menos complexo sistema de planejamento espacializado. Ambos cumprindo o papel de ação e controle. Neste exemplo, o Estado, surgido dentro do modo de produção dominante, é o agente da regionalização (CORREA, 1987, p. 48).

A demarcação oficial das fronteiras se expressa em atos de Estado que, para nossa pesquisa, distinguiremos como recortes. Segundo Cataia, a produção de recortes modifica as relações entre norma e território "a partir de novos poderes estatais, mas também a partir da preparação de um território apropriado ao exercício do poder” (CATAIA, 2001, p. 15). Ruy Moreira destaca que o recorte "é o princípio do conceito do território: o recorte qualificado por seu sujeito do recortamento" (MOREIRA, 2011, p. 80). É nesse sujeito de recortamento, poderoso, que radica invariavelmente a prerrogativa do Estado e sua projeção estratégica enquanto "trama das territorialidades que faz do conjunto do arranjo um complexo de micropoderes" (MOREIRA, 2011, 85). Dita trama e conjunto de arranjo, por sua vez, depende de articulação dos recortes territoriais. Segundo Moreira, "Cada recorte territorial é um nível escalar de domínio, o plano do corpo-sujeito na escala total dos recortes, o todo da espacialidade diferencial expressando o poder plural dos sujeitos em embate dentro de todo da sociedade e do Estado, e sua espacialidade diferencial sendo" (MOREIRA, 2011, p. 8586).

É importante remarcar o significado do recorte que propõe Moreira, pois, implica entender a fonte do poder territorial do Estado e suas múltiplas estratégias que procuram definir as regras e normas do comportamento e ordenamento espacial da sociedade (MOREIRA, 2011). Quer dizer, um recorte é uma estrutura-forma-conteúdo do espaço que modifica o sistema territorial. Portanto, segundo Moreira, os recortes não podem ser entendidos sem seu correspondente arranjo no espaço: o recorte é a expressão da implícita função e regulação de um determinado arranjo. Para Moreira em cada sociedade existem dois tipos de arranjos: 1) o arranjo infraestrutural onde radica a "função genética do espaço" (carreteiras, redes técnicas, portos, etc.); 2) o arranjo superestrutural que opera como "função genealógica", é dizer, a esfera dos ajustes espaciais onde se definem os "aparelhos jurídicopolíticos e ideológicos-culturais segundo os quais se organizam a sociedade civil e o Estado" 
(MOREIRA, 2011, p. 84). Isto implica pensar, entre outras ocorrências, que o arranjo da superestrutura é fundamentalmente "um campo de correlações de forças, e do espaço um elemento de caráter essencialmente político em sua determinação sobre a organização global da sociedade" (MOREIRA, 2011, p. 84). Todas essas forças, imposições e consensos no percurso histórico conseguem estabelecer e criar uma ordem, produto de um arranjo do espaço previamente estabelecido/resultado da luta e os interesses de classe ${ }^{11}$. Nas palavras de Ruy Moreira:

O arranjo do espaço aparece em linha direta como o resultado do confronto de forças, organizadas institucionalmente na oposição orgânica da sociedade civil e do Estado. Aqui, o arranjo do espaço é fruto do processo de seletividade definido pelo interesse de classe, arrumado por isso a partir da propriedade privada dos recursos do espaço. E o ordenamento já nasce orientado para a regulação desse estado de coabitação classistamente assimétrico (MOREIRA, 2011, p. 87).

A partir desses recortes e arranjos, simultaneamente emergem também diferenciados escalonamentos do poder estatal. Lacoste destaca que, qualquer processo de divisão de um território envolve um debate de escala, pois sempre se altera a escala geográfica e os recortes são elaborados a partir de uma determinada problemática (LENCIONI, 2014). Dessa maneira, mais que definir e delimitar esses recortes, o significativo é compreender sua função e projeção como prática social (LENCIONI, 2014). Swyngedouwn destaca que a importância teórica e política dos escalonamentos radica em que as contradições sociais nunca residem em apenas uma escala geográfica, mas sim na interligação de várias escalas particulares que se reestruturam como processo histórico de conjunturas importantes (SWYNGEDOUW 2013, p. 506). Com efeito, a reconstituição de escalas ou escalonamentos pode ser domínio de disputas políticas transcendentes, pois, "las posiciones relativas de poder social variarán considerablemente, dependiendo de quién controla qué y a qué escala" (SWYNGEDOUW 2013, p. 506). As escalas, então, são essencialmente móveis ("nunca están fijas") e cada certo tempo entram em processos de redefinição e reestruturação de seus conteúdos e competências que atualizam sua extensão e influências como produto social (SWYNGEDOUW, 2013).

\footnotetext{
${ }^{11}$ Edward Thompson define que, a classe é fundamentalmente um fenômeno histórico que "unifica uma série de acontecimentos díspares e aparentemente desconectados, tanto na matéria-prima da experiência como na consciência" (THOMPSON, 1987, p. 9). Desse modo, afirma Thompson, "Não podemos ter amor sem amantes, nem submissão sem senhores rurais e camponeses. A classe acontece quando alguns homens, como resultado de experiências comuns (herdadas ou partilhadas), sentem e articulam a identidade de seus interesses entre si, e contra outros homens cujos interesses diferem (e geralmente se opõem) dos seus" (THOMPSON, 1987, p. 9).
} 
Uma abordagem em escalonamentos, portanto, enfoca sua análise na agenda dos mecanismos de mudança e conteúdos transgredidos das escalas enquanto deslocações e distribuições de poder, procurando distinguir no processo de reestruturação como alguns atores e grupos avançam posições, ao passo que, simultaneamente, outros perdem poder (SWYNGEDOUW, 2013). Através do seguimento dessas políticas espacializadas ou escalonamentos, é possível distinguir vários tipos de relações de dominação-subordinação, assim como também aprofundar nos elementos de participação-exclusão que definiram as correlações de força do processo político mais amplo. Seguindo o trabalho de Neil Smith (1984), Swyngedouwn destaca que as escalas sempre expressam uma função intermediaria: "entre la cooperación y la competencia; entre la homogeneización y la diferenciación; entre el empoderamiento y la pérdida de poder" (SWYNGEDOUW, 2013, p. 510). O significativo dos escalonamentos é que, implicitamente, desafiam as relações de poder vigentes a partir de um jogo de poder que pode se expressar tanto de maneira horizontal como vertical. Enquanto à tecnologia espacial do Estado os escalonamentos manifestam o cambio substantivo das relações de poder dos grupos e classes sociais (SWYNGEDOUW, 2013, p. 510). Os processos de escalamento de poder do Estado, portanto, estão diretamente interrelacionados ao problema da hegemonia (BRENNER, 2013), ou seja, "vincula-se intrinsecamente às mudanças na configuração organizacional e espacial dessa formação social historicamente específica" (BRENNER, 2013, p. 209). Todo escalonamento implica três movimentos analíticos fundamentais: 1) "explorar as dinâmicas sociais diversas nas quais e por meio das quais as configurações político-econômicas escalares são ativamente produzidas e continuamente transformadas no curso do desenvolvimento geo-histórico capitalista" (BRENNER, 2013, p. 214); 2) "rastrear as maneiras pelas quais essas ordens político-econômicas escalares estruturam (isto é, ao mesmo tempo constrangem e possibilitam) relações sociais de poder, dominação, exploração e luta" (BRENNER, 2013, p. 214; 3) "desnaturalizar, historizar e interrogar criticamente as próprias unidades espaciais e hierarquias nas quais as relações sociais são travadas" (BRENNER, 2013, p. 215) pois, “o léxico da escala geográfica é mais potente quando seus limites analíticos são explicitamente compreendidos” (BRENNER, 2013, p. 216).

Embora os estudos da regionalização chilena incorporam certas dinâmicas e mudanças neoliberais, como a privatização de certos recursos públicos e as transformações territoriais a partir da exportação dos recursos naturais, no geral ditos estudos desvalorizam e omitem o conjunto de saberes, tecnologias e práticas que implicaram os recortes, arranjos e escalonamentos no período autoritário no contexto da regionalização. Em outras palavras, 
não existe um debate aprofundado em torno dos comportamentos políticos de classe inseridos no processo de regionalização chilena, nem tampouco dos mecanismos e dispositivos que possibilitaram a articulação de ditos arranjos e recortes em chave hegemônica. Nesses marcos, teoricamente se busca argumentar e explicitar como a regionalização correspondeu fundamentalmente à um movimento político de classe que buscou na estrutura territorial do Estado, uma forma de assegurar relativamente sua hegemonia e, desse modo, expandir seu poder no conjunto da sociedade chilena. Nossa particular preocupação é o questionamento no momento de selecionar os materiais e fontes, seguindo Ana Clara Torres Ribeiro, para descrever e analisar como "a luta de classes inscrevese na regionalização" (RIBEIRO, 2014, p. 9). 


\section{CAPÍTULO 2}

\section{Regionalizar para Governar}

\subsection{A regionalização antes do Golpe de Estado}

Quando os militares perpetraram o Golpe de Estado do 11 de setembro de 1973, já existia no Chile importantes experiências em políticas regionais. Além de propostas geográficas interpretativas do território nacional inferidas a princípios do século XX, a criação da Corporación de Fomento a la Producción (CORFO) em 1939 desenvolveu influentes estudos que estruturaram o território em cinco macrorregiões (Norte Grande, Norte Chico, Zona Central, Zona Sul, Zona Austral) e um pujante processo de urbanização que foi permitindo uma industrialização dirigida fundamentalmente pelo Estado de Compromisso (ARENAS, 2009; ESTEFANE, 2017). Nessa mesma década, em 1954, também foi aprovada uma divisão regional com propósitos de planejamento, que ao fim das contas, funcionou apenas para coordenar o Ministério de Obras Públicas e disponibilizar sua infraestrutura para a indústria privada, latifúndios e outros setores empresariais (BEDRACK, 1974, p. 10). Mais adiante, em 1966, se estruturou nacionalmente o Ministerio de la Vivienda y Urbanismo e, junto com ele, criou-se a Dirección de Planificación del Desarrollo Urbano (DPDU), um importante escritório técnico que impulsou ações pioneiras no planejamento físico das cidades (BEDRACK, 1974).

Se bem todos esses esforços formaram parte de uma tentativa estatal de planejamento regional, foi no governo do democrata cristão Eduardo Frei Montalva, entre 1964-1970, e especificamente com a criação da ODEPLAN em 1966, quando se criaram as primeiras políticas efetivas de planejamento regional do país. A ODEPLAN foi uma importante oficina técnica de assessoria estratégica para o Presidente da República, que tinha como função interpretar as contas nacionais que anteriormente realizava CORFO (SOMS, 2010; OSSES, NUÑEZ, 2013). Na década de 1960, assim, se começou a ter um foco econômico nas análises e projeções do comportamento da economia nacional, estabelecendo "un paso decisivo en la configuración del rol superior de asesoría al Presidente y de coordinación con los organismos sectoriales" (SOMS, 2010, p. 39). No fim do governo Frei, a ODEPLAN reorganizou espacial e economicamente em regiões, baseados na teoria dos pólos de desenvolvimento (SOMS, 2010; ARENAS, 2009). No documento intitulado Política de Desarrollo Nacional. Directrices Nacionales y Regionales del Desarrollo, se definem os conteúdos de como será entendida a regionalização: 
La regionalización del país se entiende como un agrupamiento de las actuales provincias, tendiente a acelerar el desarrollo económico y social en forma balanceada a lo largo del país. Las regiones deben contar con una relativa autonomía socio-económica dentro de un marco de integración nacional, esta es una condición esencial para que cada región pueda iniciar un proceso de desarrollo auto-sostenido y no simplemente tributario del desarrollo del centro. En consecuencia, el criterio fundamental para individualizar una región, es que constituya una unidad integrada desde un punto de vista territorial, social y económico. Si bien esta condición no siempre se cumple estrictamente al tener como restricción los límites provinciales, en una primera etapa parece aconsejable ajustarse a esta limitación administrativa. Por otra parte es importante destacar que cada región debe contar por lo menos con un centro integrador que actúe como polo de crecimiento (ODEPLAN, 1968, p. 49).

Eram os primeiros passos do processo de planejamento regional. Seguindo os limites administrativos provinciais, os critérios de integração nacional e os pólos de desenvolvimento, a regionalização da ODEPLAN definiu então onze regiões além de uma Zona Metropolitana correspondente de Santiago. Esse importante trabalho de projeção estratégica do país contou com a assessoria do planejador austríaco-canadense John Friedmann e a colaboração da Fundação Ford (1965-1969) (BOISIER, 2010) que, por sua vez, conectava um importante apoio de Washington para Chile no marco da Aliança para o Progresso (DELAMAZA, 2018). Dessa forma, a contratação de John Friedmann para o estudo do desenvolvimento regional no Chile marcou um sofisticado trabalho que derivou em um importante material técnico para as escolhas regionais do Estado chileno. O subdiretor regional da ODEPLAN da época, Sergio Boisier, após do estudo concluiria junto com Friedmann: "Sería altamente conveniente para Chile crear otro referente geográfico para la población: la región" (ENTREVISTA SERGIO BOISIER, abril 2017).

Friedmann, quem já havia participado em experiências regionais na Venezuela e em outros países da Europa, aplicou sua teoria de integração urbano-regional ao modelo territorial chileno, solicitando os serviços do geógrafo polaco Walter Stöhr. O desenvolvimento regional se entendeu como um todo-sistémico que, segundo as respectivas regiões geoeconômicas, devia integrar-se e polarizar-se através de uma síntese urbana regional da política (ODEPLAN, 1968). Por sua vez, se definiram uma série de objetivos econômicos nacionais e urbano-regionais com o aceleramento da taxa de crescimento, a busca do pleno emprego e o freno da inflação, onde o conceito de planificação se entendia como uma ação sistemática de governo, destinada a maximizar a distribuição espacial dos recursos e a coordenação dos diferentes mecanismos públicos e sociais (ODEPLAN, 1968). Porém, havia severas restrições estruturais. O país possuía um sistema institucional profundamente centralizado em termos orçamentais e políticos e, para piorar, não existiam 
instrumentos técnicos e participativos que pudessem influir na distribuição dos orçamentos e investimentos regionais (ACHURRA, 1968). Em 1970 o destacado geógrafo chileno, Pedro Cunill, destacava:

La actual división geográfico-administrativa de nuestro país no ha demostrado ser eficaz ante las urgencias del desarrollo socioeconómico. Es imposible enfocar la planificación del desarrollo tomando en forma autónoma cada una de las veinticinco provincias, tampoco tendría posibilidades reales una planificación teórica general que no tomara en cuenta el marco geográfico regional. Por ello es necesario definir las regiones de planificación, en las cuales se puede estimular el desarrollo progresivamente (CUNILL, 1970, p. 475).

A regionalização da ODEPLAN supunha implicitamente uma descentralização efetiva da administração pública refletida em mecanismos de coordenação a nível regional e a criação paulatina de entidades regionais autônomas e/ou semiautônomas de fomento e desenvolvimento. Dessa maneira a ODEPLAN começou a instalar Oficinas Regionais de Planejamento (ORPLAN) nas principais cidades e províncias, segundo suas prioridades e tentando guiar-se na teoria dos pólos de desenvolvimento (CAÑAS, 1968).

\section{Imagem n ${ }^{\circ}$ 1. Polos de Desenvolvimento}

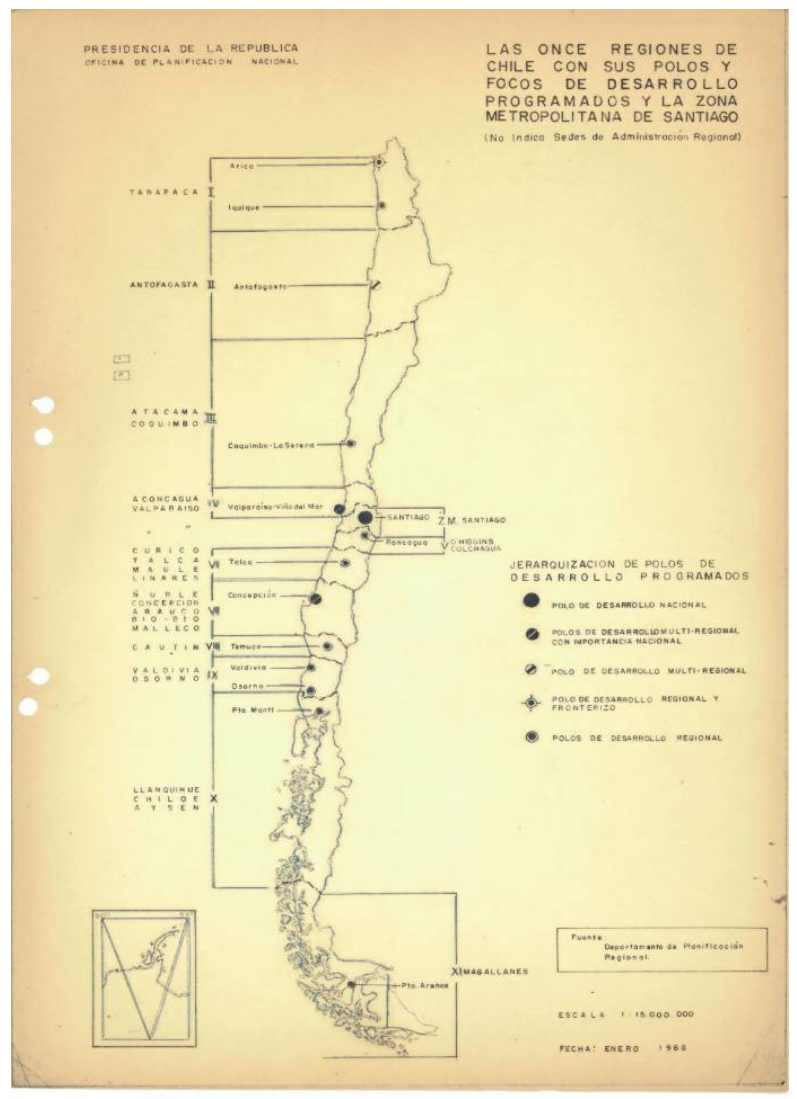

Fonte: ODEPLAN, 1968. 
A ODEPLAN deveria articular fundamentalmente uma rede econômica de fluxos e pontos que internamente iria criando uma polarização hierarquizada dos centros produtivos (imagem $\mathrm{n}^{\circ}$ 1), que seriam estrategicamente distribuídos como "ubicaciones prioritarias para el desarrollo integrado urbano-regional y en particular, la localización de nuevas industrias" (ODEPLAN, 1968, p. 343). Contemplaram-se assim três níveis hierárquicos de pólos de desenvolvimento: 1) Polo de Desenvolvimento da Ordem Nacional: Santiago como sede da administração e de instituições que servem para o conjunto do país; 2) Pólos de Desenvolvimento Multiregional e de Importância Nacional: Antofagasta, Valparaíso e Concepción, cidades que, seja no norte, centro ou sul do país, devem constituir efetivos contrapesos ou compensações ao crescimento de Santiago; 3) Pólos de Desenvolvimento da Ordem Regional: cumprem e servem diferentes tarefas de acordo a seu tamanho e localização: Arica, Iquique, Serena-Coquimbo, Rancagua, Talca, Temuco, Valdivia, Osorno, Puerto Montt e Punta Arenas. Para implementar ditas políticas as ORPLAN deveriam criar estratégias de desenvolvimento regional (papel da região, desequilíbrios, potencialidades, metas regionais por setores, investimentos, participação, áreas de desenvolvimento, etc.), as quais orientavam os assuntos internos dos territórios regionais nos esquemas institucionais devidamente coordenados no plano nacional e seus respetivos planos setoriais (ODEPLAN, 1968). No seguinte quadro $n^{\circ} 3$ podemos observar a projeção regional de ODEPLAN em termos de prioridades e objetivos em 1968. É interessante destacar que, salvo a Zona Metropolitana de Santiago, todas regiões estão nomeadas com números romanos, um elemento que posteriormente vai ser incorporado pela regionalização do regime autoritário.

Quadro $N^{o}$ 3. Tipos de desenvolvimento e prioridades regionais

\begin{tabular}{|c|c|c|c|}
\hline \multirow{10}{*}{$\begin{array}{l}\text { Classificação de } \\
\text { Regiões }\end{array}$} & \multirow{5}{*}{ Zona de Colonização } & \multirow[b]{3}{*}{ Norte } & I Tarapacá \\
\hline & & & II Antofagasta \\
\hline & & & $\begin{array}{l}\text { III } \\
\text { Coquimbo }\end{array}$ \\
\hline & & \multirow[t]{2}{*}{ Austral } & X Los Canales \\
\hline & & & XI Magallanes \\
\hline & \multirow{5}{*}{ Zona Consolidada } & \multirow[t]{4}{*}{ Regiões Periféricas } & VI Maule \\
\hline & & & VII BioBio \\
\hline & & & VIII Cautín \\
\hline & & & IX Los Lagos \\
\hline & & & ZM Santiago \\
\hline
\end{tabular}




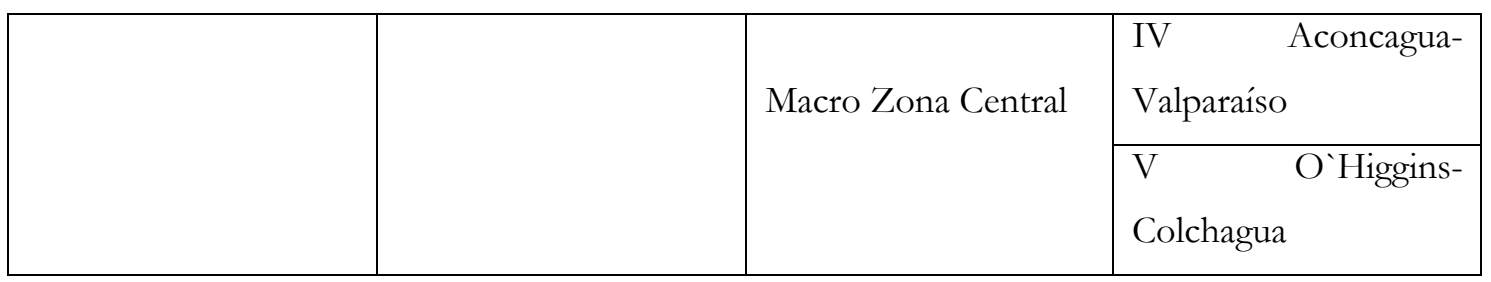

Fonte: ODEPLAN 1968.

Estrategicamente a ODEPLAN organizava o país em duas grandes zonas (consolidada e colonização), das quais, internamente, também tinham uma condição central e periférica, ligada aos extremos norte e sul e os níveis de desenvolvimento. Todos esses estudos e esforços dessa primeira regionalização foram refletidos no decreto lei $\mathrm{n}^{\circ} 1104$, aprovado um 19 de Agosto de 1969, no qual foi definido oficialmente as onze regiões de planejamento, mais uma Zona Metropolitana de Santiago. Seguindo os termos da ODEPLAN de 1968, o decreto-lei no 1104, intitulado Establece División Geoeconómica del País, considerava um plano nacional de desenvolvimento que exigia uma adequação dos serviços públicos à divisão geoeconômica do país. Além disso, se estipulava que ODEPLAN devia elaborar programas de desenvolvimento regional para as novas unidades e que a divisão geoeconômica estava fundamentada em critérios sociais, espaciais, econômicos, técnicos e administrativos "que facilitarán el proceso de desconcentración administrativa y que agilizarán el funcionamiento de los Servicios del Estado a nivel regional' (GOBIERNO DE CHILE, 1969, s./r.). Por sua vez, se assinalava que os serviços públicos que no futuro se modificariam deveriam ajustar-se para aquela divisão geoeconômica e que, nos casos que ainda não havia correspondência, cada serviço público deveria designar um funcionário cujo qual coordenaria a integração de dito serviço à região correspondente estipulada pelo decreto. Por último, o decreto assinalava que o respectivo recorte de regiões de planejamento não se aplicava espacialmente ao Poder Judicial, Municipalidades, Universidades do Estado, nem tampouco as Forças Armadas, Carabineros de Chile e a Contraloría General da República (GOBIERNO DE CHILE, 1969).

Todas essas informações demostram que, se bem as regiões existentes em 1969 tinham um sentido de fomento produtivo regional, na prática, também deveriam servir de guia para um ordenamento da administração pública do Estado com um particular destaque no planejamento interministerial. A ODEPLAN, assim, foi abrindo o caminho para criar uma rede de monitoramento e acompanhamento dos desenvolvimentos regionais que iriam melhorando as funções técnicas do Estado provincial e suas burocracias. Segundo o economista e funcionário da ODEPLAN até o Golpe de Estado, Esteban Soms, nessa etapa se conseguiram importantes avanços em relação às dinâmicas regionais e a capacitação de 
funcionários públicos em províncias, criando uma ótima base cartográfica e documental do território interno e a criação das primeiras redes institucionais entre universidades e profissionais do governo, destinados especificamente ao desenvolvimento regional (SOMS, 2010; BOISIER, 2010; ARENAS, 2009). Essas bases regionais, por sua vez, permitirão começar as pioneiras reflexões sobre os instrumentos de financiamento regional compensatório e outros sistemas de assessoria para as futuras burocracias das regiões, dos quais se destacaria um importante convênio de cooperação entre a ODEPLAN e o Instituto Tecnológico de Massachusetts (SOMS, 2010).

\section{Imagem n ${ }^{\circ}$ 2. Organigrama ODEPLAN}

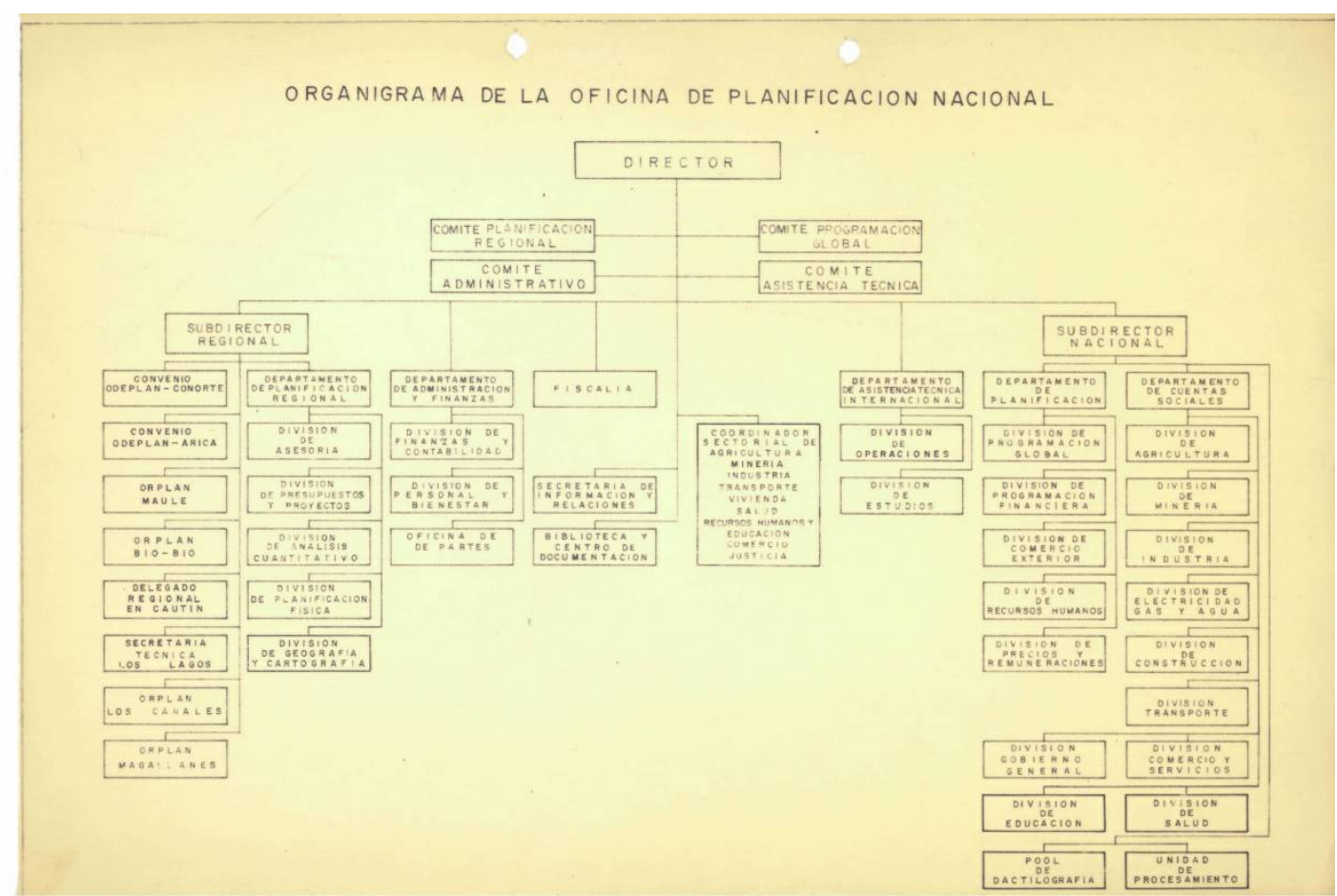

Fonte: ODEPLAN, 1968.

Quando se iniciou o governo da Unidade Popular em 1970, assim, a ODEPLAN já contava com uma significativa estrutura nacional e uma direção regional (imagem $n^{\circ} 2$ ) que se espalhava espacialmente através de quatro ORPLAN (Biobío, Maule, Los Canales, Magallanes), além de outros convênios que posteriormente abririam novas ORPLAN (Arica, Cautín e Los Lagos) (SOMS, 2010; CUNILL, 1970; ODEPLAN, 1968). Dessa forma, o governo de Allende continuaria as políticas regionais de Frei Montalva, desenvolvendo as primeiras estratégias de desenvolvimento ancoradas nas dinâmicas e recursos próprios onde se haviam instalado as ORPLAN. No entanto, na prática, as ORPLAN não tinham maiores orçamentos nem competências para o desenvolvimento territorial efetivo (ENTREVISTA 
LUIS LIRA, outubro 2019). Por outro lado, o arquiteto argentino Moisés Bedrack, diretor da DPDU durante o governo da UP (1970-1973), destaca que, apesar dos importantes avanços do período do presidente Frei Montalva, a forte estrutura centralista permanecia praticamente intacta e de forma problemática, pois, os próprios instrumentos da ODEPLAN induziam "a acentuar desiquilibrios entre regiões e cidades, expressadas nos efeitos negativos" (BEDRACK, 1974, p. 11). Segundo Bedrack, a política dos pólos com maior hierarquia praticada até esse momento, na realidade havia significado um detrimento para as outras regiões fora da zona central dos polos e, além disso, também havia criado efeitos negativos sobre cidades da mesma região que formavam o pólo (BEDRACK, 1974). Ao mesmo tempo, o fenômeno da concentração em Santiago e seus circuitos industriais continuavam sendo integralmente dominantes, concentrando os projetos de maior desenvolvimento. Essas dinâmicas se traduziam em que, fora de Santiago, os parques industriais não contavam com uma infraestrutura suficientemente desenvolvida e, portanto, se reproduziam desigualdades de tecnologia entre os centros metropolitanos e o resto do país, sobretudo entre a industria urbanizada mais avançada em cidades e a mineira regional mais tradicional das provinciais (BEDRACK, 1974). Em outras palavras, a forte concentração demográfica, tecnológica e econômica de Santiago, tendia a desequilibrar estruturalmente as outras províncias, principalmente aquelas de base agropecuária e incluindo os próprios pólos urbanos-regionais incipientes. Todas essas lógicas dão conta de uma contraditória política de pólos. Diz Bedrack:

La armaduría automotriz de San Felipe, la industria metal-mecánica y la minería del cobre en Los Andes, la refinería de petróleo de ConCon, la planta Ford de Casablanca, etc., no produjeron los efectos multiplicadores en el sector terciario en su propia región, sino que acrecentaron la dependencia con respecto a Santiago y la inevitable reversión del excedente hacia la Metrópoli, haciendo estéril el esfuerzo de descentralización productora y/o desconcentración postulado. La creación de "centros fuertes" en regiones débiles ha traído como consecuencia, no el desarrollo de las regiones débiles, sino por el contrario, un debilitamiento y dependencia mayores del polo de gran concentración (BEDRACK, 1974, p. 14-15)

Em vista de uma carente polarização produtiva e com vários efeitos negativos, a ODEPLAN e a DPDU firmaram um convênio de coordenação com o propósito de estabelecer critérios únicos de localização de investimentos que permitissem uma integração e coordenação da função pública na escala urbana-regional. Dessa maneira, se pretendia superar a original polarização inacabada e guiar outras regulamentações físicas espaciais com sentido de integração territorial como os planos de desenvolvimento econômico, a infraestrutura estratégica e os planos reguladores urbanos (BEDRACK, 1974; SOMS, 2010). 
Ambas instituições, se tornaram as principais agências estatais destinadas a impulsionar o desenvolvimento regional e superar as filtrações e efeitos indesejados da polarização. Nesse mesmo espírito, em 1972, também se articulou a Estrategia del desarrollo espacial de largo plazo, principal instrumento da questão regional durante a UP. Sua gestação originaria contou com a participação de variados e importantes serviços públicos e centros de pensamento, começando pela Dirección de Planificación del Desarrollo Urbano (DPDU), o Centro de Planificación da Universidad de Chile (CEPLA), o Programa de Naciones Unidas para el Desarrollo (PNUD), o Ministerio de Obras Públicas y Transporte (MOPT), o Instituto de Investigaciones de Recursos Naturales (IREN), a Corporación de Fomento de la Producción (CORFO), o Centro de Estudios Urbanos Regionales (CEUR) do Departamento de Geografía da Universidade de Chile. A estratégia do desenvolvimento espacial a longo prazo buscou redefinir a política de desenvolvimento regional e o ordenamento territorial, estruturando um sistema nacional de planejamento com novas competências na ODEPLAN, permitindo ampliar a reflexão do processo anterior, além de integrar organizações sociais, agentes intermediários e instituições públicas que, por primeira vez, acordavam e projetavam um pacto social pelo desenvolvimento regional (BEDRACK, 1974). No livro La estrategia del desarrollo espacial en Chile (1970-1973), publicado pela editorial SIAP em Buenos Aires, em 1974, Moisés Bedrack explica os principais assuntos teóricos excursionados do desenvolvimento regional da UP. Segundo ele, a nova estrutura espacial da economia, com efeito, deveria:

Romper la actual funcionalidad del espacio geográfico del país, en que predominan las relaciones de dominación que ejerce la región metropolitana sobre el resto del territorio y enriquecer el análisis económico con las variables territoriales de tal modo que no sea el propio modelo global el que contribuya a mantener y agravar la estructura espacial deformada (BEDRACK, 1974, p. 24).

Não obstante, diz Bedrack:

La nueva estructura espacial debe materializar entonces un sistema de regiones en que cada una de ellas cumple un rol y una función productiva especializada en un esquema de complementariedad e interrelaciones, donde los énfasis de desarrollo relativo están en concordancia con la funcionalidad de todo el sistema. Sólo una estructura de este tipo hace factible incorporar racionalmente a las diversas realidades regionales en el marco de lineamientos estratégicos espaciales de nivel nacional (BEDRACK, 1974, p. 25)

A estratégia regional da UP, entretanto, continuava o caminho traçado pelos estudos de Friedmann. Mas, simultaneamente, aprofundava sua orientação na desconcentração de um conjunto de centros modelados em função das diferenças econômicas e suas potencialidades. A economia regional da transição ao socialismo se dividia em duas áreas: por um lado, a incorporação de recursos ociosos e, por outro, a maximização dos excedentes 
econômicos da produtividade industrial. O desenvolvimento regional, portanto, deveria ser entendido no "marco del desarrollo nacional, como parta de él y por ende, plenamente integrado y compatibilizado, y no como un subproducto de lineamientos globales o sectoriales" (BEDRACK, 1974, p. 37). Por sua vez, se definiam três áreas de desenvolvimento estratégicos: a) Zona Norte que incluía as províncias de Tarapacá, Antofagasta e Arica; b) Zona Central que incluía entre a província de Coquimbo até Llanquihue e Chiloé, também denominada "Corredor de desarrollo"; c) Zona Austral que incluía as províncias de Aysén e Magallanes (BEDRACK, 1974). Cada uma dessas grandes zonas projetava uma base material diferenciada para o planejamento regional e, consequentemente, deveria desenvolver um foco alternativo.

Tratava-se de integrar a zona central nas outras zonas através de uma redução dos custos de transporte e uma maior acessibilidade para os lugares mais isolados. "La tesis central de desconcentración plantea los conceptos de integración longitudinal y áreas de integración, de acuerdo a la forma alargada natural de Chile que implica un intercambio y relación espacial lineal de Sur a Norte" (BEDRACK, 1974, p. 43). A zona central ou Corredor de Dessarrollo se projetava como um sistema integrado de centros urbanos e de tráfico, ao qual internamente respondia a um sistema de transporte "a partir del flujo de relaciones entre áreas distantes entre si que cuenta con una actividad de intercambio minimo" (BEDRACK, 1974, p. 43). Para as zonas Norte e Austral, inversamente, se projetavam centros industriais ligados a recursos naturais e seu aperfeiçoamento como serviço. Algumas cidades como Arica, Antofagasta e Punta Arenas, foram reforçadas como centros urbanos e industriais maiores (BEDRACK, 1974). Na zona central se previa um maior crescimento da população, sobretudo em três centros urbanoregionais: La Serena-Coquimbo, Concepción e Valdivia-Osorno-Puerto Montt. Se pretendia que esses centros fossem industrializados e que, paulatinamente, contassem "con servicios de todo orden para que alcancen una dinámica económica tal que determine la consolidación del Corredor en su parte centraly en sus prolongaciones norte y sur, en torno a las áreas desconcentradoras de primera prioridad" (BEDRACK, 1974, p. 45).

Por outra parte, a estratégia contemplava um sistema nacional de transporte que deveria guiar a construção de uma estrada central que integrara as principais áreas metropolitanas da Zona Central. Ao mesmo tempo, a via férrea deveria alcançar até a cidade de La Serena, assegurando a eletrificação e melhorias das redes técnicas (BEDRACK, 1974). Enquanto a implementação setorial, a estratégia de desenvolvimento espacial se dividia no setor agropecuário e o setor industrial. No setor agropecuário a estratégia procurava 
aumentar a superfície agrícola utilizada: passar dos 2,8 milhões a 5,1 milhões de hectares de solos produtivos (BEDRACK, 1974). Entre 1920-1970 a agricultura chilena teve um baixo patamar de crescimento agrícola e se caraterizava pela escassa inovação industrial. Assim, buscava-se potenciar as províncias mais retardatárias com maior investimento e produtividade agrícola interligada. Diferentemente, na estratégia espacial do setor industrial, se consideraram dois níveis. No primeiro nível, se destacava a ação industrial definida por áreas alternativas de localização, na qual, ao menos, se projetavam duas áreas de desconcentração: Serena-Coquimbo e Valdivia-Osorno-Puerto Montt. O segundo nível se derivava das possibilidades de desconcentração e aproveitamento dos recursos naturais e a "vocación productiva que les asignan la existencia de ciertos recursos" (BEDRACK, 1974, p. 65).

Um dos assuntos mais complexos da industrialização nacional da UP foi a criação da Área de Propiedad Social. A partir dessa política, o Estado do Chile tomou posse de um significativo número de empresas privadas que representavam os interesses de grandes monopólios e históricas oligarquias empresariais chilenas. Após dois anos da UP, segundo Bedrack, a Área de Propriedade Social tinha em seu poder mais de 150 empresas industriais, as quais contribuíam no "30\% de la producción del sector manufacturero chileno" (BEDRACK, 1974, p. 15). A banca e as exportações de cobre estavam em grande parte sob controle total do Estado. A forte validação popular dessas formas estatais foi uma das razões que incubaram o Golpe de Estado. No entanto, para a estratégia espacial da UP, os investimentos da Área de Propiedad Social conduziriam a integração de complexos industriais com altos níveis de especialização e facilitação de novos investimentos regionais. A estratégia considerava etapas de mediano e longo prazo, tais como proporcionar emprego produtivo, economizar divisas via substituição de importações, ampliar a área social e eliminar o poder de monopólio, financeiro e proprietário de terras, etc. (BEDRACK, 1974, p. 99-100), sempre na lógica de "elaborar la carpeta de los principales proyectos industriales, con sus estudios especificos y calendario aproximado de inversión, que materializarán en la fase siguiente y cuy a localización propuesta en la estrategia regional permitirá decididamente configurar la nueva estructura espacial de la economía chilena" (BEDRACK, 1974, p. 102).

É importante assinalar que antes da formulação da estratégia, por sua vez, a ODEPLAN de Allende elaborou um novo sistema nacional de planejamento com maiores níveis de coordenação entre os ministérios, órgãos setoriais e as empresas da área social, os quais definiram um mecanismo integrador dos órgãos orçamentais dirigidos pelo Ministério 
de Fazenda. Esse processo de investimento integrado nas unidades territoriais regionais também era a expressão do avanço das corporações de desenvolvimento regional e comitês programadores de investimento que, segundo SOMS, existiam em Arica, Iquique, Tocopilla, Taltal, Atacama-Coquimbo, Valparaíso-Aconcagua, Bio-Bio-Malleco-Cautín e significavam um "extraordinario instrumento de dirección económica y de participación ciudadana, capaces de movilizar gran cantidad de ideas y proyectos locales. Asi lo demuestra el balance de las experiencias de los años 1971, 72 y 73 y el creciente interés de los actores regionales, públicos y privados, por integrar tales organizaciones" (SOMS, 2010, p. 51) $)^{12}$.

Por outra parte, durante o governo da UP se aprovaria o Conselho Nacional de Desenvolvimento (decreto-lei $\mathrm{n}^{\circ} 303$ ), um dispositivo estratégico de investimento a nível nacional que orientaria a coerência das políticas econômicas e sociais a longo prazo com a participação de vários Ministérios e serviços públicos, além de seis representantes dos trabalhadores e dos empresários, respectivamente, mais um representante dos Colégios Profissionais e dois representantes da Juventude (SOMS, 2010; ARENAS, 2009). Por sua vez, analogamente, em cada região se instituíam Conselhos de Desenvolvimento Regional onde se estudavam e definiam as políticas estratégicas territoriais de cada região, colocando maior atenção na participação ativa dos operários organizados (SOMS, 2010). Esse instrumento participativo inaugurava na história do Chile o reconhecimento dos trabalhadores organizados na forma de representação da questão regional. Segundo Arenas, "La creación de un comité ODEPLAN-CUT ${ }^{13}$ constituyó la puesta en marcha de una organización técnica y politica en la gestión de la planificación. El mismo esquema de participación fue reproducido en las oficinas regionales de planificación" (ARENAS, 2009, p. 26).

Além da abertura da participação regional ao movimento operário, existe outro assunto significativo da ODEPLAN durante o primeiro mês do governo de Allende. O cargo de Diretor da ODEPLAN passou a ter a hierarquia de Ministro (SOMS, 2010, p. 50). Se trata, pois, de um sinal político de autoridade no interior do gabinete da UP e suas prioridades, onde se dá um maior peso político à ODEPLAN, projetando o planejamento nacional como uma prioridade fundamental do processo de desenvolvimento do governo popular. $\mathrm{O}$ Ministro Diretor da ODEPLAN, tinha então a hierarquia para coordenar o comitê econômico de ministros e liderar plenamente as políticas de desenvolvimento, tanto no

\footnotetext{
${ }^{12}$ Além disso, também existiam os Institutos CORFO de Antofagasta e Chiloé, Aysén e os comitês programadores de investimento de Iquique-Pisagua e O'Higgins (SOMS, 2010, p. 48).

${ }^{13}$ Sigla em espanhol Central Única de Trabajadores.
} 
âmbito interno como nos intercâmbios internacionais (SOMS, 2010). Esse ímpeto planejador, por sua vez, também será refletido em uma maior dotação das ORPLAN: das oito secretarias regionais criadas no governo de Frei Montalva (Arica, Iquique, Maule, Biobío, Cautín, Valdivia-Osorno, Los Canales e Magallanes), passou-se a contar com dezessete ORPPLAN (Antofagasta, Atacama, Coquimbo, Aconcagua, Valparaíso, Santiago, O’Higgins, Colchagua e Aysén)(SOMS, 2010). Segundo Soms:

Las Oficinas Regionales de ODEPLAN, vieron fortalecidas sus atribuciones en materia de planificación y gestión del desarrollo, así como su influencia en las decisiones regionales de corto plazo. Es importante recordar, en este sentido, que además de los Intendentes, los únicos funcionarios en regiones de la confianza exclusiva del Presidente eran los Directores de ORPLAN, lo que los colocaba como primus inter pares, respecto al resto de las autoridades regionales (SOMS, 2010, p. 51).

É importante desatacar o desígnio de primus interpares, o primeiro entre iguais, uma distinção de caráter hierárquico na esfera da autoridade e o poder político exercido pelas autoridades regionais, neste caso, pelos diretores das ORPLAN que iriam representar o Presidente da República no território regional. Com efeito, assim como na ODEPLAN a nível nacional, os diretores regionais das ORPLAN passam a representar diretamente ao Presidente da República, o qual, perfilava incipientemente em uma estrutura de governo regional desconcentrado, que coordenava as tarefas econômicas e sociais estratégicas, já seja nos comitês de investimentos ou nos conselhos regionais e outras formas de participação territorial onde se reconhecia a representação política dos operários de todo o país. Contudo, durante o governo de Salvador Allende, o desenvolvimento regional foi aprofundado através da coordenação de uma extensa rede de planos e programas de desenvolvimento a nível nacional, setorial e regional, todas múltiplas experiências e aprendizados que finalmente implicaram uma maior influência da ODEPLAN no governo. Essa maior influência radicou especialmente na propriedade dos meios de produção e nas contas nacionais e nos diferentes projetos de interesses regionais e locais. Porém, a partir do Golpe de Estado de 1973, essas múltiplas experiências regionalistas encaminhadas pelo Estado foram intervindas de maneira supressiva e violenta. A estratégia espacial da UP de 1972, assim, não conseguiu ser impulsionada nas políticas públicas, ficando apenas como um estudo de difícil aceso no arquivo da memória do país. Uma forte inflação, somada ao forte clima de polarização e conflito de classes, alterou profundamente o programa regional sem poder ser executado em sua totalidade. No entanto, as experiências territoriais da Unidade Popular foram fundamentais e cheias de significações, embora foram abruptamente interruptas pela reação autoritária. 


\subsection{Geografia dos Estados Maiores, crise social e representação nacional}

Não existem repostas únicas nem totalmente rigorosas para explicar a profunda violência perpetrada a partir do Golpe de Estado do 11 de setembro de 1973. Trata-se de uma mudança radical da tradição que, até 1973, caracterizava o Chile como um Parlamento forte e amplo, composto de partidos de esquerda a direita e, certamente, alheio ao uso da violência militar característica da América Latina (VALENZUELA, 2016). O governo da UP enfrentou múltiplas dificuldades e conturbações políticas, inéditas até então. Mesmo antes que Salvador Allende fosse ratificado Presidente do Chile pelo Congresso, um grupo de extrema direita tentou sequestrar ao General Comandante em Chefe do Exército, René Schneider, ferindo-o de morte o 25 de Outubro de 1970. Esse episodio terminou com a vida do general Schneider e marcou o início e a intensificação dos grupos de extrema direita que articulariam uma agenda de boicote que torpedearia cada uma das medidas da $\mathrm{UP}^{14}$.

O período da Unidade Popular, assim, foi uma intensa experiência de politização e movimentações institucionais. Embora se multiplicaram avanços, como a nacionalização da grande mineração do cobre em $1971^{15}$, o governo de Allende assegurou um papel ativo do Estado nas relações de produção e, por consequência, na incipiente projeção dos espaços regionais (SOMS, 2010). Entre 1971 e 1973 a reforma agraria dirigida pela UP conseguiu a expropriação de mais de 4.400 prédios, alcançando uma superfície de 6,4 milhões de hectares (BEDRACK, 1974). Dessa maneira, o governo de Allende favoreceu a mais de 500 mil camponeses e passou a ser o maior governo expropriador de proprietário de terra da história do Chile (OLEA, 2016). Nas áreas urbanas, os partidos políticos da UP junto com um importante coletivo de movimentos de moradores, operários e partidos inspirados na revolução cubana como o Movimiento de Izquierda Revolucionaria (MIR), disputariam e recriariam diferentes formas de controle da propriedade na emergência de um poder popular e tipos de apropriação social onde se puseram em questão a ordem espacial hegemônica ${ }^{16}$

\footnotetext{
${ }^{14}$ Só na primeira semana de agosto de 1972 se contabilizaram mais de quarenta atentados de diverso tipo de explosivos e dinamitas, "afectando líneas férreas y puentes, postes eléctricos, oleoductos y gaseoductos, buses de pasajeros de Vía Sur y de la Empresa de Transportes Colectivos del Estados, industrias e instituciones públicas, casas particulares, bombas bencineras y caminos en el trabajo" (MOLINA, 1989, p. 173).

${ }^{15}$ A nacionalização significou uma importante arrecadação de fundos para a ativação do programa da UP e também acelerou a nacionalização de outros minerais, tais como o ferro, o salitre, o iodo e o carvão. A votação foi aprovada por unanimidade, todos os partidos políticos chilenos, de direita a esquerda, definiram que o cobre era para Chile e as chilenas e chilenos.

${ }^{16}$ Dois exemplos importantes da legitimação do processo político liderado pela UP foram o movimento popular de moradia e os cordoes industriais de operários. Ambos movimentos tiveram importantes avances organizativos, os quais, por um lado, trouxe disputas com o próprio governo da UP, mas, por outro,
} 
(MOREIRA, 2011; CORTÉS, 2018). O governo da UP expressou assim uma ampla aliança política e social de diversos movimentos sociais (camponeses, moradores, universitários, operários, etc.), grupos profissionais ilustrados e uma importante politização de setores populares que participaria nas primeiras linhas das esferas governamentais.

A forte legitimidade do poder presidencial representado em Salvador Allende correspondia a uma correlação de forças inédita que, até essa manhã do 11 de setembro, era respeitada por uma tradição militar herdeira de sua função profissional e subordinada às leis democráticas refletidas na pluralidade de partidos políticos no Parlamento (HUNEEUS, 2016). O que essencialmente inaugura o Golpe de Estado, assim, não foi apenas a destruição do governo popular, mas sim uma inversão radical entre o tecido social dos partidos políticos e a sociedade chilena que, desde diversos projetos ideológicos, vinha sendo mobilizada por agências democráticas. A violência contra as representações de esquerda e os direitos políticos conquistados pelo movimento social chileno espalhou-se rapidamente através de diferentes práticas e símbolos, como o ataque aéreo ao Palácio de Governo e a transformação do Estádio Nacional em centro multitudinário de detenções políticas, entre muitos outros. Segundo Huneeus (2016), uma das características fundamentais do período foi a identidade coercitiva aplicada de forma permanente ao longo do período do regime (1973-1990). Essa lógica de Estado Policial foi refletida através da criação de aparelhos de inteligência e a perseguição sistemática das forças políticas opositoras ${ }^{17}$. Uma segunda caraterística do regime chileno foi a concentração absoluta do poder do general Augusto Pinochet, que gradativamente foi galgando posições de chefia máxima ${ }^{18}$. Um elemento fundamental que também explica a configuração econômica do país nas sucessivas etapas da ditadura e suas estruturas políticas antidemocráticas. A partir desses diferentes dispositivos de controle e coerção sobre a população e as representações da esquerda, o Golpe de Estado se constituiu num projeto hegemônico destinado a transformar a base material e subjetiva do Chile.

significou uma pesada perseguição contra suas lideranças uma vez ativado o Golpe de Estado (CORTÉS, 2018; GAUDICHAUD, 2016).

${ }^{17}$ No início do regime se destacou a Dirección de Inteligencia Nacional (DINA) e posteriormente foi a Central Nacional de Inteligencia (CNI).

${ }^{18}$ Pinochet concentrou a máxima autoridade ao longo do período autoritário. Imediatamente após o Golpe foi eleito presidente da Junta de Governo, e posteriormente, em dezembro de 1974, foi nomeado Presidente da República e Chefe de Estado da Nação, além de seguir sendo Comandante-Chefe do Exército até 1995, ou seja, cinco anos após do termino do regime autoritário Uma situação inédita considerando as outras experiências na região, onde existiu uma rotativa da representação política e executiva pelos próprios militares e civis afines (HUNEEUS, 2016). 
Em termos operativos o Golpe de Estado foi uma coordenação das três FF.AA. do Chile e a Polícia Nacional Uniformizada (Carabineros de Chile), sendo comandado por Augusto Pinochet Ugarte como comandante em chefe do Exército, José Toribio Merino no comando da Marinha (Armada de Chile), Gustavo Leigh Guzmán na comandância da Força Aérea de Chile (FACH), em conjunto com Cesar Mendoza Durán, diretor general de Carabineros de Chile. O Golpe foi um movimento organizado pelo alto mando militar do país, sem maiores resistências internas na alta oficialidade (FAJARDO, 2012) ${ }^{19}$. Aliás, contou com a ajuda de grupos civis de extrema direita e o beneplácito do governo dos Estados Unidos e seus agentes da CIA que, antes da insurreição, alentaram e financiaram diversas ações para instabilizar o governo da UP (HUNEEUS, 2016; VERDUGO, 2004). A Junta de Governo militar internalizou assim rapidamente um nacionalismo corporativo (NETO, 2019) no sentido de uma integração conservadora do social com o nacional e a necessidade de manter uma determinada ordem econômica que instrumentalizou a representação do nacional como projeto de poder hegemônico que, a curto e longo prazo, favoreceu a um pequeno grupo de poder.

No dia do Golpe, o palácio de governo do Chile, La Moneda, foi bombardeado por aviões Hawker Hunter que romperam e incendiaram boa parte das instalações, e o próprio Presidente Allende veio a falecer em seu interior. Por sua vez, as pequenas resistências nos setores industriais e comunidades ligadas ao projeto da UP rapidamente foram sufocadas e ocupadas por comandos militares e policiais, os quais não só procederam ao controle das moradias e recintos, mas também deram início a uma pesada repressão e vigilância permanente sobre as organizações de esquerda e seus simpatizantes. Esse caráter repressivo naturalizou o uso da violência e a doutrina de Segurança Nacional no interior das FF.AA., instrumentalizando a definição de Estado de guerra contra o inimigo interno. Até o dia do Golpe de Estado, a influência da doutrina de Segurança Nacional haveria penetrado relativamente no interior das FF.AA., não sendo totalmente incorporada na formação militar oficial. Isto explica a forçada saída do anterior general em Chefe do Exército, pouco antes do Golpe, o general Carlos Prats, quem foi Ministro do Interior e Ministro de Defesa durante

\footnotetext{
${ }^{19}$ Embora o Golpe foi dirigido pelo Alto Mando, durante os primeiros meses após existiram pesadas perseguições no interior das FF.AA., especialmente contra aqueles oficiais que participaram no governo da UP. O livro Contra Bachelet y otros. Los militares que se opusieron al Golpe (Quimantú, 2012), do jornalista Marco Fajardo mostra esse processo.
} 
o período da UP pela solicitude de Allende ${ }^{20}$. Prats assumiu a comandância do Exército após o assassinato do general Schneider e, desde o primeiro dia em seu cargo, foi publicamente respeitoso da Constituição e da subordinação dos militares ao regime democrático. Um ano depois do Golpe, em 30 de setembro de 1974, junto com sua esposa Sofia Cuthbert, foi assassinado por agentes da inteligência chilena em Buenos Aires. Essa violência impulsionada ao interior das próprias filas militares, dirigida a uns dos máximos referentes militares da instituição ${ }^{21}$ (PEÑA, 2015), marcou a negação da tradição constitucionalista do Exército e as FF.AA. chilenas. A doutrina de Segurança Nacional por um lado, permitia que os militares tivessem "legitimidad para tomar parte en el proceso politico interno de cada país” (FAJARDO, 2012, p. 35). Mas, por outro, fundamentava e profissionalizava a política coercitiva de seus métodos repressivos ${ }^{22}$. Com a acensão do Golpe se ampliou o movimento reacionário e punitivo ao interior da formação nas FF.AA. do Chile, como bem fica refletido no terceiro aniversário do Golpe de Estado e as palavras do Pinochet:

El marxismo no es una doctrina simplemente equivocada, como ha habido tantas en la historia. No. El marxismo es una doctrina intrínsecamente perversa, lo que significa que todo lo que de ella brota, por sano que se presente en apariencias, está carcomido por el veneno que corroe su raíz. Eso es lo que quiere decir que su error sea intrínseco y, por eso mismo, global, en términos que no cabe con él ningún diálogo o transacción posible (PINOCHET, 1976, p. 2)

Essa inusitada violência reacionária tentou ser fundamentada a partir de uma suposta guerra civil incipiente que, entre outras coisas, devia desarticular um Exército Popular Revolucionário de mais de 15 mil homens, entre eles, cubanos e brasileiros treinados e apoiados logisticamente pela URSS. O denominado Plan Z, segundo os golpistas, seria um plano secreto para a posse militarizada do poder no Chile para impor um governo marxista de corte totalitário. Décadas mais tarde, os próprios documentos desqualificados da CIA mostraram que nunca existiu nem o plano nem os guerrilheiros (VERDUGO, 2004), sendo uma das múltiplas manobras midiáticas das autoridades para justificar a violência e a vulneração de direitos aos quadros e simpatizantes da UP (HUNEEUS, 2016). No entanto, o uso sistemático e desproporcional da violência contra os militantes da esquerda ao longo

\footnotetext{
${ }^{20}$ Pouco tempo após do Golpe, Prats retrata a figura do Pinochet da seguinte maneira: "La niebla se extendió sobre el campamento y la bestia, que dormita en lo intimo del ser civilizado, despertó súbitamente con frenética avidez de víctimas, ante las incitaciones interesadas, voceadas desde la sombra por los instigadores de siempre" (PEÑA, 2015, p. 21).

${ }^{21}$ Diferentes fontes e arquivos mostram a condição inata de líder do general Prats no comando do Exército (ARANCIBIA, BALART, 2006; PEÑA, 2015). Com uma brilhante carreira militar, a melhor qualificação de sua geração, professor da Academia de Guerra, tinha uma presencia simbólica muito importante na instituição.

${ }^{22}$ Segundo Fajardo ditos métodos de repressão anticomunista se baseavam na tradição militar francesa (FAJARDO, 2012).
} 
do período, criou dois efeitos de diversa conotação política. Em primeiro lugar, existiu uma desaprovação e oposição internacional a partir de organismos ligados na defesa dos direitos humanos e outros governos ocidentais, como França e Alemanha oriental, ativando-se ações diplomáticas contra o regime pela desaparição de cidadãos estrangeiros no Chile. Em segundo lugar, a raiz da pesada violência, também se produz uma resposta político-militar dos setores da esquerda, uma vez reconfiguradas as posições de clandestinidade e o trabalho de massas na década seguinte, especialmente com a rearticulação do Movimento de Esquerda Revolucionária (MIR) e a criação do Frente Patriótico Manuel Rodriguez (FPMR), aparelho militar do Partido Comunista do Chile (PCCH). Ambas estruturas destinadas a desestabilizar o regime autoritário mediante ações diretas que incluíram a execução de agentes militares, assaltos de bancos, sequestros, tomas parciais de rádios, atentados contra a infraestrutura pública e enfrentamentos com as polícias repressivas, entre outras. Todas essas ações evidenciaram importantes contradições do modelo social de mercado e questionariam a legitimidade do regime ${ }^{23}$. Não obstante, contraditoriamente, também acabaram sendo o principal argumento de Pinochet para concentrar e manter o controle político autoritário até o final do período. Segundo Guillermo O’Donell (1984), a forte repressão sobre os partidos da esquerda chilena tinha uma explicação estrutural diferente da realidade dos partidos na Argentina e no Brasil:

En Chile, donde la sociedad política ocupaba el gran espacio que nunca ocupó en Brasil ni en Argentina, los partidos eran los articuladores de la sociedad, a la que realmente representaban, como sus mediadores y generalizadores, en la escena política y en el aparato estatal. En esa sociedad intensamente politizada, fue por los caminos de la institucionalidad de esos partidos, y del régimen por ellos formado, que la izquierda llegó a controlar parte del aparato estatal. Esto dibujó los principales blancos contra los que se dirigió la represión a partir del golpe de 1973 en Chile: el personal de la izquierda en el gobierno, los partidos de izquierda, y el denso tejido de organizaciones populares (incluso sindicales) que estaba, casi literalmente, "afiliado" a esos partidos. Así, porque la amenaza al "orden establecido", mediada por la franja izquierda de la sociedad política, recorría verticalmente esa formación social, la represión en Chile tuvo -con lógica perversa pero no ilógica que tienen estas cosas- no solo la brutalidad sino también la extensión que tuvo (O’DONELL, 1984, p. 32).

Como resultado da permanente repressão e das múltiplas violações aos direitos humanos, ao mesmo tempo se criaram outras dinâmicas, como a sensação de terror, que não se limitava às organizações ou direções políticas da oposição e atingia ao conjunto da sociedade chilena, cada vez mais espoliada de seus direitos e liberdades. Um reflexo

\footnotetext{
${ }^{23} \mathrm{Um}$ estudo a fundo desse processo pode se encontrar em ROJAS, Luis. De la revelación popular a la sublevación imaginada. Antecedentes de la Historia Política y Militar del Partido Comunista de Chile y del FPMR 1973-1990. Santiago: LOM, 2017.
} 
importante dessa violência estrutural foi o desenho de um regime político com baixos níveis de institucionalização e uma estrutura decisória altamente centralizada na figura do general Pinochet: Presidente da República, Presidente da Junta de Governo e Comandante em Chefe do Exército. Ambos fatores, o terror e a concentração do poder em Pinochet, favoreceram um tipo de poder arbitral de Pinochet no exercício de deliberação e resolução da Junta e o Governo, "haciéndose indispensable su permanencia en la jefatura del Estado para la continuidad del régimen y de sus políticas" (HUNEEUS, 2016, p. 93). No entanto, diferente de um regime estritamente totalitário em que o poder se concentra e aplica sem limitações, Pinochet teve que lidar com as outras FF.AA. que mantiveram sua autonomia, a Junta de Governo que tinha que aprovar suas leis e decretos por unanimidade, e, finalmente, com a Constituição de 1980 que elaborou um mecanismo e prazos de saída para o regime autoritário: o plebiscito de 1988. Como destaca o historiador Manuel Domingos Neto em torno ao poder corporativo das FF.AA.:

A segmentação entre o "social" e o "nacional" amesquinha demandas dos "de baixo" que os "de cima" não querem atender. Lutar pelo "interesse nacional" separadamente do "interesse social" é uma manobra para imprimir respeitabilidade aos desígnios dos que detêm ou querem deter a hegemonia no Estado, entre os quais se destaca o estamento militar. Este procedimento lastreia o "nacionalismo corporativo" (NETO, 2019, p. 29).

Se durante as décadas de 1930-1970 a política no Chile poderia ser associada a mudanças sociais e demandas populares, sendo uma fonte importante de legitimidade da ação social coletiva e politizada, inversamente, após o Golpe de Estado de 1973, a política foi ativada e disciplinada negativamente, sendo sinônimo de mesquinho, apátrida ou subversivo. Esse profundo processo de despolitização determinou que as tradicionais representações do campo político se deslocassem para outros tipos de legitimação, baseada na suposta neutralidade do técnico, do científico e a representação dos interesses nacionais e gremiais, principiados na segurança nacional e na subsidiariedade do Estado (GOBIERNO DE CHILE, 1974a). Legitimação cientifica-tecnológica, por um lado, e segurança nacional e subsidiariedade, por outro, serão parte dos elementos fundacionais da enquistada agência da regionalização e o novo ciclo de transformações estruturais dos seguintes anos. Tratava-se de uma visão conservadora e restritiva da política que, implicitamente, fazia das unidades territoriais uns labirintos destinados a romper com os antigos laços e redes políticas das esquerdas, mas sobretudo, montar uma estrutura estatal territorial com redes técnicas e políticas a favor do governo central. O processo de regionalização, assim, nasce e emerge em meio a uma profunda crise social e de representação do nacional. 
Quando se anunciou oficialmente o começo da reforma administrativa e a criação da CONARA, mês de dezembro de 1973, paralelamente, a esquerda passava dramaticamente à clandestinidade, sendo suas principais lideranças presas e torturadas, quando não executados em vertiginosos julgamentos de guerra. Essas encruzilhadas inversas, violentas, radicalmente opostas na condução econômica e política do país, implicitamente também foram inseridas na fundamentação da regionalização. A possibilidade de criar uma ordem regional rapidamente foi-se espalhando como uma representação diferente da questão social e política do período anterior, bem como uma questão nacional estratégica além de qualquer interesse político partidário. No jornal El Mercurio do 5 de dezembro de 1973, por exemplo, se apresentava uma extensa editorial ligada aos fundamentos e razões objetivos da regionalização: longitude do território, diversidade climática, cultural e produtiva, histórico centralismo, etc. Mas também, trata-se de criticar a escassa preocupação regional impulsionada pela UP: "La culminación del abandono de las provincias tuvo lugar precisamente cuando los partidos marxista-leninistas pusieron en marcha el fatal proyecto de economía centralmente planificada, cuyo fracaso impone boy pesadísimos sacrificios a todos los sectores de la nación" (EL MERCURIO, 5 dezembro 1973).

Esse pensamento reacionário contra a UP, entendida com uma força contrária ao processo da descentralização e à regionalização, foi uma marca permanente do período e se conectaria estruturalmente com uma explicita geografia dos Estados Maiores. Como diria o general Canessa, máxima chefia da primeira etapa da divisão territorial: "nuestro proceso de Regionalización, no es una mera división geográfica del país, sino que obedece a definidos objetivos geopolíticos" (CANESSA, 1982, p. 21). A geopolítica foi uma estratégia e prática militar que acompanharia permanentemente a validação do conjunto de fronteiras interna, condicionando de maneira estrutural o fundamento da distribuição do poder territorial regionalizado: um comando centro-periferia em cada uma das regiões posto em jogo a partir do conjunto das autoridades políticas e funções públicas verticalizadas. Dessa maneira, se permitia projetar um sentido de unidade nacional, reconhecendo as configurações políticas internas do Estado e o território enquanto funções públicas, além de afirmar um tipo de governo estratégico capaz de distinguir os assuntos domésticos versus os assuntos da grande política. Esses assuntos sempre estariam ligados a um poder central e a objetivos estratégicos de longo prazo, em contrapartida dos assuntos domésticos de administração que, via regionalização, seriam reforçados com uma maior velocidade do Estado frente às necessidades das comunidades de unidades inferiores. A regionalização assim deveria corrigir as históricas desigualdades 
geográficas, procurando a integração expressada na configuração soberania, defesa e segurança nacional (CANESSA, 1982).

Em dezembro de 1973 altas patentes do regime se reuniram com representantes empresariais e discutiram sobre uma possível estrutura regional de governo em termos de participação e estruturas do mesmo. Teoricamente, a possibilidade de encaminhar uma regionalização projetava um mecanismo institucional que permitiria sair do enraizado centralismo e ativar grupos empresariais que fariam uma genuína representação da comunidade com o governo, pois seriam entendidos como corporações livres e expressões democráticas (LA TERCERA DE LA HORA, 4 dezembro 1973). Em outras palavras, a regionalização tecnicamente permitiria abrir espaços de participação da comunidade em todo o território nacional, mas sem os partidos políticos, acusados de mesquinhos, apátridas e não patriotas. Por sua vez, a imprensa da época destacava que os grêmios afins conduziriam as políticas específicas de cada território subnacional, superando executivamente as "desordens" administrativo-burocráticas e o escasso poder resolutivo das entidades estatais provinciais antes do Golpe. A identidade empresarial, por consequência, rapidamente passava a ser fonte de mobilização transversal do regional e a coordenação regional. Entre os diversos grupos sociais em um território comum, se projetaria como independente da classe social, o poder econômico ou a orientação política, um processo supostamente inverso à divisão ou viés ideológico próprio do período da UP (EL MERCURIO, 12 dezembro 1973). Como destacava a nota do jornal El Mercurio de dezembro de 1973:

\footnotetext{
Los comandos multigremiales son estructuras de coordinación integradas por gran parte de organizaciones existentes a nivel provincial y zonal sin distinción de situación socio-económica y con prescindencia absoluta de cualquier tipo de contingencias que tienden a dividir a los chilenos. En estas organizaciones junto al empresario está el obrero, el campesino, todos los trabajadores unidos en torno a valores y metas comunes [...] Están unidos entre sí por una estructura de coordinación y no por una directiva nacional, para evitar caer así nuevamente en el centralismo que elimina las condiciones logradas en las distintas provincias y regiones y como una forma de impedir el personalismo y las ambiciones que llevará a la destrucción de estas organizaciones de hombres de trabajo en busca del desarrollo y el bien común (EL MERCURIO, 12 dezembro 1973).
}

A singularidade dos comandos multigremiais empresariais fundamentava-se não apenas por sua lógica descentralizada, mas, sobretudo, pela estrutura comunitária sem partidos e a recriação de um tipo de participação em terreno (cotidiano) que prescindia de identidades de classe ou instituições tradicionalmente políticas como o Parlamento. No 
entanto, embora os comandos multigremiais ${ }^{24}$ pudessem se integrar ao conjunto da comunidade local e as estruturas técnicas do planejamento, na prática, esses mecanismos sempre deviam estar subalternizados ao poder da hierarquia política militar definida pela Junta de Governo e o estratagema definido pela CONARA. O poder político da regionalização do período autoritário, assim, será comandado estritamente pela presença das FF.AA. e, por consequência, será a projeção definida pela CONARA e a supervisão do general Pinochet e a Junta de Governo. Como destaca a revista Ercilla em 1976:

CONARA - aunque se define como un organismo meramente asesor - ha pasado a constituirse en la "eminencia gris" en el manejo de la administración interna. Sus proposiciones son presentadas a la Junta de Gobierno para que ésta resuelva. Y no es que no tenga oponentes: para decidir en cuántas regiones podría dividirse el país se presentaron a consideración del Gobierno tres alternativas (ERCILLA, 14 janeiro 1976)

Um elemento interessante da regionalização foi que a direção executiva da CONARA foi composta por oficiais próximos ao general Pinochet e membros do Estado Maior do Exército do Chile (imagem $n^{\circ}$ 3). Essa representação militar de altas hierarquias militares também se manifestou nas cabeceiras regionais e provinciais, as quais efetivamente serão dirigidas e vigiadas exclusivamente pelos oficiais das Forças Armadas quase durante todo o período autoritário ${ }^{25}$ (HUNEEUS, 2016). Essa lógica fechada de representação militar no poder estatal territorial, por sua vez, também explica a sistemática cobertura midiática das autoridades militares nos assuntos territoriais e a própria emergência da figura do General Pinochet como principal liderança do processo de regionalização: "Cada paso se lo explicaba a mi general que me daba nuevas orientaciones" (ARANCIBIA, BALART, 2006, p. 211), confessa em seu livro de entrevista a fundo, o general Canessa, máxima chefia da CONARA e rapidamente ascendido a general entre 1973 a 1974. Essa conexão orgânica do processo de regionalização com o general Pinochet também é confirmada pelo geógrafo Dionisio Vio, assessor do Departamento de Regionalização e membro de CONARA entre 1973 e 1981. Segundo Vio, o trabalho comandado pela CONARA era diretamente apresentado a Pinochet e só uma vez obtido seu visto bom, posteriormente era levado à Junta e às outras autoridades (ENTREVISTA DIONISIO VIO, dezembro 2019). Dessa forma, os estudos da CONARA funcionavam, em primeiro lugar, como uma assessoria de Estado Maior vigiada e dirigida pelo próprio general Pinochet, quem procedia a intervir e reconhecer os recortes territoriais em detalhe, marcando e discutindo, inclusive, as próprias linhas imaginarias dos mapas

\footnotetext{
${ }^{24}$ Também chamados Consejos Civicos Multigremiales (EL MERCURIO, 12 de dezembro de 1973).

${ }^{25}$ Somente após o plebiscito de 1988 a direção política das regiões e províncias teve uma relativa presencia de civis.
} 
(ENTREVISTA DIONISIO VIO, dezembro 2019). Em 1978, o comandante Alejandro Gonzalez Samohod era consultado pela lógica militar na resolução dos assuntos na regionalização, primordialmente na hierarquia e presença dos militares. Segundo ele, apesar da presença de oficiais na regionalização, acima de tudo, CONARA era:

[...] un organismo participativo. Lo que ocurre es que se aplica un concepto de Estado Mayor: para poder decidir hay que conocer previamente la situación, mediante un análisis procesado que compatibilice debidamente las diversas alternativas o cauces de acción, que puedan ser diferentes. Entonces se proponen soluciones. En el caso de la Regionalización, después de conjugar criterios se han pasado todos los antecedentes por un primer cedazo interno y la instancia final corresponde al Presidente de la República (ULTIMAS NOTICIAS, 2 abril 1978)

Segundo Vio, Pinochet tinha um grande conhecimento geográfico do Norte e do Altiplano em termos da Guerra do Pacífico. Uma informação que também é reforçada pelo historiador Cristián Garay quem afirma que "Pinochet era más de geografía militar que geopolítica. El fue el que hizo el primer mapa de la geografía de Perú y Bolivia. Y ese era un libro importante: es el libro con el que hacían los juegos de guerra" (ENTREVISTA CRISTIÁN GARAY, junho 2016). Aliás, seguindo o relato de Vio, existia uma casualidade significativa entre a regionalização e o comandante em chefe do Exército, pois, justamente o general era a referência da geografia e a geopolítica no interior do Exército. Dessa maneira a discussão dos termos territoriais da regionalização era um assunto de genuína empolgação e maior interesse, ao contrário dos diversos problemas e crises do governo como o abastecimento, a economia e a oposição política ao regime (ENTREVISTA DIONISIO VIO, dezembro 2019). Para Pinochet e as máximas autoridades do regime, a regionalização era um assunto de alto interesse, aberto a inovações e, sobretudo, sensível da tradição geopolítica dos militares (BOISIER, 2000). 


\section{Imagem $n^{\circ}$ 3. Estrutura hierárquica da CONARA}

PRESIDENCIA, VICEPRESIDENCIA Y JEFATURA DE DEPARTAMENTOS

DE LA COMISION NACIONAL DE LA REFORMA ADMINISTRATIVA
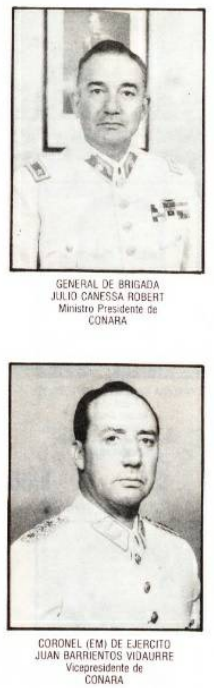

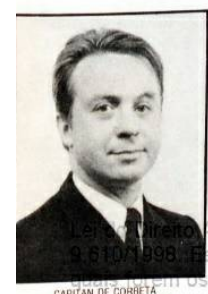

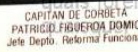

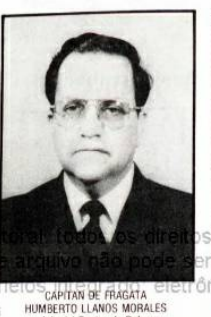

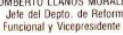

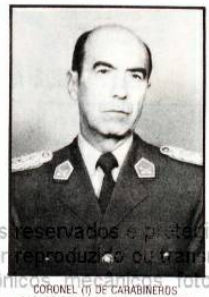

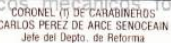

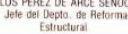

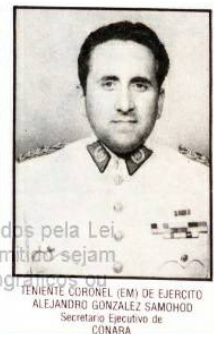

Fonte: CONARA, 1976.

A CONARA rapidamente legitimou essa hegemonia militar do processo e revisitou um importante número de documentos e estudos preexistentes, percorrendo o país através de terrenos que iriam sendo retroalimentados com relatórios das respetivas autoridades territoriais e instituições publicas do país - Instituto Nacional de Estatísticas (INE), Instituto Geográfico Militar (IGM), entre outros -. Segundo Vio, “habia regiones más ágiles para enviar los informes, mejores dotadas. De todos estos informes se preocupaba la gente de ODEPLAN" (ENTREVISTA DIONISIO VIO, dezembro 2019). Se bem o exercício de regionalizar era uma tarefa dirigida pela CONARA, o desenho interno de seu funcionamento contava com a participação significativa da ODEPLAN que, como vimos anteriormente, tinha sido a principal instituição encarregada de levar à diante o desenvolvimento regional no interior do Estado. Nesse sentido, a rapidez do processo de regionalização do regime deveu-se ao produto da sólida base institucional criada entre 1966-1970 pela antiga administração de Frei Montalva e ao partido da Democracia Cristã (DC) (ENTREVISTA DIONISIO VIO, 
dezembro 2019). Daí que uma importante colaboração de profissionais ligados à DC, após do Golpe de Estado, participou ativamente nas equipes da ODEPLAN e na CONARA. Como destaca o coronel em retiro de Exército e secretario executivo da CONARA entre 1980-1982, Luis Alfonso Rivas, em relação aos avanços da etapa anterior:

Los estudios fueron muy bien hechos. Esa fue la razón que cuando comenzó la regionalización en 1974, esa gente, entre varios otros, fue la que nos asesoró, además de expertos internacionales contratados con recursos provenientes del Convenio PNUD-CONARA [...] De hecho, en el Departamento de Reforma Estructural de CONARA había muchos personas o asesores que fueron militantes de la democracia cristiana y que habían trabajado en estos temas en ODEPLAN durante el gobierno de Frei. Entre ellos, puedo citar a don Arturo Aylwin (ENTREVISTA LUIS ALFONSO RIVAS, 14 novembro 2019).

A citação do irmão do, por aquele momento, Presidente da DC, será reiterativa nos estudos e avanços do processo como veremos mais adiante. A ODEPLAN será coprodutora do processo de regionalização e teve um papel estratégico no desenvolvimento das políticas econômicas da Junta de Governo e na consulta da CONARA nos diversos caminhos técnicos da regionalização e suas unidades operativas (CONARA, 1976). Na lógica de coordenação dos membros da Junta de Governo, na ODEPLAN se estabeleceram dois conselhos de ministros dependentes de dois membros da Junta: o Comitê Econômico com responsabilidade no almirante José Toríbio Merino (Marinha) e o Comitê Social dirigido pelo general Gustavo Leigh (Força Aérea). Para ambas instâncias a ODEPLAN apoiava seus desenvolvimentos como uma assessoria técnica (SOMS, 2010). O economista Sergio Boisier conta que, pouco depois do Golpe, Kelly mandou pedir seus serviços para trabalhar uma proposta de regionalização:

Y entonces, había que ser muy cuidadoso con esas respuestas. Yo dije que estimaba mucho la oferta pero que no estaba en condiciones de aceptarla porque tenía perspectivas, destinaciones al exterior. Pero que no tenía inconveniente en participar en la preparación de algún documento básico para la regionalización. Bueno, y sí, estuve tal vez dos meses, no recuerdo bien. Mi propósito era otro completamente distinto: utilizar un cierto poder intelectual que yo tenía para ayudar y salvar a funcionarios que habían trabajado conmigo y eran de izquierda que, algunos los mataron, los asesinaron simplemente (ENTREVISTA SERGIO BOISIER, abril 2017).

Poucas semanas após ao Golpe, dois altos funcionários de ODEPLAN em províncias foram executados. Se tratou do engenheiro comercial e militante do PS, Winston Cabellos (28 anos), diretor da ORPLAN de Atacama ${ }^{26}$ e o geógrafo e militante do PS, Freddy

\footnotetext{
${ }^{26}$ Foi retenido o dia 12 de setembro de 1973, sendo confinado no Regimento de Copiapó. Foi executado pela comitiva do General Arellano Stark encarregado por Pinochet para agilizar os processos contra as
} 
Taberna $^{27}$ (30 anos), diretor da ORPLAN de Iquique. A violência estrutural do Golpe se encarnava no incipiente escopo regional e seus jovens funcionários. Eram execuções que tentavam desestruturar qualquer tipo de resistência ao Golpe de Estado, criando um clima de guerra que desmobilizaria tentativas de organização política em oposição ao regime. Nessa paisagem de guerra, assim, entre setembro e novembro de 1973, Boisier junto com uma equipe técnica da ODEPLAN, elaborou uma proposta de regionalização. O trabalho se intitulou Restauración nacional y desarrollo regional. Bases para una política, e haveria sido entregue pelo próprio Boisier ao Ministro Diretor, o almirante Roberto Kelly, apenas uns meses após do Golpe (1973). Segundo Boisier, aqui estariam as bases das agudas semelhanças entre a regionalização da ODEPLAN de 1968 e a regionalização da CONARA e seu particular Manifiesto por la Regionalización, assinado pelo próprio Pinochet em julho de 1974. No entanto, em fevereiro de 1974, diferentes jornais faziam reportagens dos estudos feitos e incorporados pela CONARA, onde se anunciava que a regionalização seria cristalizada em onze regiões (EL MERCURIO, 18 Fevereiro 1974; LA TERCERA DE LA HORA, 20 Fevereiro 1974).

\section{Imagem $n^{\circ} 4$. As onze regiões}

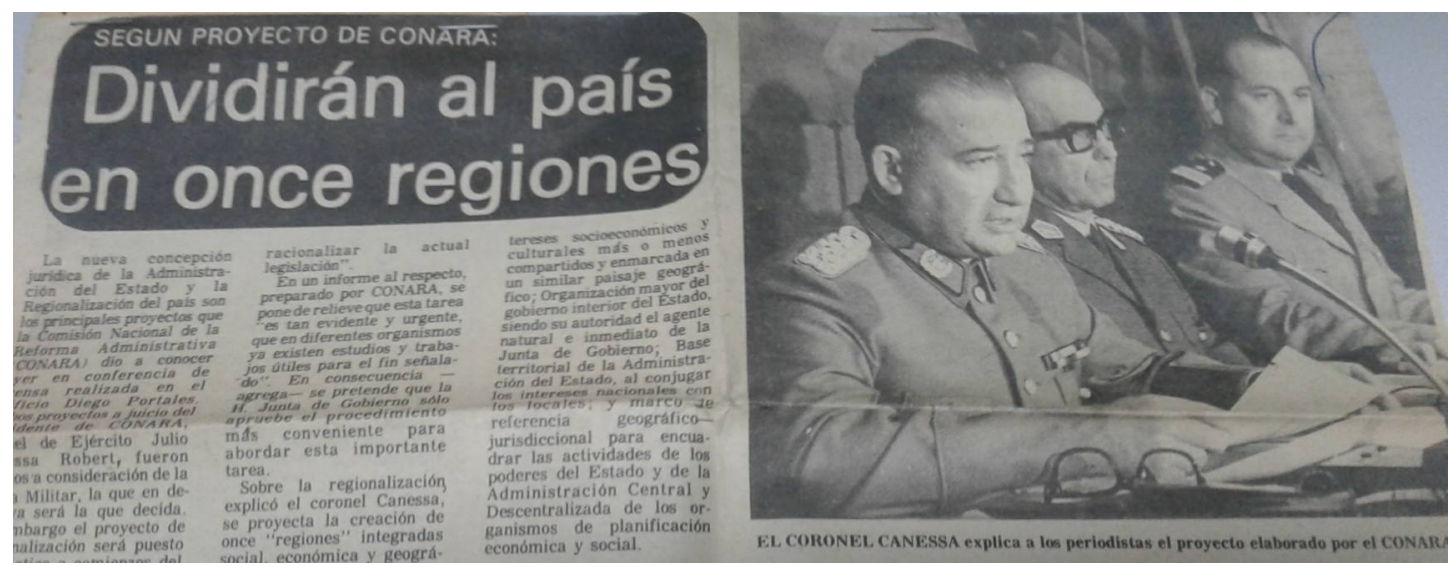

militâncias da UP, a famosa "Caravana de la muerte", que percorreu o país durante o mês de outubro deixando um saldo de 97 vítimas fatais. Seu corpo foi encontrado o 27 de julho de 1990 (SOMS, 2010).

${ }^{27}$ Freddy Taberna oficialmente foi detido o 16 de setembro de 1973 e seu corpo ainda não é encontrado. Em homenagem seu amigo e vizinho, o arqueólogo e Premio Nacional de História (2002), Lautaro Nuñez, escreveu o emocionante livro "Avísale, Freddy. Historia de un hombre y sus razones (1943-1973)" (LOM, 2015). 


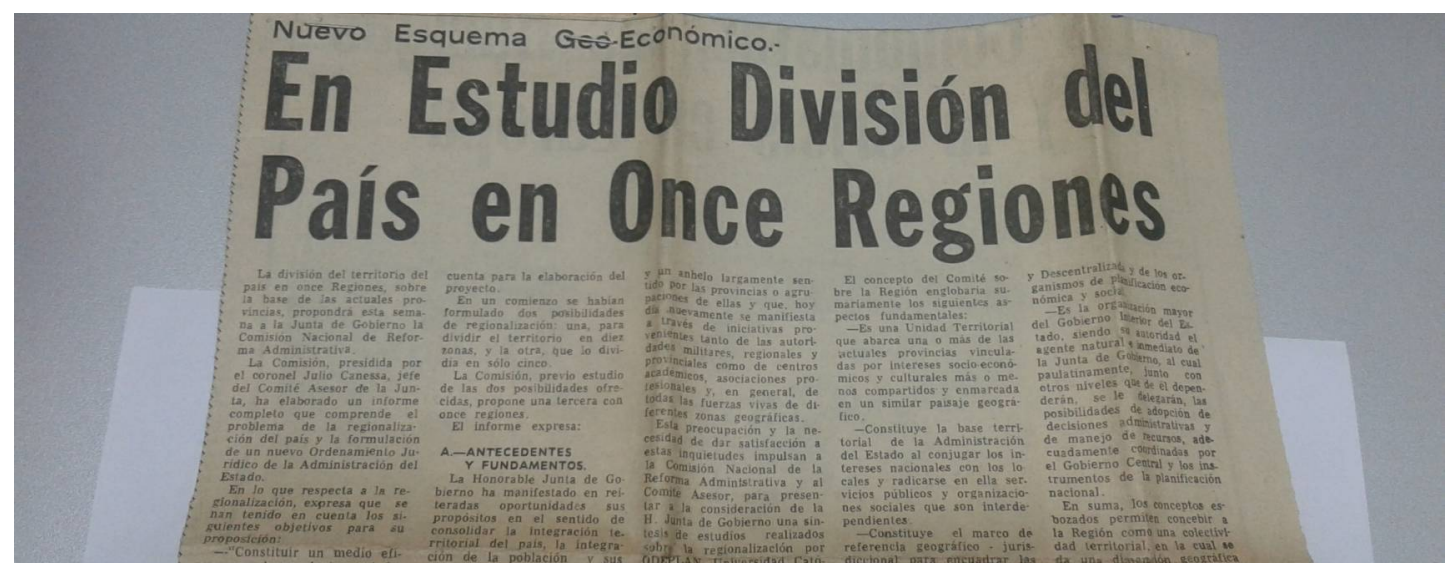

Fonte: acima El Mercurio, 18 de Fevereiro 1974; embaixo La Tercera de la Hora, 20 de Fevereiro 1974.

Ao mesmo tempo que se anunciava a emergência de uma nova divisão política do território em termos de onze regiões, se revelava também que existiam três propostas técnicas de regionalização em avaliação. Essas propostas haviam sido elaboradas pelo Centro Interdisiciplinario de Desarrollo Urbano (CIDU) da Universidade Católica de Chile, a ODEPLAN e a CONARA ou Comitê Assessor da Junta de Governo, como apontava o jornal (EL MERCURIO, 18 de Fevereiro 1974). Cada uma dessas regionalizações agrupava as antigas províncias administrativas (25 unidades) através de diferentes critérios que fundamentavam linhas de desenvolvimento regional e administrativo, onde se revelava uma maior descentralização e eficiência na gestão do território regional como formas econômicas estratégicas.

Quadro ${ }^{\circ}$ 4. Propostas de Regionalização Fevereiro de 1974

\begin{tabular}{|c|c|c|c|c|c|}
\hline \multicolumn{2}{|r|}{ CIDU } & \multicolumn{2}{|c|}{ ODEPLAN } & \multicolumn{2}{|r|}{ CONARA } \\
\hline Região & $\begin{array}{c}\text { Província } \\
\text { Administrativa }\end{array}$ & Região & $\begin{array}{c}\text { Província } \\
\text { Administrativa }\end{array}$ & Região & $\begin{array}{c}\text { Província } \\
\text { Administrativa }\end{array}$ \\
\hline I & $\begin{array}{l}\text { Tarapacá e } \\
\text { Antofagasta }\end{array}$ & I & Tarapacá & I & Tarapacá \\
\hline II & $\begin{array}{l}\text { Atacama, } \\
\text { Coquimbo, } \\
\text { Aconcagua e } \\
\text { Valparaíso } \\
\end{array}$ & II & Antofagasta & II & Antofagasta \\
\hline III & $\begin{array}{c}\text { Santiago, } \\
\text { O`Higgins, } \\
\text { Colchagua, } \\
\text { Curicó, Talca, } \\
\text { Maule e Linares } \\
\end{array}$ & III & $\begin{array}{c}\text { Atacama e } \\
\text { Coquimbo, } \\
\text { exceto } \\
\text { Departamento } \\
\text { de Illapel } \\
\end{array}$ & III & $\begin{array}{l}\text { Atacama e Coquimbo, } \\
\text { exceto Departamento } \\
\text { de Illapel e territorios } \\
\text { insulares }\end{array}$ \\
\hline IV & $\begin{array}{c}\text { Ñuble, } \\
\text { Concepción, } \\
\text { Arauco, Biobio, } \\
\text { Malleco, Cautín, } \\
\text { Valdivia, } \\
\end{array}$ & IV & $\begin{array}{c}\text { Aconcagua e } \\
\text { Valparaíso } \\
\text { incluido o } \\
\text { Departamento } \\
\text { de Illapel e os }\end{array}$ & IV & $\begin{array}{c}\text { Aconcagua e Valparaíso } \\
\text { incluido o } \\
\text { Departamento de } \\
\text { Illapel e os territorios } \\
\text { insulares } \\
\end{array}$ \\
\hline
\end{tabular}




\begin{tabular}{|c|c|c|c|c|c|}
\hline & $\begin{array}{l}\text { Osorno, } \\
\text { Llanquihue e } \\
\text { Chiloé }\end{array}$ & & $\begin{array}{l}\text { territorios } \\
\text { insulares }\end{array}$ & & \\
\hline \multirow[t]{7}{*}{$\mathrm{V}$} & $\begin{array}{c}\text { Aysén e } \\
\text { Magallanes }\end{array}$ & V & $\begin{array}{l}\text { Santiago e } \\
\text { O`Higgins }\end{array}$ & $\mathrm{V}$ & Santiago e O`Higgins \\
\hline & & VI & $\begin{array}{c}\text { Colchagua, } \\
\text { Curicó, Talca, } \\
\text { Maule e Linares }\end{array}$ & VI & $\begin{array}{l}\text { Colchagua, Curicó, } \\
\text { Talca, Maule e Linares }\end{array}$ \\
\hline & & VII & $\begin{array}{c}\text { Ñuble, } \\
\text { Concepción, } \\
\text { Arauco, BioBio } \\
\text { e Malleco }\end{array}$ & VII & $\begin{array}{l}\text { Ñuble, Concepción, } \\
\text { Arauco e BioBio }\end{array}$ \\
\hline & & VIII & $\begin{array}{l}\text { Cautín, Valdivia, } \\
\text { Osorno, } \\
\text { Llanquihue e } \\
\text { Chiloé }\end{array}$ & VIII & $\begin{array}{c}\text { Malleco, Cautín e } \\
\text { Valdivia, exceto o } \\
\text { Departamento de Rio } \\
\text { Bueno }\end{array}$ \\
\hline & & IX & Aysén & IX & $\begin{array}{c}\text { Osorno, Llanquihue e } \\
\text { Chiloé, incluido o } \\
\text { Departamento de Rio } \\
\text { Bueno } \\
\end{array}$ \\
\hline & & $\mathrm{X}$ & $\begin{array}{l}\text { Magallanes e } \\
\text { Territorio } \\
\text { Antártico }\end{array}$ & $\mathrm{X}$ & Aysén \\
\hline & & & & XI & $\begin{array}{c}\text { Magallanes e Territorio } \\
\text { Antartico }\end{array}$ \\
\hline
\end{tabular}

Fonte: elaboração própria sobre a base da reportagem Nuevo Esquema Geo-Económico- En Estudio División del País en Once Regiones, El Mercurio, 18 fevereiro 1974.

Na notícia do jornal El Mercurio, por sua vez, se faz menção ao trabalho da CONARA enquanto ao tamanho das regiões e suas diferenças internas com as outras propostas. Segundo Sergio Galilea, acadêmico do CIDU da época, de um dia para outro foram chamados pela CONARA:

Un jueves, muerto de susto el Pato Feliu entra a mi oficina y me dice: me llamaron del Diego Portales, donde funcionaban las comisiones legislativas, donde funcionaba la CONARA. Y nos piden una posición. ¿Cuales crees tú que deberían ser las regiones del país? Y nos sentamos, así como estamos conversando y yo le dije yo creo que las regiones deberían ser pocas para que sean fuertes (ENTREVISTA SERGIO GALILEA, outubro 2019).

A CONARA se comunicou de último momento com o CIDU. De tal forma, a proposta do CIDU foi uma consulta mais simbólica que real, considerando a lógica de buscar alternativas. Dessa maneira, criava-se uma aparência de amplitude de visões e respaldo científico do processo de avaliação regional. CONARA reconhecia uma maior afinidade com a proposta da ODEPLAN: "el Comité Asesor considera que la proposición de ODEPLAN se ajusta en mayor medida a los requisitos que debe cumplir una región como apoyo al proceso de desarrollo" (EL MERCURIO, 18 fevereiro 1974). É interessante destacar que a proposta da ODEPLAN não era a mesma proposta definida em 1969, embora muito similar. Por sua vez, o recorte de 
regiões da ODEPLAN e da CONARA era praticamente o mesmo, ainda que diferiam em alguns traços. Em contraste, as lógicas territoriais no momento de regionalizar se articulariam a partir de uma base conceitual e espacial comum ligada ao período anterior. Por outro lado, as leves diferenças se circunscreviam nas áreas do extremo sul com a separação das províncias austrais e a agregação da VIII região respetivamente. Para CONARA a VIII região da ODEPLAN era exageradamente extensa pois incluía as cidades de Temuco, Valdivia, Osorno e Puerto Montt (quadro $n^{\circ}$ 4). Dessa maior conformação geográfica refletida em quatro centros urbanos de hierarquia, se projetaria uma potencial disputa pela capital, sendo impossível uma "buena administración y control del territorio" (EL MERCURIO, 18 fevereiro 1974). Além disso, o significativo é que, pela primeira vez, se fundamentava teoricamente como seria entendida a região no regime autoritário:

Es una Unidad Territorial que abarca una o más de las actuales provincias vinculadas por intereses socio-economicos y culturales más o menos compartidos y enmarcada en un similar paisaje geográfico. -Constituye la base territorial de la Administración del Estado al conjugar los intereses nacionales con los locales y radicarse en ella servicios públicos y organizaciones sociales que son interdependientes. -Constituye el marco de referencia geográfico jurisdiccional para encuadrar las actividades de los poderes de Estado (Judicial, Electoral, Legislativo y de la Controlaría General de la República); de la Administración Central y Descentralización y de los organismos de planificación económica y social. -Es la organización mayor del Gobierno Interior del Estado, siendo su autoridad el agente natural e inmediato de la Junta de Gobierno, al cual paulatinamente, junto con otros niveles que de él dependerán, se le delegarán, las posibilidades de adopción de decisiones administrativas y de manejo de recursos, adecuadamente coordinados por el Gobierno Central y los instrumentos de planificación (...) Em suma, los conceptos esbozados permiten concebir a la Región como una colectividad territorial, en la cual se da una dimensión geográfica a todos los aspectos posibles de una política de Desarrollo y Seguridad Nacional (EL MERCURIO, 18 fevereiro 1974).

A partir do agrupamento administrativo das províncias e os componentes geográficos específicos da estrutura do Estado, a regionalização passou a ser entendida como fixação de limites territoriais organicamente funcionais aos serviços públicos do país, fomentando uma "razonable" autonomia na gestão das tarefas públicas, sempre no marco da “Integración, el Desarrollo y la Seguridad Nacional” (EL MERCURIO, 18 fevereiro 1974). Se anunciava, assim, que a regionalização tenderia a um sistema de integração a nível nacional entendido como "un instrumento de participacióny de administración que sirva para alcanzar los objetivos ya señalados en un marco más armónico, en términos geográficos, de lo que ha sido la experiencia histórica chilena" (EL MERCURIO, 18 fevereiro 1974). Esse tipo de arranjo geográfico do mapa nacional também significava que a regionalização tinha que ser interpretada como um instrumento flexível da administração do Estado e não um fim em si mesmo, pois: 
$[\ldots]$ no existe una regionalización mejor que otra, en términos absolutos [...] una determinada regionalización puede o debe ser cambiada, en el transcurso del tiempo, si ha dejado de prestar utilidad como instrumento, sea porque se han variado los objetivos originales que la fundamentaron o porque se haga inadecuada para administración territorial (EL MERCURIO, 18 fevereiro 1974)

Entre janeiro e abril de 1974, o regime decidiu apoiar a criação de onze regiões mais uma área metropolitana, encaminhando a consulta dos decretos-leis com as diferentes províncias e outras instituições, como a Comissão de Reforma Constitucional e outras. Desses intercâmbios e recomendações de outros órgãos públicos se haveria discutido a distância e acessibilidade do Atacama, a postergação da Aconcagua, a base econômica de Valdivia, mais alguns casos de antagonismo regional e a complexidade administrativa da área metropolitana de Santiago (SUAREZ, 1975). No entanto, finalmente, a Junta de Governo aprovou oficialmente uma nova regionalização do país com doze regiões mais a Área Metropolitana de Santiago em julho de 1974: treze unidades operativas. Além disso, é importante destacar que essas unidades territoriais estavam ancoradas em uma nova hierarquia territorial do Estado ou sistema de governo interior que definiam autoridades e funções territoriais através de três subsistemas coexistentes: participação, hierárquico e técnico.

Mapa $n^{\circ} 1$. Regiões decreto-lei no 575 

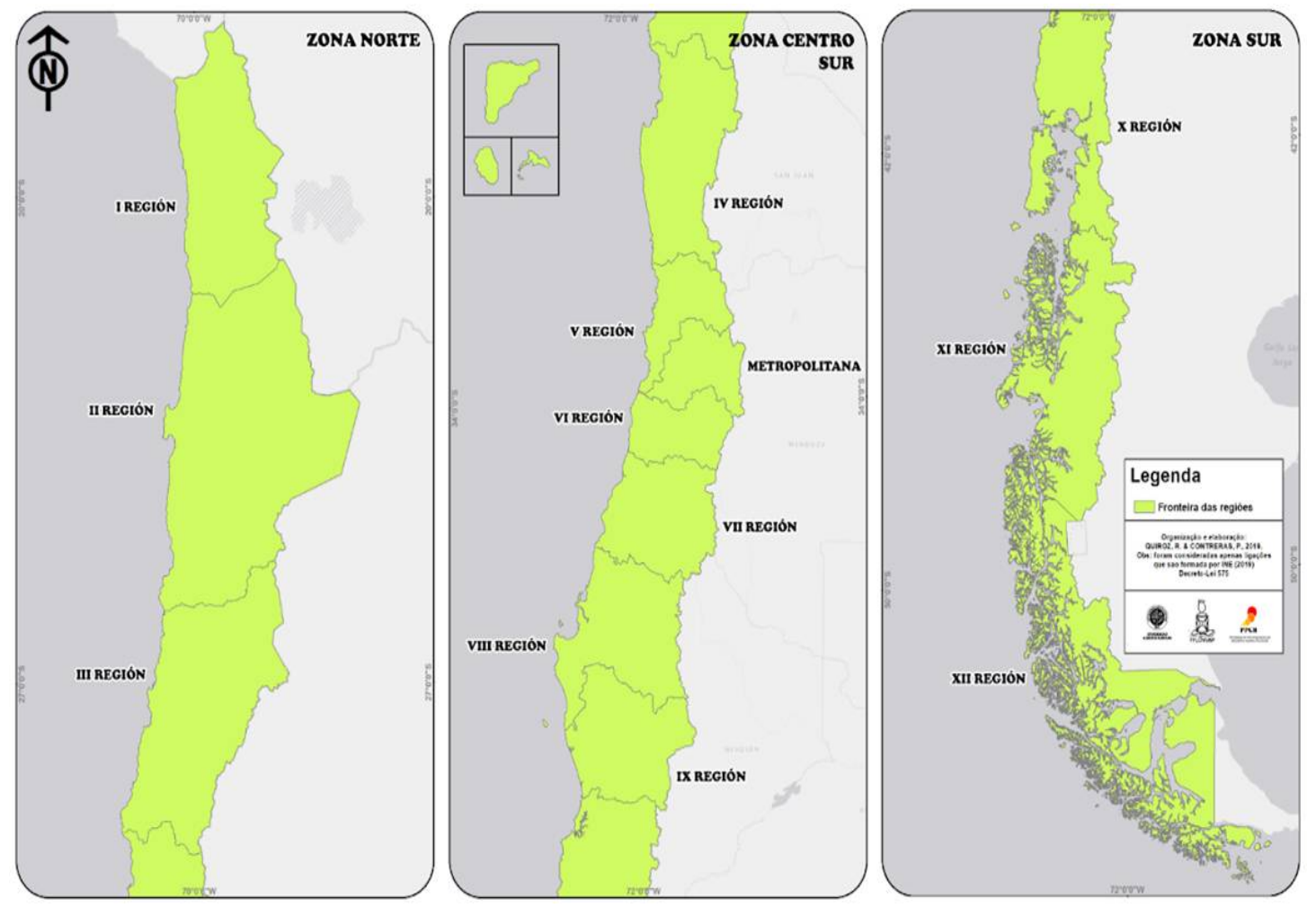

Fonte: Elaboração própria com base a CONARA (1976).

Seguindo a mesma nomenclatura da ODEPLAN de 1968, as regiões oficializadas em julho de 1974 foram nomeadas por números romanos, de norte a sul, salvo a Área Metropolitana de Santiago (GOBIERNO DE CHILE, 1974b). Dessa forma o território ficou dividido oficialmente em uma área metropolitana - a Área Metropolitana de Santiago - e em doze regiões com suas respetivas cidades capitais (quadro no 5 )

\section{Quadro $n^{0}$ 5. Cidades capitais}

\begin{tabular}{|c|c|}
\hline Região & Capital \\
\hline I & Iquique \\
\hline II & Antofagasta \\
\hline III & Copiapó \\
\hline IV & La Serena \\
\hline V & Valparaíso \\
\hline VI & Rancagua \\
\hline VII & Talca \\
\hline VIII & Concepción \\
\hline IX & Temuco \\
\hline X & Puerto Montt \\
\hline XI & Coyhaique \\
\hline
\end{tabular}




\begin{tabular}{|c|c|}
\hline XII & Punta Arenas \\
\hline AMS & Santiago \\
\hline
\end{tabular}

Fonte: Decreto lei $\mathrm{n}^{\mathrm{o}} 575$.

Se bem as similitudes das regiões da ODEPLAN e CONARA eram evidentes, existiam diferenças na separação de Atacama com Coquimbo, a anexação de Chiloé com Llanquihue e a divisão da região de Aysén (SOMS, 2010). Com efeito, era também a expressão da necessidade de maior controle territorial nas comunicações e rotas do país, onde, finalmente, a estrutura militar se confundia por uma influência real e operativa enquanto dispositivo de segurança e exercício do poder territorial.

\subsection{A construção de uma imagem: a naturalização das regiões}

A passagem da regionalização à uma estrutura de governo territorial foi um processo de altas significações políticas nas práticas estatais históricas. A naturalização do território pátrio, fundamento principal do projeto corporativo da CONARA, comtemplou uma descrição pormenorizada dos recortes regionais e suas estruturas históricas e naturais, que tentariam integrar os recursos geográficos do país como uma forma mais moderna e operativa do desenvolvimento regional. Em palavras do general Canessa:

La división político-administrativa del país responde a las más serias exigencias de tipo científico y técnico, conjugando los factores geográficos, geopolíticos, de desarrollo integral y de seguridad nacional, con miras lograr un más adecuado Sistema de Gobierno y Administración Interior del Estado, que haga posible alcanzar los objetivos postulados por el Supremo Gobierno en materia de integración y de progreso en todos los ámbitos y órdenes del país (CANESSA, 1982, p. 23)

A regionalização integrava assim uma série de fundamentos - desde a geografia até a segurança nacional - que se conectavam a partir de uma visão científica e técnica que permitiria operar um regime territorial integrado. Apesar do espírito científico e técnico declarado pelo general Canessa, segundo Dionisio Vio, as primeiras projeções territoriais foram confecionadas de maneira muito precária, correspondendo aos mapas nacionais de escala 1:1.000.000 (ENTREVISTA DIONISIO VIO, dezembro 2019). Po certo, a CONARA não contava com um centro cartográfico consolidado. Lembra Vio que pessoalmente projetava algumas cartas de mais de um metro unidos por uma tela na parte posterior no chão de sua casa, onde começava a traçar os limites territoriais:

Los primeros mapas eran los cuarterones del mapa 1:1.000.000, de esos que ponen a la pared, de tres tiras. Entonces, en el fondo son unos cuarterones, son pedazos que están pegados y 
por atrás tienen una tela que les da unidad [...] Entonces, en ese mapa proyecté los primeros límites definitivos. Siempre recuerdo que le saqué a mi niño que estaba en segundo o tercero básico, mi hijo mayor, le saqué los lápices de colores y con esos marqué en mi casa, en el piso. En el comienzo no teníamos nada en realidad, no había instalaciones de cartografía, absolutamente nada (ENTREVISTA DIONISIO VIO, dezembro 2019).

Além da aparente arbitrariedade técnica e pessoal do geógrafo, as cartografias da CONARA respondiam ao Estado Maior do general Canessa e a visão final do general Pinochet. Dessa maneira, para a definição técnica dessas grandes cartas, Vio contava com instruções claras e precisas dos limites oficiais. Quando ele tinha alguma dúvida dos traçados e percursos geodésicos, contrastava com outras cartas topográficas em escala 1:500.000, onde poderia visualizar as linhas das mais altas cimas e assim poderia regularizar as linhas exatas dos limites que continuavam as velhas linhas administrativa das províncias: "Y en buena medida, también aproveché los límites de las antiguas provincias que tenía el país. Uno no puede ser alquimia, digamos, de alguna manera esos eran limites relativamente reconocidos" (ENTREVISTA DIONISIO VIO, dezembro 2019). Na medida em que o mapa oficial do território ia sendo relativamente modificado, paralelamente suas estruturas de funcionamento burocrático interno iam se projetando nas diferentes destinações territoriais. Segundo Vio, os ajustes da antiga divisão administrativa teriam sido menores e traçados em algumas zonas pontuais das regiões do Norte, particularmente em algumas áreas mineiras pelos efeitos da tributação e pelo fato que alguns povoados precisariam de uma integração de caminhos e rotas. Dessa maneira, a regionalização da CONARA seguia rigorosamente o ritual dos atos de Estado que, segundo Bourdieu, podem entender-se como:

[...] ações realizadas por agentes dotados de uma autoridade simbólica, a que se seguem efeitos. Esta autoridade simbólica remete, gradualmente, para uma espécie de comunidade ilusória, de consenso final. Se estes atos obtêm o consentimento, se as pessoas se inclinam - mesmo que se revoltem, a sua revolta pressupõe um consentimento -, é porque, no fundo, participam consciente ou inconscientemente numa espécie de "comunidade ilusória" - é uma expressão de Marx a propósito do Estado-, que é a comunidade de pertença a uma comunidade a que chamaremos nação ou Estado, no sentido de conjunto de pessoas que reconhecem os mesmos princípios universais (BOURDIEU, 2014, p. 29).

Lenta ou rapidamente, o ato de regionalizar foi reconhecido e espalhado pelo tecido social do país, destacando-se a partir da própria participação da máxima autoridade no processo. A figura do general Pinochet e a própria CONARA liderada pelos oficiais do Estado Maior projetaram o poder simbólico da regionalização e o sentido irreversível e 
hegemônico do processo de governo ${ }^{28}$. As linhas imaginárias da regionalização deveriam ser aceitas e reconhecidas como regiões naturais e políticas do Chile, através da ação do conjunto de agentes do Estado e instituições oficiais, mas sobretudo, na operação interna do Estado territorial e suas autoridades de governo. Nesses termos, a regionalização foi apresentada como a mais "trascendente iniciativa para el desarrollo nacional materializada en los últimos años" (TERCERA DE LA HORA, 12 julho 1974). Essa oficialização das fronteiras internas, aliás, foi acompanhada por uma série de publicações escolares que foram distribuídas por diferentes meios editoriais e inculcariam uma adesão ao projeto territorial do regime (ULTIMAS NOTICIAS, 14 abril 1975). No entanto, na prática real das estruturas sociais e suas tradições locais, as formas de regionalização não impactavam nem alteravam a vida cotidiana dos chilenos e chilenas. O poder territorial modificado era uma mudança para o funcionamento dos dispositivos de governo e suas estratégias de contenção e legitimação. Se conformava assim um processo análogo a naturalização das regiões vidalianas que descreve acidamente Lacoste em seu A geografia, isso serve, em primeiro lugar, para fazer a guerra (1976). Mas que, para o caso chileno, se conjugou como uma ferramenta de analise técnica, neutral e operativa que, acima de tudo, deveria justificar os novos limites políticos e administrativos do país. Condições climáticas e geomorfológicas do país foram ensambladas com heranças históricas e administrativas, que no fundo, legitimariam e procurariam a definição de um novo estatuto ontológico do regional como seria definido na divulgação da CONARA de 1976, Chile hacia un nuevo destino. Su reforma administrativa integral y el processo de regionalización.

A distribuição geográfica e agrupação regional da CONARA traçava uma única forma de dividir o território chileno, ao tempo que, paralelamente, fechava e ocultava outras manifestações sociais ou fenômenos políticos que potencialmente serviriam para interesses contrários ao regime. A escala geográfica regional seria a extensão máxima do poder nacional fora das fronteiras da capital do país. Simultaneamente, essas escalas geográficas regionais deviam dar o suporte as outras escalas geográficas menores contidas em seus espaços internos: províncias e comunas. As regiões da CONARA de julho de 1974, assim, rapidamente se configurariam em dispositivos monográficos, descritivos e burocráticos, que, no fundo, negavam qualquer potencial reorganização do espaço social fora das pautas oficiais

\footnotetext{
${ }^{28}$ Como diria Bourdieu, para que as linhas da regionalização sejam efetivas e operativas, foi necessário que fossem impulsionadas "à vista de todos e em nome de todos, publicamente e oficialmente, ele as subtrai ao arbitrário, sanciona-as, santifica-as, consagra-as, fazendo-as existir como dignas de existir, como conformes a natureza das coisas, "naturais"” (BOURDIEU, 1987, p. 114)
} 
e, em contrapartida, sustentavam uma série de mecanismos de homogeneização e integração que ampliavam a estrutura do governo nacional e sua particular malha territorial. Como diz Lacoste em torno das regiões vidalianas: "essa forma de ocultar todas as demais configurações espaciais, às vezes bastante usuais, foram difundidas, com um enorme sucesso na opinião, através de manuais escolares e também pela literatura e pela mídia" (LACOSTE, 2012, p. 62).

A regionalização do regime autoritário chileno oficializou suas estruturas de governo como fronteiras naturais e próprias de um novo estágio de desenvolvimento nacional universal que permitiriam um novo pacto regional. Se afirmou, em primeiro lugar, que sua validez técnica era propiciada a partir do trabalho de uma comissão de especialistas ou expertos - a CONARA - que, aliás, haveria percorrido as diversas zonas do país, escutando e analisando cada uma das carências do espaço provincial e mais esquecido das localidades urbanas e rurais (TERCERA DE LA HORA, 12 julho 1974). Essa neutralidade cientificatécnica ademais, logo permitiu que os partidos políticos e as organizações sindicais da CUT fossem expulsos do processo: "han sido contrarios, en la práctica, a la descentralización, puesto que su poder era más fácil de ejercer sin disputa desde la Metrópoli” (EL MERCURIO, 14 julho 1974). É interessante essa citação porque desvenda como a própria forma de descentralizar projetava internamente um exercício de depuração política contra as práticas que precisamente haveriam dado maior suporte aos setores populares ligados as tradições da esquerda e, simultaneamente, abriam passo a outros mecanismos de validação. Nessa narrativa proclive a despolitização, o Intendente de Antofagasta e general de Exército Rolando Garay Cifuentes, destacava que a regionalização era uma reivindicação muito sentida das antigas províncias e que certamente requeria o apoio de toda a comunidade regional e nacional, sobretudo dos funcionários públicos e dos trabalhadores. Diz Garay:

No basta el esfuerzo de la provincia, agregó. Deben tener conciencia que la dirección natural del proceso puede no ser suficientemente amplia si no existen una participación y colaboración unánime que permitan mejorar las ideas que se tengan de la materia. Debemos desarrollar nuestras cualidades y hacer buen uso de los elementos de trabajo que nos han dado. En caso contrario, ello implicaría retroceder otros 40 años, aparte de que las posibilidades como ésta solo se dan una vez en la vida (EL MERCURIO, 16 julho 1974).

A citação é significativa porque ao mesmo tempo que naturalizava a imposição dramática e violenta da regionalização na história do Chile, simultaneamente se assumia de entrada que a regionalização tinha um imperativo social de desburocratização das unidades territoriais, sendo, sobretudo, uma possibilidade única na história do país (QUÉ PASA, 19 
julho 1974). Dessa maneira, se romperia a velha estrutura geográfica do país que naturalmente propiciava a centralização manifestada nas antigas desigualdades com a hegemonia de Santiago. Porém, a regionalização não rompia com o Estado unitário, pois o Chile não era e nem podia ser um país federal (EL MERCURIO, 25 julho 1974). Como destacaram as duas máximas chefias da CONARA, o general Canessa e o coronel Barrientos. Substancialmente, a regionalização trata-se de estimular um "sano regionalismo, esto es a las aspiraciones de progreso local dentro del claro reconocimiento de la unidad de la nación y de su organización superior" (EL MERCURIO, 25 julho 1974). Não obstante, um regionalismo fechado, hesitante e exclusivo, fecharia as possibilidades de uma regionalização baseada nos "sagrados intereses nacionales que son comunes a todos los chilenos" (EL MERCURIO, 25 julho 1974). Um regionalismo saudável se entendia como instrumento de pólos produtivos estratégicos em diferentes zonas do território, sempre funcionais ao interesse supremo da nação. A regionalização, assim, era um desafio para todos os chilenos, embora tinha sido vigiada e desenhada em um estrito alto comando militar e de equipes técnicas e profissionais da ODEPLAN e da CONARA.

\section{Imagem $n^{\circ}$ 5. Cambio total do país}

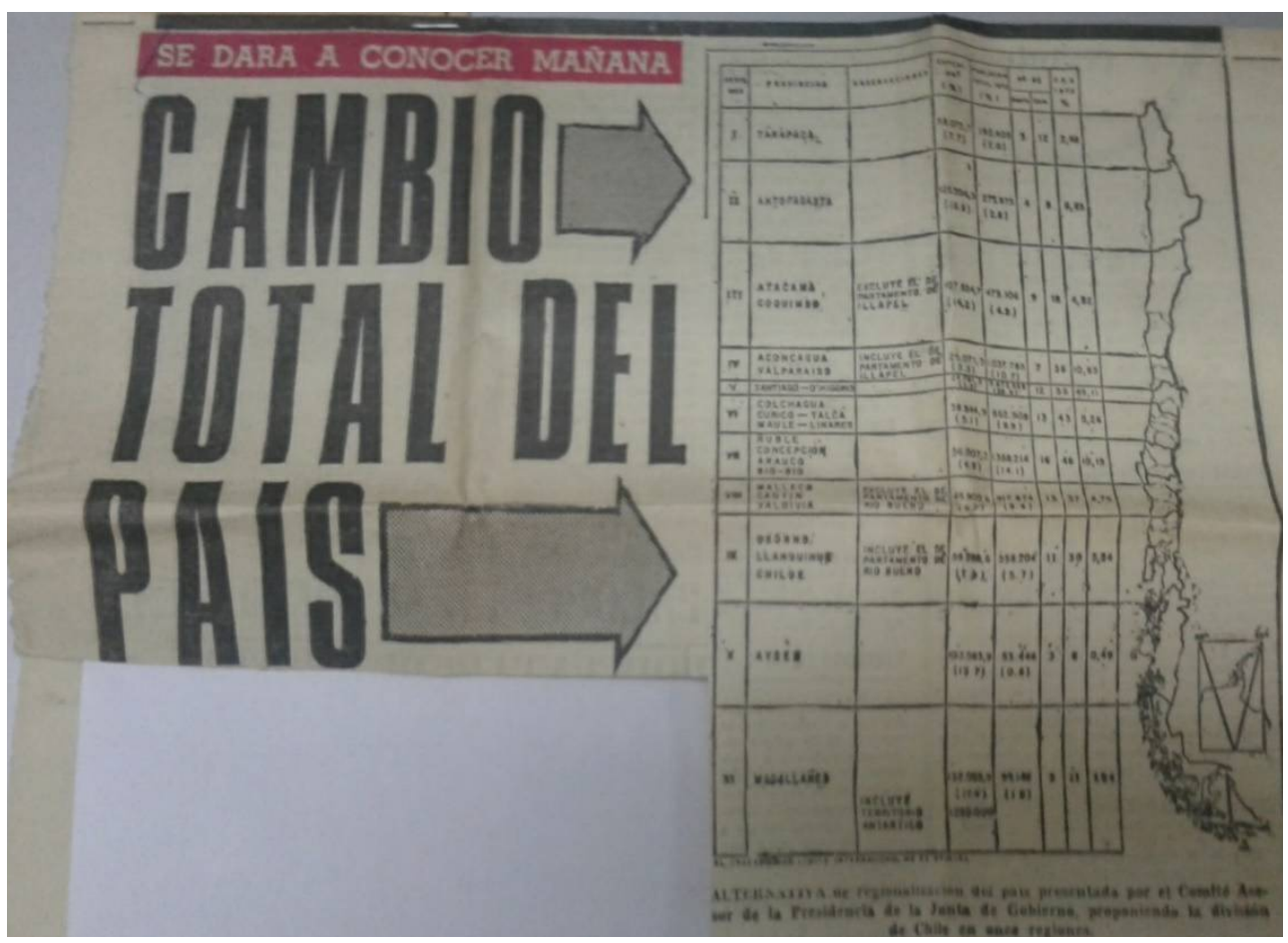

Fonte: La Prensa, 18 de julho 1974. 


\section{Imagem no 6. A Regionalização: um Desafio para Chilenos}

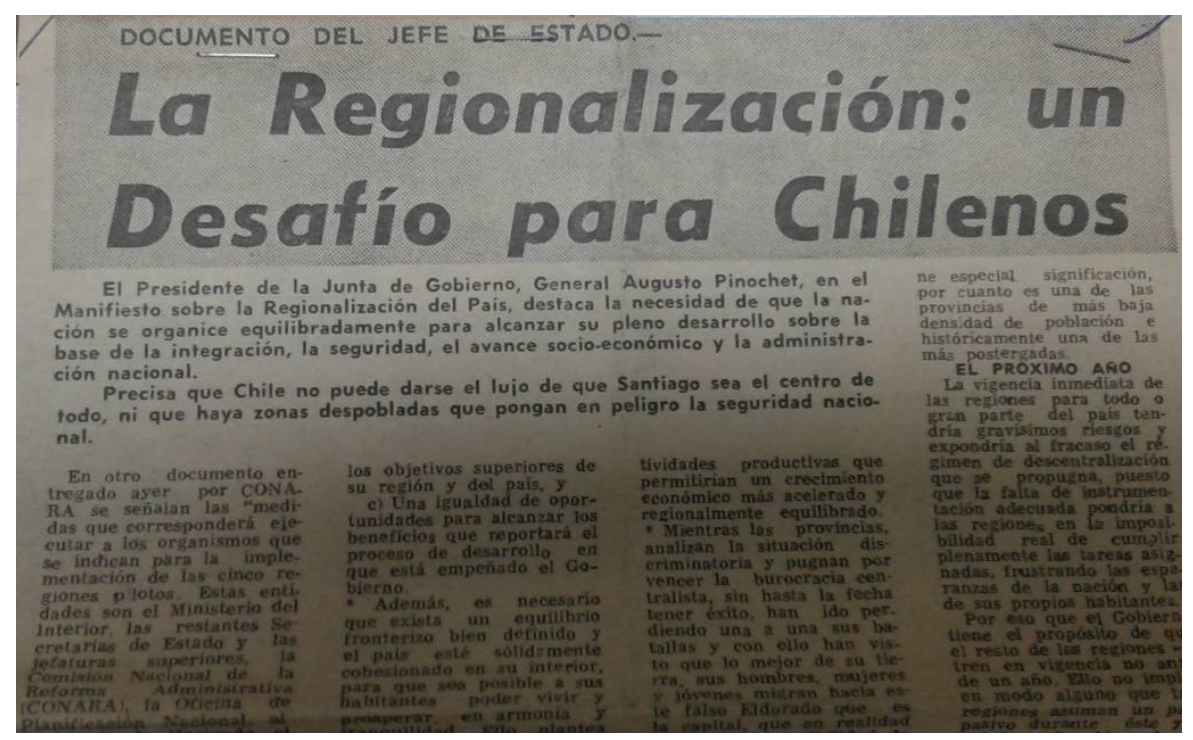

Fonte: Últimas Noticias, 17 de julho 1974.

Um elemento particularmente interessante da oficialização da regionalização, é que ela foi acompanhada por um documento chamado Manifiesto de la Regionalización assinalado pelo próprio general Pinochet, a propósito da iniciação oficial do processo o 11 de julho de 1974. Além das similitudes quase textuais dos decretos-leis $\mathrm{n}^{\circ} 573$ e $\mathrm{n}^{\circ} 575$ e o texto Restauración nacionaly desarrollo regional. Bases para una politica da ODEPLAN de Boisier de 1973, o interessante da divulgação é o sentido direto e conciso sobre o poder político explicitamente ligado ao processo da regionalização. Embora o regime sempre explicitou que o processo de regionalização não tinha nenhuma expressão política partidária nem tradicional, pois se colocava acima dos interesses particulares, Pinochet, de outro lado, assinava um Manifesto da Regionalização. Existe um gênero narrativo mais político que um manifesto? Segundo Pinochet, em especial, deveria ficar muito claro que a regionalização não debilitaria o poder nacional ou central, mas sim melhoria a gestão do território e se organizaria de maneira mais aprofundada e hierárquica entre as unidades territoriais, pois: “el ejercicio del poder delegado, debidamente supervisado, lo robustece al convertirse en decisiones y acciones que, siguiendo su propio pensamiento y superiores instrucciones, se manifestarán en resultados que apoyarán su gestión y acrecentarán su base de sostenimiento" (CONARA, 1976, p. 12).

Também se fundamentava que a regionalização deveria propiciar um equilíbrio fronteiriço ligado à uma estratégica distribuição espacial da população do centro para os extremos do país, sendo Chile um país tri-continental (soberania no Oceano Pacífico, 
América do Sul e na Antártica). Essa distribuição, segundo Pinochet, deveria enfrentar o perigo de "numerosos espacios vacios dentro del territorio nacional" que implicavam, por um lado, uma perda e desaproveitamento de recursos naturais, mas, por outro, se prolongava uma permanente migração rural-urbana em direção a Santiago que recriava "cinturones de poblaciones marginales, donde proliferan ciudadanos frustrados, inadaptados, proclives a la delincuencia, a aceptar ideas foráneas o a la subversión" (CONARA, 1976, p. 11). Dessa forma, a regionalização emergia a partir de uma visão geopolítica do território em termos de poder nacional e uma projeção dos órgãos territoriais internos que, implicitamente, abriam diagnósticos punitivos contra as populações marginais que deviam reconverter suas práticas econômicas e sociais via regionalização. Na prática, as regiões que iniciariam o processo seriam qualificadas como regiões "imanes porque serán los polos de crecimiento y desarrollo que deben proyectar la regionalización a nivel país" (CONARA, 1976, p. 13). Diz Pinochet em seu Manifesto:

Se han elegido las regiones extremas como regiones pilotos considerando su especial situación geográfica y porque en ellas se han iniciado desde hace varios años experiencias de planificación desde desarrollo y manejo de recursos a nivel regional mediante sus Corporaciones de Desarrollo. En el caso de la región de Aisén tiene especial significación, por cuanto es una de las provincias de más baja densidad de población e históricamente una de las más postergadas (CONARA, 1976, p. 13).

A transformação da antiga malha territorial de províncias à regiões foi sendo mediado pelo início paulatino das zonas estratégicas fronteiriças do Norte, do Sul e da VIII região circunscrita à cidade de Concepción, terceira capital demográfica do país. Se expressava que a regionalização continuaria as políticas de desenvolvimento regional e as necessidades de reverter o histórico processo de centralização e superconcentração de Santiago. Por outro lado, é interessante notar que, embora o Manifesto de Pinochet procurava enfatizar uma ação integral e economicamente relevante, a projeção estrutural da regionalização foi uma mudança no máximo nível hierárquico do Estado que não implicou uma movimentação econômica na base regional e suas relações territoriais. Em outras palavras, a movimentação econômica nunca foi sua centralidade, embora existisse um esforço permanente de imprimir à regionalização um sentido de integração e conectividade que respondia a uma questão nacional general e não necessariamente a uma questão regional geograficamente diferenciadora. Esse elemento ficou mais evidente com o percurso da década de 1970 a 1980 e a consolidação das reformas econômicas. 
Continuando o sentido de unidade nacional, em abril de 1975, o jornal Últimas Notícias publicou um completo relatório de cada uma das regiões, integrando mapas e descritores das formações territoriais para o uso escolar e da comunidade em geral que, ao fim, estariam sendo integrada ao processo de regionalização. Diz o suplemento regional do jornal:

A partir de hoy - y diariamente - publicaremos la semblanza Regional de Chile. Cada día una región, con los datos indispensables para lograr una visión integrada del país [...] Aunque podría parecer innecesario, creemos oportuno señalar la conveniencia de que nuestros lectores coleccionen este material informativo que, como está dicho, abarcará el conjunto de las 12 regiones y el Área Metropolitana en que se ha dividido administrativamente el país (ÚLTIMAS NOTICIAS, 14 abril 1975)

Dentro das múltiplas operações discursivas e traçados desses primórdios regionais, é interessante destacar a seleção de símbolos e paisagens que tentavam particularizar a materialidade dessas unidades regionais, sempre funcionais ao projeto nacional. Com efeito, os diferentes materiais jornalísticos distinguiam uma serie de diferenças e práticas sociais alternativas do cenário central que, de uma ou outra forma, permitiam personificar as novas unidades regionais em chaves identitárias. Cada escala geográfica oficial deveria impulsar a ideia particular de ser chileno em seu território regional e, portanto, instituir uma forma de terrunho ou topofilia particular aderente nas diferentes localidades e regiões. Um exemplo paradoxal nesse sentido pode-se reconhecer na seleção de certos símbolos do povo originário mapuche (imagem no 7), associado a IX Região da Araucanía.

\section{Imagem $\mathbf{n}^{\circ}$ 7. Mulher mapuche}

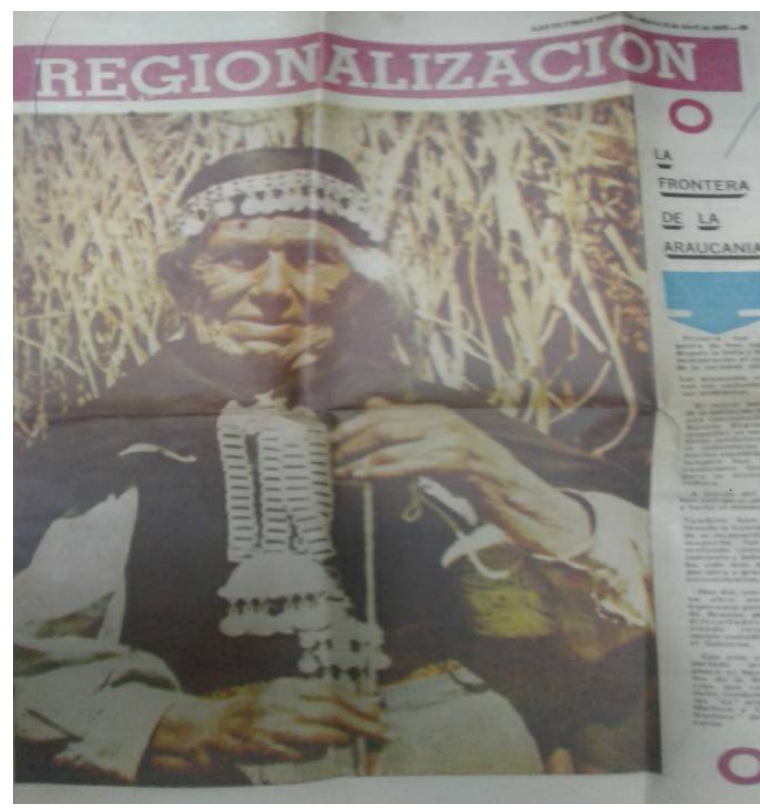


Fonte: Ultimas Noticias, 22 abril 1975.

$\mathrm{Na}$ portada do relatório regional aparecia uma mulher com a vestimenta indígena e se projetavam algumas imagens típicas de jogos e paisagens característicos das comunidades mapuches (ULTIMAS NOTICIAS, 22 abril 1975). Esse elemento de distinção territorial já tinha ressaltado em fevereiro de 1974 quando se destacava que "El problema mapuche es de tal trascendencia tanto nacional como regional, que debiera ser tratado, como un todo distinto al resto de la región y otorgandole una alta prioridad" (EL MERCURIO, 18 fevereiro 1974). De uma ou outra forma, o regime tentava projetar uma territorialidade regional ao povo mapuche, enquanto maior concentração populacional no sul do Chile da IX Região. Dita seleção simbólica particular, no entanto, se subordinava a uma visão nacional-colonial onde a regionalização sempre se ligava a uma esfera de governo que iria abrir maiores ventagens e possibilidades históricas. Como se destacava na fundamentação do jornal Ultimas Noticias:

\begin{abstract}
El mayor porcentaje de la población indígena está concentrado en la Novena Región. Los mapuches ya no son los fieros combatientes que se enfrentaron a las huestes españolas, pero tampoco han logrado condiciones favorables para su acceso a la cultura. A través del tiempo han sufrido el abandono y hasta el menosprecio. También han sobrellevado la leyenda negra de su incapacidad. Si el mapuche fue estigmatizado como un ser indolente y bebedor, ello ha sido más que nada por obra y gracia de las circunstancias. Hoy día, sin embargo, se abre una nueva esperanza para los hijos de Arauco, porque sus dificultades están siendo responsablemente consideradas por el Gobierno. Con este símbolo de portada, presentamos ahora el Noveno Informe de la Regionalización, que contiene los datos fundamentales de las "ex" provincias de Malleco y Cautin, "la frontera" de la Araucanía (ULTIMAS NOTICIAS, 22 abril 1975).
\end{abstract}

O texto está cheio de interpretações e preconceitos que, aliás, reconhecem uma diferença geográfica regional para ser inserida no projeto nacional e territorial oficial. De fato, a discussão do nome "A Fronteira" será uma polêmica de não menor transcendência no processo posterior de nomeação oficial da IX Região até hoje (CANIUQUEO, 2013). Nesse mesmo espírito de diferenciar regiões para nacionalizar (politizar) o projeto oficial, em julho de 1975, a editora Lord Cochrane lançou a série GEOCHILE: La Regionalización en 14 fascículos. É interessante essa coletânea porque continua a mesma lógica do jornal Ultimas Noticias. Em cada um dos 14 fac-símiles publicados se projetava uma localidade regional com imagens ilustrativas que emanavam símbolos regionais, diferenças culturais, sinais paisagísticos, informações territoriais específicas, mas sempre unidas na lógica de um continuum nacional guiada pela estrutura nacional do país. 


\section{Imagem $n^{\circ}$ 8. A regionalização de GeoChile}

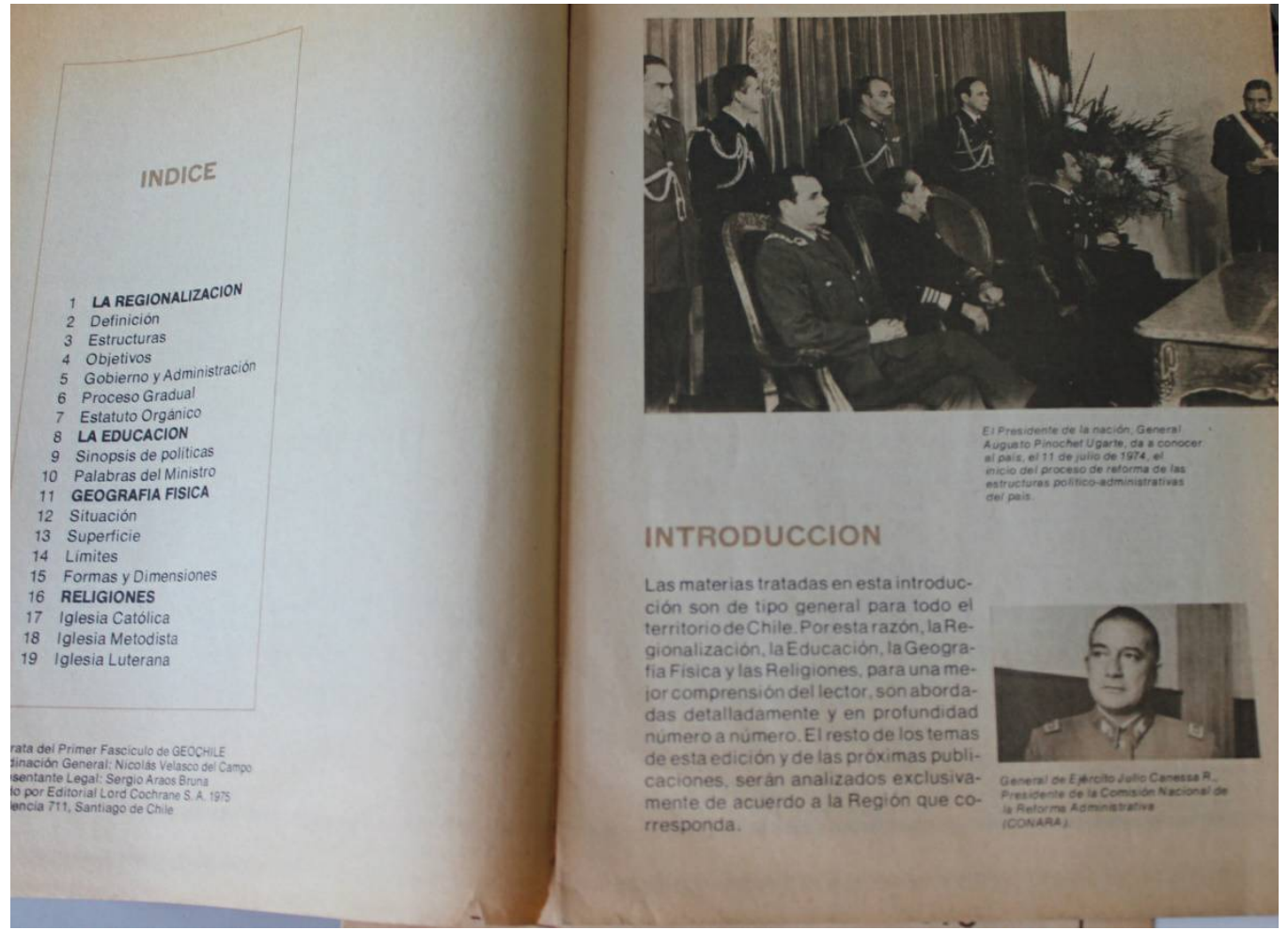

Fonte: GEOCHILE, 1975.

Os textos realmente são didáticos porque junto com os símbolos e descrições especificas das relações geográficas, em seu interior também se publicavam os decretos-leis da regionalização, documentos oficiais da CONARA e resenhas dos pareceres das autoridades responsáveis pelo processo (imagem $n^{\circ} 8$ ). Um assunto de fato curioso a respeito da coletânea foi que, por cada fac-símile, se difundiu um mapa de $0,85 \times 0,75 \mathrm{~cm}$ de cada região do país. No último fac-símile, GeoChile $n^{\circ} 14$, se estabelecia um completo instrutivo para armar o mapa modular gigante do Chile na parede de sua própria casa com a largura total de $5 \mathrm{mts}$ e $55 \mathrm{cms}$. Era apenas uma geografia didática e cotidiana do novo país em construção? Na prática, o processo de ritualização continuava acelerado junto à naturalização das fronteiras internas do país. No mês de agosto de 1975 se publicava uma longa reportagem a propósito dos nomes e símbolos das regiões, encarregado pelo próprio Pinochet:

Por estas razones el propio Presidente Augusto Pinochet ordenó estudiar una denominación paralela (patronímica, geográfica, histórica), para cada región. Lo mismo se está haciendo con flores que la simbolicen (...) Pero éstos y otros propósitos de la regionalización no se lograrán, como por milagro, subdividiendo el país de otra manera, ni creando cargos u organismos nuevos (...) Así lo dijeron, jcon insistencia! A este diario el comandante Jorge Lucar (Jefe del 
Departamento de Regionalización de CONARA) y el geógrafo Dionisio Vio Urrutia (asesor de CONARA, master en Geografía Económica de la U. De Maryland, profesor de las Universidades de Chile y Católica) (EL MERCURIO, 25 agosto 1975).

As diversas edições escolares e jornalísticas das regiões, no fundo, representaram a ideia de realidade ou atualização geográfica do país no sentido de uma expressão de um território modernizado e geograficamente mais próximo de seus habitantes. Ao mesmo tempo, a regionalização ficou ancorada em uma seletiva geografia nacional sem conflitos nem mediações ideologicamente declaradas. Se inculcava assim a presença de um estatuto ontológico acorde à modernização do país:

La regionalización no es un paso al azar. Se trata del reconocimiento de la realidad que vive nuestro país hoy. La actual estructura administrativa data de 1925. En casi 50 años se han producido cambios básicos que exigen una nueva organización, medidas audaces y modernas que lancen a Chile por la senda definitiva de su bienestar (ÚLTIMAS NOTICIAS, 14 abril de 1975).

Embora as regiões pilotos já estivessem operando paulatinamente com novos funcionários e novas repartições técnicas públicas, socialmente ainda não eram inteiramente reconhecidas. Portanto, era necessário instituir, ensinar e reproduzir um imaginário regional, mas desta vez, espacialmente integrado e nacionalmente unificado:

Las regiones tienen por delante la responsabilidad de convertirse en verdaderos factores de integración nacional, desplegando al máximo sus recursos. Pero la participación de todos los chilenos en esta tarea trascendental requiere de un conocimiento de nuestra realidad, en todos los niveles (ÚLTIMAS NOTICIAS, 14 abril 1975).

Foi assim que, além das práticas econômicas concretas enfatizadas em seus fundamentos, via regionalização, também se buscou educar e massificar os conteúdos da geografia cidadã do país. Inegavelmente foi uma tarefa de grande esforço, pois não somente se deveria reeducar a forma científica de entender o território para todos os educandos. Simultaneamente, também se deveria instituir um sentido de localização e participação que imprimisse pertencimento e apropriação dos espaços vividos. 


\section{Imagem $n^{\circ}$ 9. Regionalização e pertencimento}
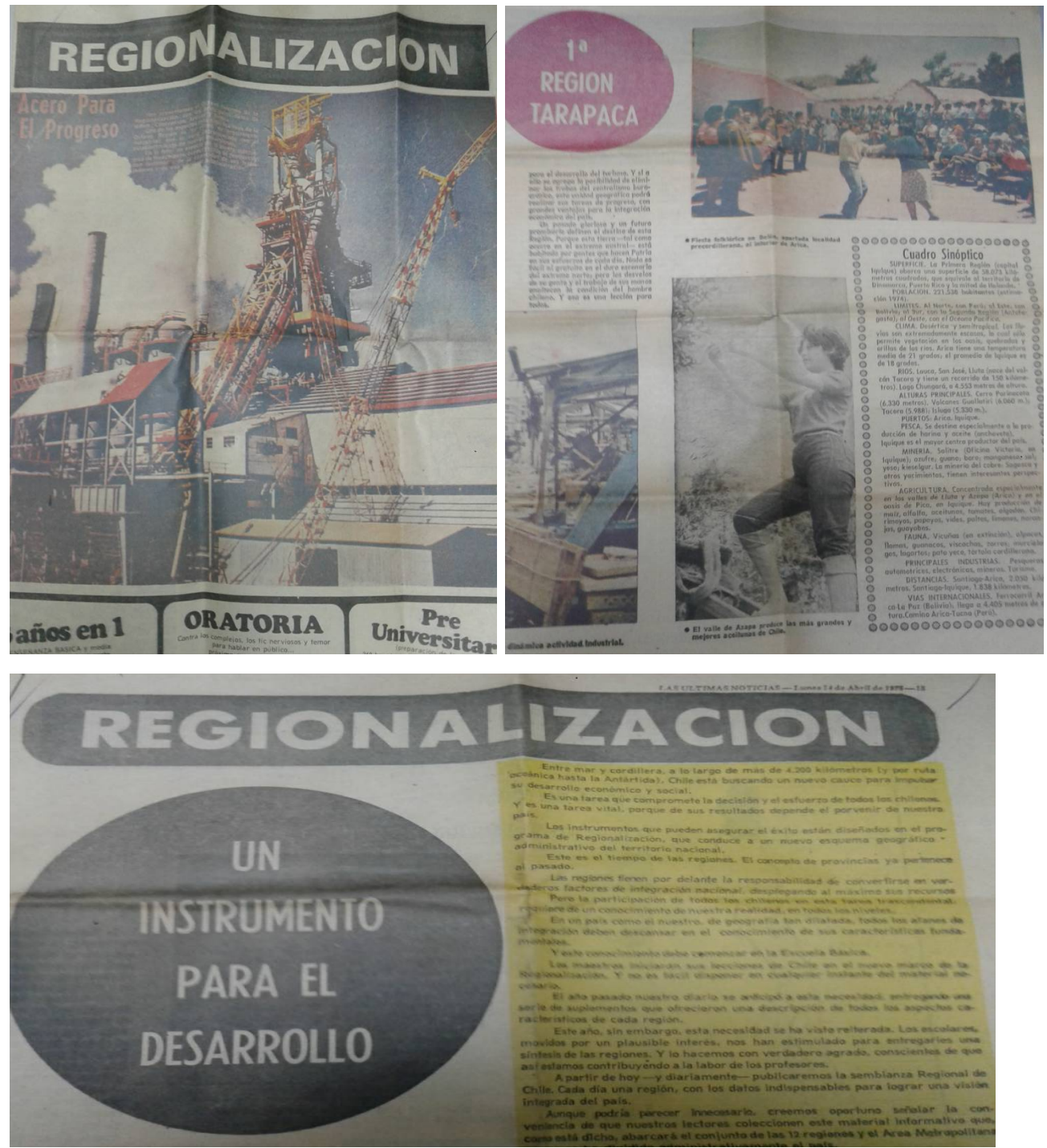

Fonte: em cima e embaixo à esquerda, Últimas Noticias, Santiago, 21 de Abril 1975; embaixo à direita, Últimas Noticias, Santiago, 22 de Abril 1975.

No entanto, a geografia regional difundida pela CONARA, implicitamente, desumanizava sua condição epistemológica do social, ao passo que permitia explicar cientificamente os contornos naturais e "culturais" das regiões de um Estado burocratizado no regional, mas sobretudo, de unidade nacional. No fundamental, o geográfico ficava na explicação natural das formas físicas, geomorfológicas, climáticas e fluviais dos territórios regionais. Entretanto, essa mesma narrativa geográfica natural dialogava fluidamente com outras incursões, tanto da geografia quantitativa, quanto da geografia econômica regional pólos de desenvolvimento e modelos de povoamento urbano -, de maneira que a regionalização constituía uma combinação de diferentes abordagens e aproximações que tributavam da epistemologia tradicional ou mais de vanguarda. Acima de tudo, porém, a 
geografia era um produto ontológico do processo da regionalização oficial, que permitia olhar e atualizar a realidade do novo país. Como destacavam as autoridades da CONARA em 1976:

Es deber de todo buen chileno preocuparse de conocer lo mejor posible la historia de nuestro país, tan certeramente descrito por Ercilla en su inmortal obra "La Araucana", pero es deber ineludible además conocer las realidades geográficas de nuestro peculiar país, y creemos que este ha sido otro de los grandes méritos del Proceso de Regionalización que impulsa CONARA, con el apoyo decidido de S.E. el Presidente de la República, ya que este proceso ha obligado a académicos, universitarios, escolares, profesionales y padres de familia a repasar y actualizar sus conocimientos geográficos de nuestro interesante territorio y mar de Chile (CONARA, 1976, p. 164).

É interessante a citação pois a regionalização deveria induzir promessas do bem-estar, “do contrário não interessaria aos pobres e marginalizados; encanta porque promete a todos um destino comum" (NETO, 2019, p. 19). A regionalização havia permitido uma atualização geográfica do país que haveria contado com a autoridade do próprio Presidente e os diferentes especialistas na matéria. Esse esforço ficou representado com a publicação do Chile hacia un nuevo destino (CONARA, 1976). Esse monumental livro, desenhado pela editora Gabriela Mistral, de mais de 500 páginas e com numerosas imagens e cartografias, foi a descrição geográfica mais importante da regionalização. Não apenas pela qualidade e especificidade das informações, que trouxe uma guia pormenorizada e fundamentada dos novos recortes (as regiões e províncias do primeiro período), mas também porque se inscreviam explicitamente as tramas políticas e econômicas do processo de institucionalização. Dessa forma, Chile hacia un nuevo destino se abria com o Manifesto de Pinochet, o qual era acompanhado de outros relatórios técnicos de diversos organismos do Estado, além de uma projeção de objetivos e tarefas para cada uma das regiões. Estrategicamente ia pautando uma estrutura de governo regional-nacional. Seu lançamento foi feito por grande parte da imprensa e se repetiu em cada uma das regiões junto com a exibição do filme La Regionalización: un nuevo futuro para Chile, como seria destacado pela imprensa da época: "La cinta muestra diversos aspectos del territorio chileno desde Arica a la Antártica e intervenciones del Presidente Augusto Pinochet (...) La película fue dirigida por el comandante González. y los guiones fueron escritos por el periodista Hugo Goldsack"” (EL MERCURIO, 15 dezembro 1976). 


\section{Imagem $n^{\circ} 10$. Equipe civis CONARA}

DEPARTAMENTO DE REGIONALIZACION

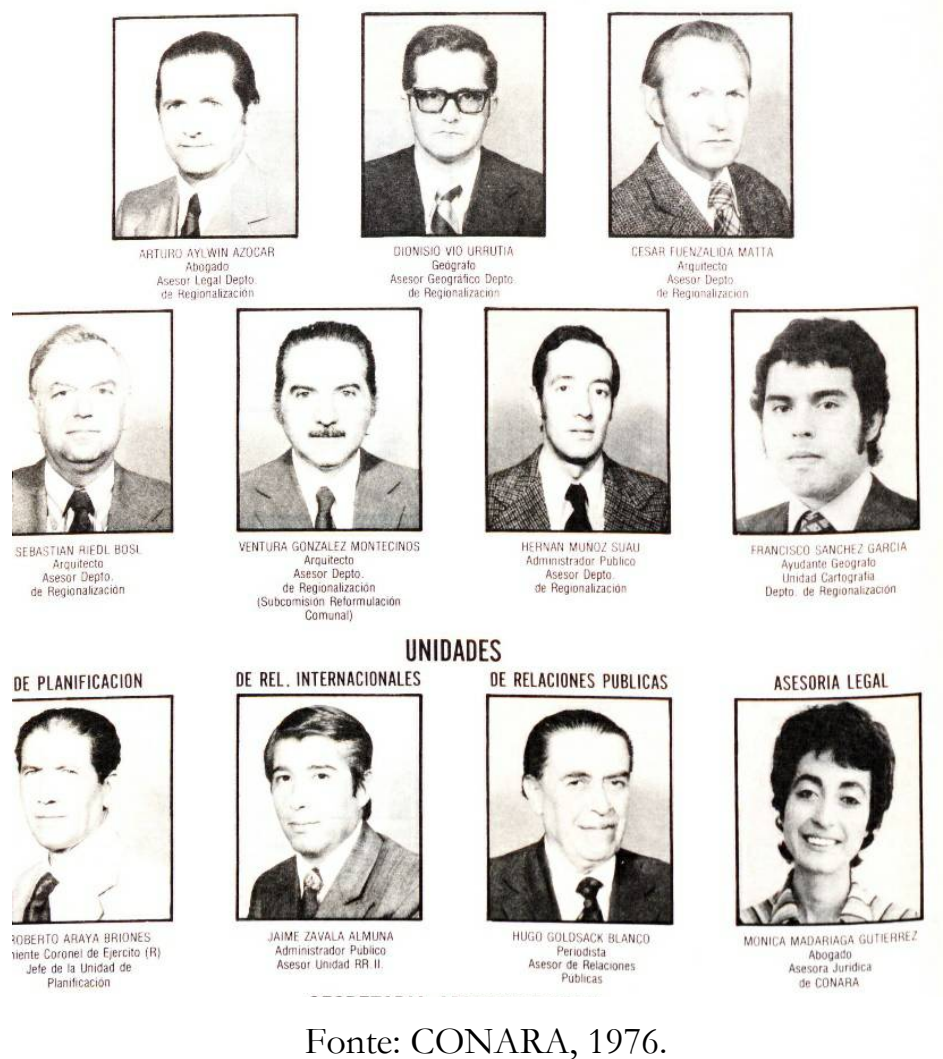

Segundo Vio, Chile hacia um nuevo destino (1976) foi uma iniciativa particular do comandante Alejandro Gonzalez Samohod, secretário executivo da CONARA até 1979 (ENTREVISTA DIONISIO VIO, dezembro 2019). O suporte científico da geografia, significativo para a demarcação das fronteiras internas e a fundamentação dos conteúdos regionais, contou com a supervisão de Dionisio Vio, oficialmente assessor geográfico do Departamento de Regionalização da CONARA. Epistemologicamente, assim, a geografia tem uma conotação essencialmente física e descritiva regional, associada à própria tarefa de entender os fluxos econômicos e as formas naturais diferenciadas de cada uma das regiões. Dessa maneira, a orografia, a degradação climática, a hidrografia, a vegetação, etc., todas essas dimensões físicas também se incorporavam a características demográficas, produtivas e paisagísticas que projetavam regiões particulares. Já na coleção GEOCHILE, por exemplo, distinguia-se também uma geografia política, uma geografia do transporte, uma geografia humana - povoamento - e uma geografia econômica para cada uma das regiões. A nosso ver, trata-se de um catálogo ratzeliano da geografia moderna que, como esclarece Paul Claval, pretende sistematizar as relações que se tecem entre o homem e o meio, procurando leis 
naturais (CLAVAL, 1987). Esse catálogo ratzeliano, por sua vez, se originava do pacto geopolítico da regionalização entendida como uma política do Estado Maior que buscava projetar um poder territorial nacional: definição de fronteiras internas, segurança nacional e fortalecimento do núcleo central de governo enquanto integração das informações políticas oficiais (CHATEAU, 1978).

\subsection{As controvérsias do recorte regional}

Como toda reforma que modifica o reconhecimento oficial do Estado no território, a regionalização de 1974 não foi menos dolorosa e trouxe algumas controvérsias, embora as possibilidades de oposição em um regime autoritário eram sumamente limitadas. Antes da oficialização das fronteiras internas em julho de 1974, o jornal La Prensa fazia um destaque com todas suas letras:

Cuando se adopta una iniciativa de cambios que modifican de manera drástica un sistema tradicional, siempre hay intereses que se sienten heridos y que pugnan por mantener el rutinarismo; también existen sectores que pretenden extraer ventajas egoístas, alejadas del bien común, y que también protestan por no haber tenido ubicación prioritaria. Estas intervenciones complican el estudio de la materia fundamental y, en no pocas ocasiones, han hecho fracasar proyectos de autentico beneficio general (LA PRENSA, 20 fevereiro 1974)

As polêmicas e manifestações contrárias da demarcação das fronteiras internas, pelo geral, criticavam a delimitação dos limites espaciais regionais enquanto perda de centralidade de antigas províncias, sobretudo na definição particular das capitais regionais e das novas estrututuras. Ao mesmo tempo, também questionavam a definição nominativa em números romanos dos territórios regionais como uma expressão da perda de identidade provincial e práticas culturais e símbolos locais. Uma perda burocrática, aliás, do reconhecimento e a hierarquia das antigas categorias de províncias e departamentos. Ambas lógicas de oposição crítica ao recorte das 13 regiões, no entanto, se enquadravam como manifestações internas toleradas pela agenda das próprias autoridades locais nomeadas pelo regime. Dessa maneira se contrariavam as decisões formais da CONARA no sentido que se abria uma particular demanda local especifica ao processo que não questionava os fundamentos, reatualizando, muitas vezes, históricas rivalidades entre comunas e localidades vizinhas.

Para entender a dinâmica e a sucessão das manifestações pela oficialização, é importante lembrar a lógica territorial do avanço dos recortes regionais no país, a qual contemplou uma primeira etapa nas regiões pilotos (I, II, VIII, XI, XII), posteriormente 
uma segunda etapa com as regiões mais próximas ao centro (III, IV, V, VI, VII, IX, X), até finalmente definir uma terceira etapa de recorte territorial de Santiago ou a área metropolitana, sempre a última fronteira de experimentação territorial do regime. Essa ordem espacial, a partir dos extremos até Santiago, também estará refletida nos recortes de províncias e comunas, embora as províncias tiveram uma relativa variação espacial-temporal nos recortes de 1979, como veremos no capítulo V. Entre julho de 1974 e janeiro de 1976, o arranjo regional apenas estava instituído nas regiões pilotos (I, II, VIII, XI, XII). De modo que o país funcionava em uma estrutura dupla entre a nova e a velha malha territorial.

Os recém-nomeados intendentes regionais (I, II, VIII, XI, XII), no entanto, como primeira função de governo, deveriam criar e encaminhar relatórios de suas respetivas províncias, comunas e capitais para CONARA, que prontamente entrariam a uma avaliação técnica e "científica" dos recortes territoriais. Foi nesta zona de especulação, ainda em avaliação, que apareceram os primeiros questionamentos públicos do processo, como foi, por exemplo, a disputa pela capital provincial entre Los Andes e San Felipe, ambas comunas localizadas na província de Aconcagua da V Região. O caso é interessante porque teve uma pública cobertura noticiosa de confrontos entre os prefeitos e autoridades de ambas comunas. No jornal Ultimas Noticias do 11 de junho de 1975 se publicava que, finalmente, depois de uma árdua revisão dos antecedentes apresentados pelas autoridades de Los Andes e San Felipe, CONARA haveria resolvido o problema mediante um decreto salomônico:

Un salomónico fallo de CONARA resolvió el contrapunto que surgió entre las ciudades de San Felipe y Los Andes, a propósito de la sede del Gobierno provincial de Aconcagua (...) Como es de conocimiento público. Los Andes impulsó una activa campaña fundamentando su mejor derecho para ascender al rango de ciudad capital. San Felipe a su vez, expuso sus razones para conservar el titulo. Planteadas así las cosas, la CONARA analizó la impases, determinando que ambas ciudades ostenten la jerarquía de Capital de Aconcagua, aplicando un nuevo concepto administrativo que se define como CONURBACIÓN. La Conurbación involucra la proximidad geográfica de dos polos de desarrollo, que es precisamente el caso de San Felipe y Los Andes separados por una distancia de apenas 20 kilómetros (ÚLTIMAS NOTICIAS, Santiago, 11 de junho 1974) ${ }^{29}$.

Certamente eram disputas de baixa intensidade e relativas a possíveis entradas orçamentarias ligadas aos novos escritórios públicos que implicavam a localização das capitais provinciais. Segundo o decreto-lei $\mathrm{n}^{\circ} 575$, cada capital provincial implicaria a localização de serviços públicos e autoridades (GOBIERNO DE CHILE, 1974c). Com efeito, cada entidade territorial eleita capital provincial necessariamente envolvia dinâmicas

\footnotetext{
${ }^{29}$ Esse mesmo conceito de conurbação, diz o jornal, também vai ser aplicado a Valparaíso e Viña del Mar, sendo ambas prefeituras co-capitais da V Região.
} 
econômicas de aglomeração e uma maior presença de órgãos técnicos e burocráticos que impulsavam possíveis fluxos e investimentos. Um atrativo não menos disputado pelas agências locais, principalmente nos casos de províncias e comunas rurais de menor circulação comercial ou historicamente isoladas dos centros produtivos e populacionais. No caso anterior, chama a atenção o forte nível de debate público entre as autoridades (EL MERCURIO, 6 maio 1975) e a rápida resolução conciliatória e arbitral da CONARA, muito preocupada pela legitimidade do processo. O conceito de conurbação se aplicava de uma maneira discricional e arbitrária, pois, não era uma resposta universal para ser aplicada ao conjunto do sistema de cidades e capitais onde, efetivamente, muitas capitais provinciais estavam interligadas em menos de vinte quilômetros. No entanto, era uma maneira de processar o conflito, conciliar as energias dirimidas e validar que, basicamente, a unidade do processo da regionalização oficial tinha que ser o principal suporte do conjunto das unidades territoriais. Nesse sentido, em março de 1974, se publicava a seguinte carta:

Sr. Director: El Mercurio en su edición del lunes 18 de febrero, recién pasado, se refiere a los estudios que se hacen para divivir el territorio nacional en once regiones, para llegar de esta forma a la descentralización del país. Una de las regiones estaría formada por las provincias de Atacama y Coquimbo, desglosando esta última el Departamento de Illapel para anexarlo a la de Aconcagua-Valparaíso. Si los integrantes de la Comisión de Estudios conocieran las condiciones de vida de las dos provincias que forman el Norte Chico, llegarían a la convicción de que ellas han sido y siguen siendo las cenicientas de Chile [...] Muchas veces se han postergado legitimas pretensiones de las provincias de Atacama-Coquimbo, para favorecer a la zona central, que cuenta con mayores recursos naturales. $\mathrm{Y}$ el hecho de desvincular el Departamento de Illapel, constituye un golpe más artero a los medios que la Creación le negó al sufrido Norte Chico. F. Antonio Viera Martell, La Serena (El MERCURIO, 24 março 1974)

Na prática, vários questionamentos pela localização das sedes regionais e provinciais serão traduzidos a viagens de prefeitos e autoridades locais em direção às dependências da CONARA em Santiago (ESTEFANE, 2017). No entanto, nenhum desses questionamentos terá a transcendência como os casos das províncias de Valdivia e Maule ${ }^{30}$. Ambos casos serão emblemáticos no sentido de provocar uma reposta ativa da comunidade durante anos, obrigando a uma negociação no interior da própria Junta de Governo e uma resolução de leis particulares e medidas políticas compensatórias a curto prazo. A definição da cidade capital regional da X Região em Puerto Montt foi a principal fonte de críticas para o arranjo regional da CONARA. A partir do primeiro instante da regionalização, a província de Valdivia nunca aceitou que Puerto Montt fosse sua capital regional. Rica em tradição econômica e cultural - com destaque para a Universidad Austral de Chile (1954) na mesma

\footnotetext{
${ }^{30}$ A desintegração da antiga província do Maule que passou a ser parte de Linares e Talca, será matéria do capítulo V.
} 
cidade -, a Província de Valdivia historicamente sempre teve uma importância política na zona sul do país que, com a definição de Puerto Montt como capital, parecia não ser reconhecida pelo regime. No terceiro aniversário do Golpe de Estado, 11 de setembro de 1976, o coronel Juan Barrientos Vidaurre, sutilmente destacava que a regionalização haveria tido "pequeños problemas. Esencialmente, por lealtad sentimental" (EL MERCURIO, 11 setembro 1976). Segundo o vicepresidente da CONARA, o argumento oficial da capital da província da X região esgrimia uma ordem geográfica: "se escogió Puerto Montt por estar equidistinta de las provincias que la integran. Si se seleccionaba Valdivia, por ejemplo, Chiloé quedaba completamente aislado. De esta forma el Intendente podrá estar en un lugar central que le permita imponerse de las cuatro provincias" (EL MERCURIO, 11 setembro 1976).

No entanto, a situação de Valdivia foi muito além de uma mera sentimentalidade e geometria espacial. De fato, diferentes documentos oficiais e de imprensa dão conta que a própria CONARA haveria feito estudos para criar a Región de Valdivia, mantendo o apoio do general Pinochet (CONARA, 1977, 1978, 1983). Essa situação possibilitou a permanência da polêmica de Valdivia durante quase todo o período autoritário. Segundo o coronel em retiro Luis Alfonso Rivas, membro de CONARA entre 1977-1982, o caso de Valdivia foi uma experiência inesquecível. Junto com a hierarquia maior da CONARA, ele precisamente haveria participado na reunião resolutiva da Junta de Governo que terminou institucionalmente o assunto em 1977. Segundo suas palavras, foi “una discusión impresionante, nunca me habia tocado estar en una reunión con estos personajes" (ENTREVISTA LUIS ALFONSO RIVAS, novembro 2019). Em termos operativos, a Junta de Governo era o órgão legislativo encarregado de dirimir todas as resoluções técnicas dos recortes territoriais apresentados pela CONARA. Para 1977 a Junta de Governo se articulava pelas máximas hierarquias das FF.AA e a Policia Uniformada Nacional, principiadas com o general Pinochet em representação do Exército e presidente da Junta de Governo, o almirante José Merino pela Marinha, o comandante Gustavo Leigh pela Força Aérea, e também o diretor general Cesar Mendoza em representação de Carabineros de Chile. Para aprovar qualquer decreto-lei a Junta precisava de unanimidade, portanto, não existiam possibilidades para dissensos. Essa política era uma forma de manter o espírito de corpo no governo, próprio das FF.AA., e fazer do plano legislativo um órgão de unidade governamental entre às altas chefias militares. Implicitamente, assim, se fechava a possibilidade de ruturas no interior do comando das FF.AA., projetando o controle da esfera política pelo estrito comando militar, essencialmente na figura de Pinochet como Presidente da Junta de Governo e Presidente do Chile. No 
entanto, segundo Rivas, a discussão pela região de Valdivia era protagonizada com intensidade e se articulava pelas duras posições do admirante Merino (Marinha) e o comandante Leigh $(\mathrm{FACH})$, tendo seu climax quando este último declarou: "Usted es un marinero de chalupa, ¿cuando ba andado en un buque? Asi le dijo. Y Merino le contesta, usted es un piloto de zepelines. Así, con esas palabras, de chalupay zepelines. Y Pinochet se sonrie y dice, bueno señores, cuando los niños dejen de pelear me avisan y vuelvo" (ENTREVISTA LUIS ALFONSO RIVAS, novembro 2019).

O episodio não foi apenas uma anedota, pois representava uma significativa tensão entre as altas patentes militares. Paralelamente, também expressava uma estreita relação colaborativa entre o almirante Merino e o general Pinochet, e a dissidência do comandante Leigh em não aceitar a vontade de poder do Pinochet no interior da Junta. A contenda entre o general Pinochet e o comandante Leigh seguiria crescendo e, precisamente, no ano seguinte esse último seria demitido da Junta de Governo pela vontade de Pinochet ${ }^{31}$. Antes de apresentar uma proposta na Junta, a CONARA já tinha a avaliação do Pinochet, sendo proclive a criação da nova região com capital em Valdivia. Diz Rivas: "CONARA trabajó con criterios de Estado Mayor y propuso diferentes cursos de acción, concluyendo que la alternativa o curso de acción favorable era crear la región”"(ENTREVISTA LUIS ALFONSO RIVAS, novembro 2019). No entanto, a resolução pela região de Valdivia também traria uma outra questão envolvida. Logo após o Golpe de Estado do 11 de setembro de 1973, a administração territorial se dividiu em 28 unidades encarregadas e vigiadas pela comandância das FF.AA. do país. Foi via decreto-lei nº 4 de Estado de exceção que se impôs a administração das províncias e departamentos como responsabilidade dos oficiais das FF.AA.. Efetivamente, essa primeira divisão administrativa de Estado de emergência do país também foi uma divisão política das FF.AA. na estrutura territorial e repartição de autoridades. Das 28 unidades territoriais -25 províncias mais três departamentos - em que foi dividida o território nacional do decreto, a maior parte correspondia ao Exército. Dessa forma, apenas duas unidades correspondiam à Marinha e uma última unidade estava em responsabilidade da Força Aérea ${ }^{32}$. Essa distribuição do poder administrativo do Estado, com clara hegemonia do Exército e escassa

\footnotetext{
${ }^{31}$ Diversas pesquisas dão conta da rivalidade entre Pinochet e Leigh (VALDIVIA, 2003; HUNEEUS, 2016). No ano seguinte, 1978, o comandante Leigh foi demitido da Junta de Governo pela decisão do Pinochet e o apoio dos outros membros da Junta. Isso gerou uma profunda instabilidade no interior da Força Aérea do Chile, pois, junto com a saída do Leigh, também implicou a saída de quase a totalidade do Alto Mando da Força Aérea.

${ }^{32}$ A Polícia Uniformada não teve nenhuma unidade territorial nesse recorte sub-nacional da posse do Golpe do 11 de setembro de 1973. No entanto, no transcurso da regionalização posteriormente vai ter responsabilidades em outras escalas.
} 
participação das outras ramas castrenses, foi o equilíbrio de poder pactuado no comando territorial entre as FF.AA. durante todo o período autoritário. Por sua vez, também foi a expressão do peso institucional da rama mais antiga e poderosa do país, com mais homens e distribuição no território nacional, reflexo da autoridade de Pinochet e da importante participação de oficiais do Exército em destinações no governo: ministérios, subsecretárias, intendências, governações, embaixadas, prefeituras, entre outras (HUNEEUS, 2016).

A partir do decreto de Estado de Emergência de 11 de setembro de 1973, as províncias de Llanquihue e Chiloé se tornaram responsabilidade da Força Aérea. De tal maneira que quando se criou a X Região em 1974, com a integração das províncias de Valdivia, Osorno, Chiloé e Llanquihue, se determinou que Puerto Montt fosse a capital da região com autoridade na Força Aérea. O argumento dessa definição radicava em que nessa mesma cidade estava localizada a segunda base área mais importante do país. Daí que a criação da nova região de Valdivia, internamente, implicava a fragmentação e perda de poder da única região em responsabilidade da Força Aérea. Como destaca Rivas: "bay que entender la región de Puerto Montt, X región, era la única Intendencia que tenian los aviadores, entonces, la defendían mucho" (ENTREVISTA LUIS ALFONSO RIVAS, novembro 2019). Desse modo, o comandante em chefe da Força Área não aceitou a proposta da CONARA e, ao não ter unanimidade, a criação da região de Valdivia foi rejeitada pela Junta de Governo. Essa resolução seria difundida nos titulares internos da seguinte maneira: Junta no aceptó dividirla. Se Mantiene Integridad de la Décima Región (EL MERCURIO, 7 dezembro 1977). Paralelamente, o regime também anunciava a criação de medidas complementárias para impulsar o desenvolvimento regional na totalidade da X Região. Na semana seguinte se destacava a coordenação de um plano de investimento em conjunto com universidades e outros organismos públicos, incluindo a ODEPLAN de Santiago, tendo o governo regional que "trasladarse en pleno a las capitales provinciales, por lo menos una vez al año, para contribuir a solucionar en terreno los problemas existentes" (EL MERCURIO, 17 dezembro 1977). Essas medidas, de alguma forma, eram medidas compensatórias ao desejo de ter Valdivia reconhecida com maior hierarquia territorial e fechar o confronto com algum nível de legitimidade. No entanto, como assinalávamos mais cima, o debate sobre a criação da região de Valdivia seguirá circulando, apesar que não será aprovada durante o período do regime. 


\section{Imagem n ${ }^{0}$ 11. Controvérsia da X Região}

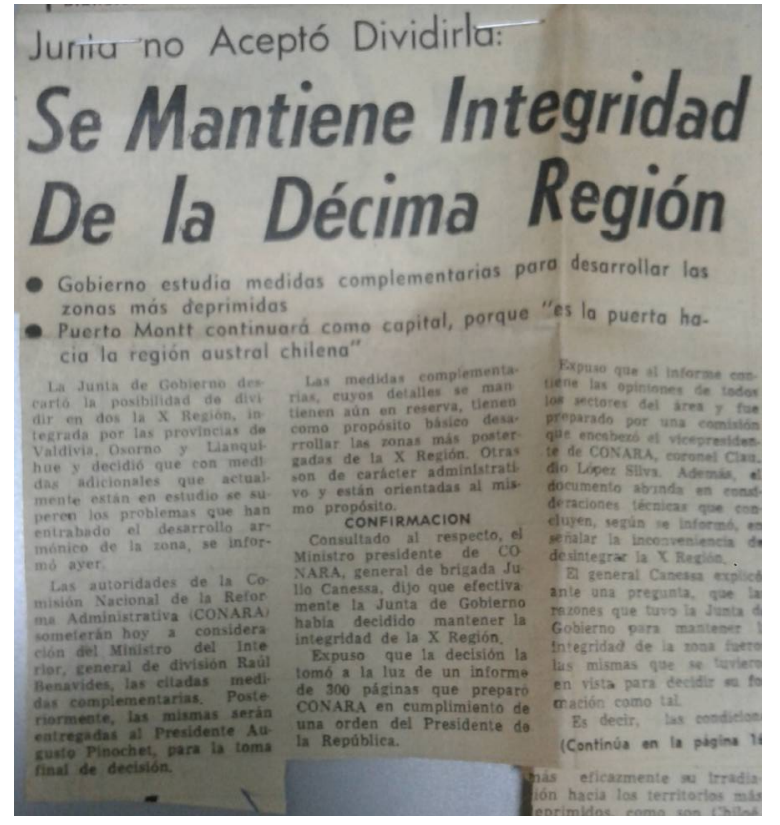

Fonte: El Mercurio, Santiago, 7 de dezembro de 1977.

Simultânea e paralelamente, mas sem uma tensão militar de fundo, também emergia uma segunda fonte de críticas ao recorte regional ligada ao sentido identitário simbólico, perdido pela nomeação romana das regiões. A nomeação romana das regiões de julho de 1974 foi uma continuidade da regionalização da ODEPLAN de 1968, na qual Santiago se definia como uma Área Metropolitana, mais doze regiões em direção norte-sul. Como lembra Sergio Boisier, "los patronimicos numéricos no son invento militar. Fueron establecidos por los civiles al inicio de la regionalización en 1966 como máxima expresión de la racionalidad iluminista" (ENTREVISTA SERGIO BOISIER, abril 2017). No entanto, uma parte da literatura relacionou a expressão numérica das regiões à sua lógica militar de controle e ordem interna, especialmente enquanto sua dimensão geopolítica de tensões e interações nas fronteiras externas, e sobretudo pelos reiterados conflitos com Perú, Bolívia e Argentina durante o período autoritário (1974-1980). Entretanto, a preocupação simbólica do regime pela nomeação numérica das regiões não foi um assunto desatendido. Em outubro de 1974, só três meses depois da oficialização das regiões com números romanos, a Junta de Governo aprovou o decreto-lei n 712 que estabeleceu que a XI Região fosse nomeada como "Región Aysen del General Carlos Ibáñez del Campo" pela "necesidad de rendir homenaje a la memoria del General Carlos Ibánez del Campo por su destacada administración y constante lucha por levantar nuestra Nación" (GOBIERNO DE CHILE, 1974d, s./r.). Foi o primeiro passo de uma série de preocupações simbólicas que, com o passar do tempo, alteraram a nomeação oficial das regiões. O regime apelava a valores ancestrais e tradicionais que mostravam seu conservadorismo político. 
Como destaca Neto, o pensamento militar se estabelece, justamente, a partir da "preservação da estabilidade e da ordem” (NETO, 2019, p. 18). Dai que, junto com a divulgação dos textos escolares e materiais editoriais da imprensa, nos primeiros anos da regionalização, o regime tentou criar símbolos regionais ancorados a repertório históricos e pertencimento nacional que articulasse essa comunidade de interesses. Em uma longa reportagem do ElMercurio, em agosto de 1975, se publicou um interessante estudo feito pela CONARA, onde se anunciava por primeira vez que a Área Metropolitana de Santiago se denominaria Região Metropolitana $^{33}$, na lógica de homogeneizar as unidades territoriais em treze regiões ${ }^{34}$. Por sua vez, as autoridades da CONARA representadas por general Julio Canessa, comandante Jorge Lucar e também pelo geógrafo Dionisio Vio, explicavam metaforicamente que, por seu caráter prematuro, a regionalização ainda era um sistema de canais que não conseguia alimentar todas as regiões do país. Porém, em um futuro próximo, diziam, as regiões deveriam impulsar uma racionalização dos "servicios públicos, de las universidades, de la justicia, de la salud, de las formas de seleccionar y promover a los trabajadores del Estado" (EL MERCURIO, 25 agosto 1975), graças a uma efetiva regionalização do público conectado no social. $\mathrm{Na}$ reportagem também se distinguiam tipos de flores que, simbolicamente, deviam inserir significados particulares das paisagens, sendo emblemas internas das identidades regionais ancoradas na regionalização. A flor do copigue, ao ser a representação do Chile não poderia representar a nenhuma região, diz a reportagem. A necessidade de repensar o nome das regiões, inclusive, havia significado uma preocupação para o próprio general Pinochet, quem consideraria um segundo estudo paralelo ao trabalho da CONARA, precisamente para ampliar alternativas patronímicas, geográficas e históricas de cada região (EL MERCURIO, 25 agosto 1975), as quais, por primeira vez, seriam reveladas ao público em geral.

\section{Quadro nº 6. Nome regiões, províncias e símbolos florais El Mercurio (1975)}

\begin{tabular}{|c|l|l|l|}
\hline Região & \multicolumn{1}{|c|}{ Províncias } & \multicolumn{1}{|c|}{ Nome } & \multicolumn{1}{c|}{ Símbolo floral } \\
\hline I & $\begin{array}{l}\text { Arica, due, } \\
\text { Parinacota, Puchultiza }\end{array}$ & $\begin{array}{l}\text { Región de Tarapacá del } \\
\text { Capitán Prat }\end{array}$ & El chuvé \\
\hline II & Tocopilla, Antofagasta. & $\begin{array}{l}\text { Región de Antofagasta de } \\
\text { José Santos Ossa ou Región } \\
\text { de Antofagasta de Rafael } \\
\text { Sotomayor }\end{array}$ & Chaguar del jote \\
\hline III & $\begin{array}{l}\text { Chañaral, Copiapó, del } \\
\text { Huasco }\end{array}$ & $\begin{array}{l}\text { Región de Juan Godoy } \\
\text { (descobridor de Chañarcillo) }\end{array}$ & Garra de León \\
\hline
\end{tabular}

\footnotetext{
${ }^{33}$ Oficialmente o decreto-lei n ${ }^{\circ} 1230$ se aprovou o 27 de Outubro de 1975. Significou dois novos nomes para a regionalização. A Área Metropolitana de Santiago passa a ser denominada Região Metropolitana e a Região XII passa a ser nomeada como XII Região de Magallanes e a Antártica Chilena.

${ }^{34}$ Simultaneamente por esses dias se anunciavam algumas províncias novas.
} 


\begin{tabular}{|c|c|c|c|}
\hline IV & Elqui, Limarí, Choapa & Región de Gabriela Mistral & Añañuca \\
\hline $\mathrm{V}$ & $\begin{array}{l}\text { San Antonio, } \\
\text { Valparaíso, Aconcagua, } \\
\text { Isla de Pascua, Quillota }\end{array}$ & $\begin{array}{l}\text { Región del Ministro Diego } \\
\text { Portales }\end{array}$ & Ainda em estudo \\
\hline VI & Cachapoal, Colchagua & \begin{tabular}{lcr} 
Región del & \multicolumn{2}{c}{ General } \\
O’Higgins ou & Región & del \\
Cardenal Caro & &
\end{tabular} & Zarcilla \\
\hline VII & Curicó, Talca, Linares & Región de Antonio Varas & $\begin{array}{l}\text { Puñeñe (pudeñi según } \\
\text { algunos) o chupalla }\end{array}$ \\
\hline VIII & $\begin{array}{l}\text { Ñuble, Concepción, } \\
\text { Arauco, Biobio }\end{array}$ & $\begin{array}{l}\text { Región del Presidente Joaquín } \\
\text { Prieto ou Región Biobio del } \\
\text { Presidente Joaquín Prieto }\end{array}$ & $\begin{array}{l}\text { Flor de la maravilla } \\
\text { (también podría ser el } \\
\text { lluto) }\end{array}$ \\
\hline IX & Cautín, Malleco & $\begin{array}{l}\text { Región del Cacique Lautaro } \\
\text { ou Región de Alonso de } \\
\text { Ercilla }\end{array}$ & $\begin{array}{l}\text { Notro (llamado también } \\
\text { ciruelillo) }\end{array}$ \\
\hline $\mathrm{X}$ & $\begin{array}{l}\text { Valdivia, } \\
\text { Llanquihue, } \\
\text { Palena }\end{array}$ & $\begin{array}{l}\text { Región de Los Lagos de } \\
\text { Vicente Pérez Rosales ou } \\
\text { Región de Vicente Pérez } \\
\text { Rosales }\end{array}$ & Pelú \\
\hline $\mathrm{XI}$ & $\begin{array}{l}\text { Aisén, General Carrera, } \\
\text { Capitán Prat }\end{array}$ & $\begin{array}{l}\text { Región Aisén del general } \\
\text { Carlos Ibañez del Campo }\end{array}$ & Ainda em estudo \\
\hline XII & $\begin{array}{ll}\text { Última } & \text { Esperanza, } \\
\text { Magallanes, Tierra del } \\
\text { Fuego, } \\
\text { Chilena }\end{array}$ & $\begin{array}{l}\text { Región de Magallanes del } \\
\text { general Bulnes }\end{array}$ & $\begin{array}{l}\text { Coicopuhue } \\
\text { magellanica) }\end{array}$ \\
\hline $\mathrm{RM}$ & Ainda em estudo & Región de Pedro de Valdivia & Ainda em estudo \\
\hline
\end{tabular}

Fonte: El Mercurio, 31 de agosto de 1975.

O fato singular da reportagem dos nomes de regiões se contextualizava no decidido culto a personagens históricos, principalmente ligados a figuras de homens e políticos, algumas presidenciais, entretanto, todos de setores conservadores (X, VIII, VII, V, II), ou membros do imaginário militar (XII, XI, VI, I) e da história colonial do país (RM-IX). Por sua vez, também se projetava a presença de duas figuras religiosas (VI e III) e, apenas, uma presença feminina, a poetisa e Premio Nobel de Literatura (1945), Gabriela Mistral, com o nome da IV Região. Dessa maneira, políticos, militares, religiosos e personagens históricos da época colonial, mais uma poetisa, formavam parte do acervo unitário-nacional selecionado para instituir pertencimento às unidades regionais. Todas a regiões, além de que eventualmente levariam um nome geográfico, tinham uma identificação ancorada a um personagem que expressaria parte significativa da representação nacional do país, uma representação coerente com a nova projeção política do Estado e seu território. Pouco tempo depois, em maio de 1976, um leitor da revista Ercilla destacava o escasso sentido de apropriação na numeração romana das regiões, além de uma escassa lógica geográfica e histórica com os territórios internos. No final da carta, com assinatura de H.F. Valparaíso, se destacavam nomes para as regiões: 
Ahora, con respecto a la denominación de las regiones, estimamos que sería conveniente que cada región lleve un nombre que la identifique instantáneamente en la mente del hombre o la mujer común, un nombre que sea expresión de la geografía y la tradición [...] La denominación por un número ordinal correlativo la sentimos fría, impersonal, difícil de recordar y ubicar geográficamente en la memoria del hombre de la calle, ya sea en el estudio, la información o el trabajo. Con ánimo de colaborar en esta materia me permito sugerir que las Regiones Administrativas del territorio lleven los siguientes nombres: $1^{a}$ Tarapacá, 2 da Antofagasta; $3^{\circ}$ Atacama; 4ta Coquimbo; 5ta Aconcagua; Distrito Metropolitano; 6ta Colchagua; 7ma Maule; 8va Bío-Bío; $9^{\mathrm{a}}$ Frontera de Araucanía o simplemente Araucanía; $10^{\mathrm{a}}$ Los Lagos; $11^{\mathrm{a}}$ Aisén; $12^{\mathrm{a}}$ Magallanes (ERCILLA, 26 maio 1976).

Dois anos após dessa carta, com o decreto-lei no 2339 do 02 de outubro de 1978, o regime aprovou a nomeação oficial das regiões, bastante similar da proposta da carta em Ercilla, embora bastante diferente dos estudos apresentados pela CONARA e Pinochet em 1975. Antes disso, como vimos, já haviam sido aprovados os nomes da Região de Aisén del General Carlos Ibañez del Campo em novembro de 1974, da Região Metropolitana e a Região de Magallanes y la Antártica Chilena em outubro de 1975. O novo sistema regional assumiu uma nomeação tradicional ancorado na toponímia histórica e a incorporação de algumas referências militares (quadro $n^{\circ} 7$ ).

\section{Quadro $\mathbf{n}^{\circ}$ 7. Regionalização números romanos e nomes}

\begin{tabular}{|c|c|}
\hline $\begin{array}{c}\text { Região números } \\
\text { romanos 1974 }\end{array}$ & Nome regiões 1978 \\
\hline I Región & Región de Tarapacá \\
\hline II Región & Región de Antofagasta \\
\hline III Región & Región de Atacama \\
\hline IV Región & Región de Coquimbo \\
\hline V Región & Región de Valparaíso \\
\hline VI Región & $\begin{array}{c}\text { Región del Libertador } \\
\text { General Bernardo } \\
\text { O'Higgins. }\end{array}$ \\
\hline VII Región & Región del Maule \\
\hline VIII Región & Región del Bío-Bío \\
\hline IX Región & Región de la Araucanía \\
\hline X Región & Región de Los Lagos \\
\hline XI Región & $\begin{array}{c}\text { Región Aysen del General } \\
\text { Carlos Ibáñez del Campo }\end{array}$ \\
\hline XII Región & $\begin{array}{c}\text { Región de Magallanes y de la } \\
\text { Antártica Chilena }\end{array}$ \\
\hline Área Metropolitana de & $\begin{array}{c}\text { Región } \\
\text { Santiago }\end{array}$ \\
\hline
\end{tabular}

Fonte: elaboração própria a partir dos decretos-leis no 575 e n 2339.

De uma ou outra forma, a oficialização do processo de regionalização se aprofundava como ritual e poder simbólico. O território nacional ancorado em regiões procurava 
legitimar-se a partir do fortalecimento dos significados nacionais e uma ordem linguística que internamente negava a qualquer fórmula de dissidência na lógica de um patriotismo que "não apenas sacraliza o território: sobretudo, acata e privilegia estruturas sociais iníquas" (NETO, 2019, p. 32). A partir de 1978 as regiões passaram a ter nomes oficiais, embora continuassem sendo distinguidas com números romanos. Uma ordem simbólica, racional e política que, paralelamente, articulava uma identidade autoritária inserida na forma de governo nacional regionalizado. Segundo o secretario executivo da CONARA, o comandante Alejandro Gonzalez Samohod, a decisão de nomear as regiões haveria sido o resultado de múltiplas petições da comunidade, onde, “las regiones debian singularizarse con un nombre en lugar de un número [...] Indicó que para las denominaciones se tomaron en cuenta antecedentes históricos, culturales, geográficos y la tradición" (EL MERCURIO, 11 outubro 1978). Em complemento disso e como estrutura regional nacionalizada, a historiadora Karen Donoso destaca que

eventos deportivos como "La Gran Posta de Chile" - una carrera realizada de manera simultanea en todas las regiones del país, que comenzaba paralelamente en Visviri y la Antártica y concluía en Santiago - y la "Vuelta de Chile", competencia del ciclismo que también recorría el país desde el sur hasta el norte, eran interpretados por el régimen como una metáfora: la unidad espacial que hacían los deportistas la homologaban como el encuentro emocional que debía tener la comunidad nacional; igualmente, el esfuerzo físico realizado por los competidores representaba la lucha de los chilenos por reconstruirse como nación (DONOSO, 2012, p. 104).

A construção imaginária das regiões, assim, foi matéria de importantes movimentações conservadoras. Em um interessante artigo, Politizar el paisaje, ilustrar la patria: nacionalismo, dictadura chilena y proyecto editorial (2011), Isabel Jara destaca que durante o período autoritário as editoriais cumpriram uma importante tarefa estética e ideológica de limpar as representações da UP e, simultaneamente, criar uma restauração da tradição conservadora do nacional, onde a paisagem da zona central do Chile seria entendida como a metáfora da nação e o presente político da pátria (JARA, 2011). Dessa maneira se veiculava uma ideia de paisagem em três direções enquanto fator de integração e chilenidade. Primeiro, para remarcar o projeto cultural das direitas e ampliar seus aderentes; segundo, para impugnar as representações da UP, particularmente suas identidades camponesas, popular e nacional, "desmovilizando así, simbólicamente, a los vencidos" (JARA, 2011, p. 237). E, por último, para “legitimar el nuevo orden político como expresión de un determinado orden naturaP” (JARA, 2011, p. 237). Sobre essa naturalização, sustenta Jara, "la interpelación del paisaje local fue, antes que un argumento estético o geopolitico, un argumento histórico — como espacio de un pasado a reivindicar -, para asentar el nuevo sistema político sin Parlamento ni partidos" (JARA, 2011, p. 237). Precisamente, trata-se do mesmo espírito de despolitização que iria ser posicionado pela regionalização enquanto 
fundamento histórico de justiça para as províncias, como destacaria o jornal La Tercera no terceiro aniversario do Golpe de Estado: "La regionalización ha cumplido un anhelo bistórico de justicia en Chile. Es la rebelión de las provincias que necesitan tomar sus propias decisiones" (LA TERCERA, 11 setembro 1976). Embora não houvesse uma vinculação aparentemente direta, a regionalização permitia um arranjo territorial alternativo do antigo sistema político. Nas regiões se recriaria uma ordem socio-espacial que prescindia das práticas democráticas históricas e populares. Essa naturalização do poder autoritário foi estratégica e sutilmente acompanhada através de notas, entrevistas ou reportagens da CONARA que, uma e outra vez, disponibilizavam uma geografia regional sem conflitos nem atritos, mas funcional aos objetivos do governo central.

A geografia da regionalização foi um veículo administrativo ancorado nos princípios conservadores e patrióticos das regiões naturais que não conseguiam se politizar com a comunidade social. O uso do saber geográfico do arranjo regional em 1974, então, não operou somente como uma ferramenta de legitimação científica para justificar as novas demarcações e funções estatais. A geografia da regionalização oficial, acima de tudo, funcionou como um fundamento para a naturalização e subordinação das comunidades com o Estado autoritário. Dita legitimação, em busca da subordinação, tinha a função específica de naturalizar as hierarquias ou escalas geográficas de mando, que validavam um determinado tipo de política na sociedade: um governo autoritário forte dos militares no topo e uma participação local de baixa deliberação na base. Em outras palavras, a regionalização e suas formas geográficas deviam conduzir a práticas cotidianas que fortalecessem o sentido de autoridade geográfica do regime: uma autoridade nomeada e vertical. Assim, no processo da regionalização se expandia uma invisível - porém pujante - geografia disciplinadora da realidade, que atualizará a posição do Estado em seu território como uma regra básica da antiga geopolítica: o Estado sobre a sociedade (COSTA, 2013).

A regionalização de julho de 1974, por consequência, respondeu à uma manobra política que particularmente buscou mitigar e compensar sua legitimidade num particular momento do regime: forte isolamento internacional, crise econômica pela inflação e forte repressão política contra as esquerdas. Foi um dispositivo que permitiu abrir uma agenda política do público, mas sobretudo, acelerar linhas e redes políticas do governo no espaço social. Além disso, a agência comum entre empresários e autoridades do regime procurava ampliar a base social relativa aos interesses do regime e, rapidamente assim, projetar uma ilusão de 
representação nacional, ignorando o processo de politização vivido antes do Golpe de Estado. Isto é, inverter o tradicional espaço de representação das esquerdas e paulatinamente recriar um território da comunidade nacional despolitizada em busca de ser chileno e chilena. Dessa forma, paulatinamente, tecia-se uma rede de poder entre as corporações empresariais, agentes estatais e as organizações comunitárias vigiadas, constituindo-se uma micropolítica local e regional que aparentava representar a vontade popular. Como destacava um alto funcionário do Ministério do Interior em 1975, Helio Suárez, para governar o país era preciso uma "tranquilidad social interna que no sea perturbada por la marginalidad de parte de nuestros compatriotas" (ULTIMAS NOTICIAS, 18 abril 1975). A regionalização se inseria diretamente na ideia de cidadania que devia reconhecer as diferenças geográficas do país, a distribuição dos recursos e, sobretudo, a autoridade territorial de uma administração do Estado que articularia uma única linha de mando hierarquizada. Referindo-se às linhas hierárquica, técnica e participativa, Suárez, também destacava que as regiões funcionariam como:

\footnotetext{
Estas entidades operarán como Gobierno Regional y sus funciones serán las de Administrar a la región para lograr su desarrollo. Ello significa que recogerán las ideas, proyectos, inquietudes y necesidades de la población que habita en ese territorio, medirán las posibilidades que ofrecen sus recursos humanos, naturales y financieros y aplicarán las políticas generales que dicta el Gobierno Central para el desarrollo del país en su conjunto. De aquí surgirá un Plan de Desarrollo Regional que signifique una coordinación imperativa para todas las instituciones y servicios del Estado que trabajan en la Región y un conjunto de indicaciones y orientaciones al sector privado, para que éste pueda actuar de acuerdo a la política social de mercado adoptada por el Supremo Gobierno (ULTIMAS NOTICIAS, 18 abril 1975)
}

Regionalizar para governar? Em conjunto com orientações do setor privado? A regionalização colocada em jogo em julho de 1974, assim, foi expressão de uma Geografia de Estado Maior, uma decisão e intervenção própria da alta patente militar que, desde o inicio, projetou um determinado cenário onde o regime autoritário e o general Pinochet se apresentaram como uma alternativa de governo que poderia transcender e permanecer irrevogavelmente no tempo, sem a necessidade de um regime político de deliberação popular. Foi nesse complexo movimento político institucional e simbólico que o antigo sistema territorial foi alterado, inscrevendo-se um novo tecido de técnicas burocráticas e de cálculos descentralizadores na capilaridade territorial estatal. Foi uma reconquista do poder autoritário no interior do Estado do Chile contra os direitos políticos do século XX, contra o poder político histórico acumulado pelo povo chileno, conseguido após importantes movimentações, energias e conquistas sociais das três décadas antecedentes. De uma ou outra maneira, o regime seguia uma das máximas de Maquiavelo: "para gobernar justamente hay que delegar el poder concentrado originalmente en las distintas unidades territoriales, para asi alcanzar un 
desarrollo armónico entre las distintas partes del territorio. Si se quiere reinar, hay que dividir el poder con que se ejercen las funciones" (MAYORGA, 2012, p. 4). Nesse primórdio da regionalização, que coincide com a naturalização simbólica das regiões com nomes e números romanos (19741978), precisamente, se redefiniram as condições do uso político do território através das regiões, projetando um tipo de participação vigiada que, na contramão de suas legitimações tradicionais como o voto popular e múltiplos partidos, também ampliará o repertorio politico e burocrático do regime. Uma luta técnica pelos conteúdos territoriais do plano operativo político do regime? Um dispositivo estratégico próprio da geopolítica em um contexto de dramática politização e luta de classes? Uma resposta ao profundo processo de politização e avanço popular da sociedade chilena durante o seculo XX? 


\section{CAPÍTULO 3}

\section{Regiões: um imperativo estratégico do poder nacional}

\subsection{O arranjo regional estrutural: centralização, poder regional e politização}

A rápida implementação da regionalização da CONARA da conta da continuidade dos itinerários da primeira regionalização de planejamento em 1968. No entanto, conforme a definição econômica do projeto autoritário, essas continuidades irão sendo reorganizadas a partir de outros fundamentos totalmente contrários da teoria dos pólos de desenvolvimento. Se bem o governo de Frei Montalva (1964-1970) tentou criar uma maior equivalência entre as ORPLAN e as funções do planejamento territorial do Estado, é importante destacar que essas mudanças não alteraram a dimensão centralista dos procedimentos e organizações públicas do território subnacional (VALENZUELA, 2015; BULNES, 1990; TOBAR, 2016). Efetivamente, as bases ministeriais do Chile, até 1976, foram profundamente dispares do ponto de vista territorial. Isso quer dizer que cada ministério tinha sua própria forma de organização territorial e se distribuía pelo país com burocracias espacialmente inconexas umas com as outras, de maneira que era absolutamente complexo ou, quase impossível, estabelecer integrações ou coordenações entre as diferentes carteiras ministeriais e seus respetivos serviços públicos. Para o ano de 1970, apenas alguns poucos ministérios tinham uma presença burocrática organicamente uniforme em todo $\mathrm{O}$ território nacional, como seriam os casos do Ministério de Fazenda e Obras Públicas. Como assinala o geógrafo especialista em desenvolvimento regional e estudante do ILPES da época, José Abalos, a situação da antiga estrutura pública do país era paupérrima, com escassos recursos orçamentais e diminuídas competências integradoras capaz de reverter a instrumentalização burocrática das províncias (ENTREVISTA JOSÉ ABALOS, outubro 2019). Essa situação, além de minimizar as políticas públicas estratégicas e as capacidades de desenvolvimento regional do país, também reproduziam uma ordem hierárquica das relações internas entre o Estado central e seus órgãos territoriais.

Com exceção das vigorantes políticas regionais da década de 1960, a estratégia política e econômica do país seguia dependendo fortemente das definições do governo central. Os Ministérios estavam estruralmente ancorados na agenda do poder político em Santiago e as províncias administravam os poucos recursos orçamentais que se coordenam via setores públicos. Como relata Abalos, "cada ministerio tenía una forma de organizar, agricultura tenía na sé cuantas zonas, el Ministerio de Obras Públicas tenía otras tantas, Salud tenía unas zonas 
prioritarias, etc., entonces, la verdad es que la planificación quedaba en las ganas, porque, en la práctica habia autoridades que tenían unas visiones muy distintas unas de otras" (ENTREVISTA JOSÉ ABALOS, outubro 2019). Essa situação também coincide com o funcionário de CONARA da época, Jaime Zavala, quem destaca que, antes do Golpe de Estado, a administração pública nos territórios internos carecia de uniformidade e critérios orgânicos, pois, se criavam instituições com diversas funções, responsabilidades e autonomias que, na prática, deram origem " $a$ un grave detrimento en la unidad de la acción administrativa del Estado" (ZAVALA, 1990, p. 64). Dessa maneira se produziam duplicidades entre os organismos do Estado, o qual gerava uma dispersão de energias e descoordenação para satisfazer mesmas tarefas e necessidades estruturais (CONARA, 1982). No caso de Ministérios e Serviços Públicos nas províncias, segundo Zavala, "se habian organizado sin criterios racionales y con proliferación de unidades de distintas denominaciones, lo que dificultaba gravemente el trabajo eficiente de la Administración Pública" (ZAVALA, 1990, p. 64). Como lembraria o general Canessa em seu livro de entrevista, logo nos primeiros meses após do Golpe e origem da CONARA:

Estando en medio de los mil problemas que debía resolver el Comité Asesor, me pidieron que recibiera a un señor Sáez, de la oficina de Organización y Método del Ministerio de Hacienda. Accedí sin mucho entusiasmo y lo cité al día siguiente a las tres de la tarde. Corría el mes de noviembre y hacía calor en mi oficina en el edificio Diego Portales, que no tenían aire acondicionado. Me expuso su preocupación por la enorme desorganización de la administración pública. Lo escuché con paciencia pues no decía nada nuevo. Yo había nacido escuchando que la burocracia era un desastre, pero lo único que conocía las instituciones armadas, no funcionaban mal. La verdad que los temas administrativos no me gustaban, siempre les hice el quite, considerándome un oficial de combate. Sin embargo, a medida que este señor hablaba me comenzó a interesar lo que planteaba e intuía que detrás de este frondoso orden feudal que me describía -cada órgano tenía un estatuto particular- había intereses muchas veces contrapuestos, incluso anacrónicos, que explicaban la ineficiencia de su actividad. Todos los gobiernos habían lidiado con este monstruo de mil cabezas sin haber logrado hacerlo trabajar concertadamente. Remediar esa situación era un desafío tentador, el problema tenía una real magnitud tal que solo el Gobierno Militar, libre de las ataduras de los intereses creados, podía acometerlo. No había que dejar pasar la oportunidad. Esa conversación planteó en mí la semilla de CONARA. Lamento no recordar el nombre completo de ese funcionario, a quién nunca más vi (ARANCIBIA, BALART, 2006, p. 202-203).

Controlar e, portanto, vigiar esse "monstruo de mil cabezas" e precariedades institucionais, seria o principal desafio da CONARA. As principais estruturas subnacionais, as províncias, por regra geral, não contavam com sistemas de assessorias para a toma de decisões, tendendo a uma escassa regulação dos direitos dos usuários e uma constante incerteza do sistema público enquanto mecanismo de desenvolvimento de serviços e tarefas burocráticas cotidianas, alheias e inconexas às necessidades da população (CONARA, 1982). Toda essa descoordenação de funções e tarefas, no fundo, acrescentava a dependência e 
concentração do poder de Santiago sobre as províncias e a projeção de uma desordem administrativa que evidenciava precariedade na ação nacional. Nesses termos, é interessante destacar o relato do comandante em chefe da Força Aérea de Chile (FACH), Gustavo Leigh, um mês após do início oficial da regionalização. Sendo coordenador da área social dos ministérios e com o apoio da ODEPLAN, Leigh descreve pormenorizadamente a precária situação administrativa dos ministérios em províncias e as escassas capacidades de controle do poder central no gasto efetivo das políticas ministeriais. Com profunda preocupação, o membro da Junta de Governo mostra exemplos dos fortes níveis de incongruência entre a precariedade das operações burocráticas nas províncias e a escassa capacidade de controle ou acompanhamento do sistema central para uma efetiva projeção dos gastos orçamentais. $\mathrm{Na}$ ata da Junta de Governo de agosto de 1974, Leigh também informa aos outros membros da Junta que nesse ano começou um sistema central de acompanhamento e ajuda de ODEPLAN encontrando os seguintes resultados:

\begin{abstract}
Este año lo hicimos en forma experimental para cinco provincias, y con ODEPLAN hemos descubierto, con horror, que desgraciadamente los Ministros no tienen un conocimiento detallado de qué es lo que estaban haciendo en el país - estas serían las metas nacionales -, y nos encontramos con que estas metas llegaron incompletas, con errores aritméticos, errores de cálculo, no tenían conocimiento de si eso estaba financiado, habían pedido fondos que no se iban a ocupar, etc. Entonces, ahora como que los Ministros se asustaron, porque vieron que existe un control, que se están pidiendo sus metas y se las está revisando ODEPLAN. Recuerdo un detalle: la directiva del Servicio de Minas del Estado sencillamente no sabía cuál era su misión y, en cambio, tenía fondos asignados en el Presupuesto. ¿Qué pasaba antes? Que, por ejemplo, el Ministerio de la Vivienda estaba construyendo viviendas en una provincia y, sin embargo, el Intendente respectivo no tenía idea de que se estaban construyendo casas; tampoco lo sabía el Gobernador, y mucho menos el Alcalde. Los únicos que lo sabían era el personal del Ministerio de la Vivienda. Ahora, todo eso, las metas, se centralizan aquí; están organizadas por ODEPLAN y llegan a conocimiento del Intendente. El sabe ahora qué está haciendo Impuestos Internos en su provincia; que está haciendo Vivienda, Trabajo, Salud; en fin, tiene un conocimiento regional completo. ¿Y quién lo asesora? La Oficina de ODEPLAN que en provincia o región se llama ORPLAN, donde están los especialistas en planificación que lo van asesorando (ACTAS DE LA JUNTA DE GOBIERNO, 1/8/1974).
\end{abstract}

Como podemos distinguir, o general explica a maior preocupação do poder central e suas estruturas de governo na operação do orçamento público nos territórios internos. Aliás, mostra didaticamente a importância da informação entre as autoridades territoriais que antigamente careciam de um mínimo de programa conjunto e fluxo de conhecimentos informações entre o serviço público do setor e as autoridades de governo das províncias. Se descreve assim o sentido prático da regionalização e sua necessidade de articular uma rede burocrática mais eficiente e ativa do poder central nas unidades territoriais do país. Uma vez instaladas as secretarias da ODEPLAN nas regiões, todas as autoridades territoriais (prefeitos comunais e governadores provinciais) se integrariam ao sistema nacional de planejamento. 
Em outras palavras, Leigh adverte implicitamente o que está em jogo: a criação de uma rede de governo com autoridades efetivamente interligadas nos territórios (poder espacial estatal), sempre controladas e vigiadas pela estrutura nacional, e, neste caso, pelas faculdades técnicas de fiscalização do Ministério do Interior e a ODEPLAN. Através do arranjo regional de 1974, o regime autoritário modificaria essa dinâmica discordante das administrações territoriais, criando um particular tipo de descentralização, equivalente a uma gestão do território de corte autoritário embora mais eficiente que o sistema público anterior. Com efeito, ao homogeneizar as estruturas públicas em regiões, se reforçaria a importância das autoridades territoriais mediante uma maior direção dos procedimentos e tarefas públicas, agora homogeneizadas espacialmente. Por sua vez, os Intendentes eram informados dos diferentes tipos de investimento público nos territórios a partir de equipes e burocracias mais profissionais e interligadas (SEREMIS de Moradia, Trabalho, Saúde, etc.) que começariam a olhar mais sistematicamente as dinâmicas envolvidas nos territórios internos. O problema do estatismo centralista chileno era, precisamente, sua ineficácia "desde el punto de vista del ejercicio práctico del poder" (EL MERCURIO, 18 março 1974). A maior homogeneização e coordenação mediante um arranjo regional permitiria assim superar o problema histórico de falta de capilaridade do Estado chileno, que até antes do Golpe: "no tiene alcance a todos los resortes de la maquinaria estatal, porque no existe un sistema apropiado de delegación del mando que permita el control superior de las decisiones importantes y la aplicación de éstas en forma oportuna y en todos los niveles jerárquicos" (EL MERCURIO, 18 março 1974). A autoridade do governo central deveria ter foco nos problemas do conjunto do sistema nacional versus os órgãos territoriais descentralizados, que deveriam manobrar suas próprias problemáticas zonais e locais concretas com seus devidos recursos e orçamentos. No caso de Chile, contudo, o poder central apresentava um excesso de concentração de autoridade nas decisões, não resolvendo as questões provinciais nem locais, de maneira que, "El poder se desvanece en la frondosidad centralista y burocrática" (EL MERCURIO, 18 março 1974). Dessa forma, a descentralização era uma política consistente e necessária para um governo autoritário:

[...] no hay contradicción entre postular un gobierno autoritario y exigir la descentralización del poder. A la inversa, este último es condición necesaria para que juegue efectivamente el otro. La verdadera autoridad es la que está en aptitud real de ejercerse y no la que consta simplemente de atributos nominales. Un gobierno autoritario es el que está en situación de mandar y de imponerse en toda la órbita de su jurisdicción. Para ello ha de tener tiempo dedicado a cada asunto específico y contar con que sólo los grandes temas son materia de su decisión, pues hay otras autoridades convenientemente instruidas en los planes de acción que están llevando a cabo el estudio y resolución de los asuntos de menos jerarquía. Solo entonces cada autoridad atiende eficazmente su propia órbita de competencia y todo se organiza en un un régimen armónico de disciplina y de iniciativa (EL MERCURIO, 18 março 1974) 
A citação é sumamente detalhada e certeira dos elementos que conjugam a regionalização e seu projeto hegemônico: o recorte de regiões deveria permitir uma maior hierarquia nos territórios internos para acrescentar a presença do poder central. O regime precisava ter autoridades com competências certeiras e apropriadas de suas funções operativas no território. Embora se tratasse de uma imposição autoritária com a declaração do inimigo interno e de perseguição assassina às forças políticas opositoras, a descentralização foi uma tarefa estratégica que tornou possível governar mais capilarmente os territórios internos. Os termos políticos dessa função estratégica territorial se refletem na eficácia dos procedimentos burocráticos e o reconhecimento simbólico hierárquico dessas novas autoridades territoriais que permitiriam executar coerentemente o programa do governo nas regiões. Um programa regional, ademais, que não possuía aspirações democráticas: "Un Estado autoritario y fuerte necesita ser ágil para sus decisiones, lo que siempre se conseguirá más fácilmente con una organización administrativa territorial descentralizadora e iniciativa dentro de las respectivas zonas" (EL MERCURIO, 17 julho 1974). Acima de tudo, o arranjo regional definido em julho de 1974 era uma questão prática da organização política do regime. Em virtude disso, deveria impulsionar uma reorganização territorial do Estado que permitisse uma mais rápida execução das políticas públicas ou uma maior fluidez das coordenações entre os planos definidos pelas autoridades do poder central em Santiago e a nova rede técnica-política criada em cada uma das regiões do país. Desse cálculo político-técnico de maior regionalização e mais poder territorial nas regiões, se estabelecia que as autoridades regionais tenderiam a acrescentar seu poder de gestão territorial e as autoridades centrais, instintivamente, poderiam manobrar uma maior articulação dos projetos econômicos estratégicos no nível nacional.

Mas, não se tratava de qualquer tipo de gestão do território. No mesmo momento que se dividiam estrategicamente as fronteiras internas, o país estava em meio a uma das crises mais dramáticas da sua história política recente, com uma forte repressão que deixava um setor significativo da população, literalmente, desterrado do país. Segundo o trabalho de Jorge Chateau, Geopolitica y Regionalización: algunas relaciones (FLACSO, 1978), o arranjo regional pode ser explicado por razões fundamentalmente geopolíticas que basicamente tenderiam a reforçar a estrutura central do Estado e sua lógica de projeção de poder nacional. Esse arranjo, em primeiro lugar, estabeleceu a mudança do antigo modelo de 25 Intendentes províncias ao de 13 Intendentes Regionais, reduzindo assim o número de interferências entre 
o nível nacional e o nível regional, o qual permitiu um maior monitoramento da autoridade central sobre as regiões (CHATEAU, 1978). Paralelamente, os novos Intendentes tiveram mais atribuições e recursos técnicos para construir uma gestão de governo regional. Porém, essas funções e possibilidades se limitavam a âmbitos particulares ou administrativos, pois a definição política estratégica a executar era previamente estabelecida pelo poder central, o qual podia focar-se exclusivamente na elaboração de políticas estruturais que deveriam ser aplicadas a nível nacional, ganhando tempo e energia (CHATEAU, 1978). A administração territorial nas regiões, assim, supunha a edificação de mecanismos para o uso do poder do aparato público, procurando "identificar las necesidades socioeconómicas de los diferentes sectores de la comunidad" e "traducir esas necesidades en objetivos explícitos" (CHATEAU, 1978, p. 205). Mas, em última instância, todas as autoridades territoriais do novo governo interior eram designadas e dependiam da confiança de Pinochet, o qual, criava "una sola línea de verticalidad de mando" (CHATEAU, 1978, p. 203), similar a um organismo militar. Em outras palavras, a regionalização concentrava e ampliava a representação política do general Pinochet no território nacional, quem disponha de informação direta dos territórios, com intermediários políticos relevantes e subalternos militares que deveriam aplicar estratégias definidas nos termos decididos pelo poder político central em Santiago: treze unidades operativas, treze subalternos militares, treze hierarquias diretas para ativar o plano do governo nacional.

O arranjo regional de julho de 1974 projetava uma atuação conjunta das diferentes institucionalidades públicas, intensificando o fluxo das informações políticas entre os diferentes organismos e níveis públicos territoriais. Do ponto de vista da reconfiguração territorial estratégica, os decretos-leis no 575 e 573, Regionalización del país e Governo Interior, foram os dispositivos mais importantes de todo o período autoritário pois, a partir deles, se estruturaram praticamente todas as formas orgânicas dos níveis territoriais e a definição das competências burocráticas: a organização territorial do Estado com a divisão de fronteiras internas, a formação ministerial no território junto com a organização espacial das unidades de planejamento e a definição de orçamentos especificamente destinados a favorecer as burocracias regionais e locais. Em outras palavras, a partir dos decretos leis 573 e 575 todo o território nacional foi inserido nas bases institucionais da regionalização, com um sentido geopolítico de totalidade e hierarquia nacional, em um único sistema político de comando. A diferença da regionalização da ODEPLAN em 1969, na qual se definiram regiões de planejamento independente da forma regional pública das províncias, delegações e prefeituras, o arranjo regional de 1974 restaurou o entrelaçado interno de toda a organização 
pública dos territórios. Efetivamente, reconfigurou os limites administrativos e as respetivas fronteiras internas que manobravam o tecido institucional, formando uma outra teia de relações burocráticas, até esse momento, sem a capilaridade territorialmente hierarquizada. Institucionalmente, a criação de regiões implicou uma reorganização escalonada do sistema de autoridades e competências por cada unidade geográfica, a qual foi acompanhada por um sistema técnico de administração e planejamento e uma coluna de espaços de participação dirigidos e vigiados pelos projetos e programas oficiais (GOBIERNO DE CHILE, 1974b). Esse novo tecido institucional foi chamado oficialmente de Estructura del Sistema de Gobierno e Administración Regional (doravante SIGORE) e foi gravitante para o conjunto de reformas e programas que iriam se aprofundar e movimentar na malha territorial do país

O SIGORE fez sua primeira aparição oficial em julho de 1974. A partir desse momento nunca deixou de ser aperfeiçoado e aprofundado, sendo permanentemente citado e promovido pelo regime como o novo marco institucional de governo (imagem $n^{\circ} 12$ ). (CONARA, 1976, 1982). Como mencionamos mais acima, O SIGORE se estruturou em três subsistemas coexistentes: no centro, o subsistema hierárquico que conectava a nível nacional do Presidente da República até o Prefeito da comuna em quatro níveis (nacional, região, província e comuna); na coluna esquerda, o subsistema participativo que organizava três instancias de conselho participativo (nacional, regional, e comunal) mais um comité de províncias; na coluna direita, o subsistema técnico ou de planificação e coordenação que também contava com quatro níveis de coordenação: uma oficina nacional que assessorava diretamente ao Presidente (ODEPLAN), e três Secretarias Técnicas de planejamento relativas ao escalamento do território no nível regional, provincial e comunal (imagem $n^{\circ} 12$ ). Com o transcurso do tempo, o SIGORE foi aprofundando-se através de diversos decretos leis ou dispositivos que foram fixando e acoplando-se às instituições e equipes internas nas burocracias regionais do subsistema técnico regional (SERPLAC e SEREMIS) que foram espalhados pelo território de maneira coordenada e sistemática, muito diferente do subsistema participativo que foi escassamente institucionalizado e projetado pela praxis de governo (ABALOS, LIRA; 1986; LIRA, 1998; LIRA, MARINOVICH, 1999). 


\section{Imagem n ${ }^{\circ}$ 12. Estrutura do Sistema de Governo e Administração Regional}

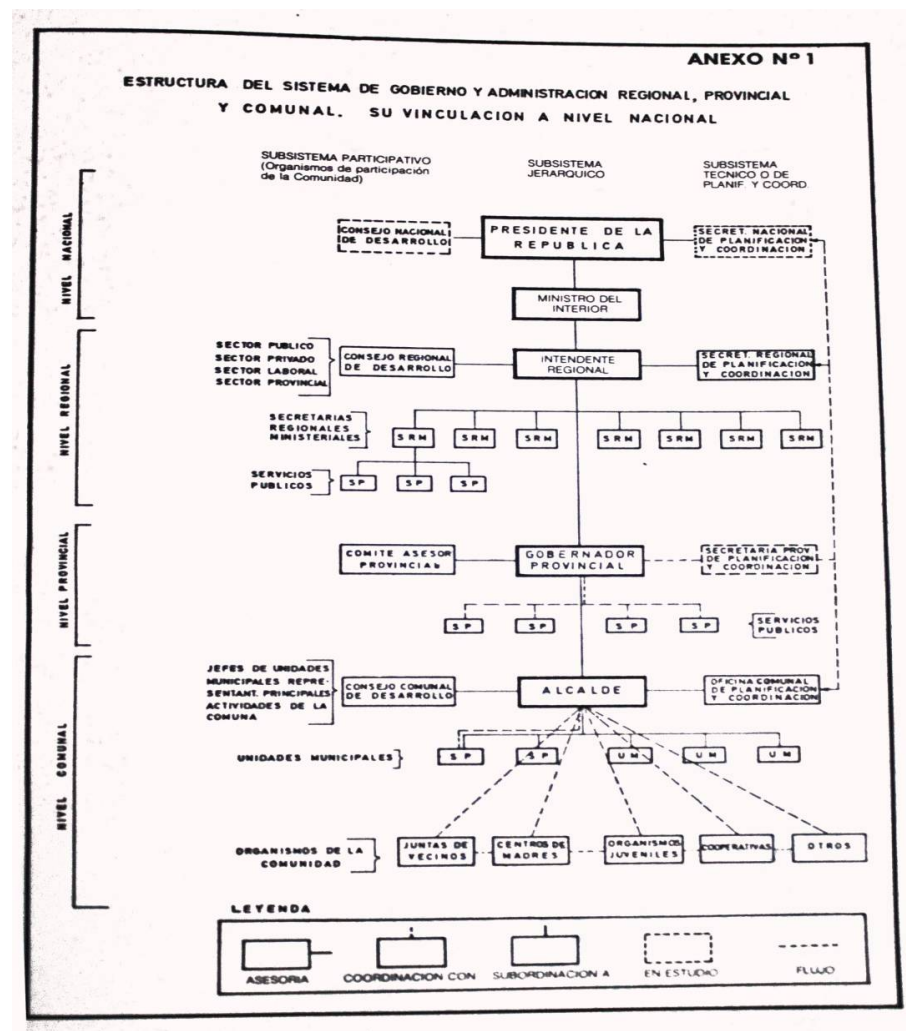

Fonte: CONARA, 1976.

Conforme o SIGORE, o subsistema técnico tendeu a coordenar as políticas públicas das autoridades territoriais do subsistema hierárquico, o qual permitiu uma maior integração das informações entre as autoridades de regiões, províncias e comunas que se complementou, aliás, com outros serviços e secretarias técnicas regionais que antigamente se expressavam apenas em algumas províncias. Se bem é certo que o SIGORE contava com um subsistema de participação que, como dizia o general Canessa, devia promover uma "participación más real de la población en la determinación de su propio destino, contribuyendo y comprometiéndose, al mismo tiempo, con los altos intereses de la región y del país" (QUÉ PASA, 19 julho 1974), na prática, essa participação foi absolutamente limitada por elementos que inibiam qualquer possibilidade de exercício democrático. Como explica a estruturação dos conselhos regionais e comunais, o economista Sergio Boisier:

Ambos consejos fueron concebidos como estructuras corporativas, con representación estamentaria, fuerte presencia de las Fuerzas Armadas y representación mayoritaria del sector privado. La oposición política de la época acusó sistemáticamente de "no democráticos" a estos Consejos, principalmente al COREDE; pasó por alto en realidad que la ausencia de democracia estaba radicada en las organizaciones de base y en la forma cómo allí se designaban los representantes 
en el Consejo y pasó por alto también el hecho de que estos Consejos habían sido copiados de los respectivos organismos franceses, aún más corporativos y más ligados al Primer Ministro, sin que en su país de origen fueran acusados de poco democráticos (BOISIER, 2000, p. 8)

A partir desses elementos, não aprofundaremos maiores informações dessas estruturas participativas, embora certamente farão parte do arranjo regional e algumas trajetórias dos dispositivos da regionalização. Cabe assinalar que os COREDES praticamente nunca funcionaram nem tiveram maiores atribuições. Segundo um informe da CONARA em 1982, por exemplo, apenas setes das treze regiões tiveram registos das sessões periódicas de COREDES, das quais dois se desenvolviam sem contar com um regulamento específico (CONARA, 1982). Até 1982, assim, os COREDES das VI e X regiões ainda não haviam sido constituídos nenhuma vez (CONARA, 1982). Só após 1988 esses conselhos participativos (regional e comunal) tiveram uma lei de funcionamento interno, embora já estivessem formalmente reconhecidos pela Constituição de 1980 (ERRAZURIZ, 1988). De tal maneira, os órgãos encarregados de fazer a participação da regionalização nunca foram significativos, nem no início, nem no final do período autoritário. A imagem do secretario executivo de CONARA, Alejandro Gonzalez Samohod, explicando a relevância do SIGORE no edifício de convenções Diego Portales, é significativa desde o ponto de vista da ordem militar e geopolítica, e também do conjunto de relações e sistemas do arranjo regional (imagem $\mathrm{n}^{\mathrm{o}}$ 13). Na prática, toda a estrutura de decisões estava fortemente escalonada de uma forma tal que, embora as autoridades subnacionais interiores tivessem seus recursos e projetos territoriais ajustados e definidos, no final das operações, sempre era o governo central via Ministério do Interior quem “tendrá facultades de supervigilancia sobre los Intendentes Regionales, los Gobernadores Provinciales y los Alcaldes, a fin de velar por el cumplimiento de las políticas y planes de desarrollo regionales en relación con los nacionales" (GOBIERNO DE CHILE, 1974b, s./r.). Esse escalonamento do poder nacional dirigido e vigiado nas regiões, porém, aumentou a hierarquia da autoridade regional nos territórios interiores, ao tempo que permitiu ao sistema público espalhar-se técnica e horizontalmente no interior de cada unidade regional do país. A representação do poder presidencial na região dava maior estatuto de autoridade e poder aos representantes do poderio regional no território com as outras unidades e burocracias públicas. Cada região internamente tendia a reproduzir uma ordem piramidal emanada do máximo nível nacional, ao passo que as funções administrativas nas regiões, paulatinamente iriam e tenderiam a uniformizar-se com uma maior representação e capacidade técnica da função governamental. 
Imagem $n^{\circ} 13$. SIGORE na prensa

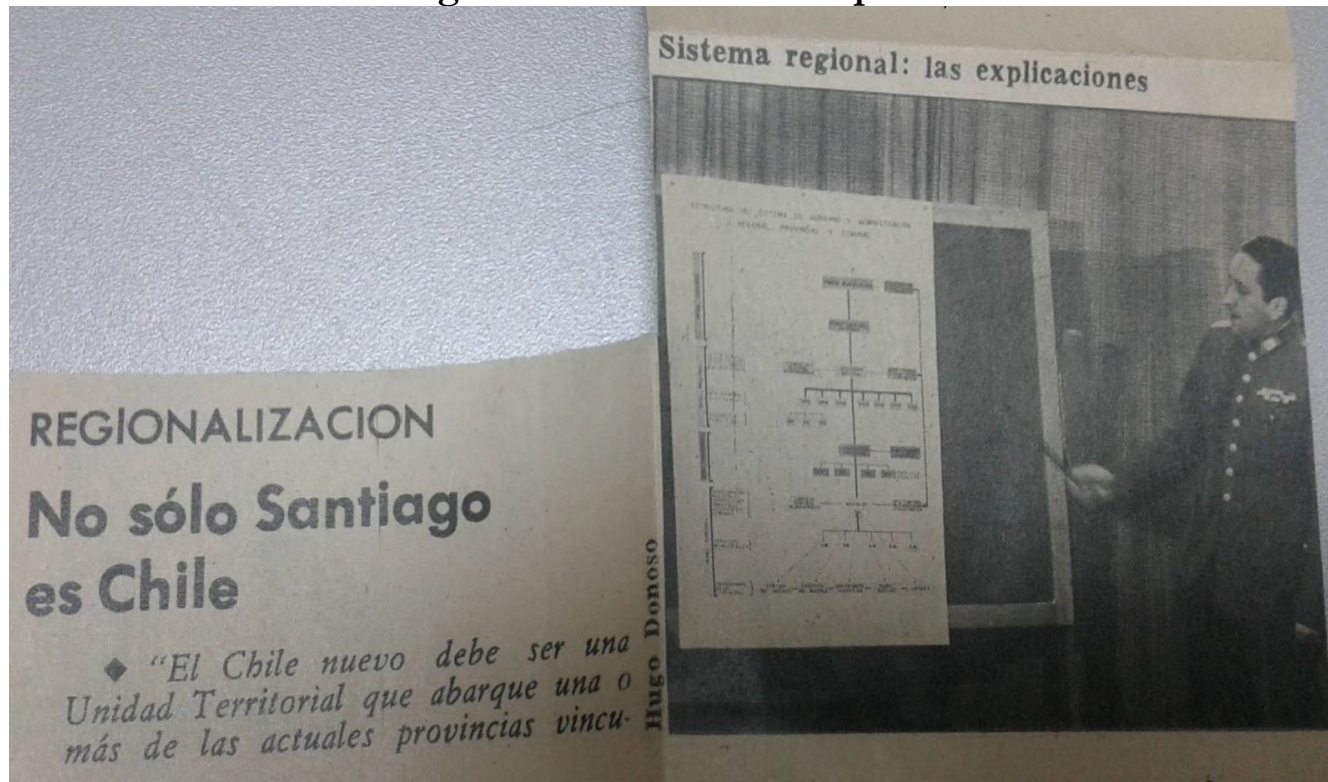

Fonte: El Mercurio, Santiago, 13 de julho 1974.

Segundo o acadêmico do ILPES da época, Luis Lira, o autor intelectual dessas três colunas (participativa, hierárquica e técnica) do SIGORE havia sido o engenheiro industrial Helio Suárez (ENTREVISTA LUIS LIRA, outubro 2019). Autor de importantes artigos e documentos da regionalização (SUAREZ, 1975, 1976) com presença na imprensa da época, Suárez influenciou como chefe da unidade de Administração Regional no Ministério do Interior (imagem $\mathrm{n}^{\circ}$ 14). As contribuições de Suarez são ilustrativas da amplitude dos desdobramentos que poderia significar a regionalização, muito além da questão exclusivamente administrativa, sendo um dos primeiros em anunciar as funções dos governos regionais e seu sentido capitalista privatizador. Para o chefe da área regional do Ministerio do Interior, a regionalização tinha implicâncias no "campo económico, en el social y en el territorial, conjuntamente con las posibilidades de perfeccionamiento que ofrece a los aspectos administrativos y de gobierno, sin dejar de considerar su utilización en el sistema politico que implante en Chile" (SUAREZ, 1976, p. 89). Suárez, por sua vez, foi uns dos primeiros autores que anunciou a descomposição da teoria dos pólos de desenvolvimento, ainda que fosse um ativo promotor das Secretarias Regionais de Planejamento e Coordenação (SERPLAC) anunciando-as como a filosofia da regionalização (imagem n ${ }^{\circ}$ 14). A regionalização oficial deveria mudar o sistema de intervenção econômica, mas já não era necessária uma responsabilidade maior do Estado. Pelo contrário, deveria-se ir apoiando as áreas menos desenvolvidas do país, mas sempre quando sejam necessárias atividades econômicas "que sólo necesitan un estímulo o una mínima preocupación del Estado para lograrlo" (SUAREZ, 1976, p. 90). A intervenção territorial 
econômica ancorada nos princípios dos pólos de desenvolvimento rapidamente iria perdendo força por uma intervenção burocrática regional que iria promovendo a privatização e a liberdade empresarial coexistente com a gestão territorial autoritária do Estado.

\section{Imagem no 14. Filosofia da Regionalização}

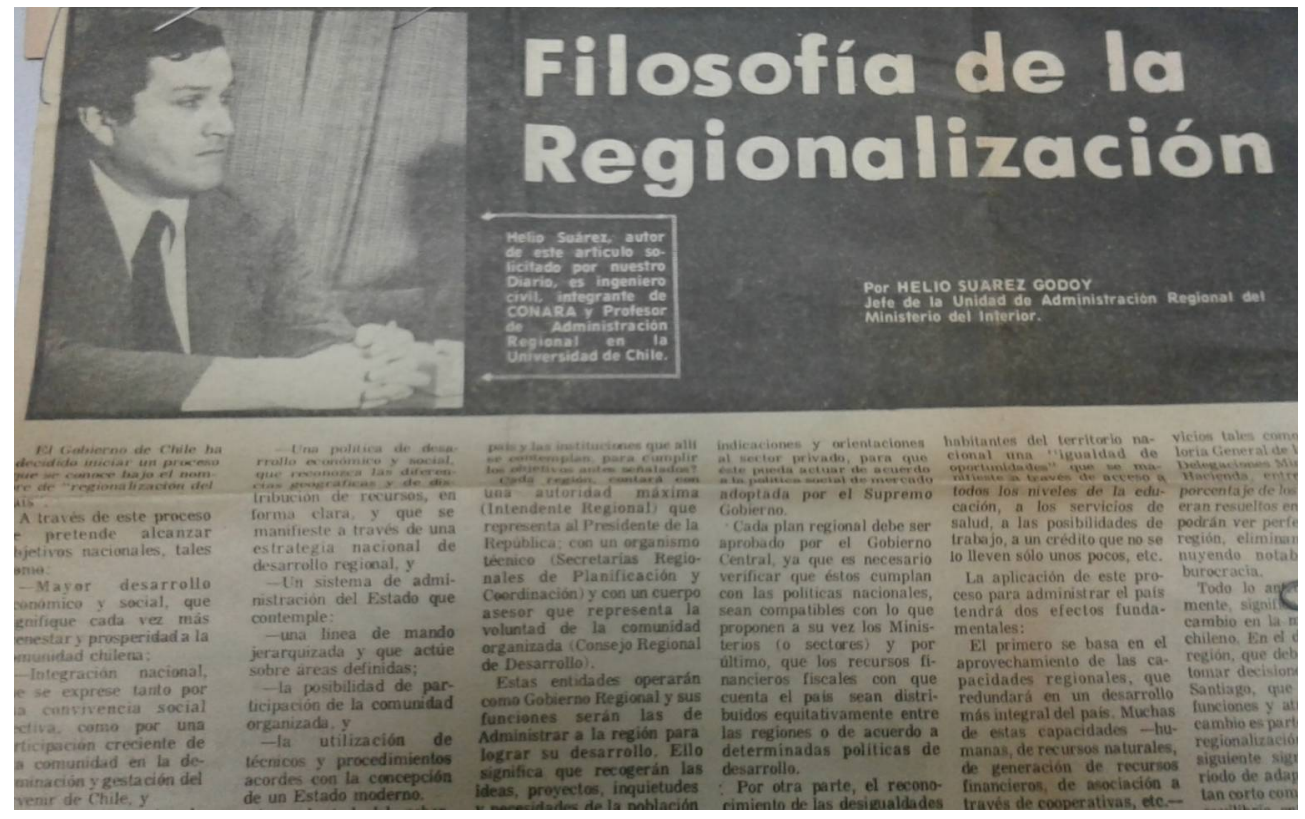

Fonte: Ultimas Noticias, 18 abril 1975

As Secretarias Regionais de Planejamento, Coordenação (SERPLAC) e as Secretarias Regionais Ministeriais (SEREMIS) seriam as principais inovações do arranjo regional de 1974. Segundo o artigo $n^{\circ} 7$ do decreto-lei no 575 se estabelecia que os Ministérios e serviços públicos deveriam apresentar planos de desconcentração territorial administrativa que não significasse em aumento de funcionários, mas sim levar à frente a questão operativa do novo sistema regional (GOBIERNO DE CHILE, 1974c). Ao mesmo tempo, as Intendências Regionais eram as estruturas administrativas dos governos regionais que deveriam dirigir com a liderança do Intendente regional o conjunto dos programas e planos do território regional. $\mathrm{Na}$ prática, tecnicamente, seriam as SERPLAC as unidades territoriais encarregadas de tornar operativo o programa do governo regional. Essas novas capacidades de gestão e inovação, por sua vez, emergiam pela primeira vez na história do país graças a um dispositivo de financiamento exclusivo para o uso e desenvolvimento das regiões, o Fondo Nacional de Desarrollo Regional (FNDR). Segundo o decreto-lei no 573, o FNDR tinha que destinar " a lo menos un 5\% del volumen total de los ingresos calculados para los sistemas tributarios y arancelarios, excluida la contribución de bienes raíces" (GOBIERNO DE CHILE, 1974b, s./r.). No entanto, durante todo o período autoritário essa cifra nunca se respeitou e o FNDR foi inferior a essa soma 
(GARCIA, 1985). Essa complexa situação financeira, somada ao quadro de crise econômica do país, implicou que a regionalização contara com escassos recursos, embora tivera o apoio de outros aportes financeiros, como o caso do Programa da Naciones Unidas para el Desarrollo (PNUD). Em 1976 o general Canessa, em representação do Centro Latinoamericano de Administración para el Desarrollo (CLAD), assinava em Nova York um importante convênio com o PNUD para financiar a reforma da regionalização:

Dicho convenio reviste una importancia exepcional para América Latina en general y para Chile en particular, por cuanto representa un apreciable aporte en dinero que hace el PNUD para activar los númerosos proyectos en marcha o en estudio que impulsa en estos momentos el CLAD y cuya meta fundamental es procurar una mayor racionalización, dinamismo y efectividad de la administración pública de cada país, a fin de que sea un instrumento realmente eficaz en la promoción del desarrollo economico y social [...] La ceremonia se efectuó en la sede de la ONU en Nueva York, participando en ella, además del general Canessa, los señores Mourse Bradford, administrador del Programa Mundial y Gabriel Valdés, administrador del Programa Latinoamericano, el coronel de Ejército, Juan Barrientos, vicepresidente de CONARA y funcionarios de las Naciones Unidas (ULTIMAS NOTICIAS, 5 outubro 1976).

Ainda que sempre existiu uma política restritiva do gasto público devido as crises econômicas e o direcionamento monetarista das políticas centrais, a regionalização sempre contou com orçamentos e recursos para seus diferentes estudos e requerimentos básicos. Segundo Vio, o PNUD colaborou mais em tipos de assessorias que em recursos para projetos de investimento regional ou local (ENTREVISTA DIONISIO VIO, dezembro 2019). Na prática, as políticas descentralizadoras no arranjo regional, por um lado, modificavam relativamente o marco descentralizador do Estado do ponto de vista financeiro, mas, por outro, reforçavam e qualificavam ainda mais os dispositivos centralistas: o FNDR dependia globalmente das projeções do Ministério de Fazenda (GOBIERNO DE CHILE, 1974b). Similar ao palimpsesto, a regionalização debilitava a antiga administração de províncias, departamentos, subdelegações e distritos, mas, simultaneamente, abria fórmulas descentralizadoras que mantinham algumas das velhas estruturas de poder centralizado. As antigas províncias passavam a ser regiões com uma outra morfologia institucional interna, entretecendo novas relações e combinações do regional - nacional ao local que, na prática, tenderiam a fazer desaparecer a estrutura territorial anterior. O que mudou a regionalização?

A Constituição de 1925, vigente até o Golpe de Estado, distinguia o Chile como um Estado unitário onde se separavam as funções administrativas versus as funções do poder executivo do governo interior. Dessa maneira, o país se dividia em 25 províncias que tinham simultaneamente formas de governo interior e formas de administração nos territórios 
interiores (quadro $\mathrm{n}^{\circ}$ 8). No sentido administrativo, se reconheciam dois níveis territoriais, províncias e comunas, sempre subordinado a uma hierarquia nacional do Presidente da República (VALENZUELA, 2016). A província era administrada mediante uma Assembleia Provincial e a comuna dependia da administração de uma Prefeitura. Em relação ao governo interior, se consideravam quatro autoridades a níveis territoriais entrelaçados hierarquicamente (província, departamento, subdelegação e distritos), todos eles sempre na dependência a nível nacional e do Presidente da República (quadro no 8). Esses níveis eram representados pelos cargos do Intendente, Governador, Subdelegado e Inspetor, todos nomeados pelo Presidente da República (quadro no 8). Em outras palavras, cada um desses níveis territoriais do governo interior, por sua vez, projetava uma representação do executivo em seu respetivo território interior, e portanto, respondia a uma autoridade hierárquica que defendia aos interesses do Presidente.

\section{Quadro n $^{\circ}$ 8. Regime territorial Constituição de 1925}

\begin{tabular}{|c|c|c|c|}
\hline \multicolumn{2}{|c|}{ Administração Interior } & \multicolumn{2}{c|}{ Governo Interior } \\
\hline Unidade & Administrador & Unidade & Executivo \\
\hline País & Presidente & País & $\begin{array}{c}\text { Presidente, Ministro } \\
\text { do Interior }\end{array}$ \\
\hline $\begin{array}{c}\text { Província } \\
(25)\end{array}$ & $\begin{array}{c}\text { Assembleia } \\
\text { Provincial }\end{array}$ & Província & Intendente \\
\cline { 3 - 4 } & Departamento & Gobernador \\
\hline $\begin{array}{c}\text { Comuna } \\
(302)\end{array}$ & $\begin{array}{c}\text { Prefeito do } \\
\text { Municipio } \\
(277)\end{array}$ & Subdelegação & Subdelegado \\
\cline { 3 - 4 } & Distrito (2.537) & Inspetor \\
\hline
\end{tabular}

Fonte: Valenzuela (2016) baseado na División Politico-administrativa da Dirección de Estadísticas y Censos, 1966.

Segundo a Constituição de 1925, no governo interior, a máxima unidade territorial eram as províncias, presididas pelo Intendente provincial que era responsável por manter a ordem pública e garantir a segurança, sempre dependente do Presidente (DIAZ, 1989). Não obstante, os órgãos da administração eram eleitos democraticamente - províncias e prefeituras - e se "preocupaban de la marcha cotidiana del país, aplicando las medidas necesarias para el cumplimiento de las leyes y de las ordenes del gobierno relativas al manejo y dirección de los intereses públicos a los fines que los propios órganos se han dado cuando autónomos" (DIAZ, 1989, p. 200). A té a vigência da Constituição de 1925, em 11 de setembro de 1973, as prefeituras tinham eleições democráticas de suas autoridades (prefeito e vereadores), à diferença das Assembleias Provinciais da Constituição de 1925 que nunca foram levadas na prática. Segundo Bulnes, os constituintes da época sempre tiveram um medo de diminuir a unidade nacional do Estado e nunca regulamentaram o funcionamento das assembleias provinciais (BULNES, 1988). Daí 
que as diminuídas funções administrativas e escassos orçamentos das províncias, em efeito, recaíram nos Intendentes provinciais do governo interior que dependiam do Presidente. Também é importante assinalar que, embora a Constituição de 1925 declarasse funções exclusivamente administrativas nas prefeituras, na prática, essas últimas eram fonte de significativas disputas políticas fortemente ideológicas e competitivas entre os partidos políticos, expressão de uma complexa rede de intermediações de poderes locais, legislativos e centralizados que se combinavam horizontal e verticalmente pelo conjunto territorial do país (VALENZUELA, 2016). Dentro do governo interior, as Províncias se constituíam internamente por Departamentos que eram um agrupamento de subdelegações, as quais dependiam de um Governador do Departamento que, ao mesmo tempo, era subalterno do Intendente (quadro $n^{\circ} 8$ ). No referente mais local do governo interior, se encontravam os subdelegados a nível de comunas e inspetores nos distritos eleitorais (intra-comunais). Mas, tanto subdelegados como inspetores tinham escassas funções e competências públicas e respondiam mais aos níveis superiores da hierarquia do Estado que a uma agenda própria, ou seja, na realidade, não tinham uma maior representação do público ou do governo. Dessa maneira, a Constituição de 1925 permitia que praticamente todas as autoridades territoriais fossem nomeadas e dependessem da exclusiva confiança do Presidente. Entre 1925 e 1973, assim, o regime territorial chileno se caraterizava por uma estrutura fortemente centralizada e verticalizada na figura do Presidente (quadro $n^{\circ} 8$ ). O que mudou, então, com o arranjo regional de 1974 ?

O regime autoritário, se bem manteve essa lógica nominativa das autoridades territoriais administrativas e de governo interior, em sua execução, reorganizou integralmente ambas, ficando uma só estrutura vertical de comando: o governo interior e de administração (quadro $n^{\circ}$ 9). Dessa forma, discursivamente se separou a lógica administrativa só a nível de prefeituras e se retiraram alguns intermediários sem maiores competências, como por exemplo, os antigos inspetores e subdelegados. Estrategicamente, assim, se verticalizou ainda mais a estrutura de governo interior, que internalizava as prefeituras de uma forma subordinada. Essas últimas se situavam na cadeia de mando inferior da hierarquia, em seguida da província e da região, máxima hierarquia do sistema integrado. A hierarquizada integração das prefeituras ao corpo executivo do governo interior, se aprofundava e consolidava, também, com a nomeação de todas as autoridades territoriais, designadas pela exclusiva confiança do Presidente da República: o general Pinochet. 


\section{Quadro nº 9. Governo e Administração Interior 1974}

\begin{tabular}{|c|c|}
\hline Unidade & Executivo \\
\hline País & $\begin{array}{c}\text { Presidente, Ministro do } \\
\text { Interior }\end{array}$ \\
\hline Região & Intendente \\
\hline Província & Governador \\
\hline Comuna & Prefeito \\
\hline
\end{tabular}

Fonte: elaboração própria a partir dos decretos-leis no 573 e n ${ }^{\circ} 575$.

Com o arranjo regional de 1974, toda a estrutura territorial, administrativa e de governo, passou a depender do poder central e da manobra política do general Pinochet, quem desempenhou o cargo de Presidente até 1990. Como diz Díaz, a antiga arquitetura institucional se fusionou: "en un solo mecanismo integrador lo que antes se diferenciaba - en forma no muy nitida - entre el gobierno interior del Estado y el régimen de administración interior (DIAZ, 1989, p. 200). Em efeito, ambas lógicas de administração e governo interior estavam absolutamente subalternizadas e integradas ao governo central. A Constituição de 1925, assim, foi modificada estruturalmente com um novo sistema de delegações e nomeações dependentes do poder central. O quadro de poder hierárquico, via regionalização, verticalizou ainda mais as relações de poder no território e permitiu que o regime pudesse colocar energia política de maneira mais ordenada e homogênea: regiões, províncias e comunas. Em suma, se sofisticou e ampliou a estrutura centralista e autoritária do governo através de um sistema regional integrado de serviços e procedimentos públicos territorialmente concordantes que, implicitamente, recriaram uma alternativa ao antigo sistema político do país.

A malha territorial se projetou como uma reforma de prerrogativas do poder presidencial que aumentaria a capilaridade e representação do governo autoritário. Se por um lado, discursivamente, o regime destruiu simbolicamente as representações políticas regionais associadas ao projeto da UP, por outro, também mantiveram certas escolhas do Presidente Allende. Por exemplo, se continuou outorgando a qualidade do Ministro ao Diretor de ODEPLAN (SOMS, 2010), dando enfase à hierarquia do cargo, tendo um lugar de primeira relevância no planejamento nacional das profundas reformas econômicas e territoriais. Essa mesma lógica e estrutura hierárquica, anos mais tarde, também foi inserida na regionalização, com o general Canessa sendo denominado Ministro Presidente da CONARA. Por sua vez, o regime continuou com o esquema de assessorias regionais (ORPLAN), porém, trocou radicalmente seus direcionamentos a partir das novas posições do arranjo regional de 1974, sendo rebatizadas como SERPLAC. Em termos práticos, isso significou que das dezessete 
ORPLAN da UP, passaram então a ser doze SERPLAC em $1975^{35}$, com novas competências e burocracias, entretanto, continuando com sua lógica de primus interpares, uma definição que também tinha sido definida pela UP e sua busca de maior hierarquia regional ancorada no vínculo de confiança da autoridade regional com o Presidente da República (SOMS, 2010). Paralelamente, também se reconheceram oficialmente os Conselhos de Desenvolvimento Regional (COREDE) como mecanismo de participação, outra criação do governo de Allende, mas que o regime incorporaria com uma lógica corporativa totalmente diferente. Por último, se manteve e aprofundou o Sistema Nacional de Planejamento e Investimentos, criando um novo tipo de reparto orçamental nas regiões (FNDR) que iria articulando diferentes dispositivos de controle e coordenação que aprofundariam a pauta do padrão econômico em curso.

A regionalização da CONARA era tributária das políticas regionais anteriores, porém, em seu núcleo estratégico central trazia um direcionamento antagônico e adverso, que se diferenciava estruturalmente das políticas regionais anteriores. Não era apenas uma divisão político-administrativa com maiores serviços públicos que tenderiam a um maior planejamento territorial. Segundo o coronel Juan Barrientos Vidaurre, Vice-presidente da CONARA, o novo emaranhado público e territorial do país que havia propiciado o regime era, sobretudo, uma restauração do poder nacional interno. Se trataria de um arranjo regional que tenderia a construir uma democracia concreta e real, sem parlamento nem partidos políticos, mas com um forte sentido da autoridade estatal e a propensão a uma comunidade local organizada e comunitária. A regionalização, segundo Barrientos, permitiu que a sociedade chilena pudesse organizar-se de forma comunitária, regional ou localmente para enfrentar problemáticas da ordem cotidiana, mas sem a intermediação dos partidos e o questionamento das velhas disputas dominantes. Diz o coronel Barrientos em 1975:

La temática de fondo de la regionalización chilena se centra en la búsqueda e implementación de los mecanismos que tiendan a dar satisfacción a las aspiraciones de toma de decisiones que afectan a su futuro individual y social, participando así en el movimiento hacia la democracia concreta, real, no parlamentaria y hacia el perfeccionamiento de la responsabilidad ciudadana ante los problemas inmediatos que la afectan más que a la habitual tendencia, inducida por los partidos políticos de raíz foránea, que movilizan a sectores de la ciudadanía con consignas o cuestiones valorativas de alcance internacional, ajenas a nuestra realidad social y cultural. Se trata, por lo tanto, de contrarrestar la ideologización que casi destruyó nuestra vida social antes del 11 de septiembre de 1973 y lograr una adecuada educación cívica que desarrolle fundamentalmente, la preocupación por los problemas regionales, que coayude a la toma de conciencia de las comunidades regionales sobre su realidad y les facilite la fijación de objetivos comunitarios a esa escala [...] Insistiendo en el sentido socio-político de la regionalización,

\footnotetext{
${ }^{35}$ A parir do decreto lei $n^{\circ} 575$, todas as regiões contaram com uma SERPLAC, menos Santiago que só foi criado em 1980.
} 
creemos que la redistribución espacial del poder que conlleva deberá llegar a constituir un eficaz correctivo a la burocratización y politización intensa que afectaron y aún están presentes en la vida social chilena y esto se obtendrá, como está previsto, aproximando los centros de decisión (intendentes regionales, secretarios regionales ministeriales, alcaldes, etc.) a las comunidades, permitiéndoles una más justa y efectiva comunicación con el sistema políticoadministrativo que el que brindaba el aparataje tradicional. En este sentido, consideramos de gran importancia el fortalecimiento de los frentes regionales y frentes vecinales para crear una nueva conciencia cívica en el pueblo y un régimen institucional en el país (EL MERCURIO, 23 dezembro 1975).

Como pode-se identificar, os desdobramentos ideológicos da politização do período anterior do Golpe seriam parte nuclear do processo da regionalização oficial. Para as autoridades da CONARA, o centro da projeção estratégica radicou na questão política e a forma-conteúdo do Estado territorial. Segundo Barrientos, a regionalização explicitamente conferiu a ideia de uma democracia concreta e real, e o fechamento da atividade parlamentaria que, aliás, superaria o passado democrático do país. Em outras palavras, a regionalização haveria transcendido o período de politização anterior e veiculava uma nova consciência cívica sem partidos, que agiram uma ação responsável de cidadãos espacialmente ligados com seus assuntos geograficamente locais e comunitários. Nesses termos, a razão comunitária ou participação se integrava natural e espacialmente subalternizada ao poder político das autoridades superiores do regime que, estrategicamente, projetavam a malha territorial como a única teia válida das intermediações sociais e técnicas oficiais. A regionalização, assim, permitiu uma maior condução ao processo político-econômico do governo central, ao tempo que deu condições de enlace e coordenação territorial para a ação operativa do Estado central que, no fundo, projetou uma estrita hierarquia estatal sobre a representação da sociedade civil. Dessa maneira, se institucionalizou o autoritarismo como forma de governo e a regionalização redirecionou o antigo estado de relações sociaisterritoriais, permitindo o desenvolvimento de conteúdos funcionais as transformações econômicas e políticas em curso. A partir da divisão geográfica regional verticalizada e a possível aceleração da circulação das informações entre o poder central e o poder regional, o programa de governo autoritário se difundiu integralmente nas comunidades e no conjunto geográfico do país. Tudo isso, inversamente, clausurou qualquer tipo de participação popular deliberativa das decisões territoriais, mas, ao mesmo tempo, naturalizou a representação política do regime constituída burocraticamente pelos funcionários, tecnocratas e militares em cada uma das unidades territoriais. A regionalização, como bem afirma Barrientos, permitiu ir "aproximando los centros de decisión (intendentes regionales, secretarios regionales ministeriales, alcaldes, etc.) a las comunidades, permitiéndoles una más justa y efectiva comunicación con el sistema políticoadministrativo que el que brindaba el aparataje tradicional' (EL MERCURIO, 23 dezembro 1975). 
Talvez esse último parágrafo seja o elemento em jogo mais estratégico do arranjo regional de 1974. Como instituir ao interior do regime territorial uma condição hierárquica, embora mais próxima da população e eficiente burocraticamente? $\mathrm{O}$ arranjo regional se materializou como uma política-técnica mais coordenada e entrelaçada no sistema regionalintegrado, o qual permitiu precisamente mais interações das autoridades territoriais com as comunidades e seus territórios. Se constituiu assim o que Ana Clara Torres denominou um ato regionalizador: "o ato regionalizador compreende a institucionalização de fronteiras e limites, com vistas à implementação de uma determinada ação: analítica, política, econômica, enfim social” (RIBEIRO, 2004, p. 200). A regionalização da CONARA definiu limites e fronteiras para cada uma das autoridades territoriais e seus respetivos programas de governo nos territórios. No entanto, a partir dessas fronteiras e programas, também se estabeleceu um cenário particular de ação: diferentes escalas de governo coexistentes e correspondentes às geometrias e cálculos do poder nacional que articularam uma nova capilaridade estatal e função territorial. Assim, como funcionou a nova malha territorial das regiões neste contexto de transformação e recriação da política oficial do Estado e o desterramento de determinadas interpretações da sociedade? Foi o arranjo regional um tipo particular de representação da política do país?

\subsection{Intendentes militares e estrutura regional: o sistema territorial de Pinochet}

Segundo o decreto-lei $\mathrm{n}^{\circ}$ 573, o Intendente Regional era o máximo depositário hierárquico do governo interior e exercia seu cargo pela ordem de leis e instruções diretas do poder executivo, "de quien es agente natural e inmediato en el territorio de su jurisdicción" (GOBIERNO DE CHILE, 1974b, s./r.). Como as outras autoridades hierárquicas, o Intendente Regional era dependente da exclusiva confiança do presidente da República e, por consequência, deveria desenvolver uma gestão territorial estritamente envolvida nas diretrizes nacionais, ainda que aberta aos diferentes assuntos e particularidades da região. Entre as funções dos Intendentes, destaca-se a execução dos planos orçamentais com prioridade de desenvolvimento regional, e com a criação e vigilância estratégica da coordenação do funcionamento dos serviços públicos na região (GOBIERNO DE CHILE, 1974b). Esse último assunto é muito importante especificar, pois, o decreto-lei no 575 definia explicitamente que o Intendente devia "Coordinary regular la forma en que deben actuar los servicios de la Administración del Estado, de carácter civil, para la debida ejecución" (GOBIERNO DE CHILE, 1974c, s./r.), de maneira que todos os chefes de serviços e profissionais importantes na região 
permaneciam subordinados ao Intendente (exceto da Controlaria General da República), sem prejuízo das faculdades técnicas e seus respectivos superiores na estrutura nacional (GOBIERNO DE CHILE, 1974c). Aliás, com a lei orgânica de municipalidades de 1976 (decreto-lei $\mathrm{n}^{\circ}$ 1289), os Intendentes Regionais tiveram faculdades para "coordinar y regular la forma en que deba actuar la Municipalidad, entre otros servicios del Estado, para la debida ejecución, por su intermedio, de las políticas, planes y proyectos de carácter regional' (GOBIERNO DE CHILE, 1976a). Esse dispositivo reafirmou a máxima hierarquia territorial do Intendente, sendo o encarregado de dirigir as políticas globais da região, como também intervir nos assuntos técnicos e específicos das prefeituras e de qualquer serviço público da mesma.

Desse modo, o Intendente foi a única autoridade da região que poderia dispor de funcionários em comissão de serviço, criar comitês coordenadores com os secretários regionais ministeriais ou prefeitos, ditar regulamentos e fomentar a atividade privada procurando "su coordinación con la actividad estatal" (GOBIERNO DE CHILE, 1974b, s./r.). Sobre esse último ponto é interessante destacar que, se bem as políticas neoliberais foram impulsionadas alguns anos após do inicio da regionalização, é possível notar o prevalecente sentido capitalista do arranjo regional de 1974, onde se distingue que a gestão regional representada no Intendente devia "promover la acción del sector privado" (GOBIERNO DE CHILE, 1974b, s./r). Por certo, uma promoção privada-estatal na contramão dos principais Estados ocidentais da época, onde muitos serviços e atividades estratégicas não eram e nem podiam ser de competência privada pois o Estado deveria ser, justamente, um ente fiscalizador e contraparte da ação privada e não seu sócio colaborador. Eram os primórdios das orientações neoliberais que rapidamente passariam ser parte da agência da regionalização. Nesse sentido, os Intendentes tenderiam a articular e defender dois grandes princípios orgânicos fundamentais do Estado subsidiário. Por um lado, os Intendentes deveriam reforçar a noção de gestão territorial profissional espalhada a partir do emaranhado técnico e orçamental das províncias e prefeituras sem questionar as privatizações das economias regionais. Por outro lado, os Intendentes tinham que apoiar a noção da propriedade e ação privada como marco de desenvolvimento regional cooperativo das atividades dos serviços públicos do Estado e seus usuários (LABBE, 1984). A partir desses grandes princípios, o regime estabeleceria uma particular condução política das regiões e sua máxima autoridade, o Intendente. 
Com efeito, durante o período de 1974-1988 invariavelmente a representação da autoridade regional foi ocupada por membros das FF.AA. Essa distribuição territorial dos Intendentes regionais pelos oficiais das FF.AA. foi similar ou análoga a conformação da Junta de Governo, embora com matizes. Trata-se basicamente de um pacto entre as máximas comandâncias castrenses, onde se distribuía o poder regional sobre a base do peso políticoinstitucional de cada instituição. Se definia assim, implicitamente, que a regionalização era uma continuidade do poder executivo de Pinochet e o programa legislativo da Junta de Governo. Dessa maneira, a máxima estrutura regional era univocamente responsabilidade das FF.AA. sem contrapontos nem outras forças políticas afins. Nesse sentido, é interessante destacar que o pacto político-militar-regional que seria vigiado e impulsionado pela Junta de Governo e Pinochet durante o período do regime autoritário, teve uma distribuição análoga do decreto lei no 4 do 11 de setembro de 1973, no qual o país foi dividido em 28 unidades territoriais dependentes de hierarquias das FF.AA. (quadro no 10 ). De fato, esse decreto lei do 11 de setembro de 1973 definiu 28 unidades territoriais de emergência que operariam imediatamente como estruturas de governo, com oficiais das FF.AA. que seriam os responsáveis da operatória pública e militar do país. Diz o decreto lei no 4: "Todas las Fuerzas de Ejército, Armada, Fuerza Aérea, Carabineros de Chile e Investigaciones que se encuentren o lleguen al territorio jurisdiccional de estas Zonas de Emergencia, se pondrán bajo la autoridad del Jefe respectivo" (GOBIERNO DE CHILE, 1973a, s./r.). O recorte territorial do 11 de setembro verticalizou o conjunto de instituições públicas, privadas e do mundo civil ao comando de uma autoridade militar que representou o poder político-militar da Junta de Governo e começou a entretecer o lugar hierárquico dos oficiais das FF.AA. nas burocracias territoriais do país. Dessas 28 unidades territoriais, apenas duas unidades seriam controladas pela Marinha e só um território seria responsável da FACH (quadro no 10). Dessa maneira, a manifestação de Helio Suarez de que, o processo de regionalização "surgió inmediatamente después del 11 de septiembre de 1973, como una necesidad inherente a la reestructuración de la administración pública chilena" (SUAREZ, 1976, p. 89), não foi apenas uma projeção nacionalista do Golpe ou a reivindicação técnico-administrativa do projeto da regionalização. Foi também a expressão do rápido posicionamento político militar no centro do comando do regime territorial e sua continuidade na condução da estrutura regional do período autoritário.

O primeiro recorte oficial das regiões de 1974 foi um desdobramento da mesma estrutura militar territorial do Golpe de Estado espalhada no decreto lei $n^{\circ} 4$ (quadro $n^{\circ} 10$ ). Um desdobramento que se projetou no transcurso da institucionalização das treze regiões 
no país (1 janeiro 1976) e se manteve intacto até o plebiscito de 1988. A parte da V Região dependente da Marinha e a X Região da FACH, as onze regiões restantes, incluída a Área Metropolitana de Santiago, foram conduzidas pelo Exército. Essa distribuição do poder regional entre as FF.AA. rapidamente consolidou a hegemonia do Exército e o general Pinochet na condução das unidades regionais e suas principais representações políticas e dispositivos burocráticos.

\section{Quadro ${ }^{\circ}$ 10. Unidades territoriais do Golpe de Estado}

\begin{tabular}{|c|c|c|c|}
\hline $\mathbf{N}^{\mathbf{o}}$ & Unidade Territorial & Autoridade Militar & $\begin{array}{c}\text { Rama } \\
\text { Castrense }\end{array}$ \\
\hline 1 & $\begin{array}{c}\text { Provincia de Tarapacá (Exceto } \\
\text { Departamento de Arica) }\end{array}$ & $\begin{array}{l}\text { General de Brigada Carlos } \\
\text { Forestier Haensgen }\end{array}$ & Exército \\
\hline 2 & Departamento de Arica & Coronel Odlanier Mena Salinas & Exército \\
\hline 3 & $\begin{array}{l}\text { Provincia de Antofagasta. } \\
\text { (Exceto Departamento de El } \\
\text { Loa) }\end{array}$ & $\begin{array}{l}\text { General de Brigada Joaquín } \\
\text { Lagos Osorio }\end{array}$ & Exército \\
\hline 4 & Departamento de El Loa & $\begin{array}{l}\text { Coronel Eugenio Rivera } \\
\text { Desgroux }\end{array}$ & Exército \\
\hline 5 & $\begin{array}{c}\text { Provincia de Atacama (Exceto } \\
\text { Departamentos de Huasco y } \\
\text { Freirina) }\end{array}$ & $\begin{array}{l}\text { Teniente Coronel don Oscar } \\
\text { Haag Vlaschke }\end{array}$ & Exército \\
\hline 6 & $\begin{array}{c}\text { Provincia de Coquimbo y } \\
\text { Departamentos de Huasco y } \\
\text { Freirina. }\end{array}$ & $\begin{array}{l}\text { Teniente Coronel don Ariosto } \\
\text { Lapostol Orrego }\end{array}$ & Exército \\
\hline 7 & Provincia de Aconcagua & $\begin{array}{l}\text { Coronel Héctor Orozco } \\
\text { Sepúlveda }\end{array}$ & Exército \\
\hline 8 & Provincia de Valparaíso & $\begin{array}{l}\text { Contralmirante Adolfo } \\
\text { Walbaum Wieber }\end{array}$ & Marinha \\
\hline 9 & Provincia de Santiago & $\begin{array}{l}\text { General, de Brigada don } \\
\text { Herman Julio Brady Roche }\end{array}$ & Exército \\
\hline 10 & Provincia de O'Higgins & $\begin{array}{l}\text { Teniente Coronel Cristián } \\
\text { Ackerknecht San Martin }\end{array}$ & Exército \\
\hline 11 & Provincia de Colchagua & $\begin{array}{l}\text { Coronel Hernán Brantes } \\
\text { Martínez }\end{array}$ & Exército \\
\hline 12 & Provincia de Curicó & $\begin{array}{l}\text { Teniente Coronel Sergio } \\
\text { Angelotti Cádiz }\end{array}$ & Exército \\
\hline 13 & Provincia de Talca & $\begin{array}{l}\text { Teniente Coronel Efraín Jaña } \\
\text { Giron }\end{array}$ & Exército \\
\hline 14 & Provincia de Linares & $\begin{array}{l}\text { Coronel Gabriel Del Rio } \\
\text { Espinoza }\end{array}$ & Exército \\
\hline 15 & Provincia de Maule & $\begin{array}{l}\text { Teniente Coronel Rubén } \\
\text { Castillo Whyte }\end{array}$ & Exército \\
\hline 16 & Provincia de Nuble & $\begin{array}{l}\text { Coronel Juan Guillermo Toro } \\
\text { Dávila }\end{array}$ & Exército \\
\hline 17 & $\begin{array}{c}\text { Provincias de Concepción y } \\
\text { Arauco (Exceto Departamentos } \\
\text { de Talcahuano y Tomé) }\end{array}$ & $\begin{array}{l}\text { General de Brigada don } \\
\text { Washington Carrasco } \\
\text { Fernández }\end{array}$ & Exército \\
\hline 18 & $\begin{array}{c}\text { Departamento de Talcahuano y } \\
\text { Tomé }\end{array}$ & $\begin{array}{l}\text { Contralmirante Jorge Paredes } \\
\text { Wetzer }\end{array}$ & Marinha \\
\hline
\end{tabular}




\begin{tabular}{|c|c|l|l|}
\hline 19 & Provincia de Bío-Bío & Coronel Alfredo Rehren Pulido & Exército \\
\hline 20 & $\begin{array}{c}\text { Provincia de Malleco (Exceto } \\
\text { Departamento de Angol) }\end{array}$ & $\begin{array}{l}\text { Teniente Coronel Elios } \\
\text { Bacigalupo Soracco }\end{array}$ & Exército \\
\hline 21 & Departamento de Angol & $\begin{array}{l}\text { Teniente Coronel Alejandro } \\
\text { Morel Donoso }\end{array}$ & Exército \\
\hline 22 & $\begin{array}{c}\text { Provincia de Cautín (Exceto } \\
\text { Departamento de Temuco) }\end{array}$ & $\begin{array}{l}\text { Coronel Hernán J. Ramírez } \\
\text { Ramírez }\end{array}$ & Exército \\
\hline 23 & Departamento de Temuco & $\begin{array}{l}\text { Teniente Coronel Pablo } \\
\text { Iturriaga Marchesse }\end{array}$ & Exército \\
\hline 24 & Provincia de Valdivia & $\begin{array}{l}\text { General de Brigada Héctor } \\
\text { Bravo Muñoz }\end{array}$ & Exército \\
\hline 25 & Providencia de Osorno & $\begin{array}{l}\text { Teniente Coronel Lizardo } \\
\text { Simon Abarca Maggi }\end{array}$ & Exército \\
\hline 26 & Provincias de Llanquihue y & $\begin{array}{l}\text { Coronel de Aviación Sergio } \\
\text { Leigh Guzman }\end{array}$ & Força Aérea \\
\hline 28 & Provincia de Aysen & $\begin{array}{l}\text { Coronel Humberto Gordon } \\
\text { Rubio }\end{array}$ & Exército \\
\hline
\end{tabular}

Fonte: decreto lei $n^{\circ} 4$ (1973).

A condução político militar dos Intendentes se estruturou como uma prolongação dos esquemas nacionais fixados pelos órgãos assessores do Presidente da República: a CONARA e a ODEPLAN. Dessa maneira se deu uma continuidade à verticalização do poder centralizado do general Pinochet, quem concentrou as principais prerrogativas e faculdades para a definição dos Intendentes (subalternos diretos) e suas políticas regionais mais significativas. Nesse sentido, é importante destacar que as cinco regiões pilotos estratégicas onde começou o processo de regionalização (I, II, VIII, XI, XII), foram comandadas invariavelmente pelo Exército. Os câmbios institucionais foram sendo impulsionados de forma gradual e experimental nos extremos do país, sem mudar a forte estrutura centralista da capital de Santiago. A estrutura de poder regional, enquanto distribuição de Intendentes exclusivamente militares, não apenas expressou uma desconfiança radical nos setores civis em funções chaves do regime político, mas, também, demostrou um particular cuidado na projeção regional do regime como uma estratégia de controle social e fonte de poder político para o governo autoritário. 


\section{Mapa no 2. Divisão territorial FF.AA. no Golpe de Estado}
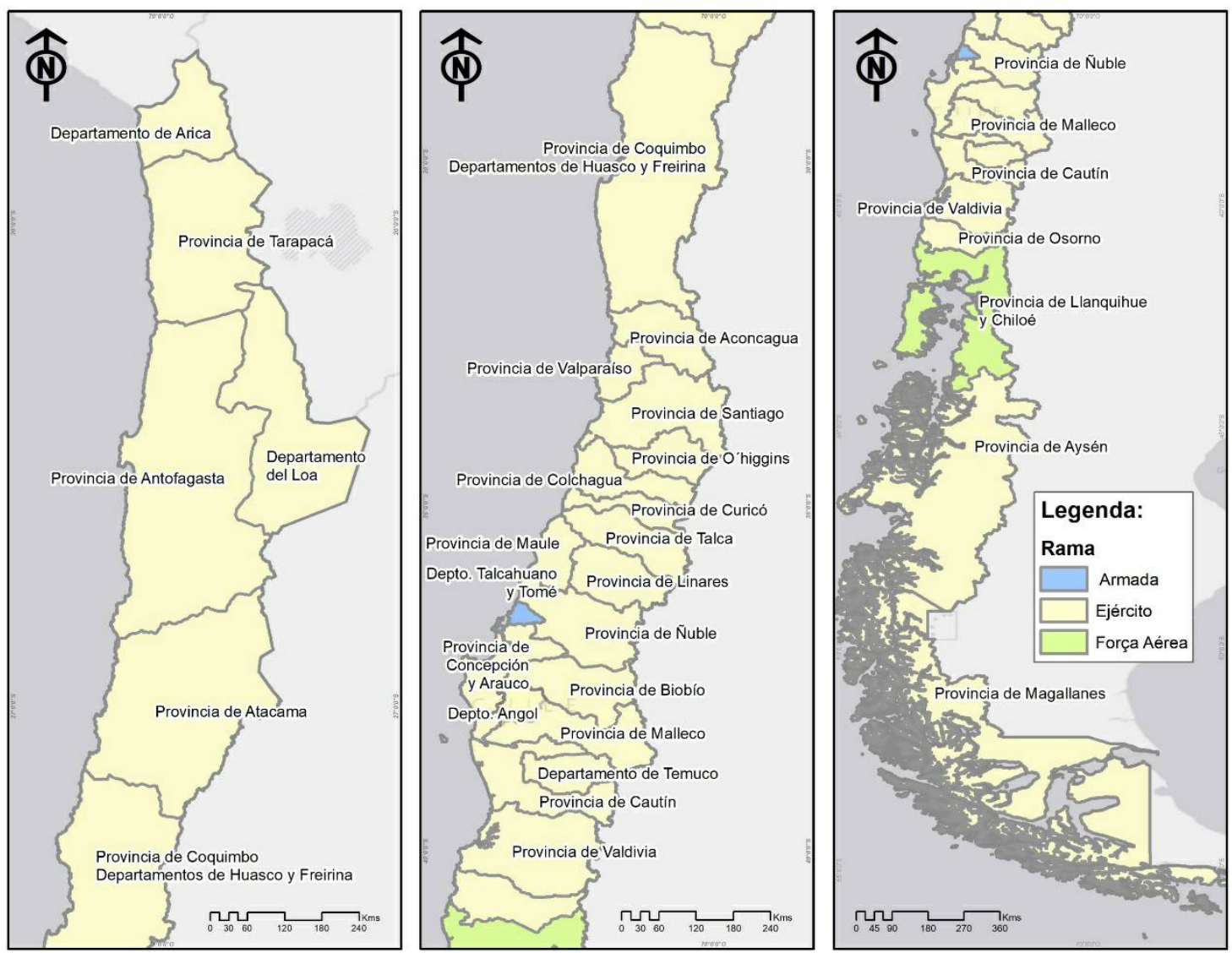

Fonte: elaboração própria sobre a base decreto lei no 4 (1973).

A distribuição das FF.AA. constituídas em autoridades regionais, invariavelmente, projetavam o peso cada vez mais hegemônico do general Pinochet ao interior da Junta de Governo e em sua tendência a concentrar o poder político do país. Dessa forma, é importante lembrar que Pinochet foi finalmente erigido Presidente do país pela Junta Militar o 17 de dezembro de 1974, embora a resistência do comandante em chefe da FACH, Gustavo Leigh, quem firmou com a ameaça da ruptura entre as FF.AA. (HUNEEUS, 2016). Portanto, Pinochet nunca deixou suas funções de comandante em chefe do Exército e, precisamente, dessa posição de alta patente militar, fortaleceu seu poder como chefe do Estado e organizador do poder político da regionalização. Um dos acertos orgânicos da relação governo-Exército, segundo Huneeus (2016), foi a criação do Estado Maior Presidencial (EMP em diante) a fines de 1974. Esse pequeno grupo de oficiais do Exército altamente qualificados tinha a missão de assessorar a Presidência do Pinochet, levando o controle das tarefas dos ministros e também recrutando outros oficiais e membros das FF.AA. nas quantiosas tarefas de governo, como era o caso das destinações regionais. Através do EMP, Pinochet conseguiu não misturar as funções políticas do governo daquelas 
estritamente profissionais do Exército, separando as tensões políticas entre os mesmos, pois, os oficiais que executavam determinadas funções de governo eram separados das suas funções militares pelo EMP, entretanto, mantinham um estrito controle de seus retornos e carreiras profissionais que eram vigiadas e continuavam ascendendo. Dessa maneira, se impediam e minimizavam as possibilidades de politização no corpo de generais, criando estrategicamente um pequeno corpo militar afim ao governo autoritário (EMP) que assessorava e coordenava diretamente as atividades de Pinochet e suas estratégias na ação do governo (HUNEEUS, 2016). Conforme as lógicas de controle e hierarquia de Pinochet, se criou um círculo de confiança militar que deu consistência às escolhas políticas que influenciariam em determinadas áreas do governo, mas sem ter que envolver uma direção orgânica do Exército. Como diria o historiador Luis Vitale:

Si bien es cierto que no tuvo la estructura de un partido político tradicional, la alta oficialidad actuó de hecho como un partido político; con una estructura orgánica especial, para discutir los planes de gobierno, la política económica, la forma de enfrentar los conflictos sociales, la política internacional y todo aquello relacionado con el quehacer político de una nación (VITALE, 2000, p. 64)

Essa necessidade de agentes militares no governo, no fundo, manteve intato o espírito de corpo do Exército como forma de governo. E, ao mesmo tempo, deu um poder discricional a Pinochet no interior do Exército, "sacando oficiales que no eran de su confianza y reemplazándolos con otros que sabía legales, siguió una cuidadosa y gradual política de nombramientos para conseguir un cuerpo de generales fiel a sus decisiones" (HUNEEUS, 2016, p. 156). Um poder discricional que também permitiu influenciar e dirigir no caso das destinações de Intendentes regionais baixo sua dupla estrutura de agente militar e governo regional. Entre 1974 e 1977, Pinochet mandou a retiro praticamente todo o conjunto do corpo de generais (GARATE, 2012), com um saldo de 39 oficiais superiores fora do Exército (FAJARDO, 2012). Esse comportamento depurativo das filas militares começou nas primeiras horas do Golpe de Estado com uma violenta perseguição dos oficiais constitucionalistas e próximos ao general Carlos Prats (FAJARDO, 2012). A ação depurativa no Exército implicou, a mediano e longo prazo, ampliar o corpo de generais e acelerar as promoções hierárquicas, desta vez mais pela afinidade do general Pinochet que pelos méritos estritamente profissionais dos oficiais que respeitavam e premiavam a antiga tradição da corporação (HUNEEUS, 2016). O poder discricional de Pinochet, por consequência, reforçou sua centralidade no comando das destinações militares na política de Estado e se expressou formativamente no corpo de oficiais através dos princípios da doutrina de Segurança Nacional, que passou a ser matéria 
obrigatória da Academia Superior de Guerra e da Academia Superior de Segurança Nacional desde 1975, dando um fundamento prático à presença dos oficiais no governo (FAJARDO, 2012).

Antes do Golpe de Estado, as FF.AA. chilenas não tinham uma posição hegemônica e unívoca do desenvolvimento e a política social do país (VALDIVIA, 2001). Se bem se caraterizavam dentro de um ideário conservador de progresso econômico e unidade nacional (GARATE, 2012), nas FF.AA. coexistiam diversas posturas onde assomavam traços anticomunistas com visões de um Estado promotor da economia, forte e corporativo (HUNEEUS, 2016). A partir da década de 1930 a oficialidade militar chilena mantinha uma visão profissional maioritariamente respeitosa da Constituição e do poder político. Daí que na década do 1960, antessala do Golpe de Estado, dentro das FF.AA. não existia uma posição absolutamente ligada ao ideário da doutrina de Segurança Nacional, embora alguns oficiais já haviam participado dos cursos estendidos pelos Estados Unidos e conheciam os métodos de tortura e instrução contra o inimigo interno (GUZMÁN, 2014). A tradição constitucionalista nas comandâncias e as principais antiguidades do Exército do Chile também se explicava pelo desenvolvimento histórico das corporações militares no seculo XX e sua legitimidade profissional. Como assinala o historiador Manuel Domingos Neto:

A composição do corpo de oficiais dispensou a seleção por castas ou origem de classe e valorizou a formação profissional em escolas especializadas. A carreira militar passou a ser regida pela promoção hierárquica baseada na avaliação de mérito fundada em critérios que contribuíram para a autonomia corporativa. Essas mudanças corresponderam ao empenho na superação do regime político dinástico e ensejaram ao militar a possibilidade de se apresentar como guardião de toda a sociedade (NETO, 2019, p. 15-16)

Porém, no caso do Chile, a corporação militar seria fortemente tencionada pelo sentido de casta ou grupo de poder, funcional aos interesses dos históricos setores conservadores e empresariais ainda no governo da UP. Já próximo a finalizar o governo de Frei Montalva (1969), o Exército chileno viveu uma importante crise institucional devido à renúncia de duas gerações completas da Academia de Guerra (ENTREVISTA CARLOS GARAY, junho 2016). Esse incidente refletia os baixos salários dos oficiais e a escassa preocupação dos governos por atualizar o equipamento bélico e sua posição institucional como funcionários públicos (HUNEEUS, 2016; MOLINA, 1989). Naquela época, a inédita situação significou a saída do Ministro de Defesa, o Comandante em Chefe do Exército e o Diretor da Academia de Guerra (Pinochet era o Subdiretor da Academia, quase perdeu sua carreira). Essa crise institucional, significativamente, também demostrou algumas lógicas de 
rebelião no interior do alto mando que posteriormente foram impulsionadas para o desenvolvimento do Golpe de Estado de 1973. A formação das FF.AA. tendeu a extrapolarse separadamente da sociedade civil, fato que marca desde o início as possibilidades de mando ou obediência e seus limites extrainstitucionais. Mas, também, e sobretudo, incide em cada uma das relações do ordenamento sociopolítico e econômico (NETO, 2019). Para ser uniformado é preciso manifestar uma vocação especial de mando e obediência no contexto de sua própria realidade autônoma, "un consenso cognitivo forzado o acuerdo básico, acerca de qué es lo real' (BALBONTIN, 1984, p. 5). Esse princípio cognitivo de mando-obediência define toda uma estrutura organizativa de funções que, de maneira disciplinada e hierarquizada, assegura a unidade do conjunto como um sólido corpo cada vez mais altamente qualificado e integrado. Como assinala Neto:

Os comandantes puderam contar com serviços de estado-maior, um colegiado de assessoramento formado por especialistas capazes de estabelecer de forma autônoma as bases doutrinárias da corporação, planejar e conduzir operações complexas, efetivando a interoperabilidade. Por "doutrina" se deve compreender, em essência, a definição da finalidade da Força Armada, sua organização, a maneira de formar e treinar os combatentes, as regras hierárquicas e disciplinares corporativas e as relações entre a corporação e a sociedade. A unidade de doutrina é peça-chave para a eficácia militar (NETO, 2019, p. 16).

A projeção do Estado Maior junto com a doutrina de segurança nacional foi a marca da gestão territorial das regiões e os Intendentes militares. Se trata de um conhecimento estratégico do exercício do poder, somado a uma formação centrada no inimigo interno e as possibilidades de aprofundar as fronteiras interiores. Precisamente, foi esse espírito de corpo que permitiu que Pinochet contara com um Exército com altos grados de profissionalização e um disciplinado sentido de hierarquia e respeito a sua comandância como chefe máximo. Não é muito contraditório, assim, que até pouco antes da ascensão de Pinochet ${ }^{36}$ como comandante em chefe (agosto de 1973), manteve sua subordinação do poder político ao Presidente Allende e ao comandante em chefe Carlos Prats. Isso explica porque nas primeiras horas após do Golpe de Estado, o presidente Allende no Palácio de Governo pensou que o general Pinochet tinha sido detido pelos militares conspiradores, porém, coincidentemente, os próprios oficiais conspiradores haviam notificado a Pinochet apenas alguns dias antes do

${ }^{36} \mathrm{Na}$ carreira político-militar, Pinochet destacava um breve passagem como Intendente suplente na província de Iquique entre abril e outubro de 1969. Nesse período, teve que lidar com algumas greves estudantis, conhecer algumas problemáticas locais por moradias, negociar com sindicatos e figuras da esquerda da cidade, como o futuro prefeito no período de democracia, Jorge 'Choro' Soria, "marxista disfrazado de socialista" segundo as palavras do Pinochet (PALMA, 2016, p. 95). Pela responsabilidade de seu cargo teve que organizar as forças militares para o bom funcionamento das eleições parlamentares em 1969, onde conseguiu, segundo ele, "adquirir un cabal conocimiento de la provincia en sus aspectos sociales, económicos y políticos” (PALMA, 2016, p. 95). 
Golpe, pois nenhum deles tinha certeza e plenitude da posição de Pinochet: ou apoiava o Golpe ou rompia a unidade das FF.AA.

Desde o início do golpe, Pinochet manifestou uma profunda rejeição às representações políticas tradicionais. Essa rejeição seria um fundamento chave da militarização dos Intendentes durante todo o período. Os oficiais que foram nomeados Intendentes, na prática, formavam parte de uma primeira linha do alto mando militar e a supervisão direta do EMP. Em termos formais, ocupavam sua autoridade como destinações a título individual, mas eram entendidas como formas próprias da carreira militar e sua divisão territorial corporativa. Isso quer dizer que se integravam na administração pública sem classificação institucional, no entanto, mantinham o caráter profissional e hierarquizado das FF.AA. Segundo o coronel em retiro, Jorge Sanz, apenas um superior militar da zona era destinado ao cargo de Intendente regional, imediatamente "se separaba de la unidad militar, porque era muy fácil contaminarse de la política" (ENTREVISTA JORGE SANZ, novembro 2019). Essa lógica despolitizadora, mas de estrito controle político militar do território, será uma permanência no programa de governo no território.

Os Intendentes militares se dedicariam exclusivamente a governar as regiões, embora continuassem sendo as principais hierarquias militares do território caso existisse alguma contingência militar. Dessa maneira, o comando político da região era definido pela assessoria do Estado Maior da região e o conjunto de unidades burocráticas que integrariam os serviços públicos regionalizados (SERPLAC e SEREMIS fundamentalmente). A seleção dos Intendentes foi dirigida pelo EMP e a sistemática vigilância-autoridade de Pinochet, embora as Regiões da Marina (V) e FACH (X) eram organizadas pelas suas respectivas comandâncias em chefe. Formalmente, os Intendentes se separavam das funções militares, delegando o mandato para o interior da instituição castrense. A máxima antiguidade da instituição castrense no território regional passava a ser o Intendente regional, e seu segundo subalterno na instituição castrense passava a ter o comando operativo militar. Assim se resguardavam as funções estritamente militares das tarefas de governo, sem ter que involucrar as tropas e recursos com o mesmo. Como destaca Sanz, "El comandante de la división era el Intendente, pero el Intendente tenía un vicecomandante que era él quien mandaba militarmente la división del Ejército. Eran funciones distintas" (ENTREVISTA JORGE SANZ, novembro 2019). 
Sendo a principal corporação militar do Chile, o Exército controlava praticamente o país inteiro (menos a V e X Regiões). Essa distribuição regional se encruzilhou territorialmente com as seis divisões do Exército no território nacional, nas quais cada general da divisão automaticamente passava a ser o Intendente da região político administrativa da CONARA onde se localizava. Por sua vez, cada divisão do Exército tinha uma cidade capital onde se exercia o poder político, que era coincidente com a estruturação das capitais definidas pela CONARA. Essas seis divisões do Exército nominalmente se reconheciam por números romanos, sendo I divisão de Antofagasta, II divisão de Santiago, III divisão de Valdivia, IV divisão de Punta Arenas, V divisão de Coyhaique e VI divisão de Iquique. Daí que alguns autores assumiram que a regionalização haveria sido um arranjo das divisões do Exército ${ }^{37}$. No entanto, como vimos no capítulo anterior, essa numeração romana antecedia a divisão da CONARA com a ODEPLAN de 1968 (BOISIER, 2000). E, na prática, apenas organizou uma ordem hierárquica para seis regiões e alguns limites provinciais que foram simultaneamente sede das divisões do Exército. Portanto, não definiu os recortes regionais nem tampouco explicou as dinâmicas internas de nomeação e rotação do conjunto de Intendentes militares espalhados nas treze regiões.

Em nossa maneira de ver, além das seis divisões militares, a regionalização foi um assunto fundamentalmente dirigido pela visão geopolítica de Pinochet, apoiado no Estado Maior da CONARA e EMP. Segundo a ordem das fronteiras internas definidas pela CONARA, cada governo regional tinha uma capital ou cidade-centro que deveria facilitar a eficiência administrativa do conjunto e nuclear assim as diversas atividades econômicas e sociais da região. Por sua vez, esse núcleo espacial também deveria articular uma rede de infraestrutura e articulações internas-externas, onde o Intendente pudesse controlar um sistema de comunicações estratégico entre cada uma das cidades interiores. Ditas informações estratégicas e interligações entre a capital regional e a rede de infraestrutura, impulsionada nos espaços internos, seriam a chave para fundamentar os limites administrativos operativos de cada região. A partir desse arranjo regional, tecnicamente, se procurou uma maior comunicação entre as unidades territoriais, ao tempo que se ampliou o reportório do governo regional com soluções diretas em populações isoladas e historicamente esquecidas (EL MERCURIO, 27 novembro 1975). A gestão territorial que deveriam liderar os Intendentes, assim, se ancorava nas convicções depurativas da

\footnotetext{
${ }^{37}$ Em contrapartida, o interessante das divisões militares do Exército, porém, é que, salvo a VIII região político-administrativa, todas elas também coincidiram e foram parte das regiões pilotos impulsionadas em julho de 1974 e, portanto, tiveram plena participação do Exército.
} 
regionalização e nas ações diretas e técnicas do terreno que fariam desaparecer as intermediações políticas inúteis:

La realidad es que la agrupación de las provincias en regiones y la redistribución del poder administrativo y económico a lo largo del territorio harían desaparecer a muchos intermediarios inútiles y eliminarían la influencia puramente política para asuntos que requieren soluciones técnicas, directas y en el terreno (EL MERCURIO, 5 dezembro 1973).

Os intermediários inúteis, em primeiro lugar, eram os partidos políticos. No entanto, a reforma regional também implicou uma reorganização das estruturas burocráticas internas com maiores funções e comunicações com as comunidades locais. A regionalização, acima de tudo, esvaziaria a influência dos partidos políticos tradicionais como ferramenta de governo e criaria uma outra rede burocrática ancorada em procedimentos técnicos, sobretudo, a partir do conhecimento dos terrenos que a antiga administração púbica não concorria. Dessa forma, ampliavam-se os repertórios da administração pública nos territórios enquanto políticas e diferentes possibilidades de intervenção afines ao programa do governo, além da antiga intermediação dos partidos. No fundo, era substantivo projetar a regionalização como uma forma de desenvolvimento, mas, primordialmente, um apoio para aqueles mais vulneráveis do país, sempre postergados por uns e outros representantes da política tradicional (EL MERCURIO, 27 novembro 1975). Em março do 1975 o Intendente da VIII Região, o general Nilo Floody Buxton, fazia um positivo balanço para o jornal El Mercurio, entregando luzes da comunicação das autoridades territoriais inseridas no esquema regional:

El Gobierno Regional está funcionando, con la designación de todos los secretarios ministeriales (jefes zonales de cada ministerio que forman el gabinete del Intendente). Igualmente, trabaja la Secretaria Regional de Planificación, el Consejo Regional de Desarrollo, y desde luego, los Gobernadores Provinciales. La Contraloría presta igualmente gran apoyo en este proceso. Tenemos un presupuesto regional de 22 mil escudos, que ha sido distribuido de acuerdo con las necesidades locales. Estamos invirtiendo lo correspondiente al primer trimestre. En las obras programadas con este presupuesto regional, se consideró con prioridad a las provincias o a las zonas más pobres. Se están realizando, entre otras, obras de electrificación en Arauco, en Tirúa y Punta Levapié, y proyectos para desarrollar la agroindustria en áreas atrasadas de Nuble. A estos trabajos se unen por cierto, las que se efectúan con el presupuesto general de la nación (EL MERCURIO, 18 março 1975).

A regionalização do Chile se projetou como uma forma de governo inédita na história centralista do país e refletiu uma escolha particular do governo nacional que, por primeira vez, organizou o poder regional com autoridades e competências claramente definidas, onde, ademais, "El Presidente de la República visita periódicamente las regiones-piloto para imponerse de la marcha de los programas" (LA TERCERA DE LA HORA, 09 julho 1975). A regionalização 
cumpria um ano de reforma e o regime projetou um balanço positivo que, em termos materiais, expressou significativas cifras de metros quadrados em habitações, reparação de escolas públicas, novos recintos educacionais substantivamente melhores, construção de hospitais e serviços públicos vitais que davam maior valor aos recintos públicos e suas demandas sociais. Da gestão do primeiro ano dos Intendentes militares, é interessante destacar a referência sistemática de três assuntos cruciais: moradia-infraestruturas, saúde e educação. Na matéria do jornal Tercera de la Hora intitulado, Regionalización celebra su primer cumpleaños, se fazia um completo resumo dos avanços numéricos em cada uma das regiões pilotos (I, II, VIII, XI, XII), destacando a função pública e social que havia significado a implementação de um ano de regionalização. Entre as dinâmicas e responsabilidades próprias dos Intendentes, se destacavam os principais responsáveis e os altos níveis de gestão de ditas iniciativas. Por exemplo, no caso da I região, uma voz informante do Ministério do Interior destacava:

En la Primera Región se construyeron $6500 \mathrm{~m}$. cuadrados en viviendas para albergar a los empleados públicos y sus familias que se trasladaron a Iquique con motivo del comienzo del proceso. Se adquirió una unidad coronaria, un electrocardiógrafo y una moderna ambulancia para el Hospital de Iquique [...] Fueron reparados 67 establecimientos educacionales, lo cual significó mayor confort para 35 mil estudiantes. Además, se construyeron 5 nuevos locales, con un total de 60 salas, para la enseñanza básica. En obras públicas se han invertido 16 mil 500 millones de escudos. Por otra parte, se ha desarrollado una acción coordinada para evaluación y explotación de los recursos mineros (LA TERCERA DE LA HORA, 09 julho 1975)

Esse balanço positivo de resultados concretos em moradia, saúde e educação em cada uma das regiões pilotos (II, VIII, XI, XII), também era complementado diferencialmente no espectro econômico, onde se adicionavam projetos segundo as vocações produtivas de cada região. Por exemplo, se para a XII região de Magallanes se anunciou o desenvolvimento de trabalhos de uma ampliada oferta de serviços turísticos que iriam construindo aproximadamente "20 mil metros cuadrados de camping en el Parque Nacional Torres del Paine", para a VIII região se anunciu a instalação do "Complejo Agrícola de Bío Bío y la habilitación del terminal pesquero de Los Angeles" (LA TERCERA DE LA HORA, 09 julho 1975). Além dos assuntos sociais mais sensíveis, o resultado da regionalização também refletiu em uma condução efetiva das economias regionais que, a partir de sua diversidade de recursos e a coordenação das autoridades territoriais, tenderia a desenvolver projetos produtivos que acelerariam uma mudança progressiva para a superação da pobreza dos postergados das regiões. Em síntese, a um ano da regionalização, se evidenciou uma busca de legitimidade do processo, sobretudo, no funcionamento coordenado das autoridades territoriais e sua direta relação com o poder 
central: "en las regiones piloto trabajan activamente los intendentes regionales, con la colaboración directa de los secretarios regionales ministeriales, quienes tienen la representación de los diversos ministerios" (LA TERCERA DE LA HORA, 09 julho 1975).

De alguma maneira, o esquema administrativo territorial já tinha uma maior coordenação das informações territoriais, agora, definidas e impulsionadas através de autoridades regionais de maior hierarquia. A partir de primeiro de janeiro de 1976, a regionalização se fez efetiva em todo território nacional - se fusionaram as províncias pendentes -, conformando as treze unidades territoriais regionais. A diferença dos recortes de comunas e províncias que foram definindo-se por zonas e etapas (1974-1981), o recorte das treze regiões foi invariavelmente mantido durante todo o período autoritário (19741990). O balanço positivo nas regiões pilotos se projetou como uma nova realidade geográfica para o país que tendeu ao funcionamento administrativo com níveis mais técnicos profissionais e uma fortalecida agencia em terreno que dissolveria, tecnicamente, qualquer tipo de agenciamento "ideológico" proclive a ideias forâneas como a luta de classes e a centralização da economia via Estado promotor da economia.

Para manter a coerência do programa de governo e os objetivos da regionalização, a partir de 1975 o Ministério do Interior e a CONARA coordenou reuniões com todos os Intendentes militares no edifício Diego Portales em Santiago (BOISIER, 2000). Nessas reuniões, junto com escutar as inquietudes e sensibilidades dos Intendentes enquanto suas respetivas experiências de governo regional, participava o general Pinochet, quem parlamentava diretamente com os Intendentes militares de todo o país. Por sua vez, também se explicavam os marcos globais e procedimentais da reforma administrativa, e as caraterísticas do funcionamento do sistema de planejamento nacional que faziam concreta a operação orçamentaria das regiões, províncias e prefeituras (ENTREVISTA MARIO ROCHA, outubro 2019): Dessa maneira, as reuniões se dividiam em duas partes: a) uma parte técnica-operativa encarregada pela ODEPLAN, que delineava os assuntos globais dos recursos, procedimentos e projetos que deviam impulsar os Intendentes com as autoridades mais técnicas; b) uma segunda parte, mais programática e ideológica, dirigida pela CONARA e o Ministério do Interior, onde se reforçava o programa nacional de governo, e principalmente, o sentido das prioridades e projeções nacionais-regionais, destacando a colaboração direta e certeira entre os Intendentes, secretários regionais ministeriais, governadores e prefeitos como uma expressão de governos regionais. Pouco antes do 
começo da regionalização em todo o país e suas respetivas treze unidades territoriais subnacionais (até esse momento, apenas operavam as cinco regiões pilotos), o jornal La Segunda intitulava Impaciencia y esperanza provoca regionalización:

Desde ayer y hasta mañana viernes, los Intendentes Regionales de todo el país revisan la situación de las cinco regiones piloto y se preparan para la extensión del sistema al resto de las divisiones administrativas que surgieron con la Regionalización. Por eso, es importante lo que sienten los habitantes de Tarapacá, Antofagasta, Concepción, Aisén y Magallanes sobre el nuevo sistema. Y conocer las esperanzas que existen al respecto en otras regiones [...] $\mathrm{La}$ Segunda conversó con varios de los Intendentes que asisten a las jornadas de trabajo que se efectúan en el Edificio Diego Portales. Conoció lo que se siente, lo que se hace y lo que se espera de la regionalización (LA SEGUNDA, 13 novembro 1975).

Similar ao resumo do aniversário de julho, a reportagem destacava mais uma vez os avanços sociais das regiões, e particularmente, a necessidade de combater a extrema pobreza e as expectativas econômicas derivadas do incerto cenário inflacionário. É interessante reconhecer nesse sentido, duas direções fundamentais: por um lado, a posta em cena dos próprios Intendentes militares como representantes do desenvolvimento em cada uma de suas regiões e as possibilidades de experiências regionais com o apoio do Estado central e, por outro, a relativa projeção de mecanismos corporativos industriais como ressábios do Estado empresário comprometido com as respetivas economias regionais. Por exemplo, o coronel Manuel Barros Recabarren, Intendente da província de Coquimbo, destacava que o principal impedimento da extrema pobreza de seu território era "la escasez de vivienda y el de la distribución del agua a las poblaciones y para regadio" (LA SEGUNDA, 13 novembro 1975). Mas também, simultaneamente, o coronel reconhecia que suas principais expectativas estavam no âmbito econômico com a reativação das minas de Andacollo e Pelambres e a Corporación para el Desarrollo Industrial Regional (SIDERE) que, aliás, implicaria adquirir um Banco Regional através dos recursos da CORFO (LA SEGUNDA, 13 novembro 1975). Por outro lado, o Intendente da XI região, o tenente coronel Gustavo Rivera Toro, haveria conseguido um verdadeiro milagre com "103.000 kilómetros cuadrados” em construção de obras públicas nunca antes visto, em uma lógica similar de progresso estrutural da região. Diz o Intendente da XI região:

Ahora, en un año de la regionalización piloto, Aisén cuenta con un Hospital Regional, con postas equipadas con radio para la atención de colonos que viven aislados. Se están instalando una planta telefónica automática para dos mil aparatos [...] En Coyhaique se construyó el Teatro Municipal. Se abrieron nuevos caminos de penetración a lugares apartados, construyen puentes y se lleva la electricidad a localidades aisladas (LA SEGUNDA, 13 novembro 1975). 
Esses direcionamentos positivos e materiais concretos da gestão territorial dos Intendentes militares foram a pauta sucessiva dos diferentes enquadramentos públicos da regionalização. A coreografia burocrática recriada pelos Intendentes militares apelava a significados como ferramenta de progresso, superação da extrema pobreza ou solução aos problemas reais, embora alguns, como o Intendente da I Região, o general Hernán Fuenzalida advertia que, "En algunos aspectos todavia se mantiene la centralización y ello impide el despegue, lo que crea impaciencia entre los habitantes" (LA SEGUNDA, 13 novembro 1975). Uma boa síntese do otimismo cooperativo era resumida pelo Intendente da XII Região, o general Washington Carrasco, quando assinalou que um ano da regionalização havia implicado: "la inauguración de innumerables proyectos, porque hemos trabajado ganándole al tiempo. Ahora venimos a recibir nuevas instrucciones y a aprender de otros intendentes (LA SEGUNDA, 13 novembro 1975). Entretanto, o assunto mais relevante do processo piloto destacado pelo Intendente da VIII região, o general Nilo Floody, era que o avanço da regionalização haveria criado uma "indispensable comunicación entre los Intendentes y las autoridades centrales" (LA SEGUNDA, 13 novembro 1975). O que tinha acontecido? Foi realmente um avanço do ponto de vista administrativo do território nacional? Segundo o geógrafo e funcionário da ODEPLAN nesse período, Ignacio Irarrázaval, os Intendentes haviam tido maiores faculdades com o processo de regionalização:

Mi impresión es que los Intendentes, a partir de 1975, tienen otras atribuciones a las que tenían antes de 1975, más allá de ser el representante del presidente de la República en las regiones. Si bien es un modelo de desconcentración precario, la creación de las Seremis va instaurando en cada una de las regiones una burocracia administrativa sectorial interesante que le da una potencialidad y autonomía (ENTREVISTA IGNACIO IRRARAZAVAL, novembro 2019).

O melhoramento do fluxo da informação entre os Intendentes e o poder central era significativa, sobretudo, em comparação com a antiga divisão das 25 províncias onde não existia uma burocracia funcional e homogênea de apoio, estreitamente ligada as estruturas do centro. Essa potencialidade administrativa, mais interligada entre os Intendentes e seus respectivos serviços desconcentrados regionais, permitiu uma maior sinergia entre os recursos e as funções regionais ministeriais. Os Intendentes, pelo geral, eram generais que estavam no momento mais alto de suas carreiras militares e contavam com um sistema de Estado Maior com altas capacidades técnicas e administrativas (SERPLAC) que reforçavam sua autoridade no mando na região. A partir do arranjo regional de 1974, os Intendentes militares contavam com uma importante informação organizada regionalmente, que os colocava em uma posição de autoridade com maiores possibilidades de manobrar e distribuir os recursos entre as unidades burocráticas interiores. No entanto, ao ser funcionários 
militares e estritamente dependentes do poder central, suas capacidades reais de fazer políticas genuinamente regionais eram restritas e não poderiam contrariar aos grandes princípios encabeçados pelo Estado subsidiário: minimizar o papel do Estado na economia e os direitos sociais e promover a competência privada em toda arena produtiva, incluindo os serviços antigamente públicos.

Dentro dos trabalhos da regionalização e do regime autoritário, não existem estudos a fundo do papel dos Intendentes militares no quadro político do período. Se bem Huneeus destaca o papel político dos Intendentes de Santiago e Concepción, principalmente após os primeiros protestos de 1982 (HUNEUUS, 2016), pelo geral, não existe uma visão específica de seus desdobramentos e articulações no regime autoritário. Dessa forma, os Intendentes se associavam a uma função de hierarquia e vigilância do desenvolvimento social ou econômico das regiões que, embora fossem fundamentais na estrutura de poder, antes de tudo, eram funcionários. Nessa lógica, a figura do Intendente seria mais passiva enquanto líderes efetivos do imaginário político e da ação governamental do território. Como destaca o acadêmico do Departamento de Geografia UCH da época e geógrafo Hugo Romero:

El papel de los Intendentes fue más militarizado y jerárquico dentro del Ejército que como líderes regionales [...] Esta economía de enclave tiene sus propias reglas del mercado, sus propios movimientos y regulaciones. Lo que le interesa es que no se altere el marco general, que no haya regulaciones, que la libertad de los recursos sea la mayor posible, el agua, la energía, la mano de obra y el acceso a los yacimientos o a las propiedades. Entonces, la figura política del Intendente regional yo la veo bastante disminuida, salvo el control militar del territorio (ENTREVISTA HUGO ROMERO, novembro 2019)

Efetivamente, os Intendentes regionais não foram figuras públicas mediáticas como os Ministros ou Subsecretarios, porém, no cotidiano da marcha do regime, foram os enlaces chaves que levaram à diante o funcionamento da maquinaria estatal nos territórios, sendo os primeiros em informar e aplicar as políticas públicas definidas no governo central e nas burocracias interiores. Por sua vez, é interessante o dito por Romero, no sentido que leva implicitamente a refletir sobre a participação dos Intendentes militares nos assuntos ligados a situações de violência política. Nesse sentido, se bem nossa pesquisa está ligada a compreender o direcionamento político dos recortes e arranjos, sem dúvida, o fato da existência de Intendentes regionais em casos de perseguições políticas da época e posteriormente processados pelas demandas civis na democracia ${ }^{38}$, é um dado importante

${ }^{38}$ Embora não aprofundaremos nessa direção, nossa pesquisa detectou vários casos de Intendentes vinculados a casos de detenções irregulares, demandas e condenas pela situação de vítimas políticas em democracia levantadas pelas organizações de direitos humanos. O complexo e paradoxo dessa dimensão, 
para situar a hierarquia e o nível de emaranhamento do poder territorial da época e a influência capilar dos Intendentes no desenvolvimento político do país. Sendo as principais autoridades militares dos territórios, é um fato que tivessem algum tipo de responsabilidade ou ideia das diferentes situações ligadas ao processo repressivo.

Outro assunto significativo da imagem pública dos Intendentes, como explica o sociólogo e pesquisador do FLACSO da época, Gonzalo Delamaza, era o efeito indiferenciador da verticalidade das autoridades ministeriais e o próprio exercício de poder do general Pinochet (ENTREVISTA GONZALO DELAMAZA, abril 2019). Essa verticalidade indiferenciadora, na prática, condicionou que os Intendentes, como outras autoridades regionais da época, não tinham uma representação relevante no quadro político do país, principalmente naquelas regiões historicamente excluídas ou que não fossem demográfica e economicamente relevantes, como Santiago, Concepción ou Valparaíso, por assinalar três exemplos. Um desdobramento da própria estrutura centralista do Estado do Chile é a consecutiva centralidade de Santiago como núcleo chave das decisões e políticas estruturais do poder político nacional. No entanto, segundo o economista regional do ILPES da época, Juan Cavada, os Intendentes sim teriam uma maior figuração pública:

El Intendente designado se convirtió efectivamente en una figura pública de la región. Los SEREMIS muy poco, excepto los que tenían que ver con un tema muy directo, por ejemplo, el SEREMI de Vivienda, Obras Públicas, el SEREMI de Educación no, el de Planificación sí. Pero ¿qué pasa? La gente se da cuenta que tienen competencias limitadas. A veces hubo choque de competencias (ENTREVISTA JUAN CAVADA, outubro 2019).

Além da autoridade e a significação pública da máxima hierarquia regional, por regra geral, os Intendentes militares se desempenharam aproximadamente dois anos e meio nos cargos (quadro no 11). Essa rotação, por sua vez, respondia a uma lógica hierárquica de promoções no corpo militar que, embora se projetava na estrutura do governo interior, era análoga a sua permanência e temporalidade de avanços na carreira hierárquica militar. Isto quer dizer que os oficiais destinados a funções políticas como Intendentes e Governadores, embora não estivessem em funções estritamente militares, se avaliavam e iam ascendendo de acordo a suas carreiras militares e posições de menor a maior hierarquia na patente institucional. Dessa maneira se permitia que suas carreiras militares continuassem avançando posições, embora os cargos políticos implicavam separação de suas tarefas estritamente

está na lógica de controle e descentralização territorial dessa potestade repressiva dos Intendentes militares que, embora suas projeções particulares e casos, em última instância, eram operações definidas e respaldadas pela ordem e ação do governo nacional e suas autoridades centrais. 
profissionais (ENTREVISTA JORGE SANZ, novembro 2019). Ser Intendente regional se entendia como uma lógica de destinação militar e uma tarefa de Estado em uma só linha de mando e projeto de sociedade.

\section{Quadro no 11. Intendentes regiões Metropolitana, VIII, XII, IV e III}

\begin{tabular}{|c|c|c|c|c|c|}
\hline Año & $\begin{array}{c}\text { Región } \\
\text { Metropolitana }\end{array}$ & VIII Concepción & XII Magallanes & IV Coquimbo & $\begin{array}{c}\text { III } \\
\text { Atacama }\end{array}$ \\
\hline 1974 & \multirow[t]{2}{*}{$\begin{array}{l}\text { Tulio Espinosa } \\
\text { Palma }\end{array}$} & $\begin{array}{c}\text { Washington } \\
\text { Carrasco Fernández }\end{array}$ & Augusto Lutz & \multirow[t]{3}{*}{$\begin{array}{c}\text { Manuel Barros } \\
\text { Recabarren }\end{array}$} & \multirow{4}{*}{$\begin{array}{l}\text { Arturo } \\
\text { Álvarez } \\
\text { Sgolia }\end{array}$} \\
\hline 1975 & & $\begin{array}{c}\text { Fernando González } \\
\text { Martínez }\end{array}$ & $\begin{array}{l}\text { Washington } \\
\text { Carrasco }\end{array}$ & & \\
\hline 1976 & \multirow[t]{4}{*}{ Rolando Garay } & Nilo Floody & Fernández & & \\
\hline 1977 & & Buxton & Nilo Floody & \multirow{8}{*}{$\begin{array}{c}\text { Luis Patricio } \\
\text { Serré }\end{array}$} & \\
\hline 1978 & & Roberto Rubio & Buxton & & \multirow{3}{*}{$\begin{array}{l}\text { Jaime } \\
\text { Núñez } \\
\text { Cabrera }\end{array}$} \\
\hline 1979 & & \multirow{4}{*}{$\begin{array}{l}\text { Luis Prüssing } \\
\text { Schwartz }\end{array}$} & \multirow{2}{*}{$\begin{array}{c}\text { Sergio Covarrubias } \\
\text { Sanhueza } \\
\end{array}$} & & \\
\hline 1980 & \multirow[t]{3}{*}{ Carol Urzúa } & & & & \\
\hline 1981 & & & \multirow{4}{*}{$\begin{array}{l}\text { Juan Guillermo } \\
\text { Toro Dávila }\end{array}$} & & Alejandro \\
\hline 1982 & & & & & González \\
\hline 1983 & \multirow[t]{3}{*}{ Roberto Guillard } & \multirow{6}{*}{$\begin{array}{l}\text { Eduardo Ibañez } \\
\text { Tillería }\end{array}$} & & & Samohod \\
\hline 1984 & & & & & \\
\hline 1985 & & & $\begin{array}{l}\text { Luis Danús } \\
\text { Covián }\end{array}$ & $\begin{array}{c}\text { Claudio } \\
\text { Guzmán Pérez }\end{array}$ & $\begin{array}{l}\text { Gabriel } \\
\text { Alliende }\end{array}$ \\
\hline 1986 & \multirow{3}{*}{$\begin{array}{c}\text { Osvaldo } \\
\text { Hernández } \\
\text { Sergio Badiola }\end{array}$} & & $\begin{array}{c}\text { Claudio López } \\
\text { Silva }\end{array}$ & \multirow{3}{*}{$\begin{array}{l}\text { Hernán } \\
\text { Ramírez } \\
\text { Rurange }\end{array}$} & Figueroa \\
\hline 1987 & & & Mario Navarrete & & Juan \\
\hline 1988 & & & Barriga & & $\begin{array}{l}\text { Emilio } \\
\text { Cheyre }\end{array}$ \\
\hline
\end{tabular}

Fonte: elaboração própria sobre a base de informação disponível de governos regionais do Chile.

Dentro do quadro regional dos Intendentes militares, também aparecia uma lógica de ascensão territoriais que se ligavam diretamente com a estrutura do subsistema hierárquico definido pela regionalização da CONARA. Por exemplo, antes de ser Intendente da VII Região em 1988, o general Patricio Gualda já tinha sido Governador da província de Linares e diretor da Escola de Artillería (1977-1981) do mesmo território regional (HUNEEUS, 2016). Um segundo caso, de uma forma inversa e relativamente contrária, foi o acontecido com o general Alejandro Gonzalez Samohod, quem, posterior à sua passagem pela CONARA, foi nomeado Intendente da III Região de Atacama (1981-1984) e logo Governador da província de Melipilla (RM) em 1985. No entanto, ao ser essa última Região parte da RM - o centro neurálgico do poder do país - a nomeação poderia ser entendida como uma promoção hierárquica. Também pode se apreciar que um grupo pequeno de Intendentes militares ocuparam seus cargos em mais de uma região do país, o que faria pensar em uma capacidade de ofício ou certas condições particulares na gestão territorial. São os casos dos generais Carol Urzua (RM e II), Washington Carrasco (VIII e XII), Nilo Floody (VIII, XII), Alejandro Gonzalez Samohod (III, XII) e Luis Prüssing Schwartz (VIII e X). 
Por outro lado, segundo Huneeus, os Intendentes que se mantiveram mais tempo nos cargos foram o Intendente da IV Região de Coquimbo (cinco anos aproximadamente), o general Luis Patricio Serre, e por fim, o Intendente da VIII de Concepción (quase seis anos), o general Eduardo Ibañez Tillería. Sobre esse último, Huneeus destaca:

Ibañez mostró gran destreza política en su larga permanencia en el cargo, superando con pragmatismo el conflicto universitario de 1985, en que la movilización de los profesores y estudiantes en contra del rector, el mayor (R) Guillermo Clericus, tuvo un amplio apoyo en la población de Concepción. También pudo demostrar su buen desempeño manteniendo una relativa tranquilidad social al impulsar programas de empleo a través de las municipalidades y del Gobierno regional (HUNEEUS, 2016, p. 203-204).

Acima de tudo, os Intendentes militares eram representantes do governo nacional e não das regiões. Segundo o prefeito da época, Carlos Cantero, mais que funções eminentemente de governo, os Intendentes tinham tarefas de administração (ENTREVISTA CARLOS CANTERO, novembro 2019). Essa forma de administração, no entanto, contou com uma estrita supervigilancia do conjunto das autoridades da região, a qual organizou cada uma das funções públicas nesses territórios de uma maneira verticalizada. Dessa maneira, a nosso entender, os Intendentes militares contavam com maiores capacidades de exercer formas de governo e influir politicamente na região, embora não tinham possibilidades de criar suas próprias iniciativas territoriais dependentes das necessidades urgentes. Isto significa que, se bem tinham aceso e controle estratégico dos comandos públicos nas regiões, paralelamente, sempre tinham que administrar no marco das políticas nacionais pautadas pelo Ministério do Interior e a ODEPLAN de Santiago. Essa situação foi muito mais evidente na esfera da principal ferramenta de investimento e ação pública que tinham os Intendentes: o FNDR. Com efeito, durante quase todo o período do regime (1974-1985), o FNDR teve baixos orçamentos, condicionando escassos investimentos para a gestão dos Intendentes. Até 1985, o FNDR não conseguiu cumprir seu objetivo original "tanto en términos de recursos asignados al presupuesto del Fondo, como en términos de inversión efectiva de sus recursos" (GARCÍA, 1985, p. 104).

Além dos escassos recursos que tiveram os Intendentes para o desenvolvimento em cada uma das regiões, o fundamental do arranjo regional era acrescentar e organizar racionalmente a presença do governo nacional no território interno. Trata-se de estabelecer e consolidar uma rede de informações em cada uma das regiões e, dessa maneira, articular uma unidade programática através de um conjunto de procedimentos e autoridades, desta vez, sistematicamente mais integrado com o governo nacional: um governo de serviços e 
unidades técnicas regionais, integradas e promotoras de uma gestão cooperativa que foi consolidando um acompanhamento dos assuntos sociais. Os Intendentes militares operaram como genuínos representantes do sistema regional integrado, sem representação partidária da política tradicional, mas com uma profissional e ativa racionalidade burocrática que, supostamente, mudaria os históricos e péssimos balanços regionais. Como intitulava o jornal El Cronista em 1976, En dos Años se ha realizado en Copiapó más que en Veinte años (EL CRONISTA, 09 dezembro 1976). O corpo da notícia, desse modo, indicava a melhoria da cidade de Copiapó e suas principais intervenções realizadas por estrita ordem do general Pinochet, quem, além disso, visitava a região periodicamente e se reunia com seu Intendente, o coronel Arturo Alvarez:

Pinochet se reune con el Intendente por dos horas [...] Copiapó y en general la III Región, fue postergada siempre por las administraciones elegidas políticamente, siempre la dejaron de lado, antes las pocas posibilidades electoreras que aquí se tenían. De una estructura casi colonial, Copiapó ahora ha comenzado a despegar, en los aspectos vivienda, obras públicas, a pesar de que quedan algunos logros que no se han obtenido (Intendente Coronel Arturo Alvarez) [...] Finalmente, el Intendente hizo ver la necesidad de contar con un presupuetso mayor en los sectores educacionales, en vivienda, en el primer caso, para renovar escuelas, que en su mayoría llegan al centenar de años y hasta ahora lo que se ha hecho es producto solamente de los fondos del desarrollo regional (EL CRONISTA, 09 dezembro 1976).

É curioso o caso de Copiapó no sentido de entender seu desdobramento como capital da III Região de Atacama. A partir da conformação dos governos regionais e a localização e construção das SERPLAC e SEREMIS, as capitais regionais das unidades territoriais tiveram um crescimento mais significativo que o conjunto do território regional e suas cidades intermediárias ou interiores (ENTREVISTA VÍCTOR LEIVA, janeiro 2018). Durante o processo de regionalização, se favoreceram exponencialmente aquelas cidades que foram escolhidas como novas capitais. Um exemplo concreto dessa dinâmica de centralismo regional seriam as cidades de Puerto Montt e Coyhaique, capitais da X e XI Regiões que, com o percurso do regime, sistematicamente foram crescendo econômica e urbanisticamente. Como destaca o geógrafo Victor Leiva, o centralismo regional se manifestou na "construcción de los edificios necesarios, si tuvo impactos [...] Lo que cambió es que bubo un marcado centralismo regional, se hizo porque la lógica de los Intendentes militares, que son concentradores de poder" (ENTEVISTA VÍCTOR LEIVA, janeiro 2018). Os Intendentes tinham que promover o desenvolvimento social de suas capitais e territórios. Todas as capitais regionais tiveram um maior impulso de investimentos públicos e movimentos de população associadas ao estabelecimento dessas burocracias regionais. Em substantivo eram as áreas sociais da educação, saúde e moradia, onde os Intendentes deveriam manifestar uma maior prioridade 
no momento de organizar seus escassos orçamentos. A professora de instrução primaria no período autoritário, e ainda habitante da cidade de Copiapó (III Região), Carla Brown, para nossa pesquisa confirma algumas informações:

Se construyen también colegios. Porque tal como decía la nota, eran pequeños, antiguos, feos, en muy malas condiciones [...] No solamente crecimos en infraestructura, cuando se va Arturo Álvarez de Intendente, porque los intendentes eran nombrados los comandantes del regimiento. Entonces, se va él porque ya se tiene que hacer otras cosas y nombran Alejandro González, que el había sido agregado militar en Israel, y en Israel él conoce el riego a goteo, y él implementa acá el riego a goteo, en el valle y donde empiezan a crecer los parronales que hasta el día de hoy son los que nos traen retornos a muchas familias copiapinas y a otras que no lo son, todo el retorno en dólares a la uva que sale de acá [...] Yo no soy de derecha, pero hubo un crecimiento notorio, había empleo. En un minuto en Copiapó había pleno empleo, conseguir una persona para trabajar era muy difícil. Porque la agricultura se llevaba mucha gente [...] Independiente de lo feo de la época, en cuanto a crecimiento tanto cualitativos como cuantitativo de la región, el desarrollo fue grande y notorio (ENTREVISTA CARLA BROWN, maio 2020).

A citação é duplamente significativa pois, de um lado, valida a gestão do Intendente regional da época com resultados concretos nas áreas sociais e também produtivas e, de outro, inclui um novo assunto que anteriormente não tínhamos considerado como possibilidade analítica: a gestão de um Intendente em um assunto específico de inovação, particular da Região, representada neste caso pelo Intendente Alejandro Gonzalez Samohod, e a técnica de irrigação por gotões. Assim sendo, até onde as regiões e suas máximas autoridades tinham capacidades de ação? Ou, até onde essas eventuais inovações são resultado das capacidades pessoais dos Intendentes ou do conjunto do sistema regional posto em jogo pelo regime? Contudo, o sistema regional dava maiores possibilidades de enlace e comunicação ao conjunto do território nacional. Como destacavam os pesquisadores de FLACSO da época: "La regionalización chilena está marcada por un fuerte presidencialismo personalizado: todo sale del Jefe del Estado y todo vuelve a sus manos" (MORALES, POZO, ROJAS, 1988, p. 49). O sistema territorial de Pinochet se ancorava em um duplo sistema de Estado Maior em escalas geográficas estratégicas altamente conectadas e complementarias. Por um lado, a nível nacional, a CONARA projetou o conjunto de procedimentos e recortes territoriais para fazer efetiva a regionalização. Por outro, a nível regional, cada Intendente fez um conjunto de operações de governo e recoleção de informações estratégicas que complementou e puxou os requerimentos do governo central e as linhas do Pinochet e o EMP. A Geografia dos Estados Maiores se valorizava em cada um dos enlaces centrais e regionais da malha territorial do regime. 


\subsection{Da coesão territorial integrada as tensões na estrutura regional}

Além do propósito de coesão governamental e legitimidade da representação nacional nas regiões, na prática, os Intendentes começaram a dirigir uma rede de serviços e prestações públicas para a população nos territórios. Uma das melhoras importantes que trazia o sistema regional foi que os trâmites burocráticos, que antigamente radicavam exclusivamente no órgão central de Santiago, agora poderiam ser levados nas regiões com consideráveis níveis de eficiência sem depender das prerrogativas do centro (ENTREVISTA JORGE NEGRETE, junho 2019). Isso, junto com a representação regional da Controlaria General da República e o Ministério de Fazenda, criava a aparência de um Estado regional homogêneo e forte em todo o país, o qual podia ser entendido como uma maior hierarquia das autoridades regionais ou: "un significativo cambio en la mentalidad del chileno. En el de provincia o región, que debe adaptarse a tomar decisiones, y en el de Santiago, que debe delegar funciones y atribuciones" (ULTIMAS NOTICIAS, 18 abril 1975).

Apesar do otimismo e a difusão dos resultados concretos da regionalização em termos burocráticos mais autônomos, a reforma regional ainda tinha sérios assuntos que resolver. Assim se manifesta em um estudo realizado pelo fiscal da Contraloría General da República, o advogado e assessor da CONARA, Arturo Aylwin Azocar, em 1977. Se bem no relatório se destacam avanços significativos, como por exemplo, o melhoramento das funções administrativas associadas à delegações e uma ótima distribuição dos recursos do FNDR, por outro lado, também se advertem problemas nas funções públicas e privadas das autoridades. Essas últimas, segundo Aylwin, ainda não haviam entendido sua esfera de atribuições no sistema regional: "No se ha entendido que a ese sector le corresponde un papel dinámico en el proceso y que su deber es colaborar activamente en la solución de sus propios problemas" (EL CRONISTA, 5 maio 1977). O relatório foi apresentado aos Intendentes em uma reunião em Santiago no mês de maio de 1977:

Aylwin entregó estos antecedentes a todos los Intendentes reunidos en la sede de gobierno, haciendo la salvedad de que la Contraloría plantea problemas, pero no se pronuncia sobre soluciones, y partiendo desde esos planteamientos, formuló otros más detallados [...] está surgiendo un nuevo cuadro problemático y es que muchas de las autoridades en la región no tienen los recursos suficientes ni la capacidad para ejercer la plenitud de las facultades delegadas [...] Aylwin agregó también que cada vez demuestra con mayor urgencia la necesidad de dar una estructura y organización adecuadas a las Intendencias Regionales y a las Gobernaciones Provinciales, a pesar de que hay casos en que las actuales autoridades han tratado de organizar esos servicios con el apoyo de lo que tienen (EL CRONISTA, 5 maio 1977). 
As regiões ainda não contavam com uma regulamentação administrativa operativa nem com os recursos necessários, aliás, suas autoridades não estavam totalmente inseridas em suas faculdades. No entanto, continua Aylwin, também emerge uma melhora histórica a partir dos procedimentos e reestruturações do espaço institucional instituído pela regionalização em curso:

Pero hay una mejoria que se detecta con mayor énfasis y que es la superación de algo que aquejó por años a las autoridades del país, aun desde que eran meros intendentes provinciales. Los sistemas de comunicación dentro de la administración de las autoridades regionales entre sí y con sus subordinados y con el nivel central. Ahora ellos saben con quién tratar, a quién llamar y a quién pedir instrucciones. Hay una claridad beneficiosa desde la máxima autoridad del país hasta la más pequeña [...] es probable que las soluciones salgan de esta reunión de Intendentes en Santiago son: Consejos Comunales de Desarrollo (constituidos en pocas comunas); Consejos Regionales de Desarrollo (constituidos, pero son pasivos); Comités Asesores de Gobernadores (sólo en algunas regiones) y, por último, el papel pasivo del sector privado (EL CRONISTA, 5 maio 1977).

Se bem Aylwin destacava que os governos regionais efetivamente ainda não contavam com os recursos necessários para impulsionar um programa regional, por outra parte, e aqui o significativo, afirmava que os funcionários regionais sabiam com quem falar, com quem tratar e, sobretudo, pedir instruções. Além dos orçamentos efetivamente executados, se articulava um emaranhado mais orgânico das relações e comunicações oficiais na região, ou bem, se ia consolidando uma rede de funcionários e representantes do regime nas regiões que conseguiam instaurar uma complementaridade efetiva entre suas funções de governo. Como alguns anos depois resumiria o general Canessa em seu balanço:

No se trata de una dispersión de acciones en el espacio, a través de una simple división geográfica del país, sino, por el contrario, de una acción sistemática y programada, que se apoya en la estructura regional para una mayor eficiencia en el empleo de los recursos y una más oportuna y justa atención de las necesidades sociales (CANESSA, 1982, p. 18).

Os Intendentes eram parte de uma estrutura regional que os conetava diretamente com a autoridade Pinochet. $\mathrm{O}$ arranjo regional se validou internamente por seus agentes diretos: os burocratas. Ao mesmo tempo, se impulsionou uma forma operativa de governo que, vertical e horizontalmente, permitiu circular as informações de uma maneira integrada que possibilitou uma maior consistência aos programas oficiais territorializados e seus possíveis planos de intervenção. Se permitiu assim ampliar o repertorio de funções públicas na região e, implícita e simultaneamente, cumprir o advertido por Lacoste:

Num Estado, quanto mais o sistema político se tornou complexo, mais as formas de poder se diversificam e mais se emaranham os limites das circunscrições administrativas, eleitorais e os 
contornos mais ou menos vagos e discretos, de formas múltiplas de organização, que tem um papel político (LACOSTE, 2012, p. 48).

Nascia paulatinamente uma forma de poder regional que iria tecendo um papel político do emaranhado burocrático regional, até esse momento, totalmente inédito nas estruturas subnacionais. No entanto, também existiram diversas tensões e contradições, como os conflitos nas regiões associados a atividades produtivas dos produtores de trigo e leite das IX e X regiões (BOISIER, 2000). Nesse contexto de experimentação política e distribuição do poder regional, emerge uma controvérsia entre Pinochet e os Intendentes militares que destacam alguns autores em 1977 (BOISIER, 2000; LIRA, 2004). Embora não existem registros e detalhes nos documentos oficiais, segundo o relato de Boisier, em 1977 os Intendentes haviam manifestado a Pinochet rejeição à política econômica (neoliberal) do regime que, "en regiones mostraba de una manera muy nitida, cruel, el costo social del ajuste estructural" (BOISIER, 2000, p. 10). Em resposta a essas posições, Pinochet respondeu veementemente, fechando o conflito com uma famosa frase: "Recuerden los señores Intendentes que son representantes del Presidente de la República en las regiones y ino representantes de las regiones ante el Presidente!" (BOISIER, 2000, p. 10). Por sua parte, na mesma linha, Lira destaca que os Intendentes militares solicitaram a "reposición de instrumentos de discriminación territorial de la política nacional" (LIRA, 2004, p. 5) em um clima de forte descontento que também se somava a posições críticas dos representantes empresariais nas regiões que, internamente, defendiam "que el nombramiento de Intendentes y Gobernadores debería ser independiente de sus cargos militares y recaer en personas de las regiones" (LIRA, 2004, p. 5), questionando-se assim a condição militar e não civil dos cargos na alta hierarquia territorial do país. A controvérsia, segundo o governo, se interpretou como uma tentativa política de setores tradicionais da direita que não entendiam o processo global e a definição do poder regional oficial.

Outro exemplo dessa dissidência dos Intendentes militares foi o episodio protagonizado pelo Intendente da I Região de Tarapacá, o general Gastón Frez Arancibia que, no contexto da crise de 1981-1983, explicitou uma crítica ao modelo neoliberal que estava começando a ser impulsionado nas regiões (DIAZ, 1989). Essa crítica ficou no texto Reformulación Estrategia Regional de Desarrollo (1987-2006) onde o general fundamentou a necessidade de uma política de desenvolvimento regional autossustentável baseada em três pontos: 1) um frente econômico destinado aproveitar de estrategicamente os recursos naturais, sobretudo a pesca, mineração, zona franca e turismo; 2) uma frente interna de distribuição da população nas regiões com o apoio de Santiago e procurando mais 
infraestruturas para as desconcentrações dos centros maiores; 3) uma frente internacional destinado a reforçar o intercambio comercial da zona franca (DIAZ, 1989). No fundo, a crítica do general Frez procurou aumentar a presença do Estado como ciência e fomento produtivo nas regiões (princípios bases da teoria dos pólos de desenvolvimento) e além do mais, procurou um maior poder político dos Intendente sobre as Secretarias Regionais Ministeriais (SEREMIS) que vinham "con politicas pauteadas por el nivel central y los respectivos ministérios" (DIAZ, 1989, p. 206).

Certamente esses questionamentos não foram considerados pelo regime e o general Pinochet. Com efeito, nossa pesquisa tentou verificar essas informações através de consultas ao pessoal da CONARA e militares informantes. No entanto, nenhum dos entrevistados confirmou uma tensão significativa entre Pinochet e os Intendentes, nem constataram uma polêmica aprofundada pelos efeitos sociais do neoliberalismo nas regiões. O coronel em retiro Luis Alfonso Rivas, diz que "me cuesta creer una actitud corporativa de los Intendentes, a lo mejor habia alguno particular" (ENTREVISTA LUIS ALFONSO RIVAS, novembro 2019). No entanto, também afirmava que "el presidente le creía mucho más a los asesores civiles y económicos que a los propios militares que trabajábamos en el gobierno" (ENTREVISTA LUIS ALFONSO RIVAS, novembro 2019). Por sua parte, o coronel em retiro Jorge Sanz afirma que, embora não tem informações da polêmica, o trabalho de organizar o território era muito intenso, portanto, não se estranharia de alguma confusão por assegurar o funcionamento das regiões, pois, "los recursos eran tan pocos, tan escasos, que la solución era sangre" (ENTREVISTA JORGE SANZ, novembro 2019). Do material da imprensa escrita, no entanto, aparecem declarações do Pinochet em um tom de desconforto e busca de esclarecimento, o qual, implicitamente, demostraria um problema real com as autoridades regionais. Diz a nota:

Cuando se pierde de vista la perspectiva global de la realidad nacional, suelen influir en el ánimo de las autoridades regionales los enfoques localistas del problema, impulsándolas a patrocinar soluciones que vulneran la política general del Gobierno. Contra este riesgo formuló el Primer Mandatario precisas advertencias a los Intendentes Regionales. De acuerdo a la ley, ellos son representantes del Presidente de la República en las regiones y no, "como representantes de las regiones ante el Presidente de la República [...] No me cansaré de insistir - dijo - que los Intendentes Regionales han sido investidos de mayor poder para la toma de decisiones, en sus respectivos niveles de autoridad, pero ello no significa de modo alguno que estas decisiones puedan, bajo ninguna circunstancia o condición, estar reñidas con las políticas, planes, programas o proyectos que emanan directamente del Presidente de la República a través de sus Ministros de Estado y que son válidos para todo el territorio nacional, ya que son éstas las herramientas e instrumentos que se han definido para lograr un desarrollo armónico y equilibrado del país. No conduce, por lo tanto, esta investidura, a ir implementando un sistema federado de Gobierno (EL CRONISTA, 6 maio 1977). 
É difícil compreender a profundidade da tensão entre Pinochet e os Intendentes militares. Não obstante, é um fato que o processo de regionalização continuou nos termos definidos pelo poder central de Santiago e pela vontade política do próprio Pinochet, além da posição desses Intendentes militares. No final da nota de El Cronista, Pinochet, aliás, destacava que as regiões estavam sendo favorecidas pela abertura a "nuevos mercados internacionales para sus productos: está beneficiando directamente, a través de politicas cambiaria, arancelaria $y$ de fomento a las exportaciones a sectores que pasan a ser prioritarios como la agricultura, la pesca, la minería, la forestación" (EL CRONISTA, 6 maio 1977). Essa visão positiva da abertura neoliberal em 1977, contudo, ainda tinha diversos assuntos inconexos na operatória burocrática da regionalização. O coronel secretário Executivo da CONARA, Alejandro Gonzalez Samohod, em 1978 reconhecia limitações e dificuldades desde o ponto de vista administrativo. Se bem a regionalização havia significado um ordenamento geral do sistema nacional unificado, ao mesmo tempo, segundo Gonzalez Samohod, ainda estavam inacabadas muitas competências e regulamentações do governo regional (ULTIMAS NOTICIAS, 2 abril 1978). Por exemplo, as SEREMIS não tinham um número determinado de funcionários nem contavam com regulamento orgânico, espalhando-se territorialmente de forma heterogênea. De fato, ao não existir uma equivalência de uma escala única nacional para os funcionários regionais, alguns Secretários Regionais Ministeriais se instituíam com uma forma laborista ad-honorem (ULTIMAS NOTICIAS, 2 abril 1978).

Em 1982, um profundo estudo da CONARA que tinha consultado 635 organismos públicos, entre as quais, destacavam-se os treze governos regionais e mais de 267 organizações e serviços pertencentes as doze Intendências regionais, confirmava algumas das limitações advertidas pelo coronel Gonzalez Samohod: apenas nove das treze regiões contavam com Intendências Regionais formalmente constituídas. Diz o informe de CONARA:

[...] las Intendencias Regionales, éstas sólo cuentan con estructuras orgánicas en nueve de las trece regiones, es decir no las tienen en cuatro, esto constituye un hecho que se debe tener en alta consideración entre las medidas inmediatas tendientes a acelerar y profundizar este proceso, ya que no es posible concebir una adecuada administración regional, sino se cuenta con un organismo rector regional, adecuadamente implementando (CONARA, 1982, p. 64).

Por sua vez, prevaleciam problemáticas estruturais do processo de regionalização: 1) problemas técnico-substantivos na entrega de bens e serviços à comunidade; 2) problemas contextuais devidos aos arranjos geográficos; 3) problemas administrativos, entendidos 
como limitações na contabilidade governamental, estatística, informática, administração de pessoal, abastecimento, administração do orçamento, planejamento, controle e racionalização. Das três problemáticas, os assuntos administrativos ocupavam a grande maioria das dificuldades, com um 92\% de deficit a nível nacional-regional (CONARA, 1982, p. 58). Em relação aos assuntos mais específicos, se relevava o problema do reduzido pessoal de contrato em regiões, sua escassa qualificação e a dupla dependência dos organismos regionais que, além disso, pela falta de atribuições das autoridades regionais, muitas vezes, deveriam pedir autorização a Santiago para cumprir suas tarefas:

También se debe señalar que el esquema de Administración Regional, establece una doble dependencia de los Organismos Regionales, por un lado con el Ministerio respectivo a nivel central y por otro con el Intendente Regional, y esto implica una mayor probalidad de problemas de coordinación, lo aparentemente se corrobora a través de la información recopilada [...] La falta de atribuciones es otro de los problemas típicos regionales derivados de la resistencia del nivel central a entregar las atribuciones que las organizaciones públicas localizadas en las regiones necesitan para un adecuado ejercicio de sus funciones, es esta indicando, por otra parte, una falta de desconcentración de funciones, a pesar de los ocho años que lleva el Proceso de Regionalización chileno (CONARA, 1982, p. 60).

Assim sendo, em 1982, a transferência de competência do nível central em direção aos governos regionais ainda não conseguia satisfazer o esquema idealmente definido pela CONARA. O processo de centralização do poder de Santiago e a configuração dos órgãos regionais tinham desiguais resultados como na distribuição das SEREMIS. Dos dezesseis setores ministeriais contidos nas SEREMIS definidas pela regionalização de 1974, apenas cincos deles se configuravam em todo o território nacional: saúde, educação, moradia, obras públicas e bens nacionais (CONARA, 1982). Precisamente, se trata das SEREMIS, que articulam um tipo de gestão social dos recursos públicos e que poderia trazer comunicações efetivas entre as comunidades mais carentes, fazendo do governo nacional-regionalizado um instrumento de intermediação social via suas agências comunais e regionais. Por outra parte, apesar das insuficiências do plano de desconcentração, no entanto, o relatório da CONARA destacava que tanto as Controladorias Regionais como as SERPLAC se espalharam com " $u n$ 100\% de estructuras orgânicas" em cada uma das regiões (CONARA, 1982, p. 66). Como se explica que, em 1982, todas as regiões tivessem SERPLAC com regulamentações definidas e equivalentes para todo o território nacional, embora as Intendências Regionais só tivessem formalização em nove regiões? Eram as Intendências Regionais estrategicamente menos significativas que as SERPLAC? O que estava em jogo nas SERPLAC? 


\section{CAPÍTULO 4}

\section{Regiões, burocracia e neoliberalismo}

\subsection{De burocracias regionais a informações estratégicas}

O arranjo regional de 1974, se bem reafirmou o histórico poder central do Estado chileno com burocracias regionais que dependiam da assessoria técnica ODEPLAN de Santiago e as diretrizes políticas do Ministério do Interior, por outro lado, também possibilitou uma organização espacial diferente dos procedimentos e unidades burocráticas que permitiriam ir ajustando e avaliando de maneira operativa a gestão territorial interna das 13 regiões definidas pela CONARA. Em 1975, rapidamente, se espalharam as Secretarias Regionais de Planejamento e Coordenação (SERPLAC) e as Secretarias Regionais Ministeriais (SEREMIS) dos diferentes ministérios setoriais, sendo as principais tecnologias territoriais criadas para articular internamente o arranjo regional. Uma caraterística significativa do arranjo dessas secretarias se encontrava no duplo comando de hierarquização ou dependência do poder central que havia fixado o sistema de governo interior ${ }^{39}$. Assim, as SERPLAC e SEREMIS oficialmente descentralizavam as funções regionais através do assoreamento do Intendente, e, simultânea e subalternamente, também eram vigiadas pelo Ministro Diretor de ODEPLAN - caso da SERPLAC - e pelo Ministro setorial correspondente no caso das SEREMIS. Cada uma dessas SEREMIS, por sua vez, contava com uma autoridade máxima chamada Secretario Regional, a qual, "será el representante del respectivo Ministerio en la región, actuará como colaborador directo del Intendente Regional, al que estará subordinado para los efectos previstos en el artículo" (GOBIERNO DE CHILE, 1974b, s./r.). Dessa maneira, cada região ia estruturando-se a partir de representações ministeriais e uma secretaria de coordenação geral no território, que fundamentalmente deveria planejar, organizar e executar o plano de governo Intendente ${ }^{40}$, embora o governo central tivesse $\mathrm{o}$ domínio de suas ações e partidas orçamentais.

\footnotetext{
${ }^{39}$ A fórmula de duplo controle do regime e a lógica centralista também se expressaria no desenho financeiro das recém-criadas estruturas regionais. O Ministério de Fazenda e sua Direção do Pressupostos (DIPRES) somado ao controle da ODEPLAN, todos dispositivos centrais, seriam os órgãos encarregadas de definir os termos globais da proporção das partidas orçamentais em cada um dos territórios regionais (GOBIERNO DE CHILE, 1974c).

${ }^{40}$ A desconcentração regional dos Ministérios não contemplaria os ministérios do Interior, Defesa e Relações Exteriores, que não teriam uma expressão de governo regional (GOBIERNO DE CHILE, 1974a).
} 
O arranjo das secretarias regionais, segundo a CONARA, permitiria conectar espacialmente os serviços públicos com as necessidades sociais, pois, se abriria uma melhor distribuição geográfica das "prestaciones esenciales minimas en materias, fundamentalmente, de educación, de salud, de recreación y otros" (CONARA, 1983, p. 18). As SERPLAC e SEREMIS se tornaram as maquinarias administrativas de maior hierarquia na nova arquitetura institucional do regime territorial e as responsáveis de viabilizar o governo das regiões. Através de um conjunto de decretos leis ( $\mathrm{n}^{\circ}$ 69, $\mathrm{n}^{\circ}$ 937, $\mathrm{n}^{\circ}$ 746), no decorrer do ano de 1975, foram espalhadas espacialmente de norte a sul, doze SERPLAC, correspondentes ao conjunto de regiões (I, II, III, IV, V, VI, VII, VIII, IX, X, XI, XII), com exceção da SERPLAC da Região Metropolitana de Santiago. Entre suas tarefas mais indispensáveis, a lei estabelecia que as SERPLAC deveriam executar as políticas regionais em conjunto com os seus diretores e chefes dos sistemas públicos da região, também coordenar e informar sistematicamente sobre as políticas públicas regionais e nacionais ao Intendente e aos respectivos órgãos ministeriais desconcentrados, além de construir o orçamento da carteira de projetos regionais em função do plano de trabalho anual (GOBIERNO DE CHILE, 1975a). O decreto-lei $n^{\circ}$ 573 de 1974, por sua vez, estabeleceu que a edificação material das SERPLAC se concretizaria a partir da apropriação das oficinas de corporações, comitês programadores, juntas de adelanto e ORPLAN (GOBIERNO DE CHILE, 1974a). Dessa forma, a fundação das SERPLAC se instituía a partir das rugosidades regionais do Estado promotor da economia da UP, embora com um sinal absolutamente inverso ao desenvolvimento das décadas anteriores. O decreto-lei no 937 de 1975, ademais, estipulava a distribuição de 312 funcionários ao longo das regiões do país (exceto Santiago) para conformar as SERPLAC (GOBIERNO DE CHILE, 1975b). Esse ponto é importante porque o decreto-lei da regionalização de 1974 ( n⿳0 575) estabelecia que:

Los planes aludidos no podrán contemplar aumento de cargos o funcionarios de los respectivos Ministerios, servicios e instituciones existentes. La dotación del personal de las intendencias y demás organismos contemplados en el presente decreto ley se hará preferentemente sobre la base del traslado o sustitución de cargos y de la destinación de funcionarios que trabajan en Santiago (GOBIERNO DE CHILE, 1974b, s./r.)

Nesses termos, as SERPLAC foi uma das poucas instituições burocráticas do período onde havia contratação de pessoal novo (administrativos e profissionais), embora suas direções centrais fossem destinações de Santiago. A lei também estabelecia que as SERPLAC deveriam assegurar o funcionamento eficiente das formas técnicas do sistema regionalmunicipal integrado, facilitando a coordenação dos “diferentes Ministerios y organismos que tienen 
mayor responsabilidad en la conducción y ejecución del proceso de desarrollo regional' (GOBIERNO DE CHILE, 1975b, s./r.). Do ponto de vista da organização interna, cada SERPPLAC se conformava diretivamente a partir de sua máxima autoridade: o Secretario Regional de Planificação e Coordenação (o SERPLAC), dois respectivos Chefes de Departamento e Pessoal Administrativo e uma pequena dotação de profissionais, administrativos e técnicos, entre outros serviços. O SERPLAC, aliás, deveria subordinar-se simultaneamente ao Intendente Regional e ao Ministro Diretor da ODEPLAN. Daí que, em última instância, os cargos nomeados deveriam ser validados pelo Presidente da República e o Ministério do Interior. Cada SERPLAC, portanto, foi compreendido como um funcionário da "exclusiva confianza del Jefe del Estado y serán designados por decreto supremo del Ministerio del Interior" (GOBIERNO DE CHILE, 1975ª s./r.). Era uma maneira de traspassar o poder do governo central ao processo de regionalização, sendo os SERPLAC as principais autoridades técnicas na distribuição dos recursos e contratações do pessoal na região. Já nos artigos transitórios do decreto-lei $n^{\circ}$ 937, se estabelecia explicitamente que o Ministro Diretor de ODEPLAN "podrá proveer los cargos de la planta que se crea, por una vezy a medida que se constituya cada Secretaría Regional de Planificación y Coordinación, con personal de dicha oficina" (GOBIERNO DE CHILE, 1975b, s./r.).

Desde o início, o Ministro Diretor da ODEPLAN se tornou um ator chave do processo de regionalização, pois, foi a partir desse organismo central que se selecionaram e distribuíram as máximas chefias e equipes nas diferentes regiões do país, permitindo estabelecer modificações nos orçamentos e prioridades. Em julho de 1975, o decreto-lei n ${ }^{\circ}$ 756 definiu um regulamento específico do funcionamento das SERPLAC onde, por um lado, se reafirmavam as funções de assoreamento ao Intendente e coordenação do gabinete regional (SEREMIS), por outro, se agregavam algumas especificações às faculdades e tarefas. Entre elas, se afirmava que as SERPLAC deveriam vigiar tecnicamente o trabalho das prefeituras e províncias enquanto planificação e informar permanentemente ao Intendente, Diretor de ODEPLAN e a Direção de Pressuposto (DIPRES), sobre o estrito cumprimento de metas e programas do projeto regional executado (GOBIERNO DE CHILE, 1975b). Inegavelmente a SERPLAC ia se consolidando como a principal unidade de controle territorial das unidades locais e de enlace regional com as unidades centrais de Santiago.

A partir do regulamento de 1975, por sua vez, as SERPLAC eram as encarregadas de instituir as relações técnicas com o setor privado na região. Esse regulamento interno 
constituiu o funcionamento das SERPLAC a partir de um Departamento de Estudos e Planejamento ademais de um Subdepartamento de Programação Orçamentário que, fundamentalmente, deveria "Compatibilizar técnicamente los planes y programas sectoriales de desarrollo regional, de acuerdo al Plan de Desarrollo de la Región" (GOBIERNO DE CHILE, 1975b, s./r.). Assim, as SERPLAC se tornaram o dispositivos coordenadores das operações na região, tendo que enlaçar tecnicamente os assuntos preparatórios para a formulação do projeto regional e sua coerência com o Sistema Nacional de Investimento (SNI). Esse seguimento de registo financeiro pormenorizado e atualizado dos projetos e investimentos, por sua vez, permitiu que as SERPLAC rapidamente incorporassem os comandos do sistema regionalintegrado, dando um sentido de unidade ao conjunto do sistema e uma efetiva integração entre as novas burocracias territoriais (SEREMIS, diretores de serviços) e as unidades geográficas interiores (províncias e prefeituras).

Em 1975 se aprovou a lei orgânica de prefeituras (decreto-lei $\mathrm{N}^{\circ}$ 1289) onde se reafirmou em detalhe que as Secretarias Comunais de Planejamento e Coordenação (SECPLAC) - escala comunal no subsistema técnico de governo interior (quadro $\mathrm{n}^{\circ} 1$ ) deveriam subordinar-se ao direcionamento técnico das SERPLAC que, inclusive, seria seu vínculo com o Plano de Desenvolvimento Regional (GOBIERNO DE CHILE, 1975b). Essa hierarquia burocrática acima da prefeitura, que aparentemente projetava uma parceria apenas técnica, no fundo, ampliava o controle estratégico das SERPLAC na territorialidade das unidades inferiores e outras burocracias da região. Com efeito, as SERPLAC seguiram ampliando capilaridade como mecanismo retor do ordenamento espacial nas regiões através de diversos procedimentos técnicos e obrigatórios para o funcionamento das prefeituras e governações. Um exemplo interessante dessa estrutura hierárquica e de controle foi a elaboração dos Planes Reguladores Comunais (PRC) ${ }^{41}$. Diz o decreto-lei no 1289, "La supervigilancia técnica de la confección del Plan corresponderá a la Secretaría Regional de Planificación y Coordinación" (GOBIERNO DE CHILE, 1976a, s./r.). A partir do controle do Plano Regulador Comunal da SECPLAC, de forma técnica e também orgânica, a SERPLAC se espalharia horizontal e verticalmente nos territórios internos transformando-se nos órgãos chaves do processo de circulação da informação e decisão política, da distribuição dos recursos públicos e dos diferentes projetos e orçamentos públicos. Do ponto de vista estratégico, precisamente, seria a SERPLAC a responsável de distribuir e organizar a gestão

\footnotetext{
${ }^{41}$ Esse dispositivo de poder comunal deveria configurar tecnicamente o uso territorial da infraestrutura comunitária e a regulação de obras enquanto compatibilidades urbanas e ambientais.
} 
integrada das novas SEREMIS e o FNDR, máxima inovação administrativa da região. O poder do SERPLAC, então, não se tratava apenas de um poder de autoridade regional no sentido hierárquico, mas, fundamentalmente, de uma capacidade técnica de controle dos projetos e programas sociais que deveriam executar as diferentes autoridades territoriais na região.

Quadro no 12. Sistema de Governo e Administração Regional

\begin{tabular}{|c|c|c|}
\hline $\begin{array}{c}\text { Subsistema de } \\
\text { Participação }\end{array}$ & Subsistema Hierárquico & Subsistema Técnico \\
\hline $\begin{array}{c}\text { Conselhos de } \\
\text { Desenvolvimento } \\
\text { Regional }\end{array}$ & Intendente Regional & $\begin{array}{c}\text { Secretaria Regional de } \\
\text { Planificação e Coordenação } \\
\text { (SERPLAC) }\end{array}$ \\
\hline Conselhos de & Governador Provincial & $\begin{array}{c}\text { Secretaria Provincial de } \\
\text { Planificação e Coordenação }\end{array}$ \\
\hline Pesenvolvimento & & $\begin{array}{c}\text { Secretaria Comunal de } \\
\text { Planificação e Coordenação } \\
\text { Conselhos de }\end{array}$ \\
(SECPLAC) \\
\hline Comunal
\end{tabular}

Fonte: elaboração própria baseado em CONARA (1976).

Seguindo a estruturação do SIGORE, a implementação oficial das SERPLAC em todo o país vinha a consolidar a escala geográfica regional como a máxima rede pública territorial e o centro das novas articulações administrativas integradas (embora sem a SERPLAC da RM de Santiago). É importante destacar esse ponto pois ele reflete como o regime impulsionou territorialmente a articulação das secretarias públicas, sempre a partir de comandos espaciais maiores a menores, reafirmando nesse transpasso as autoridades e hierarquias do arranjo regional, mas sem alterar a estrutura e hierarquia centralizada do Presidente e os Ministérios (precisamente localizados em Santiago). Este último foi mais notório no subsistema técnico do SIGORE, onde as Secretarias Provinciais de Planificação e Coordenação dependeram técnica e funcionalmente da SERPLAC (escala regional), sendo uma destinação burocrática de menor intensidade e capilaridade enquanto funcionários e profissionais destinados. No caso das Secretarias Comunais de Planificação e Coordenação (SECPLAC) na escala comunal, a situação também foi parecida, entretanto com outras lógicas. Com efeito, apenas em prefeituras mais urbanizadas e historicamente mais tradicionais conseguiram criar-se SECPLAC. Eventualmente, na maioria das prefeituras com 
escassos orçamentos, mas principalmente aqueles territórios mais isolados e rurais alheios, não se conformou nenhuma SECPLAC, sendo precisamente as SERPLAC as unidades encarregadas de fazer a assessoria e conexão das políticas regionais nos espaços locais (CONARA, 1982).

As SERPLAC eram os únicos dispositivos burocráticos que se espalharam de forma equivalente em todo o território, e já desde os primeiros anos do processo de regionalização (1974-1975). Em vista disso, de onde é possível explicar a centralidade do poder territorial das SERPLAC? Em relação ao rápido giro neoliberal do regime, o historiador Manuel Garate destaca que os militares no governo: "no tenían la menor competencia técnica ni menos una idea de cómo lograr esto, pues su mayor interés y capacidad estaba en asegurar el orden público" (GARATE, 2012, p. 184). A necessidade do regime de contar com um grupo de civis altamente formados na questão econômica que não questionassem o autoritarismo, foi a base da rápida ascensão burocrática dos Chicago Boys, e com isso, também a rápida centralidade burocrática das SERPLAC, que dependiam diretamente das pautas da ODEPLAN de Santiago. As SERPLAC expressavam a necessidade de construir rapidamente um emaranhado burocrático para consolidar a figura do militar governante - o Intendente - que também fosse um dispositivo profissional eficiente tecnicamente. As SERPLAC, assim, deveriam ser as principais ferramentas de governo nas regiões, pois, permitiriam a posta em terreno dos diferentes dispositivos do novo sistema territorial guiando o processo oficial da regionalização ao longo do território nacional. Dessa maneira, a escala regional teve uma maior consistência governativa através de serviços públicos regionalizados, subordinados e coordenados uns com outros, como por exemplo, o Servicio Regional de Vivienda y Urbanismo (SERVIU) criado em 1976. Nesse esquema regionalmente burocratizado, as SERPLAC consolidaram sua posição hierárquica na toma de decisões projetando-se como o fundamento do governo despolitizado e mais eficientemente inserido no conjunto regional do país. Pela primeira vez em sua história, unidades subnacionais poderiam fazer uma gestão do público sem a intermediação dos tradicionais partidos políticos, e ainda, sobre a base de procedimentos técnicos que se avaliavam e se coordenavam pela execução dos recursos regionais-locais homogêneos em todo o país.

Porém, a reorganização homogénea-equivalente dos órgãos ministeriais regionais (SEREMIS) a finais da década de 1970, ainda continuava com problemas. Embora o decreto $n^{\circ} 575$ encaminhava sua implementação, paralelamente, se expressaria uma situação de 
deficit de funcionários públicos e uma magra agenda pública. O jornalista do El Mercurio, Juan Ganderats, distinguia um elemento contraditório das autoridades e o sistema público regional: "¿porqué se cambian con tanta frecuencia las autoridades regionales que han logrado trabajar eficientemente, mereciendo el apoyo de la comunidad?’' (EL MERCURIO, 2 abril 1978). A pergunta ia dirigida ao Secretario Executivo da CONARA, o comandante Alejandro Gonzalez Samohod, quem ao ser questionado pela alta rotação das autoridades regionais, contestava o seguinte:

Los reemplazos se han producido, ciertamente. Pero se ha evaluado la necesidad de continuidad y actualmente los cambios son poco frecuentes. Además, los organos típicos de continuidad, que son Secretarias Regionales de Planificación, si están bien dotados no van a resentir su labor debido al cambio de las autoridades regionales. Al fin de cuentas el proceso de regionalización es para siempre. Podrán cambiar los gobiernos, pero las estructuras, el esquema básico, tendrá que permanecer vigente (EL MERCURIO, 2 abril 1978).

O destaque da primeira hierarquia institucional das SERPLAC é evidente, no entanto, o que continua é ainda mais interessante. Para umas das máximas chefias da CONARA poderiam existir múltiplas mudanças das autoridades no sistema regional, inclusive na rotação das autoridades, porém, no fundamental, a estrutura de poder e o esquema de funcionamento da regionalização era irreversível, era para sempre (EL MERCURIO, 2 abril 1978). O coronel Gonzalez Samohod dava conta do sentido hegemônico que estava no arranjo regional instituído e a forma-conteúdo da regionalização enquanto particular ferramenta do governo regional. Embora as autoridades territoriais hierárquicas Intendentes, governadores ou prefeitos - poderiam ser trocadas, as práticas estatais, os limites de suas funções burocráticas, o sistema de controle dos projetos financiados pelo Estado, em outras palavras, as formas políticas do arranjo regional distribuído pelos territórios internos do país, já eram para sempre e não estariam em questionamento. As SERPLAC expressaram a hegemonia dos dispositivos de governo desenhado pela CONARA, que para finais da década de 1970, já estavam consolidando a fórmula de governo do Estado. Na reportagem da Revista Qué Pasa de novembro de 1978, se destacava o lugar das SERPLAC na metáfora do Estado mínimo, desenvolvendo uma "labor ardua, silenciosa y lenta, conducente a descubrir las verdaderas potencialidades de cada región para que su desarrollo futuro tenga una base sólida" (REVISTA QUÉ PASA, 9-15 novembro 1978).

\section{Imagem $n^{\circ}$ 15. SERPLAC}




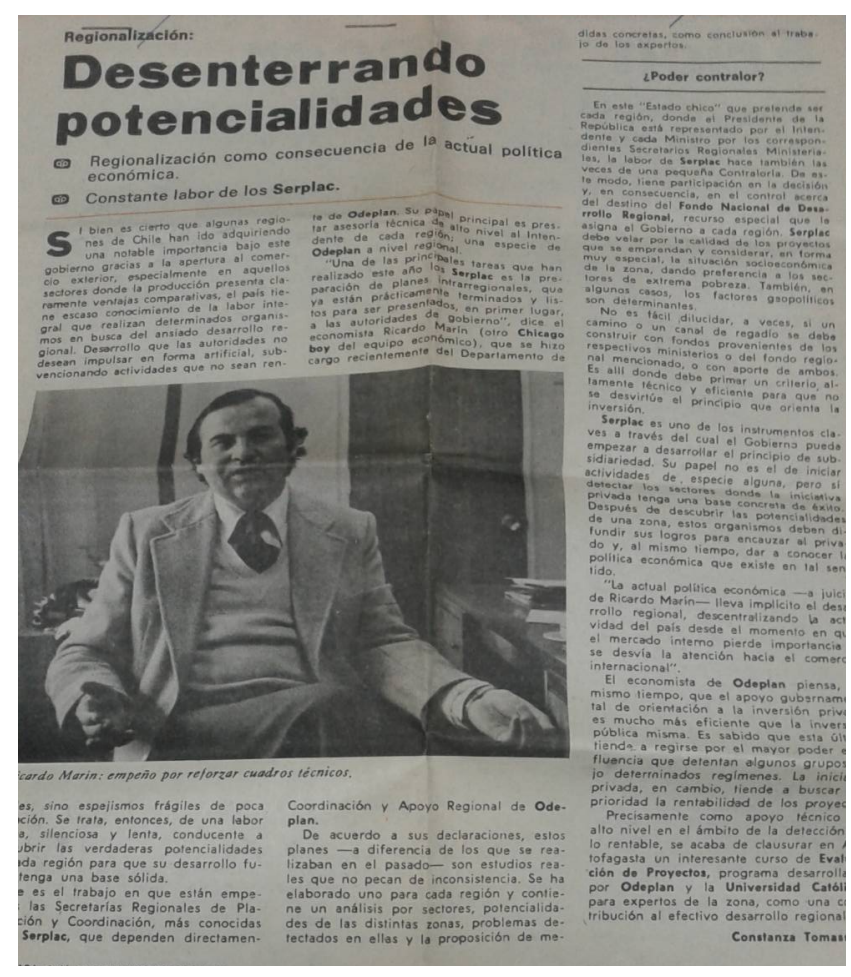

Fonte: Qué Pasa, Santiago, 9-15 de novembro 1978.

Chama a atenção a reportagem porque também se reconhecia que, à diferença de outras experiências burocráticas, as projeções das SERPLAC eram estudos reais que já não tinham inconsistências como no passado. O primeiro chefe do recém-criado Departamento de Coordenação e Apoio Regional de ODEPLAN, encarregado de dar suporte as SERPLAC, era o economista Ricardo Marín, "otro Chicago boy del equipo económico" (REVISTA QUÉ PASA, 9-15 novembro 1978). Seguindo os termos do arranjo regional, se anunciava que os planos inter-regionais definidos pela ODEPLAN de Santiago seriam prontamente apresentados pelas autoridades de governo regional. Dessa forma, cada região contaria com analises setoriais, onde se avaliariam potencialidades e problemas que terminariam com medidas concretas e operativas. Entre a assessoria dos Intendentes e a coordenação das SEREMIS, as SERPLAC cumpririam analogamente a função de "una pequeña Contraloría" (REVISTA QUÉ PASA, 9-15 novembro 1978), pois existiam mediante seus dispositivos técnicos de avaliação de projetos, onde se definiam quais projetos e recursos impulsionariam na região, sobretudo, nos setores mais pobres. As SERPLAC eram dispositivos encarregados de estabelecer as interações públicas que iriam ser conduzidas pelo setor privado no território. Diz a reportagem:

SERPLAC es uno de los instrumentos claves a través del cual el Gobierno puede empezar a desarrollar el principio de subsidiaridad. Su papel no es el de iniciar actividades de especie 
alguna, pero sí detectar los sectores donde la iniciativa privada tenga una base concreta de éxito. Después de descubrir las potencialidades de una zona, estos organismos deben difundir sus logros para encauzar al privado y, al mismo tiempo, dar a conocer la política económica que existe en tal sentido [...] La actual política económica - a juicio de Ricardo Marín- lleva implícito el desarrollo regional, descentralizando la actividad del país desde el momento en que el mercado interno pierde importancia y se desvía la atención hacia el comercio internacional (QUÉ PASA, 9-15 novembro 1978).

A nota marca a função chave das SERPLAC enquanto mecanismo operativo do Estado subsidiário e ferramenta de circulação de empreendimentos empresariais que seriam apoiados pelo Estado regional. Mas, simultaneamente, também tinham que coordenar e manobrar os recursos públicos destinados a terminar com a extrema pobreza. Este fim último será mais evidente a partir da década de oitenta, quando as SERPLAC se consolidariam no sistema regional cumprindo três tarefas fundamentais; 1) formular o plano de desenvolvimento regional, 2) constituir e atualizar um Banco Integrado de Projetos (BIP) regionais e 3) administrar o orçamento do FNDR e os investimentos públicos da região junto com os SEREMIS. Contudo, essas SEREMIS ainda eram escassamente equivalentes e homogêneas pelas regiões do país. Segundo CONARA, apenas três das dezesseis SEREMIS tinham uma presença regional que cumpria com as funções declaradas pela lei aproximada a uma ordem de 80\%. Essas SEREMIS exemplos seriam as carteiras regionais da saúde $(81,3 \%)$, moradia $(83,3 \%)$ e educação $(90,7 \%)$ (CONARA, 1982). Com efeito, tratava-se de SEREMIS eminentemente ligadas a um entramado político-social do governo autoritário e sua conexão com as comunidades mais pobres do país. Do ponto de vista territorial, entretanto, a CONARA destacava que apenas oito das dezesseis SEREMIS se espalhavam de maneira orgânica em cada uma das regiões do país. Essas oficinas regionais correspondiam as SEREMIS de Saúde, Educação, Moradia, Obras Públicas, Bens Nacionais, Transportes e Telecomunicações, Agricultura e Justiça (CONARA, 1982, p. 37).

Embora o arranjo regional havia avançado com a distribuição das SERPLAC e SEREMIS, ainda existiam incongruências no entramado técnico-político nas regiões que se traduzem em uma ausência de cumprimento do desenho da regionalização de CONARA. Por outro lado, se bem o sistema integrado de SEREMIS e SERPLAC melhorava as comunicações e fazia um funcionamento mais orgânico na gestão da burocracia regional, paralelamente, o duplo mecanismo de controle de mando centralizado reproduzia centralidades e não conseguia contrapor iniciativas adequadas aos requerimentos e necessidades das populações regionais e locais (ZAVALA, 1990, p. 87). Como destaca Szary (1997), existia uma série de incoerências nas funções das SEREMIS produzidas 
fundamentalmente pela dupla chefatura Ministro-Intendente. Segundo o funcionário SERPLAC da época, Diego Benavente, a questão do poder central nos SEREMIS era mais útil para cenários nacionais de confrontos e direcionamentos políticos de tipo autoritário, porém, tinha consequências na gestão do território regional devido à geopolítica da hierarquia das chefaturas dos SEREMIS (ENTREVISTA DIEGO BENAVENTE, fevereiro 2021). Dessa forma, seguindo o arranjo centralista do Estado territorial nacional, na prática, os SEREMIS dependiam mais do Ministro que o Intendente Regional, portanto, não se lograria executar uma efetiva descentralização das funções administrativas e priorizar os interesses técnicos da região. Essa situação seria ainda mais ilustrativa nos casos dos Ministérios tradicionais com mais orçamento, como por exemplo, os casos de um "SEREMI de Vivienda o de Obras Públicas siempre mandaba más el Ministro que el Intendente" (ENTREVISTA DIEGO BENAVENTE, fevereiro 2021). Segundo a geógrafa francesa, embora o discurso oficial entendia a lógica da descentralização das regiões, o sentido mais profundo da regionalização do período foi imbricar de maneira direta as regiões com a circulação econômica internacional, deslocando o problema da regulação do Estado e o caráter produtivo da propriedade privada ao recorte regional:

El objetivo manifiesto era poner las regiones (en lo sucesivo, en contacto directo con el extranjero) en competencia sobre los mercados internacionales, con cada entidad libre de capitalizar sus "ventajas comparativas". La carta de la CONARA (ver en anexo) ilustra bien esta voluntad de apertura, hasta en su grafismo. Para cada región, los recursos exportables son destacados (SZARY, 1997, p. 67).

É interessante essa interpretação de Szary pois implicaria uma mudança da escala e perda do poder nacional enquanto mecanismo de regulação da economia. O efeito político dessa decisão favorecia diretamente os capitais externos, pois as novas autoridades subnacionais, neste caso os Intendentes Regionais e SERPLAC, tenderiam a ter menos poder de negociação frente ao poder das corporações privadas internacionais, do que teria o antigo Estado central antes do Golpe de 1973. Assim, o regime privilegiaria ter menos sócios e interlocutores, favorecendo a privatização do investimento regional e seus processos de especialização produtiva. Se trataria então de uma política regional diametralmente oposta à da década anterior, a qual dava maior ênfase na criação de pólos de desenvolvimento regionais e inter-regionais, numa lógica de compensação dos desequilíbrios espaciais (SZARY, 1997, p. 97). Para que essa abertura comercial fosse possível, criaram-se as condições político-administrativas necessárias por meio de uma burocracia regional e nacional estratégica (ODEPLAN), que foi ensamblando equipes, metodologias e uma maior 
coordenação das autoridades territoriais que, precisamente, para princípios da década de 1980, expressariam a consolidação hegemônica da escala regional via SERPLAC. Quais eram as principais mudanças do arranjo das SERPLAC? Que tipo de perfil político-técnico tinham os SERPLAC? Como foi se consolidando a gestão territorial integrada das SERPLAC?

\subsection{Secretários Regionais de Planejamento e Coordenação: o poder burocrático do capital?}

A estrutura operativa mais relevante no interior da SERPLAC era o Departamento de Estudo que se compunha por aproximadamente vinte profissionais, e que poderiam variar segundo o tamanho da região. No interior do Departamento de Estudo, a cada profissional da SERPLAC lhe corresponderia atender a um determinado setor do governo (moradia, educação, saúde, governo interior, etc.) e facilitava a comunicação com as respetivas equipes das SEREMIS e prefeituras na região. Nesse esquema, uma das funções mais relevantes das SERPLAC era impulsionar o Conselho Regional que seria integrado pelos correspondentes representantes (todos nomeados) do setor privado, operários, funcionários do sector público, governadores e acadêmicos que decidiriam a proposta priorizada dos projetos apresentados ao FNDR (ENTREVISTA PEDRO RAMIREZ, fevereiro 2021). Dessa especialidade técnica associada à administração do FNDR, se fundava o poder da SERPLAC que, em primeiro lugar, se respaldava através de suas equipes de profissionais. Como destaca o SERPLAC da Região do Bío-Bío Pedro Ramirez: "teníamos ingenieros civiles, forestales, geógrafos, ingenieros agrónomos, un equipo bien variado de distintas profesiones, lo cual enriquecía mucho" (ENTREVISTA PEDRO RAMIREZ, fevereiro 2021). O interior das SERPLAC se compunha de vinte pessoas, distribuídas por pessoal administrativo e profissional. Esse poder profissional burocrático permitia ter um maior controle financeiro da gestão territorial, pois, cada profissional se incorporava a unidades especializadas na contabilidade e à estrutura administrativa do FNDR. Uma tarefa relevante das SERPLAC era impulsar o Conselho de Desenvolvimento Regional (COREDE) presidido pelo Intendente Regional Militar, sendo um poder burocrático que também respondia à proximidade e às alianças das estruturas sociais e econômicas afins do território regional. Em representação da SERPLAC estava o Secretario do Conselho dessa estrutura que, aliás, deveria aprovar o Plano de Desenvolvimento Regional em conjunto com os serviços públicos regionalizados. $O$ Intendente Regional e a SERPLAC, assim, levavam à diante tudo o que era relacionado às decisões políticas e a coordenação das unidades territoriais internas da região. Como 
destacava o engenheiro industrial da Universidade de Concepción (UDEC), Diego

Benavente:

El SERPLAC hablaba con el Intendente y definía en la semana. Por ejemplo, se van a visitar tales comunas, hay que preparar carpetas para esta región, hay que ver los problemas que tiene. Lo típico que se le prepara a un presidente cuando va a terreno. Información basada eminentemente en proyectos, la priorización de los proyectos, qué se ha aprobado, qué falta, los llamados de atención al mismo municipio. Decirle, por ejemplo, cómo quieres que te dispongamos proyectos si no han hecho esto, no me has llenado la carpeta, no tienes el certificado de esto, no tienes saneado el terreno. Ningún proyecto podía postularse si no tenía elementos mínimos. Eso marcó una diferencia en Latinoamérica de lo que hizo Chile. Y eso en parte se basó en lo que hizo la CONARA. Hay que reconocerle a Julio Canessa que fue insistente y convenció a Pinochet. Pero no logró todo. La diferencia fue de usar bien las pocas platas que tenía porque Chile era el país más pobre. Entonces, se empezó a usar bien sus recursos [...]. Pero sí, no se hacían proyectos sin una recomendación. Por ejemplo, a mi me impresionaba, uno visitaba Lonquimay y Curacautín y daba la vuelta y miraba una construcción de paso sobre nivel ejecutado y construido sobre la línea férrea que no llevaba a ninguna parte. Entonces, tu decías dos cuestiones: que se hacían por política. Hoy en día nunca más realiza un proyecto sin recomendaciones [...] No se hace ningún proyecto que no tiene los recursos para terminar (ENTREVISTA DIEGO BENAVENTE, fevereiro 2021)

Dessa forma, se definiam as tarefas com o Intendente e o tipo de assessoraria. Benavente demarca bem o que foi o trabalho técnico-político das SERPLAC em função da gestão territorial integrada e o sistema de avaliação e coordenação dos projetos que deveria ser incorporado pelas unidades territoriais inferiores. O poder das SERPLAC se expandia mediante um conhecimento técnico da região e suas equipes profissionais que dariam informações cada vez mais precisas para o conhecimento do Intendente e a baixada dos orçamentos no resto das autoridades e suas escalas geográficas. Essa estrutura territorial de assessoria política também é destacada pela máxima autoridade local da prefeitura de Sierra Gorda da época (III Região), o geógrafo Carlos Cantero, quem reflexiona sobre o tipo de assessoria que exercia a SERPLAC da época, funcional a lógica militar dos Intendentes:

En realidad, eran generales. Eran personas que ya habían llegado al punto más alto de su carrera y tenían una buena calificación en general porque además tenían una buena asesoría, particularmente en SERPLAC. En realidad, era porque SERPLAC en esa época era una instancia de Estado Mayor, ósea, asesoraba directamente a esa autoridad (ENTREVISTA CARLOS CANTERO, novembro 2019).

A citação é interessante porque desvenda o desdobramento particular que tinham essas SERPLAC: assessorar com uma lógica de Estado Maior as decisões territoriais dos Intendentes. Dessa maneira, as SERPLAC deveriam ampliar as capacidades técnicas e administrativas que reforçavam a autoridade de mando na escala regional através do reconhecimento mais aprofundado das diferentes carteiras, serviços públicos regionais e 
unidades territoriais interiores que, internamente, sempre necessitavam cautelar a autoridade e a decisão do Intendente, embora fossem agendas especificamente técnicas ou locais específicas. Como explica a funcionaria da SERPLAC de Santiago a finais da década de 1980, Julia Standen:

A veces se presentaban ciertas situaciones y al SERPLAC había que prepararle la minuta correspondiente. Así se usaba: uno hacía el oficio que quería despachar y hacías una minuta explicando el porqué del oficio, porque los oficios no los firmaba exclusivamente el SERPLAC. Ósea, algunos los firmaba el SERPLAC de la época y otros los firmaba el Intendente. Entonces, el SERPLAC iba con todos esos oficios para la firma del Intendente y tenía que saber explicarle al Intendente de qué se trataban (ENTREVISTA JULIA STANDEN, fevereiro 2021)

As SERPLAC deveriam traduzir as decisões burocráticas em atos e decisões políticas que, se bem tinham sua prioridade na agência social dos possíveis instrumentos de governo, por outro lado, também precisavam articular qualquer tipo de impedimento burocrático ou descoordenação entre as diferentes estruturas da região e as escalas geográficas interiores das mesmas. Se destaca na citação de Julia Standen, ademais, a explicação de como a distribuição de tarefas administrativas burocráticas tinham que terminar na aprovação do SERPLAC e do Intendente, combinando os controles técnicos e políticos. A distribuição dos profissionais em cada uma das SERPLAC deveria fortalecer as necessidades administrativas e geográficas do comando da região, mas sobretudo, cuidar do funcionamento do sistema regional integrado (SEREMIS - serviços públicos regionais - governadores - prefeitos). Embora os decretos leis da regionalização não chegariam a dar conta das habilidades profissionais, também se cruzavam seletivas qualidades e trajetórias dos funcionários que fariam parte das SERPLAC. Nesse sentido é interessante destacar a trajetória do engenheiro comercial da UDEC, Alejandro Fernández, quem com apenas 22 anos conformou a equipe da SERPLAC do Bío-Bío em 1981. Diz Fernández:

Uno tenía a cargo sectores. Por ejemplo, unos tenían obras públicas, otros tenían agricultura y así. En mi caso me correspondió ver lo que era gobierno interior: quienes asesoraban a los municipios, de cómo estaban haciendo los proyectos, darle orientación respecto al presupuesto municipal en el sentido que no se gastara los recursos en las plazas o áreas verdes sino provocando mejoras. Estamos hablando de un tiempo atrás cuando no había alcantarillado ni agua potable, muchas deficiencias. Este era un país pobrísimo (ENTREVISTA ALEJANDRO FERNÁNDEZ, fevereiro 2021).

A citação é significativa por vários sentidos. Primeiro, porque se desvenda o caráter técnico-político das SERPLAC enquanto suas lógicas de controle dos projetos sociais e subunidades territoriais. Segundo, porque visualiza como as SERPLAC se espalhavam de maneira vertical e horizontalmente no território regional através da coordenação das 
diferentes carteiras ministeriais, mas sobretudo, pelo controle e coordenação das prefeituras que tinham que informar as SERPLAC das ações e projetos. Enquanto as funções da secreataria, Fernández destaca como se conformava a equipe ao interior da SERPLAC, sendo seus profissionais selecionados pelas competências e qualidades carismáticas, pois tinham que se comunicar diretamente com os prefeitos e governadores. Sobre o setor governo interior, destaca Fernández:

Yo creo que se elegía por un tema de aptitudes, más que lo técnico por temas personales. Yo en esos años era muy joven, recién saliendo de la universidad. Pero los más grandes captaban las cosas, más menos que uno tenía que ser empático, tener cierto carisma. A nosotros nos tocaba directamente hablar con los alcaldes y los gobernadores (ENTREVISTA ALEJANDRO FERNÁNDEZ, fevereiro 2021).

É interessante destacar o perfil técnico-político dos profissionais que que formavam as SERPLAC, e especialmente suas comunicações internas na hierarquia regional enquanto capilaridade no interior do território regional. Um perfil que combinava a incorporação de jovens profissionais com boas atitudes na questão técnica da agência social, qualidades pessoais que permitissem a comunicação direta com os governadores e prefeitos, os quais, deveriam aceitar e comunicar suas ações ou orientações, sobretudo, no terreno técnico da elaboração e avaliação dos projetos. Esse último dispositivo é chave porque da conta da tecnologia política da SERPLAC para exercer sua hierarquia na escala regional e o novo roteiro burocrático das relações públicas territoriais. Diz Fernández em sua qualidade de funcionário profissional da SERPLAC:

Entonces, nuestra misión era mitad política, política, pero en el buen sentido, de lo que te acabo de contar, de que se hicieran inversiones sociales focalizadas y que tuvieran impacto en las personas. Por lo tanto, todos nosotros teníamos nuestros cursos de evaluación de proyectos. Entrado allí tu te recordarás que teníamos que hacer los cursos de evaluación de proyectos de Ernesto Fontaine, un tipo muy famoso, de los primeros chicagos. Y él trabajaba en el mantenimiento de esta escuela que era la evaluación de proyectos sociales para el sector público, un convenio con la Católica en esos años. Entonces, nosotros estábamos obligados a pasar por ahí, en el CIAPEP. En mi caso yo hice el corto porque el largo era mucho rato [...] Entonces, los que estábamos en primera línea de andar metido en todas las comunas, la verdad es que un año o más era mucho. Pero dos o tres meses sí era suficiente. Además, uno venía saliendo recién de la universidad y tenía cosas muy frescas, entonces, el curso de dos meses para uno que era comercial era suficiente. Lo hicimos en Villarica. Fue muy bonito porque nos llevaron de varias partes de Chile y nos concentraron ahí dos meses y medio. Eran funcionários de SEREMIAS, municípios y SERPLAC (ENTREVISTA ALEJANDRO FERNÁNDEZ, fevereiro 2021).

A citação é ilustrativa da gestão técnica do sistema regional e a centralidade do sistema de avaliação de projetos na integração das equipes territoriais. Precisamente, através dessa 
formação na avaliação dos projetos, as SERPLAC poderiam vigiar cada um dos projetos de investimento da região e dar orientações que deveriam ser acolhidas nas prefeituras e governações como uma política de governo nacional. Fernández explica que nessa época todas as autoridades e funcionários da SERPLAC precisariam ter recebido, ao menos, um curso no CIAPEP, que pela sigla, significa Curso Interamericano en Preparación y Evaluación de Proyectos de Inversión (CIAPEP). Com efeito, o CIAPEP foi um indispensável dispositivo de governo que estruturou paulatinamente as formas geográficas e burocráticas internas do sistema de administração do orçamento público ${ }^{42}$ e foi a vanguarda dos princípios neoliberais na circulação política do Estado chileno. Sua origem radica entre 1976-1978, quando o Banco Interamericano de Desenvolvimento (BID) em aliança com a ODEPLAN criou um programa de capacitação profissional para projetos de investimentos que procuravam priorizar e utilizar de maneira mais eficiente os recursos públicos, sendo dirigido pelo economista chileno e doutor em economia pela Universidade de Chicago, Ernesto Fontaine, na PUC de Santiago. Posteriormente, a partir de 1978, o curso perdeu o apoio do BID, mas foi financiado integralmente pelo regime chileno através da liderança do subministro da ODEPLAN Miguel Kast, também outro destacado membro dos Chicago boys (FONTAINE, 2003). Dessa maneira, o CIAPEP foi transformando-se em um importante dispositivo de formação e recrutamento de profissionais que formariam parte das burocracias públicas do todo o país. Como destaca Fernández, os cursos do CIAPEP recebiam uma inovadora formação na formulação e avaliação de projetos sociais de investimentos, que poderia variar de modalidades em cursos longos ou curtos, mas sobretudo, onde as equipes territoriais iriam se consolidando e articulando uma linguagem própria que marcava a pauta das mudanças estruturais do sistema econômico e político chileno. Como destaca o funcionário SERPLAC da Região da Araucanía, Diego Benavente:

Se fueron preparando los cuadros profesionales del mundo público. La SERPLAC decía, bueno, en el área de obras públicas nos falta alguien que entienda esta cuestión de los proyectos en la región porque en el fondo había que conversar en un cierto lenguaje. Es decir, las metodologías eran buenas. Era un lenguaje como para poder evaluar los proyectos y no estar con subjetividades. Eso fue muy útil para hacer una buena asignación de recursos que eran escasos (ENTREVISTA DIEGO BENAVENTE, fevereiro 2021)

\footnotetext{
42 É interessante destacar que já em 1966, o governo de Frei Montalva havia montado um estudo de 26 projetos nas principais cidades e províncias do país com o objetivo de estabelecer critérios únicos para a localização de investimentos (BELDRACK, 1974). Com o governo de Salvador Allende, esse sistema haveria sido ampliado com a ODEPLAN mediante a criação do Sistema Nacional de Planejamento (SOMS, 2010).
} 
Através das metodologias do CIAPEP os profissionais iriam homogeneizando seus procedimentos burocráticos, o qual permitiria definir um tipo mais técnico de avaliação dos projetos de investimento na região e a coordenação das autoridades. No fundo, o CIAPEP era uma linguagem da questão pública que, se bem procurava romper os desequilíbrios das regiões e a desordem dos recursos públicos, internamente recebia as orientações estruturais comandadas pelos Chicago boys de Santiago. O curso principal do CIAPEP incluía uma primeira fase teórica de quatro meses e meio e uma segunda fase mais prática de cinco meses e meio, onde os profissionais tinham que modelar a execução real de um projeto de investimento. Em um artigo de balanço histórico do programa (1976-2000), o próprio Fontaine explica as diversas fases e ganhos que foram consolidando profissionalmente esse dispositivo de governo, com formatos e avaliações cada vez mais tecnicamente ancorados aos princípios da Escola de Chicago por seu colega e professor Arnold C. Harberger, outro reconhecido exponente de Chicago e membro ativo do staff acadêmico do CIAPEP (FONTAINE, 2003). A cada ano o CIAPEP, entretanto, somava quatro cursos regionais intensivos de um mês e meio, que incluíam aos profissionais das regiões continuas onde se estabelecia, como seria o caso do Fernández e seu curso de Villa Rica, XI Região do sul.

No entanto, o curso principal se fazia nas dependências da PUC em Santiago e contemplava dedicação exclusiva dos participantes por nove meses contínuos, o qual dificultava a participação de funcionários e profissionais de regiões ou prefeituras menores, reproduzindo com isso a lógica centralista no comando centralizado das autoridades territoriais do sistema regional integrado. Sobre a seleção dos participantes no modelo teórico, se estabelecia um máximo de 45 profissionais correspondentes do setor público, universidades e FF.AA. e Carabineros com um máximo de 32 profissionais na fase prática (FONTAINE, 2003). Os cursos contemplavam uma série de exercícios permanentes de alta avaliação e exigência técnica que se traduziam em que não todos os participantes conseguiam aprovar. Dessa maneira, aqueles que conseguiam finalizar o processo, tinham uma maior legitimidade profissional para exercer os cargos de SERPLAC, SEREMIS ou prefeituras. Essa exigência profissional se aprofundava sobretudo na fase prática onde cada ano se avaliavam quatro projetos de investimento do regime. Articulados em grupos de trabalho que mesclavam participantes e acadêmicos do CIAPEP, os quatro projetos terminavam tendo uma avaliação técnica consolidada que fundamentaria os altos custos do programa. Segundo Fontaine, o custo anual do CIAPEP era de aproximadamente 220 mil dólares, um valor muito inferior ao custo que eventualmente fariam as agências consultoras pela avaliação 
desses quatro projetos estratégicos que, a cada ano, equivaleriam a 440 mil dólares (cada projeto com um custo de 110 mil dólares) (FONTAINE, 2003). Uma das regras fundamentais do CIAPEP era a criação de estândares de benefícios e rentabilidade social dos projetos, onde o valor dos benefícios não poderia ser maior que os custos obtidos pelos benefícios considerados estrategicamente no programa da ODEPLAN. Diz Fontaine:

[...] siguiendo la tradición impuesta por Miguel Kast R. -subdirector de ODEPLAN y gran impulsor de este programa- se incluyó al menos un proyecto "social" cada año, relacionado con el ataque a la pobreza, en lo posible. En el primer curso de BID-ODEPLAN se hizo una evaluación de lo que denominó "Centros de Atención Integral a Menores (de 2 a 6 años) en Extrema Pobreza Urbana” (CAI). La valoración de este proyecto supuso la primera aportación significativa de nuestro programa a la profesión: Necesidades Básicas (Tradução própria, FONTAINE, 2003, p. 600).

Dessa forma, cada ano o CIAPEP tinha que produzir um projeto social de investimento considerável do ponto de vista do investimento público. É interessante o destaque do economista Miguel Kast na ação social da ODEPLAN, pois, também será uma referência permanente nos diferentes relatos dos funcionários SERPLAC da época. Miguel Kast Rist (1948-1983) foi um destacado economista e autoridade do regime autoritário. $\mathrm{Na}$ época da UP foi estudante de economia da PUC, sendo uns dos principais líderes do movimento gremialista opositor da UP (HUNEEUS, 2016). Posteriormente, no período autoritário, se converteu em uns dos mais relevantes e influentes economistas do regime, pois, uma vez concluído seu mestrado em economia na Universidade de Chicago em 1973, foi convidado a fazer parte da ODEPLAN, obtendo rapidamente o cargo de sub-diretor (1974-1978). Com uma dupla militância, gremialista e Chicago boys, Kast liderou o conjunto de programas sociais e convênios de estudos estratégicos que deveriam impulsionar o regime nas diretrizes do neoliberalismo. Em reconhecimento a esse trabalho, entre 1978-1980, passou a ser o Ministro-Diretor da ODEPLAN, sendo a primeira autoridade civil a ocupar esse cargo após do Almirante da Marinha Roberto Kelly. Diferentes estudos refletem e confirmam as profundas capacidades de recrutamento que Miguel Kast exerceu nas gerações mais jovens ligadas ao desenvolvimento do gremialismo, abrindo um estilo particular da política neoliberal chilena: a focalização nos pobres (LAVIN, 1986; MUÑOZ, 2016; HUNEEUS, 2016; VALDIVIA, 2012). Segundo o relato do economista Juan Cavada, funcionário da ODEPLAN antes do Golpe de Estado, em 1975 Miguel Kast fez um convénio-curso com ILPES-CEPAL com o propósito de formar aos funcionários das SEREMIS e SERPLAC de todo o país. Sobre Kast e esse convênio, lembra Cavada: 
El hizo un convenio con el ILPES para formar a los SEREMIS y a los SERPLAC, seminarios diferentes. Y el coordinador de esos cursos más administrativos era un funcionario de ODEPLAN. Y me dice: tenemos un problema, Miguel Kast se metió con tu programa. Eliminó una parte de la bibliografía y el ILPES no dijo nada. Eliminaba la parte de los polos de desarrollo. Lo prohibió porque no quiere que los SEREMIS piensen en los polos de desarrollo [...] Los equipos más competentes en regiones eran los equipos de la SERPLAC, por la variedad de profesionales, por la planificación, eran los cargos claves, manejan el equipo técnico, eran los más capacitados. Pero él pensaba que estos debían convertirse en la nueva biblia. Darle una formación de polos de desarrollo entonces era peligroso. Los polos de desarrollo implican que el gobierno haga algún tipo de acción determinada (ENTREVISTA JUAN CAVADA, outubro 2019).

O curso que relata o economista Juan Cavada foi o último convênio de cooperação profissional entre a ODEPLAN e o ILPES-CEPAL. Posteriormente, toda a formação profissional das SERPLAC e SEREMIS foi realizada através do CIAPEP liderado pelo economista Juan Fontaine e suas metodologias econométricas de rentabilidade social. As SERPLAC lideradas por Miguel Kast rompiam com a tradição regional de desenvolvimento e fortalecia a privatização da economia que iria acompanhada pela busca da focalização de subsídios e apoio aos pobres, sem encaminhamentos produtivos e industriais que caraterizavam as antigas funções das ORPLAN. Por outro lado, é importante analisar as trajetórias dos SERPLAC e como essas formas de gestão interna do CIAPEP - e a figura do Miguel Kast - vão sendo incorporadas nas autoridades territoriais. No caso do Pedro Ramirez, sua incorporação à SERPLAC de Bío-Bío foi uma mistura de redes familiares e finalização de seu plano de estudo em engenheira industrial na UDEC em 1980. Nesse tempo, o SERPLAC era a figura de José Pedro Undurragada (também próximo do Miguel Kast), quem tinha redes com familiares indiretos com Ramírez:

Yo cuando entré a ODEPLAN en diciembre de los años ochenta. Pero antes me habían entrevistado. Y en eso son las cosas que ocurren a veces. Me encontré con una persona en el matrimonio de un primo. Y la novia era pariente de este profesional que es Enrique Montero Contardo - antigo funcionário do Ministério de Agricultura da época -. Y el ese día del matrimonio me pregunta oye tú que haces. Yo le digo me acabo de recibir de ingeniero civil. Entonces me dice, anda a hablar con José Pedro Undurraga que es el SERPLAC porque se están buscando profesionales. Partí hablar con él, me entrevisté con él y con el director del Departamento de Estudios Rodrigo Moncada. Y ahí me enviaron a Santiago y en Santiago me entrevisté con José Yuraszeck que venía de regreso de Coyhaique y con Julio Dittborn que era subdirector regional y luego con Miguel Kast. Y te estoy hablando que eso debió haber sido el mes de noviembre del ochenta y entré el 01 o 02 de diciembre a trabajar en la SERPLAC, del departamento de estudios. Y Miguel estuvo algunos meses y lo enviaron como Ministro del Trabajo a arreglar el tema de los puertos (ENTREVISTA PEDRO RAMIREZ, fevereiro 2021).

A citação destaca o perfil dos SERPLAC e também os mecanismos de seleção e recrutamento para configurar essas equipes. No caso de Ramírez, rapidamente foi aprovado 
após prestar entrevista com o SERPLAC José Pedro Undurragada em Concepción, e logo, com o diretor regional José Yuraszeck, o subdiretor regional Julio Dittborn e o ministro diretor Miguel Kast em Santiago. No momento de ser nomeado SERPLAC, Ramírez tinha 31 anos e havia passado três anos pela Escola Naval da Armada, somada à sua formação de engenheiro industrial da UDEC (ENTREVISTA PEDRO RAMIREZ, fevereiro 2021). É interessante o caso do Ramírez porque da conta da preocupação significativa do processo de seleção de um SERPLAC, avaliado por três autoridades das altas patentes da ODEPLAN, entre elas o Ministro Kast. O SERPLAC deveria responder a um determinado perfil de profissional jovem ligado às áreas econômicas da burocracia regional. Segundo o relato do funcionário CONARA da época, Mario Rocha, as SERPLAC eram as peças com maior presença regional pois eram as máquinas encarregadas de tornar efetivo o planejamento regional-nacional:

\begin{abstract}
En esa época sí se hacia planificación, entonces, a nivel nacional estaba ODEPLAN y después a nivel regional se crearon las SERPLAC. Ellas coordinaban la actuación de todas las otras carteras ministeriales en la región [...] No nos olvidemos que ministerios se desconcentran a través de la figura de los secretarios regionales ministeriales. Entonces, este jefe de la SERPLAC, en cada región, coordinaba a los 16 SEREMIS. Tenían atingencia con las inversiones a nivel regional porque ellos, insisto, coordinaban, no sólo eran la parte administrativa del nivel regional, sino que también veían los aspectos sustanciales, que tienen que ver con la inversión y la coordinación de los SEREMIS [...] Era muy llamativo trabajar ahí, era una escuela, se aprendía mucho [...] Era muy difícil entrar ahí y se pagaba muy bien. Había una planta de la SERPLAC, un jefe, un departamento de estudios y había otra área de la inversión [...] Los jefes de la SERPLAC después con los años se transformaban en grandes figuras de la región: ocupaban puestos como alcaldes, digamos también como SEREMI, gobernadores. Era un organismo que tenía mucho peso (ENTREVISTA MARIO ROCHA, outubro 2019).
\end{abstract}

Os SERPLAC tinham uma projeção significativa da ação política da região e muitos deles passariam ser parte das representações políticas do regime. Mario Rocha se incorporou ao trabalho da CONARA em 1981 e também era engenheiro comercial da UDEC. Profissional oriundo da localidade de Jumbel no interior da cidade de Concepción, ele tentou entrar na SERPLAC de Bío-Bío, mas não foi selecionado por Miguel Kast (ENTREVISTA MARIO ROCHA, outubro de 2019). Com efeito, não era qualquer profissional que fazia parte das altas chefias ou burocracias regionais que, em primeiro lugar, tinham que ter o visto da ODEPLAN de Santiago. No livro de homenagem Miguel Kast. Pasión de vivir (1986), Joaquín Lavín - outro importante Chicago boys - explica como Miguel Kast difundia suas ideias nos quadros da juventude do regime (militantes do movimento gremialista), particularmente entre seus alunos graduados que eram enviados para trabalhar nas regiões (LAVIN, 1986). Paralelamente à sua condição de subdiretor de ODEPLAN, Miguel Kast 
exercia como professor na Escola de Economia da PUC, onde recrutava jovens estudantes para unir-se às tarefas da ODEPLAN e as SERPLAC. Dessa maneira, a formação de jovens profissionais se tornou uma tarefa permanente e reconhecida ao interior da ODEPLAN, sendo chamadas coloquialmente como "os almoços da ODEPLAN" (LAVIN, 1986). Nessas reuniões, coordenadas por Kast, se intercambiavam palestrantes entre os próprios profissionais e autoridades da época. Segundo Lavín, até quatrocentos alunos e profissionais universitários assistiam os encontros desenhados e impulsionados por Miguel Kast. Mais especificamente, segundo Lavín, foi a partir de 1979 que Kast começou a projetar a necessidade de encaminhar jovens profissionais-economistas para as regiões, tanto para as SERPLAC como para as universidades, sobretudo como um suporte técnico das políticas nacionais impulsionadas à nível regional (LAVIN, 1986, p. 22). Kast pessoalmente era quem recrutava aos SERPLAC, embora a desvantajosa relação dos salários entre a ODEPLAN e as empresas privadas fosse motivo de disputa pelo recrutamento dos jovens engenheiros comerciais: "Consciente de todo esto, Miguel comenzó a elegir personas y a hacer una labor de convencimiento con cada una" (LAVIN, 1986, p. 22). Diz Lavín:

\begin{abstract}
A lo largo del año, alrededor de ciento cuarenta profesionales jóvenes de distintas áreas, se instalaron en las regiones. Pedro Arriagada viajó a Arica, Norman Bull a Temuco, Cristóbal Philippi a Punta Arenas, José Yuraszeck a Coyhaique, José Pedro Undurraga a Concepción, entre muchos otros. A su vez, varios de los alumnos de éstos en regiones, comenzaron a ingresar en ODEPLAN o en otras reparticiones públicas. Miguel les ofrecía todo su apoyo y muchos de los profesionales que viajaron a regiones recurrían frecuentemente, a través del teléfono, a su consejo y ayuda [...] La mayoría tomaba la decisión de irse a vivir a alguna región porque Miguel lo pedía, y... más importante, porque lo convencía. Joaquín Brahm, uno de los alumnos más destacados de su generación en la Escuela de Economía de la Universidad Católica, había firmado recién contrato con una prestigiada empresa de la época en el momento en que Miguel estaba buscando una persona para hacerse cargo del Serplac en Puerto Montt. Se acordó de Joaquín Brahm, a quién había conocido como profesor, y lo citó un día domingo a su casa. Luego de dos horas de conversación, éste aceptó irse a Puerto Montt, dejando su recién firmado contrato, siempre y cuando Miguel le solucionara el problema con sus jefes, por cuanto resultaba difícil renunciar pocos días después de haber sido contratado en ventajosas condiciones (LAVIN, 1986, p. 23).
\end{abstract}

Esse modelo de recrutamento centralizado e carismático que fazia Miguel Kast também se refletia nos destaques de várias autoridades e funcionários da época. Pedro Ramírez coincide que as SERPLAC nas regiões permitiam o recrutamento de profissionais jovens que precisamente responderiam ao modelo estabelecido pelo Ministro da ODEPLAN. Diz Ramirez:

La SERPLAC era una de las sólo dos puertas de entradas del punto de vista de reclutar profesionales. La gran mayoría eran recién egresados con muy poca experiencia. Había 
algunos profesionales de mucha experiencia que llevaban varios años cuando yo llegué allí. Y estos además de seguir trabajando en el Bío-Bío después podrían seguir trabajando en otras regiones. De hecho, varios se fueron a Antofagasta, otros a Magallanes, a distintos lugares. Era un poco, diría yo, el modelo que implementó Miguel Kast cuando fue Ministro de ODEPLAN, donde envió a regiones a ingenieros profesionales jóvenes de muy buen nivel. A Punta Arenas Cristóbal Filippi, José Yuraseck en Coyhaique, aquí en Concepción José Pedro Undurraga, que hoy día es representante de las universidades de Las Américas y Andrés Bello, de las inversiones. Y eso más o menos duraba dos años que era entre comillas era un servicio militar. A mi me correspondió en 1980 trabajar con José Pedro que era el Secretario Regional. Luego Miguel Kast, cuando pasó de ODEPLAN al Ministerio del Trabajo, se lo llevó con él y luego se fue a Chicago a hacer su posgrado (ENTREVISTA PEDRO RAMÍREZ, fevereiro 2021)

A citação é significativa porque descreve a lógica de recrutamento dos SERPLAC, e também explica como as redes das SERPLAC seguiam sempre ancoradas pela figura do Miguel Kast. É importante destacar que o cargo na SERPLAC, de maneira geral, tinha uma duração aproximada de dois anos (quadro $n^{\circ} 13$ ), entretanto, alguns funcionários excecionalmente puderam permanecer na região por mais tempo, como são os casos dos SERPLAC das III, VI, IX, X e XII, onde alguns se estenderam no cargo por mais de três anos (quadro $\left.\mathrm{n}^{\circ} 13\right)$.

Quadro $n^{\circ}$ 13. SERPLAC 1981-1985

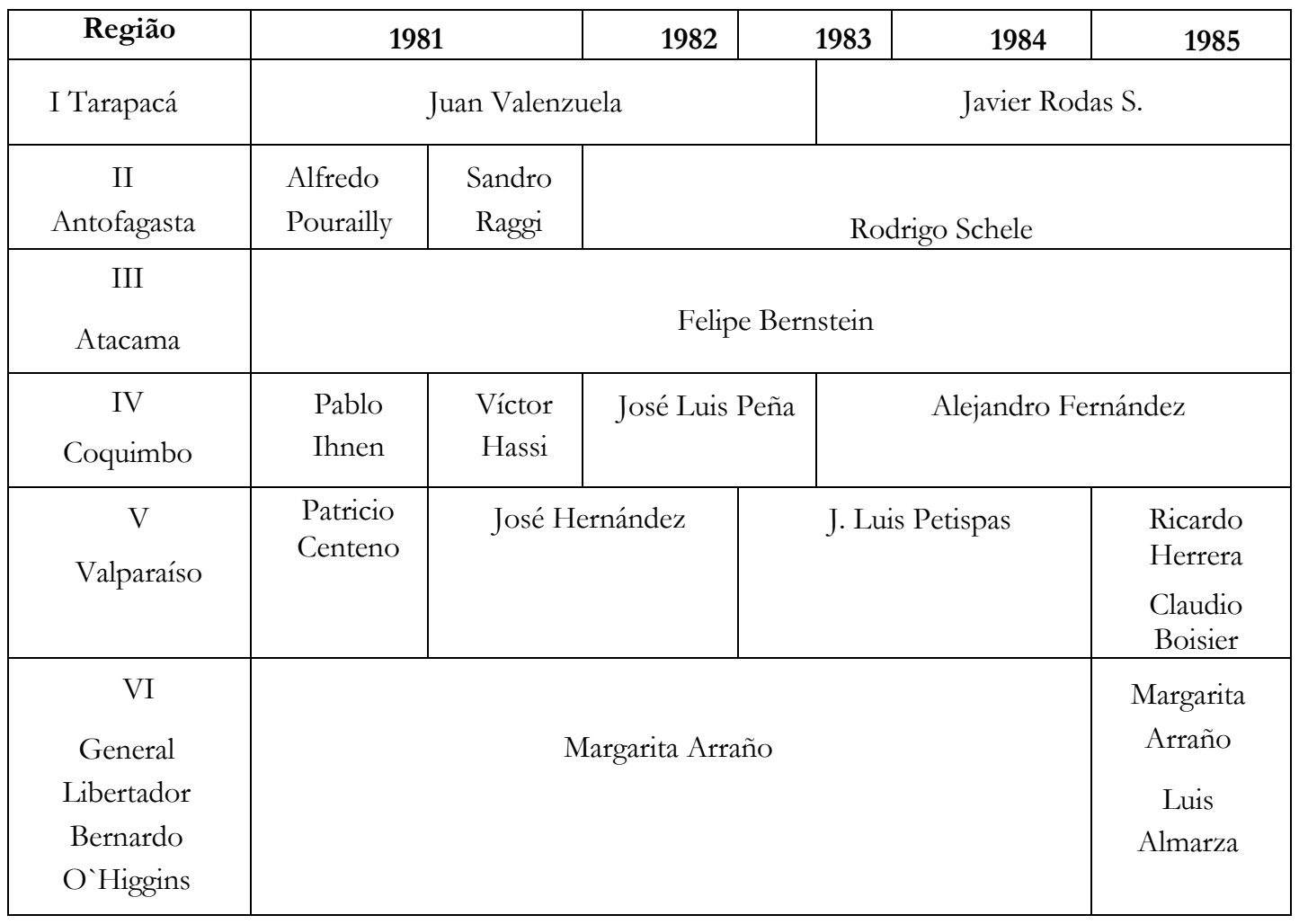




\begin{tabular}{|c|c|c|c|c|c|}
\hline $\begin{array}{c}\text { VII } \\
\text { Del Maule }\end{array}$ & Edmundo Subiabre & \multicolumn{2}{|c|}{$\begin{array}{l}\text { Hugo Tortilla } \\
\text { Rodrigo Soler }\end{array}$} & $\begin{array}{c}\text { Hugo } \\
\text { Tortilla } \\
\text { Rodrigo } \\
\text { Soler }\end{array}$ & $\begin{array}{c}\text { Pedro } \\
\text { Ramírez }\end{array}$ \\
\hline $\begin{array}{l}\text { VIII IX } \\
\text { Bío-Bío }\end{array}$ & $\begin{array}{c}\text { José Pedro Undurraga } \\
\text { Rodrigo Moncada }\end{array}$ & $\begin{array}{l}\text { Jorge } \\
\text { Eugenin }\end{array}$ & \multicolumn{3}{|c|}{ Pedro Ramírez } \\
\hline $\begin{array}{c}\text { IX } \\
\text { Araucanía }\end{array}$ & & \multicolumn{3}{|c|}{ José Navarro } & $\begin{array}{c}\text { Rodrigo } \\
\text { Moncada } \\
\text { René } \\
\text { Araneda } \\
\text { Julio Maiers }\end{array}$ \\
\hline $\begin{array}{c}\mathrm{X} \\
\text { Los Lagos }\end{array}$ & \multicolumn{4}{|c|}{ Julio Maiers } & Luis Valdes \\
\hline $\begin{array}{c}\text { XI } \\
\text { Aysén }\end{array}$ & Santiago Irarrázaval & $\begin{array}{c}\text { José } \\
\text { Ramírez }\end{array}$ & $\begin{array}{c}\text { José } \\
\text { Ramirez } \\
\text { Luis } \\
\text { Valdés }\end{array}$ & Luis Valdés & $\begin{array}{c}\text { Arturo Lillo } \\
\text { Carlos } \\
\text { Wobbe }\end{array}$ \\
\hline $\begin{array}{c}\text { XII } \\
\text { Magallanes }\end{array}$ & $\begin{array}{l}\text { Cristobal Philippi } \\
\text { Arturo Lillo }\end{array}$ & & Jain & Fuenzalida & \\
\hline
\end{tabular}

Fonte: HUNEEUS, 1998.

Um segundo elemento significativo de destaque dos SERPLAC era que vários deles seriam transferidos de uma a outra região, o qual evidenciava uma forma mais orgânica e funcional do cargo com a estrutura nacional, como nos casos dos SERPLAC das III, VI, IX, X, XI e XII regiões (quadro $n^{\circ} 13$ ). Esse modelo de circulação nas regiões também aparece nas trajetórias dos nossos próprios entrevistados Pedro Ramírez e Diego Benavente, ambos engenheiros industriais da UDEC, que participaram em mais de uma SERPLAC. Ramirez nas secretarias de Atacama e Bío-Bío, e Benavente nas secretarias de Bío-Bío e a Araucanía. Entretanto, o controle da ODEPLAN de Miguel Kast e o fortalecimento das lógicas neoliberais da administração pública, permitiu que muitos jovens profissionais buscavam fazer uma pós-graduação em universidades estrangeiras (principalmente na Universidade de Chicago) após haver cumprido dois anos no cargo da SERPLAC. Dessa maneira, o cargo da SERPLAC passaria a ser implicitamente um pré-requisito interno para aceder às bolsas que eram encaminhadas pelo regime a seus quadros profissionais (HUNEEUS, 2016), o qual transferiria também outros tipos de desdobramentos entre as autoridades territoriais. Embora muitos SERPLAC tivessem começado a trabalhar para as secretarias ainda muito jovens, e, após finalizar seus estudos de pós-graduação, regressariam à administração do 
regime - como foi o caso do engenheiro comercial Rodrigo Moncada -, em geral, os jovens recrutados por Miguel Kast voltariam a dedicar-se completamente as atividades do setor privado, sem retribuir suas carreiras ao Estado. Não obstante, um grupo menor dos SERPLAC se manteriam em suas respetivas regiões e seriam importantes referentes da organização pública do período, como foi o caso do Pedro Ramírez, quem exerceu como SERPLAC entre 1983 e 1988. De uma ou outra forma, a rotação dos SERPLAC também era expressão do centralismo e o tipo de gestão tecnocrática do território, gerando diferenças ao interior dos próprios escopos burocráticos regionais afins do regime. Como destaca o funcionário da SERPLAC do Bío-Bío Alejandro Fernández:

Entre los técnicos también teníamos peleas, te fijas, entre los que se quedaron haciendo patria versus los que se iba a estudiar a Chicago y después se olvidaron del tema y se fueron y se convirtieron en gerentes de empresas privadas. Porque tu te ibas a estudiar a Chicago o cualquier otro lado y no tenías ni siquiera que saber hablar inglés porque estaba garantizado seis meses de aprendizaje (ENTREVISTA ALEJANDRO FERNÁNDEZ, fevereiro 2021).

As diferenças internas seriam diversas, mas se justificavam a partir das trajetórias e compromissos dos SERPLAC com seus territórios internos. Então, que tipo de projeção territorial se inseria na SERPLAC dirigida pelo jovem profissional que não pertencia àquele determinado território? Em suma, dado o forte sistema centralizado e o perfil da seleção das chefias, se configuravam lógicas mais privadas que eminentemente públicas. Conclui-se então que as SERPLAC eram um passo prévio significativo, mas não fundamental e nem último dessas trajetórias tecnocráticas que se espalhariam nos setores privados. Ao final de contas, a própria gestão pública conduzida pela ODEPLAN tenderia a aperfeiçoar o modelo subsidiario e de privatização da economia chilena. Daí a centralidade da figura de Miguel Kast e sua lógica de recrutamento de jovens profissionais proclives a espalhar as metodologias do CIAPEP. Como destaca mais uma vez o funcionário da SERPLAC BíoBío, Alejandro Fernández, que após sua passagem funcionário na SERPLAC, passaria a ser prefeito de Curanilahue no sul do Chile:

Nosotros estábamos en la línea de Miguel Kast. Él es clave. De hecho, él me recomendó a mí. Cuando yo escucho hablar a Kast y lo que quería hacer con el país, y como al cabo de una generación y media o dos, transformar a un país bananero que es lo que éramos, en un país con vías en desarrollo con grandes posibilidades de ser desarrollado, que nuestros hijos, que nuestros nietos tuvieran acceso a lo que nunca nosotros tuvimos. Cuando yo di la prueba de aptitud y se lo digo a un montón de niños, había cupos entre todas las universidades, 180 mil y dábamos la prueba como 800 mil. Osea, había un montón que la única esperanza era trabajar con cuarto medio fuera y hoy día sobran las vacantes. Entonces, la igualdad de oportunidades que se creó en esos años para los que están hoy en día, ósea, la gente no tiene idea como era este país antes. Yo escuché a Miguel Kast en Concepción un día que nos fue 
a ver cuando yo ya estaba en ODEPLAN. Y ahí, a raíz de eso, yo elijo irme a las alcaldías y a ese sector. Tremendo inspirador (ENTREVISTA ALEJANDRO FERNÁNDEZ, fevereiro 2021).

O modelo Kast implicava não apenas uma questão técnica e de visão econômica da administração pública, mas também um compromisso com o regime e uma particular visão ideológica da gestão pública, que se reforçava com o CIAPEP e a circulação de autoridades territoriais ao ir consolidando o processo de transformações neoliberais no interior do Estado. Como destaca o SERPLAC do Bío-Bío Pedro Ramírez:

Más que recibir y dar órdenes era una motivación de hacer país. En esa época estaba Joaquín Lavín de decano de la Facultad de Economía de la Universidad de Concepción (UDEC), recién vuelto, muy joven, de Chicago. Y también hizo grandes labores. También había una relación muy cercana con la universidad. No hay que olvidar que en esa época los rectores eran delegados. Pero había una relación con las comunas a través de las universidades o algunas facultades, sobre todo de la Facultad de Economía de la UDEC. Relaciones donde se hacían los estudios del traspaso de los colegios, de las escuelas, etc., por dar un ejemplo (ENTREVISTA PEDRO RAMÍREZ, fevereiro 2021)

Com efeito, os SERPLAC iriam puxando o processo de reformas neoliberais definidas pela ODEPLAN de Santiago através de um modelo de gestão territorial que se espalhava por meio da coordenação dos diferentes atores e autoridades na região. Longe de uma seleção heterogênea e guiada exclusivamente pelos princípios de qualidade profissional, os SERPLAC conformariam um grupo compacto politicamente, mas, sobretudo, funcional a circulação dos princípios técnicos do neoliberalismo na operatória burocrática de Estado. Aqueles que exerciam como SERPLAC, no geral eram jovens economistas graduados da PUC, ou outras universidades tradicionais, que mantinham redes e laços com o movimento gremialista. Esses laços, no transcurso da década de 1980, se desdobrariam politicamente com a criação do partido Unión Democrata Independiente (UDI). Para o geógrafo e profissional de ODEPLAN de Santiago da época, Ignacio Irarrázaval, uma chave importante da hierarquia da função do SERPLAC estava precisamente na capacidade de controle dos tipos de investimentos nas regiões, e desse modo, a orientar e conduzir os setores públicos e privados de uma maneira paulatinamente desconcentrada e, sobretudo, estratégica:

Las SERPLAC eran los centros de pensamiento de la región [...] fue una cuestión bien estratégica [...] Claramente era un modelo de delegación, pero bastante eficaz, ósea, ¿cómo el gobierno central es más eficaz en la región? Las SERPLAC fueron nichos muy importantes [...] Sí, funcionó en instalar capacidades en ese modelo, yo trabajé en aquel minuto en revisar los planes de desarrollo regional, y claro, los planes de desarrollo regional eran, como buena dictadura, definidos de Santiago. Pero les ponían metas a las regiones. Entonces, el modelo era cómo hago más eficaz el gobierno nacional en la región y para eso tengo, entre comillas, buenos soldados, que son estas cabezas técnicas profesionales [...] son personas de elite, gente 
joven, que iba a las regiones, a comandar estos servicios públicos y alinearlos con las metas que se habían trazado a nivel nacional. En aquel minuto fue una cosa interesante (ENTREVISTA IGNACIO IRARRÁZAVAL, novembro 2019)

Os SERPLAC respondiam a um perfil do cargo muito particular: profissionais de elite e jovens dependentes e rigorosamente selecionados pela ODEPLAN. É interessante essa citação no sentido que evidencia o controle e a preocupação do poder central sobre as SERPLAC nas regiões, enquanto representantes e executores do projeto do regime e suas políticas públicas territoriais. Se bem o modelo de desconcentração não rompia a inercia centralista do país com os planos de desenvolvimento regional sendo decididos em Santiago, paralelamente, ao definir metas e programas na região, as SERPLAC permitiam uma maior circulação das decisões e coordenações entre os níveis locais-regionais, os quais deveriam conseguir resultados e ampliar suas competências ainda que monitoradas pela ODEPLAN de Santiago. Nas palavras de Irarrázaval: "se va estructurando una manera de toma de decisión, no diría autonomía, pero una visión de que la región es algo y no solamente un espacio donde el gobierno central manda, un espacio distinto" (ENTREVISTA IGNACIO IRARRÁZAVAL, novembro 2019). No plano prático, sua estrutura e forma de potencializar o neoliberalismo também implicou uma maior coordenação e comunicação entre as unidades técnicas do sistema regional (SEREMIS, governações, serviços públicos e prefeituras), o qual favoreceu sua hierarquia como máxima estrutura administrativa a nível sub-nacional. Dessa maneira, seria entendido com a figura do primus interpares, o primeiro entre iguais, que significava que junto com o Intendente Regional, os SERPLAC eram as máximas autoridades políticas no território, pois, lideravam as articulações entre o local e o regional, e interligavam as capacidades e diretrizes entre o regional e o nacional. Como destaca o analista da CEPAL e funcionário do ILPES da época, Luis Lira:

Los SEREMI pasaron a ser elementos bien importantes y el SEREMI SERPLAC era el primo interpares, ósea, el SERPLAC. Acuérdate que además ellos manejaban el FNDR. Era un tipo poderosísimo, y él asesoraba directamente al Intendente en la denominación de los otros SEREMIS [...] Es el ministro de la Región y eso empezó a influenciar mucho a los funcionarios [...] En definitiva, el modelo de Helio Suarez, esas tres columnas funcionaron porque en las regiones se montó un aparato importante y, de hecho, mucho antes de la nominación de los gobiernos regionales, varios edificios, se llamaban así. Sí tu ibas a la Serena antes del noventa, el edificio que hoy día está ahí decía Gobierno Regional de Coquimbo. En los ochenta, entonces, la gente comenzó a hablar de gobiernos regionales [...] En definitiva, la columna técnica, hubo una oferta política y hubo capacidad de respuesta técnica (ENTREVISTA LUIS LIRA, outubro 2019). 
De uma ou outra forma, a tecnologia política do arranjo regional permeou uma maior hierarquia das funções administrativas do sistema regional no interior do Estado central. Sem romper o marco autoritário, mas acoplando as estruturas administrativas ao neoliberalismo, o entramado técnico-político das SERPLAC começou a articular uma malha territorial de governo que administrou os assuntos sociais mais eficientemente que no período anterior das antigas províncias ${ }^{43}$. As SERPLAC permitiram impulsionar a forma regional-neoliberal como uma configuração profissional de governo, trocando a representação tradicional e histórica dos agentes políticos por uma gestão vertical, técnica e militarizada da gestão burocrática, com uma maior presença de profissionais e um sistema de avaliação de projetos que aparentemente permitia uma gestão sem tendências políticas. Se tratava de uma gestão territorial que valorizava a iniciativa privada como a fonte principal de distribuição, naturalizando assim a hierarquização dos assuntos regionais proclives ao capital. Como destacava o SERPLAC Pedro Ramírez e os primórdios das secretarias públicas chamadas Pro-Chile:

En esa época también nos correspondió recibir e iniciar dentro del equipo a un profesional de Pro-Chile que dependía y trabajaba con nosotros y también a dos profesionales [...] Entonces, en esa época, sobre todo aquí en Concepción, nos tocó recibir e iniciar con profesionales propios a otras unidades que después se independizaron [...] Pro-Chile aquí era fundamentalmente ver cuál es el potencial de exportaciones y promover esas exportaciones y organizar coordinadamente con Pro-Chile Santiago encuentros con los agregados comerciales de Pro-Chile en las distintas embajadas de Chile en el mundo. Entonces, venían acá y había reuniones previamente acordadas según el producto y según el país que estaba interesado en recibir ese producto. Y de ahí salían entre comillas negocios de exportaciones y entonces el Pro-Chile de allá, de Paris, por ejemplo, le promocionaba este productor x de Chillán o de Los Ángeles para venderlo en Francia. Durante muchos años era uno más del equipo, pero estaba exclusivamente para ver el tema de Pro-Chile. Hoy día Pro-Chile tiene una oficina propia regional y tiene equipo de apoyo de profesionales y administrativos. Pero nosotros partimos con eso (ENTREVISTA PEDRO RAMÍREZ, fevereiro 2021).

As SERPLAC, assim, iriam expandindo diferentes formas de privatização nos dispositivos públicos da regionalização que não questionassem o modelo centralizado e autoritário do país. Embora fossem burocracias de exclusiva desconcentração e delegação, essas movimentações de uma ou outra forma assentaram as bases de uma futura descentralização, pois, paulatinamente, iriam coordenando e reconhecendo suas próprias autoridades regionais e seus mecanismos de administração orçamental. O modelo de gestão

\footnotetext{
${ }^{43}$ Segundo Lira, as antigas ORPLAN do período Frei Montalva e Salvador Allende eram definitivamente menos relevantes que a hierarquia das SERPLAC no regime autoritário: "Antes de eso, los ORPLANES nadie les daba importância. Yo estuve en la región de Los Lagos, que era Valdivia y Osorno y no tenían ni presupuesto, eran dos o tres personas" (ENTREVISTA LUIS LIRA, outubro 2019).
} 
territorial da SERPLAC de Miguel Kast marcava um particular direcionamento neoliberal da regionalização e suas principais autoridades governamentais distribuídas horizontal e verticalmente nos territórios interiores. Por um lado, as SERPLAC deveriam gerar condições de funcionamento para uma economia cada vez mais primaria exportadora e neoliberal, no sentido de identificar as necessidades de infraestrutura e de investimento que permitissem uma maior fluidez no livre jogo desses agentes produtivos não estatais. Por outro, as SERPLAC deveriam projetar uma carteira ampla de instrumentos e programas sociais dirigida nos setores mais pobres, dado o complexo cenário econômico e a queda do produto interno bruto em meio de uma sistemática inflação e de fortes taxas de desemprego, especialmente entre 1976-1986.

Nesse quadro, as SERPLAC se conformam como as unidades burocráticas superiores de enfrentamento às fortes crises econômica e social do regime na década de 1980. Através da sua distribuição homogênea nos territórios interiores e a direção de Miguel Kast ${ }^{44}$ na ODEPLAN, as SERPLAC foram o roteiro institucional que deram espírito de corpo ao processo territorial oficial para enfrentamento da pobreza. As SERPLAC se estabelecem como um ente político que apoia o conjunto da ação territorial das autoridades, tendo a visão global da região e o contato com a máxima autoridade do governo regional. Como relata o prefeito de Curanilahue:

Dependía mucho del apoyo de la SERPLAC y de las SEREMIS también. Es una buena pregunta porque los SEREMIS, tu necesitabas de mucho de ellos para hacer cosas con los sectores. Pero si tu tenías problemas políticos, por todo lo que te dije antes, cuando yo era alcalde tuve que hacer una declaración. Una vez declaré -me acuerdo- de que los alcaldes éramos tapa hoyos. Fue un escándalo, salió en el diario de Concepción. Entonces, el único brazo armado del equipo técnico profesional era ODEPLAN y ODEPLAN te defendía. Y el Ministerio del Interior te quería hacer castigar con tu salida. Y ahí estaba nuestro amigo que hablábamos antes. La SERPLAC tenía mucha jerarquía política, sobre todo cuando estaba Miguel Kast. Después se mantuvo, pero no era lo mismo (ENTREVISTA ALEJANDRO FERNÁNDEZ, fevereiro 2021)

\footnotetext{
${ }^{44}$ O Mapa de Extrema Pobreza foi um estudo resultado de um convênio de cooperação entre o Instituto de Economia da PUC e a ODEPLAN liderada por Miguel Kast, que delimitou espacial e tecnicamente a pobreza através de uma série de mecanismos de focalização que, no caso das regiões, foram desenvolvidas pelas SERPLAC. Baseado em uma série de dados sobre as condições materiais e indicadores socioeconômicos do Censo de 1970, os resultados do primeiro estudo de 1974 estabeleceram aproximadamente quase dois milhões de pessoas no grupo de extrema pobreza, é dizer, um $21 \%$ da população chilena, sendo mais concentradas nas províncias urbanizadas (1.300.000) que nas províncias rurais (61.600 pessoas) (MOLINA, 1974, p. 15). Nos próximos anos essas cartografias de maior pobreza serão aprofundadas e acompanhadas com diferentes estudos e políticas sociais-territoriais.
} 
O relato de Fernández constata como os SERPLAC exerciam uma hierarquia política superior no comando da região que, eventualmente, poderia intervir na seleção das autoridades locais ou inferiores, e nesse caso, a defesa da posição do prefeito de Curanilahue. No fundo, a SERPLAC era a unidade encarregada de manter ativa as iniciativas do governo e a legitimidade do sistema territorial em todo seu conjunto. Embora as SERPLAC fossem os órgãos com melhor dotação de profissionais nas regiões do país, ainda a princípios de 1980 tinham certos problemas associados à racionalização conjunta que deveriam impulsionar a partir dos outros setores ministeriais, onde, muitas vezes, emergia uma "inadecuada asignación de funciones" (CONARA, 1982, p. 86). Esses assuntos, diz o informe de 1982, estavam ancorados na complexa função multissetorial das SERPLAC, que deviam se interrelacionar, não sem resistências, com numerosos serviços e setores ministeriais de maneira permanente e resolutiva (CONARA, 1982, p. 86). Das treze SERPLAC em 1982, todas efetuam atividades de assessoria aos organismos públicos e Intendentes regionais, entretanto, dez faziam estudos conjunturais da situação socioeconômica regional, nove atualizavam e mantinham estatísticas regionais e apenas oito tinham vinculação de caráter técnico com o setor privado (CONARA, 1982, p. 41). Em outras palavras, o funcionamento das SERPLAC, como toda a reforma regional, ainda estava em muitos planos inacabada. No entanto, o rendimento das SERPLAC era satisfatório, "alcanzando el grado relativo máximo en las actividades de planificación y administración presupuestaria (...) Es decir, las SERPLAC cumplen en un alto porcentaje con las actividades para las cuales fueron creadas" (CONARA, 1982, p. 41). Esse espírito de corpo e alta chefia de Estado Maior também se expressava no tipo de reuniões e programas que as SERPLAC lideravam no cenário nacional. Como lembra Pedro Fernández na reunião nacional da SERPLAC realizada na cidade de Puyehue no sul do Chile (VIII Região), no final da década de 1980:

Recuerdo perfectamente en una de estas reuniones. Fue para el mes de julio para celebrar la batalla de la Concepción y se hacía aquí en el regimiento de Chacabuco de la Concepción. Y vino el presidente Pinochet y Sergio Melnick que estaba de Ministro. Terminó esa actividad y nos fuimos en el auto de él con su PPI, sus carabineros de seguridad, a Puyehue. ¿Y por qué Puyehue? Porque ahí tuvimos una jornada ese año, que era una reunión al año Pensando el futuro. Y había temas distintos y se armaban equipos de trabajo que si no terminaba el trabajo tenía que quedarse después de la comida y se saltaba la piscina temperada también. Y siempre se llevaba a uno o dos expositores. En esa oportunidad fue un norteamericano para hablarnos del futuro, de cómo planificar el futuro, etc. Y eso se hacía, como te decía, mínimo una vez al año y ahí nos juntábamos todos los SERPLAC y los Subdirectores de ODEPLAN y algunos directores de Departamento de Odeplan, según el tema que se iba a abordar (ENTREVISTA PEDRO RAMÍREZ, fevereiro 2021). 
A citação reafirma o duplo comando centralizado dos SERPLAC em relação a sua estreita dependência do poder central, representado neste caso pela presença do próprio general Pinochet (Presidente do país) e o engenheiro comercial Sergio Melnick, ministro e diretor nacional da ODEPLAN da época. Diante da forte crise econômica, as SERPLAC tinham que afinar os instrumentos ao conjunto de operações do governo. Assim, como foi possível que as SERPLAC pudessem exercer essa hierarquia técnica e política? Sem dúvida, um elemento central que articulou o processo foi criação e consolidação do Banco Integrado de Projeto (BIP). Esse dispositivo burocrático permitiu a criação de um sistema anual de registo do conjunto de projetos no Sistema Nacional de Inversiones (SNI). Dessa maneira, todas as burocracias regionais, incluindo as SERPLAC, deveriam ordenar e projetar anualmente suas carteiras de financiamento que, por sua vez, teriam uma avaliação socioeconômica única, homogênea e coordenada, independente de suas funções ou localizações. Com a criação do BIP o regime contou com uma ferramenta de governo eficiente na tomada de decisões sobre o investimento público nas regiões. Com efeito, o BIP iniciou com programas pilotos nas regiões de Valparaíso, Santiago, Antofagasta e Concepción, sendo as SERPLAC as unidades encarregadas de liderar sua programação em finais da década de 1970. Posteriormente, entre 1982 e 1984, se definiu o marco lógico e a plataforma física e tecnológica das diferentes etapas que deveriam integrar os projetos. Segundo o SERPLAC de Bío-Bío, Pedro Ramírez: "Recuerdo que debe haber sido alrededor de 1982 diseño del marco lógico, diseño físico en las distintas etapas del proceso con tarjetones. Luego Banco Integrado de Proyectos (BIP) en línea 1984 con SONDA. En régimen 1985 y todo proyecto debia pasar por el BIP” (ENTREVISTA PEDRO RAMÍREZ, fevereiro 2021). Em 1985, assim, já estaria funcionado de maneira coordenada todo o sistema do BIP nos serviços público do país. É sumamente interessante esse dado pois, precisamente em 1985, se cria a Subsecretaria de Desenvolvimento Regional (SUBDERE) no Ministério do Interior que modificaria o desenho de distribuição do FNDR liderado pelas SERPLAC. O BIP seria uma expressão do conjunto de modificações burocráticas que iriam aperfeiçoando o esquema técnico dos orçamentos e o planejamento do sistema público regional. No entanto, em termos de poder territorial estrutural, o BIP ainda continuaria reproduzindo as lógicas centralistas. Como lembra o SERPLAC de Bío-Bío sobre o funcionamento do BIP e suas viagens a Santiago, a propósito da defessa dos projetos de investimento da região:

Se hacía un ranking según la rentabilidad social y se presentaban al Consejo Regional que hoy día es el GORE, donde participaban el sector privado, el público, los cuatro gobernadores de la época, por ejemplo. Y se tomaba la decisión de cuáles eran los proyectos 
que se les otorgaba la inversión correspondiente. También me correspondía coordinar a los SEREMIS e ir con ellos, liderando a ese equipo, a Santiago a la discusión presupuestaria. Entonces, nos tocaba ir al Ministerio de Educación, Ministerio de Salud, MOP, etc. Y luego se defendían al respectivo ministerio los proyectos y después se consolidaban en un listado en conjunto ODEPLAN a nivel nacional (ENTREVISTA PEDRO RAMÍREZ, fevereiro 2021)

Mesma lógica de controle e coordenação destaca o funcionário da SERPLAC da Araucanía, Diego Benavente:

Y después, una vez al año lo que se hacía era partir a ODEPLAN Santiago con una reunión con Hacienda y la DIPRES para defender los proyectos que uno había priorizado. No sé, septiembre o octubre, ya no me acuerdo, donde se hacían estas reuniones en ODEPLAN. Iba la región a levantar sus proyectos, a llevar sus proyectos que había levantado, por qué le habían bajado o querían aprobar determinados proyectos. Generalmente iba el SERPLAC y el Intendente (ENTREVISTA DIEGO BENAVENTE, fevereiro 2021).

Ambas citações são significativas porque demostram a incapacidade de romper com o centralismo e suas lógicas de coordenação hierárquica. Embora o SERPLAC e o Intendente defenderiam sua carteira de projetos em Santiago, a última decisão sempre estaria nas estruturas centrais da ODEPLAN, do Ministério de Fazenda e sua Direção de Orçamento (DIPRES). Através do BIP, no entanto, a administração territorial pública do país se ordenava com maior espírito de corpo e racionalidade. Todos os projetos passariam ter um maior controle técnico de suas etapas e requerimentos, fortalecendo o SNI. Nesse esquema se reforçava a centralidade estratégica das SERPLAC no funcionamento do sistema territorial do país, sobretudo suas redes profissionais e políticas que seriam aprofundadas mediante os cursos do CIAPEP. Em 1983 o CIAPEP já havia formado várias gerações de profissionais, autoridades territoriais e funcionários públicos que foram espalhados nas diferentes burocracias regionais e municipais do país. Dessa maneira, se reforçava a estrutura centralista nos termos do neoliberalismo, mas agora com dispositivos tecnicamente mais integrados entre si nas unidades regionais. Através das carteiras de projetos que elaboravam as SERPLAC, o Banco Integrado de Projetos (BIP) arquitetava o plano geográfico dos recursos e orçamentos fundamentais no conjunto do território nacional, que seria refletido no Sistema Nacional de Investimentos (SNI). Era uma significativa inovação da administração pública do Estado que também expressava uma década de reforma integral encabeçada pela CONARA (1973-1983). O poder nacional ampliava sua capilaridade territorial com um sistema verticalizado e coordenado em suas diferentes estruturas burocráticas regionais, muito mais eficiente e ativo dos poderes territoriais internos em 
comparação aos primeiros anos da regionalização (1974), onde as estruturas centrais não tinham controle e vigilância dos orçamentos e os comandos públicos das províncias.

Porém, ainda continuaram aprofundando-se as desigualdades geográficas entre Santiago e as regiões. A tecnologia do BIP nos termos neoliberais implicou que a condução do FNDR tendesse a uma perda paulatina da orientação original nacional-desenvolvimentista, para uma definição de investimentos de infraestruturas mínimas condicionadas à lógicas extrativistas e de focalização (LIRA, 2004). Em outras palavras, de ser um mecanismo de financiamento de projetos de crescimento produtivo regional, o FNDR na década de 1980 passou a ser um fundo de caráter social, particularmente dirigido ao combate da pobreza (BOISIER, 2011). Tal mudança se explica fundamentalmente pela abertura regional e a implementação do Estado subsidiário, deixando que cada região fosse inserida na esfera do livre comércio sem a intervenção do Estado (JORDÁN, VILLARROEL, 1990; ARENAS, 2009; RACZYNSKI, 1986). Em relação a esse redirecionamento estrutural da regionalização, Jordán e Villarroel apontam dados importantes sobre as lógicas da descentralização impulsionada pelo regime. Primeiro, que o FNDR fundamentalmente favoreceu as regiões extremas, validando o argumento da integração limítrofe e o caráter geopolítico da regionalização, com quatro regiões (I, X, XI, XII) que teriam concentrado um 46\% dos recursos do FNDR. E, segundo, apesar das políticas descentralizadoras, durante o período autoritário se manteve a tendência dominante da Região Metropolitana de Santiago sobre as outras regiões quanto aos âmbitos demográfico, econômico e tecnológico (JORDAN, VILLARROEL, 1990, p. 83). Dessa maneira: "Las regiones extremas, junto a la metropolitana, fueron las que captaron mayor cantidad de recursos del Estado durante este periodo, lo que evidencia que el Estado decidió no actuar como agente compensador de los desequilibrios regionales" (JORDÁN, VILLARROEL, 1990, p. 88). Nesse sentido, é expressiva a evolução orçamental global do FNDR que foi sistematicamente baixa (quadro $\mathrm{n}^{\circ} 14$ ) e nunca projetou o $5 \%$ do global nacional que estabeleceu o decreto lei $\mathrm{n}^{\circ}$ 575 (GARCÍA, 1985). A partir de 1979 se observa uma queda significativa de suas contas, diminuindo radicalmente no ano 1985, com menos de três mil milhões de pesos chilenos. Uma situação que refletia a escassa projeção operativa em termos de orçamentos reais para o desenvolvimento de infraestruturas estratégicas nas regiões.

\section{Quadro no 14. Evolução FNDR (1976-1989)}

\begin{tabular}{|c|c|}
\hline Ano & $\begin{array}{c}\text { Miles de pesos chileno \$ } \\
\text { (Dezembro 88) }\end{array}$ \\
\hline 1976 & 12.519 .557 \\
\hline
\end{tabular}




\begin{tabular}{|l|c|}
\hline 1977 & 13.166 .442 \\
\hline 1978 & 14.812 .533 \\
\hline 1979 & 17.564 .826 \\
\hline 1980 & 15.096 .656 \\
\hline 1981 & 14.198 .392 \\
\hline 1983 & 7.554 .921 \\
\hline 1984 & 4.409 .853 \\
\hline 1985 & 2.862 .032 \\
\hline 1986 & 12.250 .724 \\
\hline 1987 & 19.096 .161 \\
\hline 1988 & 22.800 .822 \\
\hline 1989 & 23.009 .797 \\
\hline
\end{tabular}

Fonte: González (1990)

Nesses termos, as políticas territoriais da CONARA e as SERPLAC não haveriam criado um agente compensador dos desequilíbrios regionais, mas, ao contrário, validou a desigualdade estrutural dos fluxos e áreas geográficas deprimidas economicamente versus capitais e regiões mais exportadoras. Segundo o geógrafo Alfredo Apey, a evolução espacial das atividades econômicas entre 1976-1982 implicou no quase desaparecimento da política de planejamento regional (APEY, 1983, p. 84). Segundo a estratégia econômica da ODEPLAN de 1976, a simples abertura internacional geraria um efeito imediato e espontâneo de desenvolvimento menos concentrado espacialmente. Porém, tanto o predomínio do centro metropolitano, quanto as fortes desigualdades competitivas entre as regiões nas décadas de 1970 a 1980, demostraram uma lógica contrária: a concentração espacial se consolidou na economia a nível nacional. Segundo Apey:

[...] si bien prácticamente la totalidad del sistema regional ha sido afectada por el proceso de reestructuración económica, la aplicación de los diversos indicadores señala que la evolución presentada por éste guarda escasa relación con los planteamientos teóricos oficiales, en lo referente a su estrategia de desarrollo regional: una situación en la que la explotación de las ventajas comparativas implicaba de por si el advenimiento de una estructura interregional más balanceada a través de su sostenido proceso de especialización económica en los recursos primarios (APEY, 1983, p. 97).

Um exemplo da concentração significativa, entre muitos outros, foi a distribuição de postos de trabalho na Região Metropolitana que, entre 1976 e 1981, aumentou de 42,6\% para um 51,2\% (APEY, 1983). Por outra parte, apenas duas regiões baseadas economicamente na mineração manifestaram certas tendências econômicas de crescimento ligadas às vantagens comparativas. Essas regiões (II e VI), segundo Apey, apresentaram uma polarização setorial que inseria a extração de recursos naturais. No entanto, o conjunto do território nacional não se integrou ao processo de criação de especialização de produtos de exportação, permanecendo mais vinculado ao mercado interno. Até a entrada da década de 1980, a maior 
parte das regiões evoluía num padrão setorial mais "homogéneo debido fundamentalmente al significativo aumento de las actividades de servicios y a la disminución de la agricultura doméstica, actividad en que la mayoría de las unidades territoriales se especializaba en 1976" (APEY, 1983, p. 97). É importante destacar, aliás, que em termos produtivos se favoreceram aquelas regiões ligadas a atividades de exportação de recursos naturais, como a mineira, a pesca, a silvicultura e a fruticultura; entretanto o conjunto de regiões, maioritariamente agrícolas e indústrias, retrocedeu sua participação do produto geográfico nacional (APEY, 1983).

Dessa maneira, o princípio de neutralidade espacial e independência das localizações do neoliberalismo certamente tiveram efeitos diferenciais e desiguais na composição territorial do país, destacando-se uma forte taxa de crescimento econômico nas regiões mineiras (RIFFO, 2005). Não obstante, é importante assinalar que, apesar da vocação externa das políticas econômicas aprovadas pelo regime, e em comparação com os períodos dos governos democráticos, os níveis de investimento estrangeiro mantiveram-se relativamente baixos no período autoritário: "enquanto o total acumulado de IED entre 1974 e 1989 atingiu 8,6 bilhões de dólares, no período 1990-2002, chegou a um total de 53,1 bilhões de dólares” (RIFFO, 2005, p. 165). Em termos sociais se comprova que, em geral, o pacote de políticas econômicas neoliberais ampliou as desigualdades históricas "tanto nos níveis absolutos de pobreza quanto nos termos de uma situação distributiva altamente regressiva" (RIFFO, 2005, p. 168). Essa situação pode ser explicada basicamente por dois fatores chave: primeiro, a perda do poder de negociação dos operários frente às novas condições de trabalho que favorecem o mercado; em segundo lugar, o fortalecimento de conglomerados econômicos que tendem a concentrar a riqueza e a centralizar o capital. Apesar das limitações estatísticas do período, Riffo destaca que o forte poder de concentração econômica de Santiago e a prevalência de conglomerados econômicos ligados ao comércio exterior são também fatores do crescimento em âmbito nacional dos grupos mais pobres, chegando a estados históricos. Em 1987 quase a metade do país estava abaixo da linha da pobreza, com algumas regiões com níveis mais extremos ainda (RIFFO, 2005, p. 169). As SERPLAC e SEREMIS seriam as principais unidades burocráticas na escala regional para defender a articular uma perspetiva social do governo nacional. No entanto, a concentração do poder econômico e burocrático de Santiago continuaria sendo o principal obstáculo da descentralização e as políticas de CONARA. 


\subsection{O Artifício da Região Metropolitana de Santiago}

Apesar que nos primeiros decretos da regionalização já se estabelecia a faculdade de criar áreas metropolitanas para áreas urbanas significativas ${ }^{45}$, foi só em 1980 que se aprova um regime administrativo para a Região Metropolitana de Santiago (RM). O que significavam esses seis anos (1974-1980) de diferença entre o primeiro decreto da regionalização e a definição do poder territorial na capital do Chile? Durante a existência da CONARA (19731983) a definição das fronteiras interiores da RM foi o mais complexo arranjo regional instituído. As autoridades se viam atravessadas pelo seguinte dilema: como administrar diferenciada e descentralizadamente na capital do país uma forma de poder metropolitano alternativo? A possibilidade de criar uma administração metropolitana que pudesse diminuir as estruturas de poder do governo central e equipar as diferenças materiais econômicas e burocráticas com as regiões, foi uma prova didática da escassa vontade política de Pinochet em modificar os termos estruturais do centralismo. Embora a CONARA criasse diversos estudos que foram evidenciando a necessidade técnica de estabelecer um distrito metropolitano diferenciado, foi o governo central e sua pesada estrutura centralista que negou qualquer tipo de diferenciação metropolitana.

Pelo geral, a literatura do período centrou suas análises nos efeitos da concentração econômica (DE MATTOS, 1992; 1998) de Santiago e na evolução de certas tendências do neoliberalismo no uso de solo urbano da capital do país (HIDALGO, 2005), sem questionar e aprofundar nas contradições políticas do arranjo regional da capital e seus possíveis desdobramentos como marco estrutural do regime político chileno. A concentração econômica e tecnológica e o poder político do Santiago sempre foram uma preocupação das políticas regionais da CONARA, porém, nunca existiu um consenso básico para definir as condições do estatuto metropolitano. A pergunta que emerge implica compreender porque era tão complexo criar um consenso político da administração na RM? A partir do início do processo de regionalização (julho 1974) a RM sempre teve um tratamento diferenciado com o resto das regiões, evidenciado com a rápida mudança de suas definições formais. No primeiro recorte de regiões de 1974, com efeito, Santiago não se projetou como uma região e foi definida como a Área Metropolitana de Santiago (AMS). Dois anos depois (1976), junto com a oficialização de todas as regiões em termos operativos e a definição do recorte de

\footnotetext{
${ }^{45}$ Como diz o decreto-lei $\mathrm{n}^{\circ} 573$ de julho de 1974, se poderá levar uma "planificación integral del desarrollo metropolitano y la coordinación de las inversiones y de los servicios estatales y municipales que existan en el área" (GOBIERNO DE CHILE, 1974b, s./r.)
} 
algumas províncias, se decretou que a AMS passaria a ser XIII RM de Santiago (decreto-lei $\mathrm{n}^{\mathrm{o}}$ 1230). Porém, no interior das leis e dos documentos oficiais, Santiago continuou sendo entendida como a Área Metropolitana de Santiago e não a RM de Santiago. De maneira que, só a partir do decreto-lei no 2339 em 1978, finalmente, Santiago passaria a ser entendida como a XIII RM de Santiago. Nesse último recorte oficial, todas as regiões do país passavam ter números romanos de norte a sul junto com um nome.

Essa diferença conceitual, aliás, também se expressava na composição de suas estruturas internas burocráticas. A partir de 1975 se definiria que todas as regiões deviam articular-se através das SERPLAC e SEREMIS, formando parte do sistema de integração regional impulsionado pela ODEPLAN. Contudo, até 1980 na RM ainda não se havia instituído formalmente um SERPLAC, porém, simbolicamente passou a ser denominada XIII Região Metropolitana com o propósito de equipar o "tratamiento a todas las zonas del país que se busca a través de la nueva legislación" (EL MERCURIO, 04 janeiro 1976). Mais uma vez Santiago não estava sendo modificada nas estruturas e funções estatais fundamentais que havia realizado a CONARA nas regiões. Até 1980, assim, oficialmente a XIII RM Santiago apenas começava seu processo de reforma administrativa, embora suas estruturas centralistas - Ministérios e gabinete central - não tinham sido reformulados.

Os problemas de Santiago estavam fundamentalmente ancorados no significativo peso político de suas burocracias locais e centrais - Ministérios e prefeituras - que eram mais difíceis de intervir pela regionalização da CONARA ${ }^{46}$. Entre 1974 e 1980, assim, através da CONARA o regime elaborou diversos anúncios que alertavam de vários estudos e possibilidades institucionais para, ao fim, romper com a inércia do poder da capital e inverter as consequências negativas da forte concentração demográfica de Santiago, sobretudo aquelas migrações que eram consideradas ameaças sociais e fontes de subversão (CONARA, 1976). Contudo, Santiago era “un hueso duro de roer" (EL MERCURIO, 27 novembro de 1975). Consultado pela imprensa em 1975, o geógrafo Dionísio Vio informava:

Santiago será la única región que no entrará en funcionamiento a partir del próximo primero de enero, ya que solucionar sus complejos problemas de concentración no es de cinco minutos [...] Cuando se tomó el proyecto de la regionalización se pusieron etapas a seguir. Lo primera era dividir en regiones, luego dividir estas en provincias, a continuación la redefinición comunal

\footnotetext{
${ }^{46}$ Nesse sentido é interessante destacar que, inclusive, no próprio governo da UP entendia a necessidade de romper "las relaciones de dominación que ejerce la región metropolitana sobre el resto del territorio" (BEDRACK, 1974, p. 24). No entanto, nunca se conseguiu criar dispositivos compensatórios e de disputa que permitissem uma legislação que envolvesse uma perda do poder central de Santiago.
} 
y como última etapa la región metropolitana. Esto no significa que no hayamos pensado en ella con anterioridad, pero la decisión a tomar requiere de muchos estudios y todavía no está lista (EL MERCURIO, 27 novembro 1975).

A posteriori, regiões, províncias, comunas e RM, implicitamente, mostravam uma evidente contradição do processo: a regionalização era uma política para o conjunto do território, no entanto, pelos complexos problemas Santiago não se integrava efetivamente nas reformadas estruturas burocráticas: “Con sus cuatro millones de habitantes, que ocupan el dos por ciento del territorio nacional y consumen el 35,6\% del presupuesto de la Nación, Santiago es un caso único. En toda la provincia operan 34 municipios y sólo en el llamado caso urbano actúan 17 alcaldes" (ERCILLA, 14 janeiro 1976). Com efeito, entre as razões que existiram para definir um estatuto administrativo diferenciado de Santiago, pelo geral, se destacavam quatro argumentações centrais: a forte concentração demográfica, a necessidade de freiar o crescimento horizontal da cidade como limite urbano, o maior ordenamento e proteção dos melhores solos agrícolas da região localizados nas zonas circundantes de Santiago e, por último, o planejamento e a integração das comunas mais densas e urbanizadas, incorporando investimentos de tipo construção em altura (EL MERCURIO, 27 novembro 1975). Como afirmava o assessor geógrafo da CONARA, Fernando Torres:

Entre los objetivos que se persiguen con Santiago está el de que su crecimiento no sea superior al del resto del país y el de integrar a las diversas comunas que forman, ya que cada una marcha por donde quiere [...] "Es indispensable racionalizar las entradas para integrar la ciudad. Aparte de que se hace imprescindible detener su crecimiento. En este momento la ciudad cuenta con 17 mil hectáreas de extensión, en circunstancias que gran parte de esta tierra sería magnífica para cultivo. Habrá que construir en altura, pero para eso se necesita una infraestructura muy cara", decía el asesor geógrafo Fernando Torres [...] Por todo esto y por ser además sede del Gobierno Nacional, su adecuación al nuevo sistema será más lento, pero a la larga llegará pues para que el proceso madure en perfectas condiciones, se requiere que todos sus organismos estén en funcionamiento (EL MERCURIO, 27 novembro 1975).

Embora a imprensa e o governo procuravam desenvolver estudos que iam "rápido y muy bien encaminados" (EL MERCURIO, 27 novembro 1975), na prática, passaram-se seis anos para que a Junta de Governo tomara uma resolução sobre o assunto. Se bem existia o consenso de que era necessário criar uma administração mais integrada dos aspetos físicos e urbanísticos da cidade, ao mesmo tempo, prevaleciam as tensões e desacordos para chegar a um projeto de lei. Em 1977 o governo nacional anunciava que a partir de janeiro de 1978 a Região Metropolitana contaria com um sistema especial de governo e administração interna, incluindo uma divisão territorial projetada pela CONARA, depois de um longo período de estudo (EL CRONISTA, 6 fevereiro 1977). 


\section{Imagem no 16. Anúncio prensa Região Metropolitana de Santiago}

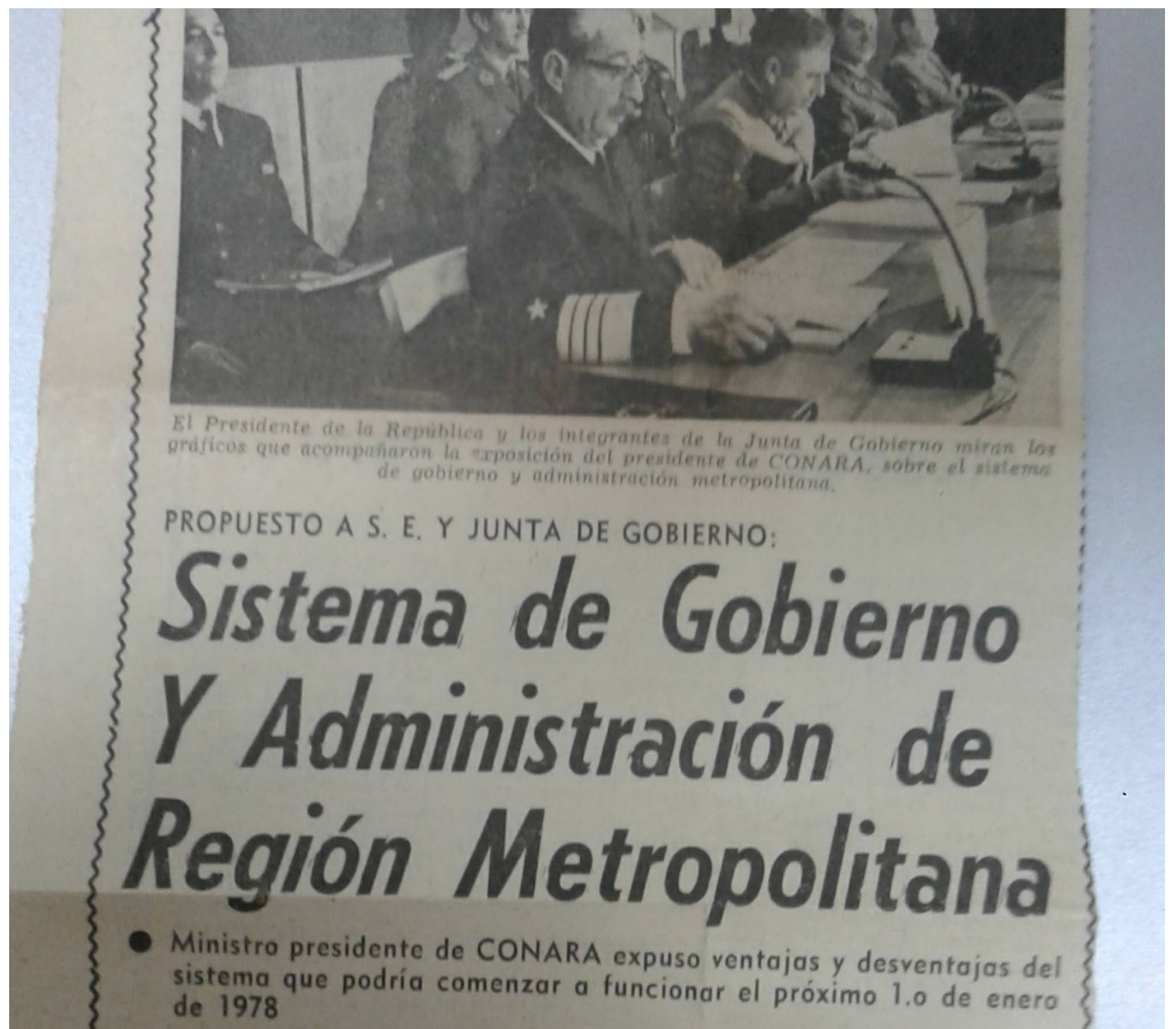

Fonte: El Mercurio, 21 de Junho 1977, p. 21

Em 1978 seria o momento de conclusão do processo de restruturação de todos os ministérios e serviços públicos, seguindo o processo de reforma dirigido pela CONARA. Dessa maneira Santiago começaria, tal como o resto das regiões, a ter um marco espacial diferenciado do nacional em SEREMIS e Direções Regionais de Serviços que dariam uma gestão "eficiente y expedita” (EL CRONISTA, 6 fevereiro 1977) aos problemas da capital. 


\section{Imagem n ${ }^{\circ}$ 17. Cinco Províncias e Área Metropolitana}

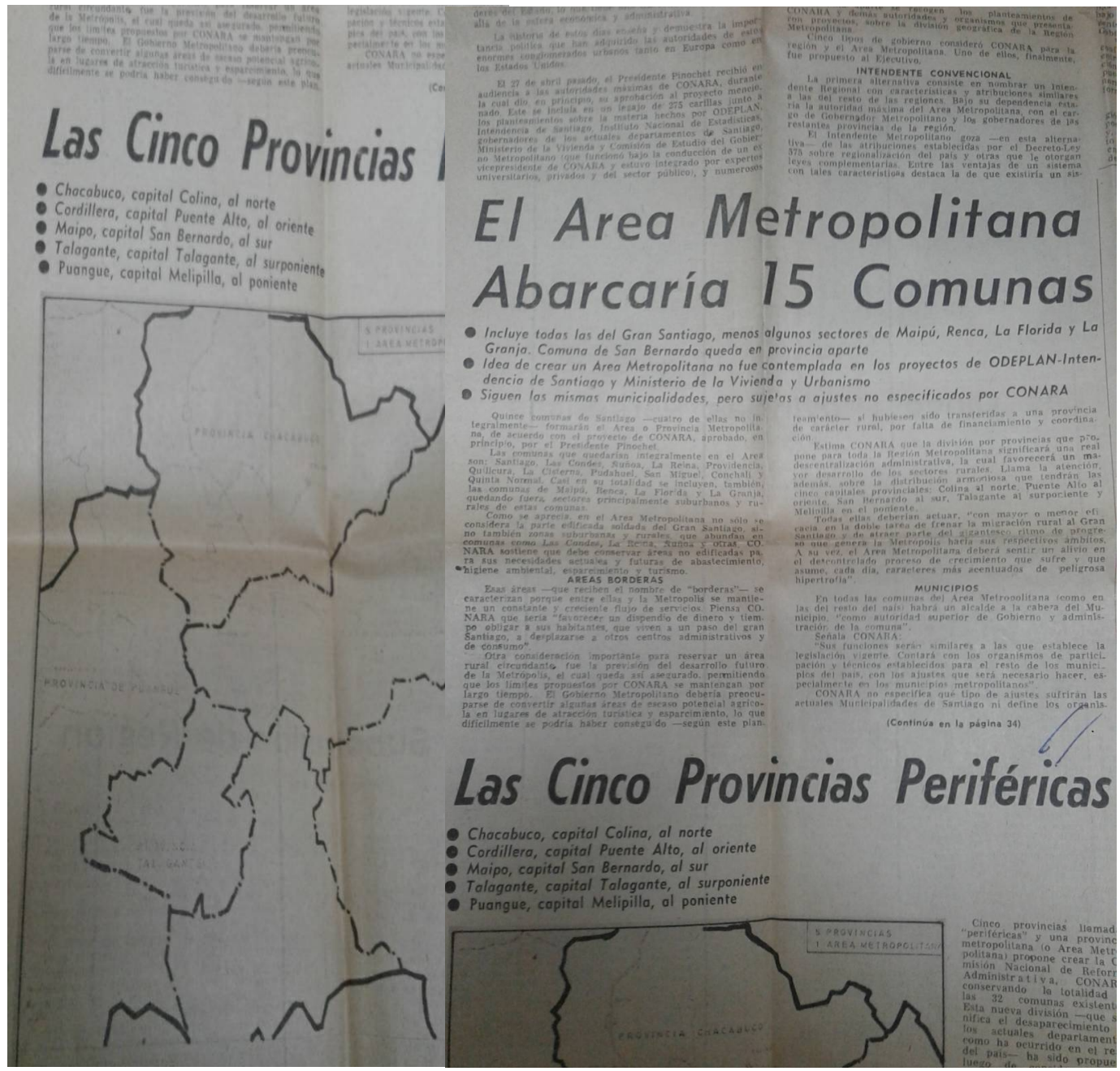

Fonte: El Mercurio, 22 Maio 1977.

Nessa organização metropolitana de ordenamento, ademais, também se integrariam canais de participação que permitiriam ir solucionando problemáticas a níveis comunais e provinciais, sendo uma marca da "nueva institucionalidad que está estructurando el Supremo Gobierno" (EL CRONISTA, 6 fevereiro de 1977). Faltando um pouco mais de dois anos para a criação da nova Constituição, a capital de Santiago representava um 35\% da população do país, chegando a concentrar mais do $40 \%$ das atividades comerciais e econômicas. Em palavras do general Canessa a Região Metropolitana:

Tiene una tasa de urbanización del 95 por ciento. Santiago absorbe el 85 por ciento de la población regional del país. Pero hay más: en 1970, un tercio de la inversión de Chile fue utilizada por Santiago. Todo esto configura una realidad muy distinta a la del resto del país, a lo que se agrega que en 25 años más la capital puede duplicar su población (HOY, 13 julho 1977) 
$\mathrm{Na}$ nota de imprensa se terminava assinalando que "Los oficiales de Conara mostrarán si con el ataque técnico ganan la batalla" (HOY, 13 julho 1977). Esse destaque técnico da autoridade militar da CONARA - supostamente acima das lógicas tradicionalmente políticas -, implicitamente demostrava que não existia um consenso sobres as posições do arranjo da RM, embora tampouco manifestassem publicamente suas diferenças. Sucessivamente se argumentava o seguinte: "Existe clara conciencia de los problemas que acarrea el crecimiento desmesurado, desordenado y concentrador de la RM, cuya presencia distorsiona todo el funcionamiento geoespacial a lo largo de la geografía chilena, con el consiguiente perjuicio para las demás regiones del país" (CONARA, 1976, p. 432). Na prática, as vias e formas de solução não tinham realidade política. Finalmente, em março de 1978, a CONARA anunciava que o Governo Metropolitano contaria com uma única autoridade de mando para a coordenação da ação das prefeituras, o Intendente, e, por sua vez, também se criaria uma SERPLAC e um conjunto de SEREMIS para o planejamento interno da região. Com isso, "los ministros dejarán de preocuparse de los problemas de la capital, que suelen distraer gran parte de sus preocupaciones, para mirar más el panorama nacional' (El MERCURIO, 26 março 1978). Porém, o Governo Metropolitano de Santiago, em concreto, se tornava bastante similar aos governos regionais do país. A ideia de um estatuto administrativo especial para Santiago rapidamente começava a dissolver-se em outro estratagema. Em 1978 a CONARA definia cinco províncias, as quais contariam com uma coordenação municipal (conselho de prefeitos) em torno a uma área específica mais urbanizada, a Área Metropolitana:

Dijo el general Canessa que el sistema de gobierno metropolitano se asemeja en mucho al que tienen las demás las regiones, naturalmente, con una diferencia importante, porque está rodeado de un área poblada o urbana donde se han creado cinco provincias [...]Explicó que esta región o Área Metropolitana está dirigida por un Intendente, quién delegará funciones fiscalizadoras y coordinadoras en un Subintendente [...] Añadió que también se propone crear un Consejo de Alcaldes, el que estará integrado por los 14 jefes edilicios de las comunas que componen esta zona, y que tendría que proponer medidas de coordinación sobre las siguientes materias: Prevención del medio ambiente, incluyendo conexión y el tratamiento final de la basura, problema de vital importancia para Santiago (EL MERCURIO, 09 setembro 1978).

A particularidade da RM radicaria na estrutura coordenada da Área Metropolitana, particularmente uma gestão integrada desde os prefeitos, porém controlada pelo Intendente da RM. Em um seminário para melhorar o sistema de toma de decisões em 1979, o coronel Juan Barrientos especificava que, em relação às províncias que compunham as regiões no país, na RM se constituiriam “Delegaciones Regionales” diretamente ligadas à Intendência Regional (CONARA, 1979). Aliás, novamente se afirmava a criação de um comitê de prefeitos que assessoravam as escolhas do Intendente regional, sobretudo, nas competências 
ligadas a uma "coordinación intercomunal del transporte y tránsito público, la de preservación del medio ambiente contra la contaminación y la de ordenamiento físico-espacial de las comunas, con el fin de dar unidad al gran centro-urbano de la capital nacional' (CONARA, 1979, p. 14). O sistema de governo e administração da RM, no fundo, não tinha maiores diferenças com as estruturas regionais. As atribuições metropolitanas não estavam por fora das competências dos Intendentes que, segundo os decretos-lei n ${ }^{\circ} 573$ e 575 , efetivamente poderiam coordenar tarefas e políticas a níveis provinciais ou no conjunto de prefeituras como máxima autoridade da região.

Em definitiva, o projeto de lei que finalmente estabeleceu o Regimen de Gobierno y Administracion de la Región Metropolitana de Santiago (GOBIERNO DE CHILE, 1980a), dois anos após (o decreto-lei no 3260, abril de 1980), não produziu realmente um regulamento administrativo diferente para a RM. Em 1980 se recortou a RM de Santiago em uma Área Metropolitana ${ }^{47}$ e cinco províncias (Melipilla, Chacabuco, Cordillera, Maipo e Talagante). Mais que um estatuto de administração diferenciado da capital, a lei de administração da RM começava a criar seus órgãos burocráticos funcionais ao sistema de planejamento regional integrado como o resto do país, incluindo, a criação da SERPLAC e SEREMIS. Por sua vez, se afirmava que, embora os organismos municipais iriam se reger com a mesma lei de municipalidades de 1975 (decreto-lei no 1289) a nível nacional, aquelas comunas que faziam parte da Área Metropolitana de Santiago teriam certas atribuições especiais para coordenar e avaliar ações conjuntas. Essas ações conjuntas, com efeito, seriam desenvolvidas em um comité de prefeitos presidido pelo Intendente Regional que, segundo o decreto-lei 3260, "podrá disponer que los Municipios aporten fondos para la realización de programas y tareas comunes, con sujeción a las normas financieras o presupuestarias que les sean aplicables" (GOBIERNO DE CHILE, 1980a, s./r.). Entretanto, como se demostrou anteriormente, aquelas atribuições já estavam contidas na lei e o regime de administração de Santiago não parecia ser uma real política diferenciada territorialmente. O que havia ocorrido? Em palavras do general Canessa, principal autoridade da CONARA desse arranjo, o processo de definição da RM terminou sendo "un incordio que tardó cinco años en resolverse, y la solución no me pareció satisfactoria" (CLAVEL, BALARD, 2006, p. 211). Essa insatisfação de Canessa se havia contrastado com os vários modelos estudados pela CONARA, tais como os casos de grandes cidades como Washington DC, México DF, Paris, Londres e Madrid. Para RM nunca existiu um consenso necessário

\footnotetext{
${ }^{47}$ A Área Metropolitana estava conformada por quinze comunas: Santiago, Las Condes, Providencia, La Reina, Ñuñoa, La Florida, San Miguel, La Granja, La Cisterna, Maipú, Quinta Normal, Pudahuel, Renca, Quilicura y Conchalí.
} 
para fazer um arranjo alternativo de serviços públicos e administração metropolitano de Santiago. Diz Canessa:

La instalación de un gobierno metropolitano dotado de autonomía fue debatida en muchas oportunidades. Establecimos que el área metropolitana de la región capital, a diferencia de las demás regiones, no formaría parte de una provincia, dejando así la puerta abierta para el paso siguiente, un gobierno metropolitano. Pero, desgraciadamente en los seis años que estuve en la cabeza de CONARA, no pude lograr un acuerdo final sobre Santiago y es una materia que todavía está pendiente $[. .$.$] En ese momento, simplemente, no encontré ambiente para hacer$ algo diferente (ARANCIBIA, BALART, 2006, p. 212)

Segundo Hernán Muñoz, funcionário de CONARA e administrador público da época, a estrutura de governo metropolitano fracassou em vários sentidos (ENTREVISTA HERNÁN MUÑOZ, maio 2020). Uma das razões centrais desse fracasso foi, acima de tudo, a distribuição do poder concentrado de Santiago entre suas unidades nacionais versus as formas locais e regionais que deveriam equilibrar as influências e a política territorial na capital. Ao concentrar as principais autoridades e hierarquias de todos os níveis institucionais do país, a RM criava uma situação muito difícil de modificar. Diz Muñoz:

Aquí estaban las municipalidades más importantes de Chile. Santiago, Providencia, Las Condes, Ñuñoa, etc., ¿qué ocurría en la práctica en el antiguo esquema? Los alcaldes se entendían directamente con los ministerios y las jefaturas de servicios nacionales, que estaban aquí mismo. El tema es extremadamente complejo porque se superponen autoridades, autoridades que usted no puede realmente controlar. Las municipalidades tienen autonomía, entonces, no pueden depender conceptualmente de nadie. Los municipios son organismos descentralizados territoriales. Además, como se ubican en el más importante lugar de concentración demográfico, económico, financiero, político y administrativo, que es la capital nacional de un Estado Unitario que, por diversas razones históricas, ha sido altamente concentrado. Imagínese usted las dificultades de crear un mecanismo territorial intermedio con funciones de gobierno y administración, en ese contexto. Es absolutamente difícil porque las fuerzas de la realidad se oponen. CONARA tuvo la intención que hubiera una autoridad metropolitana, en la cual, las autoridades comunales y los servicios públicos pudieran ser coordinados. Pero por el otro lado están los ministerios y los servicios. Había un tironeo en ambos sentidos. Por un lado, las municipalidades se negaban a perder su autonomía y, por otro, las autoridades nacionales no estaban dispuesto a tener que coordinarse con una autoridad que dependía del gobierno. Entonces, la buena intención se quedó en eso (ENTREVISTA HERNÁN MUÑOZ, maio 2020).

A citação é muito eloquente porque esclarece o pano de fundo de como foi pensada a regionalização: a reorganização administrativa do poder territorial para acrescentar o poder de representação nacional nas regiões e os territórios locais interiores, sem modificar a estrutura nacional centralista. O problema de estabelecer um mecanismo diferenciado da administração metropolitana, foi que, potencialmente, implicaria refazer as estruturas de poder central e as lógicas orgânicas da regionalização em seu centro orgânico de poder. Por 
isso, na prática, o regime autoritário nunca permitiu uma reestruturação orgânica daquela fonte de poder e suas diferentes estruturas nacionais-regionalizadas. Segundo o economista regional, Arturo Orellana, esse foi "el gran problema de la Regionalización, el gran error de la CONARA fue que no supo resolver el tema del Área Metropolitana de Santiago" (ENTREVISTA ARTURO ORELLANA, maio 2020). Embora as razões são múltiplas, sem dúvida, a força unitária-presidencialista foi uns dos principais limites que inabilitou qualquer possibilidade de um governo metropolitano, pois, no fundo, a política de Santiago historicamente tem sido resultado de políticas nacionais de La Moneda. Em termos de regionalização, segundo Orellana, a RM não foi mais que um artifício, perdendo-se então uma possibilidade histórica. A chave da indeterminação da RM foi uma questão política ancorada na clausura de qualquer disputa do poder hegemônico da capital e suas autoridades centrais. Contraditória e inversamente, as políticas metropolitanas voltam a ser as políticas menos territoriais enquanto gestão territorial descentralizada. Segundo Orellana:

Si aceptáramos la idea de una RM tendríamos que haber planteado un gobierno como distrito capital, como existe en Bogotá, México, etc. Es decir, que la ciudad más grande, capital, sea un distrito político administrativo propio. Pero si tú tienes un distrito administrativo propio tienes que crear una ley para decidir quién es la autoridad de ese distrito, y probablemente tienes que apelar a un alcalde mayor, a una figura de ese tipo, que en general la lógica es que sea elegido. La resistencia fundamental a la figura del distrito capital tiene que ver con la posibilidad de levantar un liderazgo para un universo electoral poco más grande del $40 \%$ de la población. Ese es el problema de fondo [...] Entonces, finalmente, yo diría, la RM es un artificio. Y siempre lo ha sido (ENTREVISTA ARTURO ORELLANA, maio 2020).

Embora a RM não era expressão de um poder realmente descentralizado, as fronteiras internas do território metropolitano continuaram sendo avaliadas pelas autoridades da CONARA. Um ano após, em março de 1981, o decreto-lei no 3642 da CONARA mais uma vez recortou territorialmente a RM, criando a Província de Santiago que, urbanística e internamente, estaria sendo objeto de importantes modificações. Era o golpe final de qualquer dúvida de distrito ou geografia política metropolitana. Técnica e linguisticamente, assim, a lei apagava a histórica promessa de uma Área Metropolitana de Santiago e com ela, qualquer possibilidade de criar uma administração territorial alternativa da escala metropolitana. Santiago voltaria a ser parte do processo de regionalização: região, províncias e comunas. Porém, paralela e internamente, a criação da Província de Santiago trouxe múltiplas significações. A nova província de Santiago da CONARA continha 17 novas prefeituras (decreto-lei $n^{\circ} 1-3260$ ) que projetavam uma rearticulação da escala urbana e o tecido socio-espacial das prefeituras na capital do país. Assim, a antiga Área Metropolitana de Santiago, agora Província de Santiago, ficava administrativamente mais fragmentada e 
organizada com 34 prefeituras (antes eram quinze), quase o dobro do conhecido historicamente até esse momento. O que estava acontecendo? Seriam as faculdades da administração e o governo da RM que estavam em jogo? Porque a CONARA homogeneizava por cima o nível da Província de Santiago, mas por baixo criava uma operação maior de recortes comunais e novas prefeituras?

A criação do Regime Administrativo e de Governo da RM foi mais uma formalidade da estrutura centralista comprometida pela regionalização, que uma política territorial para administrar o poder de Santiago. O reordenamento geopolítico das seis províncias e 34 prefeituras que regulamentaram os decretos em 1981, responderam mais a uma operação política de controle social e a reestruturação urbana neoliberal que, efetivamente, uma reorganização do poder político da capital. Com efeito, um ano antes do regime administrativo de Santiago, o Ministério de Moradia e Urbanismo modificou o Plano Intercomunal de Santiago via decreto-lei no 420 (GOBIERNO DE CHILE, 1979c). Esse dispositivo compreendia, objetivamente, a integridade da antiga Área Metropolitana que se organizava em nove setores geográficos ${ }^{48}$, cada um composto por uma ou mais comunas. A lei regulava a edificação e urbanização do território metropolitano, distinguindo três tipos de zonas entendidas em uma área urbana, uma área de expansão urbana e outras áreas de restrição. Na prática, a política de liberalização do solo urbano, a grandes rasgos, ampliou os limites urbanos da cidade de Santiago, desregulando a planificação das construções urbanas e suas estruturas de serviços, localizando moradias em espaços cada vez menos densificados e mais precarizados (HIDALGO, 2005), os quais, foram se acoplando a estruturas municipais com sérias desvantagens e condições de administração e governo. De tal modo, o arranjo das prefeituras na RM e a Província de Santiago de 1981 foram funcionais à reestruturação do limite urbano expandido (1979) e à política nacional de moradia que, a partir de 1982, começaria a ser intensificada através de um maior número de moradias construídas ao longo do país, mas sobretudo, pela intervenção espacial no interior dos espaços periurbanos destinados aos setores mais pobres da RM. Esse complexo movimento de intervenção nos setores populares, por sua vez, foi entrelaçado por outro complexo e violento processo de erradicações e relocalização de importantes grupos sociais na RM que também veremos mais adiante (capítulo VI). No entanto, como mencionamos mais acima, a

\footnotetext{
${ }^{48}$ Os setores foram 1) centro composto por Santiago; 2) No-Oriente por Las Condes e Providencia; 3) Oriente por La Reina e Ñuñoa; 4) sur-Oriente por La Florida, Puente Alto; 5) Sur por La Cisterna, San Bernardo, La Granja, San Miguel; 6) sur-poniente por Maipú; 7) Nor-poniente por Pudahuel, Quinta Normal; 8) Poniente por Quilicura, Renca; 9) Norte por Conchalí.
} 
partir de 1979 as políticas territoriais em Santiago traziam importantes dispositivos combinados que configurariam o governo da RM. Dessa forma, o decreto-lei $n^{\circ} 420$ de 1979 também estipulava que seria a SEREMI de Moradia e Urbanismo da RM, a instituição encarregada de definir cada uma das áreas urbanas, extensão e restrição (GOBIERNO DE CHILE, 1979c). Diz a lei:

Corresponderá a la Secretaría Ministerial de Vivienda y Urbanismo, Región Metropolitana, previo informe favorable de las instituciones u organismos legalmente competentes, declarar, modificar o derogar Áreas de Restricción, como asimismo establecer sus límites y usos permitidos, mediante decretos supremos del Ministerio de Vivienda y Urbanismo, cada vez que corresponda" (GOBIERNO DE CHILE, 1979c, s./r.).

Totalmente diferente do conjunto territorial do país, assim, a SEREMI de Moradia e Urbanismo volta a ser um agente fundamental no desenvolvimento territorial da RM, inclusive, antecipando o organigrama da CONARA. A SEREMI de Moradia e Urbanismo da RM, segundo a lei, deveria fiscalizar cada uma das condições de edificação e subdivisão predial que resguardariam a densidade urbana, com setores geograficamente definidos e níveis técnicos específicos: "coeficiente máximo de constructibilidad, porcentaje máximo de ocupación del suelo y superficie minima de los predios, aplicables a los distintos Subsectores Geográficos del área de expansión urbana, aparecen definidos por tramos" (GOBIERNO DE CHILE, 1979c). Dessa maneira, a presença da SEREMI de Moradia e Urbanismo da RM em 1979 foi o dispositivo que marcou a pauta dos limites territoriais da Região Metropolitana, sendo prova das diferenças do processo regional de Santiago do resto do território nacional. Era uma diferença sumamente significativa, pois, como vimos anteriormente, a estrutura regionalizada de Santiago apenas começaria sua reforma em 1980, com a criação do regime administrativo e de governo da RM e a criação da SERPLAC da RM. Então, mais uma vez, se esclarecia o tratamento diferenciado do poder central em Santiago e o comportamento institucional de todas as outras regiões do país. A SERPLAC que deveria definir a estrutura de governo da RM, em Santiago, foi criada após a SEREMI de Moradia e Urbanismo que liderou a estrutura das parciais mudanças da capital andina. Essa informação, mais uma vez, demostra que Santiago foi um caso diametralmente diferente do conjunto do país e nunca esteve efetivamente integrado ao processo de regionalização. O que tinha acontecido estruturalmente na relação Santiago e as regiões nesses sete anos de reforma (1974-1981)?

Segundo De Mattos, em comparação ao crescimento da população do país que flutuou entre um 16,8\%, a RM aumentou a um 19,7\% durante o período, sendo, por sua vez, um 
39,4\% da população nacional em 1990 (DE MATTOS, 1998). Esse crescimento, aliás, foi resultado de uma "persistente expansión de la mancha urbana central que la ha desbordado continuamente los límites de la $A M S$, extendiéndose hacia las áreas rurales aledañas de otras provincias de la AMS" (DE MATTOS, 1998, p. 65). De igual maneira, Santiago continuou sendo o principal centro de localização dos serviços altamente especializados e das oficinas financeiras das principais atividades econômicas do Chile (DE MATTOS, 1992, p. 24), atraindo também os setores industriais e tecnológicos que escasseavam nas regiões (DE MATTOS, 1998, p. 66). Esse informe crítico de De Mattos também se complementa com um balanço da própria CONARA em 1985 dizia:

\begin{abstract}
Las estadísticas de población de acuerdo a los Censos elaborados por el Instituto Nacional de Estadísticas (INE), para los años 1960, 1970 y 1982, indicarían que al mantenerse la mayor concentración en la Región Metropolitana de Santiago, con una tendencia a aumentar su participación, pues pasa de un $32,1 \%$ en 1960 a un $38,1 \%$ en 1982, ello reflejaría cierta incapacidad del Proceso de Regionalización para cambiar la tendencia concentradora [...] El objetivo de armonizar el crecimiento espacial del país, no se habría alcanzado si se considera solamente el factor población, puesto que los niveles relativos de habitantes por región no han tenido cambios importantes, siendo las variaciones experimentadas por las poblaciones regionales insuficientes para cambiar la ubicación de cada región, de acuerdo al número de habitantes, con la sola excepción de la VII Región, cuya tasa de crecimiento le permitió superar la evolución de la población de la IX Región (CONARA, 1985, p. 189).
\end{abstract}

Os números eram eloquentes. Apesar do processo de regionalização, diferentes indicadores confirmavam que a concentração e o peso econômico substantivo de Santiago em relação às regiões, não era alterado substantivamente. No entanto, seria esse resultado de maior concentração e hierarquia do poder de Santiago um fracasso absoluto da regionalização? Acaso a conformação metropolitana em termos de distribuição do poder tinha sido uma prioridade do regime? As dificuldades e contradições na capital do país mostravam fielmente o programa da regionalização: acrescentar o poder nacional do governo através de uma maior capilaridade territorial. Embora Santiago continuava sendo absolutamente concentrado demográfica e economicamente, através do arranjo regional instituído entre 1974 e 1981, as 13 regiões incluída a XIII Região Metropolitana e suas respetivas SERPLAC, o governo territorial nacional efetivamente reforçou sua estrutura organizativa e com isso a projeção política da Junta de Governo e o General Pinochet, permitindo maior coesão e unidade aos governos regionais. Entretanto, isso não significou um desenvolvimento compensatório das desigualdades geográficas estruturais entre Santiago e as regiões ou no interior das próprias regiões. Nesse sentido, mais que uma forma de poder político afim aos processos territoriais, os dispositivos técnicos e políticos da regionalização impulsionaram e ampliaram a representação do governo nacional na região, criando 
burocracias mais tecnicamente eficientes que o período anterior, com seleto time de profissionais e pessoal administrativo, embora sem os recursos de autoridade e poder suficientes para fazer efetivos os governos regionais. 


\section{CAPÍTULO 5}

\section{Províncias, geopolítica e vigilância}

\subsection{Províncias: novas ou velhas fronteiras internas?}

O século XIX se caraterizou pela construção inorgânica das fronteiras internas. À diferença de um processo de sistematização e projeção de unidades territoriais proporcionais e relativamente homogêneas, os limites administrativos se consolidaram a partir de uma consecutiva reestruturação fragmentaria e cambiante que, aliás, alterou os regulamentos e regimes territoriais. Dois fatos chaves dessa configuração inorgânica e fragmentaria do regime territorial foram, por um lado, o desconhecimento científico das caraterísticas geográficas do conjunto do território nacional e, por outro, a extensão das fronteiras no extremo norte pela resolução da guerra contra a Confederação Perú-Boliviana e o processo de ocupação militar-colonial nos históricos territórios das comunidades mapuches na zona centro Sul do país (ESTEFANE, 2017). Com a ampliação dos domínios da soberania chilena no transcurso do século XIX para o XX, as províncias concentraram as principais discussões do papel do Estado territorial chileno, sobretudo, a particular demanda de contar com os maiores mecanismos administrativos e recursos burocráticos sem a dependência política da capital de Santiago. Nas províncias de Concepción, Copiapó e Magallanes se organizaram os principais levantamentos contra as definições centralistas, incluindo tropas e batalhas militares.

Porém, cada um desses movimentos foi derrotado e nunca conseguiram ampliar um poder territorial significativo da representação provincial (TOBAR, 2016; VALENZUELA, 2015). Segundo Estefane, os debates em torno da regulação do território interno estiveram presentes em todas as fórmulas constitucionais, inclusive, nos primeiros fundamentos liberais que precisaram romper com a estrutura colonial da Espanha e fixar os termos da unidade nacional e o poder deliberativo das suas competências internas (ESTEFANE, 2017). A máxima expressão liberal descentralizadora se constitui nos inícios do século XIX com o efêmero ensaio federal de 1826 e a constituição de 1828 que, a juizo do historiador, demostrou "que el problema no pasaba por la división territorial octopartita, ya asimilada en el discurso político, sino por la organización del gobierno interior" (ESTEFANE, 2017, p. 95). Embora existiram diversas manifestações a favor da autonomia das províncias, desde logo se articulou burocraticamente um poder centralista de Santiago, especialmente nas constituições de 1833 e 1888 que reinstalam as prerrogativas do Presidente da República frente a qualquer tipo de 
descentralização política. De 1833 adiante, a ideia de um Estado-central-unitário dominou as disputas e decisões políticas que, mais que defender a unidade nacional ou algum tipo de republicanismo liberal, permitiram a naturalização de um modelo autoritário e conservador de concentração do poder político de Santiago (VALENZUELA, 2015).

A partir de um conhecimento estatístico e científico do território nacional no decorrer do século XX, as províncias foram se agregando e reavaliando indistintamente. A Constituição de 1925 reconheceu 25 províncias que, na prática, continuaram o papel subordinado das províncias frente a Santiago através do mecanismo de nomeação das autoridades principais e de um regime de governo interior verticalizado no Presidente (BULNES, 1989; TOBAR, 2016). Em 1927 o governo autoritário de Carlos Ibañez do Campo começou um importante processo de redefinição do marco espacial das províncias, que a partir de uma agenda de redução do gasto público, terminou reduzindo o seu número de vinte e cinco para dezessete. Contudo, rapidamente após a queda de Ibañez, as províncias foram se restabelecendo até voltar ao modelo de 1925 (ESTEFANE, 2017). Nesse contexto fortemente centralista, as reformas regionais das décadas de 1960 e 1970 - com pólos de desenvolvimento e criação de secretarias públicas destinadas a reagir no regional-provincial -, certamente ampliaram os repertórios das possibilidades territoriais, principalmente no econômico. No entanto, a estrutura política interna do regime centralista nunca foi questionada (SOMS, 2010; BEDRACK, 1974).

Desse modo, até o momento da regionalização da CONARA, as províncias foram as principais formas de organização do governo sub-nacional e, portanto, símbolos das demandas descentralizadoras ou de um poder territorial mais equitativo e com maiores níveis de autonomia em relação com Santiago. Daí a forte significância simbólica que implicou o arranjo regional e que consolidou o nível subnacional nas regiões. As províncias perderam sua hierarquia, porém, continuaram presentes junto com outras unidades territoriais prefeituras -, mudando seu papel simbólico e operativo no regime territorial. Das originais, vinte cinco províncias no início do processo autoritário em 1973, passaram a duplicar-se à cinquenta e uma unidades provinciais operativas no início da década de 1980 (quadro no 15). Essa ampliação interna, inscrita no processo de regionalização e no SIGORE, entendia as províncias como o nível intermediário entre a região e a comuna, sendo uma maneira de desburocratizar o antigo governo interior provincial organizado internamente em departamentos, delegações, subdelegações e distritos. A principal autoridade da província era 
o Governador provincial, quem devia coordenar o programa oficial de governo entre as unidades subnacionais e locais. Assim, se deslocaria aquelas unidades burocráticas inoperativas e disfuncionais do antigo sistema territorial e também se reforçaria o sistema de planejamento nacional e o escalamento de poder regional integrado do SIGORE.

Entretanto, à diferença das regiões que possuíam uma burocracia montadas nas pautas nacionais (SERPLAC e SEREMIS), as províncias careceram de um apoio administrativo-burocrático capaz de guiar e estabelecer funções de coordenação e planejamento territorial como supunha a lei. Em contrapartida, os decretos leis da regionalização foram tecendo, desde o ponto de vista dos orçamentos públicos, uma rede de comunicações cada vez mais orgânica e direta entre o nível central, o nível regional e o nível municipal que prescindia da gestão territorial do Governador Provincial. Segundo a CONARA, a criação das novas províncias continuou na mesma sequência espacial das unidades regionais, sendo considerada como a segunda etapa do processo geral de subdivisão das fronteiras internas. Temporalmente as províncias se recortaram em quatro ocasiões (quadro $\mathrm{n}^{\circ}$ 15). Primeiro, o recorte das províncias dos extremos do país (1975), seguida imediatamente pelo recorte nos espaços centrais e intermédios (1976). Posteriormente, com um particular ajuste do arranjo anterior distribuído em diversas áreas do país (1979), para finalizar com a divisão provincial na RM de Santiago (1981), sempre a última fronteira dos recortes oficiais.

Em termos estritamente espaciais do recorte, se algumas províncias passaram a ser reconvertidas integralmente em unidades regionais da máxima hierarquia do sistema, em outras foram subdivididas em unidades menores do que suas originais articulações administrativas. Precisamente essa foi a tendência da CONARA: províncias menores, embora territorialmente significativas do ponto de vista geoestratégico da comunicação do centro regional e da capilaridade das fronteiras interiores e externas. Do ponto de vista técnico dos recortes cartográficos, as províncias continuaram agrupando-se nos antigos limites departamentais da Constituição de 1925, embora muitos deles desapareceriam ou se reagrupariam a partir de outros limites ou contornos espaciais. Só em alguns casos, realmente muito significativos, se efetivaram estritamente novas linhas político-administrativas provinciais que romperam com as antigas linhas interiores. Daí a importância de mergulhar em seus recortes e distinguir quais foram seus principais fundamentos enquanto dispositivo de governo do regime autoritário. Dentro dos diversos trabalhos e pesquisas no campo da 
regionalização, o arranjo das províncias têm sido o fenômeno político menos estudado no processo autoritário $^{49}$ (DIAZ, 1989).

Quadro no 15. Recortes Províncias (1974-1981)

\begin{tabular}{|c|c|c|}
\hline Ano/data & Decreto & Províncias \\
\hline $27 / 10 / 1975$ & 1230 & 16 \\
\hline $31 / 12 / 1975$ & 1317 & 24 \\
\hline $20 / 09 / 1979$ & 2867 & 5 \\
\hline $07 / 03 / 1981$ & 3642 & 6 \\
\hline
\end{tabular}

Fonte: elaboração própria.

Logo após um ano do recorte de regiões, se iniciou a criação oficial dos primeiros recortes das províncias. Como dizíamos mais acima, a sequência das províncias continuou o mesmo roteiro das regiões pilotos de julho de 1974. Apenas nomeados os primeiros Intendentes Regionais (das I, II, VIII, XI, XII regiões), eles tiveram que configurar um estudo de suas respetivas particularidades territoriais para argumentar a mudança dos possíveis limites de suas províncias. Uma vez consultado e discutido pelas autoridades locais da região, o Intendente Regional encaminhava um informe à CONARA, quem finalmente o avaliaria e definiria os últimos detalhes das fronteiras provinciais. A eficácia desses informes era contrastada com visitas a terreno dos próprios oficiais e assessores da CONARA, nas quais iam diagramando as escalas cartográficas para ter a maior precisão na descrição dos limites, e dessa maneira, assegurar uma coesão técnica e operativa das fronteiras internas. Em janeiro de 1975, ainda sem a lei oficial, o general Canessa desestimava alguns nomes e delimitações das novas províncias difundidas pela imprensa, onde aliás, destacava que as províncias ainda não estavam aprovadas pelo Presidente, embora já se encontrassem na parte final do trabalho da "Comisión Consultiva de Microrregiones nombrada para el caso y que preside el Sr. General de Brigada Jorge León Villarreal, el que una vez. analizado por $\operatorname{CON} A \mathrm{R} A$, será expuesto al Presidente de la República y la H. Junta de Gobierno" (LA PATRIA, 04 janeiro 1975). Na nota de imprensa também se destacava que a comissão de microrregiões era conformada por diferentes especialistas da CONARA, além de uma importante contribuição do Colégio de Arquitetos do Chile, que havia formulado o estudo Nuevas provincias de Chile, Proposición de

\footnotetext{
${ }^{49}$ Praticamente não existem estudos especializados no recorte das províncias e suas principais autoridades. As razões se trasladam, em primeiro lugar, às escassas análises geográficas e históricas da regionalização e sua estruturação enquanto processo político e dispositivo de governo. Mas não apenas isso. Talvez uma explicação mais abrangente da ausência de reflexões foi a ainda escassa informação pública referente ao papel dos governadores enquanto sua condição militarizada das decisões que, possivelmente, deveriam ser feitas na província, sobretudo considerando a complexa situação política repressiva que definia a escolha de manter uma hierarquia militar na estrutura de funcionamento do sistema regional integrado.
} 
unidades micrroregionales o provincias, sendo este o documento base da discussão. Nesses primeiros debates públicos das províncias, começaram a reconhecer-se publicamente os fundamentos daquela nova função provincial, como destacou o general Canessa: "En sintesis la Microrregión o provincia, debe desarrollarse intensificando su producción típica, en cambio la Región lo hará sobre la base de integrar diversos sectores de producción, representados por las provincias" (LA TERCERA DE LA HORA, 30 janeiro 1975). Dessa maneira, o recorte provincial deveria se projetar em uma condição produtivista que, geograficamente, se especificaria e reconheceria economicamente como zonas de maior intensificação e especialização no interior da região. No entanto, a questão prática do arranjo provincial se ligava a um outro assunto mais administrativo: suprimir os antigos distritos, delegações e departamentos da Constituição de 1925. Em relação a esses últimos, se destacava a perda de identidade e integração social pelo desaparecimento dos departamentos:

\begin{abstract}
En cuanto a la supresión de los departamentos ello podría crear un vacío, porque entre la comuna y la provincia o microrregión existirá una notable diferencia de tamaño. La ausencia de organismos intermedios en ese nivel puede ser obstáculo para la integración de los ciudadanos a la comunidad [...] Se trata de originar nuevas fuentes de trabajo, mantener radicados en las regiones a sus mejores elementos para que no se trasladen a Santiago, donde a menuda arrastran una existencia apremiada, e infundirles esperanza en el despegue de sus lugares de origen. Habrá que subrayar una vez más la necesidad indispensable de crear un espíritu nuevo para enfrentar la vida en las regiones [...] Autoridades y funcionarios públicos tendrán que acostumbrarse a tomar decisiones por sí mismos, eliminando trámites innecesarios de consulta. Sólo en esa forma las regiones conseguirán autonomía real (EL MERCURIO, 13 junho 1975).
\end{abstract}

A nova escala da província se homologou no lugar dos antigos departamentos que agrupavam um conjunto de subprefeituras e que se intermediavam entre as antigas províncias e os níveis locais. Além disso, segundo a CONARA, a nova província tinha que articular uma coesão produtiva e populacional capaz de imprimir um maior nível de desenvolvimento territorial, no sentido de ampliar as possibilidades de locação de infraestrutura e oportunidades para seus habitantes. Desde os primeiros anúncios das autoridades da CONARA e das diferentes projeções da imprensa, oficialmente, as criações das novas províncias vieram a reforçar o sentido produtivista das regiões. Porém, ditas projeções e possibilidades não necessariamente tinham uma correlação direta com a criação dos instrumentos e mecanismos de intermediação econômica efetiva. Na prática, a criação de províncias ou microrregiões não implicou nenhuma política de fomento produtivo ou aceleramento de corporações públicas tendentes ao fortalecimento de projetos de infraestrutura territorial estratégica. Mais bem, o arranjo provincial tinha um sentido administrativo que procurava ampliar e vigiar o sistema de intermediação territorial 
verticalizado no centro regional, sendo uma coluna de intermediação dos territórios interiores, particularmente ligada ao desenvolvimento das prefeituras e as trajetórias políticas dos prefeitos.

No entanto, o fato de anunciar a criação de novas capitais provinciais gerou altas expetativas e permitiu surgir velhas rivalidades entre as históricas comunidades locais. Primeiro foi a disputa pela capital da província de Aconcagua entre os prefeitos das comunas de Los Andes e San Felipe, como já vimos no capítulo II. Pouco tempo depois, foram os prefeitos das comunas de Quillota, La Cruz, La Calera, Nogales, Hijuelas, Llay-Llay, Limache e Olmué, todas pertencentes à região de Valparaíso. Através de uma carta os prefeitos comunicaram expressamente ao Presidente da República a necessidade da criação efetiva da Província de Quillota (V Região) e sua preocupação frente a um possível "centralismo porteño" (LA SEGUNDA, 21 agosto 1975). O não reconhecimento de Quillota, embora estivesse presente em todos os estudos anteriores da CONARA, para os prefeitos se criava assim uma "centralización administrativa y hará ilusorios los beneficios que se esperan de esta nueva estructura creada por el Supremo Gobierno" (LA SEGUNDA, 21 agosto 1975). Possivelmente em diversas regiões do país existiram múltiplas situações ou disputas similares aos casos de Aconcagua e Quillota, onde um conjunto de prefeitos ou autoridades locais manifestaram suas preocupações diante de possíveis perdas de centralidades, sobretudo, no referido ponto da localização da capital provincial entendida como símbolo de poder político ou fonte de atividades econômicas apoiadas desde o nível central.

A partir desses debates iniciais e da criação de novas capitais provinciais, a CONARA resolveu uma primeira provincialização do território em janeiro de 1976. Em concreto, foram dois decretos leis que oficializaram os recortes provinciais da primeira etapa com uma leve diferença temporal ${ }^{50}$. Nas regiões I, II, III, IV, V, XI, XII praticamente todos os departamentos passaram a ser províncias, com certos casos onde sumiram alguns departamentos e outros unificados passaram a articular uma nova, como foi o caso da Província de Choapa na IV região. Em contrapartida, as áreas onde mais existiram movimentações e alterações dos antigos limites departamentais foram os casos das regiões do centro sul do país, particularmente nas regiões VI, VII, VIII, IX e X. Nessas regiões se suprimiram um importante número de departamentos, permanecendo um número inferior

\footnotetext{
${ }^{50}$ Primeiro, o decreto-lei $\mathrm{n}^{\circ}$ 1230, promulgado o 27 de outubro de 1975 com dezesseis unidades provinciais e, posteriormente, o decreto-lei $\mathrm{n}^{\mathrm{o}} 1317$, promulgado o 31 de dezembro de 1975 , com vinte e quatro unidades provinciais.
} 
de províncias que integraram os antigos departamentos. Por exemplo, a X Região, que possuía quinze departamentos, passou a ter quatro províncias, e por consequência, daí se dissolveram onze departamentos (Panguipulli, La Unión, Rio Bueno, Río Negro, Puerto Varas, Maullín, Calbuco, Palena, Ancud, Castro, Quinchao).

A zona sul do país tinha uma maior fragmentação de departamentos por províncias do que na zona norte ou centro do país. Essa intensificação das fronteiras internas se inicia no processo de ocupação colonial da zona da Araucanía e nos históricos territórios do povo mapuche (VII, VIII, IX, X regiões), que até meados do seculo XIX, ainda tinham um importante deficit do controle nacional. Foi pouco antes do fim do século XIX que o Estado chileno conseguiu organizar territorialmente as fronteiras internas da Araucanía (ESTEFANE, 2017). A lógica colonial do Estado chileno tendeu a criar uma maior fragmentação das unidades locais da divisão político-administrativas nessas zonas. Daí que, para o momento da regionalização da CONARA, existia um significativo número de comunas e departamentos nesses territórios. Apenas nessas quatro regiões (VII, VIII, IX, X) do setor Sul existiam cinquenta e cinco departamentos, um número bem representativo da vontade estatal com o antigo território da Araucanía, considerando que até 1975 existiam noventa departamentos em todo o país.

Passado um ano e meio após o início da regionalização, das originais vinte e cinco províncias em 1974, o território nacional se fragmentou em quarenta unidades provinciais. Trata-se de um agrupamento espacial que modificava o sentido da original província chilena até esse momento: "Las provincias, no corresponderán, como se ha hecho evidente desde el comienzo de este proceso, a las antiguas unidades territoriales del mismo nombre [...] En general las nuevas provincias serán de menor tamaño y, por consiguiente, más numerosas que las tradicionales" (EL MERCURIO, 4 janeiro 1976). Das quarenta províncias que iniciavam oficialmente o recorte em janeiro de 1976, é interessante notar que as capitais provincias, em sua maioria, eram cidades mais tradicionais e historicamente relevantes. Salvo contadas exceções, como por exemplo, o desaparecimento da antiga Província de Maule (uma província de fundação colonial com importantes representações agrícolas e culturais do campo chileno tradicional), as novas províncias tinham uma conexão histórica com as antigas centralidades, recriando, de alguma forma, um micro centralismo regional do sistema provincial na reforma. 


\section{Mapa $\mathbf{n}^{\circ}$ 3. Províncias decreto-lei $\mathrm{n}^{\circ} \mathbf{1 2 3 0}$}
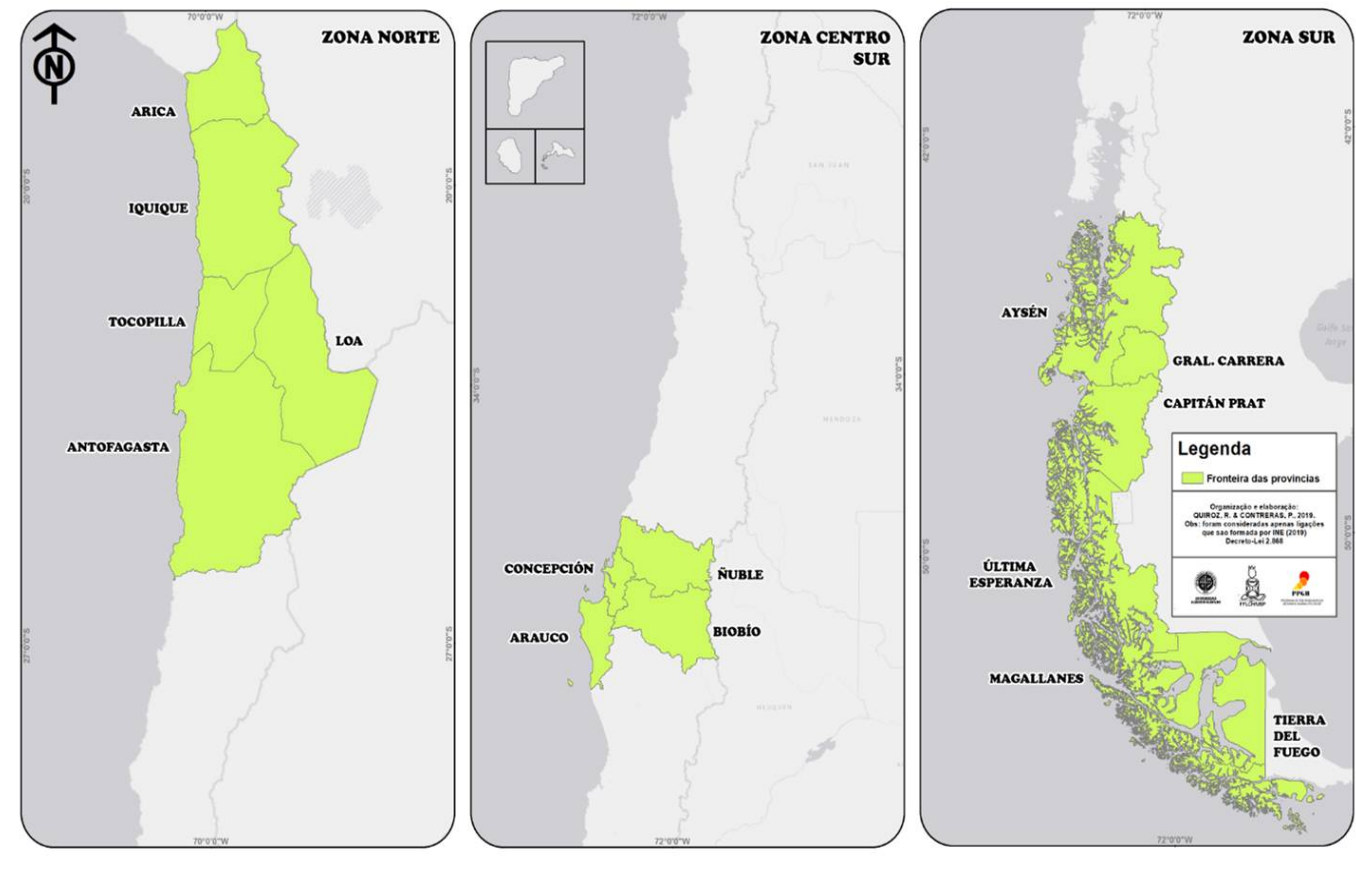

Fonte: elaboração própria com base no decreto-lei no 1230 .

Desse primeiro recorte provincial do território nacional, rapidamente o caso da dissolvida província do Maule significaria a primeira controvérsia. Efetivamente, a comunidade maulina começou uma ativa campanha para reativar sua condição de província e enfrentar as possíveis perdas territoriais, sobretudo em relação à remoção de funcionários, oficinas, maquinarias e investimentos no território. A perda da província do Maule, segundo a imprensa da época, significava o "término de actividades de casas comerciales, cierre de industrias, disminución de trabajo, emigración de familias y cuyos resultados negativos contradicen el espiritu de la regionalización" (LA TERCERA DE LA HORA, 22 janeiro 1976). Sobre a base desses influxos negativos e uma agitada organização de indicados locais, em março de 1976, se constituiu o Comité de Defensa de la Provincia del Maule com um presidente, Artemio Arellano, quem destacou que já havia começado o êxodo de funcionários públicos e profissionais a outros lugares do país que, aliás, tinha se produzido uma singular baixa no sistema escolar, provocando uma situação de desuso dos recintos educacionais (EL MERCURIO, 30 março 1976). 


\section{Imagem no 18. Província do Maule Unida}

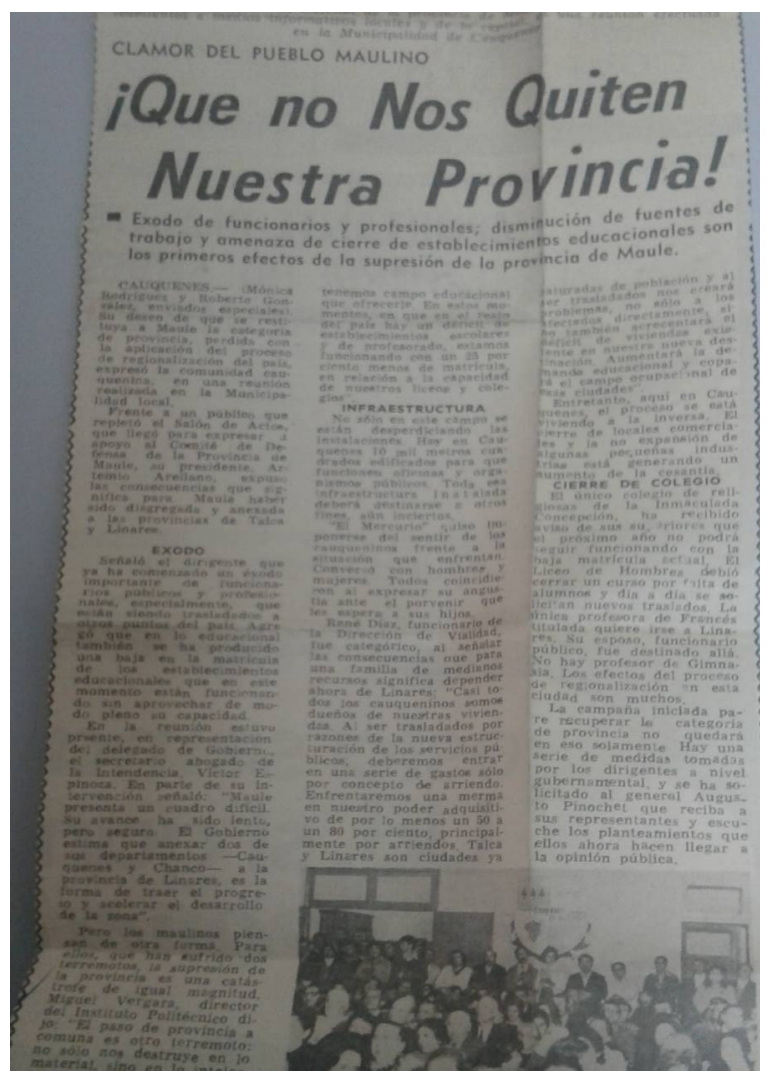

Fonte: El Mercurio, 30 de março 1976.

Rapidamente, assim, se esboçaram propostas de restituição da província e se anunciou uma viagem a Santiago onde o comitê se reuniria com a CONARA, buscando anexar a antiga província do Maule com Linares (LA TERCERA, 7 de abril de 1976). Segundo Miguel Vergara, diretor do Instituto Politécnico de Maule:

El paso de provincia a comuna es otro terremoto: no sólo nos destruye en lo material, sino en lo intelectual. En el sector educacional pasaremos a depender de Linares, lo que entraba considerablemente la acción. Nuestra juventud tiene que emigrar a otras ciudades porque aquí no tenemos campo educacional que ofrecerle. En estos momentos, en que en el resto del país hay un déficit de establecimientos escolares y de profesorado, estamos funcionando con un $25 \%$ menos de matrícula en relación a la capacidad de nuestros liceos y colegios (LA TERCERA, 7 abril 1976).

Para a comunidade do Maule a perda da província seria uma perda múltipla em infraestruturas e organismos públicos básicos que, no transcurso do tempo e com a consolidação das outras capitais provinciais, tenderia a prejudicar os ingressos das famílias e economias locais, inclusive na área de moradias. Além da veracidade dos argumentos para defender a restituição da província, a comunidade da antiga província do Maule esteve 
fortemente organizada nos seguintes anos e mantiveram contínuos diálogos com a CONARA. É interessante distinguir que o arranjo das províncias se entendeu como um dispositivo de equidade territorial e diminuição das históricas desigualdades geográficas, embora as províncias continuavam sendo entes mais administrativos que uma coordenação estratégica de instrumentos produtivos territoriais.

\section{Mapa $\mathbf{n}^{\circ}$ 4. Províncias decreto-lei no 1317}
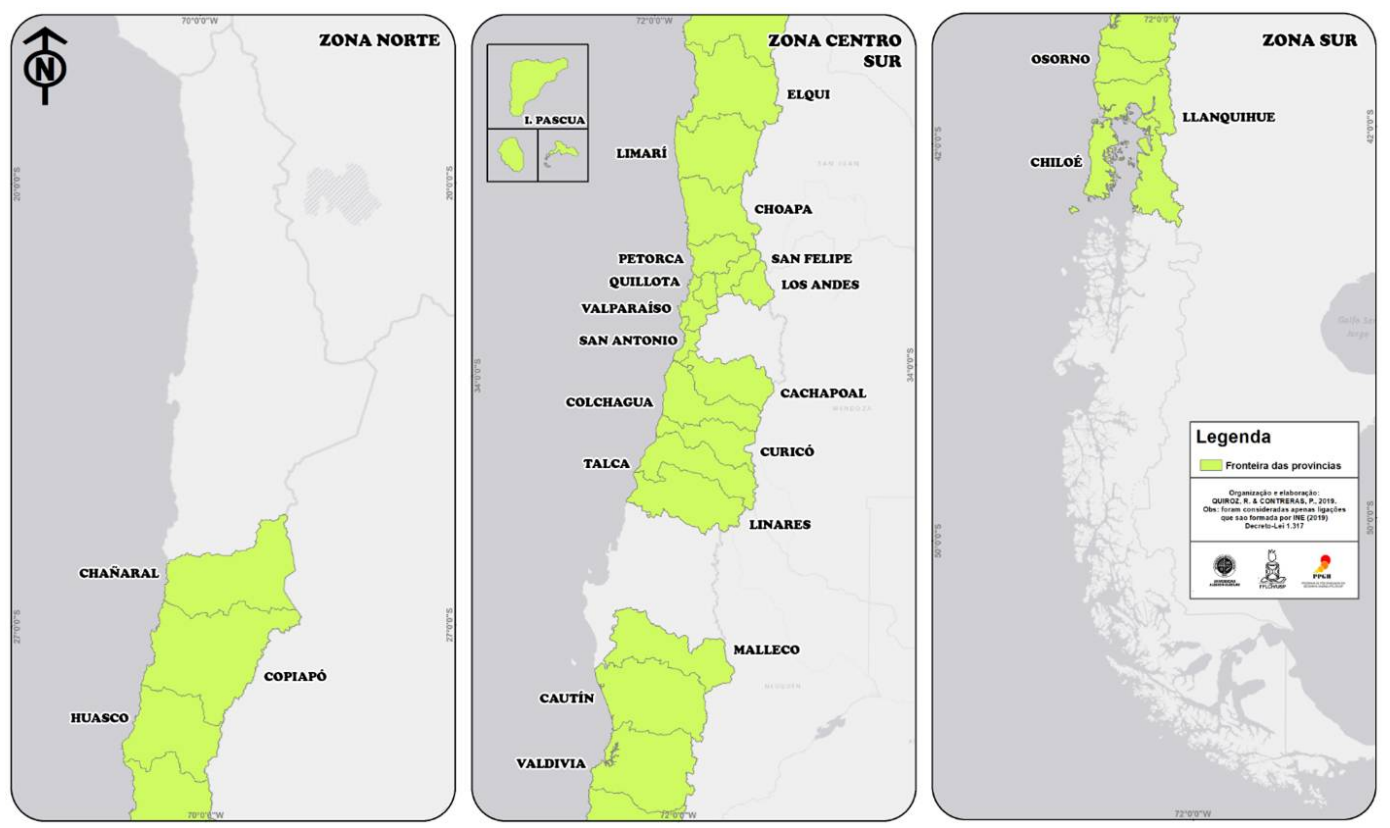

Fonte: elaboração própria com base no decreto-lei no 1317.

A busca para reverter a medida oficial mostra também a diversidade de repertórios de movimentação que transmitiam um forte sentido de identidade da malha territorial do país e o desejo político de reconhecimento enquanto território provincial. Para o acadêmico Esteban Valenzuela, a escolha por uma desconcentração de autoridades territoriais parece plausível, considerando os paupérrimos recursos que contavam as antigas províncias. No entanto, os antigos departamentos tinham um papel significativo na coesão mais identitaria e operativa dos territórios locais, assim, seu desaparecimento significou um assunto políticocultural relevante:

Es muy importante la extinción de los departamentos porque tenían una estructura, tenían un delegado, tenían una unidad de desarrollo y generaban una cierta identidad. Por ejemplo, la provincia de O`Higgins tenía el departamento de Rapel, Caupolicán y Rengo y así, cuando se revivió, cuando se creó la región de O’Higgins me llamó mucho la atención que se haya creado [...] esa historia departamental está muy subvalorizada (ENTREVISTA ESTEBAN VALENZUELA, outubro 2019). 
Para a CONARA, as províncias eram apenas um escalão de uma operação maior do ordenamento do Estado e suas funções públicas. Embora os discursos oficiais projetavam uma significação identitária das bases sociais e territoriais do país, as províncias nunca foram ligadas à um mecanismo que permitisse ressaltar maior diferenciação do local ou de suas práticas culturais. Pelo contrário, a regionalização tendeu a criar mais homogeneização das fronteiras internas, tendo um sentido mais operativo para a desconcentração do poder central e uma verticalização interligada entre suas autoridades territoriais. Em 1978, no jornal Últimas Noticias, se questionava ao tenente Alejandro Gonzalez Samohod sobre o padrão espacial das províncias, e particularmente sobre o caso da província de Parinacota pertencente à I Região. O secretário executivo da CONARA respondia:

Hay gente que no ha entendido el nuevo concepto de provincia que ha establecido CONARA. El concepto básico era más bien político-electoral. El enfoque de CONARA es eminentemente técnico. Entendemos la provincia como una unidad geográfica con un destino productivo propio, que se integra al ámbito de la región. Este es un país largo y díficil de desarrollar. Hay áreas con espacios vacíos, que tienen escasas posibilidades de radicación de pobladores por falta de expectativas. Es el caso de Palena - capital de Chaitén -, cuyo destino aparece muy ligado a las proyecciones del camino que unirá Aysén y Chiloé con el resto del país. Esa unidad geográfica la justifica como província (ÚLTIMAS NOTICIAS, 2 abril 1978)

É interessante a citação porque se bem se reafirma o assunto produtivo original da regionalização, também remarca uma outra variável orgânica da sua constituição: os espaços vazios. O arranjo das províncias, assim, passou a ter um sentido geopolítico que não necessariamente coincidia diretamente com o plano de planejamento nacional e a intensificação produtiva da região que fundamentava CONARA a inícios. No fundamental, se tratou de articular assuntos de integração e aumentar a presença do Estado naquelas zonas onde não existiam maiores assentamentos, ou onde a conetividade manifestasse algum grau de dependência ou obstáculo para a circulação do território interligado nacionalmente, como o caso da Província de Palena, mencionado pelo coronel Gonzalez Samohod. Um ano após a essa entrevista, precisamente, Palena junto a outras quatro províncias, constituiriam o terceiro recorte das províncias (decreto-lei no 2867). A CONARA atualizava tais recortes enquanto a agência do governo vivia uma particular crise de suas fronteiras internas.

\subsection{A dimensão geopolítica das províncias limítrofes}

O arranjo provincial de 1979 foi um recorte arbitrário em relação a sequência processual característica dos recortes das regiões e províncias até esse momento, pois não deu continuidade à distribuição das zonas norte-sul do país para finalmente chegar ao caso 
da RM. Com efeito, a distribuição espacial das cinco províncias de 1979 escapavam à visão continua, integrada e uniforme de como havia sido projetado pela CONARA nos recortes anteriores. O arranjo de 1979 consolidou o caráter geopolítico da integração e defesa das fronteiras externas ao interior dos comandos administrativos nacional (mapa $\left.n^{\circ} 4\right)$. Essa mudança geoestratégica na direção dos limites provinciais se fundamentava na complexa situação dos conflitos limítrofes do Chile com seus vizinhos entre 1974 e 1978, situação que implicou na quase declaração de guerra contra Argentina (sul) e Perú (norte). Como destaca o ex coronel do Exército, Jorge Sanz, a propósito do processo de regionalização:

\begin{abstract}
Pensando en la realidad geoestratégica que nosotros teníamos, era fundamental tener el control y el dominio total del territorio y había espacios que el Estado de Chile no los controlaba, no llegaba [...] Entonces, no era determinante la lejanía, sino la inexistencia de un crecimiento armónico del Estado. Por consecuencia, en la búsqueda de ese crecimiento armónico se comienza a hacer un montón de estudios y terminamos en el proyecto de las fronteras interiores. Y ese proyecto lo que decía es lo siguiente: mire el territorio nacional y sus determinadas características, hay algunos lugares desarrollados y otros donde efectivamente son fronteras, donde el Estado no llega, entendiendo el término frontera como el punto último de influencia. En ese tiempo frontera significa donde el Estado no existe, por eso se llama fronteras interiores (ENTREVISTA JORGE SANZ, novembro 2019).
\end{abstract}

O recorte das províncias de 1979 reforçou a capilaridade do Estado enquanto a necessidade de combater as áreas vazias das comunidades mais isoladas e desprovistas de equipamentos básicos, e condicionando assim a conetividade dessas áreas com o sistema de circulação regional e nacional. Entre os meses de novembro de 1978 e janeiro de 1979, o regime quase entrou em guerra com a vizinha Argentina pelo controle de uma parte do Canal Beagle. A escalada do conflito significou a movimentação conjunta das FF.AA. nos cenários de guerra fronteiriços e uma estratégia territorial para a defesa do país em toda sua extensão fronteiriça. Se bem o núcleo do conflito se centrou na possessão das ilhas Picton, Nueva e Lennox no extremo Sul chileno, dita movimentação também provocou a reativação da tensão na fronteira norte com o Perú, que também manifestou abertamente suas pretensões de redefinir as questões fronteiriças pendentes com o Chile pela Guerra do Pacífico através de uma forte tropa de artilharia instalada em sua fronteira sul. Em ambos momentos de máxima tensão (1974 e 1979), o general Canessa, então Ministro Presidente da CONARA, foi nomeado Chefe da Região Militar Norte e, portanto, comandante do Teatro Norte Conjunto responsável por todas as FF.AA., da proteção da subsistência da população civil e dos recursos logísticos da área norte ${ }^{51}$.

\footnotetext{
${ }^{51}$ Na última confrontação de 1979, Canessa lembra a composição de seu Estado Maior: "Para coordinar todas las actividades del Teatro, solicité al general Forestier el tercer año de la Academia de Guerra, y con sus profesores y alumnos, en un mes, hicimos el plan de campaña. Conté con el mejor jefe de Estado Mayor,
} 
As diferenças geopolíticas com Argentina e Perú reagruparam o arranjo dos limites províncias em 1979. É importante considerar a temporalidade desses conflitos porque, de uma ou outra forma, atualiza a continua lógica autoritária da organização burocrática dos territórios interiores, ao tempo que projeta uma gestão territorial ancorada em resolver os problemas das vias de circulação e uma maior soberania durante boa parte do período (19741984). A tensão nas fronteiras com a Argentina se apaziguou relativamente após a mediação do Vaticano e a assinatura do Tratado pela Paz e Amizade em 1984. Desse modo, a situação de conflito teve importantes efeitos no reforço da defesa dos limites fronteiriços e a necessidade de dotar uma maior integração nas fronteiras internas, especialmente, naqueles espaços desprovistos de população e comunicação que comprometiam a segurança do país. Nesse sentido, se respaldou ainda mais a militarização das províncias ao interior do sistema da regionalização e também o papel militar dos governadores provinciais como profissionais da defesa do território nacional.

As cinco novas províncias, efetivamente, se distribuíram espacialmente da seguinte forma: 1) Parinacota na I Região de Tarapacá no Norte; 2) Cardenal Caro da VI Região do Libertador General Bernardo O`Higgins; 3) Cauquenes da VII Região do Maule no setor litoral centro-Sul; 4) Palena da X Região de Los Lagos; 5) Coyhaique da XI Região de Aysén do General Carlos Ibáñez no zona Sul (mapa n 4). Cabe distinguir que, das cinco novas províncias, três delas eram espaços fronteiriços externos, diretamente ligados à defesa do país: Parinacota com Perú e Palena e Coyhaique com Argentina. Em termos estruturais do arranjo provincial, o país ficou com 45 províncias a nível nacional. No entanto, ainda estava pendente a definição do recorte das províncias de Santiago.

\section{Mapa $n^{\circ}$ 5. Províncias decreto-lei no 2867}

el general Dante Iturriaga Márchese, oficial de infantería, primer alumno de su promoción, paracaidista, un soldado extraordinariamente bien dotado para ejercer el mando de las tropas. El oficial de operaciones de mi cuartel general era un joven comandante de caballería, jefe del tercer año de la Academia, Guillermo Garín Aguirre, un hombre destinado por su conocimiento profesional y trato personal a asumir las mayores responsabilidades en la institución. Con él trabajó el capitán Juan Emilio Cheyre Espinosa, el mejor alumno de ese curso. Yo no podía estar mejor asesorado" (ARANCIBIA, BALART, 2006, p. 260). 


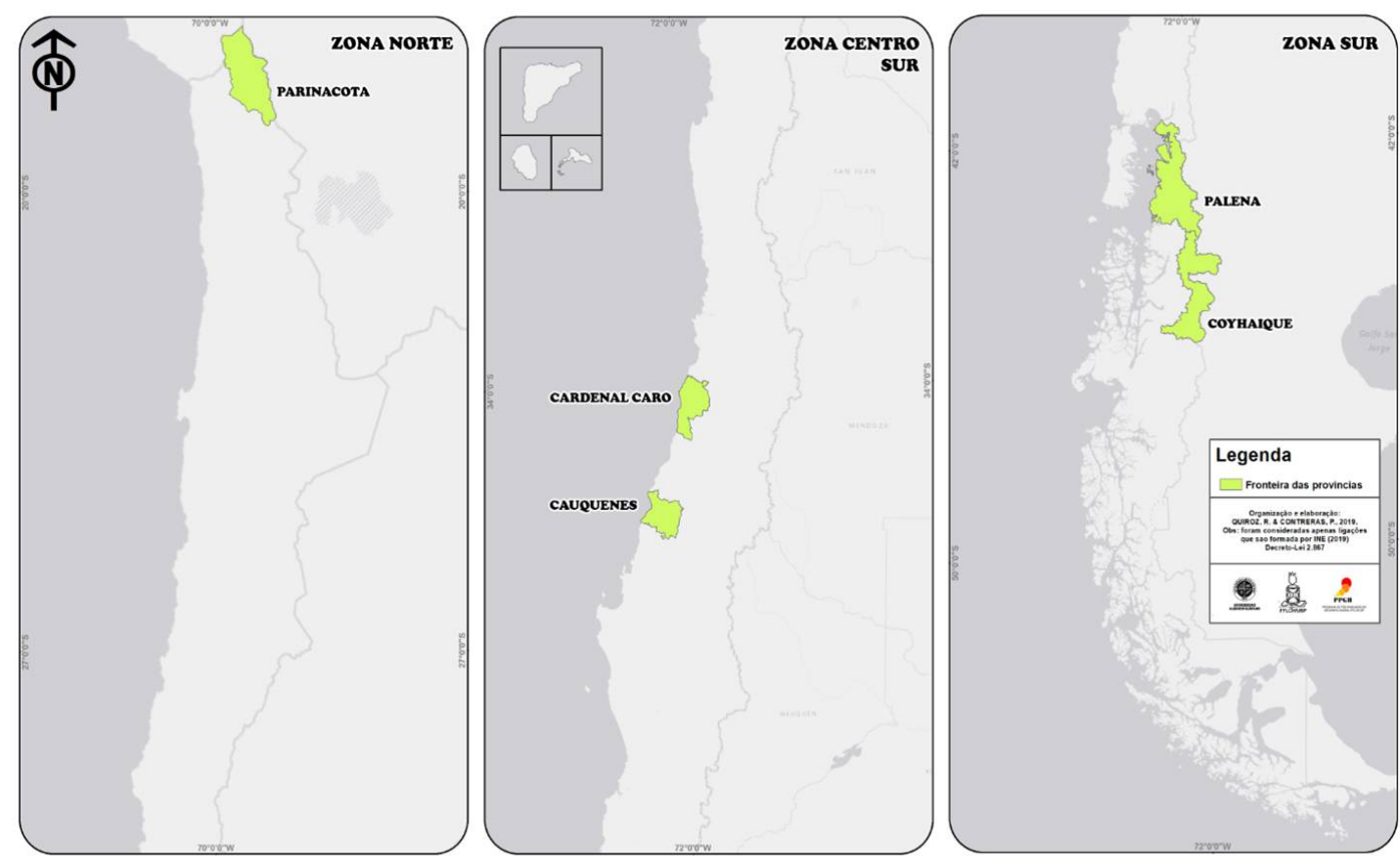

Fonte: elaboração própria com base no decreto-lei no 2867.

O recorte das cinco províncias de 1979 se localizou estrategicamente em espaços diferenciados e distanciados uns com outros, salvo a continuidade do extremo sul e a configuração do eixo das províncias Palena-Coyhaique que, por sua vez, entrelaça as X e XI Regiões com a vizinha Argentina. Para o geógrafo da CONARA Dionisio Vio, o recorte de 1979 foi um ajuste territorial que tendeu a compensar os inconiventes e desarticulações das quarenta províncias operativas a partir de janeiro de 1976. Em relação ao recorte da província de Parinacota, Vio destaca:

Parinacota siempre estuvo en la mente de hacerla. Está en el norte y en una zona tripartita, Bolivia, Perú y Chile y ahí había, por los menos, dos regimientos importantes [...] Entonces, eso estaba en torno a Putre y la idea era darle también sustentación político-administrativa a un área que era militarmente importante, pero no sólo militarmente. ¿Qué había pasado? Que los gobiernos tradicionales, digamos Frei, hizo una carretera Arica-Tambo Quemado, se hizo para darle vida al altiplano. Pero, ¿qué paso? El tiro salió por la culata. El altiplano se vació, por esa misma carretera bajaron a Arica y con buena movilidad. En Arica se concentró mucha población que era población altiplánica y eso que era la idea de reforzar la ocupación territorial ahí, salió un resultado inverso. Entonces, el problema era ese: se veía ese vacío y se creó esa provincia. Junto con eso, CONAF y otros servicios públicos hicieron esfuerzos por activar la conservación y el turismo, para darle un sustento, con sus artesanías y actividades (ENTREVISTA DIONISIO VIO, dezembro 2019).

Três elementos se destacam no relato de Vio. Primeiro, além de suas considerações administrativas, o fato de que as províncias se configuravam a partir de uma presença militar significativa que, implicitamente, tinha que reforçar a lógica de controle e segurança que articularia o recorte dessa província. Em segundo lugar, a existência de um diagnóstico 
prévio, que também configurou a necessidade administrativa do provincial, produto de um tipo de decadência da área - a construção de uma estrada que havia configurado uma fuga da população - que não permitia uma ocupação territorial efetiva. Esses dois aspetos combinados configuraram um terceiro elemento, e talvez, o mais estrutural para a configuração do recorte: a distinção de um espaço vazio e de maior vulnerabilidade, que tornava mais porosas e debilitadas as linhas de defesa e segurança do território. A província de Parinacota configurou o limite fronteiriço com Bolívia e Peru, portanto, sua disponibilidade de recursos e agentes militares para as estratégias de defesa da linha fronteiriça internacional configurava em uma maior necessidade. Distinto do caso da situação do Cauquenes onde o geógrafo explica:

\begin{abstract}
Cauquenes fue una provincia suprimida, entonces, hicimos Curicó, Talca y Linares. Hicimos tres franjas que del punto de vista del mapa se veía súper bien. Pero hubo una serie de protestas de cauqueninos [...] Cauquenes presionó mucho porque, en realidad, Cauquenes es una cuenca y tiene una tradición muy fuerte de tiempos coloniales y, de alguna manera, era como un bolsón característico de la ruralidad de la zona central del país. Y entonces, ellos miraban a Talca y Linares como sin ninguna identificación. Por consecuencia, ahí nos caímos, se fija. Y en los informes que llegaban de allá eran más o menos, porque el gobernador seguramente era un militar que no era cuaquenino. Pero después llegaron gobernadores cauqueninos y comenzaron a presionar. Así que al final restituimos Cauquenes. Pero quedó constituida una provincia más chica porque le quitamos Constitución (ENTREVISTA DIONISIO VIO, dezembro 2019).
\end{abstract}

Aqui podemos apreciar como a pressão social local, articulada desde o primeiro momento da oficialização, foi determinante para a restituição da província. No interior dessa resolução, também é importante distinguir a lógica da CONARA e do regime político da época que, embora fosse um governo autoritário, se desenvolveu como um agente político capaz de escutar, negociar e reconhecer erros, sempre na procura de imprimir maior legitimidade ao processo de regionalização. Por outro lado, também emerge um assunto significativo ligado à origem das autoridades e sua interferência na tarefa de governo nacional versus os interesses essencialmente provinciais ou particulares. Vio destaca que, apenas se incorporaram governadores militares propriamente cauqueninos na zona, notou-se uma maior pressão pela restituição do território provincial. Possivelmente muitos Governadores Provinciais foram nomeados sem possuir maiores vínculos com as destinações. Esse fato explica também a lógica militar dos cargos e suas relativamente rápidas rotações que, no geral, não se estendiam por mais de dois anos (ENTREVISTA CARLOS CANTERO, novembro 2019). Eventualmente, se esses militares estabelecessem nexos com os territórios, certamente gerariam maiores capacidades de criar consensos com a sociedade local, dando maior importância aos interesses territoriais das comunidades. Embora seja complexo 
reconhecer e determinar especificamente as trajetórias e origens das autoridades territoriais, sem dúvida, havendo uma maior pertinência, envolvimento e conhecimento de um território histórico, se amplia o nível de legitimidade da autoridade territorial e o peso de suas escolhas enquanto capacidades políticas.

Entretanto, o recorte das províncias de 1979 parece ser um aperfeiçoamento das tarefas internas, próprias dos dispositivos de integração e do déficit de ocupação espacial da política de planejamento. Tal foi o caso da província de Cardenal Caro da VI Região que, segundo Vio, "era una zona muy abandonada" (ENTREVISTA DIONISIO VIO, dezembro 2019). Sua recomposição como província buscava o desenvolvimento de um litoral mais atrativo, que pudesse reconstruir sua posição no cenário turístico, mas também como lugar de moradia e abertura de atividades produtivas. A inicios do século XIX, lembra Vio, essa zona haveria sido um importante balneário de elite. Dessa maneira, se reforçava a faixa litoral da VI região, principalmente em sua integração como espaço de maior movimentação econômica e social, aumentando suas capacidades para tal. Um caso muito diferente da província de Palena, onde se distinguem uma mistura de aspetos técnico-administrativos, produtivos, identitarios e fronteiriços:

\begin{abstract}
Palena siempre se pensó desde un comienzo. Se demoró por razones administrativas y falta de recursos. Yo me acuerdo cuando me tocó presentar a la Junta la X región, que en ese tiempo tomaba desde Valdivia hasta las Islas. Bueno, siempre estuvo claro que la vocación microregional del Palena no tenía nada que ver con Chiloé, tradicional, agrícola, costero. Me acuerdo de que uno de los militares tomó un papel blanco, lo estrujó, lo tiró y me dijo: eso es Palena, ósea, son puros cerros y nieves, diciendo, no hay que ni preocuparse, un peladero, todo lo que había era actividad forestal [...] Y había una actividad forestal a gran escala, pero extractiva. Se había extraído mucho el alerce, muchos bosques quemados, mucha erosión y, entonces, lo mismo, este es un espacio vacío. Al lado de la Cordillera había algunos lugares, como Segundo Corral, Futaleyfú, pero eran pueblitos aislados que todo el apoyo llegaba por Argentina, se fija. Entonces, eso era como un poco inconcebible. Bueno, Aysén era casi lo mismo, todo ese paño. Entonces, más o menos la idea fue esa y de ahí nació esta idea, que también era paralela de todos estos procesos regionales, la creación de la carretera austral. A mi también me tocó muchas veces recorrer eso, con un Intendente de Puerto Montt, Juan Soler Manfredini, un aviador, también de mucha perspectiva. Y el también me animaba a mí, dígale al presidente de la carretera (ENTREVISTA DIONISIO VIO, dezembro 2019).
\end{abstract}

Pelas complexidades da integração espacial do extremo sul do Chile, Palena era um desses territórios mais ligados à circulação da Argentina do que ao território nacional, uma questão "un poco inconcebible” nas palavras do geógrafo. O relatório de Vio é muito significativo porque demostra que, além das contradições florestal-agrícola tradicional, o principal argumento da criação da província era recompensar essa espacialidade desintegrada com as redes de circulação nacional e a respectiva busca de soberania nessa área: um assunto 
geopolítico. A partir da maior integração de Palena, também se iniciou uma segunda circulação de alto valor estratégico para a configuração geopolítica do extremo sul do país e sua configuração patagônica: a construção da estrada austral, uma importante rota que permitiu a conexão terrestre do eixo norte-sul entre a X e XI regiões, rompendo a histórica circulação Leste-Oeste que conectava as localidades da região Aysén e isolava tecnicamente a circulação com o resto do país das localidades interiores da região. A partir de finais da década de 1970, o regime deu uma importante ênfase na construção dessa infraestrutura viária, sendo considerada como uns dos principais frutos do processo de regionalização (URRUTIA, 2020). Segundo o coronel em retiro, Jorge Sanz, a estrada austral foi o grande projeto da regionalização que permitiria uma maior soberania nacional:

El concepto era integrar al territorio. Por eso que el gran proyecto de la CONARA o de la regionalización es la carretera austral. Lo que buscaba en definitiva era incorporar un gran espacio del territorio nacional a Chile, porque de Puerto Montt para allá estábamos perdidos, no había nada [...] Por eso se propone el proyecto de la carretera austral para no depender de Argentina y se van haciendo muchas cosas con respecto a eso [...] Esta división territorial tenía una lógica política, geográfica, social, pero además militar. Por lo tanto, desde esa perspectiva militar no podías tener un territorio nacional aislado, al cual tú no pudieras acceder, no es aceptable. ¿Cómo puedo llegar a defender Coyhaique si las personas que tengo que defender no se pueden desplazar por el territorio interno? (ENTREVISTA JORGE SANZ, novembro 2019).

Dessa maneira, a província de Palena também alongou sua consolidação territorial através do último recorte provincial: Coyhaique. Essa nova província de 1979, segundo Vio, foi uma região meta, pois, praticamente não tinha nenhuma significação produtiva, populacional ou tradicional relevante. Coyhaique passou a ser a capital regional da XI Região em um território inóspito que marcou uma das principais apostas regionais do regime, e só a partir da década de 1980 começou ter uma maior estabilidade, precisamente pela construção da carreteira austral e a vertebração do território. A mudança da histórica centralidade litoral da província de Aysén para o setor interior de Coyhaique reafirmou a ideia de compensar os espaços vazios e o fortalecimento da fronteira externa com Argentina. Uma vontade geopolítica mais ativa para terminar com a dependência de circulação de áreas transandinas em quase mil quilômetros do eixo Norte-Sul, e que atravessou a IX região de Aysén através da carreteira Austral algumas décadas depois. Como destaca Vio:

Primero, el cambio de capital a Coyhaique fue un golpe. Yo recuerdo haber estado en Coyhaique que tiene una plaza pentagonal y no había ni un metro pavimentado. En cambio, Aysén sí, pero igual Aysén era un pueblo en decadencia y el río que le había tapado el puerto y ya no era ni puerto. $\mathrm{Y}$ yo me acuerdo de haber estado ahí y un médico de Pinochet me preguntó. Me dijo, ¿usted quiere poner la capital aquí? Sí le dije yo, porque esta es una región 
meta, esto tenemos que hacerlo región, ¿y usted tiene otra solución, por ejemplo, regalarle este terreno a Argentina? Se largó a reír. Es muy drástico, me dijo. Y claro, esto va encadenado de que avanzara la carretera austral. Se fue haciendo por partes (ENTREVISTA DIONISIO VIO, dezembro 2019).

Vio confirma o sentido geopolítico das últimas províncias do sul do Chile em 1979. Mas também projeta uma mistura entre a possessão geopolítica de fronteiras externas com maior capacidade de soberania em termos de organização pública e ocupação espacial integrada, por um lado, e um explicito nacionalismo patriótico ancorado na ideia de segurança gerenciada pelo poder militar e territorial do regime, por outro. Sobre essa última dimensão, o arranjo provincial emerge como uma projeção territorial nacionalista que se reforça a partir da histórica instabilidade das fronteias externas com Argentina e a construção conflitiva de como se projeta o estrangeiro na visão corporativista dos militares.

Após do recorte de províncias de 1979, só permaneceria o arranjo da RM para finalizar o processo de delimitação de províncias. Em relação a esse último recorte provincial, segundo Vio, houve uma tensão na própria cúpula de mais alta patente da CONARA. O general Canessa e o coronel Barrientos não estavam de acordo na definição das províncias de Santiago: "Barrientos dijo, esto está listo porque yo lo acordé con el Subsecretario del Interior y Canessa le respondió a su nivel mi coronel" (ENTREVISTA DIONISIO VIO, dezembro 2019). A controvérsia se centrou na quantidade de comunas que iria conformar a Província de Cordillera, articulada no agrupamento de duas comunas de San Bernardo e Puente Alto, segundo a posição do coronel Juan Barrientos Vidaurre. O episodio é relevante porque explicita a dificuldade da CONARA para processar a reforma na capital do país que, aliás, poderia expressar-se em uma diferença entre as duas máximas hierarquias militares do processo de regionalização - o presidente e o vice-presidente da CONARA -. Por sua vez, o episódio também manifesta as lógicas contraditórias do processo interno e a centralidade do general Pinochet em cada uma das decisões territoriais. Como explicávamos no capítulo II, se bem os recortes territoriais tinham que ser ratificados pela Junta de Governo, previamente todos eles eram avaliados e aprovados pelo general Pinochet seguida da proposta técnica da CONARA. Neste caso, Pinochet restituía a hierarquia militar e a cercania do Ministro Presidente da CONARA: as províncias se limitavam tal como tinha sido previsto pelo general Canessa e o geógrafo Dionisio Vio, ficando a Região Metropolitana com seis províncias (mapa $n^{\circ}$ ). No entanto, a divergência das províncias dá conta das complexas relações pessoais e de poder que encargavam demarcação de fronteias internas, além de 
qualquer tipo de governo autoritário. Ao fim das contas, o processo de divisão espacial estatal evidentemente não era indiferente a outras configurações do poder político interno do regime que, embora sem resoluções dramáticas ou violentas, também poderiam projetar uma hierarquia de diferenças na agência territorial, como vimos na resolução de 1977 com os Intendentes. No entanto, como corolário desse mesmo processo, a comandância de Pinochet nos recortes territoriais estará por cima de qualquer gestão territorial que pudessem conectar aos oficiais das FF.AA. com seus interesses particulares e outras agencias territoriais locais, além do governo nacional. Acima de tudo, a definição das fronteiras internas, especialmente as províncias, era um assunto da máxima autoridade do país e da agência geopolítica do governo nacional.

\section{Mapa $\mathrm{n}^{\circ}$ 6. Províncias decreto-lei no 3642}

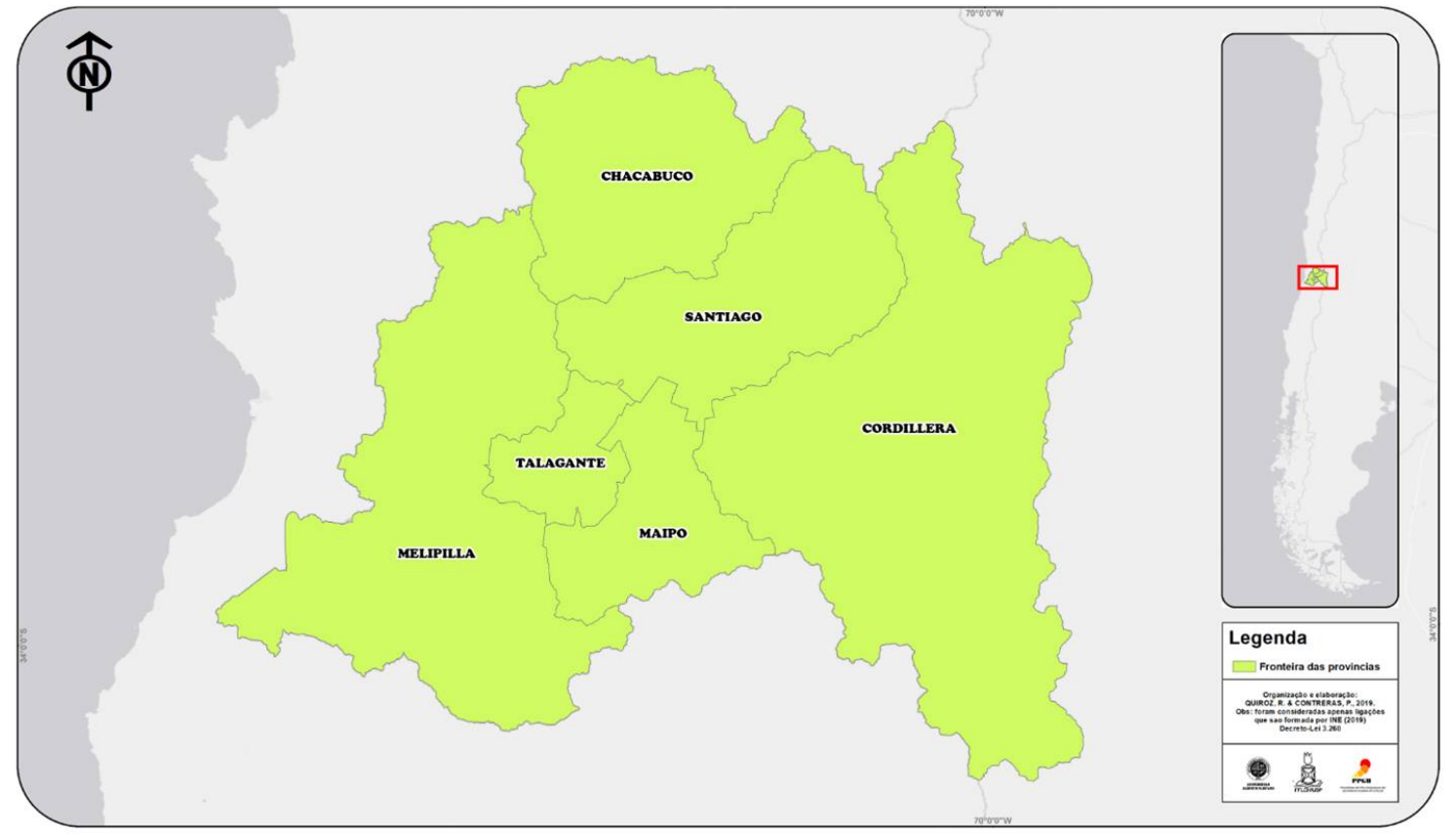

Fonte: elaboração própria com base no decreto-lei nº 3642.

Segundo o relato de Vio, a grande sintonia e força interna do processo de regionalização se dava, por um lado, na complementariedade entre a gestão eficiente da comandância hierárquica do general Canessa, que sistematicamente informava sobre as situações e especificidades ao general Pinochet, e por outro, pela a inteligência e capacidade operativa do coronel - mais tarde general - Alejandro Gonzalez Samohod, quem foi o secretário executivo da CONARA durante grande parte do processo (ENTREVISTA DIONISIO VIO, dezembro 2019). Contudo, o arranjo das seis províncias de Santiago em 1981 (mapa $n^{\circ}$ 5) foi parte simultânea de uma série de operações urbanas, econômicas e políticas que se teciam na capital do país e que também articulavam o recorte de prefeituras 
que se ampliava significativamente na área urbana de Santiago. É importante lembrar, mais uma vez, que esse recorte significou simbólica e operativamente o término da ideia de uma Área Metropolitana, deixando seis províncias similares - administrativa e espacialmente nas regiões, embora tenha-se oficializado constantemente nos anos anteriores a ideia de que Santiago necessariamente deveria ter uma política metropolitana diferente. De alguma forma se demostrou a ambiguidade da política da regionalização em Santiago e a posição conflituada no interior da CONARA, ainda após cinco anos de reforma e estudos (1974-1980). O território provincial do período autoritário ficou situado em 51 províncias, cada uma com seu respectivo Governador Provincial, exceto a província de Santiago. Segundo o funcionário da CONARA da época, Hernán Muñoz, no geral, os recortes territoriais feitos pelo regime procuravam homogeneizar espacialmente o conjunto de unidades territoriais para manobrar de maneira mais articulada e lógica o conjunto de ações públicas nos territórios. Efetivamente expressavam uma busca de desburocratizar as antigas unidades territoriais, mas também de economizar os recursos públicos que habitavam importantes desordens orçamentais. Diz Muñoz:

[...] de 25 provincias pasamos a 13 regiones, de 94 departamentos pasamos a 51 provincias, y en ese sentido, desde luego, hay una mayor homogenización territorial de lo que había antes del 73', y en segundo lugar, hay un ahorro de gasto público, hay menos autoridades y funcionarios que hay que financiar. Y por último, permitió que se manejara el desarrollo y la cotidianidad de estos territorios, reduciendo la territorialidad tradicional (ENTREVISTA HERNÁN MUÑOZ, maio 2020).

De igual maneiras que as regiões, as províncias tenderiam a simplificar o sistema de intermediação entre o regime territorial nacional e as representações interiores, pois, se antigamente existiam 94 departamentos, com a reforma, passariam a ser 51 províncias. Dessa forma, se cumpria a promessa de uma administração simplificada do Estado com um arranjo pensado mais no operativo que no estritamente econômico. Contudo, as unidades operativas se verticalizavam na articulação hierárquica em três níveis geográficos: região-provínciacomuna. Do ponto de vista administrativo, a CONARA fundamentou o arranjo provincial como um veículo de maior complementariedade, sem intermediários que não possuíssem competências operativas. Porém, na prática, as províncias não tinham um papel técnico totalmente institucionalizado na articulação territorial do novo repertorio público. As decisões, funções e competências da gestão territorial, estruturalmente estavam interligadas entre o nível regional e o nível comunal. Nesse sentido, qual era a tarefa estratégica dos Governadores no sistema territorial integrado? 


\subsection{Governadores militares: duplo controle territorial}

As diferenças entre as máximas chefias da CONARA nas províncias de Santiago implicitamente também se expressaram na Junta de Governo. Assim pode ser interpretada, ao menos, a Ata da Junta de Governo do 1 agosto de 1974. Nessa sessão se discutiu o plano social do governo e os estudos da ODEPLAN a cargo do comandante em chefe da FACH, Gustavo Leigh, nesse momento coordenador do comitê da área social do governo (SOMS, 2010). É interessante o episódio porque se explicita uma orgânica territorial de como se articulavam os novos órgãos técnicos, hierárquicos e de participação do plano social do governo. Segundo Leigh, à diferença do antigo sistema de relações territoriais do Estado onde não existiam maiores capacidades de articulação entre os entes públicos produto de uma tendência de setorização dos seus diversos organismos -, com a regionalização do regime, se configuraram três níveis de intervenção social integrados e territorialmente hierarquizados: 1) um nível nacional coordenado pela ODEPLAN; 2) um nível regional articulado com o Intendente Regional e suas Secretarias Regionais; e finalmente, 3) um nível comunal-local dirigido pelo Prefeito em apoio do Conselho Comunal. Em consequência, segundo o plano social do Leigh, não se contemplavam a presença nem de províncias nem governadores. Diz o general Leigh:

Lo que más quiero pedirle a la Junta es que, si aprueba esta orgánica, la sigamos impulsando [...] Como bien decía el Sr. General Mendoza, esto está armonizado con la regionalización [...] La organización que he mencionado se está experimentando en algunas regiones pilotos, como Tarapacá, Punta Arenas, Concepción, Valparaíso y Santiago [...] Felizmente, con la regionalización del país prácticamente desaparecen los gobernadores, por cuanto van a pasar a ser los Intendentes Provinciales, porque habrá Intendente Regional [...] Y de este nivel regional pasamos ahora al nivel comunal (ACTAS DE LA JUNTA DE GOBIERNO, 1/8/1974).

A citação desvenda explicitamente a discordância entre o marco espacial de planejamento desenhado pelo comandante em chefe da FACH e, por outro lado, a permanência hierárquica das províncias e dos governadores desenhado pela CONARA e o SIGORE. A partir da articulação regional-municipal, segundo Leigh, se permitiria verticalizar o SIGORE fazendo desnecessária a presença dos governadores nas províncias. No final da ata se destacam diversas reações à exposição de Leigh e se "intercambian opiniones respecto de la eliminación de los gobernadores y de los subdelegados, y, en general, sobre el organigrama de Desarrollo Social presentado por el señor General Leigh" (ACTAS DE LA JUNTA DE GOBIERNO, 1/8/1974). Porém, os governadores continuaram no SIGORE e a proposta do Leigh foi parcialmente aceita sem suas petições de retirar as províncias. O episodio mostra a hegemonia do general 
Pinochet no processo da regionalização e a disputa permanente com o general Leigh. Tendo isso em conta, como foi a articulação dos comandos territoriais dos governadores?

O decreto-lei n 573 definiu que a autoridade máxima da província era o Governador Provincial, sendo subordinado ao Intendente Regional e nomeado pelo poder executivo. Similar à estrutura das autoridades territoriais do sistema regional integrado, o Governador Provincial só permaneceria em seu cargo enquanto "cuente con la confianza del Jefe Supremo de la Nación" (GOBIERNO DE CHILE, 1974b, s./r.). Trata-se, então, de um funcionário de alta patente institucional, dependente da máxima autoridade política do país, embora sem uma estrutura de funcionários e corpos administrativos o suficientemente dotados para desenvolver tarefas de governo. Oficialmente, o decreto-lei $\mathrm{n}^{\circ} 575$ destacava que o Governador Provincial cumpria as seis seguintes tarefas:

Efectuar las tareas propias de gobierno y administración interiores dentro de la provincia; Fiscalizar la ejecución de los planes, programas y proyectos de desarrollo provincial; Fiscalizar los servicios públicos de la provincia; Velar por la debida coordinación de los servicios públicos; Concertar acciones comunes con las municipalidades o con otras instituciones públicas y privadas, y Proponer proyectos de desarrollo provincial al Intendente Regional respectivo (GOBIERNO DE CHILE, 1974c, s./r.).

Localizado na cidade cabeceira da província, o Governador Provincial era uma alta autoridade da administração pública dos territórios internos, podendo fiscalizar os serviços públicos, planos, programas e projetos da respectiva província, além disso, gerar condições de coordenação entre esses serviços e as diferentes prefeituras que contemplavam os interesses da província. Porém, na prática, as funções que projetava a lei poderiam ser perfeitamente assumidas pelo conjunto de autoridades territoriais que superavam sua jurisdição, sobretudo pela gestão integrada dos Secretários Regionais Ministeriais (SEREMIS) e a SERPLAC. Em suma, a participação dos governadores esteve mais ligada aos COREDES e às interações burocráticas de controle, e também na supervisão das prefeituras com o suporte da unidade SERPLAC localizada em sua jurisdição. Como lembra o SERPLAC do BíoBío Pedro Ramírez, no momento da avaliação dos projetos:

En las sesiones del Consejo Regional los gobernadores eran quienes más peleaban por sus inversiones. Pero era objetivo desde el punto de vista que se hacia en base rentabilidad social de los proyectos y eso también a quienes no tenían una cierta cantidad de proyectos los obligaba a hacer proyectos de inversión social importante. En una oportunidad un ex Gobernador de Ñuble de la época, un ex oficial de Carabineros, me dijo: oye, pero uno nunca sabe lo que ustedes hacen aquí porque llegan y presentan estos proyectos cruzados, pero es una caja negra. Entonces, le expliqué cual era la metodología. Yo diría que fue la única vez que sentí, de alguna u otra manera, una presión. Además, que la decisión yo la entendía 
perfectamente que en esa instancia era el Consejo Regional y en otro momento el Intendente. Ósea, la decisión final era política, pero en base a los antecedentes que nosotros aportábamos como SERPLAC (ENTREVISTA PEDRO RAMIREZ, fevereiro 2021)

A citação ajuda a compreender a autoridade hierárquica dos governadores e sua particular preocupação de defender projetos ou orçamentos para suas províncias. Por sua vez, cada província era assessorada por uma delegação provincial da SERPLAC que tinha a dupla intermediação estratégica de assessorar o Governador e a chefatura SERPLAC do centro do território regional (CONARA, 1985). Como destaca o SERPLAC da VIII Região do BíoBío, Pedro Ramírez:

Me entendía directamente con el delegado provincial que dependía del SERPLAC. Eran unidades pequeñas. En Ñuble, por ejemplo, había dos personas. En Lebú, provincia de Arauco, había dos personas, ósea no eran más que eso. En Biobío y Los Ángeles también, estaba Eduardo Castillo que fue el último y un asistente y otro profesional. Eran unidades muy pequeñas. El fundamento era coordinar. Además, dependían mucho del Secretario Regional que les diera importancia. Yo con ellos actuaba mucho, como te decía antes, cuando en enero íbamos a ver todas las comunas y sus proyectos de inversión, el rol importante era del delegado provincial, quien era él que tenía que estar en el día a día con los alcaldes. Pero dependía mucho de la persona, el SERPLAC, que le de importancia o no [...] En esa época era coordinar los alcaldes, ver las necesidades locales. Poder de decisión prácticamente no tenía nada (ENTREVISTA PEDRO RAMIREZ, fevereiro 2021).

Essa situação implicitamente demostra o difícil cenário logístico dos governadores que dependiam de uma unidade maior no sistema regional, a SERPLAC, a qual efetivamente se interligava como primus interpares no espaço provincial e mediava suas relações diretamente com os prefeitos. Embora os governadores deveriam coordenar as prefeituras em um raio territorial importante, certamente, não dispunham de orçamento nem dispositivos técnicos para um efetivo desenvolvimento territorial entre suas comunas. As delegações provinciais eram reduzidas e muitos prefeitos, na prática, se entendiam diretamente com os SERPLAC e os Intendentes regionais, como destaca o prefeito da época, Carlos Cantero (ENTREVISTA CARLOS CANTERO, novembro 2019). Em outras palavas, tecnicamente o governador se instalava em um terreno movediço de hierarquias funcionais e de difícil operação do ponto de vista orçamental. No sentido estritamente técnico, a particular forma do governo provincial transluzia inconsistências de uma posição subordinada e às vezes inoperativa em termos de capilaridade e funções territoriais. Qual era, então, a margem de manobra dos governadores na gestão territorial? Segundo o SERPLAC Pedro Ramirez, as divisões províncias funcionavam irregularmente, segundo caso a caso e também segundo à história e identidade dos territórios enquanto capacidade de estabelecer vínculos entre as 
prefeituras. No entanto, do ponto de vista operativo da SERPLAC, as províncias efetivamente tinham uma fundamentação:

Por ejemplo, manejar la Región de la Araucanía con 32 comunas y no hubiera ninguna provincia es complicado. Entonces, tenía que haber una escala. Un criterio de eficiencia de administración y para el control. Ahora, recordemos, para ese esquema gobierno militar versus democracia, era súper necesario para el control [...] En ese tiempo los acaldes tenían mucho menos recursos. Es un desperdicio porque se podrían hacer muchas más cosas. El gobernador tenía una función: bajar los direccionamientos que nombraba el Intendente y el gobierno central hacia comunas y hacia el territorio (ENTREVISTA PEDRO RAMIREZ, fevereiro 2021).

As províncias eram um escalamento do programa do governo das regiões e, por sua vez, permitiam direcionar e vigiar os programas locais no nível das prefeituras. Precisamente, segundo o funcionário da SERPLAC da Araucanía, Diego Benavente, os governadores tinham uma função complementaria das linhas operativas dos Intendentes e a coordenação de certos projetos territoriais que se corresponderiam com as prefeituras. Diz Benavente:

El Gobernador era un Intendente pequeño, permitía hacer economías de escala en provincias que tenían más identidad, como el caso de Malleco. Por ejemplo, cuando nos tocó ver el tema turístico de la nieve, acá en la Araucanía, teníamos tres volcanes con actitud de esquí: el Villarrica, el Llaima y el Lonquimay (este último no tenía nada). Queríamos desarrollar el tema, entonces, se hizo un estudio para convertir Lonquimay en un gran centro de esquí ya que antes no había nada [...] Y como una de las tesis del Tránsito Medio Anual (TMA) decía que había que generar un flujo para invertir, entonces, había que construir un andarivel para Lonquimay. El estudio estaba todo fundamentado. Bueno, cada municipio se coloca con un millón y finalmente hicimos el andarivel. Entonces, ese tipo de cuestiones guiadas por un Gobernador que estaba en las once comunas de Malleco [...] El Gobernador militar ejercía influencia en los municipios para que todos se cuadraran disciplinadamente (ENTREVISTA DIEGO BENAVENTE, fevereiro 2021)

A lei orgânica de municipalidades de 1976 precisamente reafirmou os decretos da regionalização de 1974, estabelecendo que os governadores tinham que fiscalizar e velar pela coordenação das prefeituras e outros serviços públicos no âmbito provincial (GOBIERNO DE CHILE, 1976a). Essa função fiscalizadora e controladora da ação nas prefeituras também coincide com o relatório do Governador da Província de Lebu (VIII Região de BíoBío) entre 1985-1989, Alejandro Fernández, quem diz:

El Gobernador lo único que tenía era el poder sobre los alcaldes. Porque los presupuestos estaban por municipalidad. Y los gobernadores tenían un presupuesto bastante pequeño que era como para emergencias [...] Pero tenían mucho poder en aquellos años porque era absolutamente dueño entre comillas de los alcaldes, era el jefe-jefe. Ósea, tú entre comillas eras el jefe de los alcaldes: un alcalde no se mandaba solo en aquella época. Entonces, el Gobernador era asesorado por este personaje que era de la SERPLAC, que iba primero a hablar con el gran jefe de la provincia digamos así. Y le decía así, mira, haber cuantos alcaldes tienes tú y el te decía el número y, además, te informaba sobre cada uno de los alcaldes. Por 
ejemplo, este alcalde presenta tales características y tiene todos estos problemas, es medio porfiado, etc. [...] Entonces, uno también tenía el diagnóstico técnico hecho al otro lado te fijas y le decías al gobernador sí, ok, yo creo que hay que decirle a este muchachón que tiene que poner énfasis aquí y énfasis allá y si no le gustaba, lo cambiaban. Era así de simple (ENTREVISTA ALEJANDRO FERNANDEZ, fevereiro 2021)

A citação é significativa porque mais uma vez reafirma a centralidade técnica-política das SERPLAC no funcionamento do sistema territorial integrado e, particularmente, na estrutura de controle e gestão das delegações provinciais que tinham que responder os governadores. Além disso, é interessante a trajetória de Fernández porque, à contramão da época, foi nomeado Governador de Lebu sendo civil e não militar, como era a tendência geral. Segundo sua experiência, a forma de expressão do poder territorial dos governadores radicava precisamente no controle direto que tinham na gestão dos prefeitos que, por sua vez, respondiam a projetos e metas estabelecidas a nível do comando superior provincial-regional. Como Governador de Lebu, Fernández lembra o tipo de instruções e controle que tinha que estabelecer sobre os prefeitos da época:

Tú le decías mira aquí tienes diez presupuestos que tienes que aplicar este año. Hay que instalar tantos alcantarillados en tu comuna, tanta luz, pavimentar tantas cosas [...] Y así. A fin de año le pasaban la cuenta, quien no lo hacía bien, lo cambiaban. Porque eran casi todos comerciales o civiles, entonces, era muy distinto. Nosotros auditábamos: el tipo que no alcanzaba metas y objetivos se iba. Porque no era político, te fijas, no había una elección de por medio, nada [...] Ponte tú no se podía resolver un problema tipo mapuche y también se cambiaba porque el tipo no tenía buena llegada o no era capaz de generar las alianzas o los convencimientos o darnos un buen informe de quien era el cabecilla que estaba detrás de todos los desórdenes (ENTREVISTA ALEJANDRO FERNANDEZ, fevereiro 2021)

Os governadores tinham uma conexão direta no controle da gestão dos prefeitos e da ordem pública dos territórios interiores. A delegação da SERPLAC nas províncias era o suporte que permitiam criar o seguimento dos níveis de gestão ou taxa de rendimento de cada umas das prefeituras. Um controle eminentemente técnico da gestão territorial oficial, embora política e economicamente ancorada nas pautas previamente estabelecidas pela autoridade regional e a SERPLAC. No caso da província de Lebú, o Governador tinha que vigiar a gestão de sete prefeitos que, de não atingir os objetivos, poderiam ir embora: "Tenía siete comunas a cargo y tenía diagnostico de todas. Tuve que cambiar al alcalde de Lebu, de Los Álamos, cambié a casi todos los alcaldes" (ENTREVISTA ALEJANDRO FERNANDEZ, fevereiro 2021). O poder do Governador da Província de Lebu estava na capacidade de exercer controle e vigilância no interior da gestão territorial das prefeituras, além da questão tecnicamente operativa. Os prefeitos que não estavam na linha dos objetivos territoriais do 
Governador poderiam continuar fora da estrutura do microgoverno provincial. Uma capacidade de controle que, acima de tudo, emanava diretamente da estrutura hierárquica do SIGORE e a prevalência do comando político-militar do país. Daí a particularidade do caso de Fernández, que mesmo sendo civil, foi nomeado Governador em 1985. Segundo seu relatório, a cada quinze dias havia uma reunião com os outros governadores e o Intendente da região, onde fundamentalmente discutiam duas questões: o avanço da gestão para eliminar a pobreza e os temas de infraestruturas para reconhecer "como estaban los caminos para que el sector privado pudiera invertir y hacer cosas" (ENTREVISTA ALEJANDRO FERNANDEZ, fevereiro 2021). O mesmo programa definido por Miguel Kast nas SERPLAC, mas escalonado em sua capilaridade e escala provincial.

Em relação aos vínculos com seus colegas governadores, Fernández destaca que não era nada de fácil porque "a los gobernadores les gustaba mucha más la gente como Moreira 52 [...] Eran coroneles todos. En lo único que sintonizábamos era con la cosa de caminos" (ENTREVISTA ALEJANDRO FERNANDEZ, fevereiro 2021). Na prática, os governadores continuaram sendo nomeados e distribuídos ao longo do território com o mesmo pacto político-militar da Junta de Governo em termos dos Intendentes. No geral, os governadores eram exclusivamente oficiais das FF.AA., mas também havia oficiais na ativa e em retiro de Carabineiros do Chile. Segundo Huneeus, só após o processo do plebiscitário em 1988, os governadores começariam a ser civis. Durante o maior percurso do regime, de forma geral, os governadores eram oficiais comandantes dos regimentos das cidades capitais de província, o qual também confirma a lógica de controle geopolítico de suas funções e uma maior presença do Exército que as outras FF.AA.. (HUNEEUS, 2016, p. 201). Diz Huneeus que para 1988:

Es interesante el análisis de quienes fueron gobernadores, puesto que esta responsabilidad era una función obligada del comandante de regimiento (o escuela matriz) correspondiente. Aproximadamente, la mitad de los oficiales que en junio de 1988 tenían el mando de un regimiento (o una escuela) fueron gobernadores, y la casi totalidad de estos pertenecían al Ejército (HUNEEUS, 2016, p. 205).

Dessa maneira, a distribuição dos governadores provinciais se projetava de uma forma similar à nomeação dos Intendentes Regionais, onde prevaleciam critérios militares e hierárquicos muito além do sistema de planejamento regional e a gestão territorial eficiente

\footnotetext{
${ }^{52}$ Se refere ao atual Senador Iván Moreira (UDI) da Região de Los Lagos que, nessa época, foi assessor municipal das comunas de Punta Arenas e La Pintana, e também prefeito da comuna La Cisterna (Região Metropolitana) nos últimos anos do regime.
} 
do território. O acadêmico e geógrafo Federico Arenas destaca que o discurso articulador dos militares no governo, sobretudo no período 1973-1979, foi um pensamento geopolítico que projetou o territorial como uma ação de governo que fundamentalmente devia "hacer sentir la potencia pública del Estado en un campo de batalla" (ENTREVISTA FEDERICO ARENAS, maio 2019). Dessa maneira, se subordinou o desenvolvimento econômico à uma questão de segurança fundamental para a sustentabilidade do regime, onde efetivamente o redesenho da estrutura política administrativa tinha que fortalecer o poder a partir do Estado central. Além disso, Arenas lembra da sua pós-graduação na Suíça e particularmente das aulas do professor Claude Raffestin, quem na época estaria muito bem informado do processo chileno e o "presidente geógrafo" Pinochet. Segundo Arenas, Claude Raffestin:

\begin{abstract}
Pensaba que la regionalización era lo que ocurría siempre en los regímenes autoritarios. Lo que hacían era subdividir más el país para mejor gobernar y controlar. Y cuando yo le repliqué, pero eso no tiene sentido porque aquí saltamos de 25 provincias a 13 regiones. Y el decía sí, eso a nivel regional, pero piensa en la estructura de control. En realidad, saltamos de 25 provincias a 51 provincias y, además, pusimos un control extra encima que serían estas nuevas autoridades regionales [...] Y ahí tenía razón el profesor Raffestin que tuvieron esa doble condición, ósea, por lo menos en un buen margen de tiempo. Se era Intendente regional designado, y claro, generalmente uniformado, entonces, doble capacidad de incidir, doble estructura de poder en el fondo. Lo jerárquico militar y mi poder de designarte del poder central, autoridad en la región. Entonces, la hipótesis sería que, el fin último era un mayor control del sistema y, por tanto, un mejor traspaso de la información política (ENTREVISTA FEDERICO ARENAS, maio 2019).
\end{abstract}

A citação é significativa por vários sentidos. Primeiro, pelo reconhecimento da lógica autoritária que tendeu aumentar o tamanho operativo das unidades territoriais para dispor um maior controle das mesmas, além do conjunto do território nacional. Uma questão aparentemente contraditória no arranjo regional da CONARA, segundo Arenas, pois internamente também se agregariam novas unidades territoriais aumentando sua vigilância e lógica de subordinação ao poder central: províncias e comunas. Em segundo lugar, a interpretação de Raffestin distingue que a divisória interna das províncias respondia a uma estrutura de controle espacial que não necessariamente devia ser conectada diretamente a uma ampliação de funções públicas no sistema administrativo. Terceiro, o signo da dupla hierarquia militar e política na estrutura territorial do país, no fundo, era o resultado de uma operatória maior que precisamente procurava um controle superior e eficaz das comunicações internas impulsionadas através do governo central aos territórios, muito além de qualquer tipo de modernização operativa do tecido público orçamental. Simultaneamente, ao configurar uma fração nacional de governadores provinciais ao longo do país, também se criava uma linha intermediaria de dupla vigilância a nível superior e inferior do sistema 
provincial. Se bem se centrou a responsabilidade do governador na vigilância a nível das prefeituras, em caso de qualquer dissidência ou interferência entre o nível superior regional - como foi a polêmica com os Intendentes em 1977-, o regime também poderia mediar através do Governador, quem era um agente de exclusiva confiança e dependência hierárquica do Presidente da República: o general Pinochet. No fundo, a criação da estrutura intermediaria dos governadores dispunha de informação concreta dos territórios interiores das linhas de mando oficial e uma rede militar disponível para servir às ordens da máxima autoridade nacional caso fosse necessário. Como diria Raffenstin em seu clássico livro: "É verdade que não vemos o Estado, mas é também verdade que o Estado se mostra em todas as formas de manifestações espaciais, da capital à fronteira, passando pelas malhas interiores hièrarquizadas e pelas redes de circulação" (RAFFESTIN, 1993, p. 16)

As linhas de comando territorial das províncias reforçavam a lógicas de controle centralizado e aumentavam as prerrogativas do comando central nos territórios internos. $\mathrm{O}$ coronel em retiro e último secretário executivo da CONARA, Luis Alfonso Rivas ${ }^{53}$, destaca que os governadores tinham uma maior presença em regiões de maior isolamento e, portanto, se justificavam em determinados casos porquê nesses territórios era mais difícil cumprir a tarefa de governar. Porém, na maioria dos casos, sua destinação de governo como autoridade de planejamento respondia a outro aspecto mais estrutural. Diz Rivas:

Bueno, yo creo que la provincia surgió más que nada por el tipo de gobierno que teníamos y se trataba de tener un control más efectivo del país. Tenía un sentido más militar y por eso que todos los gobernadores provinciales eran comandantes de regimientos [...] Pero sí, en Ñuble, yo lo miraba como un ente coordinador de las comunas. Pero sinceramente no, en lo personal no, no se justifica. Lo entendí en algunos casos, por ejemplo, en Ñuble. Bueno, las comunas estaban muy lejos de la capital regional, pero Nuble tenía, no sé, en Santiago tenían 54, en Ñuble eran 29 o 30. La relación de la Intendencia con esas comunas no era fácil y se facilitaba con la existencia de los gobernadores provinciales. Era como un mando intermedio, entonces, ellos podían coordinar y organizar estas comunas. Pero, aquí me meto en juicios muy personales, yo habría puesto gobernadores civiles. En ese momento hubiese sonado un sacrilegio de mi parte, pero hay ahí un concepto detrás de tener un espacio controlado. Ese es parte del rol que tenían los gobernadores militares (ENTREVISTA LUIS ALFONSO RIVAS, 14 novembro 2019)

Se bem Rivas ratifica a particularidade dos distanciamentos espaciais em alguns casos, também explica com singular franqueza o lugar do governador provincial no regime. Trata-

\footnotetext{
${ }^{53} \mathrm{O}$ lugar de fala de Rivas é muito significativo pois emana de um militar de alta patente nas esferas do governo e cercania a Pinochet. Rivas, lembremos, foi o último militar Secretario Executivo de CONARA e o primeiro Subsecretario do Ministério Secretaria General da Presidência criada em 1983. É dizer, se trata de uma testemunha de conhecimento direto das dinâmicas políticas do regime e suas lógicas internas.
} 
se de uma função de controle e segurança que, somente se suporta no interior de uma lógica policial própria de um regime autoritário. O relatório é muito significativo pois confirma que as províncias e regiões, no processo de regionalização, tinham uma função além do sistema de planejamento integrado. O geógrafo José Abalos também afirma que, na prática, os governadores eram porta-vozes do governo regional e nacional e ajudavam a distinguir inquietudes e problemáticas territoriais na província. Entretanto, sua principal função, acima de tudo, era o controle social e policial da cidadania na configuração territorial da província (ENTREVISTA JOSÉ ABALOS, novembro 2019). Essa racionalidade explica que até 1988 os governadores se projetaram como autoridades territoriais maioritariamente exclusivas das FF.AA. (HUNEEUS, 2016). Em junho de 1988, a distribuição interna dos governadores a nível nacional mostra a continuidade da hegemonia do Exército com o controle territorial de mais da metade das províncias a cargo de oficiais de serviço ativo e em retiro (32 unidades), seguida da participação de Carabineiros (10 unidades), representantes civis (7 unidades) e a Marinha (2 unidades). A FACH não tinha nenhuma destinação territorial (quadro no 16).

\section{Quadro $\mathbf{n}^{\circ}$ 16. Distribuição de Governadores Provinciais}

\begin{tabular}{|c|c|c|c|c|c|c|c|}
\hline \multirow{2}{*}{ Região } & \multirow{2}{*}{$\begin{array}{c}\mathbf{N}^{\mathbf{o}} \\
\text { Província }\end{array}$} & \multicolumn{2}{|c|}{ Exército } & \multirow{2}{*}{ Marinha } & \multirow{2}{*}{ FACH } & \multirow{2}{*}{ Carabineiros } & \multirow{2}{*}{ Civis } \\
\hline & & Ativo & Retiro & & & & \\
\hline I & 3 & 1 & - & - & - & - & 2 \\
\hline II & 3 & 1 & 1 & - & - & 1 & - \\
\hline III & 3 & - & 1 & - & - & 2 & - \\
\hline IV & 3 & - & - & - & - & 2 & 1 \\
\hline $\mathrm{V}$ & 7 & 4 & _- & 1 & _ & 1 & 1 \\
\hline VI & 3 & 2 & - & _ & - & - & 1 \\
\hline VII & 4 & 4 & - & - & - & - & - \\
\hline VIII & 4 & 2 & 1 & - & - & - & 1 \\
\hline IX & 2 & 1 & - & - & - & - & 1 \\
\hline $\mathrm{X}$ & 5 & 4 & - & - & - & 1 & - \\
\hline XI & 4 & 1 & - & - & - & 3 & - \\
\hline XII & 4 & 2 & 1 & 1 & - & - & - \\
\hline $\mathrm{RM}$ & 6 & 6 & - & - & - & - & - \\
\hline TOTAL & 51 & 28 & 4 & 2 & - & 10 & 7 \\
\hline
\end{tabular}

Fonte: Huneeus, 2016.

Durante o período autoritário, os governadores participavam dos COREDES presididos pelo Intendente Regional, sendo sua principal função defender e estimular a 
gestão de projetos de suas respectivas prefeituras. O mandato hierárquico e o exercício técnico-político que exerciam os governadores, acima de tudo, respondeu ao modelo hierárquico do SIGORE. No entanto, se bem os governadores deveriam patrocinar o cumprimento das tarefas de governo regional e a vigilância dos prefeitos comunais, também poderiam fiscalizar a própria linha regional hierárquica e enlaçar logística e tecnicamente os órgãos do governo central. Dessa maneira, Pinochet poderia ter sempre duplos dispositivos de informações, diretos, militarizados, que em eventual caso de maiores alterações dos planos de Santiago ou nas regiões, poderia manobrar e controlar convenientemente. Uma capilaridade militarizada que se reforçaria no caso das zonas fronteiriças e áreas de maior espaço vazio que colocassem em risco a soberania territorial. Mais estruturalmente, as províncias consolidaram a função político-militar nos territórios interiores, intermediando o comando nacional-regional com o nível local. Um policiamento da gestão do território oficial destinado a controlar qualquer tipo de interferência no SIGORE ou aplicar as ordens de Pinochet. 


\section{CAPÍTULO 6}

\section{Municipalizar para neoliberalizar}

\section{1 A batalha pelas fronteiras comunais: o poder da base?}

No transcurso da década de 1960, foram aprovadas uma série de leis que possibilitavam o aumento dos salários a partir da reivindicação do movimento operário de funcionários municipais. Uma luta de muitas décadas anteriores que, todavia, o Ministério da Fazenda da época nunca projetou nos aumentos dos financiamentos locais, o que deixou as prefeituras em uma situação pior que a anterior (SALAZAR, 1998). Desse modo, pouco iniciado o governo da UP, em setembro de 1970, as prefeituras do país estavam em estado de falência. O governo de Allende teve que recorrer de maneira urgente aos fundos excepcionais de catástrofe para salvaguardar um importante número de prefeituras que não tinham recursos suficientes para pagar seus funcionários. No momento do Golpe, por consequência, as prefeituras se estremeciam por ambas crises: a política e a financeira. Mas também, apresentavam uma diversidade importante de complicações administrativas enquanto escopos profissionais e recursos burocraticamente espalhados nos territórios. As prefeituras eram um reflexo fiel da histórica hegemonia centralista do Estado chileno que, até esse momento, projetava nos municípios um papel mais funcional e subalterno que a de um ator chave enquanto os processos políticos estruturais (DIAZ, 1989).

Um elemento interessante a considerar no contexto prévio da CONARA foi a disputa política local enquanto a organização das bases da UP que, geograficamente, seguia a linha divisora das comunas. Com efeito, após a paralização nacional dos caminhoneiros dirigida pelos grêmios empresariais em outubro de 1972, emergiu um inusitado movimento político-social que colocou ao centro os territórios locais: a criação de comandos comunais. Era uma medida urgente que tratava de unificar as energias políticas na escala local-comunal como estratégia defensiva da UP em resposta à intensa campanha de boicote da direita contra ao governo do Salvador Allende (CORTÉS, 2018). Esses comandos comunais, na prática, expressariam diferentes repertórios de organização social e setorial - desde a intensificação de iniciativas do governo como as Juntas de Abastecimento e Controle de Preços (JAP), até a reorganização micro-local de sindicatos, movimentos de moradores e estudantes. A união na base dos territórios locais permitiria combinadamente estender a influência e comunicação da UP de maneira defensiva e, principalmente, abrir repostas coletivas às diferentes 
problemáticas pautadas pelo complexo cenário de hiperinflação e o entesouramento de insumos básicos (LEIVA, 2004; VALDIVIA et. al., 2006).

No entanto, apesar da emergência popular, foi só a partir dos últimos meses da UP, precisamente após do tanquetaro $0^{54}$ de junho 1973 que, transversalmente, o governo de Salvador Allende chamou a conformar e organizar os comandos comunais ao longo do território nacional (LEIVA, 2004). Foi uma chamada desesperada e inédita, pois, por primeira vez, diferentes territorialidades populares de zonas rurais e urbanas foram confluindo para medir suas forças na base local, além de suas filiações partidárias ou orgânicas. Dessa maneira, organizações de operários, associação de moradores e de mulheres, militantes de centros esportivos e juventude se repartiriam e distribuiriam espaços na tentativa de organizar as necessidades mais urgentes na defesa do projeto popular. $O$ desespero e a pressa dos comandos comunais se fundamentavam em duas tarefas específicas: primeiro, unificar os setores que orgânica e historicamente tinham sido inconexos em termos políticos, como por exemplo, a associação de moradores com o movimento operário. E, em segundo lugar, ampliar a defesa do programa da UP em setores menos politizados ou lugares que, por diversas razões, não tinham uma representação hegemônica das esquerdas. Visto que a direita havia articulado múltiplas campanhas midiáticas e de boicote para anular as propostas do governo de Salvador Allende, e também convocou nas ruas ascendentes concentrações de massa (SANTANA, 2013).

Assim, a luta pelos espaços locais passou a ser uma questão estratégica: uma primeira linha local de prioridades e tarefas, onde militantes e partidários do campo popular defensivamente deveriam expressar uma maior organização política a nível comunal (CORTÉS, 2018). Contudo, a dramática unificação territorial dos comandos comunais foi violentamente paralisada pelo Golpe de Estado. Parte de sua demora como política oficial radicava nas diferenças internas entre a UP e os grupos de esquerda mais radical como o MIR. Onde, por um lado, os partidos políticos da UP projetavam os comandos comunais seguindo a estrutura hierárquica dos partidos, e dessa maneira, dando continuidade ao poder do governo nas estruturas administrativas locais via prefeitos e vereadores afins ao governo popular. Mas por outro, o MIR e suas forças militantes concebiam os comandos comunais,

\footnotetext{
${ }^{54}$ Em 29 de junho de 1973 um grupo de Regimento Blindado No 2 de Santiago rodeou o palácio de governo com a tentativa de sublevar as FF.AA. e destituir ao governo da UP. A tentativa foi frustrada pela ação direta do Comandante em Chefe do Exército, Carlos Prats, que junto com pessoal de unidades de Santiago paralisaram o grupo golpista e seu líder, o Tenente Coronel Roberto Couper.
} 
junto com os cordões industriais (bases operárias das fábricas), como órgãos políticos plenamente autônomos. Sua consolidação no território local expressaria o poder dual ou poder popular, e com isso, se indicaria uma alternativa concreta à política burguesa (LEIVA, $2004)^{55}$. Se trataria, pois, de diferenças onde se questionava a velocidade e a forma do poder popular da UP e também se mediria a capacidade real da influência do governo popular. No momento do Golpe de Estado, existiam aproximadamente mais de cem comandos comunais distribuídos em todo o país, com diversos níveis de organização e orgânica em ascensão ${ }^{56}$ (LEIVA, 2004).

Entretanto, a partir desse fatídico 11 de setembro de 1973, todos eles foram duramente punidos e desintegrados, não conseguindo seu objetivo de defender o governo popular. A importância estratégica que vai adquirindo o espaço político comunal e a questão do poder territorial entre as forças da esquerda, violentamente começará a ser parte dos arquivos de memória do governo de Salvador Allende. A discussão dos poderes territoriais, por consequência, foi emudecida e acompanhada de uma dramática repressão sobre as esquerdas e suas bases militantes. Um dos máximos intelectuais do Golpe de Estado e autor da Declaração de Princípios de 1974, o advogado Jaime Guzmán, o resumia nos seguintes termos:

El triunfo de la Unidad Popular no fue, como pudiera creer más de alguien, el de una combinación de partidos. Fue el de miles de comités de la Unidad Popular que tienen su fuerza en una poderosa organización gremial, poblacional y juvenil, de la cual las estructuras partidarias son meros coordinadores y representantes [...] Vamos a disputar palmo a palmo las poblaciones a la izquierda (MUÑOZ, 2016, p. 209).

O diagnóstico do regime entendeu que eram precisamente essas bases locais e populares da esquerda as que décadas passadas lhe haviam permitido construir "bistóricamente su fuerza política" (DIAZ, 1989, p. 202). Cada um dos comandos comunais da UP foi forçosamente inserido nos planos da investida autoritária e a reconstrução municipal do regime teria como principal propósito destruir as bases locais e populares da esquerda (DIAZ, 1989). Embora a noção da organização gremial de Guzmán procurasse neutralizar a

\footnotetext{
${ }^{55}$ Como assinalava o secretario general do MIR em 1972, Miguel Enriquez: "Lo fundamental en los Consejos Comunales de Trabajadores [...] es que en ellos será posible incorporar a los amplios sectores urbanos, como los estudiantes, las mujeres, y sobre todo a los sectores postergados, a los pobres de la ciudad, como lo son los pobladores, lo sin casa, los cesantes: más que incorporar, se trata de unirlos bajo la conducción del proletariado industrial, y establecer bases sólidas para la alianza de clases que permitirá avanzar" (LEIVA, 2004, s./r.).

${ }^{56}$ Entre outras tarefas, se destacava a distribuição e segurança de alimentos, formas de vínculo e articulação entre sindicatos e grupos de moradores, vigilância no interior de bairros e centros comunais estratégicos, cadastro dos motoristas e veículos na paralisação de caminhoneiros etc (LEIVA, 2004).
} 
politização dos espaços locais na sociedade chilena, o significativo da citação são outros dois elementos. Primeiro, o reconhecimento explícito de uma "poderosa organización" da Unidade Popular, composta de milhas de comitês espacial e setorialmente distribuídos nos marcos populares e micro territoriais, que, segundo Guzmán, não tinham uma direção centralizada dos partidos políticos, pois, esses últimos apenas tenderiam a uma representação e coordenação dessas forças autônomas. Por consequência, emerge, em segundo lugar, a consistência de um poder local a ser territorializado pelas estruturas tradicionais do "gremial, poblacional y juvenil', além dos partidos políticos tradicionais, mas sobretudo, em oposição à politização dos quadros populares com vontade de disputar em cada canto das comunidades sociais. Nesses termos, a escala geográfica comunal passaria a ser um laboratório de práticas autoritárias do regime e da direita no governo.

Análogo ao espírito defensivo dos comandos comunais da UP, as autoridades do regime farão um complexo enquadramento das funções e práticas municipais na lógica de salvaguardar as bases de apoio do projeto autoritário, o qual iria diretamente na direção oposta dos projetos e das práticas políticas do período anterior. Prévio ao Golpe de Estado (1930-1970), o sistema político chileno se caraterizava por um competitivo e sofisticado quadro territorial de partidos políticos nacionais, fortes e diversos ideologicamente (quadro $n^{\circ}$ 17). Já nas últimas décadas antes de sessenta e cinquenta, a disputa local não tinha uma monopolização de figuras tipo “caudillo político dominante” (VALENZUELA, 2016, p. 29). Pelo contrário, nas últimas eleições coincidentes com o primeiro ano do governo de Allende (1971), as forças políticas da UP mostravam um importante crescimento de prefeitos e vereadores, chegando a um 39,2\% das preferências a nível nacional (isto é a somatória do PS e PCCH) (quadro no 17).

Quadro no 17. Eleições Municipais (1935-1971)

\begin{tabular}{|c|c|c|c|c|c|c|c|}
\hline Partido & $\mathbf{1 9 3 5}$ & $\mathbf{1 9 4 1}$ & $\mathbf{1 9 4 7}$ & $\mathbf{1 9 5 3}$ & $\mathbf{1 9 6 0}$ & $\mathbf{1 9 6 7}$ & $\mathbf{1 9 7 1}$ \\
\hline Conservador & 26,4 & 16,3 & 20,2 & 15,4 & 13,9 & - & - \\
\hline $\begin{array}{c}\text { Liberal } \\
\text { Nacional }\end{array}$ & 20,4 & 19,9 & 13,3 & 12,8 & 15,4 & 14,1 & 18,1 \\
\hline Radical & 18,3 & 29,9 & 20 & 15,7 & 20 & 15,1 & 8,1 \\
\hline $\begin{array}{c}\text { Falange } \\
\text { Democracia } \\
\text { Cristiana }\end{array}$ & - & - & 3,4 & 4,5 & 13,9 & 35,6 & 25,7 \\
\hline $\begin{array}{c}\text { Agrario y } \\
\text { Agrario } \\
\text { Laborista }\end{array}$ & - & 1,1 & 4,5 & 18,5 & - & - & - \\
\hline
\end{tabular}




\begin{tabular}{|c|c|c|c|c|c|c|c|}
\hline Socialista & 0,1 & 14,4 & 8,7 & 11,1 & 9,7 & 13,9 & 22,3 \\
\hline Comunista & - & - & 16,5 & - & 9,2 & 14,8 & 16,9 \\
\hline Independientes & 17,1 & 12,6 & 3,6 & 14,6 & 1,6 & 0,7 & 0,9 \\
\hline Abstención & 12,6 & 30,5 & 16 & 31,4 & 30,5 & 23,7 & 25,2 \\
\hline
\end{tabular}

Fonte: Valenzuela, 2016.

Já seja nas grandes províncias e cidades como Santiago, Valparaíso e Concepción, já seja nos pequenos vilarejos e povoados rurais nos centros e extremos do país, os partidos políticos chilenos efetivamente protagonizavam uma importante disputa pelas prefeituras na mesma intensidade que os cargos no Parlamento (deputados e senadores). Dessa forma, a disputa política municipal correspondia a um sofisticado sistema de intermediação de partidos políticos nacionais que, paralelamente, combinava disputa ideológica com outras estruturas e intervenções locais, como os favores políticos (VALENZUELA, 2016). Com efeito, as autoridades locais - prefeitos e vereadores - deveriam estabelecer redes e contatos no governo nacional e/ou com a respetiva autoridade parlamentar (deputado ou senador da província), quem por sua vez, tinha que enlaçar essas demandas com Santiago e os organismos burocráticos centrais - geralmente os ministérios -, únicos capazes de distribuir os recursos e cumprir com as demandas territoriais locais (VALENZUELA, 2016). Esse esquema de relações territoriais estava, de uma forma ou outra, integrado estruturalmente ao sistema de partidos políticos (parlamentários, prefeitos e burocratas) que funcionava como representante e coordenador do processo de gestão política centralizada do Estado chileno e da aplicação de suas políticas públicas geralmente setoriais (muito dependente dos ministérios centralizados).

Foi contra esse modelo de intermediação político que o regime articulou uma exaustiva revisão do funcionamento das prefeituras no SIGORE. Imediatamente após o Golpe, os prefeitos pertencentes aos partidos políticos da UP foram demitidos e substituídos pelos militares ativos ou por oficiais em retiro das FF.AA. ${ }^{57}$. Junto com a implementação dos governos regionais pilotos, a Junta de Governo já havia formulado um importante desenho do funcionamento das prefeituras em agosto de 1974, encarregado pelo general em chefe da FACH Gustavo Leigh e o apoio técnico da ODEPLAN. Segundo Leigh, o futuro sistema

\footnotetext{
${ }^{57}$ No entanto, ao momento do Golpe de Estado, a diretiva central da DC apoiou a irrupção militar e a saída de Allende, razão pela qual o regime manteve em seus cargos os prefeitos do conglomerado do ex presidente Frei Montalava (aproximadamente uns sessenta prefeitos a nível nacional) (VALENZUELA, 2015). Só nos meses seguintes se romperam as relações entre o regime e a DC, que passava a ser parte da oposição.
} 
municipal chileno faria uma operação mais integrada das esferas pública, privada e comunitária, o qual melhoraria significativamente suas capacidades operativas, sobretudo na participação local dos vizinhos e a "factibilidad de los proyectos" (ACTAS DE LA JUNTA DE GOBIERNO, 1/8/1974). Essa última inovação se fundamentou na implementação de um sistema nacional de planejamento dirigido pelas SERPLAC e que conectaria as unidades locais com suas contrapartes regionais, agilizando suas projeções financeiras e a coordenação setorial das políticas. Nesse novo marco municipal, aliás, o principal mandato dos prefeitos seria reunir e manter ativa a participação da comunidade, propiciando condições e viabilizando suas aspirações.

Para cumprir com esses objetivos, o regime reformulou a lei $\mathrm{n}^{\circ} 16.880$ de Juntas de Vizinhos e Organizações aprovada em 1968 e estabeleceu novas prerrogativas através do decreto lei $\mathrm{n}^{\circ} 349$, onde passou a ter o controle de todas as diretivas das juntas de vizinhos do país (GOBIERNO DE CHILE, 1974f). Em virtude disso, o regime estabeleceu uma comunicação mais eficiente (rápida e direta) entre o prefeito e as organizações sociais organizadas $^{58}$, permitindo paulatinamente a constituição de um novo tecido institucional. A comunicação oficial se centralizava através de pequenas representações internas das comunas em poucas lideranças, onde a União Comunal de Juntas de Vizinhos conseguia um maior espaço de articulação junto aos prefeitos, podendo consultar diretamente o representante de várias localidades da comuna. Por sua vez, cada comuna do país - segundo Leigh - seria um "escalón ejecutor, el brazo que materializaba el progreso de Chile, uniendo los tres sectores: público, privado y comunitario" (ACTAS DE LA JUNTA DE GOBIERNO, 1 agosto de 1974). Se bem o cenário político local daria aos prefeitos um papel estratégico no relacionamento do governo com as forças sociais, ao mesmo tempo, caso o prefeito não cumprisse com as metas e instruções do governo central, "se va a tener que ir" (ACTAS DE LA JUNTA DE GOBIERNO, 1 agosto de 1974), sentenciava o general.

Nesse estrito sistema de hierarquia e dependência do poder central, se projetava a política comunal do período. Assim, nos últimos dias de 1975, junto com notificar a nova divisão de províncias, o regime também anunciava o começo do arranjo das comunas: "No serán más de 170. Regionalización reduce el número de comunas" (LA TERCERA DE LA HORA, 31 dezembro 1975) anunciava a imprensa. O anúncio era uma redução significativa, pois, a

${ }^{58}$ Entenda-se essas organizações comunitárias afins, tais como juntas de vizinho, centros de pais e apoderados da comuna, clube de escoteiros, Cruz Vermelha, entre outros. 
nível nacional o país contava com pouco mais de 300 comunas: "De las 313 comunas que habia en el país sólo 287 tenian la implementación de administración municipal y el resto sólo eran área geográfica, sin municipio" (LA TERCERA DE LA HORA, 31 dezembro 1975), se explicava na nota. A partir de critérios de eficiência e racionalidade na distribuição dos recursos públicos, se simplificaria o número de comunas do país, terminando com as históricas prefeituras desorganizadas, sem mecanismos de controle e nenhuma homogeneização de suas funções técnicas. Aliás, segundo CONARA, se terminaria com a excessiva burocratização e, sobretudo, a politização da organização local e seus circuitos de favores políticos ancorados na tradição dos partidos políticos. Diz o general Canessa:

La idea central en esta materia es reducir el número de Municipios con miras a obtener una mayor eficiencia y racionalidad de las organizaciones a este nivel, lo que sin duda se está logrando, ya que en las primeras aproximaciones presentadas por las regiones, de 245 comunas, sin considerar la Séptima y la Novena Región, ni la actual provincia de Valdivia, han quedado reducidas a 145 (EL CRONISTA, 31 dezembro 1975).

Se aplicava a mesma lógica nas províncias, onde cada Governador organizava um informe de suas respetivas comunas, escutando a suas autoridades - delegados SERPLAC e prefeitos comunais principalmente-, as quais, eventualmente, iriam acompanhado de proposições nos casos que correspondesse. Esse informe circulava logo ao Intendente regional, quem dava revisão final para fazer o envio à CONARA. Segundo o Ministro Diretor da CONARA, em total, o país tecnicamente ficaria com 170 municípios. A finais de 1975, a Junta de Governo aprovou a lei orgânica municipal (decreto lei no 1289) que começou a operar em janeiro de 1976. Essa proposta foi elaborada pela subcomissão comunal da CONARA e trazia uma tipologia de comunas, embora ainda sem recortes territoriais. Através da imprensa o general Canessa resumia os critérios de categorização comunal mais relevantes, destacando a acessibilidade, a heterogeneidade, a soberania e especialmente a questão profissional, talvez, o assunto mais estrutural e condicionante entre as diversas realidades comunais do país:

Desde otro punto de vista, hay otra consideración que tiene quizás el carácter de problema nacional, y que fue diagnosticado por los todos los delegados regionales en el seminario: una total carencia de profesionales y personal idóneo, en casi todas las comunas. Este problema se presenta en todas aquellas que no son sedes de las caberas provinciales o regionales. Excluidas éstas y las de la región metropolitana, las comunas deficitarias de personal calificado son nada menos que el 75 por ciento de las comunas del país, lo que incluso obligará al estudio del tercer nivel de planificación (EL CRONISTA, 14 março 1976). 
A reforma municipal tinha grandes obstáculos e poucos recursos para mudar a desigualdade estrutural entre as prefeituras. Para conseguir reverter esse cenário, segundo a CONARA, se deveriam criar ótimas equipes profissionais, capazes de estabelecer uma caracterização aprofundada de cada comuna e uma articulação administrativa coerente nas novas faculdades inseridas na reforma. Porém, na prática, esse fator profissional expressava a nível nacional um deficit estrutural ancorado em uma profunda desigualdade em termos da distribuição espacial dos serviços educacionais, industriais e tecnológicos que, apesar de todas as políticas da CONARA, dificilmente iriam romper diametralmente com a estrutura hegemônica-central de Santiago. Seguindo a tipologia, tecnicamente, as comunas receberiam uma categorização de acordo aos fatores sociais e econômicos da sua população em geral e em seus níveis operacionais. A CONARA chegaria a propor seis tipos de comunas (A, B, C, D, E, F) de acordo a suas densidades de população.

\begin{abstract}
Valparaíso es una de las comunas tipo A, que son muy pocas en Chile, porque tiene más de 300 mil habitantes; Temuco y todas las que sean como ella, entran en el tipo B, vale decir tienen más de cien mil habitantes y menos de 300 mil [...] De aquí bajamos a San Felipe, que entra en el tipo C, entre 70 y 100 mil habitantes. Aquí están también Los Andes y Quillota, Tipo D, entre 25 y 50 mil habitantes; están Villarrica, Lautaro, Freirina y muchas otras; Tipo E, entre 12 y 25 mil habitantes, que son como Nueva Imperial y Carahue [...]. En el tipo F entran los que tienen menos de 12.000 habitantes, y que ejemplifica con Olmué, O’ Higgins, San Fabián de Alico, Caleta Tortel. Esta última tiene exactamente 122 habitantes, según precisa el General Canessa. (EL CRONISTA, 27 maio 1976)
\end{abstract}

Também haveriam outros fatores, tais como as isocromas, que era o equivalente a uma hora de tempo de traslado entre as residências e o centro administrativo da comuna: "Este tiempo es ambicioso, porque corresponde a lo que se estila en otros países, y que en Chile tiene válidez. solo en la zona central' (EL CRONISTA, 27 maio 1976). Esse raio de tempo de distância era relevante pois, se considerava como um indicador da homogeneidade territorial dos serviços comunais que, aliás, estavam sujeitos a uma determinada estratégia de desenvolvimento regional. A tipologia da CONARA pretendia elaborar uma compreensão territorial mais integral das comunas, ao tempo de assegurar a articulação com o processo anterior de regionalização. Por isso, diz Canessa, "cuando una comuna se redefina, habrá que cuidar no cortar por la mitad un terreno o región que forme parte de un plan de desarrollo" (EL CRONISTA, 27 maio 1976). No entanto, apesar desses fundamentos regionalistas expostos pelo general e a metodologia de classificação comunal da CONARA, oficialmente as comunas não foram nem reduzidas nem aumentadas significativamente (quadro $n^{\circ} 18$ ). Embora algumas grandes cidades, como Santiago, foram objetos de uma complexa cirurgia institucional misturada em vários sentidos e fatores, próprios do contexto autoritário-neoliberal, como veremos no final deste capítulo. 
$\mathrm{Na}$ maior parte do país não se alterou significativamente o número de prefeituras. Contudo, se reconheceram certos critérios dos anunciados, como nos casos das comunas extremas de Juan Fernández, General Lagos, Colchane, Alto del Carmen, Hualaihué, Lago Verde, O’Higgins, Torres del Paine, Laguna Blanca, San Gregorio, Primavera, Timaukel y Navarino, onde primou a "seguridad del territorio nacional y la necesidad de apoyar a los compatriotas más aislados o en áreas fronterizas" (CANESSA, 1982, p. 29). De maneira geral, o arranjo das comunas a nível global nacional foi mais bem um ajuste territorial.

Quadro no 18. Recortes comunas oficiais (1979-1981)

\begin{tabular}{|c|c|c|c|}
\hline Data & Decreto Lei & Comunas & Regiões \\
\hline $26 / 10 / 1979$ & 2868 & 283 & $\begin{array}{c}\text { I, II, III, IV, V, } \\
\text { VI, VII, VIII, IX, } \\
\text { X, XI, XII }\end{array}$ \\
\hline $01 / 04 / 1980$ & 3260 & 34 & RM \\
\hline $19 / 11 / 1980$ & 1204 & 54 & I, II, III, IV, XII \\
\hline $10 / 12 / 1980$ & 1325 & 115 & $\begin{array}{c}\text { V, VI, VIII, IX, } \\
\text { X, XI }\end{array}$ \\
\hline $07 / 03 / 1981$ & 3642 & 31 & $\begin{array}{c}\text { RM (sem a } \\
\text { província de } \\
\text { Santiago) }\end{array}$ \\
\hline $17 / 03 / 1981$ & $1-3260$ & 17 & RM \\
\hline
\end{tabular}

Fonte: elaboração própria com a base nos decretos leis oficiais.

Seguindo o mesmo roteiro espacial das regiões e províncias, o primeiro recorte territorial de comunas foi decretado somente em outubro de 1979, quase quatro anos após os anúncios do general Canessa, projetando oficialmente 283 comunas em todas as regiões do país, sem contabilizar as comunas de Santiago. Praticamente se mantiveram as mesmas comunas conhecidas em todo o território nacional, sem uma redução significativa como se prometia em 1976. Assim sendo, qual foi a razão do atraso em quatro anos do recorte das comunas? Segundo o geógrafo chefe da CONARA, Dionisio Vio, no momento da modificação dos recortes comunais já existia uma discussão mais política do processo de demarcação territorial, liderada pelo Ministro do Interior Sérgio Fernández. Esse Ministro, segundo Vio, influenciaria significativamente as decisões do general Pinochet no destino das prefeituras:

El asunto de la división de las comunas - la reformulación comunal - ya no fue tan técnico, ya corrían más vientos políticos, porque ya había más influencia. Como que ya se escuchaba más a la gente, de repente había presiones para que se hiciera esta u otra comuna. Pero en general, había buena disposición. Entonces, ya no era cuestión técnica. Ósea, había dos ideas: una, que era de suprimir comunas, que eran muchas comunas y muchos alcaldes. Y, por otro lado, había otra tendencia que era un poco como una cantonización, a lo suizo. Y estaban las influencias de franceses que habían venido de otras misiones, pero de repente daban su 
opinión. Y había también influencia española porque había una serie de asesorías del régimen franquista, sobre todo en el área de administración. Había muy buena administración de gente de Barcelona [...] Entonces, hablaban de la patria chica. Todas estas ideas se las metieron a Pinochet [...] Entonces, llegamos a la conclusión: seamos realistas, no se pueden suprimir comunas, conforme, entonces, lo que vamos a hacer [...] vamos a hacer una reformulación comunal. Así se llamó el proceso. Todos quedaron marcando ocupado. No era ni lo uno ni lo otro [...] Cuando fuimos a presentarle la reformulación comunal, Pinochet como que ya tenía un ojo vivo, le metían cuentos estos dirigentes políticos. Estaba el Ministerio del Interior Fernández (ENTREVISTA DIONISIO VIO, dezembro 2019)

Precisamente nos diferentes documentos da época, se declarou a Reformulação Comunal como o conceito técnico oficial que delimitou as comunas a partir de 1979. São vários elementos a considerar do relatório de Vio. Primeiro, que existiam pressões políticas ao interior do regime que empurravam a se fazer ou desfazer comunas. Essas pressões certamente iriam além da CONARA que, por sua vez, aparentemente já não possuía a exclusiva hierarquia intelectual ou técnica do recorte territorial como nos primeiros anos da reforma. Segundo, no debate teórico, havia duas grandes tendências do que fazer com as prefeituras; a) suprimir prefeituras e, por consequência, aumentar sua escala geográfica e sua influencia em expansão territorial; b) criar mais prefeituras menores, mas a partir de uma maior proximidade das esferas comunitárias e serviços públicos locais. Terceiro, se bem no momento do recorte comunal coexistiam elementos nacionalistas para definir os limites das comunas, na prática, predominou uma ordem pragmática na resolução da CONARA ("seamos realistas, no se pueden suprimir comunas") no sentido de recriar um processo ancorado na realidade do regime e seus atores políticos, evitando possíveis conflitos ou problemas associados a uma reforma muito diferente da realidade comunal do país. Muito além das considerações técnicas e as discussões teóricas situadas nas ideias de suprimir ou aumentar prefeituras, a reorganização da patria chica ou a comuna será reflexo das transformações técnico-operativas do regime que, como bem destaca o general Canessa, tenderam "una relevancia especial en la futura convivencia Estado-ciudadano, porque es aqui donde se produce la participación directa de la ciudadanía en el Gobierno, a través de la autoridad comunal" (EL CRONISTA, 27 maio 1976). 
Mapa $\mathrm{n}^{\circ}$ 7. Comunas decreto-lei $\mathrm{n}^{\circ} 2868$

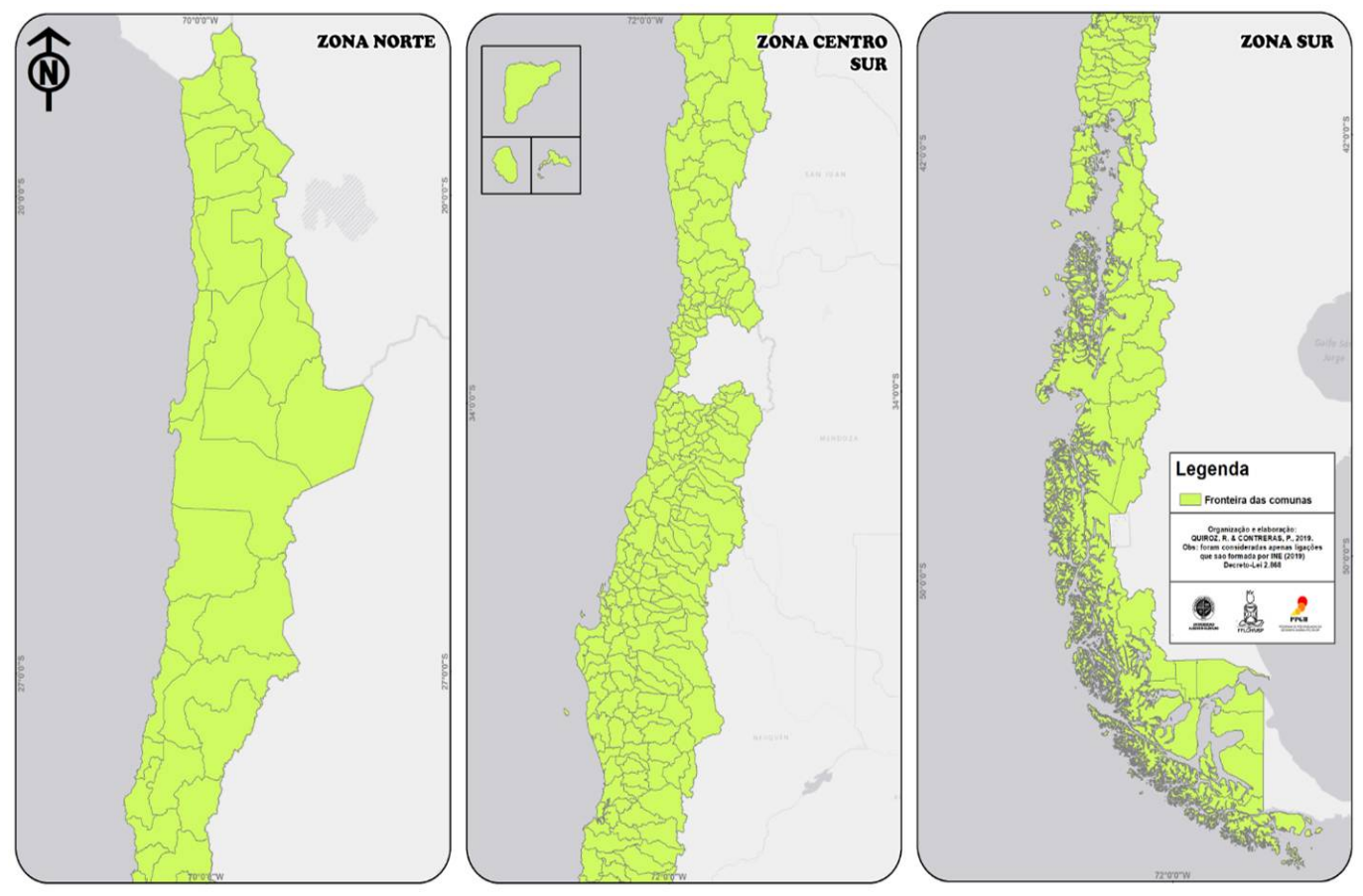

Fonte: Elaboração própria com base no decreto-lei nº 2868.

Apesar de que o regime anunciou uma participação direta da cidadania na resolução específica dos recortes comunais, de igual forma que na definição das regiões e províncias, o processo foi fechado e imposto pela autoridade hierárquica da CONARA e do general Pinochet. Em uma entrevista realizada pelo administrador público Matías Salazar ${ }^{59}$ ao engenheiro geógrafo-cartógrafo e funcionário da CONARA, e logo a SERPLAC da VI Região (1975-1979) da época, Rafael Valenzuela, se constata a questão autoritária dos recortes. Aqui de um estrato da entrevista:

MS: ¿Hubo discrepancias o discusiones respecto a las definiciones internas que había que mandar a la Junta?, ¿cómo era la definición?

RV: Hubo discrepancias, y mucha reserva. No salía del edificio donde estaba la discrepancia, donde se trataba la coyuntura y todavía hay reserva, porque algunas comunas se les quitó un distrito para anexársela a otra y podrían todavía reclamarlo. El ejemplo, Rosario de los Solís, que ahora se llama Litueche, era como Bolivia, mediterráneo, y ahora tiene salida al mar porque le quitó un pedacito a Pichilemu y un pedacito a Navidad, entonces si el Alcalde de Navidad y Pichilemu acuerdan algo, van a querer recobrar su territorio, entonces andábamos todos callados, silenciosos.

MS: ¿No se daba mucho lugar a la discusión?

RV: No, no se daba mucho lugar a la discusión. Era y era nada más. Había un mando vertical, así que nada (ENTREVISTA MATÍAS SALAZAR A RAFAEL VALENZUELA, junho 2019).

${ }^{59}$ A entrevista a Rafael Valenzuela foi realizada pelo administrador público Matías Salazar, entre 07 e 11 de junho de 2019. Ele gentilmente acedeu compartir o material da entrevista no contexto do trabalho de graduação de Administrador Público na Universidad de Talca, 2019. 
As demarcações comunais feitas pela CONARA buscavam sempre uma estrita reserva para evitar desconfortos e potenciais conflitos entre as autoridades locais, como na mencionada comuna de Litueche, localizada na sexta região do Libertador General Bernardo O`Higgins. Dessa maneira, a informação oficial final dos recortes era comunicada seguindo consecutivamente a hierarquia territorial (Intendente, Governador e Prefeito) que, por consequência lógica, não tinha um diálogo democrático. Não obstante, se bem a decisão não era democrática, existia uma coordenação e comunicação entre as autoridades territoriais que pretendia buscar consenso técnico no momento da definição e diferenças das comunas. Segundo Luis Alfonso Rivas, último secretário executivo da CONARA, a discussão dos limites comunais recaia fundamentalmente nos estudos e no trabalho de terreno com as autoridades locais, particularmente aqueles estudos comparados das realidades da França e Espanha e nos aportes dos comissionados do PNUD e de outras delegações internacionais:

Me tocó ir a diferentes regiones y provincias para fijar límites comunales, junto con el Instituto Nacional de Estadísticas (INE). Se les consultaba a las autoridades locales. Hubo muchos debates sobre las tributaciones. También hubo reuniones con privados de la zona. Se estudió la experiencia de Francia y España. Lo que se hizo en Chile fue muy serio, con participación local y externa, aprovechando la experiencia de otros países, gracias al proyecto de Naciones Unidas, trajimos muchos asesores: israelitas, gente de São Paulo, de la fundación Getulio Vargas (ENTREVISTA LUIS ALFONSO RIVAS, novembro 2019)

Como assinalávamos nos capítulos anteriores, desde o início da reforma existiu uma permanente assessoria do PNUD e outros centros de pesquisa como o CLAD, a CEPAL e o CIAPEP, sendo agentes importantes para a definição das linhas de estudos e as experiências pilotos que serão paulatinamente inseridas na gestão territorial do Estado chileno. No entanto, a decisão final das matérias sempre será prerrogativa da CONARA e a Junta de Governo. Em termos operativos, a definição de uma comuna passava por várias etapas. Primeiro, cada Governador fazia seus encaminhamentos ao Intendente que, junto com a SERPLAC, elaboraria o informe com os detalhes específicos dos limites e conteúdos de todas as comunas da região. Posteriormente, em uma segunda etapa, esses informes eram encaminhados à CONARA, quem fazia uma série de ajustes e avaliações técnicas que eram avaliados em terrenos ou trabalhos de campo. Na terceira etapa, a CONARA novamente encaminhava suas correções e consultava às autoridades locais especificas sobre as resoluções feitas para revisar suas impressões. Só após a visita em terreno e da retroalimentação com as autoridades locais, a CONARA encaminhava suas conclusões e informava Junta de Governo, quem decretava a aprovação ou rejeição da lei. Como lembra o geógrafo Dionisio Vio: "Lo que hacia yo en terreno: llegaba en un vehiculo, me bajaba donde veía ciertas zonas dudosas y 
preguntaba a la gente de la zona sobre los flujos y las orientaciones internas. En el fondo, estaba haciendo el examen de los flujos. Y yo estuve un año recorriendo el país" (ENTREVISTA DIONISIO VIO, dezembro 2019).

Porém, não sempre os limites expressavam fielmente os fluxos e nem as autoridades locais estavam conformes com as resoluções da CONARA. Ainda mais se tratando daquelas prefeituras menores e dependentes de certos tributos que incidiam de maneira importante em seu financiamento. De fato, a primeira fonte de conflitos, ou diferenças associadas ao recorte de comunas, esteve radicada no assunto da tributação. Essa dinâmica se fundamentava pelos efeitos da Lei Orgânica Municipal de 1976 e, sobretudo, posterior da Lei de Rentas Municipais de 1979, que conseguiu recolher mais fundos via tributação para as prefeituras. Tal foi o caso dos limites das prefeituras de Los Andes e San Esteban na zona interior leste da V Região de Valparaíso. Segundo Vio, o conflito se originou quando se modificou os limites comunais, tirando uma central hidroelétrica localizada originalmente na comuna de San Esteban para Los Andes

Pero había zonas en que igual ya habíamos escuchado reclamos de personas que no estaban de acuerdo. Por ejemplo, la comuna de San Esteban con Los Andes, donde hay una central hidroeléctrica importante. Entonces, lo lógico era que ésta hidroeléctrica quedara en Los Andes. Estaba un poco más cerca, todos los trámites se hacían allá y San Esteban era agrícola y un poco ganadera. Pero no era la gran cosa, entonces, yo lo saqué [...] Pero esto se mandaba de vuelta a la región [...] Y luego me llamó el alcalde de San Esteban y me dice: sabes, me vas a dejar sin recursos, si usted me saca la hidroeléctrica me va a dejar con hambre las ganas de comer60. Tal cual, entonces, no me saque el distrito siete. Eso me deja sin la tributación más importante. Así que ahí yo eché marcha atrás. Ahí privó un criterio económico (ENTREVISTA DIONISIO VIO, dezembro 2019).

É interessante o relatório porque também expressa implicitamente a dinâmica fechada, embora flexível, desses casos. Um prefeito de uma região X liga para o chefe técnico da CONARA a nível central para resolver uma diferença. Em diferentes hierarquias, ambas autoridades se reúnem, conversam e finalmente resolvem sem ter que dar maiores explicações aos níveis superiores nem inferiores. Neste caso a CONARA depõe sua modificação em favor da prefeitura de San Esteban. No entanto, é lógico pensar também que muitos desses casos não tiveram mesma consistência. Se demostra assim, que, embora as decisões do processo são tecnicamente hierarquizadas e centralizadas, ao mesmo tempo, existia uma coordenação interna entre as autoridades territoriais - neste caso as prefeituras e

\footnotetext{
${ }^{60}$ Proverbio popular que, para nosso caso, é uma metáfora para dizer que vai ficar em uma situação muito complexa de financiamento.
} 
a CONARA - que dava suportes e comunicações para tomar decisões mais integradas ou, ao menos, que considerassem os atores políticos oficiais envolvidos. Em outras palavras, a decisão final de um limite comunal não era uma decisão absolutamente verticalizada do poder central. Por sua vez, também da conta de uma continua política da CONARA: procurar legitimidade de suas decisões, apesar de que tivesse a hierarquia do poder central em sua condição de assessoria do Presidente da República. Vio também lembra de uma situação similar com a comuna de Nancagua na VI Região Libertador Bernardo O’Higgins. Uma dinâmica de tributação que implicitamente também se relaciona com a experiência do prefeito de Sierra Gorda, na II Região de Antofagasta, no período 1982-1984, Carlos Cantero, quem igualmente lembra dos debates sobre as tributações e o trabalho da CONARA na demarcação dos limites comunais:

Todo el trabajo de CONARA es muy reconocido y valorado. Tiene algunos altos y bajos como todos. Por ejemplo, cuando yo era alcalde de Sierra Gorda, para que entiendas bien la lógica. Si tú te ubicas en el mapa, tú dices aquí está Antofagasta y aquí está Sierra Gorda. ¿Por qué entonces corrieron la rayita un poquito y Manto Blancos quedó en Antofagasta, cuando yo si hubiese sido... Manto Blancos parte de mi comuna? De hecho, estaba muy cerca de mi comuna, prácticamente estaba dentro de mi comuna. Bueno, el desarrollo habría sido muy superior. Y, ¿por qué? Los tributos que pagan esas empresas terminaron siendo pagados en Antofagasta. Me habría encantado que nos hubieran pagado a nosotros. Entonces, en ese sentido, habría algunas situaciones que podrían prestarse a controversias. Pero como eran cuestiones que beneficiaban el tesoro público, tenían que ver con el bien público, en ningún caso con cuestiones de orden privado (ENTREVISTA CARLOS CANTERO, novembro 2019).

O relatório de Cantero reflete sobre o mesmo assunto da tributação, mas com o resultado contrário da situação de San Esteban e Nancagua. Trata-se de controvérsias associadas a mudanças de limites que influíam diretamente na tributação e no orçamento dos edifícios municipais, mas que tampouco tiveram uma grande manifestação ou crítica da reformulação comunal. Ao fim das contas, todas as autoridades territoriais e os próprios organismos centrais (CONARA e ODEPLAN) almejavam o mesmo objetivo de governo: fazer mais explicita a presença do Estado nos espaços interiores e com isso ampliar a legitimidade do governo. Nesse sentido, é interessante voltar no tempo prévio ao Golpe de Estado pois, se bem durante o governo da UP a definição de limites comunais não foi um assunto de maior destaque, havia algumas colocações que ajudam a compreender as lógicas inseridas na definição dos limites comunais do período. Por exemplo, em 1972 se aprovou a criação da prefeitura de Trehuaco no Sul do Chile. Na sessão especial da Câmara de Deputados de novembro de 1972, o deputado pela décima quinta agrupação Departamental San Carlos e Itata, o sr. Tomás Irribarra (PR), destacava: 
Señor Presidente, con la creación de la comuna subdelegación de Trehuaco sólo se hace justicia a los habitantes de los distritos que formarán esa comuna: Trehuaco, Las Minas y Leuque, de la comuna de Portezuelo; el distrito 4 Boca Itata, de la comuna de Cobquecura; y los distritos 12 y 13, Pachagua y Quilpolemu, de la comuna de Quirihue. Los habitantes de esa zona, para pagar impuestos muy pequeños, tienen que recorrer cerca de 100 kilómetros y perder dos días de trabajo. Con la aprobación de este proyecto se solucionarán sus problemas y tendrán éxito en esa gran meta que se han fijado desde hace muchos años. Trehuaco ya cuenta con retén de Carabineros, con oficina de Registro Civil, con posta, con estafeta, con mesas receptoras, con una linda escuela, etcétera. Por ese motivo, la mencionada Junta de Vecinos, hace meses, por mi intermedio, se dirigió al Ministro del Interior de ese tiempo, señor Del Canto, a quien le entregué los primeros antecedentes para el estudio de la creación de esta comuna subdelegación. También los entregué al Ministro señor Suárez y seguí haciendo lo que era posible para que la creación de esta comuna fuera una realidad, en conjunto con las delegaciones que continuamente viajaban a la capital (GOBIERNO DE CHILE, 1972, s./r.)

É interessante a lógica do caso de Trehuaco na UP porque ainda que o regime autoritário não tem feito uma criação significativa de novas prefeituras no país, mais internamente, houve uma diferença estrutural entre o recorte territorial das prefeituras na Região Metropolitana de Santiago versus as regiões (quadro $\left.n^{\circ} 19\right)$ ). Dessa forma, os pequenos ajustes territoriais das novas prefeituras em regiões seguiram um direcionamento similar ao caso do Trehuaco, mas sem a intermediação do Congresso Nacional (como nesse caso, via deputado Irribarra). Como sabemos, a CONARA foi o agente encarregado de coordenar a criação das novas prefeituras nas regiões. No geral, a criação de uma nova prefeitura se fundamentou a partir da necessidade de aumentar a presença do Estado e, por consequência, fortalecer a soberania do país naquelas fronteiras interiores, onde o peso do Estado tinha menor tecido territorialmente integrado, sobretudo nas zonas da fronteira norte com Peru, Bolívia e ao sul com a Argentina (mapa $\mathrm{n}^{\circ}$ 7), tal como o caso do recorte geopolítico das províncias de 1979. Paralelamente, essas novas prefeituras deverão atender à questão da tributação e o acesso à serviços públicos, procurando uma melhoria dos fluxos dos vizinhos enquanto suas necessidades e a distribuição espacial das ordens econômicas internas. Como vimos mais acima, se bem oficialmente se declaravam quase 300 prefeituras nas regiões do país, na prática, não todas elas tinham prefeituras formalmente constituídas. Daí que o trabalho da CONARA nas regiões foi basicamente organizar as prefeituras existentes e fundir aquelas que não cumpriam com os mínimos que estabelecia a lei municipal e determinar assim, caso necessário, criar eventualmente algumas novas oficinas públicas (quadro $n^{\circ} 3$ ).

\section{Mapa $n^{\circ}$ 8. Comunas novas em regiões}



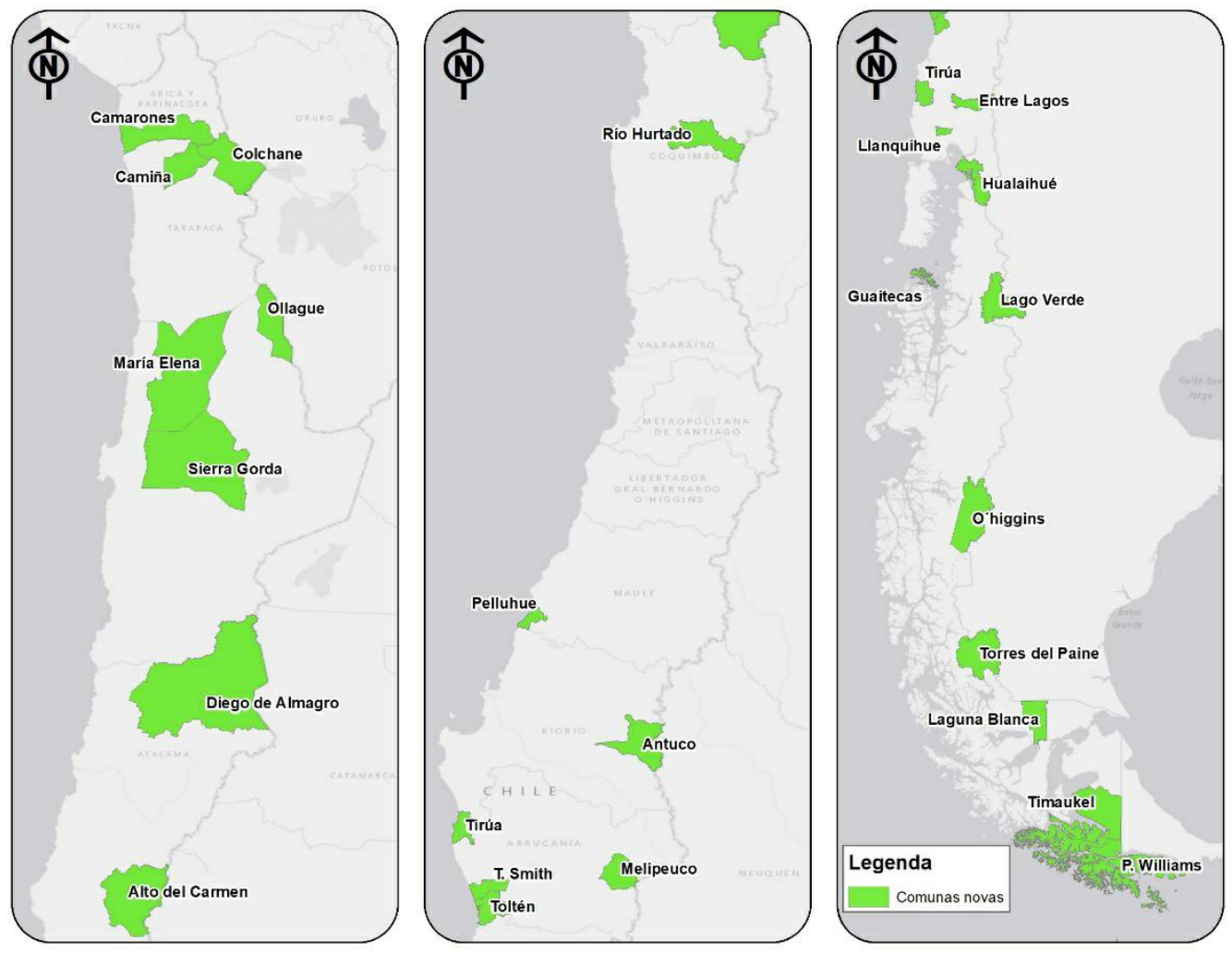

Fonte: Elaboração própria em base ao decreto-lei nº 2868 e comparação da divisão territorial do INE 1974.

Ocasionalmente esses ajustes também significaram mudanças nas toponímias das prefeituras. Tal como foi o caso da prefeitura de Pueblo Hundido do norte de Chile (III Região) que, em 1977, passou a denominar-se Diego de Almagro por "razones de indole históricocultural que aconsejan rendir un homenaje al adelantado español don Diego de Almagro" (GOBIERNO DE CHILE, 1977c, s./r.). Todavia, esse exercício de reestruturação das prefeituras nas regiões também foi uma forma de tradução do antigo sistema territorial baseado em províncias, departamentos, delegações e comunas ao processo territorial do regime. Daí que algumas das antigas delegações, departamentos e inclusive províncias - que no passado tinham oficinas públicas em representação do governo central - passaram a ser configuradas como prefeituras, como foi o caso da antiga província de Llanquihue no sul do Chile, e que também passou a ser uma prefeitura. Da mesma maneira, algumas antigas prefeituras em regiões foram eliminadas e rearticuladas a partir dos estudos da CONARA em seu espírito de reformulação comunal. 
Quadro $\mathrm{n}^{0}$ 19. Recorte comunas novas em regiões (sem Santiago)

\begin{tabular}{|c|c|c|c|}
\hline Data & $\begin{array}{c}\text { Decreto } \\
\text { Lei }\end{array}$ & Comunas & Regiões \\
\hline \multirow[t]{26}{*}{$26 / 10 / 1979$} & \multirow[t]{26}{*}{2868} & Camarones & \multirow[t]{3}{*}{$\mathrm{I}$} \\
\hline & & Camiña & \\
\hline & & Colchane & \\
\hline & & María Elena & \multirow[t]{2}{*}{ II } \\
\hline & & Ollagüe & \\
\hline & & Diego de Almagro & \multirow[t]{2}{*}{ III } \\
\hline & & Alto del Carmen & \\
\hline & & Río Hurtado & IV \\
\hline & & Juan Fernández & $\mathrm{V}$ \\
\hline & & Pelluhue & VII \\
\hline & & Antuco & \multirow[t]{2}{*}{ VIII } \\
\hline & & Tirúa & \\
\hline & & Melipeuco & \multirow[t]{2}{*}{ IX } \\
\hline & & Teodoro Smith & \\
\hline & & Entre Lagos & \multirow[t]{3}{*}{$\mathrm{X}$} \\
\hline & & San Juan de la Costa & \\
\hline & & Llanquihue & \\
\hline & & Hualaihué & \multirow[t]{5}{*}{$\mathrm{XI}$} \\
\hline & & Lago Verde & \\
\hline & & Guaitecas & \\
\hline & & O`Higgins & \\
\hline & & Tortel & \\
\hline & & Torres del Paine & \multirow[t]{4}{*}{ XII } \\
\hline & & Laguna Blanca & \\
\hline & & Timaukel & \\
\hline & & Puerto Williams & \\
\hline
\end{tabular}

Fonte: Elaboração própria.

O decreto lei no 2868 de novembro de 1979 foi a primeira formulação oficial das prefeituras a nível nacional sem a Região Metropolitana (quadro no 3). É interessente esse recorte porque, junto com o recorte comunal de Santiago de 1981, é onde se observa a presença de novas prefeituras (mapa $n^{\circ} 7$ ). Mais adiante, o recorte comunal de 1980 no resto das regiões do país (decretos lei $n^{\circ} 1204$ e $n^{\circ}$ 1325), salvo pequenas mudanças de toponímias $^{61}$, não tiveram uma criação significativa de novas prefeituras. Foram apenas 26 prefeituras novas concentrando as maiores mudanças nas I, XI, XII regiões. Um número ainda mais reduzido, considerando que algumas dessas novas prefeituras já tinham uma

${ }^{61}$ Por exemplo, no extremo sul da Região de Magallanes, em 1979 a prefeitura de Navarino passou denominar-se Puerto Williams e posteriormente em 1980 voltou a ser denominada Navarino. 
expressão pública e corresponderam a antiga demarcação territorial do governo interior (departamentos, delegações, subdelegações e distritos). Posterior aos decretos de 1979, haveriam também outras particulares demarcações que definiriam a criação dessas prefeituras. Tal como foi o caso da prefeitura de Sierra Gorda (III Região), uma antiga subdelegação do governo interior antes do Golpe de Estado, que, só a partir de 1 de junho de 1981 dá-se início à construção de um edifício de governo municipal. Caso interessante porque demostra uma materialização do poder territorial do processo de regionalização.

Quadro no 20. Sínteses recorte comunal por regiões (1979-1981)

\begin{tabular}{|c|c|c|c|c|c|c|c|}
\hline Región & 1974 & $\begin{array}{c}\text { Decreto } \\
{\text { Lei } \mathrm{n}^{\circ}} \\
2868 \\
(1979) \\
\end{array}$ & $\begin{array}{c}\text { Decreto } \\
\text { Lei } n^{\circ} n^{\circ} \\
3260(a b r- \\
80)\end{array}$ & $\begin{array}{c}\text { Decreto } \\
\text { Lei } \mathbf{n}^{\circ} \\
1204 \\
(\text { nov-80) }\end{array}$ & $\begin{array}{c}\text { Decreto } \\
\text { Lei } \mathrm{n}^{\circ} \\
1325 \\
(\text { dic-80) }\end{array}$ & $\begin{array}{c}\text { Decreto } \\
\text { Lei }^{\circ} \\
\mathbf{N}^{\circ} 3642 \\
(\text { mar-81) }\end{array}$ & $\begin{array}{c}\text { Decreto } \\
\text { Lei no } \\
\text { N }^{\circ} 1- \\
3260 \\
(\text { mar-81) }\end{array}$ \\
\hline I & 11 & 10 & & 10 & & & \\
\hline II & 11 & 9 & & 9 & & & \\
\hline III & 7 & 9 & & 9 & & & \\
\hline IV & 15 & 14 & & 15 & & & \\
\hline $\mathrm{V}$ & 32 & 37 & & & 37 & & \\
\hline $\mathrm{VI}$ & 32 & 33 & & & 33 & & \\
\hline VII & 28 & 29 & & & 29 & & \\
\hline VIII & 47 & 49 & & & 49 & & \\
\hline IX & 27 & 30 & & & 30 & & \\
\hline $\mathrm{X}$ & 39 & 38 & & & 42 & & \\
\hline XI & 6 & 14 & & & 10 & & \\
\hline XII & 11 & 11 & & 11 & & & \\
\hline $\mathrm{RM}$ & 47 & & 34 & & & 34 & 51 \\
\hline $\begin{array}{c}\text { Total } \\
\text { Nacional } \\
\end{array}$ & 313 & 283 & 34 & 54 & 230 & 34 & 335 \\
\hline
\end{tabular}

Fonte: elaboração própria com base nos decretos leis.

De tal maneira, os recortes comunais continuaram sua oficialização entre 1979 e 1981 (quadro $\mathrm{n}^{\circ}$ 20), seguindo um padrão nacional de distribuição espacial similar na implementação das províncias e regiões: primeiro um ajuste a nível nacional, logo os extremos e centros, até concluir o processo em Santiago, sempre a última fronteira da 
regionalização. É importante também assinalar, aliás, que os decretos de nomeação de novas prefeituras, onde não existiam antigas demarcações públicas e correspondia ampliar a presença e soberania do Estado, efetivamente poderiam demorar alguns anos em sua construção. Para oficializar uma demarcação territorial da comuna, como assinalávamos, as resoluções técnicas e políticas dos limites comunais foram percorrendo as hierarquias das comunas às províncias e das províncias as regiões, para que finalmente a CONARA e seu pessoal "de mayor solvencia intelectual" (EL CRONISTA, 27 maio 1976) agissem sobre o assunto. A escala geográfica comunal, assim, estava internamente ligada às províncias e às regiões e não fugia da rede social e técnica do SIGORE. Porém, é interessante refletir que ao fim da década de setenta, o regime ainda não tinha um consenso hegemônico em relação ao tratamento das estruturas municipais da capital do país: Santiago não tinha uma nova divisão comunal oficial. Na prática, coexistiam posições distintas do que fazer com suas estruturas e as formas locais mais interconectadas da gestão municipal. Criar ou suprimir comunas? O debate teórico-prático para estabelecer os limites comunais em todo o país se expandiu por vários anos (1974-1979) e só na década de 1980 tenderia a uma resolução espacial-total. O que estava em jogo nessa reformulação comunal oficial que estabeleceu a CONARA entre 1979 e 1981? Qual foi o centro da reforma municipal? Um poder de base?

\subsection{Espírito de corpo, profissionalização e neoliberalismo: o modelo municipal do regime}

A nova estrutura municipal do regime, em termos jurídicos, rapidamente foi organizada pelos decretos da regionalização (nº 573 e no 575) aprovados em julho de 1974. Entretanto, dois anos após (janeiro de 1976), se aprofundou através da Lei Orgânica de Municipalidades (decreto-lei $n^{\circ}$ 1289) e entregou mais especificações às faculdades municipais. Dessa maneira, as prefeituras eram parte do regime do Governo Interior e dependiam hierarquicamente de suas respetivas províncias e regiões, onde se localizavam o Intendente Regional e o Governador Provincial, ambos chefes hierárquicos dos prefeitos como definia o SIGORE. Seguindo a tradição constitucional chilena, também se definiu que as prefeituras continuariam cumprindo funções administrativas, embora fossem o espaço político institucional do poder central: "Las Municipalidades son instituciones de Derecho Público, funcional y territorialmente descentralizadas, cuyo objeto es administrar la comuna para satisfacer las necesidades locales y promover el desarrollo comunal. Forman parte del sistema de Administración Interior del Estado" (GOBIERNO DE CHILE, 1976a, s./r.). 
Em estrito rigor, durante o período autoritário as prefeituras nunca foram descentralizadas. Não obstante, a diferente disposição das prefeituras ajudou a desintegrar o antigo sistema de intermediação dos partidos políticos e, junto com isso, permitiu desenvolver novos repertórios políticos: programas sociais via formulação de projetos e suportes profissionais com mais experiência em trabalho de campo e o contato direto com as comunidades. A lei orgânica municipal de 1976 precisamente articulou uma gestão dos serviços públicos locais, destinada, sobretudo, "a proteger al ciudadano medio de la burocracia o desidia funcionaria o administrativa; se establece un sistema de procedimientos a la vez que se fijan sanciones para quienes resulten responsables de no dar un servicio rápido y oportuno a los recurrentes" (ERCILLA, 14 janeiro 1976). Desse modo, a reforma municipal se entendeu também como um saneamento das lógicas burocráticas que historicamente não tinham maiores estândares nem compromissos com a cidadania. Assim sendo, as prefeituras deveriam propiciar e ativar redes e espaços de participação nos assuntos vizinhais ou cotidianos, precisamente integrando à suas tarefas aquelas demandas organizadas pelos grupos locais. Esse escalamento comunitário ou participativo das prefeituras configurou uma base local que ampliou a forma de uma administração comunal efetivamente mais ligada aos assuntos comunitários e também projetou uma alternativa ao antigo cenário de relações políticas. Segundo o general Canessa:

Para el chileno, que elegía sus mandatarios (regidores, parlamentarios, Presidentes) a través del sufragio, su participación comienza ahora en los organismos de base que -según la nueva Ley de Municipios y las disposiciones emanadas de CONARA- tendrán una amplia representación en los Consejos de Desarrollo Comunal (CODECOS). De la antigua comuna autónoma, de tantos episodios históricos en el pasado, se marcha ahora hacia la comuna integrada, en forma administrativa y planificada y no política (ERCILLA, 14 janeiro 1976).

Porém, a participação dos CODECOS era efetiva sempre e quando as organizações aceitassem e colaborassem com as decisões do prefeito e das equipes municipais. Os CODECOS que destacava o general Canessa, na prática, eram unidades conselheiras do prefeito que agrupavam de maneira estamental as diferentes agrupações e lideranças de seu território. A lei municipal de 1976 estabeleceria que organicamente os CODECOS se compunham de $1 / 4$ da União Comunal das Juntas de Vizinhos, 1/4 da União Comunal de Centros de Mães e outras organizações comunitárias e culturais, 1/4 dos representantes das atividades econômicas da comuna (empresários) e, por último, $1 / 4$ dos chefes municipais ${ }^{62}$

\footnotetext{
${ }^{62}$ A lei municipal de 1976 estabelecia que o CODECO devia ter uma composição que não podia ser superior de vinte nem inferior a oito membros. Aliás, junto com as organizações sociais também se estabelecia que o funcionário Secretario Municipal era o relator oficial das atas e, por outro lado, se estabelecia que o
} 
(GOBIERNO DE CHILE, 1976a). Se bem formalmente se declaravam múltiplas funções de gestão e participação, na prática, os CODECOS não tinham nenhuma atribuição vinculante no funcionamento dos municípios e nem seus projetos executados. Diz a lei orgânica municipal sobre o CODECO:

Conocer y proponer los proyectos de políticas y planes de desarrollo de la respectiva comuna y formular las observaciones que estime convenientes [...] Conocer el Plan Financiero y el proyecto de Presupuesto Municipal y formular las observaciones y hacer las proposiciones que estime pertinentes [...]Proponer prioridades en la formulación y ejecución de los programas y proyectos específicos[...]Proponer al Alcalde medidas de general aplicación relativas a las materias indicadas en los números anteriores [....] Pronunciarse sobre los demás asuntos que le asignen otras disposiciones legales (GOBIERNO DE CHILE, 1976a, s./r.).

Concretamente, todas as decisões territoriais recaiam no Prefeito comunal previamente fiscalizado pelo Governador provincial, o Intendente regional e sua equipe da SERPLAC. Mais que uma participação popular, o regime cívico-militar precisava, de uma ou outra forma, que os CODECOS legitimassem sua hierarquia territorial. Além disso, a lei municipal estabeleceu maiores instrumentos e funções que tenderam a dar mais atribuições às prefeituras, embora também reforçaram a estrutura vertical do SIGORE. Por exemplo, na esfera das atribuições e deveres dos municípios, a lei estabelecia que o prefeito seria o encarregado da administração comunal de todos os estabelecimentos, oficinas, serviços e obras. No entanto, no momento da operatória do poder, o prefeito paralelamente também deveria obedecer as "instrucciones generales que imparta el Gobernador Provincial" (GOBIERNO DE CHILE, 1976a, s./r.). Seguindo a linha técnica do SIGORE, em cada comuna existia uma Secretaria Comunal de Planejamento e Coordenação (SECPLAC) que seria a encarregada de assessorar o Prefeito e o Conselho de Desenvolvimento Comunal mediante a coordenação e preparação das políticas comunais, assim como também avaliar planos, programa e projetos, dando suporte técnico às repartições comunais, etc. (GOBIERNO DE CHILE, 1976a). Dessa forma, cada SECPLAC deveria subordinar-se às “instrucciones generales de carácter técnico" da sua respetiva SERPLAC (nivel regional), ao tempo que a seleção do cargo de Secretario Comunal de Planejamento e Coordenação devesse ser vigiado "por el Intendente Regional, a proposición del Alcalde, oyendo al respectivo Secretario Regional de Planificación y Coordinación" (GOBIERNO DE CHILE, 1976a, s./r.). A reorganização interna burocrática da patria chica, assim, dependia explicitamente das autoridades técnicas e políticas do nível superior

SECPLAC junto com os chefes de departamentos e delegações municipais também tinham direito a voz (GOBIERNO DE CHILE, 1976a). 
(província e região), o qual fixava sua interligação a partir das ações governamentais do programa nacional.

Em termos de classificação ou reconhecimento de diferenças geográficas, segundo a lei, as prefeituras poderiam ser rurais ou urbanas, dependendo de suas infraestruturas e níveis de concentração demográfica e econômica estabelecidas pelo Instituto Nacional de Estatística (INE) (GOBIERNO DE CHILE, 1976a). Mas do ponto de vista operativo, todas as prefeituras do país tinham que cumprir indistintamente duas ferramentas de gestão municipal que eram consideradas universais: o Plan de Desarrollo Comunal (PDC) e o Plan Regulador Comunal (PRC) ${ }^{63}$. De tal maneira, todas as prefeituras do país tinham que elaborar planos de desenvolvimento e regulamento de uso de solo, que, paralelamente tinham que estar inseridos, subordinadas e aprovadas no respectivo Plano Regional de Desenvolvimento da Intendência Regional (escala regional) (GOBIERNO DE CHILE, 1976a). Em relação ao processo de aprovação do Plano de Desenvolvimento Comunal (PDC) a lei municipal diz:

\begin{abstract}
Esta tarea se efectuará con la colaboración de las reparticiones comunales y de otros servicios de nivel comunal que deban participar en razón de su competencia y de la naturaleza de sus funciones. Una vez aprobado por el Alcalde, previa consulta al Consejo Comunal de Desarrollo, se remitirá al Intendente Regional, a través del Gobernador Provincial respectivo. El Intendente Regional dará la aprobación definitiva al Plan, previos la consulta al Consejo Regional de Desarrollo y el pronunciamiento técnico de la Secretaría Regional de Planificación y Coordinación, a fin de asegurar que se ajuste al marco programático del Plan Regional. Las proposiciones del Plan serán de largo, mediano y corto plazo. Las de largo y mediano plazo se consultarán en el correspondiente Plan Financiero y las de corto plazo se formularán en el Presupuesto Municipal, a través de programas y proyectos específicos (GOBIERNO DE CHILE, 1976a, s./r.).
\end{abstract}

A aprovação do plano de desenvolvimento de qualquer comuna do país era a expressão de uma vigiada comunicação interna entre as autoridades territoriais que, no final da cadeia, tendia a reforçar o poder territorial da SERPLAC e o respetivo comando político do Intendente regional. Dessa maneira todas as projeções estratégicas na escala comunal estavam inseridas no SIGORE. À diferença do Plano de Desenvolvimento Comunal, que era um instrumento indicativo que não tinha incidência legal concreta no espaço urbano ou rural da comuna, o Plano Regulador Comunal era um instrumento normativo que definia técnica e juridicamente as condições do uso de solo. O Plano Regulador Comunal definia

\footnotetext{
${ }^{63}$ Chile tinha uma importante tradição em matérias legislativas urbanas. Segundo Beldrack, os primeiros PRC foram aprovados em 1928 pela Lei General de Construções e Urbanização que estabelecia que, "todas las ciudades con una población superior a 7.000 habitantes tiene la obligación de contar con planos reguladores, ejecutados por el respectivo municipio y aprobados por Decreto Supremo" (BELDRACK, 1974, p. 10)
} 
áreas consolidadas da comuna onde não poderia haver alterações ou bem estabelecia zonas de ampliação ou remodelação via projetos de investimento regional ou comunal (GOBIERNO DE CHILE, 1976a). Portanto, poderia incidir diretamente nos tipos de equipamento e a infraestrutura que iriam ser impulsionadas na comuna. Dada essa radical importância, a aprovação final do Plano Regulador Comunal, por consequência, deveria contar com a "supervigilancia técnica" da SERPLAC que, paralelamente, também deveria organizar seus conteúdos a partir de um Plan Regulador Intercomunal ou Provincial que era coordenado conjuntamente com a SEREMI do Ministerio de Vivienda y Urbanismo (MINVU) (GOBIERNO DE CHILE, 1976a). Assim, qualquer possível mudança do solo urbano a nível comunal estava plenamente integrada ao nível regional (SERPLAC) e a um sócio estratégico: a SEREMI do Ministério de Moradia e Urbanismo (MINVU).

Porém e apesar de que todas essas atribuições e procedimentos haviam melhorado as condições das prefeituras, no fundo, ainda eram parcialmente desenvolvidos. O problema estrutural do modelo municipal até início da década de 1980 era o ainda escasso nível de financiamento, tal como tinha acontecido nos finais do século XIX (SALAZAR, 1998) ${ }^{64}$. De tal maneira que, apenas a partir da Lei de Rentas Municipalidades aprovada nos últimos dias de 1979 (decreto-lei n 3063), as ditas atribuições e procedimentos municipais conseguiriam um maior impacto nos cenários locais do país, mudando a triangulação da gestão territorial das prefeituras. Segundo González (1990), a lei de rentas municipais teve três efeitos significativos em relação a antiga fórmula de arrecadação municipal. Em primeiro lugar, se incorporaram recursos municipais da ordem do $100 \%$ do imposto territorial e do aval de circulação de veículos. Em segundo lugar, se eliminaram a classificação de tributação das comunas (patentes comunais, indústrias e álcoois). E terceiro, se criou o Fondo Común Municipal (FCM), um financiamento extra da antiga divisão histórica das prefeituras com a pretensão de criar uma distribuição mais equitativa entre as comunas e prefeituras, entendendo suas necessidades e densidades demográficas (GONZALEZ, 1990). Esse último dispositivo de financiamento, o FCM, estava constituído por um 55\% das arrecadações anuais por cada comuna em termos do imposto territorial e procurava ser distribuído por

\footnotetext{
${ }^{64}$ A reforma municipal de 1891 foi o primeiro dispositivo que aumentou a arrecadação das prefeituras via impostos de patentes industriais. No entanto, em termos operativos burocráticos, as prefeituras continuaram tendo escassas faculdades e orçamentos para cumprir suas tarefas fundamentais, não conseguindo um estatuto orgânico relevante a favor de suas aspirações históricas. Na prática, trata-se de uma prefeitura mínima, subalterna e ancorada na disciplina do governo central que via autoridades delegadas no interior das comunas - Intendentes e subdelegados principalmente -, iam fortalecendo "las agencias del gobierno central" (VALENZUELA, 2015, p. 127) no territorio interior.
} 
"criterios de población y capacidad de generación de recursos propios de la comuna" (GONZALEZ, 1990, p. 100).

\section{Quadro no 21. Ingressos Municipais (1975-1988)}

\begin{tabular}{|c|c|}
\hline Ano & $\begin{array}{c}\text { Millones de pesos } \\
\text { chilenos (Dic. } 88 \text { ) }\end{array}$ \\
\hline 1975 & $27.184,1$ \\
\hline 1976 & $44.116,3$ \\
\hline 1977 & $34.087,5$ \\
\hline 1978 & $40.359,6$ \\
\hline 1979 & $46.564,2$ \\
\hline 1980 & $61.164,9$ \\
\hline 1981 & $115.232,0$ \\
\hline 1982 & $204.187,7$ \\
\hline 1983 & $170.767,2$ \\
\hline 1984 & $120.750,1$ \\
\hline 1985 & $120.352,4$ \\
\hline 1986 & $124.478,4$ \\
\hline 1987 & $129.860,5$ \\
\hline 1988 & $160.348,9$ \\
\hline
\end{tabular}

Fonte: Gonzalez (1990).

A lei de rentas municipais foi a principal responsável dos novos escalamentos políticos e econômicos que seriam inseridos nas próximas décadas pelas prefeituras. No percurso da década de 1980, com efeito, a fórmula de distribuição do FCM foi se ajustando-se para conseguir maiores compensações entre os municípios mais históricos e poderosos versus as comunas estruturalmente menores e de escassos recursos ${ }^{65}$ (GONZALEZ, 1990). Ao fim e na prática, nunca se conseguiu reverter essa desigualdade estrutural da arreação e distribuição dos serviços comunais: se estruturou uma renda desigual entre um número muito reduzido de prefeituras ricas versus uma grande maioria de prefeituras com recursos insuficientes (BECERRRA, BARCOSKI, 2020). Contudo, as prefeituras aumentaram seus orçamentos municipais significativamente em comparação à década anterior (quadro $n^{\circ} 21$ ), e constituiuse o FCM em uma fonte substancial para as prefeituras, sobretudo aquelas situadas em espaços rurais, isoladas e pequenas, onde às vezes, era a principal fonte de arrecadação (HUNEEUS, 2016; VALDIVIA, 2012; MONCADA, 1990; CONARA, 1985). Como diz González:

\footnotetext{
${ }^{65}$ Segundo González, o FCM em 1984 ficou composto nos seguintes termos: " $60 \%$ del impuesto territorial; $50 \%$ del impuesto por permiso de circulación de vehículos; $100 \%$ del aporte fiscal; $45 \%$ de la recaudación de las Municipalidades de Providencia y Las Condes por patentes comerciales" (GONZALEZ, 1990, p. 100).
} 
En 1988 los recursos destinados a inversión real en el total de los municipios del país alcanzó a $\$ 43.800$ millones, cifra ocho veces superior a la inversión -expresada en términos realesregistrada en 1979, año en que entró en vigencia la Ley de Rentas, y que fue de $\$ 5.600$ millones; y a su vez 43 veces superior si se compara con aquella efectuada en 1975, que alcanzó a $\$ 1.000$ millones (GONZALEZ, 1990, p. 100).

São cifras sem precedentes para esse momento da história municipal chilena. A média anual dos recursos municipais entre 1980 e 1888 ascendeu a uma ordem de 122 mil milhões de pesos chilenos, o equivalente a mais de "tres veces superior a aquellos correspondientes al período 1975-1979, que alcanzó sólo a \$38.462,3 millones" (GONZALEZ, 1990, p. 101). As prefeituras contavam com maior orçamento conforme o conjunto de tarefas e obrigações que a própria lei de 1976 havia impulsado. Paralelamente, esses maiores ingressos também tiveram que enfrentar novos custos operacionais associados a uma profunda reestruturação do tecido institucional ao interior das prefeituras. A partir de 1980, a reforma municipal justamente começou a impulsar uma particular formula de descentralização que consistiu em uma reorganização interna dos dispositivos municipais em termos de funções e serviços sociais locais, o que implicou no traspasso municipal das escolas públicas e atenção de saúde primaria que dependiam das antigas redes e serviços dos ministérios de Educação e Saúde. A descentralização a nível municipal estabeleceu que os antigos serviços públicos de edução e saúde, que durante toda a história do Chile dependiam logisticamente dos ministérios nacionais, pudessem ser controlados e administrados pelas prefeituras. De tal maneira que todas essas cifras históricas de arrecadação municipal voltaram a ser desdenhas diante dos altos custos que significariam a subvenção dos serviços de saúde e educação na administração dos municípios. O que estava em jogo?

Em 1978 o comandante Alejandro Gonzalez Samohod - Secretário Executivo da CONARA - destacava que o Estado apenas tinha que dispor os recursos necessários que permitissem assegurar as prestações de serviços básicos nas áreas de saúde, educação e outros, limitando sua ação a subsetores privados e/ou mineiros e energéticos, pois, o mercado era a "herramienta fundamental para determinar la asignación de los recursos, lo cual se logra mediante un adecuado funcionamiento del sistema de precios" (BALBONTIN, 1984, p. 23). Esse pensamento neoliberal implicava que o setor privado tinha que ocupar-se e multiplicar a subcontratação de serviços municipais em todos os assuntos - asseio, limpeza, entretenimentos, manutenção dos espaços públicos, etc. - mas sobretudo, abrir a possibilidade de transmitir educação "privada gratuita y subvencionada por el Estado" 
(MONCADA, 1990, p. 53) ${ }^{66}$. A neoliberalização do país se ensamblava nas prefeituras através de serviços mínimos em educação e saúde. O regime aumentava os níveis de arrecadação das prefeituras, mas simultaneamente incorporava dispositivos que tendiam a tencionar os serviços municipais e a perda da excelência da questão pública (entenda-se por isso a perda de saúde e educação pública de alta qualidade). A descentralização oficial nas prefeituras se fundamentou nas necessidades de entorno às comunidades, pois, as prestações municipais em saúde e educação se enfrentavam de melhor maneira na proximidade geográfica e a comodidade de aceso desses serviços com os usuários na escala geográfica comunal. Como destacava o administrador público e funcionário de CONARA, Jaime Zavala:

En un primer intento se estimó factible la localización de servicios en los niveles provinciales, no obstante, en estudios posteriores se demostró que el nivel más adecuado para la prestación de la mayoría de los servicios, cuando su escala de operación lo permite, es el comunal; por cuanto acerca sus prestaciones a los usuarios y facilita la participación y el control directo por parte de éstos. Por consiguiente, la acción tendió a la transferencia de la administración de los servicios a las municipalidades. Este acercamiento de los servicios en el territorio permite a los habitantes de los lugares más alejados de la capital regional o provincial obtener, en un lugar cercano a su residencia, prestaciones mínimas necesarias y esenciales en materias de educación, salud y otras (ZAVALA, 1990, p. 71)

Embora Zavala destaca a ideia de serviços de maneira geral, na prática, o regime selecionou os serviços da saúde e educação como os principais dispositivos da descentralização municipal oficial. A descentralização oficial suponha uma maior eficiência e distribuição geográfica dos serviços no interior das prefeituras a partir de maiores mecanismos de arrecadação e avaliação de projetos socio-territoriais. Porém, havia múltiplas outras arestas administrativas e técnicas que começavam a criar uma complexa trama de problemáticas e contradições que tencionariam as prefeituras e a próprio regime. A privatização dos serviços comunais foi uma complexa operação estatal que tencionou as relações entre as autoridades, empresas, funcionários e comunidades. Nos primeiros anos da década de 1980, o país viveu uma profunda crise econômica e social que, certamente, não permitiu visualizar os supostos benefícios da reforma. A descentralização dos serviços

\footnotetext{
${ }^{66}$ Esse pensamento neoliberal também se expressava no diretor do Departamento de Prospetiva da CONARA, o capitão do Exército Cristián Labbé, quando enfatizou que a prestação de serviços públicos dirigidos à comunidade deveria ir abrindo empregos e capacitação no pessoal da administração pública no sentido que "progresivamente pasen al ámbito privado" (LABBÉ, 1984, p. 9). Analogamente o Subdiretor Regional da ODEPLAN (1987-1988), o ex SERPLAC da época, Rodrigo Moncada, destacava que o setor privado tinha que propender e multiplicar a "subcontratación de servicios municipales, como aseo, mantención de jardines, manejo de la basura y mataderos hasta la venta de hoteles y empresas públicas o la posibilidad de impartir educación privada gratuita y subvencionada por el Estado" (MONCADA, 1990, p. 53).
} 
comunitários da educação e saúde eram parte de um novo tipo de relações sociopolíticas e um particular escalamento do poder municipal. Segundo o general Canessa:

En la esfera comunal, es decir, en el entorno natural e inmediato de cada habitante del país, nos parecía que ellos se podían desenvolver y satisfacer las necesidades comunitarias sin apelar a los partidos políticos. Esa idea era consistente con el traspaso de ciertos servicios, como la salud y la educación a los municipios. En la misma línea se establecieron los CODECO, que traían al alcalde el sentir de las fuerzas vivas de la comunidad sin intervención política (ARANCIBIA, BALART, 2006, p. 213).

A negação da política tradicional seria funcional com a privatização em todos seus níveis. A maior responsabilidade social das prefeituras estava em consonância com a negação das estruturas políticas tradicionais (partidos) e o aperfeiçoamento de um aparelho público municipal interligado e mais próximo das comunidades, nesse caso, descentralizando os serviços de saúde e educação. Nesses termos, as prefeituras tinham mais poder operativo de suas disposições e ampliavam seus dispositivos enquanto conexões burocráticas com as necessidades populares. Um particular emaranhado técnico burocrático de apoio ao regime que paralelamente incorporou uma lógica tendente à gestão empresarial dos serviços públicos. Como diz o general Canessa em seu balanço de 1982, a prefeitura era o "órgano final de la jerarquia administrativa y territorial del Estado, constituyendo el nivel politico y administrativo más directo de contacto de la comunidad organizada con sus gobernantes" (CANESSA, 1982, p. 23).

Nesse caso, as prefeituras seriam o laboratório de múltiplas inovações técnicas enquanto programas e projetos de intervenção social e de uma sistemática capacitação, acompanhamento e vigilância do SIGORE, o CIAPEP e o BID. Após o ano de 1979, as prefeituras sistematicamente foram dirigidas pelos quadros civis pertencentes aos diferentes grupos políticos afins do regime. Essas movimentações políticas, por sua vez, respondiam ao trânsito de um período mais próprio da violência política inaugural (os primeiros anos após do Golpe) e a outro segundo período, mais discricionário e complexo (a década de 1980), relativo a uma busca de maior estabilidade do regime (HUNEEUS, 2016). A partir da Constituição de 1980, o cenário do regime mudou em duas grandes encruzilhadas: por um lado, a sua preparação política e seus principais quadros e forças políticas para uma eventual transição democrática sem os privilégios próprios; por outro, a definição de estruturas e apoios ao particular desejo do general Pinochet de continuar em sua condição de chefe absoluto da nação além do regime autoritário, projetando-se como o futuro e o primeiro presidente eleito, uma vez finalizado o processo autoritário (como foi refletido no plebiscito de 1988). 
Dessa maneira, as prefeituras foram um espaço altamente prioritário para os diversos grupos partidários ao regime e, primordialmente, para o próprio general Pinochet, que a partir do reordenamento geopolítico das redes e hierarquias de Governadores e Intendentes Militares, manteve um estrito controle das ordens e resoluções nos territórios locais. Os Intendentes Regionais, assim, estavam permanentemente intercambiando e recebendo pareceres da esfera central e, mediante seus respectivos SERPLAC e SEREMIS, baixavam linhas de governo que deveriam ser executadas pelos prefeitos. Os prefeitos, assim, eram as autoridades responsáveis de levar em terreno o programa oficial do governo. Para isso deveriam estar em contato permanente com as lideranças e representações sociais locais ao interior de suas comunas, as quais, simultaneamente, deveriam ancorar-se nos dispositivos de ajuda estatal que disponibilizava a SERPLAC e suas SEREMIS. A prefeitura era parte de uma agenda regional integrada que internamente configurava um ordenamento político hierarquizado e mais interligado. Um exemplo interessante para entender esse espírito de corpo pode encontrar-se nos congressos nacionais de prefeitos. Esses encontros compreendiam uma jornada de dois ou três dias, onde se discutiam diversos temas da gestão municipal e o debate político conjuntural, onde participava o conjunto de prefeitos do país junto com altas autoridades do poder central que, aliás, contava com a intervenção do próprio Pinochet. Se bem a instância de reunir todos os prefeitos do país era uma tradição que vinha sendo colocada pelas organizações municipais ao longo do século $\mathrm{XX}^{67}$, o fato de reunir todas as autoridades locais do Chile com as máximas autoridades do governo central, marcava o interesse estrutural do regime com o cenário municipal nacional. Segundo o prefeito da época, Carlos Cantero, esses congressos eram instâncias misturadas de aprendizados e dinâmicas:

En realidad ahí había una mezcla de todo. Por un lado, una mezcla de técnica y por otro, un intento de gestión política [...] Había un poco de adoctrinamiento, de diseño de doctrina también, no había parlamento, no había consejo regional o los que había eran muy precarios, con muy pocas facultades. Entonces, ese tipo de reuniones era para discutir con respecto a las facultades e instancias que cada uno debía tener [...] Por ejemplo, congreso nacional de

\footnotetext{
${ }^{67}$ Entre 1941 e 1942 se criou a Revista Comuna Autónoma, principal órgão de difusão da Unión Nacional de Municipios. Desse movimento foram se manifestando e difundindo uma profunda consciência do cerceamento das atribuições e recursos nas operações municipais (SALAZAR, 1998). Em 1951 se criou a Confederación Nacional de Municipalidades (CONAM), a qual procurava uma agenda combinada de pesquisa e acordos realizados pelos encontros nacionais ou seus membros e comissiones particulares. Por sua vez, a CONAM criou o Instituto de Estudios de Administración Municipal na lógica de capacitar as suas autoridades e colegiados em uma gestão municipal mais avançada da época e também incluiu os representantes dos operários municipais. A importância política da CONAM radica em que se conseguiu organizar treze encontros nacionais, conseguindo assim "mantener continua la memoria histórica" (SALAZAR, 1998, p. 55) entre 1951 e 1973.
} 
alcaldes, discusión temática, el primer día se va a discutir el FCM. No sé qué es lo que ocurría ahí, unos defendían el enfoque del mundo agrario, el uso del suelo y cosas de ese estilo. ¿Y qué tiene que ver eso con lo que pasa en el norte? Nada, yo no tengo nada de eso. Entonces, ¿qué es lo que peleaba yo? Hay que meter un indicador que tenga que ver la producción, de lo que fuera, cobre, fierro, lo que sea, puede ser en tonelaje o en función de cuanto dinero generas, o puede ser en función de qué capital tienes o el número trabajadores. Esas eran las discusiones. Era para ver como los recursos se distribuían de forma equilibrada y armónica en todo el país (ENTREVISTA CARLOS CANTERO, novembro 2019)

A gestão territorial particular das prefeituras estava completamente inserida na estrutura global do governo central. Nesse sentido, é interessante o destaque técnico-político como os elementos constitutivos do congresso pois, além da estrutura autoritária da nomeação dos prefeitos, era prioritário para o regime melhorar suas linhas técnicas, sobretudo aqueles critérios que permitiriam levar uma distribuição mais equilibrada dos orçamentos e tarefas municipais. O arranjo técnico era estrategicamente funcional para os objetivos políticos: uma maneira de organizar os escassos recursos financeiros e articular tecnicamente cada uma de suas autoridades e suas funções territoriais. Por outra parte, é significativo como o prefeito Cantero destaca um maior interesses pelos indicadores econômicos gerais que eventualmente pudessem compreender a diversidade das realidades comunais e uma maior arrecadação para sua prefeitura. Parte importante desses encontros tinha relação com melhorar as bases comunicantes entre as autoridades e a consolidação das equipes setoriais públicas que, eventualmente, poderiam ser inseridas nas prefeituras, última escala geográfica da execução do SIGORE. Na escala geográfica regional também se realizavam encontros de prefeitos, como relata o SERPLAC do BíoBío da época, Pedro Ramírez, quem descreve:

En esa época también se hacían encuentros de alcaldes. Y me acuerdo de una, por ejemplo, que se hizo en Arauco. Ahí eran dos días del punto de vista de darles a conocer por parte del Intendente y de él SERPLAC cual era el plan de desarrollo de la región y saber hacia donde estábamos mirando para al año y se pedía ahí algún jefe de servicio, SEREMI o alcalde expusiera también. Eran jornadas de trabajo y de encuentro. En el caso de Eduardo Ibañez le gustaba mucho el deporte, sobre todo el voleibol. Entonces, había muchos campeonatos de voleibol, tiro al blanco, fútbol, etc. Se hacían con los alcaldes de toda la región. Se hizo en Arauco, en Bulnes, etc. y nos tocaba a nosotros como SERPLAC preparar el programa encargado con el Intendente, ver los expositores, el lugar, ver las horas, tiempo, etc. Era una iniciativa regional (ENTREVISTA PEDRO RAMÍREZ, fevereiro 2021)

É interessante destacar como a mudança de escala geográfica do nível nacional ao nível regional reconfigura também as possibilidades da gestão territorial e a lógica de conteúdos dessas instâncias. Se no nível nacional se tenderia a fortalecer o programa comum o geral dos prefeitos, através da realização de grandes debates técnicos e direcionamentos políticos do 
governo nacional, na escala regional o encontro estava mais inserido na dimensão setorial da gestão das prefeituras. Os 51 prefeitos da VIII Região, assim, eram convocados e reunidos em Arauco por dois dias para compreender e refletir sobre o plano de desenvolvimento da Região definido pelo Intendente e seu SERPLAC, máximas autoridades do território. Essa dinâmica de trabalho e encontro permitia que os prefeitos não só tivessem a possibilidade de interagir, mas de compreender os objetivos e prioridades da autoridade regional. Paralelamente, também poderiam compartilhar seus aprendizados e experiências com outros colegas e autoridades territoriais, ampliando seu conhecimento político e técnico da prefeitura, principalmente em relação ao programa oficial da região e estabelecer alianças enquanto suas vizinhanças e serviços públicos. Assim, se iria consolidando e recriando linhas de trabalho colaborativo em diferentes escalas e proximidades geográficas: alianças entre prefeitos contínuos de uma determinada província ou bem cooperações setoriais para a organização de determinados projetos comunais. Se trata de um tecido burocrático territorial que iria aperfeiçoando um padrão, não apenas nos procedimentos de controle e reposta das hierarquias do sistema territorial. Mas também, sobretudo, na complementariedade e no reconhecimento das autoridades territoriais espalhadas em cada uns dos âmbitos públicos e setoriais que deveria impulsionar a prefeitura.

$\mathrm{Na}$ escala geográfica regional, se articulavam as estruturas territoriais mais integradas do ponto de vista da hierarquia e da distribuição dos orçamentos via avaliação dos projetos. Ao mesmo tempo, na escala geográfica municipal se configuravam diversos tipos de interação social e institucional, que, sucessivamente, permitiriam ir abrindo uma representação das organizações comunais afins ao regime. Nesse sentido, emerge um segundo elemento de destaque do relatório do SERPLAC: a questão esportiva. Como destaca Ramírez, o Intendente e general Eduardo Ibañez - uns dos mais longevos em seu cargo tendeu a potenciar fortemente as atividades esportivas na região, estimulando diversas iniciativas esportivas que iriam a difundir uma maior recriação social na população. Uma tradição de longa data no interior das FF.AA. que se conectava na busca de valores patrióticos, na reorganização do tecido social despolitizado e que divulgaria o regime. $\mathrm{Na}$ própria trajetória do propulsor da geopolítica chilena, o general Ramón Cañas Montalva (1896-1977), era um exemplo formidável do espírito esportivo no interior do Exército. Cañas, em 1920, foi representante do Chile nas VII Olimpíadas de Amberes, Bélgica, na categoria ginástica. Outro exemplo análogo dessa relação Exército e atividades esportivas, foi o general do Exército e Intendente da época, Nilo Floddy (1912-2013), quem antes de 
ser general também havia sido um destacado atleta e campeão nacional de esgrima, chegando participar nas Olimpíadas de Londres 1948, Helsinki 1952 e Melbourne 1956. Como destaca a historiadora Karen Donoso, durante o período autoritário o esporte foi intervindo como uma política cultural que pretendia influir na vida cotidiana dos setores populares e promover valores morais e nacionais afins ao governo autoritário (DONOSO, 2012).

Nesse esquema cultural-político, as prefeituras deveriam impulsar projetos que permitissem a programação de obras e infraestruturas esportivas, assim como também estabelecer pontes com outros programas e planos públicos que permitiriam a circulação das bases de apoio do regime (DONOSO,2012). Com efeito, a menção esportiva do Intendente da VIII Região do BíoBio, o general Eduardo Ibañez, estava plenamente emaranhada na alta hierarquia territorial do Estado e seguia estruturalmente o esquema da regionalização. $\mathrm{Na}$ busca de abrir essa participação esportiva, as prefeituras deveriam montar uma estrutura municipal que desse suporte aos diversos planos e projetos que inscreveria a comunidade organizada, e que o regime chamou Consejo Local de Deportes. Dessa forma, cada prefeitura instituía um instrutivo onde os dirigentes de clubes esportivos e organizações sociais apresentavam os projetos, criando uma primeira etapa de avaliação. Posteriormente, os projetos que cumpriam com as bases e requerimentos técnicos passavam a um segundo nível do sistema, o Consejo Regional de Deportes y Recreación, e este dependia da avaliação do Intendente Regional e da SERPLAC, que oficializava a carteira de projetos esportivos da região que seriam apresentados na esfera superior, a Dirección General de Deportes y Recreacción (DIGEDER) a nível central. Essa direção nacional finalmente era o órgão encarregado de decidir e distribuir os recursos e projetos esportivos para que fossem executados pelas prefeituras (DONOSO, 2012), uma vez coordenados e avaliados pela SERPLAC.

Segundo Donoso, essa gestão hierarquizada de projetos esportivos foi bem-sucedida só a partir de 1982-1983 quando se procurou "fortalecer un sistema de control de los fondos que hasta entonces eran repartidos con excesiva libertad" (DONOSO, 2012, p. 92). É interessante a precisão dessa data pois, efetivamente coincide com a implementação piloto do Banco Integrado de Projetos (visto no capítulo IV). Simultaneamente é interessante distinguir como a hierarquia nacional esportiva (DIGEDER) estava diretamente interligada aos termos da regionalização e particularmente com os comandos regionais-municipais, sem uma aparente mediação dos governadores, mas sim reproduzindo a circulação do poder centralizado-hierarquizado do regime territorial da comuna à região, da região ao nível central, para logo voltar do nível 
central aos territórios internos. Por outro lado, análogo da distribuição territorial maioritária dos intendentes e governados do Exército, também é significativo que praticamente durante todo o período autoritário a DIGEDER foi dirigida pelo Exército (quadro $n^{\circ} 22$ ). Com efeito, desde os primeiros anos do regime a questão esportiva foi incorporada através de uma rede de altos oficiais do Exército, próximos ao general Pinochet. A DIGEDER foi a responsável de distribuir os orçamentos para os governos regionais e suas redes municipais, sendo burocraticamente ensamblada à estrutura regional instalada pelo processo de regionalização. Nesse sentido, é demonstrativo que três Intendentes Regionais e um destacado membro da CONARA também tenham sido nomeados diretores da DIGEDER durante o período autoritário. São os casos dos Intendentes Arturo Alvarez (III Região), Sergio Badiola (Metropolitana de Santiago), Nilo Flody (XII Região y VIII Região) e o general Ivan Dobud, quem também foi Secretario Executivo de CONARA (quadro no 22).

Quadro no 22. Diretores da DIGEDER (1973-1989)

\begin{tabular}{|c|c|c|}
\hline Nome & $\begin{array}{c}\text { Instituição ou } \\
\text { Profissão }\end{array}$ & Período \\
\hline Guido Ossandón & $\begin{array}{c}\text { Coronel de Exército } \\
\text { em retiro }\end{array}$ & $1973-1974$ \\
\hline Jorge Ehlers & Empresário & $1975-1978$ \\
\hline Patricio Guzmán & Engenheiro Comercial & 1979 \\
\hline Nilo Floddy & Mayor General & $1979-1980$ \\
\hline Iván Dobud & Brigadier General & $1981-1982$ \\
\hline Cesar Manriquez & Brigadier General & $1982-1983$ \\
\hline Sergio Badiola & Brigadier General & $1983-1985$ \\
\hline Arturo Alvarez & Brigadier General & 1986 \\
\hline Carlos Ojeda & Brigadier General & $1987-1989$ \\
\hline Carlos Meirelles & Brigadier General & 1989 \\
\hline
\end{tabular}

Fuente: Donoso 2012

A criação de atividades culturais e esportivas com as comunidades era uma questão primordial para as prefeituras e as autoridades regionais. Porém, não sempre existiu um ambiente de camaradagem e espírito de corpo como no encontro de prefeitos em Arauco. O complicado cenário político e econômico agudizado pelos efeitos da recessão de 19821983 e a ascensão de múltiplos protestos que explodiram nas principais cidades do país impactou diretamente nas prefeituras. Durante a década de 1980, os prefeitos do regime tiveram que lidar com uma complexa movimentação social e múltiplas decisões territoriais próprias do processo de transformação neoliberal do Estado chileno. Se na primeira década 
do regime se tratou fundamentalmente de depurar e reorganizar as representações sociais afins aos municípios intervindos, para a década de 1980 começou a se reorganizar estruturalmente o funcionamento dos serviços municipais e, com isso, sua própria capilaridade enquanto órgão de governo. As prefeituras foram articulando uma política cada vez mais seletiva de redes micro territoriais ancoradas a um emaranhado conjunto de programas a nível regional que tentariam criar lideranças político-sociais. De uma ou outra forma, as prefeituras deveriam preparar o caminho frente a uma possível saída do poder (caída da ditadura), mas sobretudo, assegurar os termos da futura democracia com a Constituição de 1980. Os prefeitos eram as peças chaves para uma nova engenharia política eleitoral. À diferença da situação da Região Metropolitana, onde existia uma maior disputa entre as forças políticas do regime, a seleção dos prefeitos nas Regiões se combinava com outras lógicas, também expressão de outras dinâmicas de interação e reconhecimento das trajetórias locais menos conflitadas que nos centros urbanos maiores. Como bem destaca a professora de jardim de infância de Copiapó (III Região), Carla Brown:

Los SEREMI eran gente partidaria del régimen, copiapinos partidarios al régimen. Acá en Copiapó como nos conocemos todos, no fue tan complejo. El alcalde también era nombrado por el Intendente, con venia del General Mayor. Eran nombrados por gente de la región. Tuvimos un alcalde copiapino muy bueno, Carlos Porcile. Era gente que se la jugaba por la ciudad. Y como Arturo Álvarez comenzó a pedir más recursos para la región, tenía más maniobra. Y como éramos todos más conocidos, no se notaba tanto la brecha izquierdaderecha. Era gente de Copiapó, gente que se la jugaba. Gente de familia añosa de Copiapó (ENTREVISTA CARLA BROWN, abril 2020)

A citação é ilustrativa porque informa algumas distinções na seleção das autoridades regionais e o prefeito. No geral, os prefeitos em regiões eram pessoas partidárias do regime e membros de famílias tradicionais das comunidades territoriais que, dada as relações de proximidade entre os habitantes e a prefeitura, a distinção direita ou esquerda passava a um plano aparentemente menos conflitivo que na capital. Esse elemento ideológico da seleção e controle dos prefeitos em regiões bem poderia aprofundar-se em futuras pesquisas, pois, não somente desvenda as contradições da capilaridade política do regime, mas também interroga geograficamente a lógica diferenciada que poderia haver caraterizado os programas das prefeituras nas comunas mais rurais versus as comunas mais urbanizadas. Além disso, os prefeitos eram selecionados e avaliados através de diversos mecanismos de recrutamento e controle. Todos os nomes eram revisados pela Central Nacional de Inteligência (CNI) antes de ser formalmente investidos nos cargos (HUNEEUS, 2016). Para ser nomeado prefeito, portanto, era necessário obter a aprovação da autoridade regional e provincial considerando vários fatores: o terreno das necessidades locais, sua experiência no sistema público, sua 
capacidade profissional e, sobretudo, pertencer a certos grêmios e grupos da direita distribuídos pelos territórios em específico.

Sobre a trajetória política dos grupos de poder e a permanência dos prefeitos é importante destacar que, se bem durante o regime autoritário chileno, nunca existiu um partido único encarregado de recrutar o conjunto da elite dirigente e hegemonizar a propaganda em todas as hierarquias oficiais (HUNEEUS, 2016). Sem dúvida foi a rede política liderada pelo advogado Jaime Guzmán, conhecida como o gremialismo, a estrutura de poder mais bem sucedida em relação ao uso político das prefeituras (HUNEEUS, 2016; VALDIVIA et al, 2012; MUÑOZ, 2016). Esse protagonismo político do movimento gremial foi aprofundado no transcurso da década de 1970 a 1980, quando em 1978 Pinochet designa um militante do gremialismo, Sergio Fernández, como Ministro do Interior, o qual, imediatamente, se traduz em uma ascensão das prefeituras dirigidas pelo gremialismo (MUÑOZ, 2016). Nesse mesmo período a rede gremialista foi-se consolidando tanto política como públicamente, abrindo diversas iniciativas, entre as quais se destaca a criação do movimento Nueva Democracia, a revista Realidad e o Instituto para una Sociedad Libre (MUÑOZ, 2016). Todos esses movimentos e espaços de militância foram perfilando a criação de um projeto político próprio que será refletido, poucos anos depois (1983), com a oficialização da coletividade como partido político: Unión Demócrata Independiente (UDI). De $1983 \mathrm{em}$ diante, o gremialismo será o sinônimo da UDI, o partido político da direita mais forte e próximo ao general Pinochet. Um aspecto interessante a destacar na origem da UDI foi seu comprometido sentido de salvaguarda da Constituição de 1980 e sua valorização pela descentralização e a regionalização do país que, organicamente, significava a necessidade de arraigar-se nos setores populares como uma nova geração da direita chilena (MUÑOZ, 2016). Para cumprir com esse propósito de renovação, a UDI se fundou a partir de quatro comitês (feminino, juvenil, profissional e moradia) constituídos principalmente por suas históricas bases universitárias ${ }^{68}$ " "motivándola a salir de los campos para ir a un terreno que siempre habia sido difícil para la derecha: los territorios de los pobres urbanos" (MUÑOZ, 2016, p. 189).

Dessa maneira, a UDI teve importantes desdobramentos nas prefeituras e nas paisagens mais empobrecidas do país, principalmente nos comitês de moradia que deviam conectar as prefeituras com os grupos de moradores e dirigentes sociais e impulsionar assim

68 Organizadas a partir de meados da década de 1960, principalmente nos recintos da Pontifícia Universidade Católica de Chile (PUCH). 
iniciativas sociais, como a solução habitacional dos moradores (MUÑOZ, 2016). Essa conjuntura favorável de 1979-1981 na mais alta hierarquia do Estado - a administração do Ministério do Interior - se bem não significou o controle da totalidade dos órgãos municipais pelo gremialismo, certamente demostrou uma alta coesão como grupo político, especialmente em seu posicionamento como rede no interior do regime. A expansão da rede gremialista, com seus jovens dirigentes pelo território, também expressou o funcionamento da rede territorial criada pela CONARA nas regiões. Uma das principais caraterísticas do movimento gremialista foi sua intensa e permanente capacidade de recrutamento de quadros juvenis disponíveis para a construção do cenário político afins as transformações do regime. Miguel Kast e Jaime Guzmán foram reconhecidos recrutadores de jovens universitários, primeiro, em posição de professores na PUC de Chile, logo, desde suas respectivas posições de alta hierarquia e influência no interior do regime. Tal foi o caso do prefeito da comuna de Curanilahue no sul do país (VIII Região), Alejandro Fernández, quem nos relata como foi seu processo de recrutamento antes de dirigir a prefeitura:

[...] a mi me reclutan de la Universidad [...] estaba Joaquín Lavín ${ }^{69}$ en esos años y para que tú sepas era mi Decano [...] entonces Joaquín era muy divertido porque se paseaba por los pasillos de la Universidad. Yo creo que era un reclutador oculto, entonces, esa era su misión a mi gusto. De hecho, lo hemos conversado después de años. Efectivamente era así. Y ahí claro, él se daba cuenta de quien podía tener potencial para la cosa pública y llegar con la gente, porque eso era importante igual y derrepente tú te encontrabas con él en un pasillo o en un patio de la universidad y te decía tú, ¿quieres trabajar conmigo? y ahí partía todo. Así llegué a la ODEPLAN. Lo que pasa es que Joaquín era habiloso porque creó una Fundación al interior de la Universidad para hacer estudios, para ayudar sectores, sectores asociados a la educación. Entonces, el primer paso, como te decía, ¿tú quieres trabajar aquí? y te metía a su Fundación, en este caso de la Escuela de Economía y de ahí pasábamos a ODEPLAN. Era como estar dos meses y ahí se daban cuenta si tenía dedos para el piano o no, siendo aún estudiante (ENTREVISTA ALEJANDRO FERNÁNDEZ, fevereiro 2021)

Com a mesma trajetória de Miguel Kast, Joaquín Lavín era um jovem economista da PUC e militante do movimento gremialista que, cumprido seu curso de pós-graduação na Universidade de Chicago (1977-1979), voltou ao Chile para exercer como Decano da Facultad de Ciencias Económicas y administrativas na Universidade de Concepción (UDEC). Antes de irse a Chicago, Lavín também foi assessor econômico da ODEPLAN junto com Miguel Kast e havia conhecido a importância das SERPLAC e a distribuição sistemática dos quadros gremialistas nas regiões (LAVÍN, 1986). O que não era de se estranhar que estivesse sempre

\footnotetext{
${ }^{69}$ Histórico dirigente da UDI, ex prefeito das comunas de Las Condes e Santiago em diferentes períodos. Atualmente é candidato a presidência da República do Chile pelo bloco da direita do país.
} 
muito atento para encontrar jovens estudantes pelos cantos da UDEC e assim continuar com o modelo de recrutamento nas oficinas da SERPLAC de Concepción.

No entanto, esse modelo de recrutamento que partia de um jovem universitário, muito similar ao de seu professor Miguel Kast, não era a única forma de seleção e conexão com as juventudes e quadros políticos simpáticos ao regime no período. Muito antes disso e, principalmente, graças à fundamental presença de Jaime Guzmán como assessor do Ministério do Interior, desde os primeiros dias do Golpe de Estado, o movimento gremialista esteve na cúpula do governo autoritário. Foi através de duas plataformas que se recriaram as influências do gremialismo nos primeiros anos do regime: primeiro, com a Secretaria Nacional de la Juventud (SNJ) criada em outubro de 1973 e, posteriormente, o Frente Juvenil de Unidad Nacional (FJUN), criado em julho de 1975. Ambas estruturas serão coexistentes e dirigidas pelo gremialismo, permitindo aperfeiçoar seus dispositivos de recrutamento e ampliar sua influência nos setores juvenis partidárias do regime. A SNJ e o FJUN serviam de plataformas operativas para reforçar as linhas de governo, sobretudo, a participação comunitária que deveria liderar as prefeituras. Segundo Huneeus em 1975, a SNJ tinha uma presença aproximada de 70\% nas comunas do país, distribuindo suas oficinas ao longo do território, sempre com uma "secretaría en cada una de las provincias, estando también presente en la mayoría de las comunas, donde trabajaba en colaboración con los alcaldes y las juntas de vecino" (HUNEEUS, 2016, p. 350). Similar ao processo de seleção de SERPLAC, a SNJ recrutava e organizava uma política nacional para a juventude que se aplicava na escala comunal e fiscalizava centralizadamente a partir de um comando provincial. Desses níveis de coordenação, aliás, se projetavam diferentes iniciativas comunais como práticas religiosas, esportivas ou culturais, as quais eram apoiadas e impulsionadas junto com os outros dispositivos oficiais (prefeituras, SERPLAC, SEREMIAS de educação ou saúde, DIGEDER, etc.). Assim, os quadros jovens da SNJ, e após da UDI, teriam uma ascendente capilaridade nas principais comunas do país, onde disputariam a representação popular das antigas e politizadas redes da esquerda. O diagnóstico da UDI entendeu que os pobres eram conduzidos pelas esquerdas não por uma questão ideológica, mas sim pela ausência da direita na sua cotidianidade (MUÑOZ, 2016). Daí que o movimento gremialista operou com uma lógica territorial incessante de inserção nos espaços populares. Parte importante dessa disputa foi impulsionada através de uma crescente rede profissional de quadros juvenis distribuídos pelas prefeituras do país, que irão entendendo e apropriando-se dos dispositivos técnicos do sistema territorial da CONARA, 
embora não tivessem o total controle das prefeituras. Nesse sentido, é ilustrativo o relatório do prefeito da comuna Curanilahue, ex militante da UDI da época, Alejandro Fernández:

En esa época había dos medios para llegar a las alcaldías y las gobernaciones. Recordarás que en esos años no había elecciones, por lo tanto, el sistema era otro. Las dos fuentes que había para llegar a alcaldías [...] por un lado, la Secretaria Nacional de la Juventud que era un organismo bastante más político de gente que se dedicaba más que nada a cosas que no estaban relacionadas con proyectos técnicos. Eran proyectos más políticos, ese tipo de personas tenían, además, otro perfil. Y por otro lado, la ODEPLAN donde Miguel Kast armó todo un cuento técnico $[\ldots]$ Y entonces, ellos tenían fundamentalmente dos misiones. Primero, la administración de proyectos sociales a lo largo de todo el país, cruzando todos los ámbitos digamos municipalidad, empresas públicas, grandes proyectos públicos del país y ese tipo de cosas. Por otro lado, tenían la misión de ser un semillero de personas técnicamente bien preparadas para ir a estas empresas públicas o municipalidades, entiendes. Entonces, era como un semillero y entrabamos tipo 22 años, ósea, recién salidos de la Universidad, que fue mi caso (ENTREVISTA ALEJANDRO FERNÁNDEZ, fevereiro 2021).

A citação é relevante em vários assuntos. Primeiro, porque confirma a presença gremialista através da Secretaria Nacional de la Juventud $(\mathrm{SNJ})^{70}$ como uns dos possíveis requisitos na seleção das prefeituras. Além disso, também incorpora a ODEPLAN ou SERPLAC como mecanismo de seleção das prefeituras que tenderia a um funcionamento mais integrado desde o ponto de vista técnico do planejamento. Em segundo lugar, se explicita o direcionamento particular dessas orgânicas institucionais - a SNJ e a ODEPLAN - enquanto ao perfil dos prefeitos. Com efeito, quem exercera a função de prefeito deveria cumprir com certas capacidades políticas (no caso da SNJ) ou técnicas (no caso da ODEPLAN), mas sempre dependiam de alguma das estruturas de governo. É interessante destacar como o ex prefeito de Curanilahue reconhece a figura gremialista de Miguel Kast como o autor intelectual desse desenho técnico da ODEPLAN que, simultaneamente, havia permitido e expandido um "semillero" de autoridades locais que tenderiam a uma condução técnica e profissional das prefeituras (tal como vimos no capítulo IV com as SERPLAC). Dessa forma, o perfil dos prefeitos da ODEPLAN estaria inserido em sua capacidade operativa de gestão de projetos sociais, certamente, cada vez mais integrados nos instrumentos de planejamento territorial do governo interior (FNDR e FCM). No caso da trajetória do prefeito de Curanilahue, se bem ele não era parte da SNJ, de fato cumpria com um perfil de professional jovem da ODEPLAN (tinha apenas 22 anos), uma caraterística significativa dos quadros gremialistas e da UDI. É interessante destacar que a trajetória como prefeito de Fernandez (1981-1985) justamente coincidiu com a passagem do movimento

\footnotetext{
${ }^{70}$ Institucionalmente a SNJ formava parte da División Nacional de Comunicación Social (DINACOS) do Ministerio do Interior do Chile.
} 
gremial à conformação do partido UDI e a maior importância da SERPLAC dada a direção do Miguel Kast. Pouco antes de ser nomeado prefeito, Fernández também foi parte da equipe da SERPLAC da VIII Região de BíoBio:

En mi caso entré a ODEPLAN Concepción y ahí conocí a Pedro -se refere ao SERPLAC- y Pedro llegó casi junto conmigo en esos años [...] A mi me tocó ser parte del segundo equipo y después de un año de estar ahí me plantean lo que acabo de contarte antes, sí quería irme de alcalde. Yo ya sabía de que se trataba, ósea, conocía perfectamente toda la zona y lo único que se nos pedía es que no pensáramos en municipalidades grandes ni que tuvieran fama ni nada, sino ojalá las más pobres y más complicadas. Esos como que eran los requisitos. Era un servicio país absolutamente (ENTREVISTA ALEJANDRO FERNÁNDEZ, fevereiro 2021).

Além da vigilância e afinidade política das autoridades territoriais, o que nos interessa destacar aqui é o espírito de corpo do funcionamento da gestão territorial do regime e a coerência da questão técnica específica enquanto seus mecanismos de recrutamento das autoridades. À diferença da antiga prefeitura sem recursos nem atribuição do passado, as novas prefeituras eram parte de uma cadeia de relações territoriais mais abrangentes e interligadas que se superpunham e organizavam hierarquizadamente desde a unidade regional. No caso do jovem prefeito do sul do Chile, a participação na SERPLAC teria sido fundamental para sua própria seleção como autoridade local, o que se fundamentaria em um direcionamento profissional estratégico do sistema territorial e um maior reconhecimento das redes institucionais, interligando as projeções do governo regional à prefeitura em questão, princípio base do SIGORE.

Porém, simultaneamente, essa nomeação comunal também tinha certas restrições que denotariam outro tipo de agendas e cálculos no momento da seleção dos prefeitos. Embora os prefeitos pudessem ser eventualmente mais jovens ou com maior destaque técnico, ao mesmo tempo, não poderiam ter grandes expectativas nem privilégios na seleção de suas prefeituras, posto que se trataria de unidades de menor importância simbólica ou orçamental. Além disso, as prefeituras poderiam significar o início de uma carreira técnica baseada nos resultados concretos da gestão municipal da época. É importante lembrar que, o fundamento do sistema territorial impulsionado pela CONARA e os gremialistas justamente tinha essa pretensão de fazer da administração pública uma expressão mais profissional na seleção das autoridades, sendo burocratas e altamente capacitados aqueles que seriam os principais responsáveis de levar a direção das políticas territoriais. Tal foi o caso do geógrafo Carlos Cantero, nomeado prefeito sucessivamente nos municípios de Sierra Gorda (1983-1984), 
Tocopilla (1984-1987) e Calama (1987-1988), todos eles pertencentes a II Região de Antofagasta na zona norte do país. Diz Cantero:

En el 82 a la gente joven la mandaban a esos municipios que se estaban creando. Había que constituir el municipio desde cero [...] Tenía un año de creación y que estaba armando equipos, estaba armando edificio. Era una etapa fundacional. Tenía que estar en contacto con el Gobernador y con el Intendente, pero también teníamos contacto con los otros municipios. Era un ambiente de gestión muy colaborativa. Por ejemplo, los municipios más grandes que tenían direcciones de arquitectura, de obras municipales, donde había arquitectos y urbanistas, le ayudaban a los municipios más pequeños como el mío, donde teníamos que elegir entre un arquitecto o un ingeniero constructor. Habitualmente nos quedábamos con el ingeniero y el arquitecto lo pedíamos a los municipios más grandes en un contexto de un marco de colaboración. Entonces, en resumen, en esa época la característica era una integración y colaboración muy intensa entre los municipios (ENTREVISTA CARLOS CANTERO, novembro 2019)

A trajetória de Cantero coincide relativamente com os elementos descritos mais acima. Tal como no caso de Curanilahue, o prefeito de Sierra Gorda era bastante jovem: tinha 27 anos quando foi nomeado prefeito em 1983. Contudo, ao contrário do ex prefeito da zona sul do país, não era militante da UDI nem tinha participado em nenhum dispositivo de governo (SERPLAC ou SNJ), mas havia tido um destaque profissional na área da geografia na Universidade Católica do Norte (ENTREVISTA CARLOS CANTERO, novembro 2019). Uma trajetória diferente mas sumamente interessante, pois, aliás, contextualiza a precariedade orçamental das prefeituras na década de 1980 e ilustra as lógicas particulares de colaboração interna entre prefeituras novas e velhas na II região do norte do país. Lembremos que o primeiro recorte oficial das comunas foi aprovado em 1979, no entanto, só no percurso da década de 1980 as novas prefeituras foram inseridas na ação pública territorial, como no caso do Sierra Gorda. Nesse sentido, é significativo contextualizar como se teciam essas práticas colaborativas e associativas entre prefeituras pequenas e maiores, sempre articuladas a partir da presença estreita das autoridades superiores ("Tenía que estar en contacto con el Gobernador y con el Intendente"). A gestão das prefeituras se insere a partir de uma efetiva interação das informações e recursos das autoridades regionais e provinciais que, tecnicamente, tinham que apoiar e dispor de suas necessidades. Trata-se de um funcionamento territorial altamente interligado e prático, que se funda na complementariedade dos dispositivos territoriais. Diz Cantero:

Era una tarea permanente estar en contacto con el SERPLAC, con todos - se refere aos outros SEREMIS. Pero particularmente en esa época se llamaba ODEPLAN, el área de planificación, esa era el área más importante porque en esa época se incorporó la evaluación de proyectos. Había que efectivamente ser muy rigurosos en la formulación de los proyectos. Nadie podría 
elaborar sin tener la elaboración de proyecto, un curso al menos. Nos obligaban a trabajar en la formación de capital humano bien intensamente, en planificación, coordinación (ENTREVISTA CARLOS CANTERO, novembro 2019)

A gestão colaborativa das prefeituras no território regional também se complementava e fortalecia justamente através de uma formação técnica mais rigorosa, principalmente na área de formulação e avaliação de projetos. Ao início da década de 1980, todas as autoridades territoriais, e particularmente os prefeitos, deveriam ter algum curso certificado na avaliação de projetos. Dessa maneira, se permitiu homologar os procedimentos e melhorar os esforços municipais e o sentido de unidade entre as autoridades territoriais. Como destaca o prefeito do Curanilahue da época, Alejandro Fernández:

[...] Éramos muy unidos todos. Mi mayor partner siempre fue el SERPLAC porque estaba Pedro y el tema que habíamos sido compañeros de oficina, imagínate cuando entramos los dos. Pero con las SEREMIS igual, porque tenía amigos que habían salido de ahí. Con la gente que habíamos pasado por el curso del CIAPEP, los que habíamos estado juntos en ODEPLAN era muy fácil el diálogo. Derrepente teníamos más problemas, como por ejemplo con la SEREMI de Salud, donde había un médico que era más complicado que no había pasado por estos cursos. Tenía la visión antigua, que los médicos tienen que manejar todo, que la administración la podía hacer mejor un médico (ENTREVISTA ALEJANDRO FERNÁNDEZ, fevereiro 2021).

Novamente aqui aparece a presença do Curso Interamericano en Preparación y Evaluación de Proyectos de Inversión (CIAPEP) criado pelo Chicago boys Arturo Fontaine e Miguel Kast a inicios do período autoritário como vimos no capítulo IV. Neste caso, fica mais explicito a importância estratégica desses cursos, reforçada neste caso, aliás, pelo elemento identitário da experiência entre antigos "compañeros de oficina", com tinham sido o prefeito de Curanilahue e o SERPLAC do BíoBio. Fernández destaca a importância do horizonte formativo comum que tinham as autoridades territoriais, sobretudo aquelas que tinham passado pelo CIAPEP. Essa experiência técnica profissional, no fundo, também haveria articulado outro tipo de códigos entre as autoridades territoriais, permitindo o desenvolvimento de uma linguagem comum das operações e procedimentos requeridos na burocracia. Mas especialmente, haveria consolidado um espírito de corpo da gestão territorial que permitiu aprofundar confianças e cumplicidades entre as autoridades territoriais. A formação e avaliação de projetos reforçava a unidade técnico-política do sistema territorial pois, justamente, se articulavam e aprofundavam as redes profissionais internas, e de forma elementar, suas competências técnicas que permitiriam dirigir ações e decisões no marco de projetos integrados. Por outro lado, é interessante o exemplo de diferença interna com a SEREMI da saúde que destaca o prefeito, porque o Ministério de Saúde seria um dos ministérios mais 
complexos e difíceis de incorporar na reforma administrativa da CONARA ${ }^{71}$. O intrigante desse exemplo é que, embora a SEREMI de saúde eventualmente pudesse diferir e se tencionar com a gestão do prefeito, também se encontrava em um nível superior dado pela hierarquia territorial de sua competência. Paralelamente, o chefe territorial de todos os SEREMIS, incluída a SEREMI de saúde na região, era o SERPLAC, quem, pelo geral, era um profissional da área da economia que dependia dos enquadramentos da ODEPLAN de Santiago e respectivamente do Intendente militar da Região. Embora existisse alguma diferença interna com o setor da saúde ou qualquer outro setor público, se impunha o princípio hierárquico do SIGORE e a prevalência dessa linguagem técnica de projetos adquirida no CIAPEP e a consecutiva neoliberalização das prefeituras do país.

De tal maneira, a avaliação de projetos seria o principal suporte técnico-politico das prefeituras e sua conexão com a gestão territorial oficial do governo nacional. Esse modelo da gestão pública empresarial, no entanto, também abriria o início de uma desigual competência entre as prefeituras e suas intervenções públicas. O modelo financeiro empresarial da administração das prefeituras, simultaneamente, implicaria em um aperfeiçoamento de suas equipes e mecanismos internos. Como destaca o prefeito da época, Carlos Cantero: "El tema de los fundos concursables era en función de objetivos. Mejor dicho, en función de evaluaciones más objetivas porque habia una lógica de evaluación de proyecto mucho más rigurosa de la que bay boy en día" (ENTREVISTA CARLOS CANTERO, novembro 2019). O destaque do prefeito, de alguma forma, referencia o melhoramento técnico dos procedimentos internos das prefeituras onde existiam critérios e mecanismos mais profissionais dos projetos comprometidos. A circulação entre as agencias regionais e os projetos que seriam executados pelas prefeituras, por um lado, rompiam com a antiga lógica centralista no planejamento dos municípios sem faculdades nem recursos; por outro, tecnicamente, tinham níveis de agenciamento comunal e integração com o território regional. No entanto, as prefeituras ainda continuavam dependendo de contrapartes territoriais maiores, neste caso, das unidades de planejamento regional (SEREMIS e SERPLAC) e a supervisão do Governador e o Intendente. Segundo o chefe de estudo da SERPLAC da IX Região da época, o engenheiro civil industrial, Diego Benavente, a capacidade de execução dos projetos nas prefeituras estava na ordem técnica previamente desenhada pela SERPLAC e a formação do CIAPEP.

\footnotetext{
${ }^{71}$ Em seu interior teria importantes resistências profissionais que não seriam parte do esquema hegemônico do regime (ENTREVISTA PEDRO MILOS, dezembro 2019). No entanto, devido ao contexto autoritário também terminaria sendo incorporado ao processo de decentralização e neoliberalização. O Ministério de Saúde seria parte do esquema da regionalização fundamentalmente a través da municipalização das atenções primarias e a criação de sua respetiva SEREMI em 1975.
} 
Assim, os projetos ou necessidades propostas pelas prefeituras eram avaliados pelos profissionais da SERPLAC através de uma estrutura previamente conhecida na distribuição dos recursos públicos. Diz Benavente:

Cuando llegaba un proyecto, ya sea por la municipalidad o con el ministerio respectivo, se preguntaba y verificaba si la otra red estaba o no. Y así era, por ejemplo, en los pavimentos. Cuando un alcalde $\mathrm{X}$ quería pavimentar una calle. ¿Oiga, pero tiene agua potable $\mathrm{O}$ alcantarillado? No, entonces, vamos primero con esos proyectos. Y ahí hubo mucho apoyo del CIAPEP que creó Ernesto Fontaine. En esa época había tres niveles de formación en el tema de inversión. Uno, los alcaldes que eran cursos de 15 días más o menos. Luego, el CIAPEP mismo, que tú postulabas y que tú podrías solamente dedicarte a la parte teórica, un semestre. Y, la parte práctica, donde tenías que tomar un proyecto concreto y evaluarlo según la inversión. Y ahí hubo proyectos muy interesantes que se lograron hacer del punto de vista de inversiones (ENTREVISTA DIEGO BENAVENTE, janeiro 2021)

É importante distinguir o controle efetivo da SERPLAC na circulação dos projetos que finalmente seriam impulsionados pelas prefeituras. Mais que distribuir substanciais repartos orçamentais, as SERPLAC e seus profissionais iam distribuindo efetivamente os recursos públicos municipais, continuando um emaranhado técnico definido e fiscalizado centralizadamente. Através dos cursos do CIAPEP se formavam os quadros técnicos e profissionais do regime, ao tempo que se marcava a pauta dos conteúdos e limites que deveriam ser avaliados nas carteiras de projetos das prefeituras. Não obastante, se bem essa metodologia permitia uma maior organização e, sobretudo, a organização dos orçamentos públicos (FNDR e FCM), nem sempre essa ordem técnica de avaliação de projetos permitia aprimorar as necessidades e os processos de desenvolvimento local. Para evidenciar a precariedade, muitas prefeituras na época apenas podiam responder com suas obrigações. $\mathrm{Na}$ área de investimentos locais, o chefe de estudos da SERPLAC da Araucanía reconhecia essa limitação, destacando que as prefeituras não conseguiam elaborar projetos municipais pois estavam "sumidos en el día a día, por lo tanto, nosotros escuchándolo a ellos, recorríamos y los ayudábamos con determinadas tareas, a contratar determinada gente al municipio para que le ordenara la carpeta de proyectos" (ENTREVISTA DIEGO BENAVENTE, janeiro 2021). Com efeito, esse relatório de Benavente também coincide com a lembrança do SERPLAC do Bíobio, Pedro Ramírez, quem destaca sua permanente ligação com os prefeitos e o reconhecimento das necessidades locais como parte de uma tarefa principal da SERPLAC. Diz Ramírez:

En esa época había 51 comunas y con mi equipo en enero íbamos a las distintas comunas para ver cuales eran los proyectos de inversión. Si iban a realizar con recursos municipales, cuales iban a pasar al FNDR o cuales pasaban según el monto al Ministerio respectivo. Y eso fue una práctica que nos sirvió mucho porque le ayudamos a los alcaldes también a pensar un poquito más allá del día a día. Nos apoyábamos mucho en los SECPLAC (ENTREVISTA PEDRO RAMIREZ, janeiro 2021). 
A expressão "día a día" aqui se relaciona com as limitações orçamentais e técnicas da avaliação e gestão de projetos que deveriam incorporar as prefeituras, ou melhor dizendo, uma maior capacitação profissional que se desprendia de um programa de investimento territorial efetivo. Se bem a lei municipal dava um papel relevante ao SECPLAC no planejamento comunal, ao mesmo tempo não assegurava dispositivos profissionais e orçamentais dessas tarefas. Explicando a diferença da gestão política dos prefeitos versus a gestão técnica do SECPLAC, o SERPLAC do BíoBio explica a importância desse cargo e sua projeção em termos profissionais:

El SECPLAC entre comillas estaba sólo y tenía que absorber todas las necesidades que el alcalde le iba a poniendo -entre comillas- en forma desordenada. No hay que olvidar que el alcalde es un ente-personaje político y tiene una mirada distinta. A pesar de que en esa época los alcaldes no eran elegido sino designados, también tenían que responder a la comunidad. Y como te decía el SECPLAC era solo. Y claro, en las municipalidades más grande había profesionales como el caso de Concepción o Talcahuano, lo mismo Los Ángeles o Chillán. Pero en Tirúa era él único profesional. Una cosa importante en esa época, Provincia de Arauco, por ejemplo, donde en esa época llegar a Tirúa era complicado porque era arena y cuando había viento la duna se comía el camino y no podías pasar. Y ahí, en cada una de esas comunas, Lebú, Coltún, Coltahue, Los Alamos, etc. Había un profesional en general, diría yo que en esa época eran ingenieros comerciales que se fueron o que se les envió a esas municipalidades a apoyar el alcalde y el cargo de ellos era el SECPLAC (ENTREVISTA PEDRO RAMÍREZ, janeiro 2021)

Embora o SECPLAC tinha uma missão estratégica de organizar o investimento de cada prefeitura, na prática, só em algumas existia um número de profissionais correspondentes para cumprir com esse objetivo. Em geral, os SECPLAC tinham que cumprir uma série de funções que não respondiam aos critérios definidos pela lei, sendo muitas vezes sobrecarregados em suas responsabilidades. A municipalização nesse cargo profissional, o SECPLAC, não teria significado um maior nível de planejamento territorial ou reorganização dos projetos de investimentos. Nesse sentido técnico da gestão municipal, é ilustrativo o relatório do prefeito de Curanilahue da época, quem destaca a conexão de sua experiência universitária de engenheiro comercial com suas principais tarefas no momento da posse do cargo, em conexão com a projeção estratégica da ODEPLAN das prefeituras:

Era una comuna complicada y porque además venía el plan de cambiar a muchos alcaldes no profesionales por técnicos. Eso estaba esbozado un par de años antes. Cuando yo llego a ODEPLAN el año ochenta era como una misión que había, primero, de organizar a las municipalidades del punto de vista estructural y administrativamente distinta a lo que eran. Yo hice mi tesis en la universidad, la hago justamente en como estructurar la municipalidad del futuro, digamos. Entonces, ahí tú tenías que cambiar todas las estructuras que eran súper antiguas y las conviertes como en especie de empresas públicas, el diseño estoy hablando. Pero orientados a las políticas públicas comunales. Eso venía aparejado cuando se hace todo este 
detalle técnico de proyectos. Después viene la segunda fase que es poner la gente para ejecutarlo. Entonces, la misión era que no hubiese ningún alcalde que, a lo menos, no fuera asistente social. En todos lados y dependiendo de las características de la comuna (ENTREVISTA ALEJANDRO FERNÁNDEZ, fevereiro 2021)

A política de seleção da autoridade comunal está diretamente articulada nos princípios de uma reorganização empresarial da administração pública, que supõe que o estatal como ineficiente e um gasto desnecessário e, portanto, precisa ser formulado em termos de competitividade comercial. Dessa maneira, o melhoramento técnico profissional municipal se projetaria, sobretudo, em suas equipes profissionais que fariam um uso mais especializado dos orçamentos, permitindo otimizar e executar uma avaliação de projetos cada vez mais eficiente nos termos do CIAPEP. Além das comunas e suas problemáticas específicas, acima de tudo, as prefeituras deveriam responder a um perfil profissional técnico e comercial que se fundamentava na avaliação de projetos. No caso do prefeito de Curanilahue, sua tese de engenheira comercial, que teria como tema principal a "municipalidad del futuro", foi um importante suporte em conjunto com sua experiência profissional como funcionário na SERPLAC, dando uma visão completa das necessidades técnicas e políticas do que se esperaria para uma prefeitura. Foi assim que suas principais tarefas de condução na prefeitura de Curanilahue, a partir de 1981, se basearam em mudar totalmente a estrutura municipal anterior. Diz o prefeito:

Entonces, la primera misión era reducir, dar estructura y tener los recursos técnicamente correctos, te fijas, no era solo un tema de números. Entonces, yo selecciono a asistentes, yo selecciono civiles, constructores para obras, gente que sabe. Entonces, aparte de sacar gente tuve que reemplazar los cincuenta -que la mayoría no servía- con un equipo nuevo, joven, profesionalizado total. Ahí me apoyaba con las SERPLAC, Pedro. Cuando tu destruyes para crear te haces de muchos enemigos. No solamente en el pueblo sino fuera porque dentro del gobierno militar pese a que se han dicho un montón de cosas había dos grupos de gente. Había una línea técnica que te la nombré al principio. Una línea muy técnica y una línea muy política, que generalmente era gente joven sin estudios, cuarto medio, a veces ni siquiera eso. Pero con un muy buen discurso y que tenían también sus llegadas por sus lados con los jefes de acá. Sí, eso pasa. En todo tipo de dictadura pasa lo mismo. Siempre hay corrientes internas (ENTREVISTA ALEJANDRO FERNÁNDEZ, fevereiro 2021)

A expressão "gente que sabe" do prefeito se conecta diretamente com o ideário municipal gremialista anunciado nos primórdios do regime, quando se destacava que o futuro do Chile precisava de uma "sociedad tecnificada, en que la palabra de los que saben prevalezca por sobre las consignas" (GOBIERNO DE CHILE, 1974a, s./r.). Assim sendo, se naturalizava a dimensão profissional jovem das engenharias como sinônimo de eficiência e melhoria técnica da administração municipal. No entanto, dado o histórico centralismo e abandono dos escopos municipais, também enfrentavam a possibilidade de existir dinâmicas improdutivas 
ou precárias nas funções burocráticas das prefeituras, sobretudo aquelas mais isoladas ou rurais como Curanilahue. A reestruturação municipal implicou uma redefinição significativa das plantas públicas municipais, sendo profundamente alteradas em seu número e a lógica de funcionários administrativos e profissionais contratados, cada vez mais ligados a um esquema empresarial da gestão do município. Essa visão técnica-política da gestão municipal também teve certas divergências sobre o perfil dos prefeitos da UDI, embora a hegemonia do regime autoritário e sua visão hierarquizada tenha apagado essas diferenças sutis. Mas neste caso, salientadas por prefeitos mais técnicos e profissionais versus outros prefeitos mais políticos e discursivamente mais preparados. O prefeito de Curanilahue estaria dentro do grupo dos prefeitos com um perfil técnico empresarial.

Por outro lado, a realidade de uma prefeitura rural e isolada era muito diferente de outra comuna urbana ou de cabeceira regional, onde efetivamente haveria maiores recursos e orçamentos para profissionais e/ou desenvolvimento de programas de investimento, aliás, maior número de candidatos ou interessados por dirigir essas prefeituras. Seguindo o relatório do SERPLAC de BíoBio, a inícios da década de 1980 o SECPLAC de uma comuna rural do país estava, metaforicamente, sozinho. Os escopos municipais apenas tinham um profissional encarregado do investimento e da projetiva econômica comunal, o qual, evidentemente, não era sinônimo de inovação ou do padrão de desenvolvimento local esperado para uma reforma integral que estava próximo de cumprir uma década. Ainda assim, a realidade interna das prefeituras tenderia a ser cada vez mais técnica e profissionalmente unificada na gestão e avaliação de projetos do sistema de investimentos públicos. Seria uma tecnologia política do território comunal ou do sistema regional integrado? Segundo o chefe de estudo da SERPLAC da Região da Araucania, Diego Benavente, os prefeitos recorriam permanentemente aos SERPLAC e vice-versa, pois, era entre essas equipes onde efetivamente se definia e controlava a gestão pública que seria intervinda pelas prefeituras. Diz o chefe de estudos:

Sí, llegaban los alcaldes a la SERPLAC por el tema de los recursos. No sé si has escuchado hablar del Banco Integrado de Proyectos, era todo un sistema. Por primera vez en Chile las inversiones se evaluaban en su mérito por criterios de eficiencia. Y después me costó peleas en lo personal porque no medía cosas más locales [...] Los proyectos se adjudicaban cuantiosos recursos a proyectos que se justificaban al alero o cerca de Santiago. Por ejemplo, los proyectos de obras públicas se evaluaban por el Tránsito Medio Anual (TMA). Entonces, a mayor TMA obviamente había que pavimentarlo, porque está pasando mucho auto y camión y hay que ingresar recursos. Pero el camino rural que se corta durante ocho meses y no pasa ningún auto no lo van a pavimentar nunca. Entonces, tú decías y qué culpa tiene esa gente, que culpa tiene el país, entonces, fuimos concentrando un país (ENTREVISTA DIEGO BENAVENTE, fevereiro 2021). 
A citação do Benavente é significativa em vários sentidos. Primeiro, porque reflete sobre a maneira hierarquizada e centralizada do sistema de avaliação de projetos em sua operatória interna regional-municipal, desvendando a distância entre os parâmetros quantitativos previamente estabelecidos pela ODEPLAN de Santiago - nesse caso pelo indicador de trânsito médio anual (TMA) - versus as realidades locais do sul que precisavam ser pavimentadas, embora os requerimentos burocráticos do sistema não dessem suporte. Se desvenda assim uma efetiva contradição dos instrumentos de planejamento territorial que, desde a máxima hierarquia regional, evidenciavam a lógica ineficiente da avaliação de projetos. Na prática, não se consideravam as condições particulares das prefeituras mais rurais ou pobres do país. Dessa maneira, se mostra a teia de relações centralistas na própria estrutura das metodologias que, embora procuravam repartir recursos considerando critérios geográficos equitativos, também naturalizavam e reproduziam históricas desigualdades geográficas na distribuição dos orçamentos. Por sua vez, a problemática detectada pelo funcionário da SERPLAC permite compreender mais especificamente a lógica centralizada do conjunto dos instrumentos territoriais de investimentos (BIP), incluído o dispositivo de avaliação de projetos das prefeituras. Além disso, se desvenda que a pavimentação das realidades locais mais empobrecidas e isoladas na zona da Araucanía se decidiria fora das prefeituras. Em concreto, as autoridades regionais e municipais deveriam continuar com a aplicação e avaliação dos projetos segundo os padrões definidos pela unidade central de Santiago, último comando de definição dos critérios e distribuição dos orçamentos. Um questionamento similar, mas de outra escala, também compartilhado pelo prefeito do norte, Carlos Cantero, quando destaca a lógica centralista da operação dos projetos e as autoridades de sua região:

Te estoy hablando del año 80, 81 y 82. Era una época que estaba todo empezando a funcionar. Era una etapa fundacional, imagínate que la Constitución es de 1980 [...] Siempre ha habido en la institucionalidad chilena un enfoque de centralismo muy alto. Entonces, ha habido un principio de subsidiaridad invertido en verdad. Es decir, si el más grande lo podía hacer para que se lo vamos a dejar al más chico, hagámoslo nosotros. Esa era un poco la lógica. Era un centralismo muy evidente, entonces, derrepente el SEREMI quería hacer una cosa y el alcalde quería hacer otra. Lo lógico habría sido que el municipio mandara por sobre la autoridad regional en temas de desarrollo. Sin embargo, no se daba esa situación. Normalmente la autoridad regional mandaba sobre la comunal (ENTREVISTA CARLOS CANTERO, novembro 2019).

Em contraste ao destaque interno de Benavente, o prefeito de Sierra Gorda desvenda outra problemática: a incoerência da hierarquia territorial versus à conexão dos projetos ou iniciativas locais que poderiam ser encaminhadas pelas prefeituras. Com efeito, continuando 
o modelo hierárquico da CONARA, qualquer tipo de projetos e direcionamento territorial era impulsionado respeitando a hierarquia do governo interior: Intendente, SERPLAC, SEREMI, Governador, Prefeitos. Porém, o contato do terreno e das necessidades das comunidades que se inseriam nas prefeituras daria maior suporte para liderar as iniciativas. Contudo, o SIGORE privilegiava a hierarquia antes da capilaridade. Ainda que os prefeitos fossem os mais ancorados nas comunidades locais e conheciam mais em detalhe suas necessidades, a hierarquia de mandato regional devia liderar e controlar esses processos de investimentos territoriais. Esse princípio de "subsidiaridad invertido" nas palavras do prefeito Cantero, basicamente respondia a uma lógica centro-periferia do sistema de governo interior que supunha de antemão que uma maior hierarquia territorial gerava mais controle e, por consequência, mais poder de representação do governo nacional se aderiria nas realidades inferiores. No entanto, na prática, dada as fortes desigualdades geográficas e os limitados orçamentos da época, sempre havia múltiplos desacordos e prioridades entre as unidades regionais e municipais que favorecia a determinados projetos locais ou prefeituras, além do formato de critério eminentemente técnico que supunha o sistema territorial. No fundamental, a questão era manter a hierarquia do governo nacional na escala regional e com isso projetar geograficamente uma ordem vertical na articulação e distribuição dos orçamentos que, sem desconhecer a capilaridade social das prefeituras e suas legitimas pretensões, defendesse o espírito de corpo da gestão e o funcionamento do sistema territorial regional. Como diz o prefeito de Curanilahue:

Educación y Salud no eran mis enemigos, me ayudaban. Aplicaban el rol subsidiario, pero no pasivo, sino que nos coordinábamos para ver los temas. Me preguntaban, oye qué necesitas, cómo estas viendo el tema. Yo les daba de vuelta mi retroalimentación, ósea, yo veo esto y esto otro. Con los dos sectores había bastante buena comunicación porque también en este proceso de mejorar los perfiles técnicos también se habían hecho en los sectores, te fijas, con los otros pares. Tenía que hablar con los SEREMIS y como te acuerdas que te decía que al interior de los SERPLAC había un equipo preparándose para ser SEREMIS, también se dio. Entonces, cuando yo hablaba con los SEREMIS. Eran los mismos, amigos míos, hablábamos lo mismo. Había mucha coordinación porque teníamos la misma meta, el mismo objetivo. Lo único que nos importaba era eliminar la pobreza en la medida de lo posible, que la gente sintiera que tuviera oportunidades en la vida. Había un tema político detrás. Nosotros los técnicos a diferencia de la Juventud, lo tratábamos en el sentido de demostrarle a la gente que si uno salía con desarrollo y eliminaba lo más básico de la pobreza iba a avanzar. En la primera generación era pobre-pobre. En la segunda a lo mejor le iba a alcanzar a ser lo que su padre soñó, pero su nieto sí lo podría conseguir en la medida que se dieran los pasos acotados. Así hablábamos nosotros en las poblaciones, entonces, le mostrábamos luz al final del túnel (ENTREVISTA ALEJANDRO FERNÁNDEZ, fevereiro 2021)

O relatório do ex prefeito descreve a forma mancomunada da gestão territorial, fundamentalmente na integração da autoridade comunal plenamente interligada com suas 
contrapartes regionais, nesse caso, os SEREMIS de saúde e educação. A reciprocidade das funções territoriais nascia a partir da hierarquia regional dos dispositivos públicos e uma permanente comunicação entre as autoridades. Dessa maneira, prefeitos e SEREMIS compartilhavam os mesmos objetivos e metas, independente das posições técnicas, territoriais ou setoriais, o qual assegurava e consolidava um espírito de corpo do SIGORE. Por último, é particularmente significativo como o prefeito de Curanilhue novamente incorpora a diferença da gestão municipal com o setor político da Juventude (SNJ) e sua particular compreensão técnica da pobreza como uma peça chave da função da prefeitura: "eliminar la pobreza en la medida de lo posible". Contraditoriamente, assim, as prefeituras foram cada vez mais valorizadas e sincronizadas pelas autoridades centrais, ao passo que aperfeiçoariam seus dispositivos técnicos no vínculo pobreza-prefeitura, permitindo e circulação dos grupos da direita com os setores mais populares. Como destaca o historiador Rolando Alvarez: "muchos pobres de la ciudad vieron al régimen sensible y preocupado por sus dramáticas condiciones de vida, poniendo la primera piedra de la begemonía politica y cultural del neoliberalismo en Chile" (ALVAREZ, 2012, p. 125). Nesse esquema, as prefeituras tecnicamente estariam mais inseridas nas necessidades, sobretudo nas representações e intermediações mais urgentes pela crise: trabalho e moradia.

\subsection{A disputa pelos pobres na neoliberalização municipal}

Como vimos nos capítulos anteriores, a política social do regime foi levada com persistência pela ODEPLAN e acadêmicos formados na escola de Chicago e o Instituto de Economia da PUC, destacando a participação de Miguel Kast como uns de seus principais intelectuais orgânicos (SOMS, 2010; LAVIN, 1986). Em 1975, por exemplo, se apresentaram as primeiras cartografias dos estudos da extrema pobreza do país, as quais seguiram aprofundando-se sucessivamente até a publicação do Mapa de la Extrema Pobreza em 1979. Esse importante estudo permitiu a caraterização e seguimento espacial dos setores populares ao longo do país, sendo a principal fonte técnico-geográfica de políticas de focalização e distribuição de subsídios nos setores mais pobres. As políticas de focalização da pobreza, assim, coincidiram, por um lado, com a emergência da UDI como principal referente político do regime e representação ascendente das principais prefeituras do país. Mas, por outro lado, foram contraposição de um pujante movimento de oposição e protestos populares devido a intensa crise econômica generalizada pelos efeitos da abertura e a neoliberalização da economia chilena (RIFFO, 2005). No decorrer da década de 1980, assim, a UDI paulatinamente foi perfilando-se como a rede do governo mais inserida nos dispositivos de 
focalização da pobreza. Um elemento de destaque desse crescimento fundacional foi a vocação popular de seu departamento de moradores. Os dirigentes da UDI não eram apenas os prefeitos e secretários da juventude nomeados, também se misturavam e vinculavam em pequenos grupos locais de comunidades marginalizadas e espaços vizinhais, demandando mais ajuda do Estado, especialmente relacionadas às necessidades da moradia (MUÑOZ, 2016; ALVAREZ, 2012).

Em suma, o regime tinha que prover um sistema de ajudas sociais efetivas que permitissem mitigar a forte crise econômica e, além disso, baixar linhas políticas ao processo popular aberto pelos protestos e a impugnação generalizada ao governo. Dessa maneira, a UDI ia inserindo-se em múltiplas dinâmicas populares que conectavam sua intermediação de bases militantes com as prefeituras e vice-versa. A chave dessa nova tecnologia política nascia a partir do estabelecimento de algum tipo de contato cotidiano entre os moradores e os dirigentes da UDI, que foram recriando os diversos programas sociais das prefeituras (VALDIVIA, 2012). Um exemplo didático dessas dinâmicas pode ilustrar-se na trajetória do militante UDI Alfredo Galdames, quem na década de 1970 havia sido Secretario Comunal da SNJ da prefeitura de Conchalí (Região Metropolitana) e posteriormente secretario zonal norte da SNJ em Santiago. Reverenciado nesses espaços de organização e participação oficial gremialista, no começo da década de 1980, o prefeito de Conchalí teria nomeado Galdames, presidente da União Juntas de Vizinhos e posteriormente chefe do Departamento de Organizaciones Comunitarias da prefeitura em 1982. É interessante essa trajetória pois visualiza a circulação de diferentes níveis de integração na sociedade civil do dirigente UDI, sempre em relação com a autoridade local, até chegar à posição oficial da prefeitura. Um desenho institucional que permitiria dar maior poder ao prefeito, ao passo que tornaria mais permeáveis as fronteiras entre a organização social e ajuda técnica da prefeitura, tendendo a capturar a adesão dos setores populares em uma lógica de troca de favores políticos. Uma troca de favores que evidentemente estimularia a legitimação dos quadros dirigentes UDI e, por consequência, a ampliação do gremialismo nos setores populares. Diz Galdames em relação ao seu espaço de intervenção:

Bueno, en ese tiempo era la dinámica que se usaba todos los cargos a los que se accedían eran así, desde el presidente de una junta de vecinos hasta los presidentes de los clubes deportivos, el alcalde los nominaba. Y ahí lo que había que hacer, por lo menos lo que yo entendía, era que había que legitimarse, (decir) bueno, estoy aquí, y tratar en alguna medida de representar y que la gente sintiera que uno entendía del tema y que uno realmente estaba preocupado de ayudar a resolver los problemas que ellos tenían, y es lo que yo siempre traté de hacer. En el 
fondo, fundamentalmente por que te ponían ahí era para despolitizar a la organización (MUÑOZ, 2016, p. 216)

O relatório é chave porque se destaca a necessidade de impulsionar e representar projetos e necessidades sociais efetivamente reais. Porém, estrategicamente, essas necessidades sociais deveriam ampliar em primeiro lugar a legitimação dos quadros da UDI e dessa maneira, ampliar politicamente a própria força da prefeitura. A partir desses enquadres os militantes da UDI começaram a aprofundar seus sistemas de recrutamento profissional e político, ampliando sua presença nas principais prefeituras e grupos de favelados do país. Um exemplo desse movimento político no interior do regime se ilustra na trajetória temporal das representações políticas nas prefeituras, que eram também capitais regionais do período (quadro $\mathrm{n}^{\circ} 22$ ). Entretanto, se nos primeiros anos do regime existiu uma maior presença de prefeitos das FF.AA., independentes e militantes do Partido Nacional (PN), no decorrer da década de 1980 foi-se consolidando a hegemonia da UDI e Renovação Nacional (RN). Essa hegemonia da UDI - e quase desaparição das prefeituras do PN e os oficiais das FF.AA. -, precisamente foi o reflexo da profissionalização dos municípios e o rearme político da direita enquanto representação popular. É importante destacar nesse sentido, que muitos desses prefeitos eram reconhecidos publicamente como independentes sem partido, no entanto, na prática eram assíduos militantes do gremialismo ou bem facilitadores de suas redes territoriais que dispunham da prefeitura. Essa trajetória de independente à prefeito UDI foi parte da necessidade do regime de preparar a sucessão autoritária. Durante todo o período autoritário, tanto o governo central como especialmente nos quadros gremialistas, aprofundaram a ideia de que os partidos políticos tinham sido os principais responsáveis da crise institucional que se derivou no Golpe de Estado. Daí que a nova institucionalidade do país deveria guiar-se em princípios técnicos e profissionais que impediriam as agendas politizadoras. Por isso muitas dessas prefeituras foram representadas como independentes, embora suas lideranças estariam completamente inseridas na agenda dos grupos partidárias ao governo ou das redes territoriais da UDI. Sobre esses grupos nas prefeituras, é relevante destacar que existiram várias diferenças entre eles, sobretudo na conjuntura de 1985-1987, quando o PN fez uma crítica ao regime e negou apoio à agenda política do general Pinochet como candidato oficial do governo. A partir desse momento, o PN se dissolveu e criou RN junto com outras forças de direita, sem a participação da UDI. Por sua parte, a UDI foi o único bloco de direita que deu suporte ao general Pinochet em seu desejo de ganhar o plebiscito de 1988 como candidato de continuidade, o qual, 
internamente lhe significou um novo processo de ampliação de suas prefeituras (HUNEEUS, 2016).

\section{Quadro $n^{\circ} 23$. Representações políticas nas prefeituras capitais regionais}

(1973-1988)

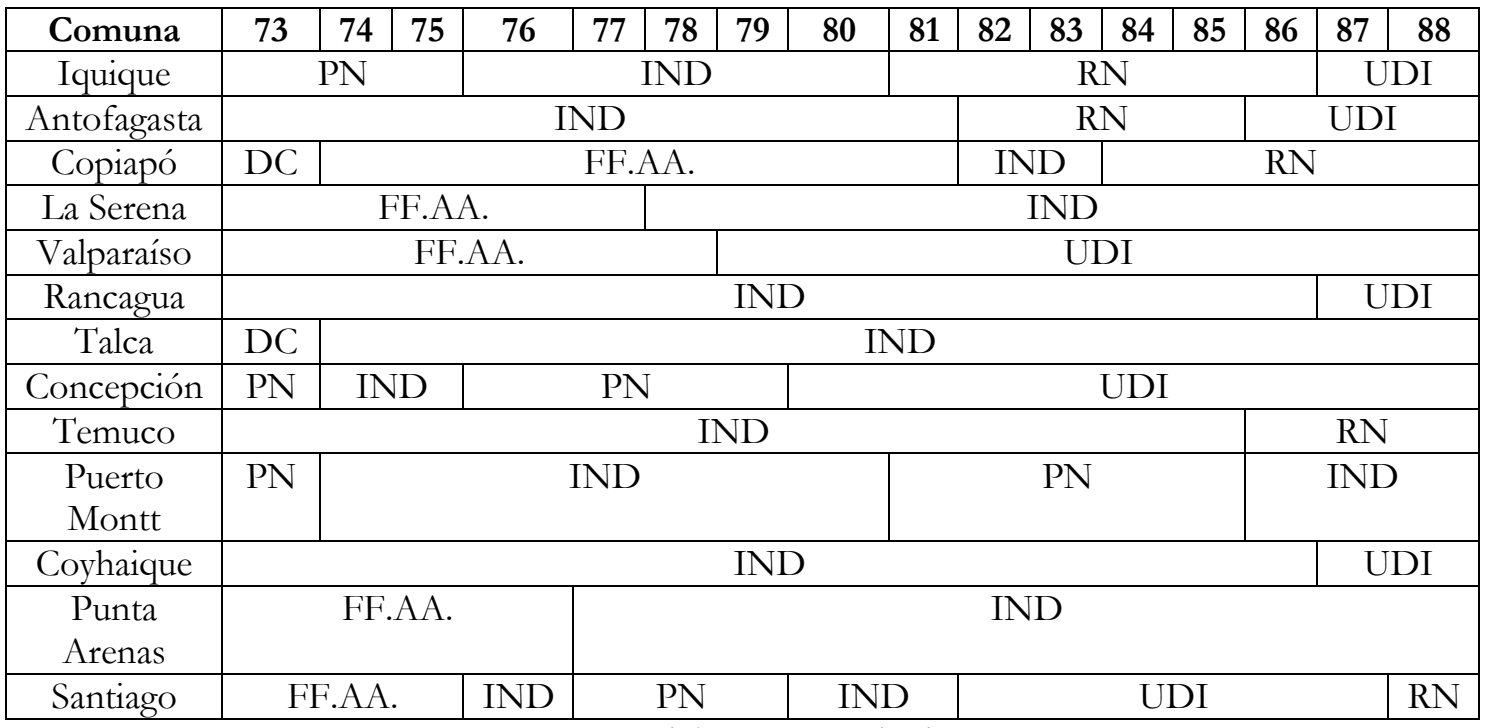

Fonte: Elaboração própria.

No entanto, como destacávamos mais cima, a força das prefeituras do gremialismo já vinha crescendo desde 1979 com a nomeação de advogado gremialista Sergio Fernández como Ministro do Interior. Esse mesmo ano, e com base nesse diagnóstico, também se criavam os Comités de Asistencia Social (CAS) em todas as prefeituras do país com o objetivo de padronizar a ajuda e melhorar a focalização dos programas sociais (SOMS, 2010). O resultado desse processo foi a aplicação da Ficha CAS em 1980, um dispositivo de coleta que permitia as prefeituras classificar as residências dos setores mais empobrecidos mediante o estabelecimento técnico de cinco níveis de pobreza, sendo os primeiros três os mais críticos ${ }^{72}$. Com isso, o regime assegurava um instrumento de estratificação socioeconômica em todas as partes do país e, dessa forma, as prefeituras poderiam identificar, priorizar e distinguir seus principais beneficiados, ao mesmo tempo que as transferências monetárias de auxílio efetivamente chegariam nas residências mais empobrecidas do país. A cada dois anos a Ficha

\footnotetext{
${ }^{72}$ Pouco tempo após se detectou que o instrumento tinha graves distorções que não permitiam focalizar os recursos nos setores mais pobres. Dessa maneira, em 1982 começou uma revisão do instrumento que terminou com uma segunda versão, a Ficha CAS II, que começou a ser aplicada em 1987. A principal inovação da Ficha CAS II foi a criação de um modelo matemático com pontuações que não poderiam ser manipuladam pelos funcionários ou beneficiados.
} 
$C A S$ deveria ser atualizada e assim, se garantia que as prefeituras estivessem em permanente comunicação com seus vizinhos e vizinhas mais empobrecidos.

Porém, como já vimos anteriormente, o regime nunca conseguiu combater os profundos níveis de pobreza (RIFFO, 2005). Daí que, muito antes da primeira Ficha $C A S$, o regime também criou outros dispositivos de ajuda social destinado a apoiar os setores mais pobres, onde novamente, as prefeituras teriam uma particular incidência. Se tratou do Programa de Empleo Mínimo (PEM), iniciado em março de 1975 devido à forte diminuição do gasto público e uma intensa recessão econômica que significou importantes níveis de desempregos no país (HUNEEUS, 2016). No entanto, essa situação de instabilidade econômica, somada a uma progressiva privatização da vida cotidiana, condicionaram a abertura de um segundo programa na década seguinte (março de 1983), o Programa de Ocupación para Jefes de Hogar (POJH), inaugurado na mesma lógica de compensar a forte recessão econômica e a particular exposição de desemprego dos setores mais empobrecidos. Ambos dispositivos foram anunciados como políticas públicas ocasionais, no entanto, se estenderiam praticamente durante todo o processo autoritário (1974-1988) sob diferentes níveis de aprofundamento. Segundo Huneeus, em 1983 os trabalhados do PEM haviam alcançado a meio milhão de pessoas e o POJH tinha enumerado umas 132.449 pessoas, o que na Região Metropolitana era o equivalente a um 15\% da população economicamente ativa (HUNEEUS, 2016).

As cifras expressavam a forte crise econômica e social do período. Mas também eram cifras que envolviam múltiplas contradições que competiam diversas capilaridades das prefeituras e o sistema territorial do regime. Se bem os setores populares eram cada vez mais visíveis pela radicalidade dos efeitos econômicos, ao mesmo tempo os benefícios dos programas não poderiam contrariar a lógica do Estado subsidiado (o neoliberalismo). Dessa forma, o PEM e o POJH criavam programas especiais de absorção de mão de obra em caráter transitório e precário, destinadas a pessoas desempregadas, permitindo um ingresso de apenas um terço do salário mínimo sem contrato de trabalho formal e pagamento de indemnizações, ou seja, ingressos muito mais baixos que qualquer mínimo de trabalho remunerado (VALDIVIA, ALVAREZ, 2012). O regime defendeu sua validez argumentando que eram trabalhos que se consideravam subsídios momentâneos de ajuda paras as famílias dos desempregados. Formalmente, assim, os programas de emprego mínimo do regime equivaliam ao salário de quinze horas de trabalho semanal em tarefas que não tivessem 
maiores custos de produção nem materiais de investimento que, no geral, correspondiam a atividades de limpeza e manutenção do espaço público. Foi precisamente as prefeituras as principais receptoras do PEM e o $\mathrm{POJH}$, sendo a institucionalidade pública oficial encarregada de operacionalizar os mecanismos e seleção de receptores e beneficiados.

A historiadora Verónica Valdivia tem feito um estudo sistemático dos direcionamentos neoliberais que mantinham esses programas de auxilio, centrando sua análise na dimensão política dos prefeitos (seu acabamento/aperfeiçoamento/padronização UDI) e, particularmente, entendendo o papel dos municípios como dispositivos intermediários de despolitização e fonte de poder de um novo tecido político criado pelo regime (VALDIVIA et, al., 2012; VALDIVIA, 2015). Sem o ânimo de romper essa interpretação, mas sim ampliar seus significados enquanto compreensão crítica do funcionamento do Estado territorial, é interessante visualizar como a execução do PEM e o POJH também estava fortemente articulada no SIGORE. Isto porque cada prefeitura deveria criar requerimentos de trabalhos como melhoramento de comunidades marginais, jardins de infância e parques, reflorestamento, irrigação, asseio geral, etc. que, técnica e hierarquicamente, se articulavam a nível regional. Tecnicamente, assim, os programas de emprego mínimo e chefes de famílias tinham que ser executados considerando um pequeno grau de investimento em materiais (apenas um 25\%) versus um máximo possível de contratação de mão de obra (70\% ou 80\%). Como explica o funcionário da SERPLAC do BíoBío, Diego Benavente:

Los municipios llenaban unas fichas bien breves como proyectos donde expresaban necesidades de empleo. Dos o tres hojitas que se llenaban a partir de las necesidades para dar empleo. Entonces, había que hacer tal obra y ellos la justificaban llenando estas fichas. Y nosotros tomábamos estas fichas, evaluábamos, veíamos las que estaban coherentes y le proponíamos al Intendente un listado a aprobar: mil empleos, dos mil empleos, pavimentación o reparación, etc. Y en esa oportunidad en Concepción nuestro estilo fue el siguiente: todos los proyectos no pueden estar contratando por contratar. La gente necesita sentirse orgullosa por lo que hizo y no hacer cualquier cosa por hacer. Ahí fue una diferencia notable: nosotros pavimentamos -digo entre comillas- muchas calles con el viejo sistema del bolón colonial empedrado. Muchas calles de barrio de Concepción la hicimos así. Y eso lo hacíamos con proyectos que tenían una limitación: que el $25 \%$ era el máximo que permitía para materiales, porque la idea era que el $75 \%$ o $80 \%$ fuera para contratación de mano de obra. De tal manera teníamos proyectos casi egipcios y lográbamos hacer varios proyectos. Hicimos poblaciones que se pavimentaron muchas calles que, en lugar de tener la calle de barro, tenían calles empedradas y así fuimos haciendo aguas rurales, etc. Entonces, todo se fue dando un bueno uso y no permitíamos el despilfarro (ENTREVISTA DIEGO BENAVENTE, fevereiro 2021)

É significativo destacar a diferença marcada pelo funcionário SERPLAC, assim como distinguir a articulação estratégica desses programas - PEM e POJH - na escala geográfica regional. De maneira geral, as iniciativas do PEM e o POJH eram considerados subempregos 
inventariados ou pouco efetivos, posto que não constituíam em tarefas relevantes. No entanto, no caso mencionado na VIII Região do BíoBio, os trabalhos do PEM e o POJH permitiram responder a uma necessidade social de qualidade de vida - pavimentação de ruas - dando efetivamente um uso territorial importante a essa força de trabalho, o qual permitia combater as exacerbadas cifras de desemprego. Além disso, do ponto de vista operativo da gestão do território, é ilustrativo a citação pois se evidencia o trabalho colaborativo entre prefeituras e a SERPLAC, sendo essa última o suporte técnico fundamental para a circulação racional dos programas e a aprovação final dos empregos nos territórios. Porém, não sempre as prefeituras consideravam esses requerimentos e tendiam a completar essas avaliações técnicas, pois as urgentes demandas e necessidades de emprego se confundiam também com uma particular agência política. Como explica o SERPLAC do BíoBío Pedro Ramírez:

\begin{abstract}
El responsable de administrar era el SERPLAC. Los alcaldes pedían cierto numero de cupos [...] Se hicieron buenos proyectos. En el caso de Concepción había poblaciones de tierra que en invierno eran barriales tremendos donde no podía ni entrar la policía o bomberos, nadie. Y se hicieron proyectos donde se les capacitó como empedrar las calles con la antigua metodología del empedrado de la colonia. Todavía está el empedrado de esa época. Yo creo que en esa época se hicieron buenos proyectos de ese tipo. Claro, después la cosa se desvirtuó. Hubo mucha presión por parte de los que integraban en eso, que los proyectos no se cortaran, de los mismos alcaldes. Creían que entre más personas tenían les iba ir mejor. Yo me acuerdo haber conocido un alcalde que lamentablemente falleció que decía que ojalá su comuna fuera la más pobre de Chile porque con eso obtenía muchos recursos de los distintos programas que se otorgaban del gobierno de la época. Entonces, tú te encontrabas con esas realidades también. El decía ojalá tuviera los índices más malos porque así recibiría más recursos del Estado (ENTREVISTA PEDRO RAMÍREZ, fevereiro 2021)
\end{abstract}

A SERPLAC tinha a responsabilidade de distribuir os cupons de empregos associados a condição da pobreza entre os prefeitos da região. Em primeiro lugar, se desvenda que além do valor de uso territorial concreto do programa de pavimentação nas periferias de Concepción, também, e contraditoriamente, emerge implicitamente a disputa pelos programas de emprego como forma de cooptação nos setores mais pobres. Com efeito, um maior nível de pobreza na comuna possibilitaria um maior nível de recursos públicos organizados pela prefeitura. Os prefeitos dos municípios mais pobres cobiçavam os cupons do PEM e o POJH para suas comunas, no entanto, esse direcionamento dos empregos também articulava outro tipo de relações e influências, principalmente políticas, dado o problema da limitação dos fundos. Segundo Valdivia, no período de protestos de 1983 existiriam denuncias feitas por trabalhadores do PEM e o POJH nas comunas de La Cisterna, La Pintana e San Ramón na Região Metropolitana. Essas denuncias descreviam pressões sofridas pelos trabalhadores por parte dos empregados municipais, quem os obrigariam 
aderir e participar em atividades ligadas aos grupos de Avanzada Nacionale Renovación Nacional (VALDIVIA, 2012). Através do PEM e o POJH, as bases militantes e oficiais da UDI, por exemplo, poderiam espalhar-se em uma dupla função: ampliar a base social do regime e capturar o apoio dos setores populares seguindo suas redes e preferências. Para distinguir esse particular direcionamento político no interior desses programas, é ilustrativo o relatório do dirigente UDI Alfredo Galdames da época, quem diz:

Había otros alcaldes que eran un poco más osados y que te daban más facilidades, no sé, por ejemplo en ese tiempo, estaba el POJH y uno podía conseguir que le metieran algunas personas [...] se le metía en los cupos del PEM, del POJH, cosas así...pero no era una cuestión masiva, sino que era: oye, me puedes meter dos o tres personas que están súper mal y que han postulado y no los han dejado (MUÑOZ, 2016, p. 225-226)

Através do PEM e o POJH se articulava uma agência social das prefeituras que permitiu estruturar um certo tipo de influências e adesão da gestão municipal oficial. Essas influências dos quadros UDI nas prefeituras - como por exemplo, na distribuição de empregos mínimos entre suas redes populares - foram uma ferramenta efetiva de ampliar a conexão com os setores empobrecidos e alimentar a complicada legitimidade do regime. $\mathrm{O}$ PEM e o POJH, assim, eram parte de uma complexa teia de dispositivos territoriais que rodeavam interesses políticos. Em termos de escala geográfica, desse modo, se faz explícita a tendência mais instrumental desses programas a nível comunal, além do uso territorial que poderia estabelecer as SERPLAC e as equipes técnicas a nível regional. No entanto, apesar da disputa instrumental e ideológica dos recursos municipais, é significativo destacar também que, precisamente, para conseguir a circulação do PEM e o POJH como política de governo territorial, era imprescindível a intermediação da SERPLAC na escala regional. Sem a intervenção dessa unidade burocrática à nível regional, dificilmente se poderia haver impulsionado esses dispositivos de governo com um mediano sentido de distribuição nos diferentes níveis comunais. As equipes da SERPLAC estruturavam tecnicamente os programas enquanto sua distribuição nos territórios comunais. De tal maneira, se esclarece a posição estratégica da SERPLAC na distribuição do PEM e POJH, sendo um desdobramento do SIGORE que, no último grau hierárquico, em contato direto com os setores populares, era definido pelas prefeituras e suas influências políticas.

A nível regional, a combinação de interesses políticos e o uso instrumental dos dispositivos de emprego ia em descompasso com a organização racional dos recursos. No entanto, na escala local as prefeituras competiriam fragmentariamente por mais recursos e, portanto, poderiam instrumentalizar o suporte racional dos dispositivos de auxílio. De tal 
maneira, se relativiza a centralidade das prefeituras como as únicas agencias governamentais encarregados do PEM e o POJH, e se demostra que seu funcionamento operativo era parte de uma rede mais sofisticada verticalizada na função da SERPLAC, embora dependente da logística das prefeituras e seus particulares agenciamentos e influências. Contudo, os programas de emprego mínimo, simultaneamente, também foram cenário de politização e rebeldia frente a máxima autoridade de governo. Na comuna de Pudahuel, e posteriormente San Miguel, se registraram importantes manifestações de paralisação dos trabalhadores do PEM e o POHJ em 1983 (VALDIVIA, ALVAREZ, 2012). É interessante esse ponto porque revela que apesar de toda a energia política do regime, enquanto sua tentativa de despolitização e cooptação (nesse caso via entrega de empregos mínimos), as redes territoriais organizadas da oposição e a esquerda continuariam de pé em um complexo cenário de movimentações estruturais.

Nesse marco, a descentralização oficial do regime concretou seu desdobramento nas áreas da educação e a saúde, gerando múltiplas problemáticas e efeitos nos termos do funcionamento orgânico das prefeituras, principalmente nas condições trabalhistas dos funcionários municipais e a qualidade estrutural dos serviços que seriam levados pela reforma. A partir da descentralização oficial em 1980, as prefeituras começaram o processo de descentralização das escolas públicas e dos serviços primários da saúde que, antigamente, dependiam dos Ministérios respectivos. Para conseguir esse objetivo, a prefeitura do regime deveria melhorar não apenas a racionalização e operacionalização dos recursos focalizados, mas também reestruturar todo o antigo tecido administrativo e suas lógicas de contratação municipal. Como explica o prefeito de Curanilhaue, no sul de Chile, no momento de sua chegada à prefeitura em 1981. Ele diz:

Me costó bastante al principio porque yo llegué a una municipalidad que tenía unos aproximadamente 300 empleados y yo necesitaba 36. Así que fue durísimo. Todo Chile era igual, estaba llena de favores políticos [...] Esto ya lo sabía porque nosotros teníamos detectado desde la SERPLAC las tremendas sobrepoblaciones de empleados públicos. Una misión era dejarla por lo menos en 50 [...] De esos 300 funcionarios, unos 200 trabajaban en especies de empresas que dependían de la Municipalidad. Por ejemplo, había una piscina municipal que supuestamente era para el esparcimiento de la comuna. Entonces, había más personal contratado de lo que se necesitaba, que eran cuatro. Y además tampoco se justificaba tener una piscina municipal que la ocupaba muy poca gente, cosas de ese estilo (ENTREVISTA ALEJANDRO FERNÁNDEZ, fevereiro 2021).

É interessante o destaque pois mais uma vez evidencia a SERPLAC enquanto órgão pensante das mudanças municipais, embora não fosse essa a oficina que devesse executar as 
novas métricas burocráticas enquanto funcionários municipais. Como destaca Fernández, a municipalização significou uma imediata e expressiva redução dos funcionários, além de uma homologação dos serviços a critérios de rentabilidade ou um impacto quantitativo no uso dos recintos municipais. Dessa maneira, os prefeitos que iniciaram o processo de reforma em 1980 tinham uma primeira tarefa: reduzir o número de funcionários e assim, introduzir sistemática e tecnicamente uma nova lógica da gestão municipal. Diz Fernández:

El primer año me tocó todo eso. Fue duro porque tú sabes lo que significa eso. Pero la ventaja es que no había democracia, por lo tanto, yo actuaba. A mí me median por resultados. Yo era como el gerente de una empresa, sobre todo el primer año [...] Imagínate que tú eres el gerente general de una empresa y me dicen ya Alejandro, tú vas a hacerte cargo de Antofagasta y tengo todos estos problemas en Antofagasta y los quiero solucionados en un año. Y yo comercial joven, actuaba. Entonces, yo decidí en ese tiempo hacerlo rápido [...] El dolor es mejor que sea potente y de una vez y no de a poco. Eso es peor, mucho peor. Primero, porque si no la gente se prepara y te boicotea. Así que sí tu tienes que hacer algo, lo tienes que hacer rápido y con sorpresa. Y después prepararte para la respuesta. La respuesta que viene del dolor y la rabia. Pero ya está hecho, te fijas, ya no lo puedes deshacer (ENTREVISTA ALEJANDRO FERNÁNDEZ, fevereiro 2021).

O prefeito da época deixa explícita a projeção empresarial de como deveriam ser avaliadas e organizadas as prefeituras, nesse caso, ligado a uma meta de reduzir exponencialmente suas plantas de funcionários. Em segundo lugar, se esclarece explicitamente a diferença de impulsionar esses processos em um contexto autoritário versus outro regime mais democrático, onde existiriam possibilidades de oposição nas políticas municipais. Um assunto tão complexo como a demissão de operários municipais, assim, terminaria impondo-se pelas condições autoritárias da época, independente das agências locais ou internas. Porém, mesmo estando em um contexto autoritário, o prefeito tinha que estabelecer uma estratégia de ação que permitisse compensar os danos à sua legitimidade e, dessa forma, conter uma possível resposta ou descontento por parte dos funcionários municipais envolvidos, em tal caso, fazendo uma redução rápida das demissões municipais sem possibilidades de negociação ou articulação das contrapartes funcionárias. Em terceiro lugar, se demostra que o modelo vertical do sistema territorial nacional também era replicado ao interior das prefeituras no sentido que se assumia uma autoridade verticalizada em todo o processo de transição. Essa verticalidade própria do SIGORE, no entanto, se compensava relativamente com uma gestão municipal extremamente ágil e cautelosa de ampliar sua legitimidade e próxima da comunidade: "Hay que estar con las comunidades en cada barrio y mucho terreno" (ENTREVISTA ALEJANDRO FERNÁNDEZ, fevereiro 2021). Uma preocupação relevante, considerando a série de elementos externos que deveriam compensar os prefeitos: 1) período turbulento de crises econômica e protestos onde se inseriam essas mudanças 
municipais; 2) relações internas nas equipes municipais que existiam nos territórios internos, onde, na maioria das vezes, as comunidades de funcionários tinham maior históricos na instituição que os próprios prefeitos; 3) pouca experiência no cargo de máxima autoridade local, embora que profissional e tecnicamente conheciam do exercício burocrático específico dessa prefeitura. Nesse sentido, é interessante destacar as diferenças internas entre os grupos políticos afins e suas projeções na gestão municipal pelos prefeitos. Ainda que todos fossem partidários do regime e ou inclusive alguns fossem militantes do mesmo partido (UDI), segundo o prefeito de Curanilahue, existia uma diferença significativa entre os prefeitos que saiam da SNJ versus aqueles que tinham passado pela SERPLAC, como em seu caso. Diz Fernández:

\footnotetext{
Nosotros tuvimos una pelea feroz dentro de la UDI con estos mismos grupos. Éramos bien diferentes [...] A ellos sólo les interesaba hacer plazas, hacer parafernalia, para que la cosa luciera porque decían que la gente no tiene idea. Por lo tanto, lo que le gusta es la parafernalia. Y nosotros decíamos sí, puede que tenga razón. Pero lo importante en el fondo y lo que va a quedar es que las segundas generaciones nuevas van a tener agua, va a haber menos mortalidad y eso es lo que en definitiva va a permitir que este país sea establemente de centroderecha el día de mañana (ENTREVISTA ALEJANDRO FERNÁNDEZ, fevereiro 2021)
}

A citação contrasta dois modelos de gestão municipal: uma gestão das intervenções públicas tradicionais com maior notoriedade simbólica versus uma gestão técnica empresarial sem maior visibilidade, embora fundamental para incidir nos estândares mínimos da pobreza do país, exemplificado na rede de água e serviços de esgoto. Precisamente, se trata de uma diferença geográfica do conhecimento da pobreza e das formas públicas de enfrentá-las nas prefeituras que, porém, não alterou a vocação de poder tecnocrático da UDI e sua particular direção política assistencial nos setores mais pobres. No caso da prefeitura de Curanilahue, Alejandro Fernández teve uma prolongação de quatro anos (1981-1985), onde impulsionou três processos que ilustrativamente expressaram a transformação do Estado chileno no que tange as garantias de direitos fundamentais, universais e de qualidade. Em suma, esses processos foram a 1) reestruturação da prefeitura do ponto de vista das funções e o tecido profissional do pessoal contratado e a organização administrativa do traspasso das 2) escolas públicas e 3) serviços primários dependentes dos Ministérios de Educação e Saúde na prefeitura de Curanilahue. O traspasso das escolas públicas para as prefeituras implicou uma série de modificações estruturais onde se destacou a mudança do sistema de financiamento estatal. As antigas repartições dos recursos históricos do Ministério passariam a ter um critério de subvenções por custo por aluno para cada prefeitura (VIAL, 2016). Em seu 
relatório, o prefeito de Curanilahue explica a diferença da situação administrativa interna da prefeitura versus a situação da educação, onde ele trocaria de estratégia. Diz o prefeito:

Esta vez lo hice al revés. Lo primero fue ir a hablar con cada colegio y cada profesor. Deben haber sido sesenta reuniones. Yo sabía que se iba hacer sí o sí. Lo primero fue por convencerlos. Esta vez opté por ir primero a convencerlos porque además los profesores son muy distintos de las otras personas de antes. Por lo tanto, fue difícil, pero fue una cosa cara cara, muy sincera. Yo ya tenía mejor fama. Cuando voy a donde los profesores que son también profesionales, ya la mirada es distinta. Me iba directo a hablar con las bases, me juntaba con todos los profesores. Estaban muy asustados porque pensaban que los íbamos echar. Y todo eso era explicar que el sistema se iba a profesionalizar e iba ser mejor. Iban a poder tener cosas que jamás tenían. El Ministerio de Educación no les entregaba nada. Apenas les pagaba el sueldo (ENTREVISTA ALEJANDRO FERNÁNDEZ, fevereiro 2021).

A citação é ilustrativa em várias perspectivas. Primeiro, pela disposição política do prefeito de encarar diretamente as bases docentes e tentar explicar as mudanças do sistema no sentido de melhorias, independente das desconfianças do corpo docente da comuna. Em segundo lugar, essa busca de legitimação e validação das bases docentes na comuna também se conectava com o abandono histórico das condições materiais dos recintos educacionais, produto do centralismo exacerbado que tinha escasso nível de investimento e monitoramento dessas realidades, sobretudo nas comunas rurais ou isoladas do país, onde efetivamente existia uma crônica carência de orçamentos públicos (VALENZUELA, 2016; SALAZAR, 1998). Assim, a busca de validação com as equipes docentes da comuna também era uma maneira de projetar a relevância da prefeitura na realidade local, sobretudo, na melhoria da gestão municipal enquanto agente responsável pelos assuntos educacionais do território, uma prefeitura mais moderna, profissionalizada e preocupada pela educação de seus vizinhos e vizinhas. A legitimação da mudança se fundamentava na profissionalização do sistema escolar e em uma maior eficiência dos recursos onde, precisamente, iriam ao resgate das precárias condições dos equipamentos e infraestruturas públicas educacionais de Curanilahue. Nesse sentido não é menos representativo que o prefeito destaque que, dos quinze estabelecimentos educacionais de Curanilahue da época, ao menos dez deles praticamente haveriam sido reconstruídos integramente graças à descentralização (ENTREVISTA ALEJANDRO FERNÁNDEZ, fevereiro 2021). No caso de Curanilahue, assim, a municipalização da educação possivelmente traçaria melhoras do ponto de vista da administração dos recursos públicos, enquanto infraestruturas educativas. Algumas melhoras foram ancoradas a partir da proximidade espacial, de escala geográfica e populacional de Curanilahue, que teria uma prefeitura mais alerta às necessidades de seus recintos educativos. Com o sistema educacional anterior, dado que os recursos públicos das escolas eram 
distribuídos a partir do Ministério a nível central, dificilmente tais melhorias consideravam as comunas mais isoladas ou rurais. Dessa forma, a descentralização das escolas públicas na prefeitura de Curanilahue conseguiria não só aprimorar e distribuir de maneira mais eficiente diferentes tipos de infraestruturas e intervenções, mas também ganhar apoios da comunidade inserida. Em relação ao traspasso de saúde primaria municipal, também é possível compreender algum tipo de melhorarias parciais dos serviços, segundo as escalas e demanda da população usuária. Nesse sentido, é importante destacar que a reestruturação administrativa do Ministério de Saúde em 1979 - parte de processo de reforma integral dirigido pela CONARA - estabeleceu a separação das funções de planejamento, controle e regulamento da logística dos serviços sanitários, rearticulando o Ministério em quatro estruturas: 1) Sistema Nacional de Servicios de Salud (SNSS), 2) Fondo Nacional de Salud (FONASA), 3) Central Nacional de Abastecimento (CENABAST), 4) Instituto de Salud Pública (ISP). Em 1981, o SNSS transferiu a responsabilidade de serviços primários entendidos como "postas" e "consultorios"73 às prefeituras, ficando sob controle do Ministério a atenção secundária e terciaria de hospitais e centros especializados em saúde (VIAL, 2016). No caso de Curanilhue, o prefeito também explica como foi o traspasso em saúde, certamente estando melhor preparado, produto de sua anterior experiência:

Y ahí se fijan en mí porque fue una de las primeras que se hizo en Chile bien, sin reclamos, sin nada -se refere ao traspasso de educação-. Entonces, ahí me dicen usted alcalde va a ir por salud, porque a nadie le daban la autorización para entrar al área de la salud. Porque en esos años todos le tenían miedo a salud, incluido Pinochet, el tenía susto al tema salud. Y los técnicos, léase ODEPLAN, dicen que este tipo lo haga, porque lo ha hecho bien. Entonces, iba a traspasar el hospital y el consultorio y fue tal la pelea en Santiago que no me dejaron traspasar el hospital. Solamente el consultorio como un plan piloto. Y fue bastante bueno, consultorio de una población grande. Y traspaso una cuestión horrible, cero máquinas, cero nada, unas colas interminables que la gente llegaba a las cuatro de la mañana. Bueno, me pasa eso, con el presupuesto que había en salud más el que yo tenía del municipal. Lo cambio, lo arreglo, compro tecnología, contrato al director del consultorio. Le pongo metas y horarios a él y a su equipo. Al principio me iba yo mismo todos los días a las siete de la mañana a ver si estaba atendiendo como corresponde o no. Y también fue un éxito te fijas, porque la gente lo respalda, porque te ven y si la cosa funciona te respaldan. En pueblo chico es fácil hacerlo $[\ldots]$ hasta mediados de densidad poblacional no es difícil hacerlo (ENTREVISTA ALEJANDRO FERNÁNDEZ, fevereiro2021).

Diferentemente da situação de educação, a citação mostra a maior tensão dos órgãos centrais na descentralização da saúde municipal e a forte convicção do prefeito de levar a diante essa tarefa. É importante esclarecer que o regime só terminaria traspassando aos municípios a atenção primaria, mantendo os hospitais e serviços de maior complexidade em

\footnotetext{
${ }^{73}$ Em Chile se chama consultorio e postas aos recintos de atenção de saúde primaria administrados pelas prefeituras, o equivalente aos postos e unidade de saúde comunitária no Brasil (SUS).
} 
mãos do Ministério de Saúde. Não obstante, é significativo como o prefeito pretendia traspassar o hospital ao controle da prefeitura, no entendimento de que a principal dificuldade do sistema público recaía na administração e eficiência dos recursos, além de sua respectiva organização logística setorial, neste casso, ligada às prestações de saúde mais complexas. Se trata efetivamente de uma lógica neoliberal da gestão municipal ancorada no sistema de avaliação e administração dos projetos e investimentos locais, que se bem permitiria uma melhoria na organização e disposição dos recursos municipais, em nenhum caso, por si mesma, implicaria uma melhora estrutural do sistema de atenção da saúde primária. Entretanto, em tal caso, dada a menor densidade populacional de Curanilahue, o traspasso desse serviço abarcou apenas um recinto de atenção primaria, o qual efetivamente possibilitaria melhoras nas infraestruturas de atenção de saúde primaria: compra de tecnologia e maior controle da administração interna do serviço. De fato, o traspasso de saúde primaria poderia ter significado, neste caso específico, uma maior legitimidade do ponto de vista da gestão municipal do prefeito e as possíveis melhoras reais para os usuários diretos.

Apesar do sentido de sucesso do prefeito de Curanilahue, a realidade conjunta do território nacional, e sobretudo, das principais cidades do país, contrastava fortemente com esse diagnóstico positivo da descentralização municipal. A crise política e econômica seguiria ampliando e gerando múltiplas contradições. Ainda com possível melhoria em certos tipos de infraestrutura dos serviços de saúde e educação em prefeituras particulares, especialmente naquelas com mais ingressos por habitante, estruturalmente a municipalização evidenciava as fortes contradições do neoliberalismo em curso. Subsídios, projetos focalizados via PEM e POJH, programas esportivos e de recriação, projetos de vizinhos de melhora de pavimentos de comunidades periféricas e bairros, etc., todos eles eram insuficientes para mudar o forte cenário de desigualdades geográficas do país. Como diz o geógrafo chefe da CONARA, Dionisio Vio, "nunca le pusieron plata a los municipios, ni en educación ni en la salud, nunca tuvieron autoridades especializadas" (ENTREVISTA DIONISIO VIO, dezembro 2019). $\mathrm{Na}$ prática, a descentralização municipal nas áreas da saúde e educação tendia a reproduzir as desigualdades estruturais do sistema, onde apenas um número muito seleto de prefeituras replicava experiências e suportes municipais bem-sucedidos em termos da qualidade desses serviços (MORALES e ROJAS, 1986). De modo geral, a maioria das comunas do país tendeu a refletir o fracasso do modelo de descentralização no sentido que os recintos de educação e saúde tenderiam a aprofundar um permanente déficit do financiamento e, com isso, um 
inadequado funcionamento e qualidade dos serviços, acrescentado a diferença social entre as comunas ricas e pobres (BECERRA e BARCOSKI, 2020). Como destaca a professora pública de Copiapó no período, Carla Brown, a mudança significou um retrocesso histórico para os funcionários e professores da educação. Diz Brown:

\begin{abstract}
Al traspasar la educación a las municipalidades se perdió la esencia de lo que es educar [...] El curriculum llega desde Santiago. Pero como se baja y administra es otra cosa. Los profesores perdimos mucho poder adquisitivo en la dictadura, perdimos muchas garantías, se perdieron todos los años de servicio. No todas las municipalidades pagaron la deuda histórica [...] La gran organización que tenía el Ministerio la empezaron ejercer las SEREMIAS de Educación. Pero también perdiendo poder. Entonces, ¿qué pasa? El municipio es el que toma las grandes decisiones. Los alcaldes empiezan a distribuir los dineros y se empiezan a ocupar los fondos de educación. Porque la ley municipal es un solo fondo, entonces, se empiezan a ocupar en otras cosas y se terminan en las plazas. El alcalde empieza a colocar a su gente, le favorece a su gente con puestos importantes. Y quien pierde, la educación. Y lo mismo pasa con la salud, es imposible de que la municipalidad reciba seis mil o siete mil pesos por usuario, en la salud primaria. ¿Cómo pueden atender a esa gente ¿cómo pueden atender a esa persona bien con esa plata? (ENTREVISTA CARLA BROWN, junho 2020)
\end{abstract}

Nesse mesmo sentido, Vial (2016) destaca que tecnicamente os traspassos municipais foram impulsionados por conceito de prestações outorgadas tipo subvenções, que, a medida que avançava a década de 1980, nunca foram reajustadas de acordo com o intenso processo inflacionário, o qual gerou um déficit exponencial e irreversível do sistema público. Era a chegada oficial de uma década de neoliberalização municipal que tendeu a ampliar e aprofundar a desigualdade geográfica na educação e na saúde do país. Uma situação que foi ainda mais didática no caso da RM de Santiago, que concentrou as principais preocupações do regime, dada sua centralidade de capital política e econômica do Chile, além das diversas modalidades de protestos e disputa pela ocupação dos espaços públicos, sobretudo pela grave situação da moradia (ALVAREZ, 2012). Para finais de 1985, as pesquisadoras Dagmar Raczynski e Claudia Serrano fizeram um interessante estudo empírico em treze municípios da RM, onde destacavam que, mesmo com as relações verticais do sistema territorial da época, efetivamente a nova estrutura municipal tinha um maior potencial para $\mathrm{O}$ desenvolvimento: "El municipio de hoy se encuentra fortalecido respecto al pasado" (RACZYNSKI, SERRANO, 1988, p. 19). No entanto, essas melhorias na gestão municipal paralelamente também tinham outros obstáculos. Com efeito, uns dos resultados mais contraditórios das pesquisadoras foi que dentro das prefeituras existiam diversos tipos de gestão municipal justificadas fundamentalmente pela influência do prefeito, a qual, "incide de manera tan fuerte sobre el estilo de la gestión municipal, que bien podrían tipificarse estas administraciones siguiendo el tipo de personalidad, posiciones y creencias de su máxima autoridad' (RACZYNSKI e SERRANO, 1987, p. 
22). Esse elemento de "alcaldización" da reforma desvendaria um menor nível de institucionalidade do processo de melhoramento da estrutura pública municipal e, por consequência, a prevalência de uma lógica mais precária do ponto de vista da organização profissional enquanto seus mecanismos e dispositivos técnicos próprios da intervenção social das prefeituras. Segundo as pesquisadoras, as prefeituras na RM se poderiam classificar a partir de três modelos de gestão municipal: a) um prefeito técnico empresarial; b) um prefeito político; c) um prefeito burocrata.

O resultado do estudo empírico destacaria que das treze prefeituras analisadas, apenas duas cumpririam com o perfil técnico empresarial (RACZYNSKI, SERRANO, 1987). Era uma expressão adversa e crítica dos efeitos da reforma municipal na capital do país, muito diferente das lógicas locais descritas anteriormente. O espírito de corpo expressado em uma gestão municipal com maior profissionalização e níveis de complementariedade entre as autoridades do SIGORE nas regiões, não seria uma projeção bem concedida nas prefeituras da RM de Santiago. Pelo contrário, na maioria dos casos prevaleceriam prefeitos tipo político ou burocrata, onde o funcionamento da prefeitura responderia mais ao agenciamento pessoal do prefeito que aos diferentes dispositivos de gestão focalizada. Essa tendência, por sua vez, significava uma perda das prefeituras mais atomizadas profissionalmente, prevalecendo relações de insegurança e disputas de poder entre funcionários e departamentos municipais que inibiam as possibilidades de equipes coletivas capazes de liderar as iniciativas municipais (RACZYNSKI, SERRANO, 1987). A verticalidade do modelo político territorial nacional também se replicaria no modelo político interior das prefeituras enquanto seleção de autoridades ou subalternos. Essa verticalidade, aliás, imprimiria inconstâncias aos cargos municipais profissionais que dependiam do critério da autoridade superior, criando ambientes profissionais de escassa autonomia e eficiência na resolução de tarefas municipais (os profissionais não tinham capacidade de discrepar ou propor alternativas).

De maneira inversa, nas prefeituras tipo prefeito empresário, existiam equipes de trabalho e sistemas de avaliação técnica mais estáveis onde também se encontravam maiores possibilidades de refletir sobre as decisões e projetos municipais, sendo eficientemente integrados aos mecanismos e faculdades da prefeitura. No entanto - concluíam as pesquisadoras - a consolidação dessas experiências municipais mais propositivas e planejadoras eram "de responsabilidad exclusiva del alcalde. El es responsable de las contrataciones y despidos municipales. El personal que contrata o trae consigo el alcalde tiende a ser personal idóneo para el 
perfil que él desea imprimir al municipio" (RACZYNSKI e SERRANO, 1987, p. 22). Nesses termos, a projeção de poder que implicou a reforma municipal no período autoritário seria o seguinte: dar maior poder ao prefeito em sua qualidade de representante do governo nacional no território local além da institucionalidade do processo. Na maioria das prefeituras da RM não existia um planejamento do diagnóstico territorial. Dessa maneira, suas ações dependiam esporadicamente dos requerimentos do governo regional e das direções particulares do prefeito, e não da estrutura municipal criada como instrumento de desenvolvimento local. Um exemplo dessa hierarquia seria o SECPLAC, que se bem realiza um número significativo de tarefas contábeis e de administração municipal, na prática, não fazia atividades de planejamento de desenvolvimento local como dizia a lei municipal de 1976. Por sua vez, a dinâmica dos projetos sociais especificamente desenhados e executados pelas prefeituras, sem uma diretiva superior, eram mínimos e limitados. Na maior parte das vezes, eram instrumentos mais paliativos que projetivos, e poucas vezes representavam uma ação organizada comunitariamente (RACZYNSKI e SERRANO, 1987). Com efeito, tratase de uma avaliação crítica do processo de municipalização do regime, aparentemente alheio à situação descrita pelas prefeituras do sul e norte do Chile. Nesse sentido, merece particular interesse quando as pesquisadoras advertem das tensões a nível central e a nível local, a propósito da hierarquia da Intendência da Região Metropolitana:

La relación del nivel central con los municipios es rígida y fiscalizadora. Aquellos de nuestros entrevistados que antes de asumir el cargo municipal trabajaron en Intendencia opinan que en ese organismo hay muy poco conocimiento de la dinámica municipal; que lo que se solicita a los municipios corresponde a un "deber ser formal" derivado de la necesidad de llevar contabilidad al nivel central [...] que no hay metas de potenciar la descentralización, de apoyar la formación de equipos municipales idóneos. Estos funcionarios hacen notar también la escasez e inestabilidad en el cargo de los profesionales en SERPLAC e Intendencia (RACZYNSKI, SERRANO, 1987, p. 24-25)

A descentralização municipal em Santiago não tinha a mesma dinâmica burocrática que se recriava nas comunas das outras regiões do país. Em Santiago, as autoridades regionais conviviam diretamente com as autoridades nacionais e as prefeituras estavam mais inseridas nos processos políticos gerais que nas articulações técnicas e executivas do modelo territorial burocrático em terreno. A possibilidade de criar um ambiente de planejamento territorial integrado na capital estava absolutamente condicionado pelos poderes centrais e pela particular agenda política da máxima autoridade do país: o general Pinochet. Dai que o SERPLAC e a Intendência de Santiago não tinham a mesma capilaridade burocrática como faziam seus pares em Concepción ou Antofagasta. Paralelamente, as prefeituras tinham que supor um maior peso e vigilância do poder central sem poder assegurar agendas 
profissionalmente integradas - como as destacadas pelos prefeitos do norte e sul do Chile-, ficando mais expostas a agência do governo nacional. Dessa maneira, a coordenação do poder metropolitano com suas prefeituras não tinha o mesmo poder coreográfico que nas regiões. Permanentemente se misturava o planejamento regional das prefeituras com as influências ou emergências do poder central, o qual tencionava as possibilidades de coordenação entre as autoridades locais e superiores, ao passo que complicava os próprios interesses do regime. Sem uma hierarquia das políticas metropolitanas, a integração das prefeituras de Santiago ficava condicionada pelas estruturas nacionais e setoriais dos grupos de poder hegemônicos que eventualmente viabilizariam as prioridades do regime central, dependendo da militância ou adscrição política dos prefeitos enquanto agenda do neoliberalismo.

Foi assim que, à diferença do caso das regiões, o recorte territorial das comunas de Santiago teve um desdobramento interno radicalmente diferente do resto do país: um programa de erradicação de moradias contra a territorialidades populares em diversas comunas da capital. Um programa impulsionado a partir da ação conjunta de uma serie de instituições - ODEPLAN, a CONARA, prefeituras de Santiago, prefeitura de Las Condes, MINVU, SERVIU, SEREMI, FF.AA., entre outras - que certamente não respondeu a um planejamento territorial do SIGORE. Segundo Raczynski e Serrano, esse processo de erradicação foi o exemplo de uma visão setorial de moradia acima de uma política territorial, pois, não apenas se desconheceu o problema dos equipamentos e serviços em saúde e educação, transporte, mas também se aprofundou o nível de desigualdade social entre as prefeituras (RACZYNSKI e SERRANO, 1987). Pior ainda, a partir dessas políticas territoriais na RM na área social interna das prefeituras estudadas pelas pesquisadoras, se manifestaram importantes concentrações de pobreza onde as atividades de tipo assistenciais absorviam quase completamente as tarefas das prefeituras e suas equipes funcionários (RACZYNSKI e SERRANO, 1987). Uma parte significativa dos recortes de prefeituras era sinônimo de assistência para pobres, um paliativo necessário e imprescindível para o enfrentamento da dura crise social do país. Mas, como foi possível uma situação tão diferente do arranjo comunal em Santiago do que nas regiões? Quais foram as dinâmicas e interesses políticos e econômicos do recorte das comunas em Santiago? 


\subsection{O recorte das comunas da Região Metropolitana de Santiago}

Após várias mudanças e conflitos, finalmente em março de 1981 o regime anunciou a criação de dezessete novas prefeituras, fato que afetou exclusivamente a Província de Santiago na Região Metropolitana (mapa $n^{\circ}$ 8). Era um recorte comunal significativo, considerando que na escala regional-nacional o máximo nível de prefeituras novas tinha alcançado apenas o número de cinco e quatro prefeituras nas regiões XI e XII, respectivamente. O Ministro Presidente da CONARA, general do Exército Roberto Guillard, fundamentou essa decisão com a melhoria da gestão territorial das prefeituras, pois, se aprimoraria a cercania dos serviços públicos com a população. Com efeito, segundo CONARA, a partir do recorte comunal de 1981, as prefeituras da Região Metropolitana teriam uma menor extensão geográfica e população podendo ser mais expeditas e rápidas enquanto a distribuição de programas sociais efetivos (GUILLARD, 1981). Uns dos fundamentos centrais do recorte comunal teria sido a procura de uma maior homogeneidade social dos habitantes das prefeituras novas, a qual, possivelmente, melhoraria o nível " $d e$ cohesión interna de la comunidad, lo que permite obtener una participación más efectiva" (GUILLARD, 1981, p. 10). Dessa maneira - argumentava o general Guillard - os prefeitos poderiam criar e distribuir melhores instrumentos e projetos sociais para abordar em suas comunidades homogêneas, ao tempo que poderiam comunicar-se e identificar-se de uma maneira mais direta com o conjunto territorial comunal. O que haveria acontecido?

O recorte comunal de Santiago foi uma continuação da política de focalização elaborada pela ODEPLAN desde 1979, com o Mapa da Extrema Pobreza. Aplicado na escala geográfica das prefeituras para Santiago, significou uma combinação entre políticas territoriais e atores políticos e econômicos que considerariam desde moradores organizados até agencias imobiliárias. Embora nesse momento ainda não começasse oficialmente o processo de erradicação, o general Guillard marcava a pauta dos desdobramentos que implicaria o recorte comunal da capital do país andino: mais segregação política e social entre prefeituras de pobres e ricos. Dai suas palavras no III congresso de prefeitos, em 1981, quando o general Guillard destacava:

Sabemos que quedarán comunas con déficit de establecimientos de salud y con superávit de establecimientos educacionales y viceversa [...] Sabemos que quedarán comunas más pobres que otras [...] Sabemos que también, a las instituciones que conforman el voluntario femenino, esta readecuación comunal puede significarle una readecuación de su orgánica, con el solo fin de poder llegar en forma más directa y más de acuerdo con la nueva división administrativa, a quienes más necesitan de vuestra preocupación y apoyo (GUILLARD, 1981, p. 2) 
O recorte territorial das novas prefeituras de Santiago, imperceptivelmente, se cruzaria com outro importante processo territorial que também modificou a dinâmica sócio espacial de grandes conglomerados de população pobre e acampamentos (faveladas) em diversas áreas centrais da RM de Santiago: o plano de erradicações. De fato, a criação das novas prefeituras da Província de Santiago estaria encruzilhada por uma intervenção nos setores populares e a política urbana de moradia. Dado o complexo panorama da capital de Santiago em termos de protestos e níveis de pobreza, as prefeituras deveriam dobrar seus esforços enquanto mecanismos de focalização e distribuição de subsídios entre os setores mais desfavorecidos, tal como tínhamos visto nas regiões: PEM-POJH, atividades esportivas, criação de projetos sociais, organização de atividades recreativas segundo as pautas do regime, etc. O principal diagnóstico feito pela CONARA sobre a situação de Santiago foi intervir em um número significativo de setores urbanos populares em condições de superlotação localizados em diferentes áreas centrais da capital. Foi assim que, dois anos antes do anúncio das novas comunas (1981), se começou a desvendar um particular processo geopolítico na distribuição territorial dos pobres urbanos com significativos desdobramentos nas prefeituras. Em 1979 o regime aprovou o Plano Intercomunal de Santiago (decreto-lei no 420) que regularizou a edificação e urbanização da Província de Santiago em três tipos de zonas entendidas como área urbana, expansão urbana e restrição. Essas mudanças, na prática, foram a base operativa do recorte comunal de 1981, pois, significaram a extensão de vastas zonas urbanas que antigamente tinham restrições, permitindo localizar moradias em espaços cada vez menos densificados e mais precarizados enquanto estruturas de serviços e construções urbanas (HIDALGO, 2005). 


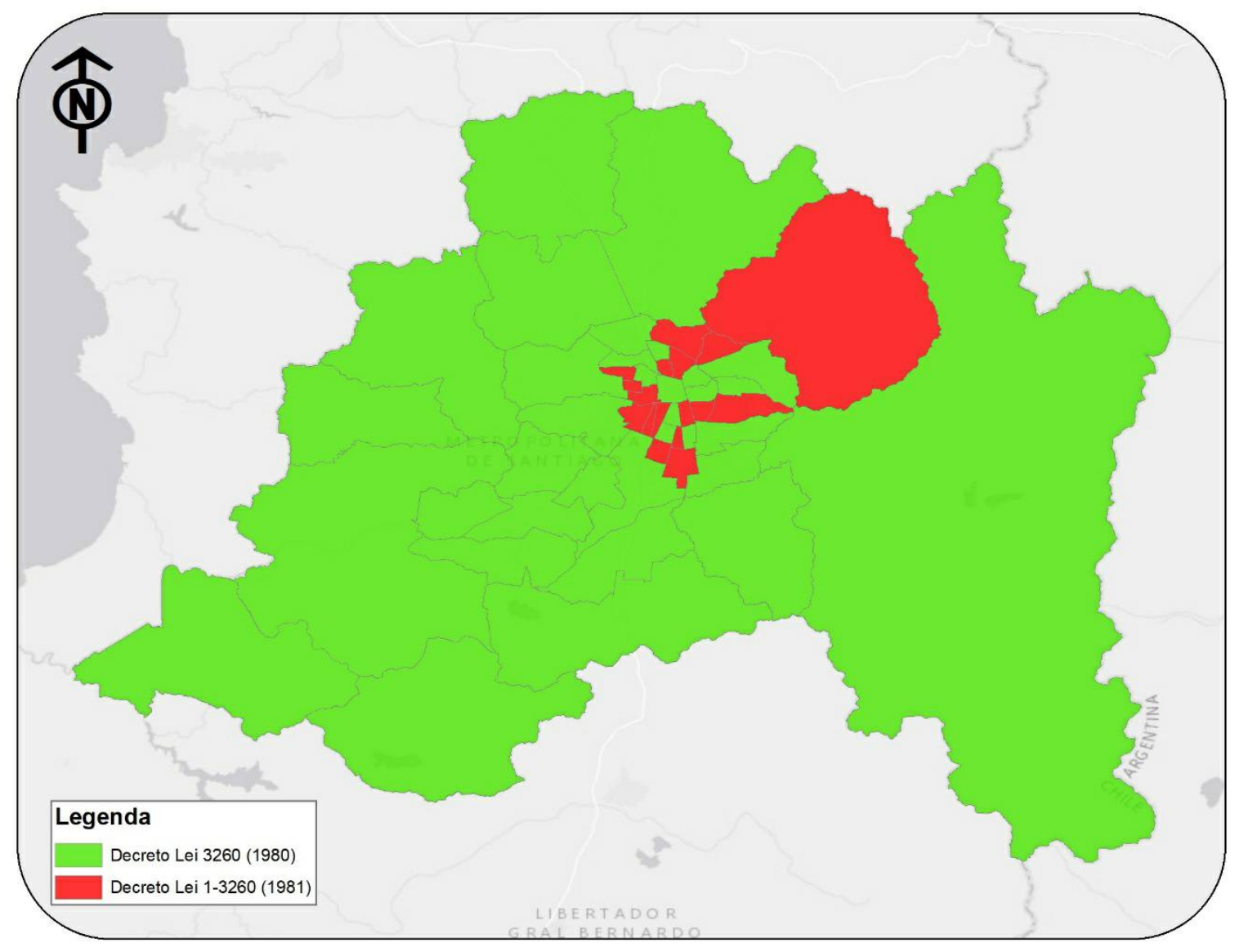

Fonte: elaboração própria a partir do decreto lei nº 1-3.260

Esse dispositivo funcional à política urbana oficial (MINVU, 1979), aliás, considerava que o solo não era bem escasso e, portanto, deveria estar aberto ao mercado de especulação financeira e às dinâmicas imobiliárias que tenderiam a pressionar valores de solos cada vez mais caros e inacessíveis para os setores populares. Como destacava um importante estudo da FLACSO de 1986:

La eliminación de las normas sobre "límites urbanos" a fines de 1979, abrió la posibilidad de incorporar al uso urbano 64.000 hectáreas en la superficie de Santiago (áreas de "expansión") siendo la superficie de la ciudad de 38.000 hectáreas. Ello marcó el cambio de una política de "densificación" que pretendía una utilización más intensiva y eficiente de la infraestructura disponible, por una política de "expansión" que permitió, entre otros efectos, la reubicación de importantes sectores de población de asentamientos precarios, en la periferia de la ciudad (MORALES e ROJAS, 1986, p. 19)

O recorte comunal de 1981, assim, paulatinamente foi articulando ambos processos com a redistribuição espacial dos setores populares cada vez mais distantes daquelas áreas centrais originais e a circulação de negócios imobiliários em novos terrenos que ainda não 
tinham sofrido intervenção produto da presença dos assentamentos precários e ocupação de moradias irregulares (LEYTON, 2020). A partir de março de 1981, o regime estabelecia um prazo de aproximadamente dois anos para montar as dependências físicas e administrativas das dezessete novas prefeituras, sendo um processo gradual dirigido pelo Ministério do Interior e a Intendência de Santiago, mas sempre e quando os "recursos presupuestarios así lo permitan" (GUILLARD, 1981, p. 15). Eram momentos de forte contração econômica que implicavam cautelar de sobremaneira o orçamento social do regime. O clima social não era favorável para as autoridades da CONARA. A partir de 1979, as organizações de moradores reativaram as ocupações de terreno, dando maiores possibilidades de negociação aos moradores e obrigando uma definição mais global à política oficial de moradia (LEYTON, 2020). A crise estrutural do sistema econômico fazia explodir a situação dos pobres urbanos que, através do apoio da Igreja Católica, ativariam significativas redes de solidariedade com iniciativas que tinham como principal objetivo assegurar a alimentação e a sobrevivência dos mais pobres (ALVAREZ, 2012).

\section{Quadro no 24. Comunas novas na RM}

\begin{tabular}{|c|c|}
\hline \multirow{4}{*}{ Provincia de Santiago } & Independencia \\
\cline { 2 - 2 } & Huechuraba \\
\cline { 2 - 2 } & Recoleta \\
\cline { 2 - 2 } & Vitacura \\
\cline { 2 - 2 } & Lo Barnechea \\
\cline { 2 - 2 } & Macul \\
\cline { 2 - 2 } & Peñalolen \\
\cline { 2 - 2 } & San Joaquín \\
\cline { 2 - 2 } & La Pintana \\
\cline { 2 - 2 } & San Ramón \\
\cline { 2 - 2 } & El Bosque \\
\cline { 2 - 2 } & Pedro Aguirre Cerda \\
\cline { 2 - 2 } & Lo Espejo \\
\cline { 2 - 2 } & Estación Central \\
\hline & Cerrillos \\
\hline & Lo Prado \\
\hline & Cerro Navia \\
\hline
\end{tabular}

Fonte: decreto lei $n^{\circ} 1-3260$

Nesse contexto de alta movimentação social, a política territorial da CONARA se foi integrando à política de moradia da realidade de Santiago e, junto com isso, a ativação das principais prefeituras e projetos imobiliários. Um dado importante desse processo foi que, em meio à crise social e da ascensão das ocupações de terrenos protagonizada pelos setores urbanos populares, Pinochet nomeia o general Roberto Guillard como Ministro de Moradia em maio 1982 (ALVAREZ, 2012). Com a direção do novo Ministro de Moradia, um mês após se aprovaria o decreto lei $\mathrm{n}^{\circ} 18.138$, um importante dispositivo territorial que permitiria 
as prefeituras elaborar, executar e desenvolver moradias econômicas e infraestrutura básica tanto no interior como fora de suas comunas. Dessa maneira, a rede social das prefeituras na Região se conectaria diretamente com a grave situação social e política da conjuntura, mas sobretudo, o que fazer com os grupos de moradores mais pobres e organizados de Santiago? Com financiamento do Ministério do Interior, o regime criou dois dispositivos de moradia de emergência: a moradia básica e o galpão sanitário, que rapidamente permitiriam dar resposta a grave situação de Santiago (ALVAREZ, 2012). As prefeituras, assim, assignariam diretamente esses benefícios entre os setores populares mais precários, geralmente habitantes de comunidades faveladas, como subsídios de moradia.

Além disso, a resposta à grave situação de Santiago também era funcional à política nacional da CONARA, onde a descentralização significava rede social de ajuda via prefeituras para os setores mais pobres, gerando, paralelamente, um inusitado protagonismo aos prefeitos que seriam os encarregados de assignar diretamente os beneficiados da política social de moradia (ALVAREZ, 2012). No entanto, para a circulação efetiva desse programa prefeitura-moradia simultaneamente as autoridades da CONARA e ODEPLAN teceriam outro importante plano de governo. Se trata do Proyecto de Saneamento de Campamentos de la Región Metropolitana, impulsionado entre junho e agosto de 1982, o qual teria como objetivo trocar a localização das favelas e moradias irregulares e entregar uma resposta de moradia final a vastos contingentes populacionais plenamente localizadas, graças ao Mapa da Extrema Pobreza. Na prática, a execução do plano de erradicações significou o deslocamento de mais de 150 mil pessoas, sendo trasladas e localizadas pelas diferentes periferias da Região Metropolitana para 1985 (MORALES, LEVY, ALDUNATE, ROJAS, 1990). O que tinha acontecido e quais foram seus principais desdobramentos?

Até 1981 os limites das prefeituras não teriam maiores desdobramentos, salvo algumas mudanças toponímicas, como foi o caso da antiga subdelegação de Barrancas que, pela construção do Aeroporto Internacional de Pudahuel, mudaria seu nome à prefeitura de Pudahuel em 1975 (GOBIERNO DE CHILE, 1975g). O recorte comunal de 1981 preparou o marco espacial que daria suporte ao processo de erradicações que se viveria nos próximos anos. Eufemisticamente, o regime batizou esse processo em alusão à ideia de erradicar pela raiz o problema estrutural da pobreza. No entanto, foi uma estratégia de expulsão encoberta dos setores populares localizados em certas áreas urbanas que tinham maior valor imobiliário, sobretudo nas comunas de Santiago, Nuñoa, Providencia e Las Condes. Uma expulsão que 
aliás, internamente, também expressava um sinal político de ordem punitiva contra o inimigo interno e as antigas redes das esquerdas que, embora ainda sob repressão, continuavam defendendo e organizando seus históricos territórios (CORTES, 2018). O cenário político da capital de Santiago expressava uma forte disputa política pelas mentes e corações dos setores populares que, de uma forma ou outra, renascia o primórdio do regime quando considerava a pobreza uma fonte de subversão e proliferação do marxismo que portanto deveria ser exterminado (PINOCHET, 1976). Como lembra o dirigente social UDI Luis Cordero:

\begin{abstract}
Nos dividimos en zonas, a mí me tocó la zona norte y poniente de Santiago. Lucho (Cordero) y Maximiano (Errázuriz) veían la parte sur y fuimos creciendo poco a poco. Y cuando tuvimos un número importante de comités, Jaime (Guzmán) empezó a trabajar con nosotros. Nos trasladamos a Livingstone, y ahí gerenteamos un poco el tema, con un plano, veíamos donde estábamos: (decíamos) estamos acá, acá estamos débiles, hay que trabajar el tema acá, hay que conseguir contactos [...] Tú estabas permanentemente con la gente, nos llamaban los evangélicos de la política [...] Había dirigentes asignados a cada una de las zonas, ellos tenían la obligación de visitar a la gente semanalmente y rendían cuenta, a dónde habían ido, con quién se habían juntado, qué había hecho, en fin [...] Cuando había gente con más condiciones, uno trataba de que esa persona fuera asumiendo un rol de liderazgo. Primero nosotros éramos un colectivo y después nos fuimos dividiendo para que no fuéramos más de veinte, así pudiera participar más gente y así hubiera una dinámica más efectiva (Alfredo Galdames) (MUÑOZ, 2016, p. 219).
\end{abstract}

Esse processo de inserção popular da UDI nas áreas mais pobres de Santiago, contraditoriamente, também coincidiu com o chamado de insurreição popular que lideraria o PCCH e seu aparelho militar - o Frente Patriótico Manuel Rodriguez (FPMR) - que junto a outras organizações, liderou um dispositivo de reorganização militar destinado a provocar a queda do regime. Nas antípodas do dirigente UDI, o historiador Luis Rojas destaca que muitos militantes do FPMR da época lembram de um particular mapa da sublevação em Santiago a meados da década de 1980: Muchos de los que participaron en la preparación de la Sublevación en Santiago recuerdan un
mapa de todo el país y uno de la capital, con la ubicación de las fuerzas represivas y sus
probables misiones, así como ordenados trazos de delimitaban "zonas y áreas de sublevación"
que envolvían a los barrios más combativos, desde donde salían símbolos que representaban
columnas desplazándose hacia nudos de avenidas principales y centros políticos y
administrativos (ROJAS, 2017, p. 51).

Dessa maneira, os mapas que permitiam organizar a inserção territorial da UDI nos setores populares, competiam invisivelmente com outros mapas do FPMR que pretendiam ativar a sublevação popular e a caída do regime. Nos primeiros anos da década de 1980 o país se tornou uma panela a pressão. A jornada de 11 de agosto de 1983 - quarta jornada de 
protestos contra o regime - significou a saída de 18 mil soldados distribuídos pelas ruas de Santiago. O resultado final do protesto marcou um saldo de centenas de feridos e dezenas de mortos, além de uma complexa restrição da mobilidade e a concentração das pessoas nos espaços públicos (HUNEEUS, 2016; VALDIVIA, 2012). Duas semanas após, em 30 de agosto de 1983, um comando do MIR executou o Intendente da Região Metropolitana, o maior-general em retiro, Carol Urzúa. O general Urzúa tinha se desenvolvido como Intendente da II Região e outras importantes posições na comandância no Exército, sendo um dos militares mais próximos ao general Pinochet. $\mathrm{O}$ atentado contra o Intendente da $\mathrm{RM}$ foi lido como um golpe significativo ao núcleo do regime. Se demostrava uma capacidade operativa seletiva, capaz de enfrentar os aparelhos militares oficiais, que inclusive era capaz de penetrar o cerco de segurança no interior do regime. Essas ações, por um lado, demostravam uma fragilidade que poderia ser ameaçada em sua lógica militar. Mas, por outro, também agudizavam sua política repressiva, que ampliava os repertórios da polícia política e intimidação frente a qualquer tipo de oposição ou manifestação contra do regime.

Imagem n ${ }^{\circ}$ 19. Assassinado Intendente Carol Urzúa

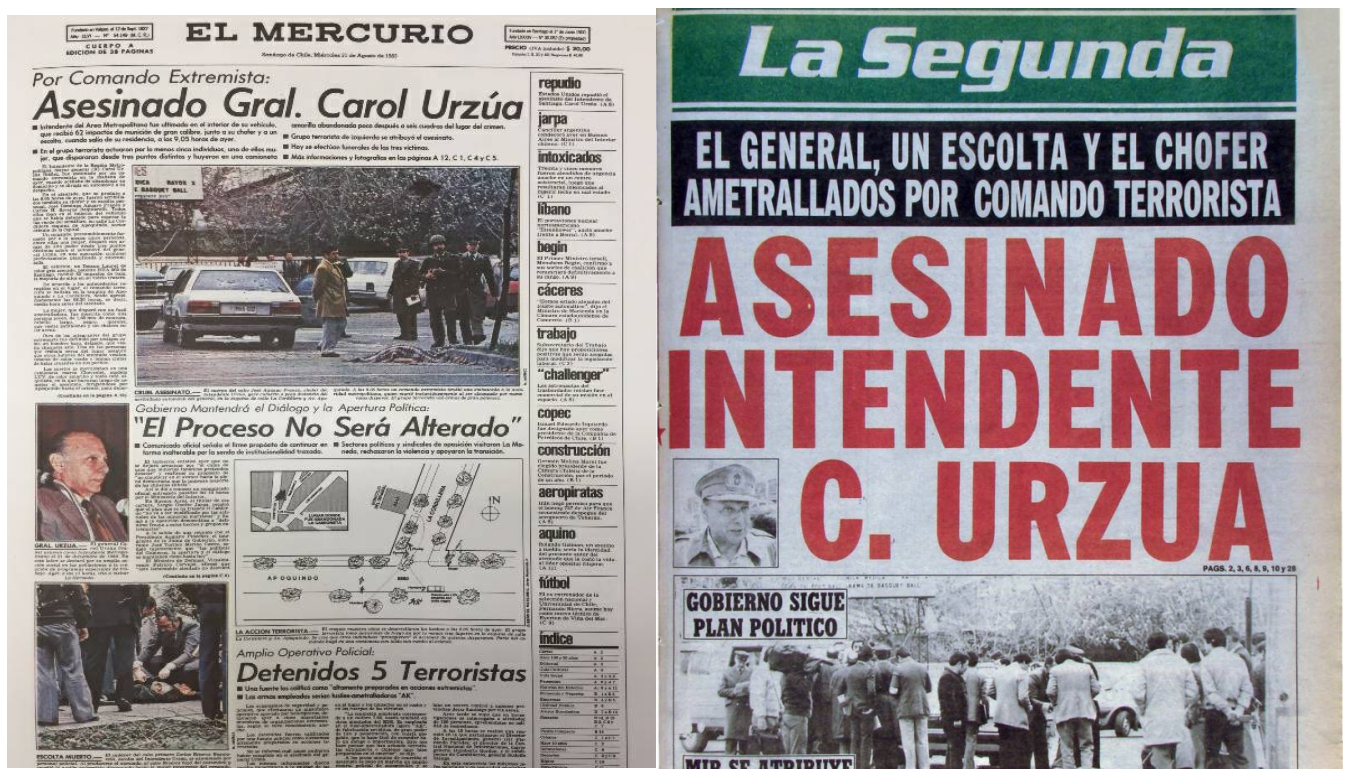

Fonte: acervo virtual do jornal El Mercurio e La Segunda, 30 agosto 1983.

Nesse contexto de altas significações militares, político-sociais e repressivas, Pinochet nomeia o general Roberto Guillard como Intendente da Região Metropolitana, movendo-o do cargo de Ministro de Moradia e Urbanismo. Dessa maneira, o último Ministro Presidente da CONARA se estabeleceu como o principal responsável do processo de erradicação e chefe direto de todos os prefeitos da capital. O plano de erradicações significou 
fundamentalmente desagregar importantes bolsões de pobreza das zonas norte-oriente e centro de Santiago e assim distribuí-los pela zona sul e ponente de Santiago, construindo grandes conjuntos habitacionais carentes de estruturas básicas para uma acolhida adequada dos setores historicamente mais desfavorecidos do sistema. As principais prefeituras articuladoras da erradicação foram Santiago e Las Condes, sendo elas mesmas as encarregadas de fazer a construção das novas moradias nas periferias de Santiago. No caso da prefeitura de Santiago, o prefeito UDI Carlos Bombal fez sistemáticas promoções e anúncios para incentivar a erradicação dos moradores, onde se destacou a construção de moradias pela iniciativa da prefeitura de Santiago, realçando o vínculo prefeitura-rede social de apoio para os pobres, embora fora de sua comuna (ALVAREZ, 2012). Em 1983 a SEREMI de Moradia e Urbanismo da RM informou que já haviam sido erradicadas doze mil pessoas correspondentes a 2355 famílias que "abandonaron definitivamente los campamentos y su situación de marginalidad' (LEYTON, 2020, p. 148).

Porém, essa suposta melhoria via erradicação se desdobraria em múltiplas problemáticas e contradições que, em primeiro lugar, destacariam a perda de centralidades e acessos dos setores populares em comunas onde historicamente sempre houve alguma presença. Tal foi o caso das prefeituras de La Reina, Nuñoa e Providencia, localizadas no setor sul-oriente da capital, onde seriam erradicados quase o $95 \%$ dos acampamentos e vilas faveladas irregulares via erradicação. Do ponto de vista demográfico, prefeituras como Santiago e Ñuña que tinham populações acima de meio milhão de habitantes, passariam a ter 180 mil e 216 mil respectivamente (MORALES, ROJAS, 1986). Assim mesmo, outro dos principais efeitos e desdobramentos do processo seria que apenas três prefeituras concentrariam os 77,3\% do total de erradicados da Região Metropolitana: La Granja, San Bernardo, Puente Alto (LEYTON, 2020). Um número absolutamente contrário e inverso do reduzido grupo de moradores que finalmente foi radicado nas prefeituras originarias, sem ter que ser deslocados para as periferias da capital. O principal problema da distribuição das erradicações foi o efeito de concentração das condições de marginalidade, posto que as habitações internas das moradias seriam insuficientes para o grupo familiar popular mais numeroso, que além do mais, que se emprazariam em "espacios deprimidos y densamente poblados por sectores en condiciones de pobreza extrema, un nuevo contingente de similares características, esto es, homogenizar los espacios en la ciudad" (MORALES e ROJAS, 1986, p. 49). 
Se bem, conceitualmente, as erradicações significaram algum tipo de melhoraria na condição de moradia ou na higiene ambiental dos espaços de superlotação originaria. $\mathrm{Na}$ cotidianidade dos moradores, no que se refere às suas comunicações, acesso aos serviços públicos e o traslado ao trabalho, suas condições foram mais deterioradas em relação à trajetórias originais (MORALES e ROJAS, 1986). Um exemplo paradigmático desses desdobramentos negativos na cotidianidade dos moradores foi a situação da nova prefeitura de La Pintana (GUEREVICH, 1990). Criada pela política de homogeneização social comunal da CONARA em 1981, essa nova prefeitura haveria sido subdividida a partir da antiga prefeitura de La Granja nos interstícios dos limites rurais-urbanos de Santiago. Entre 19841986, a prefeitura de La Pintana recebeu importantes grupos familiares e populações de favelas das doze prefeituras, além de quarenta acampamentos, principalmente de Santiago e Las Condes, incrementando exponencialmente sua população (GUEREVICH, 1990). Segundo o INE e a SECPLAC da época, a comuna de La Pintana, de uma população de 35.603 pessoas em 1970, passou ter 142.074 em 1986 (GUEREVICH, 1990). Um número populacional e de demanda de serviços que sobrepesava exponencialmente as capacidades e orçamentos da nova prefeitura.

O recorte comunal da Região, que havia sido preparado para suportar as erradicações, também expressava uma inexorável conjugação da concentração sócio espacial da pobreza. Em 1986, apenas seis das dezessete novas prefeituras estavam em pleno funcionamento. Um dado que também representava didaticamente a divisão de prefeituras de primeiro e segunda ordem social. O pano de fundo das erradicações, no entanto, foi a sistemática violência exercida pelas autoridades encarregadas. Se bem as famílias tinham sido avisadas pelas prefeituras que a erradicação seria um benefício de sua condição sanitária irregular, muitos moradores não aceitaram o oferecimento do regime e fizeram resistência em abandonar suas comunidades e pertences, sendo retirados à força através de uma multitudinária ação conjunta de diversos organismos públicos e as FF.AA., os quais seriam repudiados pela imprensa e a Igreja Católica. Aqui a simbólica entrevista do general Guillard em 1983:

Periodista: General R. Guillard, ¿se da cuenta de lo que significa 15000 familias dispuestas a subir de la noche a la mañana a un micro de la Municipalidad, con todas sus cosas y sus guaguas y partir "a lo que me toque!, como me dijo una señora? Intendente: [...] ¿Y cómo se fue la gente en los Estados Unidos al Oeste? [...]

Periodista: ¿Y la compulsión de tener que dejar a sus familias y amigos porque no pueden seguir subsistiendo aquí?

Intendente: [...] Bueno, pero si la vida es así. Yo puedo vivir en Nueva York, pero resulta que me muero de hambre allá. Y entonces tengo que irme a vivir donde pueda hacer lo que 
yo sé hacer o donde haya mayores expectativas. El mundo es así, y ni usted ni yo lo vamos a cambiar [...] (LEYTON, 2020, p. 167)

Um caso emblemático da particular violência política do processo de erradicação foi o acontecido na comuna de La Granja. O dia 22 de setembro de 1983 ingressaram milhares de homens, mulheres e crianças tomando posse dos terrenos vazios na zona sul de Santiago, criando-se espontaneamente os dois maiores acampamentos de todo o período autoritário, o acampamento Juan Francisco Fresno e o acampamento Cardenal Raúl Silva Henriquez, ambos com centenas de comitês de famílias organizadas (ALVAREZ, 2012). Embora o regime ainda tentasse impedir as ocupações de terrenos através de uma forte e rápida ação policial que ia acompanhada da criminalização das lideranças, dessa vez o governo necessitou procurar uma negociação e combinar diferentes métodos e saídas, pois, era tal o número de moradores que se tornava impossível qualquer tentativa especificamente repressiva ${ }^{74}$. No entanto, após um ano da ação de ocupação, o regime erradicou ambos acampamentos. No mês de novembro de 1984, se realizou uma massiva batida policial ao interior dos acampamentos, o que terminou com 150 moradores relegados e mais outros tantos detidos, todos eles vinculados a grupos opositores ao regime (MUÑOZ, 2016). Segundo o historiador Victor Muñoz, o resultado dessa operação significou a consolidação dos dirigentes da UDI pois, embora resultou no processo de deslocamentos de 18 mil pessoas, suas lideranças ficaram juntas nas diferentes localizações, na lógica "que en cada una de esas poblaciones los dirigentes se preocuparan de mantener viva la organización sociopolítica" (MUÑOZ, 2016, p. 131). Um resultado bastante diferente da vontade da maior parte dos moradores das erradicações.

As erradicações foram o centro da política de moradia em Santiago, concentrando-se no período 1979 e 1985, apesar de que continuariam até finais do período autoritário, com menor volume e dispositivos comunicacionais. Nesse sentido, as pesquisadoras Francisca Allende e Scarlett Olave fazem um estudo aprofundado da primeira erradicação do processo da Vila San Luis, e explicam o sentido de desapropriação posto em jogo pelas autoridades da época (ALLENDE e OLAVE, 2018). Localizada no coração de uma das prefeituras mais ricas do país, a comuna de Las Condes, durante a noite de 28 de dezembro 1978, aproximadamente setecentos moradores - equivalentes a umas 112 famílias da Vila San Luis - foram retirados violentamente de suas moradias pelo pessoal militar e funcionários

\footnotetext{
${ }^{74}$ Com efeito, o movimento de ocupações de terrenos continuaria espalhando-se pela capital e recriandose através de diversos dispositivos de organização e negociação (CORTÉS, 2018).
} 
municipais. A erradicação foi o resultado da ação conjunta do Exército, das prefeituras de Las Condes e Santiago e também da Empresa de Transportes Coletivos do Estado (ETC), que procederam fazer o traslado a altas horas da noite. Dada a particularidade do dispositivo de traslado que envolveu uma centena de agentes civis e militares, até mesmo a imprensa da época criticou a ação como uma violência deshumanizadora (ALLENDE e OLAVE, 2018; LEYTON, 2020). Junto com seus pertences os moradores da Vila San Luis foram forçosamente subidos a camiões de lixo e outros veículos policiais, todos eles acompanhados por militares vestidos de roupa de combate, dispostos a operar caso os moradores não cumprissem as ordens. $\mathrm{O}$ caso foi emblemático pois muitos desses moradores tinham seguido o processo legal durante a UP, que havia construído e entregado as propriedades de forma regular (ALLENDE e OLAVE, 2018). Como se evidencia em alguns relatórios: "Yo he vivido siempre acá, naci y me crie en este lugar. Tengo derecho a quedarme, no pueden llevarme a cualquier parte. El departamento era mío. Yo había pagado las cuotas. Por eso me negaba a abandonarlo" (ALLENDE e OLAVE, 2018, p. 16). Os moradores erradicados permaneceram por várias horas da noite perambulando pela capital até que finalmente foram abandonados em diferentes partes da periferia: vinte famílias em uma quadra de futebol do setor de Santa Rosa, oito caminho em San José del Maipo, dezessete em Pudahuel, quatro em um aterro sanitário de Lo Curro e finalmente oitenta em Renca (ALLENDE e OLAVE, 2018). Era apenas uma política urbana ou havia outros elementos políticos em jogo? Como destaca o historiador Cristián Leyton:

[...] la comunidad organizadamente se va destruyendo, los intereses colectivos se pierden. La homogenización no garantiza la identidad cultural de estos espacios de integración. Se deja atrás un espacio socialmente reconocido, lugar donde se generaban y desarrollaban relaciones comunitarias basadas en una similitud de intereses, origen y continuidad espacial, para ser reubicados en espacios perifericos, quedando desvinculados de los sectores poblacionales historicamente más estructurados y, por consiguiente, más participativos. La reinserción obligada, como consecuencia de la erradicación de campamentos, somete a los pobladores a una situación de convivencia con sectores de procedencias distintas en cuanto a su origen, experiencias y participación comunitaria con desarrollos desiguales de participación y de integración e inclusión social (LEYTON, 2020, p. 161).

Se bem nos posteriores processos de erradicação do regime, se tentaria persuadir e convencer os moradores de novas possibilidades de traslado, mas a solução habitacional definitiva, novamente, não conseguia fazer que todos aceitassem a erradicação e se reabririam os dispositivos de violência punitiva como os vistos na Vila San Luis. Se trata de uma violência sistemática que foi aprofundada e refletida através de diferentes dispositivos de controle constantes nesses grupos populares e em suas novas residências e espaços de socialização. Como destaca o antigo morador do setor Quinta Normal - próximo a Santiago 
centro - erradicado na comuna de Renca, Cristián Gajardo: "La erradicación fue un desarraigo absoluto. Yo me encontré de un día para otro arriba del techo de la casa sacando el techo, porque nos teníamos que ir [...] de un día para otro avisaron [...] mañana vienen los camiones, porque nos vamos" (VALDIVIA, 2012, p. 200). O traslado físico e espacial das populações erradicadas não apenas significou a ruptura de suas antigas trajetórias cotidianas, mas também implicou a perda de redes e um importante conjunto de reportórios sociais que paulatinamente iriam tornando-se simbólicos. À diferença das lideranças de moradores UDI dos acampamentos Juan Francisco Fresno e Cardenal Raul Silva Henriquez, que ficariam juntas nos novos locais da erradicação, pelo geral, a população ou comunidade favelada erradicada era sistematicamente fragmentada e distribuída pelas diferentes periferias da Região Metropolitana. Como diz o morador Cristián Gajardo: “Todos nuestros amigos quedaron en otros lados [...] yo creo que alli se rompió nuestro espacio de seguridad, de protección. Toda nuestra red se rompio" (VALDIVIA, 2012, pp. 193-194).

Distribuídos desigualmente pelas diferentes zonas periféricas de escassa infraestrutura e suporte de serviços públicos, em meio a desconhecidas vizinhanças, o espaço comunitário dos antigos acampamentos começou a pulverizar-se, acelerando processos criminosos, também expressivas das crises econômica e política da época. Para afirmar a violência sistemática desse novo espaço engendrado, se exerceu um constante dispositivo de segurança e vigilância, criado especificamente para restringir e sufocar qualquer tipo de oposição, sobretudo dos setores periféricos dos moradores erradicados. Em setembro de 1983 o regime aprovou o decreto-lei no 1086 que inibiu a realização de reuniões e manifestações públicas, estabelecendo que ruas, praças e outros lugares para reunião "se regirán por las disposiciones generales de Policía" (GOBIERNO DE CHILE, 1983, s./r.). A liberdade não podia ferir a convivência em sociedade, portanto, era dever da autoridade exercer a vigilância e "cuidar de la integridad de las personas, y la conservación de las plazas, calles, paseos y bienes públicos y que se respeten en el uso a que están destinados" ${ }^{\prime 75}$ (GOBIERNO DE CHILE, 1983, s./r.). Em termos práticos, o decreto-lei definiu que para qualquer tipo de reunião ou manifestação no espaço público, os organizadores tinham que avisar com uma antecipação mínima de dois dias legais hábeis ao Intendente ou Governador respectivamente. Caso contrário, "Las Fuerzas de Orden y Seguridad Pública pueden impedir o disolver cualquier manifestación que no haya sido avisada dentro del plazo fijado y con los requisitos" (GOBIERNO DE CHILE, 1983). Além disso, os organizadores da reunião tinham que informar os nomes das pessoas que participavam e uma série de

\footnotetext{
${ }^{75}$ Um ano após, 1984, esse decreto-lei vai ser cumprimentado com a vigência do Estado de Sitio.
} 
detalhes, tais como o objeto da reunião, percorrido, lugar de início, lugar onde se fariam uso das palavras, quem seriam os palestrantes e onde finalmente se dissolveria a reunião. Dessa forma, dizia o decreto-lei, "El Intendente o Gobernador, en su caso, pueden no autorizar las reuniones o desfiles en las calles de circulación intensa y en calles en que perturben el tránsito público" (GOBIERNO DE CHILE, 1983, s./r.).

Nesses termos, foi-se desenvolvendo as paisagens da erradicação: um espaço social de fortes constrições e dificuldades para as liberdades e direitos humanos dos setores populares, agora, mais distante dos centros de decisões da capital e com a presença sistemática da polícia e seus dispositivos de vigilância e intimidação. Como explica sobre sua cotidianidade, o morador erradicado Cristián Gajardo: "Esa represión de no poder pararte en la esquina era constante, de detenerte por fumar [...] con el paso del tiempo nosotros ya conociamos hasta los pacos ${ }^{76}$, a todos. Sus desplazamientos, sus movimientos. Además éstos venían dotados con trajes especiales y eran muchos" (VALDIVIA, 2012, p. 198). As detenções arbitrarias em plena luz do dia e sem provocação alguma eram parte da formação geográfica das novas gerações de moradores. Era a cotidianidade da erradicação e o começo de uma geopolítica policial que começava a petrificar-se no cotidiano com mais fortes distancias sociais e espaciais: "Cuando el ejército ocupa una población con el pretexto de perseguir terroristas, no se trata solamente de un Estado imponiendo su poder, pues es también una sociedad que cree estar defendiéndose de sus propios marginados" (DUBET et. al., 2016, p. 67).

Apesar dos diferentes dispositivos que pretendiam conseguir o apoio popular e seu disciplinamento, o regime não conseguiu ter a aprovação geral dos setores populares. $\mathrm{O}$ congresso nacional de prefeitos de 1984 foi marcado por uma avaliação crítica da gestão das autoridades locais e um questionamento da criação das novas dezessete prefeituras da Província de Santiago de 1981 (gastos inecessários), propiciando, inclusive, a própria saída do emblemático general Roberto Guillard da Intendência da RM de Santiago (VALDIVIA, 2012). Era um momento particularmente complexo para o regime e suas projeções políticas. Nos bastidores, ficava a figura do general Pinochet sintonizado com os mais pobres, como destacava o jornal La Segunda em 1982: "el general Pinochet visitaba las comunas populares, desarrollando una relación simbiótica con los alcaldes [...] me siento Presidente de los chilenos y general de los pobres" (VALDIVIA, 2012, p. 12). Não obstante, a partir dos protestos de 1983 e a forte avançada repressiva se questionou ainda mais a projeção social do regime. Exemplo

\footnotetext{
${ }^{76}$ Se refere a Polícia Uniformizada do Chile.
} 
emblemático disso foi a comuna de Pudahuel no interior da RM de Santiago que, após da intensificação dos protestos de 1983, perderia sua posição de destaque oficial de sucesso, sendo retiradas importantes intervenções públicas como o aumento dos orçamentos do PEM e o POJH (VALDIVIA, 2012). Daí que o governo tomava cartas no assunto: "Pinochet destituyó a numerosos alcaldes, aparentemente responsabilizándolos de su incapacidad para contener las oleadas de protestas [...] La nueva generación de alcaldes tendría que profundizar su perfil social' (VALDIVIA, 2012, p. 80).

Todavia, os problemas da condução política das prefeituras com a autoridade central continuaram e teriam significativas trajetórias. Como tínhamos destacado mais acima, o general Roberto Guillard teve uma particular trajetória no processo de erradicação e o funcionamento das novas prefeituras. De Presidente Diretor da CONARA e responsável direto pela criação das novas prefeituras em 1981, passou a ser ministro de Moradia e Urbanismo até o atentado contra o general e Intendente de Santiago Carol Urzua em agosto de 1983, momento quando tomou o controle da Intendência de Santiago até 1985. Nessa última trajetória, o general Guillard questionou o papel preponderante das prefeituras enquanto seu poder discricional na distribuição das moradias e denunciou o caráter precário das que foram entregues, e que não conseguiam soluções definitivas ao problema básico da moradia (ALVAREZ, 2012). Segundo Guillard, por não intervir nos critérios de administração e autárquica que tinham as prefeituras nos subsídios de moradias, se amplificariam os descontento populares contrários aos desejos de legitimidade social do regime (ALVAREZ, 2012). Essa discussão interna do regime manifestava implicitamente o tipo de descentralização que deveriam impulsionar as prefeituras, sempre ligadas a uma agência do governo central. O questionamento do general Guillard refletia no fato de que as moradias de emergência deveriam ser impulsionadas pelo Ministério de Moradia e Urbanismo e não pelas prefeituras. Diz o historiador Rolando Alvarez:

El meollo del debate era cuán liberalizada y descentralizada debía quedar la política habitacional. Por un lado, la concepción de los alcaldes aparecía más fiel al neoliberalismo, restando participación al Estado y reafirmando la importancia de la iniciativa privada. Por otro lado, el MINVU reivindicaba la necesidad de centralizar los criterios sobre cómo desarrollar la política de vivienda. Como solía hacerlo Pinochet, dejó coexistir esta diferencia por un tiempo prolongado, porque, si bien Guillard, Collados y Poduje fueron ministros de vivienda entre 1982 y 1987, las casetas sanitarias nunca dejaron de construirse; es más, su número aumentó con el paso de los años, llegando a construirse en un tercio de las "soluciones habitacionales" que el régimen entregó a los sectores extremadamente pobres del país (ALVAREZ, 2012, p. 133). 
A citação ilustra a particular contradição do poder das prefeituras versus o poder central, mas também a particular lógica neoliberal que estava plenamente ancorada nas prefeituras e os diferentes dispositivos de ajuda oficial que deveriam ser distribuídas entre os setores mais pobres do país. A gestão territorial das prefeituras, portanto, se ensamblava funcionalmente na política urbana neoliberal promovida pelo Estado central. Em outras palavras, a circulação dos dispositivos de moradia já estava totalmente integrada no conjunto do sistema territorial do país, embora com diferenças nos rendimentos políticos e escalonamentos. As prefeituras projetavam não apenas dispositivos de focalização da pobreza, mas sobretudo, ampliavam uma subjetividade política que valorizava os benefícios da iniciativa privada ou qualquer tipo de projeto de caráter empresarial nos territórios locais.

No entanto, se bem as prefeituras eram dispositivos eficientes para a distribuição de programas de moradia, para o regime, o mais importante era a projeção política do poder central. Após as divergências advertidas pelo general Guillard, Pinochet decidiu novamente outorgar as prerrogativas de distribuição das moradias ao Ministério de Moradia e Urbanismo, transferindo novamente essa competência a um órgão de poder central e sendo ele mesmo a principal figura responsável das transferências para os setores populares. Com isso, se deslocou a figura dos prefeitos como os responsáveis das melhorias e, inversamente, se projetou o governo nacional como responsável pela ajuda aos mais pobres do país (ALVAREZ, 2012). Apesar da diminuição da crise econômica e dos protestos, em 1985 ainda persistiam as críticas pelas funções e o desempenho dos prefeitos. No caso das prefeituras da capital, se destacava a "excesiva injerencia de los intendentes en las decisiones de inversión y gestión municipal, exceso de burocracia, miedo a tener iniciativas propias que provocaran su destitución" (VALDIVIA, 2012, p. 82). Às novas prefeituras, correspondiam internamente tanto os fortes déficits de moradias quanto os agudos níveis de pobreza da capital. Mas, acima de tudo, elas respondiam ao contraditório processo político e econômico que permitia restaurar uma ordem urbana conservadora e autoritária sobre os setores populares. 


\section{CONSIDERAÇÕES FINAIS}

Como podemos observar ao longo deste trabalho, a regionalização foi simultaneamente uma projeção política e geopolítica do regime que arranjou uma particular distribuição do poder territorial, modificando a divisão político-administrativa do país e sua estrutura burocrática. Essa reconfiguração dos princípios orgânicos e das fronteiras internas, respondeu fundamentalmente a uma crise de representação política-nacional e um complexo estruturamento do Estado como agente de acumulação capitalista e regulamento de redes e normas do ordenamento territorial. A contar dos dispositivos envolvidos na regionalização, o regime recriou uma ordem técnico-política diferente do período anterior que lhe permitiu ampliar estrategicamente sua representação política enquanto capacidade operativa de governo e promover as bases burocráticas do neoliberalismo no interior do Estado.

Condicionando novas práticas políticas e escalonamentos de poder estatal, a regionalização não se fundamentou em apenas uma tradição regional ou uma posição político-militar exclusiva. Acima de tudo, foi um suporte logístico da fração reinante no bloco de condução do regime que permitiu aperfeiçoar as comunicações políticas entre as oficinas públicas do conjunto do país e acrescentar as prerrogativas do poder presidencial nos territórios interiores. Os fundamentos de cada recorte territorial do país consistiram em uma combinação seletiva de vários enfoques disciplinares e tradições institucionais que foram ensamblando-se e naturalizando-se conforme os objetivos políticos e econômicos do regime. Trata-se de uma coexistência de fundamentos geopolíticos, regionalistas e administrativos, os quais foram sendo aderidos a um nacionalismo pragmático e funcional ao crescimento de redes políticas oficiais e mudanças estruturais do padrão econômico. Em outras palavras, longe de uma coerência teórica ou científica estrito senso, argumentos regionalistas e geopolíticos como de integração interna e segurança nacional, foram combinando-se lado a lado com elementos conservadores e administrativos neoliberais da gestão do território, criando-se uma malha territorial tecnicamente mais integrada, embora com maiores dispositivos de controle do aparelho central.

O arranjo de regiões, províncias e comunas consolidado entre 1974-1981, assim, pode ser lido como uma tecnologia política que demarcou novas pautas da gestão do território. Essas pautas, estrategicamente, tenderam a potenciar e agilizar a presença dos agentes privados nas materialidades técnica-locais das regiões, ao tempo, que permitiam 
recriar uma estrutura territorial de serviços públicos básicos e subsídios em determinadas áreas sociais que, no percurso do período, ajudariam a fixar as novas funções sociais do governo. Precisamente, a nossa maneira de entender, esse foi o pano de fundo que esteve em jogo na regionalização. Trata-se de recriar e direcionar uma política nacional substancialmente diferente do ciclo anterior, na qual suas unidades territoriais fora da capital projetaram uma gestão pública efetivamente mais interligada às diretrizes do governo nacional e à intervenção nos setores mais pobres do país. Dessa forma, a regionalização não apenas disputou a representação dos setores populares historicamente ancorados na esquerda chilena, mas também permitiu ampliar e reforçar a legitimidade do regime, criando outros repertórios de governo: uma burocracia territorial com mais interações com as comunidades e funcional ao neoliberalismo como mecanismo de regulação estrutural.

Contraditoriamente, assim, o arranjo regional fortaleceu um comando hipercentralizado da estrutura nacional, embora com maior capilaridade territorial enquanto burocracias públicas e ferramentas de governo nos níveis subnacionais. Esse elemento hipercentralizado de governo se basou na lógica geopolítica ensamblada na regionalização que também projetou um funcionamento piramidal das estruturas regionais e suas respectivas fronteiras internas de províncias e comunas. Não obstante, dado o próprio desejo de constituir uma forma de governo regional ao longo do país, o regime precisou de mais rapidez e eficiência na dotação de autoridades territoriais equivalentes. Dessa maneira, na mesma estrutura piramidal regional se ensamblou uma rede interior de serviços públicos regionais afins ao desenvolvimento neoliberal e o controle político dos territórios internos, criando uma gestão do território mais integrada que reforçou a escala regional como a máxima hierarquia territorial. Assim, SERPLAC e SEREMIS foram os principais dispositivos do escalonamento regional e da distribuição dos orçamentos públicos para o desenvolvimento territorial do país.

O arranjo de províncias, por sua vez, acrescentou a maquinaria política regional e a representação político-militar da autoridade nacional nos níveis intermediários da hierarquia territorial. Sua particularidade estratégica esteve no enquadramento do programa regional nas prefeituras do país e na vigilância desses programas territoriais: nenhum prefeito faz uma gestão do território comunal sem a integração de seus projetos na província e a linha definida pelo Governador. Essa hierarquia militar na estrutura provincial facilitou a circulação da informação entre as autoridades do sistema regional e as prefeituras mais isoladas e distantes 
do centro regional, sendo um enlace importante do ponto de vista da capilaridade. No entanto, as províncias responderam mais estruturalmente a uma estratégia geopolítica de controle interno dos territórios e o reforço da soberania nacional, do que a uma gestão integrada dos orçamentos.

$\mathrm{O}$ arranjo comunal foi o dispositivo mais próximo às comunidades e, portanto, o lugar da reforma territorial onde se projetaram as manobras políticas mais ativas no sentido de como o regime projetou estabelecer vínculos e apoios com a população em geral. Contrariamente à sua origem supostamente técnico-neutral, as prefeituras foram os dispositivos que melhor expressaram o desejo de "alterar la matrizpolítica del Estado y reemplazar a los partidos políticos como vínculo entre el ciudadano y el Estado" (LIRA, 2004, p. 16). Os municípios foram reforçados com mais orçamentos e faculdades técnicas que significativamente aumentaram suas capacidades enquanto gestão do território. Em geral, a literatura do período autoritário tinha destacado o fenômeno da alcaldización da política, dando maior ênfase ao poder descentralizador, neoliberal e despolitizado das prefeituras, sem considerar a inovação do conjunto do sistema territorial (VALDIVIA et. al., 2012). Entretanto, como temos podido comprovar neste trabalho, durante o período autoritário, todas as políticas comunais e o próprio poder dos prefeitos eram parte de uma rede hierárquica regional que estruturalmente condicionava e pautava seu papel como agência política. Assim, a prefeitura do regime teve mais suportes que no período anterior e se centrou na gestão de subsídios e focalização de ajudas monetárias nos setores mais pobres que, à medida que se dava o avanço do regime, foi fixando o neoliberalismo como políticas públicas em sua dimensão territorial local. Essa gestão territorial mais neoliberal e interligada na hierarquia regional, criou múltiplos desdobramentos políticos através de uma agência municipal mais permeável aos interesses dos grupos econômicos e à despolitização geral da população ou, contraria as representações tradicionais das esquerdas.

Nosso trabalho não se aprofundou nesses desdobramentos, porque se delimitou no seguimento mais específico das trajetórias dos recortes territoriais e o funcionamento do regime territorial até meados da década de oitenta (1973-1985). Porém, para futuras pesquisas, seria importante aprofundar nesses desdobramentos e contradições, sobretudo aquelas trajetórias de prefeitos e SERPLAC que, uma vez chegada a democracia, viraram importantes figuras políticas parlamentarias e representantes empresariais vinculadas principalmente ao partido Unión Democrata Independiente (UDI). Esses desdobramentos 
ajudariam a compreender mais profundamente o uso político do território da regionalização e sua particular estrutura de intermediação técnico-social que projetou estrategicamente uma agenda neoliberal hegemônica de práticas políticas territoriais. Uma particular estrutura territorial que viabilizou os interesses de classe ou dos grupos empresariais no marco estrutural das competências públicas para a agência governamental oficial do ciclo político posterior.

Nesse sentido, é singularmente expressivo que conforme a primeira década do processo de regionalização (1974-1984), o FNDR tendeu a uma perda sistemática de relevância orçamental nas regiões. Com efeito, a percentagem mínima que estabeleceu a lei de 1975 nunca se cumpriu e os principais investimentos do fundo se distribuiriam em obras públicas e serviços sociais operando de uma forma alternativa dos orçamentos setoriais, portanto, nunca cumpriu seu propósito original de encaminhamentos produtivos regionais e fomento de infraestruturas estratégicas (GARCÍA, 1985). Entre 1976 e 1981, o FNDR flutuou entre os 12 mil e 17 mil milhões de pesos chilenos, uma cifra muito menor para o conjunto de necessidades das estruturas burocráticas. Para pior, devido aos efeitos da crise econômica geral, em 1982 o FNDR começou um sucessivo detrimento de suas remessas, chegando a ter apenas 2,6 mil milhões de pesos chilenos em 1985. No entanto, ao início de 1986 houve um significativo aumento do processo de maior investimento que permitiu, teoricamente com maior força, as obras públicas sociais nas regiões até o final do período do regime. O que havia ocorrido?

Em 1985 o regime subscreveu um convênio de financiamento com o Banco Interamericano de Desenvolvimento (BID), que significou uma nova estrutura interna da gestão do FNDR que, por sua vez, aumentou a execução de projetos e obras de infraestrutura prioritária para as prefeituras nas áreas da saúde, educação, água potável, esgoto, rede caminhos rural e pavimentação (GONZÁLEZ, 1990). Se bem continuava a circulação de identificação, formulação e recomendação do BIP via SERPLAC, através do decreto lei $\mathrm{n}^{\circ}$ 1-18.359 em novembro de 1984, se criou o cargo de Subsecretario de Desenvolvimento Regional com o general do Exército Luis Patricio Serre no Ministério do Interior. Serre foi uns dos Intendentes Regionais mais longevos em seu cargo pois, entre 1977 e 1983, se desempenhou como Intendente da IV Região de Coquimbo. Próximo ao general Pinochet, Serre foi o único militar nesse cargo até o retorno da democracia (1985-1989). Em 1985, com o decreto lei $\mathrm{n}^{\mathrm{o}}$ 1-18359, criou-se a Subsecretaria de Desenvolvimento Regional 
(SUBDERE), incorporando uma parte significativa dos funcionários da CONARA, e a outra parte formou a Secretaria General da Presidência (SEGPRES). Um informe da SUBDERE no período democrático em 1993 destacava o seguinte:

La Subsecretaría de Desarrollo Regional y Administrativo tiene las atribuciones legales para asignar a los proyectos los recursos solicitados por la región, para lo cual elabora una resolución de asignación, que posteriormente es visada por la Dirección de Presupuesto del Ministerio de Hacienda y sometida a la consideración de la Contraloría General de la República, la que supervigila que se cumpla la normativa legal vigente respecto al destino de los recursos públicos y en este caso particular, del FNDR (SUBSECRETARIA DE DESARROLLO REGIONAL, 1993, p. 8)

Através desses duplos mecanismos de controle orçamental, o arranjo regional foi organicamente mais funcional a agência política do poder central. Essa mudança burocrática interna implicou uma perda de poder da ODEPLAN e dos Chicago Boys, pois, foi a nova SUBDERE e suas unidades de controle regional (UCR) as que passariam a distribuir e assignar as remessas do FNDR nas regiões. Dessa maneira, os SERPLAC e Intendentes já não precisariam ir a Santiago para defender suas carteiras de projetos pois, o general Patrício Serre e o pessoal técnico da SUBDERE de Santiago, seriam os responsáveis pela decisão técnica final das remessas regionais do FNDR, que a partir desse momento, contavam com um orçamento mais elevado, produto do convênio assinado com o BID. Segundo um informe da SUBDERE em 1993, a distribuição do FNDR entre 1985-1990 se caraterizou por uma significativa "falta de transparencia del proceso" (SUBDERE, 1993, p. 9) e haveria apontado manter uma cobertura e melhoramento das infraestruturas sociais em educação, saúde, saneamento básico e viabilidade urbana e rural, precisamente nas áreas onde avançaria a neoliberalização via prefeituras. Diferentes pesquisas apontam um uso político do orçamento distribuído pela SUBDERE desse período, sobretudo em relação a campanha do plebiscito em regiões e a coordenação conjunto dos prefeitos na última etapa do regime (HUNEEUS, 2016; ALVAREZ, 2012). Seria relevante então, para futuras pesquisas, analisar o particular tecido burocrático centralizado que significou a criação da SUBDERE entre 1985-1990, pois até hoje, contraditoriamente, esse órgão territorial é o principal instrumento público que declara oficialmente a descentralização do Estado chileno. Entretanto, esse desenvolvimento inferior dos orçamentos associados junto com o tipo de projetos que guiou o FNDR demostram a coerência sistemática entre os princípios neoliberais durante o período completo da regionalização (1974-1989). O FNDR sempre foi administrado territorialmente nos termos do neoliberalismo e não implicou uma política de 
desenvolvimento regional efetiva, simplesmente porque nunca existiu essa forma estatal de economia regional uma vez suscitado o Golpe de Estado.

Contudo, para alguns acadêmicos, o processo de regionalização foi bastante limitado segundo seus propósitos regionalistas originais, sendo, mais bem, uma reforma decorativa que acompanhou a particular aliança econômica e política que se produz no Chile autoritário. Esse limitado rendimento regional, estruturalmente, se daria pela ação territorial concentradora e desigual do neoliberalismo do período. As regiões, assim, ficariam reduzidas a simples cores cartográficas sem muita importância, posto que haveriam chocado com seus fundamentos originais: estruturalmente permaneceriam desprovidas de ferramentas. Daí que o processo de regionalização, segundo eles, não tendeu a múltiplas controvérsias e a reforma regional teria sido um fracasso do ponto de vista da compensação dos históricos desequilíbrios geográficos e da continuidade centralista. Se bem coincidimos que a regionalização não diminuiu o processo de centralização econômica e produtiva do país, discordamos na suposta contradição entre neoliberalismo e os fundamentos originais da reforma. Como podemos observar através das diferentes fontes e materiais, desde o primeiro dia da reforma os fundamentos regionalistas - incluída a teoria dos pólos de desenvolvimento - foram ferramentas discursivas e não estruturas reais da mudança operativa do regime territorial. De maneira contraria, já nos primeiros decretos-leis e na própria estrutura da ODEPLAN regionalizada nos SERPLAC (1975), aparecem os dispositivos essenciais do neoliberalismo e um entrelaçado sistêmico e ordenado de hierarquias territoriais que vai condicionando a privatização. De igual maneira, tampouco se observam círculos militares que questionaram a reforma regional e ameaçaram o desenvolvimento de suas definições estratégicas. Se bem, podemos constatar a presença de certas tensões vinculadas à contradição do desenvolvimento regional auto sustentável versus regiões sem estruturas de mando estratégico estatal produtivo, como no pronunciamento do general Gastón Frez e a polêmica dos Intendentes em 1977 - as três máximas hierarquias militares da CONARA que impulsionaram o processo de regionalização entre 1974 e 1980 -, onde aparecem permanentemente fundamentando a favor da regionalização e sua ultra liberdade econômica.

Assim sendo, não parece plausível a ideia de que a reforma regional fosse se desmantelando pelos efeitos do neoliberalismo. Na verdade, o que parece guiar o processo da regionalização, desde o início, foi um sentido político-pragmático do neoliberalismo em 
sua capacidade de integrar as estruturas administrativas do Estado através de uma burocracia dependente dos órgãos centrais estratégicos - a ODEPLAN e o Ministério do Interior -, embora mais inserida nas relações territoriais fora da capital. Daí que nos primeiros momentos da reforma, pela herança do Estado anterior, ainda coexistem expressões do desenvolvimento regional antecessor como a Junta de Adelanto de Arica e as Oficinas Regionais de Planejamento (ORPLAN). No entanto, rapidamente após o Golpe de Estado, essas mesmas práticas e materialidades regionais herdadas foram intervindas e imbricadas na regionalização oficial com particular destreza e imperativo, criando uma burocracia territorial funcional ao novo padrão econômico e às autoridades político militares da época. Em consequência, é relativo destacar um fracasso da regionalização baseado na perda dos princípios regionais originais e o avanço dos dispositivos neoliberais. $\mathrm{Na}$ prática, os princípios do neoliberalismo sempre estiveram operando e estruturando o processo de regionalização, desde o começo até o fim do período autoritário, mas com diferentes ensambles, desdobramentos e capilaridades.

Se até hoje o processo de regionalização não gerou múltiplas controvérsias e tensões, foi produto da vitória cultural e política do regime autoritário sobre o conjunto da sociedade chilena, e sobretudo, da conveniência política da máxima hierarquia do Estado central para as coalizações governantes nas últimas décadas, cada vez mais desancoradas de seus princípios democráticos e representantes genuínas do modelo neoliberal. Daí que não seria menos simbólico que só após duas décadas de democracia limitada e um processo constituinte ainda em desenvolvimento, se estejam questionando suas estruturas com mudanças políticas ${ }^{77}$. O processo de regionalização do regime autoritário, acima de tudo, foi uma ferramenta de governo de caráter estrutural e não uma política econômica particular ou uma reforma administrativa parcial. Por esse motivo a vigência e a atualidade de uma parte significativa de suas estruturas burocráticas na escala regional e as prerrogativas do poder presidencial da Constituição inserida em 1980. Por consequência, segundo nossa maneira de interpretar, não existe um suposto paradoxo entre o desenho regional de seus primeiros anos e o conteúdo neoliberal na aplicação da regionalização na última década do regime. Muito além de um suposto fracasso econômico da regionalização do período, o arranjo territorial se ensamblou sistemática e criativamente nos principais objetivos estratégicos do regime: governar o território nos termos do neoliberalismo.

\footnotetext{
${ }^{77}$ Nas últimas eleições do Chile em maio do 2021, por primeira vez em sua história, se elegeram democraticamente autoridades regionais.
} 
Por último, o arranjo territorial estrutural diligentemente desdobrou um comando centro-periferia ou uma incorporação técnico-política diferenciada dos dispositivos em Santiago e o resto das Regiões. A regionalização foi projetada de forma meticulosa para modificar o pacto territorial com os níveis subnacionais, mas sem questionar a estrutura nacional e as modalidades políticas na capital do país e seus órgãos centrais. Portanto a Região Metropolitana de Santiago foi um artifício, e sistematicamente a última fronteira dos recortes territoriais e dispositivos da reforma regionais. O mandato centro-periferia na gestão territorial em Santiago, por sua vez, implicou outras contradições na hierarquia do poder territorial das capitais provinciais e a relação das prefeituras com a estrutura de poder regional. Em contrapartida, o SIGORE aplicado nas regiões tendeu a reforçar o espírito de corpo das autoridades territoriais, estabelecendo uma maior complementaridade entre autoridades e funções proclives ao neoliberalismo. Em outras palavras, a mesma estrutura da regionalização do regime teve diferentes desdobramentos econômicos e trajetórias políticas na capital e nas regiões.

A regionalização, assim, imperceptivelmente também influenciou a hegemonia neoliberal impulsionada pelos agentes econômicos e os instrumentos de governo do regime autoritário. O fato que, durante a maior parte do regime, os Intendentes regionais e Governadores provinciais terem sido exclusivamente agentes militares e dependentes do Executivo, foi uma maneira de projetar esse consenso estrutural do neoliberalismo e resguardar a hierarquia política do Pinochet frente a qualquer outro tipo de autoridade. Através do Estado Maior da CONARA, cada cenário territorial da regionalização teve um particular direcionamento político de parte do Pinochet, fundamentalmente na projeção operativa dos governos regionais e a comunicação direta de seus funcionários hierárquicos dependentes. Dessa maneira, o regime se projetou como um governo mais inserido nas diversas "realidades geográficas" (CONARA, 1976). Isto não quer dizer que não existiram diferenças nem contradições ao interior do processo de regionalização, mas sim uma consequência política que assegurou sua coerência e transcendência na estrutura territorial do país, fundamental para a consolidação posterior das reformas neoliberais sucessivas.

O arranjo territorial, tecnicamente mais operativo nas novas burocracias regionais e seu estrito comando hierarquizado dependente do nível central, no fundo, fechou o autoritarismo no conjunto do funcionamento burocrático territorial do país. O salto de escala foi de um antigo regime subnacional de províncias mais fracas e discordantes do ponto de 
vista de suas faculdades e orçamentos, a outro regime subnacional de regiões mais eficientes e orgânicas em seus níveis inferiores, que conseguiu aproximar a autoridade do poder nacional em forma coordenada e espacialmente homogênea no conjunto do país. Esse fortalecimento do regime centralista via estruturas regionais foi uma inovação que, a curto e mediano prazo, consolidou a gestão autoritária do território como se fosse uma forma natural do poder territorial do Estado chileno. 


\section{BIBLIOGRAFIA}

ABALOS, José, LIRA, Luis. Desarrollo regional, liberalismo económico y autoritarismo político 1973-1984. Pensamiento Iberoamericano n. 10, p. 185-208, 1986.

ACHURRA, Manuel. Organización y Funciones de la Planificación Regional em Chile. In: INSTITUTO PANAMERICANO DE GEOGRAFÍA E HISTORIA. Documentos del I Seminario sobre Regionalización. Rio de Janeiro: Comisión Geografía, 1968.

ACTAS DE LA JUNTA DE GOBIERNO. Acta N²143a, 1 de agosto de 1974.

AGAMBEM, Giorgio. ¿Qué es un dispositivo? Sociológica ano 26, n. 73, p. 249-264, 2011.

AGASSINO, Rafael. Hegemonía y contra hegemonía en una contrarrevolución neoliberal madura. La izquierda desconfiada en el Chile post-Pinochet. Caracas: CLACSO, 2006.

ALVAREZ, Rolando. "Las casas de Pinochet": políticas habitacionales y apoyo popular 1979-1988. In: VALDIVIA, Veronica, ALVAREZ, Rolando, DONOSO, Karen. La Alcaldización de la política. Los municipios en la dictadura pinochetista. Santiago: LOM, 2012.

ALVES, Fernando Roberto. A dimensão espacial do poder. Diálogos entre Foucault e a geografia. Geografia em questão v. 6, n.1, p. 231-245, 2013.

ALLENDE, Francisca, OLAVE, Scarlett. El despojo de la Villa San Luis de Las Condes. Santiago: CEIBO, 2018.

APEY, Alfredo. El proceso de reestructuración económica nacional y su impacto en el sistema regional: 1976-1981. Informaciones Geográficas n. 30, p. 83-97, 1983.

ARANCIBIA, Patricia, BALART, Francisco. Conversando con el General Julio Canessa Robert. Santiago: Editorial Biblioteca Americana, 2006.

ARENAS, Federico. El Chile de las regiones: una historia inconclusa. Estudios Geográficos v. LXX, n. 266, p. 11-39, 2009.

AYLWIN, Arturo. Antecedentes, realidad actual y proyecciones del proceso de regionalización. EURE - Revista de Estudios Urbanos Regionales v.12, n. 34-35, p. 3543, 1985.

BALBONTÍN, Ignacio. Significado político-ideológico de la regionalización y municipalización en el actual régimen. Santiago: CED, 1984.

BARRIENTOS, Juan. La situación actual y perspectiva de la regionalización. In: EL MERCURIO, Santiago, 23 de diciembre de 1975, p. 2.

BARRIENTOS, Juan. Reflexiones sobre la regionalización [1975]. Memorial del Ejército n. 496, p. 205- 215, 2016. 
BARRIOS-SUVELZA, Franz Xavier. El impacto de las recientes reformas de regionalización en Colombia, Ecuador, Perú y Bolivia: conceptos y procesos. Geopolítica(s) n. 8 (1), p. 51-89, 2017.

BECERRRA, María José, BARCOSKI, Iván. Las huellas del futuro: apuntes municipales para una nueva Constitución. Santiago: Corporación Ciudad y Derechos, 2020 .

BECKER, Bertha. A geografia e o resgate da geopolítica. Espaço Aberto Rio de Janeiro, v. 2, n.1, p. 117-150, 2012.

BEDRACK, Moisés. La estrategia de desarrollo espacial en Chile (1970-1973). Buenos Aires: Editorial Siap-Planteos, 1974.

BOCCARDO, Giorgio. Clases sociales: la vigencia de una noción política. Revista Santiago, 15 de febrero de 2019.

BOISIER, Sergio. Territorio, Estado y Sociedad en Chile. La dialéctica de la descentralización: entre la geografía y la gobernabilidad. Santiago: Magoeditores, 2010.

BOISIER, Sergio Descentralización en un Estado unitario: la doctrina (oculta) de la descentralización chilena. Desenvolvimento Regional ano 1, n. 1, p. 1-21, 2011.

BOISIER, Sergio. Chile: la vocación regionalista del gobierno militar. EURE - Revista de Estudios Urbanos Regionales v. XXVI, n. 77, p. 81-107, 2000.

BORJA, Jordi, VALDES, Teresa, POZO, Hernán, MORALES, Eduardo. Descentralización del Estado, movimiento social y gestión local. Santiago: FLACSO, 1986.

BOURDIEU, Pierre. Sobre o Estado. Lisboa: Edições 70, 2014.

BOURDIEU, Pierre. Poder simbólico. Rio de Janeiro: Bertrand Brasil, 1989.

BOOKCHIN, Murray. El Proyecto Comunalista. Texto tomado de Murray Bookchin, The next revolution. Popular Assemblies and the promise of direct democracy (editado por Debbie Bookchin y Blair Taylor), Verso, London, 2015. Traducción: Felipe Correa, David Maldonado, Manuel Loyola. Revista Territorios y Regionalismos, n.1, 2019.

BRENNER, Neil. Reestruturação, reescalonamento e a questão urbana. Tradução: Daniel Sanfelici; Karen Heberle. GEOUSP - Espaço e Tempo n. 33, p. 198-220, 2013.

BULNES, Luz (ed.). La regionalización. Santiago: Andrés Bello, 1988.

CANESSA, Julio. Visión geopolítica de la regionalización. Seguridad Nacional n. 24, p. 13$31,1982$.

CANIUQUEO, Sergio. Dictadura y pueblo mapuche 1973 a 1978. Reconfiguración del colonialismo chileno. Revista de Historia Social y de las Mentalidades, v. 17, n. 1, p. 89-130, 2013. 
CAÑAS, Jorge. 1968. La Planificación Regional de Magallanes. In: INSTITUTO PANAMERICANO DE GEOGRAFÍA E HISTORIA. Documentos del I Seminario sobre Regionalización. Rio de Janeiro: Comisión Geografía, 1968.

CATAIA, Márcio. Território nacional e fronteiras internas. A fragmentação do território brasileiro. Dissertação de doutorado - 2001. Disponível em: $<$ https://www.ige.unicamp.br/geoplan/wp-content/uploads/sites/22/2014/08/tese-

Marcio-Cataia.pdf > Aceso em: jul. 2018.

CATAIA, Márcio. A geopolítica das fronteiras internas na constituição do território: o caso da criação de novos municípios na região Centro-Oeste do Brasil durante o regime militar. Scripta Nova v. X, n. 218 (22), 2006. Disponível em: <http://www.ub.es/geocrit/sn/sn218-22.htm>

Aceso em: 11abr. 2019.

CASTRO SAURITAIN, Carlos. Desarrollo Social Chileno. Seguridad Nacional no 1, 1976.

CASTRO, Iná Elias de. Geografia e Política. Território, escalas de ação e instituições. Rio de Janeiro: Bertrand Brasil, 2013.

CEA, José. La regionalización de Chile y la modernización de su Sociedad. Revista de Derecho v. V, p. 63-70, 1994.

CEA, José. Hacia un Estado Regional. Revista Chilena de Derecho v. 24, n. 2, p. 337-351, 1997.

CLAVAL, Paul. Geografía humana y económica contemporánea. Madrid: Akal, 1987.

COMISIÓN NACIONAL DE LA REFORMA ADMINISTRATIVA. Chile hacia un nuevo destino: su reforma administrativa integral y el proceso de regionalización. Santiago: Editora Nacional Gabriela Mistral, 1976.

COMISIÓN NACIONAL DE LA REFORMA ADMNISTRATIVA. Políticas de la Comisión Nacional de Reforma Administrativa: 1981-1982. Santiago s./r.

COMISIÓN NACIONAL DE LA REFORMA ADMINISTRATIVA. Instrucciones sobre medidas en la X Región. Reservado. Comunicación del presidente al Intendente de la X Región. Santiago: 16 de diciembre de 1977.

COMISIÓN NACIONAL DE LA REFORMA ADMINISTRATIVA. Reforma Administrativa Integral de Chile y el Proceso de Regionalización. Viña del Mar: Exposición de Juan Barrientos Vidaurre, 1979.

COMISIÓN NACIONAL DE LA REFORMA ADMINISTRATIVA. Diagnóstico Básico de la Administración Pública. Nivel Regional. Santiago: Departamento de Investigación y Prospectiva, 1982.

COMISIÓN NACIONAL DE LA REFORMA ADMINISTRATIVA. Exposición de la situación provincial con motivo de la visita del S.E., el presidente de la República, general de Ejército, Don Augusto Pinochet Ugarte. Valdivia: junio de 1978. 
COMISIÓN NACIONAL SOBRE PRISIÓN POLÍTICA Y TORTURA. Informe de la Comisión Nacional sobre Prisión Política y Tortura (Valech I). Santiago: Ministerio del Interior, 2005.

CORAGGIO, José Luis. Las bases teóricas de la planificación regional en América Latina (un enfoque crítico). In: BOISIER, Sergio et. al.(compiladores). Experiencias de Planificación Regional en América Latina. Una teoría en busca de una práctica. Santiago de Chile: CEPAL/ILPES, 1981.

CORREIA DE ANDRADE, Manuel. Espaço, Polarização \& Desenvolvimento. Uma Introdução à economia regional. São Paulo: Atlas, 1987.

CORTES, Alexis. Favelados e pobladores nas ciências sociais: a construção teórica de um movimento social. Rio de Janeiro: EdUERJ, 2018.

COSTA, Wanderley Messias. Geografia Política e Geopolítica. São Paulo: EdUSP, 2013.

CUNILL, Pedro. Geografia de Chile. Nuevo texto para la Educación Media. Tercera edición aumentada y corregida. Santiago: Universitaria, 1970.

CUMBERS, Andrew, MACKINNON, Danny, MCMASTER, Robert. Instituciones, poder y espacio. Evaluando los límites del institucionalismo en la Geografía Económica. IN: VALDIVIA, Marcos, DELGADILLO, Javier (coordinadores). La geografía y la economía en sus vínculos actuales: una antología comentada del debate contemporáneo. DF México: Universidad Nacional de México, 2013.

CUMPLIDO, Francisco. La estructura institucional del modelo de descentralización. Santiago: Centro de Estudios del Desarrollo, CED 1983.

CHATEAU, Jorge. Geopolítica y regionalización. Algunas relaciones. Santiago: FLACSO, Documento de Trabajo,1978.

DE MATTOS, Carlos. Reestructuración, globalización, nuevo poder económico y territorio en el Chile de los noventa. In: DE MATTOS, C., HIERNAUX, D., RESTREPO, D. (compiladores). Globalización y Territorio. Impactos y perspectivas. Santiago: Fondo de Cultura Económica y Instituto de Estudios Urbanos (PUC), 1998.

DE MATTOS, Carlos. Modernización neocapitalista, reestructuración productiva y territorial en Chile (1973-1990). EURE - Revista de Estudios Urbanos Regionales v. XVIII, n. 54, 1992.

DIAZ, Álvaro. Centralización y Descentralización del Estado en Chile. In: CLACSO (varios autores), ¿Hacia un nuevo orden estatal en América Latina? 5 Centralización/descentralización del Estado y actores territoriales. Buenos Aires: CLACSO, 1989.

DONOSO, Karen. "Deporte y recreación para todos...": política social y cultural de la DIGEDER en los municipios de Santiago. In: VALDIVIA, Verónica, ALVAREZ, Rolando, DONOSO, Karen. La alcaldización de la política. Los municipios en la dictadura pinochetista. Santiago de Chile: LOM, 2012. 
DUBET, François, TIRONI, Eugenio, ESPINOZA, Vicente, VALENZUELA, Eduardo. Pobladores. Luchas sociales y democracia en Chile. Santiago: Ediciones Universidad Alberto Hurtado, 2016.

ELDEN, S. Terra, terreno, território. Geografares, [S. 1.], n. 21, p. 42-60, 2016 (Tradução MENDONÇA, M.J.). DOI: 10.7147/GEO21.13529. Disponível em: https://periodicos.ufes.br/geografares/article/view/13529. Acesso em: 16 jun. 2021.

ERRAZURIZ, Maximiliano. La regionalización y la participación. Revista Política y Geoestrategia, ANEPE, 1988, nº 47.

ERRAZURIZ, Maximiliano. Ley Orgánico Constitucional sobre los Consejos Regionales de Desarrollo: Alcaneces y problemas planteados durante su tramitación lesgislativa. IN: BULNES, Luz (ed.). La regionalización. Santiago: Andrés Bello, 1988.

ESTEFANE, Andrés. Estado y ordenamiento territorial en Chile, 1810-2016. IN: JAKSIC, Iván, RENGIFO, Francisca (editores). Historia Política de Chile, 1810-2010. Tomo II: Estado y Sociedad. Santiago: Fondo de Cultura Económica, 2017.

EUGENIN, Jorge. Regionalización. La experiencia chilena 1974-1989. Santiago: Universidad Nacional Andrés Bello, Facultad de Ciencias Económicas y Administrativas, Centro de Desarrollo, 1990.

FAJARDO, Marco. Contra Bachelet y otros. Los militares que se opusieron al Golpe. Santiago: Quimantú, 2012.

FOUCAULT, Michel. Seguridad, Territorio, Población. Fondo de Cultura Económica: Buenos Aires, 2006.

GARAY, Cristián. Introducción. IN: CAÑAS MONTALVA, Ramón. Geopolítica Oceánica y Austral General Ramón Cañas Montalva. Santiago: Departamento Investigación y Desarrollo Academia de Guerra del Ejército de Chile, 2008.

GARCÍA, Bernardita. El Fondo de Dessarrollo Regional: um analisis descriptivo. EURE Revista de Estudios Urbanos Regionales v.12, n. 34-35, p. 92-105, 1985.

GARCÍA, Germán. Carretera Longitudinal Austral. La respuesta a un desafío. Revista Chilena de Geopolítica v. 5, n. 3, p. 51-69, 1989.

GARRETÓN, Manuel. Los nuevos regímenes militares en América Latina, una caracterización general. IN: BENAVIDES, Leopoldo, GODOY, Milton, VERGARA, Francisco. (compiladores). Antología del pensamiento crítico chileno contemporáneo. Buenos Aires: CLACSO, 2015.

GARRETÓN, Manuel. De la seguridad nacional a la nueva institucionalidad. Notas sobre la trayectoria ideológica del nuevo Estado autoritario. Revista Mexicana de Sociología v. 40, n. 4, p. 1259-1282, 1978.

GARRETÓN, Manuel. Modelo y proyecto político del régimen militar chileno. Revista Mexicana de Sociología v. 44, n. 2, p. 101-133, 1982. 
GARATE, Manuel. La revolución capitalista de Chile (1973-2003). Santiago de Chile: Ediciones Universidad Alberto Hurtado, 2012.

GAUDICHAUD, Frank. Chile 1970-1973. Mil días que estremecieron al mundo. Poder popular, cordones industriales y socialismo durante el gobierno de Salvador Allende. Santiago: LOM, 2016.

GOBIERNO DE CHILE. Decreto ley no 1104. Establece Division Geoeconómica del País.

Santiago: Biblioteca del Congreso de Chile, 19 de agosto de 1969.

GOBIERNO DE CHILE. Creación de la comuna subdelegación de Trehuaco (Provincia de Nuble). Santiago: Biblioteca del Congreso de Chile, 23 noviembre 1972.

GOBIERNO DE CHILE. Decreto ley no 4. Declara en Estado de Emergencia las Provincias y Departamentos que indica. Santiago de Chile: Ministerio del Interior. Promulgado 18 de septiembre de 1973a.

GOBIERNO DE CHILE. Decreto ley no 212. Crea Comisión Nacional de la Reforma Administrativa. Santiago de Chile: Ministerio del Interior. Promulgado 17 de dezembro de 1973b.

GOBIERNO DE CHILE. Declaración de Principios del Gobierno de Chile. Santiago: Editora Nacional Gabriela Mistral, 11 de marzo 1974a.

GOBIERNO DE CHILE. Decreto ley $n^{\circ}$ 573. Estatuto del gobierno y administración interiores del Estado. Santiago: Biblioteca del Congreso de Chile, 12 de julio de 1974b.

GOBIERNO DE CHILE. Decreto ley no 575. Regionalización del país. Santiago: Biblioteca del Congreso de Chile, 13 de julio de 1974c.

GOBIERNO DE CHILE. Decreto ley no 712. Asigna denominación a XI Región. Santiago: Biblioteca del Congreso de Chile, 28 de octubre de 1974d.

GOBIERNO DE CHILE. Decreto ley n ${ }^{\circ}$ 785. Aprueba presupuesto de la nación para el año 1975. Santiago: Biblioteca del Congreso de Chile, 4 diciembre de 1974e.

GOBIERNO DE CHILE. Decreto ley n ${ }^{\circ}$ 349. Prorroga mandato de directivas de juntas de vecinos y otras organizaciones. Santiago: Biblioteca del Congreso de Chile, 13 marzo $1974 \mathrm{f}$.

GOBIERNO DE CHILE. Decreto ley $\mathrm{n}^{\circ}$ 69. Programas correspondientes a las Secretarías Regionales de Planificación y Coordinación. Santiago: Biblioteca del Congreso de Chile, 17 enero de 1975a.

GOBIERNO DE CHILE. Decreto ley no 937. Crea plantas y establece normas para las Secretarias Regionales de Planificación y Coordinación. Santiago: Biblioteca del Congreso de Chile, 26 marzo de 1975b.

GOBIERNO DE CHILE. Decreto ley no 746. Aprueba reglamento orgánico de las Secretarias Regionales de Planificación y Coordinación. Santiago: Biblioteca del Congreso de Chile, 22 julio de 1975c. 
GOBIERNO DE CHILE. Decreto ley $\mathrm{n}^{\circ}$ 1230. Divide las regiones del país en las provincias que indica. Biblioteca del Congreso de Chile, 27 octubre 1975d.

GOBIERNO DE CHILE. Decreto ley $\mathrm{n}^{\circ}$ 1317. Divide las regiones que indica de las provincias que señala y modifica d.1. 575, de 1974. Biblioteca del Congreso de Chile, 27 octubre $1975 \mathrm{e}$.

GOBIERNO DE CHILE. Decreto ley no 870. Crea cargos de Secretarios Regionales Ministeriales del Ministerio de Obras Públicas, suprime cargos que señala y Radica funciones y atribuciones que indica. Santiago: Biblioteca del Congreso de Chile, 27 octubre $1975 \mathrm{f}$.

GOBIERNO DE CHILE. Decreto ley no 1208. Santiago: Biblioteca del Congreso de Chile, 13 octubre de $1975 \mathrm{~g}$.

GOBIERNO DE CHILE. Decreto ley no 1289. Ley orgánica de las municipalidades. Santiago: Biblioteca del Congreso de Chile, 14 enero 1976a.

GOBIERNO DE CHILE. Decreto ley $n^{\circ}$ 1367. Establece normas para el manejo del Fondo Nacional de Desarrollo Regional. Santiago: Biblioteca del Congreso de Chile, 11 marzo de 1976b.

GOBIERNO DE CHILE. Decreto ley $n^{\circ}$ 1758. Sustituye denominación del pueblo y comuna de "Pueblo Hundido" por la de "Diego de Almagro". Santiago: Biblioteca del Congreso de Chile, 21 de marzo 1977c.

GOBIERNO DE CHILE. Decreto ley no 2093. Modifica la naturaleza jurídica de la Comisión Nacional de Reforma Administrativa y fija planta de su personal. Santiago: Biblioteca del Congreso de Chile, 04 enero de 1978a.

GOBIERNO DE CHILE. Decreto ley $\mathrm{n}^{\circ}$ 2339. Otorga denominación a la Región Metropolitana y a Las regiones del país, en la forma que indica. Santiago: Biblioteca del Congreso de Chile, 02 octubre de 1978b.

GOBIERNO DE CHILE. Decreto ley n ${ }^{\circ}$ 2867. Delimita las regiones y provincias del país que indica. Santiago: Biblioteca del Congreso de Chile, 20 septiembre de 1979a.

GOBIERNO DE CHILE. Decreto ley $n^{\circ}$ 2868. Divide las provincias que señala del país en las comunas que indica. Santiago: Biblioteca del Congreso de Chile, 26 octubre de 1979b.

GOBIERNO DE CHILE. Decreto ley $n^{\circ}$ 420. Modifica plan intercomunal de Santiago y su ordenanza. Santiago: Biblioteca del Congreso de Chile, 20 de noviembre 1979c.

GOBIERNO DE CHILE. Decreto ley $n^{\circ}$ 3063. Ley de rentas municipales. Santiago: Biblioteca del Congreso de Chile, 29 de diciembre 1979d.

GOBIERNO DE CHILE. Decreto ley no 3260. Establece Régimen de Gobierno y Administración de la Región Metropolitana de Santiago. Santiago: Biblioteca del Congreso de Chile, 01 abril 1980a. 
GOBIERNO DE CHILE. Decreto ley $\mathrm{n}^{\circ}$ 1204. Describe los limites comunales de Tarapacá, Antofagasta, Atacama, Coquimbo y de Magallanes y de la Antártica Chilena. Santiago: Biblioteca del Congreso de Chile, 19 noviembre $1980 \mathrm{~b}$.

GOBIERNO DE CHILE. Decreto ley no 1325. Describe específicamente los limites comunales de las regiones de Valparaíso, del Libertador General Bernardo O'Higgins, del Maule, del Bio-Bio, de la Araucanía, de Los Lagos y Aisén del General Carlos Ibáñez del Campo. Santiago: Biblioteca del Congreso de Chile, 10 diciembre 1980c.

GOBIERNO DE CHILE. Decreto ley no 3642. Modifica decreto ley 3.260 que establece régimen de Gobierno y administración de la región metropolitana de Santiago. Santiago: Biblioteca del Congreso de Chile, 07 marzo 1981a.

GOBIERNO DE CHILE. Decreto ley no 1-3260. Determina límites en la Región Metropolitana de Santiago; crea nuevas comunas, establece y describe sus límites. Santiago: Biblioteca del Congreso de Chile, 17 marzo 1981b.

GOBIERNO DE CHILE. Decreto ley no 1086. Reuniones Públicas. Santiago: Biblioteca del Congreso de Chile, 16 septiembre 1983.

GOBIERNO DE CHILE. Decreto ley $\mathrm{n}^{\circ}$ 18.359. Crea el cargo de Subsecretario de Desarrollo Regional y administrativo en el Ministerio del Interior. Santiago: Biblioteca del Congreso de Chile, 17 noviembre 1984.

GOBIERNO DE CHILE. Decreto ley $\mathrm{n}^{\circ}$ 1-18.359. Traspasa y asigna funciones a la Subsecretaria de desarrollo Regional y administrativo. Santiago: Biblioteca del Congreso de Chile, 14 noviembre 1985.

GONZALEZ SAMOHOD, Alejandro. La regionalización: una nueva dimensión para nuestra seguridad nacional. Revista Seguridad Nacional n. 2, 1976.

GONZÁLEZ SAMOHOD, Alejandro. La regionalización chilena: un proceso histórico. Santiago: CONARA, 1978.

GONZALEZ, María Eugenia. Herramientas de apoyo al proceso de regionalización. In: EUGENIN, Eugenio. Regionalización. La Experiencia Chilena 1974-1989. Santiago: Cuadernos Universitarios, 1990.

GUILLARD, Roberto. Reformulación Comunal en el Gran Santiago. Santiago: Ministerior del Interior, Intervención, 06 mayo de 1981.

GUREVICH, Alberto. Una ciudad interminable: La Pintana. Disponível em: $<$ https://web.uchile.cl/vignette/revistaurbanismo/n1/2.html?fbclid=IwAR0OpznuQe_R EOSKuss5gLjbKPFVJ1JEubk7NQOGSTvLXQu2F1cmuOxpQyU $>$ Acceso em: 16 janeiro 2020

GUZMAN, Nancy. Ingrid Olderock, la mujer de los perros. Santiago: Ceibo, 2014. 
HAESBAERT, Rogério. Regional-Global. Dilemas da Região e da Regionalização na Geografia Contemporânea. Rio de Janeiro, 2010.

HAESBAERT, Rogerio, PORTO-GONCs,ALVES, Carlos Walter. A Nova Des-Ordem Mundial. 2a Ed. Sao Paulo: Editora UNESP, 2006.

HIDALGO, Rodrigo. La vivienda social en Chile y la construcción del espacio urbano en el Santiago del siglo XX. Santiago: Instituto de Geografía, Pontificia Universidad Católica de Chile, 2005.

HOBSBAWM, Eric. Cómo cambiar el mundo. Marx y el marxismo 1840-2011. Buenos Aires: Crítica, 2011.

HUNEEUS, Carlos. Tecnócratas y políticos en un Régimen autoritario. Los "Odeplan boys" y los "gremialistas" en el Chile de Pinochet. Revista Ciência Política v. XIX, p. 125-158, 1998.

HUNEEUS, Carlos. El régimen de Pinochet. Santiago: Penguim Random House Grupo Editorial, 2016.

INSTITUTO PANAMERICANO DE GEOGRAFÍA E HISTORIA. Documentos del I Seminario sobre Regionalización. Organizado por el Comité de Geografía Regional. Rio de Janeiro: Comisión Geografía,1968.

JARA, Isabel. Politizar el paisaje, ilustrar la patria: nacionalismo, dictadura chilena y proyecto editorial. Aisthesis n. 50, 201, p. 230-252.

JORDAN, Ricardo, VILLARROEL, Pablo. ¿Es Chile un Páis Regionalizado? Revista de Trabajo Social n. 57, p. 57-92, 1990.

LABBE GALILEA, Cristián. Reforma administrativa y regionalizacion, grandes objetivos del gobierno de Chile. Revista de Seguridad Nacional n. 33, 1984.

LACOSTE, Yves. A geografía-isso serve, em primeiro lugar, para fazer a guerra. São Paulo: Papirus, 2012.

LAVIN, Joaquín. Miguel Kast. Pasión de vivir. Santiago: Zig-Zag, 1986.

LEIVA, Sebastián. El MIR y los Comandos Comunales: poder popular y unificación de la movilización social. Cyber Humanitatis n. 30, 2004.

LEONCIONI, Sandra. Região e Geografia. São Paulo: Editora da Universidade de São Paulo, 2014.

LEYTON, Cesar. Geopolítica y ciudad gueto: erradicaciones eugenésicas en la dictadura militar. Santiago de Chile 1973-1990. IN: LEYTON, Cesar, PALACIOS, Cristián, SÁNCHEZ, Marcelo (orgs). El bulevar de los pobres. Racismo científico, higiene y eugenesia, siglos XIX y XX. Santiago: Ocho libros, 2015.

LEYTON, Cesar. Ciencia de la erradicación. Madrid: Consejo Superior de Investigaciones Cientificas, 2020. 
LIRA, Luis. La descentralización y el desarrollo regional: la experiencia chilena. Seminario Internacional Descentralización y Federalismo Fiscal. ILPES, 2004.

LIRA, Luis, RIVEROS, Fernando. La cuestión regional en la prensa. EURE - Revista de Estudios Urbanos Regionales v. XII, n. 34-35, p. 117-134, 1985.

LIRA, Luis. Aspectos político-institucionales de la descentralización. Comentarios. Reflexión y análisis del proceso de descentralización en Chile, p. 67-79, 1998.

LIRA, Luis, MARINOVIC, Fernando. Estructuras participativas y descentralización: el caso de los consejos regionales de desarrollo en Chile. ILPES. Instituciones y actores del desarrollo territorial en el marco de la globalización. Santiago: ILPES, Universidad del Bio-Bio, 1999.

LOBATO-CORREA, Roberto. Região e organização espacial. Rio Janeiro: Ática, 1987.

MARTIN, André Roberto. As fronteiras internas e a "questão regional" do Brasil. Dissertação de doutorado -1993. Disponível em: https://caph.fflch.usp.br/node/4173.

MATTELARD, Armand, GARRETÓN, Manuel. Atlas social de las comunas de Chile. Santiago: Pacífico, 1965.

MAYORGA, Ramón. Dividir para reinar: centralismo, regionalización en crisis y nuevo modelo de Estado para Chile. Valparaíso: Cámara de Diputados de la República de Chile, 2012.

MOLINA Y OTROS. Mapa de la Extrema Pobreza en Chile. Santiago: Instituto de Economía UC, ODEPLAN.Documento de Trabajo n. 29, noviembre 1974.

MOLINA, Carlos. Chile: los militares y la política. Santiago: Andrés Bello, 1989.

MORAES, Antônio Carlos Robert. Foucault e a Geografia. Boletim Paulista de Geografia n. 66, p. 129-138, 1988.

MORAES, Antônio Carlos Robert. Ideologias geográficas. Espaço, Cultura e Política no Brasil. São Paulo: Annablume, 2005.

MORALES, Eduardo. ROJAS, Sergio. Relocalización socio-espacial de la pobreza. Política estatal y presión popular, 1979-1985. Santiago: FLACSO, Documento de Trabajo, n. 280, 1986.

MORALES, Eduardo, POZO, Hernán, ROJAS, Sergio. Municipio, desarrollo local y sectores populares. Santiago: FLACSO, 1988.

MORALES, Eduardo, LEVY, Susana, ALDUNATE, Adolfo, ROJAS, Sergio. Erradicados en el regimen militar. Una evalución de los beneficiados. Santiago: FLACSO, Documento de Trabajo n. 448, 1990.

MOREIRA, Ruy. O espaço e o contra-espaço: as dimensões territoriais da sociedade civil e do Estado, do privado e do público na ordem espacial burguesa. IN: SANTOS, Milton, 
BECKER, Bertha (Eds). Território, territórios. Ensaios sobre o ordenamento territorial. Rio de Janeiro: Lamparina, 2011.

MONCADA, Rodrigo. Estrategia de Desarrollo y Regionalización. In Dirección de Desarrollo Universidad Nacional Andrés Bello. IN: EUGENIN, Eugenio. Regionalización. La Experiencia Chilena 1974-1989. Santiago: Cuadernos Universitarios Serie Investigaciones n¹, 1990, p. 43-59.

MUÑOZ, Víctor. Historia de la UDI. Generaciones y cultura política (1973-2013). Santiago: Universidad Alberto Hurtado, 2016.

NETO, Manuel Domingos. Sobre o patriotismo castrense. Perseu. História, Memoria e Política n. 18, ano 13, p. 13-35, 2019.

NUÑEZ, Lautaro. Avísale Freddy. Historia de un hombre y sus razones (1943-1973). Santiago: LOM, 2016.

OFICINA NACIONAL DE PLANIFICACIÓN. Política de Desarrollo Nacional. Directivas nacionales y regionales. Santiago: Editorial Universitaria, 1968.

OSSES, Pablo, NUÑEZ, Andrés. La geografía económica de Chile: el conocimiento de los recursos naturales como guía del desarrollo de Chile. IN: CORPORACIÓN DE FOMENTO DE LA PRODUCCIÓN. Geografía Económica de Chile. Tomo I. Santiago: Centro de Investigaciones Diego Barros Arana de la Dirección de Bibliotecas, Archivos y Museos, 2013, p. XIII-XLIV.

O’ DONELL, Guillermo. Y a vos que te importa. Working Paper \# 9. Kellogg Institute. January, 1984.

OSORIO MACHADO, Lia. Estado, territorialidade, redes. IN: SILVEIRA, María Laura. Continente em chamas: globalização e território no América Latina. Rio de Janeiro: Civilização Brasileira, 2005, pp. 243-284.

PALMA, Francisca. Iquique Glorioso. Crónicas de la Tierra de Campeones. Santiago: Ediciones Radio Universidad de Chile, 2016.

PEÑA, Juan Cristóbal. La secreta vida literaria de Augusto Pinochet. Santiago: Penguim Random House, 2015.

PEREZ, Pablo. Cómo entender y estudiar la conciencia de clase en la sociedad capitalista contemporánea. Una propuesta. Revista THEOMAI n. 29, pp. 121-140, p. 2014.

PINOCHET, Augusto. Mensaje presidencial 11 de septiembre de 1976. Seguridad Nacional, n 2, 1976.

PINOCHET, Augusto. Ejército de Chile: posibles elementos a considerar en su proyección futura. Conferencia dictada en Santiago de Chile el 19 de agosto de 1993. FASOC.nº 4.

PINOCHET, Augusto. Visión geopolítica de Chile. Pensamiento y acción. Memorial del Ejército (450): 147-165. Discurso de Clausura de las 'Primeras Jornadas Internacionales de 
Geopolíticas Academia de Guerra 1997', realizado por el sr. Comandante en Jefe del Ejército, Capitán General Augusto Pinochet Ugarte.

PITTMAN, Harold. Algunas tendencias geopolíticas especificas en los países del ABC: nuevas aplicaciones de la ley de las áreas valiosas. Revista Ciencia Política v. 3, n. 1-2, p. 27-70, 1981.

PORTO-GONCALVES, Carlos Walter. A reinvenção dos territórios: a experiência latinoamericana e caribenha. IN: COELHO NETO, Agripino, CARNEIRO SANTOS, Edinusia, ARAUJO DA SILVA, Onildo (organizadores). (GEO) grafias dos movimentos sociais. Salvador: UEFS Editora, 2010.

POZO, Hernán. Espacio cotidiano y poder. Documento de Trabajo FLACSO, n. 113, 1988.

QUINTANA, Cecilia. Implicancias espaciales y geopolíticas del modelo neoliberal en Chile: el caso de la Provincia de Palena. Estudios Político Militares ano 1, n. 2, p. 127-136, 2001.

RIFFO, Luis. Os espaços de globalização: a neoliberalização do território no Chile. IN: SILVEIRA, Maria Laura (organizadora). Continente em chamas: globalização e território no América Latina. Rio de Janeiro: Civilização Brasileira, 2005.

RIFFO, Luis. 50 años del ILPES: evolución de los marcos conceptuales sobre desarrollo territorial. Serie Desarrollo Territorial n. 15, CEPAL. Santiago de Chile: 2014.

RACZYNSKI, Dagmar. La regionalización y la política económico-social del régimen militar: el impacto regional. CIEPLAN Notas Técnicas n. 84, Santiago, 1986, pp. 98-109.

RACZYNSKI, Dagmar; SERRANO, Claudia. Descentralización y gobierno local: situación de algunos municipios en Santiago. EURE - Revista de Estudios Urbanos Regionales v. XIV, v. 41, p. 15-28, 1987.

RIFFO, Luis. Os espaços de globalização: a neoliberalização do território no Chile. SILVEIRA, Maria Laura (organizadora). Continente em chamas: globalização e território no América Latina. Rio de Janeiro: Civilização Brasileira, 2005, pp. 145-176.

RIFFO, Luis. 50 años del ILPES: evolución de los marcos conceptuales sobre desarrollo territorial. Serie Desarrollo Territorial, n. 15, CEPAL. Santiago de Chile: 2014.

RODRIGUEZ, Claudia, DUCCI, María Elena. La descentralización en Chile: el peso de las tradiciones centralistas y autoritarias. In: RESTREPO, Darío (editor). Historias DE Descentralización. Transformación del régimen político y cambio en el modelo de desarrollo. América Latina, Europa y EUA. Bogotá: 2006, p. 571 - 614.

ROJAS, Luis. De la revelación popular a la sublevación imaginada. Antecedentes de la Historia Política y Militar del Partido Comunista de Chile y del FPMR 1973-1990. Santiago: LOM, 2017.

SALAZAR, Gabriel. "El Municipio Cercenado" (La lucha por la autonomía de la asociación municipal en Chile, 1914-1973). IN: SALAZAR, Gabriel, BENITEZ, Jorge (compiladores). Autonomía, espacio y gestión. El municipio cercenado. Santiago: LOM, 1998. 
SALAZAR, Matías. Evolución y desarrollo de la descentralización en Chile. Revisión del proceso de reformas desarrolladas en el período 1974-2018. Tesis de grado para optar al título de Administrador Público. Universidad de Talca, 2019.

SANTANA, Roberto. Control sobre el espacio y control sobre social en el Estado militar chileno. Espacios v.3, n. 6, p. 13-28, 2013,

SANTANA, Roberto. Refundar la República. Santiago: Mago, 2016.

SANTOS, Milton. Sociedade e Espaço: A Formação Social como Teoria e como Método. Boletim Paulista de Geografia v. 54, p. 81-99, 1977.

SANTOS, Milton Economia Espacial: Críticas e Alternativas. São Paulo: Edusp, 2003.

SANTOS, Milton. 0 espaço do cidadão. São Paulo: Nobel, 1993.

SANTOS, Milton. O papel ativo da geografia. Um manifiesto. Laboratório de Geografia Política e Planejamento Territorial e Ambiental do Departamento de Geografia - Faculdade de Filosofia, Letras e Ciências Humanas da Universidade de São Paulo (USP) no XI Encontro Nacional de Geógrafos. Florianópolis, Brasil, Julho de 2000.

SEVILLA, Alvaro. Hegemonía, gubernamentalidad, territorio. Apuntes metodológicos para una historia social de la planificación. Empiria n. 27, p. 49-72, 2014.

SOMS, Esteban. ODEPLAN/MIDEPLAN: Una escuela para el cambio social. Santiago: Gobierno de Chile, Ministerio de Planificación, 2010.

STOHR, Walter. Ejemplo de Regionalización Nacional. El caso de la Republica de Chile. IN: INSTITUTO PANAMERICANO DE GEOGRAFÍA E HISTORIA. Documentos del I Seminario sobre Regionalización. Organizado por el Comité de Geografía Regional. Rio de Janeiro: Comisión Geografía,1968.

SUAREZ, Helio. Perspectiva histórica de la regionalización y sistema de administración. Santiago: 1975.

SUAREZ, Helio. Antecedentes y análisis del proceso de regionalización. Revista Seguridad Nacional n. 1, 1976.

SUBSECRETARIA DE DESARROLLO REGIONAL. Evaluación del Proceso de Modernización y Reforma Administrativa. Santiago: Ministerio del Interior: 1985.

SUBSECRETARIA DE DESARROLlO REgIONAL. Proceso de Regionalización, Descentralización y Desconcenración Administrativa. Monografía preparada por la Subsecretaría Regional y Administrativo del Ministerio del Interior para ser presentada en reunión técnica a realizarse en Madrid, España, en el marco del XVI Reunión del Consejo Directivo del Centro Latinoamericano de Administración para el desarrollo (CLAD). Santiago de Chile, Octubre 1986. 
SUBSECRETARIA DE DESARROLLO REGIONAL. El financiamento de la inversión pública regional y municipal. El fondo nacional de desarrollo regional y el fondo común municipal. Santiago: Ministerio del Interior, 1993.

SUBSECRETARIA DE DESARROLLO REGIONAL. Evaluación de la División Político Administrativa vigente. Informe Final. Santiago: Geografía Proyectos UC, 2007.

SWYNGEDOUW, Eric. Ni lo global ni lo local. La "glocalización" y las políticas de escala. IN: VALDIVIA, Marcos, DELGADILLO, Javier (coordinadores). La geografía y la economía en sus vínculos actuales: una antología comentada del debate contemporáneo. DF México: Universidad Nacional de México, 2013, pp. 503-526.

SZARY, Anne-Laure. Regiones ganadoras y regiones perdedoras en el retorno de la democracia en Chile: poderes locales y desequilibrios territoriales. EURE - Revista de Estudios Urbanos Regionales v. XXIII, No 70, 1997, pp. 59-79.

TOBAR, Manuel. Tratado de Derecho Administrativo. Derecho y Administración Regional. Santiago: Thomson Reuters, 2016.

THOMPSON, Edward. A formação da classe operária inglesa; tradução Denise Bottman. Rio de Janeiro: Paz e Terra, 1987.

RIBEIRO, Ana Clara Torres. Regionalização: fato e ferramenta. In: LIMONAD, Esther, HAESBAERT, Rogerio, MOREIRA, Ruy (Orgs.). Brasil, século XXI: por uma nova regionalização? Agentes, processos, escalas. São Paulo: Max Limonad, 2004..

URETA, Sebastián. Transantiago o el fallido ensamblaje de una sociedad de clase mundial. Santiago: Universidad Alberto Hurtado, 2017.

URRUTIA REVECO, Santiago. "Hacer de Chile una gran Nación”. La Carretera Austral y Patagonia Aysén durante la dictadura cívico militar (1973-1990). Revista Geográfica Norte Grande n. 75, p. 35-60, 2020.

VALDIVIA, Veronica, ALVAREZ, Rolando. "Platita poca, pero segura": los refugios laborales en la dictadura. IN: VALDIVIA, V., ALVAREZ, R., DONOSO, K.. La Alcaldización de la política. Los municipios en la dictadura pinochetista. Santiago: LOM, 2012, pp. 51-86.

VALDIVIA, V. La democracia dictatorial pinochetista: regionalización y municipios. Avances del Cesar. Año XII, Vol. XII, Nº 12, 2015.

VALENZUELA, Esteban. Descentralización ya. Conceptos, historia y agenda. Santiago: RIL, 2015.

VALENZUELA, Arturo. Intermediarios políticos en Chile. Gobierno local en un régimen centralizado. Santiago: Ediciones Universidad Diego Portales, 2016.

WHRIGHT, Erik. Análisis de clase. IN: CARABAÑA, Julio (ed.). Desigualdad y clases sociales. Un seminario en torno a Erik O. Wright. Visor: Madrid, 1995, pp. 21-53. 
ZAVALA, Jaime. La modernización administrativa y el proceso de regionalización. IN: Dirección de Desarrollo Universidad Nacional Andrés Bello. Regionalización. La Experiencia Chilena 1974-1989. Santiago: Cuadernos Universitarios Serie Investigaciones no1, 1990, pp. 61-90.

VENCESLAU, Igor. Território e Logística na América do Sul: reflexões sobre integração a partir dos serviços postais. IN: COSTA, Wanderley Messias da, VASCONCELOS, Daniel. Geografia e Geopolítica da América do Sul: integrações e conflitos. São Paulo: Humanitas, 2018, pp. 37-52.

VERDUGO, Patricia. La Casa Blanca contra Salvador Allende. Los orígenes de la guerra preventiva. Madrid: Tabla Rasa, 2004.

VIAL COSSANI, Camilo. Las Municipalidades en Chile. In: RUANO DE LA FUENTE, José Manuel, VIAL COSSANI, Camilo. Manual de Gobiernos Locales en Iberoamérica. Santiago: Centro Latinoamericano de Administración para el Desarrollo (CLAD), Universidad Autónoma de Chile, p. 111- 137, 2016.

VIERA-GALLO, José Antonio. Política y Regionalización. ILPES. Instituciones y actores del desarrollo territorial en el marco de la globalización. Santiago: ILPES, Universidad del Bio-Bio, 1999.

VIO, Dionisio. Evaluación de la Regionalización. Santiago: CONARA, 1982.

VITALE, Luis. Intervenciones militares y poder fáctico en la política chilena (de 1830 al 2000). Santiago: ARCHIVO CHILE, Centro de Estudios "Miguel Enriquez" (CEME), 2000 .

VON CHRISMAR, Julio. Trascendencia geopolítica de la Carretera Austral Presidente Pinochet. Revista Chilena de Geopolítica v. 3, n. 1, p. 35-43,1986.

ZEMELMAN, Hugo. Alcances metodológicos y la construcción de un pensamiento histórico. IN: BENAVIDES, Leopoldo, GODOY, Milton, VERGARA, Francisco. (compiladores). Antología del pensamiento crítico chileno contemporáneo. Buenos Aires: CLACSO, 2015. 


\section{LISTA DE QUADROS}

Quadro $n^{\circ}$ 1. Decretos leis associados ao processo de regionalização................................24

Quadro $n^{\circ}$ 2. Recortes territoriais (1974-1981) .................................................................27

Quadro $\mathrm{n}^{\mathrm{o}}$ 3. Tipos de desenvolvimento e prioridades regionais..........................................55

Quadro no 4. Propostas de Regionalização Fevereiro de 1974............................................77

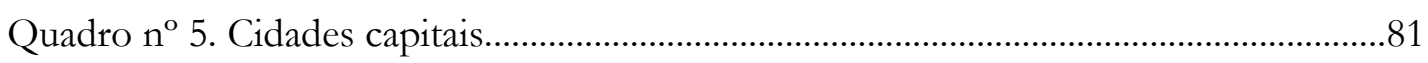

Quadro $n^{\circ}$ 6. Nome regiões, províncias e símbolos florais El Mercurio (1975)...............103

Quadro $n^{\circ}$ 7. Regionalização números romanos e nomes.....................................................105

Quadro $n^{\circ}$ 8. Regime territorial Constituição de 1925...........................................................122

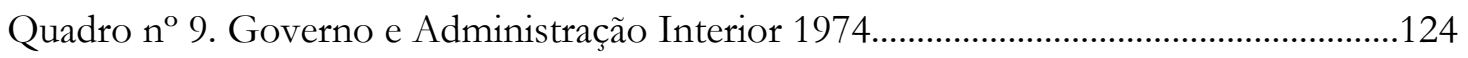

Quadro $n^{\circ}$ 10. Unidades territoriais do Golpe de Estado.......................................................130

Quadro $\mathrm{n}^{\mathrm{o}}$ 11. Intendentes regiões Metropolitana, VIII, XII, IV e III..................................145

Quadro no 12. Sistema de Governo e Administração Regional..............................................159

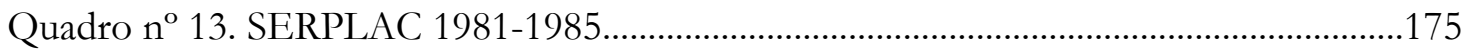

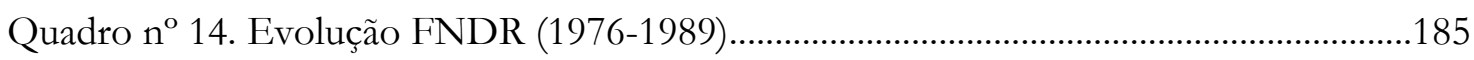

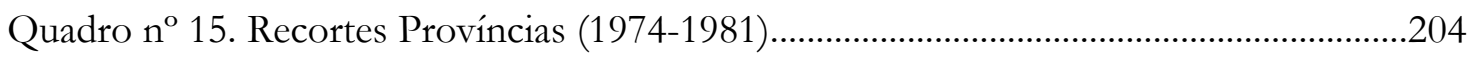

Quadro no 16. Distribuição de Governadores Provinciais........................................................229

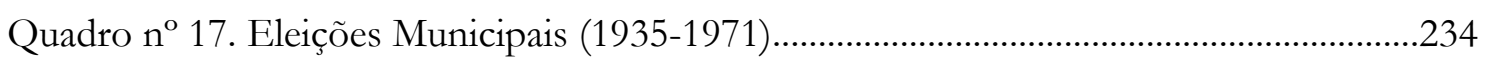

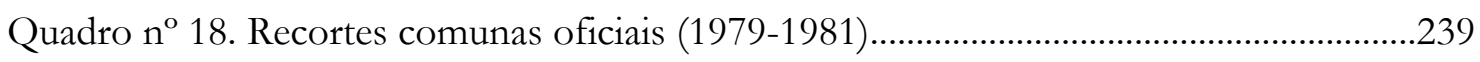

Quadro ${ }^{\circ}$ 19. Recorte comunas novas em regiões (sem Santiago).........................................247

Quadro ${ }^{\circ}$ 20. Sínteses recorte comunal por regiões (1979-1981)........................................248

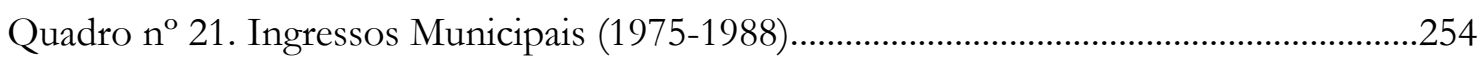

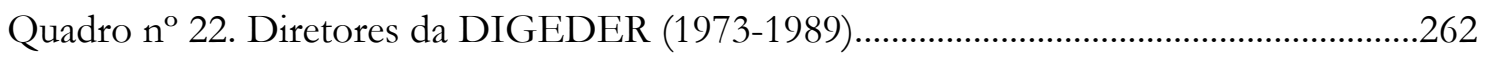

Quadro n ${ }^{\circ} 23$. Representações políticas nas prefeituras capitais regionais (1973-1988).....281

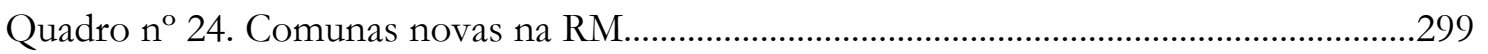

\section{LISTA DE MAPAS}

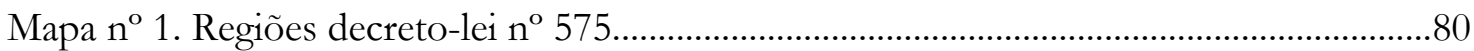

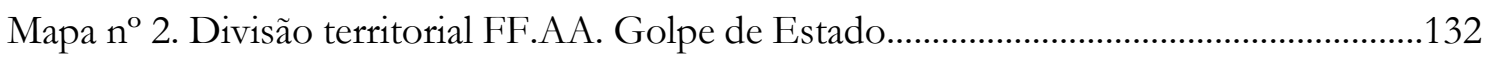

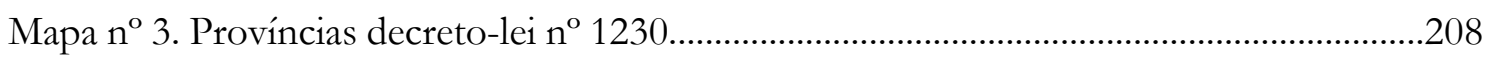

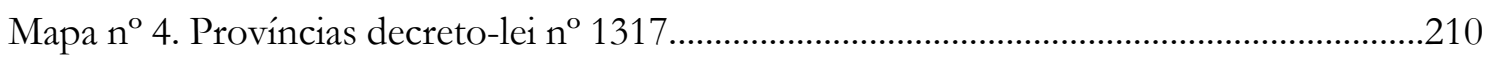

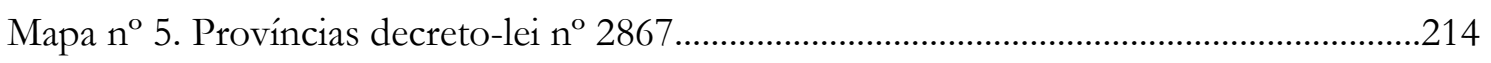

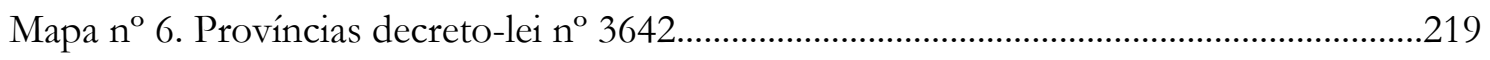


Mapa $\mathrm{n}^{\circ} 7$. Comunas decreto-lei $\mathrm{n}^{\circ} 2868$

Mapa $n^{\circ}$ 8. Comunas novas em regiões..................................................................................246

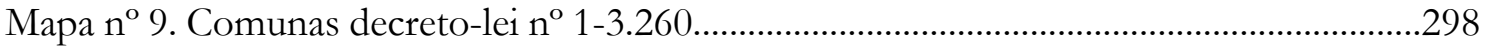

\section{LISTA DE IMAGENS}

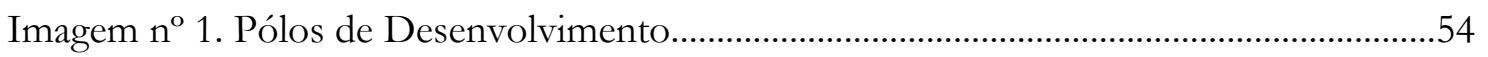

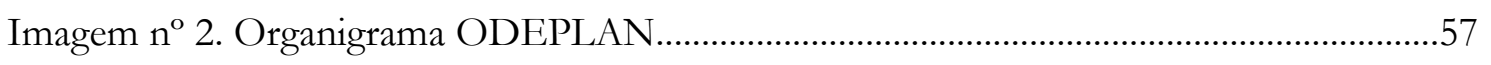

Imagem n $\mathrm{n}^{\mathrm{3}}$ 3. Estrutura hierárquica da CONARA.................................................................. 74

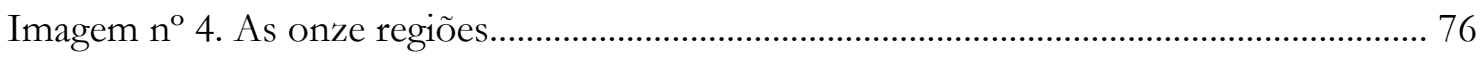

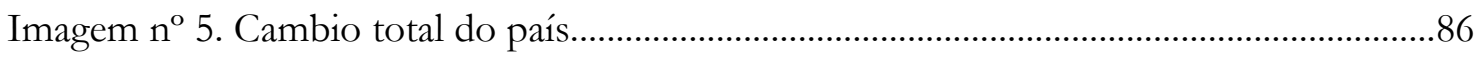

Imagem n ${ }^{\circ}$ 6. A Regionalização: um Desafio para Chilenos.........................................................87

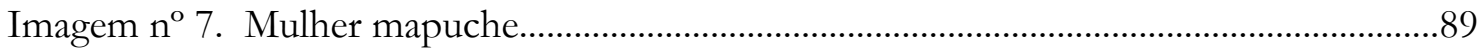

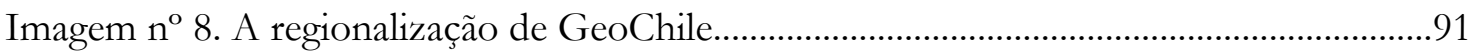

Imagem n ${ }^{\circ}$ 9. Regionalização e pertencimento............................................................................. 93

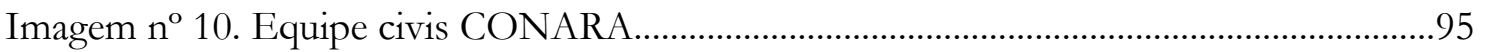

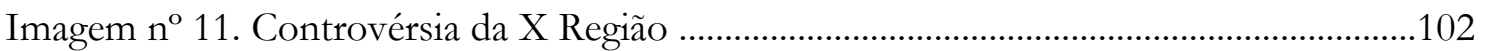

Imagem n ${ }^{\circ}$ 12. Estrutura do Sistema de Governo e Administração Regional........................117

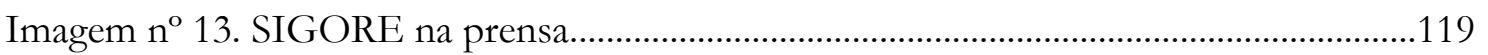

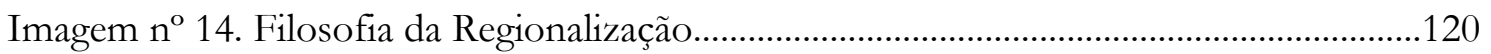

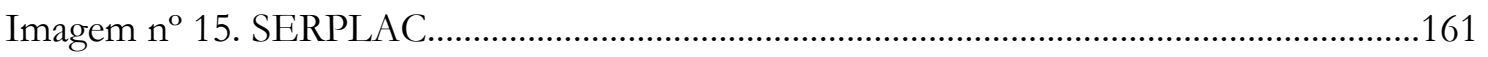

Imagem no 16. Anúncio prensa Região Metropolitana de Santiago......................................191

Imagem n ${ }^{\circ}$ 17. Cinco Províncias e Área Metropolitana............................................................192

Imagem no 18. Província do Maule Unida.................................................................................209

Imagem no 19. Assassinado Intendente Carol Urzúa....................................................................302

\section{LISTA DE FIGURAS}

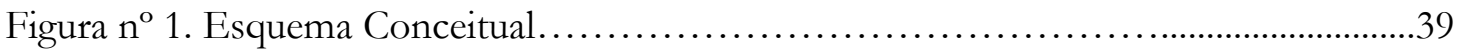




\section{ANEXOS}

Anexo $\mathrm{n}^{\circ}$ 1. Listado entrevistas feitas

\begin{tabular}{|c|c|c|c|}
\hline $\mathbf{N}^{\mathbf{o}}$ & Data & Nome & Temas tratados \\
\hline 1 & $24 / 06 / 2016$ & Cristián Garay & Geopolítica \\
\hline 2 & $30 / 06 / 2016$ & Cesar Leyton & Erradicações \\
\hline 3 & $18 / 03 / 2016$ & José Avalos & História regional e conflitos \\
\hline 4 & $29 / 03 / 2017$ & Andrés Estefane & História da regionalização \\
\hline 5 & $12 / 04 / 2017$ & Sergio Boisier & História da regionalização \\
\hline 6 & $30 / 05 / 2017$ & Carlos de Mattos & História da regionalizacão \\
\hline 7 & $04 / 08 / 2017$ & Nelson Infante & História da regionalização \\
\hline 8 & $05 / 08 / 2017$ & Sergio Boisier & História da regionalizacão \\
\hline 9 & $04 / 01 / 2018$ & Victor Leiva & História da regionalização \\
\hline 10 & $25 / 01 / 2018$ & Marcos Vergara & História da regionalização \\
\hline 11 & $18 / 03 / 2019$ & Gonzalo Delamaza & História da regionalização \\
\hline 12 & $29 / 05 / 2019$ & Federico Arenas & História da regionalização \\
\hline 13 & $20 / 06 / 2019$ & Jorge Negrete & História da regionalização \\
\hline 14 & $31 / 08 / 2019$ & Cecilia Quintana & Geopolítica \\
\hline 15 & $03 / 09 / 2019$ & Hugo Romero & Neoliberalismo \\
\hline 16 & $30 / 09 / 2019$ & Benjamín Valle & História da regionalização \\
\hline 17 & $30 / 09 / 2019$ & Luis Lira & História da regionalização \\
\hline 18 & $08 / 10 / 2019$ & José Abalos & História da regionalização \\
\hline 19 & $10 / 10 / 2019$ & Esteban Valenzuela & História da regionalização \\
\hline 20 & $10 / 10 / 2019$ & Juan Cavada & História da regionalização \\
\hline 21 & 15/10/2019 & José Galilea & História da regionalização \\
\hline 22 & $15 / 10 / 2019$ & Hugo Romero & História da regionalização \\
\hline
\end{tabular}




\begin{tabular}{|c|c|c|c|}
\hline 23 & $17 / 10 / 2019$ & Carlos Huneeus & Política y Autoritarismo \\
\hline 24 & $17 / 10 / 2019$ & Mario Rocha & História da CONARA \\
\hline 25 & $11 / 11 / 2019$ & $\begin{array}{c}\text { Jorge Sanz, Coronel em retiro } \\
\text { do Exército }\end{array}$ & Geopolítica \\
\hline 26 & $14 / 11 / 2019$ & $\begin{array}{l}\text { José Alfonso Rivas, Coronel } \\
\text { em retiro do Exército }\end{array}$ & História da CONARA \\
\hline 27 & $25 / 11 / 2019$ & Fabian Presacco & Regionalização \\
\hline 28 & $06 / 12 / 2019$ & Ignacio Irrarazaval & História da CONARA \\
\hline 29 & $29 / 11 / 2019$ & Carlos Cantero & Gestão do territorio \\
\hline 30 & $14 / 12 / 2019$ & Pedro Milos & História e memoria do regime \\
\hline 31 & $30 / 12 / 2019$ & Dionisio Vio & História da CONARA \\
\hline 32 & $03 / 01 / 2020$ & Alfredo Rodríguez & Urbanismo e autoritarismo \\
\hline 33 & $20 / 05 / 2020$ & Hernán Muñoz & História da CONARA \\
\hline 34 & $18 / 05 / 2020$ & Carla Brown & Historia local de Copiapó \\
\hline 35 & $28 / 05 / 2020$ & Arturo Orellana & Regionalização \\
\hline 36 & $15 / 01 / 2021$ & Iván Barcoski & Municipalização \\
\hline 37 & $09 / 02 / 2021$ & Diego Benavente & Gestão do território \\
\hline 38 & $10 / 02 / 2021$ & Pedro Ramírez & Gestão do território \\
\hline 39 & $11 / 02 / 2021$ & Alejandro Fernández Galaz & Gestão do território \\
\hline 40 & $23 / 02 / 2021$ & Julia Standen & Gestão do território \\
\hline
\end{tabular}


Anexo $\mathrm{n}^{\circ}$ 2. Recorte de prensa sistematizados

EL MERCURIO. Altas funciones del Estado, Santiago, 2 de octubre de 1973.

Supremo Gobierno, Santiago, 28 de octubre de 1973.

diciembre de 1973.

Regionalización del país proponen los multigremios, Santiago, 3 de

Regionalización del país, Santiago, 5 de diciembre de 1973.

Administración Profesional, Santiago, 9 de diciembre de 1973.

Multigremios promueven la descentralización, Santiago, 12 de diciembre de 1973.

Descentralización necesaria, Santiago, 13 de diciembre de 1973.

Descentralización Indispensable, Santiago, 29 de diciembre de 1973.

Regionalización administrativa, Santiago, 19 de febrero de 1974.

Descentralización del poder. Santiago, 18 de marzo de $1974 .$.

Hacia la descentralización, Santiago, 17 de Julio de 1974.

Chile es Unitario, Santiago, 25 de Julio de 1974.

. La Situación Actual y Perspectiva de la Regionalización, Santiago, 23 de diciembre de 1975. diciembre de 1975

La Universidad Católica Evaluará la Regionalización, Santiago, 24 de

Junta de Gobierno Aprobó D.L. Divididas en Provincias Las Regiones no Pilotos, Santiago, 31 de diciembre de 1975.

Autonomía Regional, Santiago, 24 de febrero de 1976.

Chile hacia un nuevo destino, Santiago, 23 de junio de 1976.

Se definirá a mediados de 1977. Delimitación Geográfica de Las Comunas, Santiago, 15 de diciembre de 1976.

. Coronel Claudio López. Nombrado Nuevo Vicepresidente de CONARA, Santiago, 23 de enero de 1977.

mayo de 1977.

Duplicidad de funciones en la Administración Pública, Santiago, 2 de 
Para evitar los "resquicios legales". SERÁ DEROGADAS LEYES

OBSOLETAS, Santiago, 8 de julio 1977.

Estrategia Para el Desarrollo Comunal, Santiago, 18 de Julio de 1977.

Convenio Para Capacitar A 70 Mil Funcionarios Suscribió

CONARA, Santiago, 6 de octubre de 1977.

Junta no aceptó dividirla. Se Mantiene Integridad de la Décima Región, Santiago, 7 de diciembre de 1977.

TERCERA DE LA HORA, Gremios plantean la descentralización, Santiago, 4 de diciembre de 1973, p. 2.

La regionalización, Santiago, 12 de Julio de 1974, 3.

diciembre de 1975.

.Firmado decreto que crea nueva división regional, Santiago, 31 de

LA TERCERA. Apareció obra completa sobre la regionalización, Santiago, 25 de junio de 1976

Septiembre de 1976.

Regionalización: El País en Busca de su Destino, Santiago, 11 de

CONARA entregó proposiciones a seis regiones. Desaparecen trece comunas y se crearían otras ocho, Santiago, 6 de noviembre de 1977.

Acuerdo de la Junta de Gobierno. Valdivia no será región, pero tendrá gran plan de desarrollo, Santiago, 17 de diciembre de 1977

LA PATRIA. La Administración Pública y la Constitución, Santiago, 9 de diciembre de 1973.

Reforma de la Administración Pública, Santiago, 28 de diciembre de

1973.

Puntualizó el General Canessa. DELIMITACIÓN DE MICROREGIONES NO TIENE APROBACIÓN PRESIDENCIAL, Santiago, 4 de Enero de 1975.

LA SEGUNDA. Renuncia, Santiago, 27 de diciembre de 1973.

2 de noviembre de 1977 .

CONARA SUBSCRIBIÓ UN CONVENIO CON BRASIL, Santiago,

ÚLTIMAS NOTICIAS. Documento del Jefe de Estado. La Regionalización: Un Desafío para los Chilenos, Santiago, 13 de Julio de 1974. 
de 1975.

Frenarán crecimiento horizontal de Santiago, Santiago, 21 de Enero

QUÉ PASA, Regionalización y desburocratización, Santiago, 19 de Julio de 1974.

EL CRONISTA. CONARA redefine las comunas. SOLO EN 170 MUNICIPIOS QUEDARÁ DIVIDIDO EL PAÍS, SANTIAGO, 31 de diciembre de 1975.

Hay que Redefinir las Comunas, Pero Sin Premuras Para no Equivocarnos, Santiago, 27 de mayo de 1976.

Santiago, 18 de noviembre de 1976.

Valiosa Colección de Mapas Donó CONARA a la U. Católica, Homenaje a CONARA, Santiago, 4 de diciembre de 1976.

6 de febrero de 1977.

La Región Metropolitana se Dividirá en Cinco Provincias, Santiago,

Desarrollo Regional, Santiago, 6 de mayo de 1977.

21 de Junio de 1977.

Nuevo Sistema de Gobierno Regional se inicia en Enero, Santiago,

Reforma Administrativa Chilena no Tiene Precedentes en el Mundo, Santiago, 16 de noviembre de 1977

ERCILLA, Regiones. La nueva participación, Santiago, 14 de Enero de 1976.

Regiones administrativas, Santiago, 26 de mayo de 1976,

Administración Publica. Difícil inercia, Santiago, 18 de mayo de 1977.

Mayo de 1977.

Regionalización. Razones y fondos para el desarrollo, Santiago, 18 de

La Burocracia: ¿Bien, Gracias?, Santiago, 20 de noviembre de 1977.

HOY. Regionalización. Santiago busca su destino. Comité Nacional de Reforma Administrativa operó con la idea que "Chile no es la capital", Santiago, 13 de Julio de 1977. 